\title{
Development and Evaluation of a Novel Integrated Vacuum Carbonate Absorption Process
}

Final Report

Project Period: October 1, 2008 to April 30, 2012

Report Authors: Yongqi Lu* (PI), Massoud Rostam-Abadi ${ }^{\star,+}$, Xinhuai Ye*, Shihan Zhang*, David Ruhter*, Arezoo Khodayari ${ }^{+}$, Mark Rood ${ }^{+}$

*Illinois State Geological Survey, Prairie Research Institute, ${ }^{+}$Department of Civil \& Environmental Engineering, University of Illinois at Urbana-Champaign

Date of Report: July 27, 2012

DOE Award No: DE-FC26-08NT0005498

Submitted by: Illinois State Geological Survey,

Prairie Research Institute, University of Illinois at Urbana-Champaign, 615 E. Peabody Drive, Champaign, IL 61820 


\section{DISCLAIMER}

This report was prepared as an account of work sponsored by an agency of the United States Government. Neither the United States Government nor any agency thereof, nor any of their employees, makes any warranty, express or implied, or assumes any legal liability or responsibility for the accuracy, completeness, or usefulness of any information, apparatus, product, or process disclosed, or represents that its use would not infringe privately owned rights. Reference herein to any specific commercial product, process, or service by trade name, trademark, manufacturer, or otherwise does not necessarily constitute or imply its endorsement, recommendation, or favoring by the United States Government or any agency thereof. The views and opinions of authors expressed herein do not necessarily state or reflect those of the United States Government or any agency thereof. 


\section{ACKNOWLEDGEMENTS}

This report is an account of research sponsored by the U.S. Department of Energy/ National Energy Technology Laboratory (DOE/NETL), through Cooperative Agreement No. DE-FC2608NT0005498. The work summarized in this report could not have been done without valuable support from Dr. Nicolas Pollack at Calgon Carbon Corporation, who contributed to numerous technical discussions and supplied activated carbon support materials over the entire period of the project. Dr. Sonja Salmon at Novozymes North America, Inc. provided carbonic anhydrase enzyme samples for the research and participated in many technical discussions involving testing of enzyme performance. Mr. Andrew Jones at the DOE/NETL, who served as manager for this project, dedicated his time in project management in all aspects and offered detailed review of this report. Thanks also go to Dr. Jonathan Goodwin at the Illinois State Geological Survey for his critical review and valuable suggestions to the report. 


\begin{abstract}
This project was aimed at obtaining process engineering and scale-up data at a laboratory scale to investigate the technical and economic feasibility of a patented post-combustion carbon dioxide $\left(\mathrm{CO}_{2}\right)$ capture process-the Integrated Vacuum Carbonate Absorption Process (IVCAP). Unique features of the IVCAP include its ability to be fully-integrated with the power plant's steam cycle and potential for combined sulfur dioxide $\left(\mathrm{SO}_{2}\right)$ removal and $\mathrm{CO}_{2}$ capture.
\end{abstract}

Theoretical and experimental studies of this project were aimed at answering three major technical questions: 1) What additives can effectively reduce the water vapor saturation pressure and energy requirement for water vaporization in the vacuum stripper of the IVCAP? 2) What catalysts can promote $\mathrm{CO}_{2}$ absorption into the potassium carbonate (PC) solution to achieve an overall absorption rate comparable to monoethanolamine (MEA) and are the catalysts stable at the IVCAP conditions and in the flue gas environment? 3) Are any process modifications needed to combine $\mathrm{SO}_{2}$ and $\mathrm{CO}_{2}$ removal in the IVCAP?

Lab-scale experiments and thermodynamic and process simulation studies performed to obtain detailed information pertinent to the above three technical questions produced the following results: 1) Two additives were identified that lower the saturation pressure of water vapor over the PC solution by about $20 \%$. 2) The carbonic anhydrase (CA) enzyme was identified as the most effective catalyst for promoting $\mathrm{CO}_{2}$ absorption. The absorption rate into the $\mathrm{CO}_{2}-\mathrm{lean} \mathrm{PC}$ solution promoted with $300 \mathrm{mg} / \mathrm{L}$ CA was several times slower than the corresponding $5 \mathrm{M}$ MEA solution, but absorption into the $\mathrm{CO}_{2}$-rich $\mathrm{PC}$ solution was comparable to the $\mathrm{CO}_{2}$-rich MEA solution. The tested CA enzymes demonstrated excellent resistance to major flue gas impurities. A technical-grade CA enzyme was stable at $40^{\circ} \mathrm{C}\left(104^{\circ} \mathrm{F}\right)$ over a six-month test period, while its half-life was about two months at $50^{\circ} \mathrm{C}\left(122^{\circ} \mathrm{F}\right)$. Enzyme immobilization improved the CA enzyme's thermal stability by up to three times compared to its free counterpart. 3) Two process modifications were proposed to improve the technical performance of the IVCAP for combined $\mathrm{SO}_{2}$ removal and $\mathrm{CO}_{2}$ capture.

The results from a techno-economic study of a $528 \mathrm{MWe}$ (gross) pulverized coal-fired, subcritical steam power plant revealed that the cost of $\mathrm{CO}_{2}$ avoidance with the IVCAP was about $30 \%$ lower than conventional MEA-based processes. The levelized cost of electricity (LCOE) of the IVCAP ranged from $\$ 40$ to $46 / \mathrm{MWh}$, an increase of 60 to $70 \%$ compared to a reference power plant without $\mathrm{CO}_{2}$ capture. The overall conclusion of this study is that the IVCAP is a technically feasible and economically more attractive process than available MEA-based processes. A scale-up study using the slipstream of an actual coal-derived flue gas and development of a more stable CA enzyme are recommended for future studies. 


\section{TABLE OF CONTENTS}

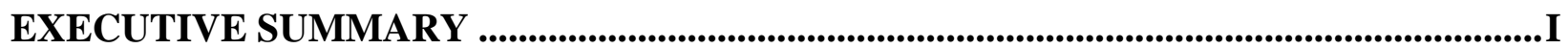

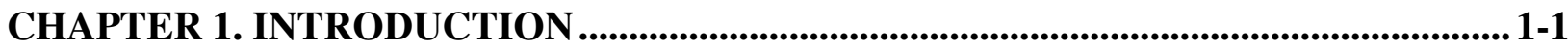

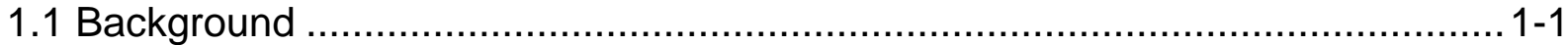

1.2 Introduction of Integrated Vacuum Carbonate Absorption Process .................... 1-2

1.3 Technical challenges to be addressed.......................................................... 1-5

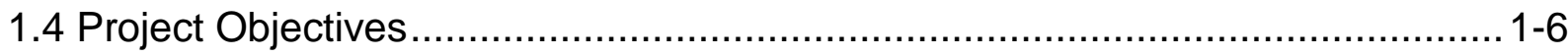

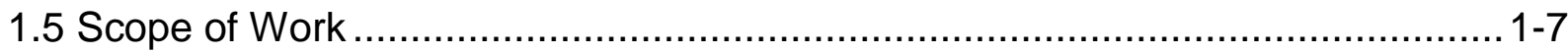

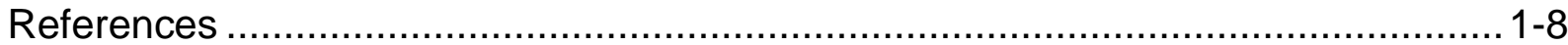

CHAPTER 2. VAPOR-LIQUID PHASE EQUILIBRIUM BEHAVIOR OF $\mathrm{K}_{2} \mathrm{CO}_{3}$ SOLUTIONS AND SCREENING OF ADDITIVES TO REDUCE ENERGY CONSUMPTION ...................................................................................................................... 2-1

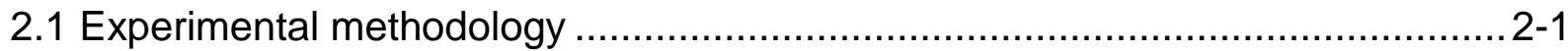

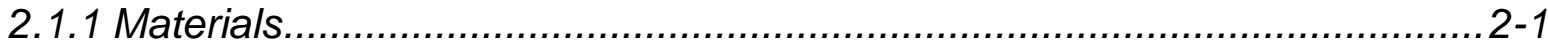

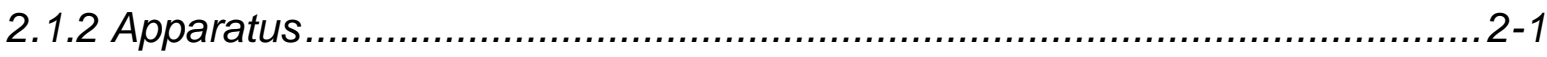

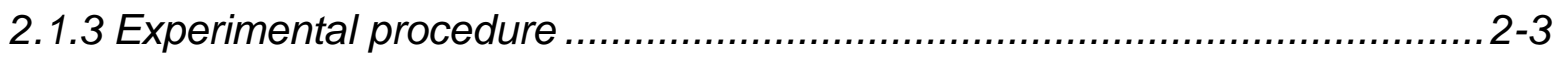

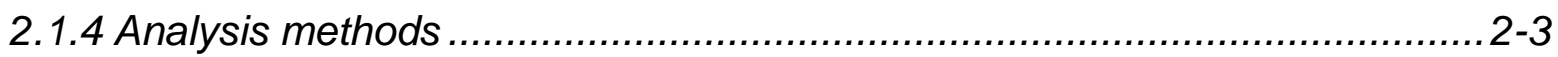

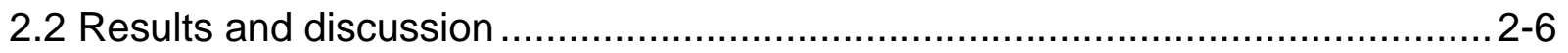

2.2. 1 VLE measurements of $\mathrm{CO}_{2}$ in PC solutions without additives....................2-6

2.2.2 VLE measurements of $\mathrm{CO}_{2}$ in PC solutions with additives........................2-8

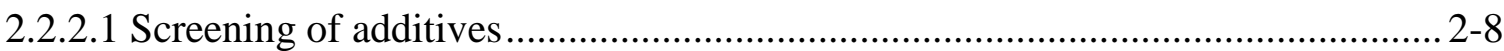

2.2.2.2 VLE measurements of $\mathrm{CO}_{2}$-PC solutions with selected additives...................... 2-9

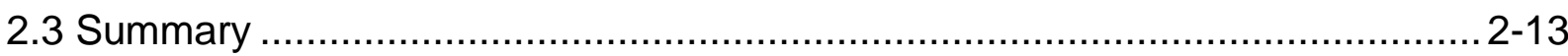

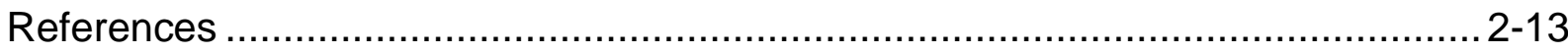

CHAPTER 3. KINETICS OF $\mathrm{CO}_{2}$ ABSORPTION INTO $\mathrm{K}_{2} \mathrm{CO}_{3}$ SOLUTIONS.................3-1

PART 3A. KINETICS OF $\mathrm{CO}_{2}$ ABSORPTION INTO $\mathrm{K}_{2} \mathrm{CO}_{3}$ SOLUTION WITHOUT A

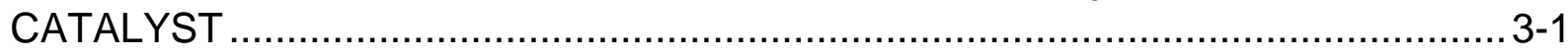

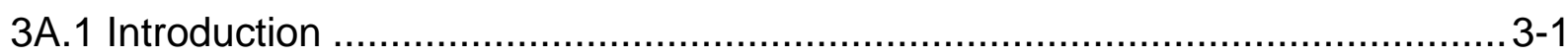

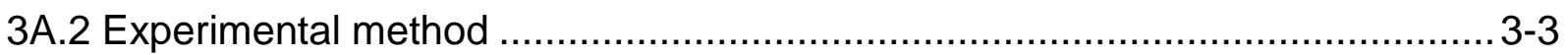

3A.3 Theoretical analysis and data interpretation ........................................... 3-4

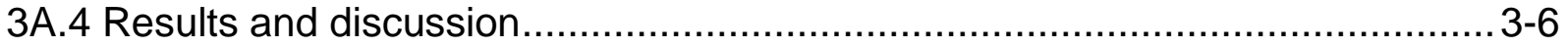


3A.4.1 Estimation of physical properties of PC solutions .................................. 3-6

3A.4.2 Determination of liquid-phase physical mass transfer coefficient............... 3-7

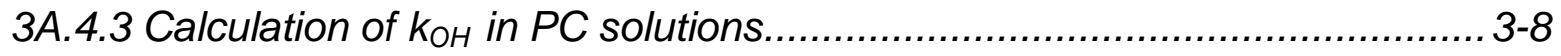

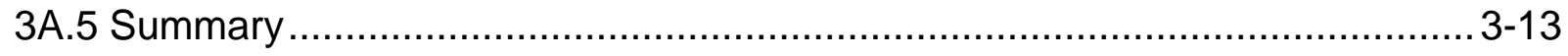

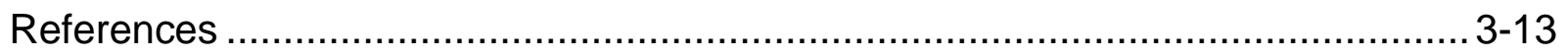

PART 3B. INVESTIGATION OF CATALYSTS FOR ENHANCING ABSORPTION OF $\mathrm{CO}_{2}$ INTO $\mathrm{K}_{2} \mathrm{CO}_{3}$ SOLUTIONS …............................................................. 3-16

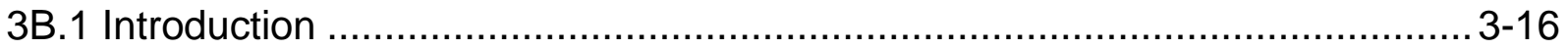

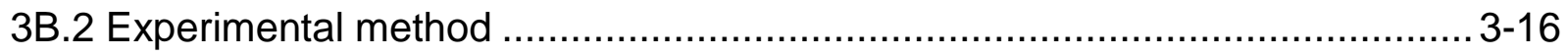

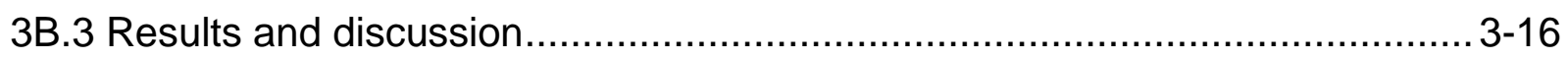

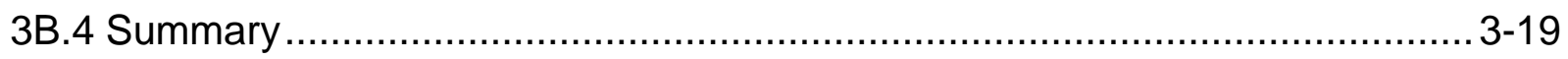

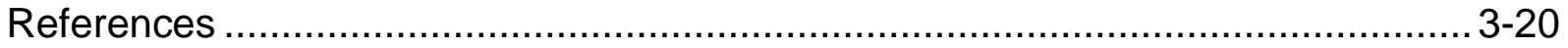

PART 3C. KINETICS OF $\mathrm{CO}_{2}$ ABSORPTION INTO $\mathrm{K}_{2} \mathrm{CO}_{3}$ (PC) SOLUTIONS PROMOTED BY CA ENZYME ...............................................................

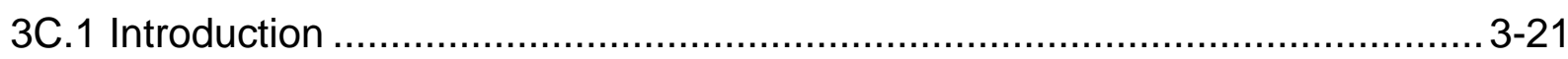

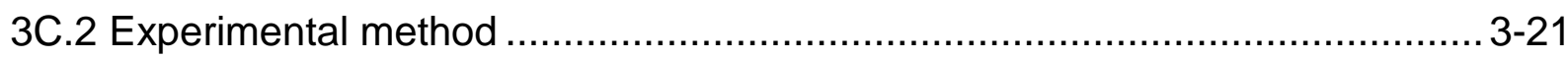

3C.3 Theoretical analysis and data interpretation........................................... 3-21

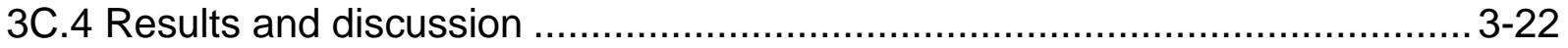

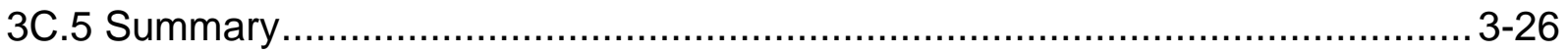

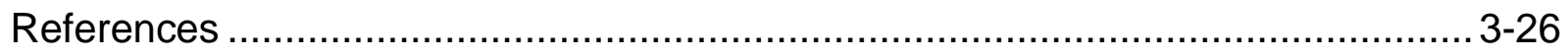

PART 3D. ACTIVITY AND STABILITY OF CA ENZYME FOR ENHANCING $\mathrm{CO}_{2}$ ABSORPTION INTO $\mathrm{K}_{2} \mathrm{CO}_{3}$ SOLUTIONS ……....................................... 3-28

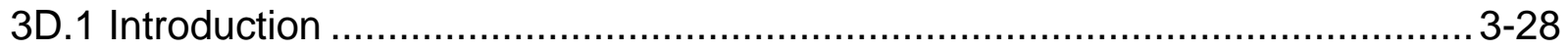

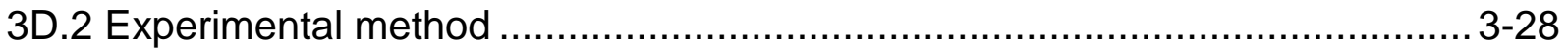

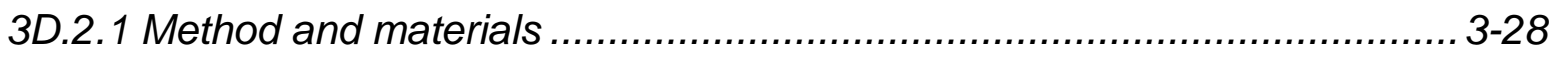

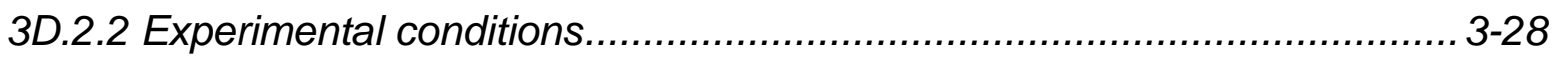

3D.3 Theoretical analysis and data interpretation ........................................... 3-29

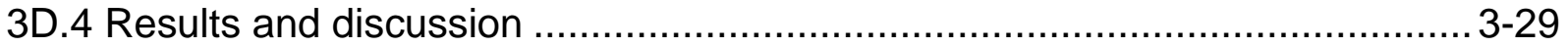

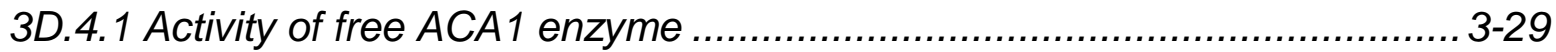

3D.4.2 Comparison of $\mathrm{CO}_{2}$ absorption rates into $P C+A C A 1$ and MEA .............. 3-32 
3D.4.3 Chemical stability of free ACA1 enzyme.

3D.4.4 Long-term thermal stability of free CA enzymes ................................. 3-41

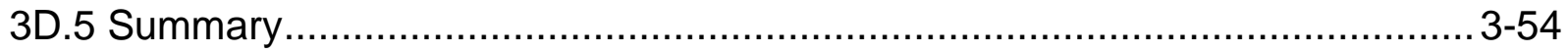

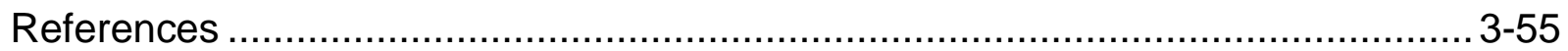

CHAPTER 4. CARBONIC ANHYDRASE ENZYME IMMOBILIZATION....................... 4-1

PART 4A. CA ENZYME IMMOBILIZATION ONTO POROUS MATERIALS............. 4-1

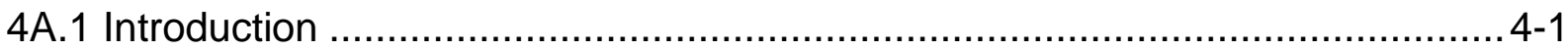

4A.2 Experimental methods ....................................................................... 4

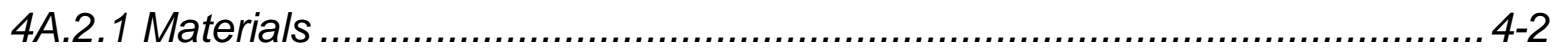

4A.2.2 Enzyme purification........................................................................ 4-3

4A.2.3 Enzyme immobilization ................................................................ 4

4A.2.4 Analysis of $\mathrm{NH}_{2}$ functional group density ......................................... 4-6

4A.2.5 Characterization of support materials and immobilized enzymes .............. 4-6

4A.2.6 Enzyme loading ....................................................................... 4-6

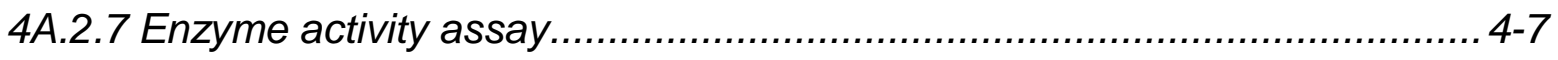

4A.2.8 Chemical and thermal stability assays ................................................ 4-8

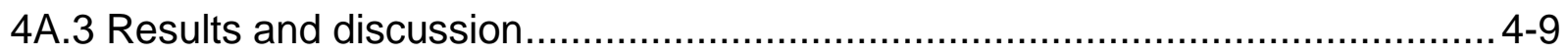

4A.3.1 Optimization of enzyme immobilization onto CPG ............................... 4-9

4A.3.2 Activity of SCA-CPG ................................................................ 4-14

4A.3.3 Immobilization of SCA onto Eupergit support ................................... 4-17

4A.3.4 Pore size of support material vs. loading and activity of immobilized CA. 4-18 4A.3.5 Thermal stability of immobilized $\mathrm{CA}$ for $\mathrm{CO}_{2}$ hydration ......................... 4-21

4A.3.6 Thermal stability based on p-NPA hydrolysis assay vs. $\mathrm{CO}_{2}$ hydration assay

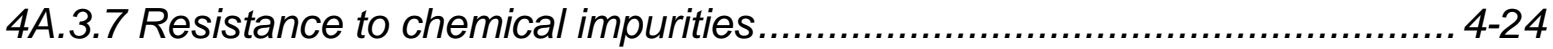

4A.3.8 $\mathrm{CO}_{2}$ absorption into carbonate solution promoted with immobilized CA... 4-25

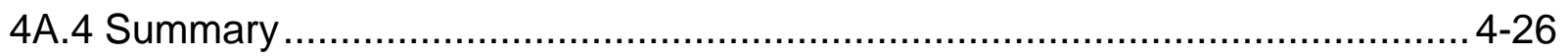

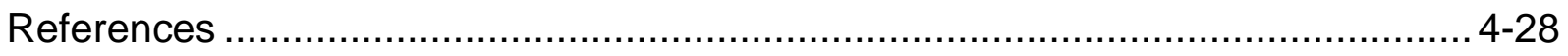

PART 4B. CA ENZYME IMMOBILIZATION ONTO NON-POROUS

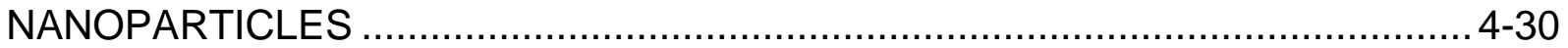

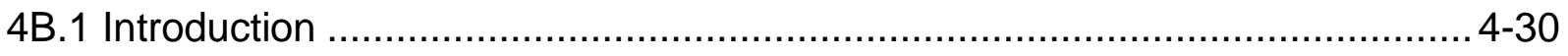


4B.2 Experimental methods

4B.2.1 Materials 4-31

4B.2.2 Flame spray pyrolysis method for synthesis of nanoparticles 4-31

4B.2.3 Characterization of nanoparticles. 4-32

4B.2.4 Enzyme immobilization onto nanoparticles. 4-32

4B.2.5 Enzyme activity assay. 4-33

4B.2.6 Effect of $\mathrm{pH}$ and temperature on activity of immobilized enzymes. 4-33

4B.2.7 Enzyme stability assay. 4-34

4B.3 Theoretical analysis of enzymatic kinetics for $\mathrm{CO}_{2}$ absorption 4-34

4B.4 Results and discussion. 4-36

4B.4.1 Characterization of nanoparticle support materials 4-37

4B.4.2 Optimization of enzyme immobilization conditions. 4-39

4B.4.3 Enzyme loading and activity of immobilized enzymes 4-42

4B.4.4 Effect of $\mathrm{pH}$ and temperature on activity of immobilized enzymes. 4-43

4B.4.5 Thermal and chemical stability of immobilized enzymes. 4-44

4B.5 Summary 4-48

References 4-49

\section{CHAPTER 5. RECLAMATION OF SULFATE DESULFURIZATION PRODUCT IN IVCAP PROCESS

5.1. Introduction 5-1

5.2 Measurement of $\mathrm{K}_{2} \mathrm{CO}_{3}$ conversion rate and extent under high-pressure $\mathrm{CO}_{2}$ gas 5-3

5.2.1 Experimental setup and apparatus.......................................................... 5-4

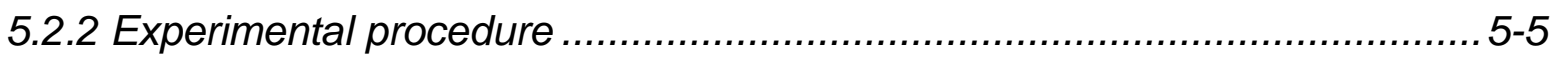

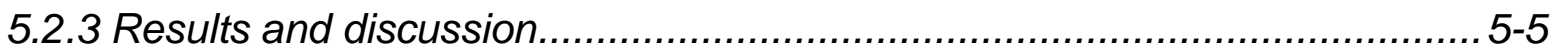

5.3. Semi-continuous test for reclaiming $\mathrm{K}_{2} \mathrm{SO}_{4}$ from simulated absorption

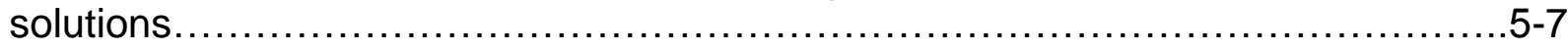

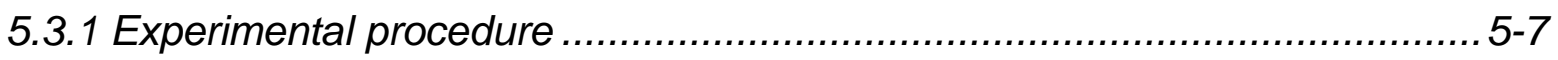

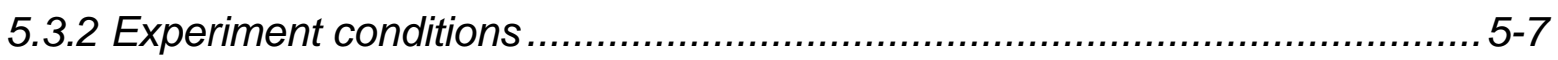

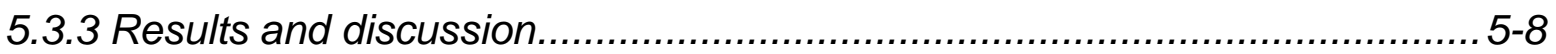

5.3.3.1 Sulfate reclamation from simulated PC solutions without additives ....................5-8

5.3.3.2 Impact of catalysts and additives on sulfate reclamation.................................. 5-11

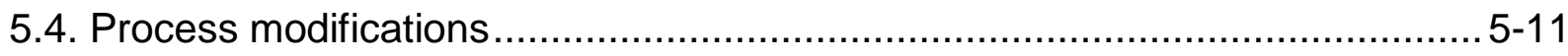




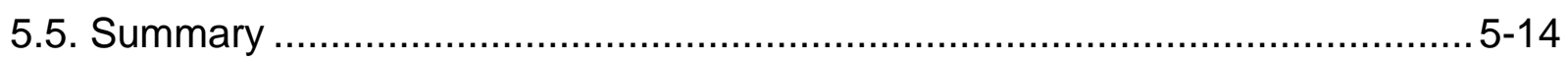

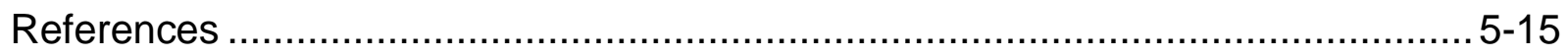

CHAPTER 6 TECHNO-ECONOMIC ANALYSIS OF IVCAP PROCESS.......................... 6-1

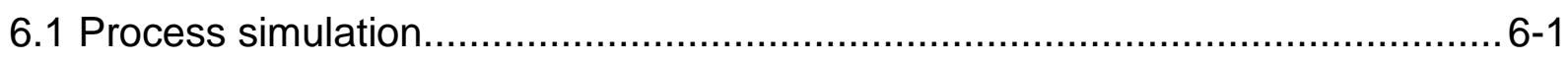

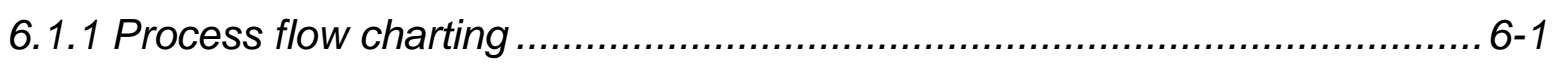

6.1.1.1 Description of IVCAP process....................................................................... 6-1

6.1.1.2 Integration with power plant ......................................................................... 6-2

6.1.2 Simulation method and assumptions................................................ $6-5$

6.1.3 Results and discussion..................................................................... $6-6$

6.1.3.1 Reference power plant without $\mathrm{CO}_{2}$ capture .................................................. 6-6

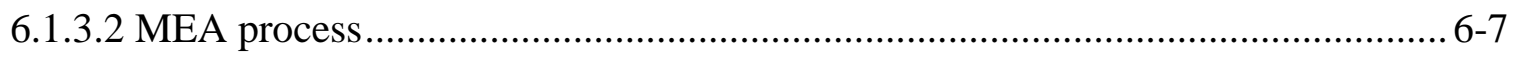

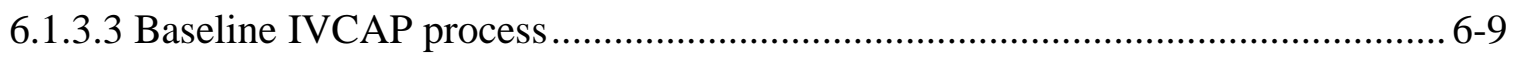

6.1.3.4 Parametric study of IVCAP process .......................................................... 6-12

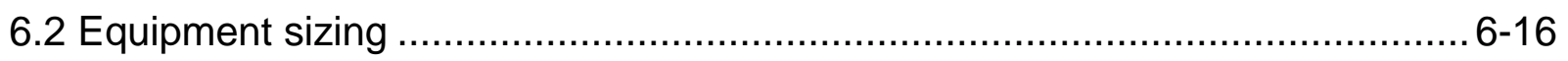

6.2.1 Sizing of absorption column ............................................................. 6-16

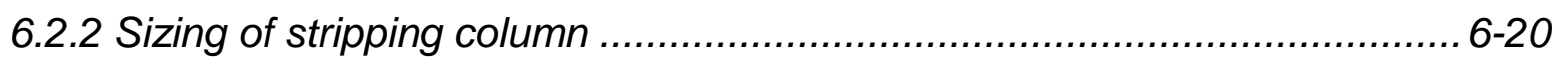

6.2.3 Sizing of steam extraction line ........................................................ 6-22

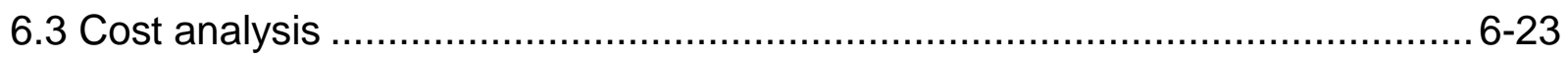

6.3.1 Method of cost analysis and assumptions .......................................... 6-23

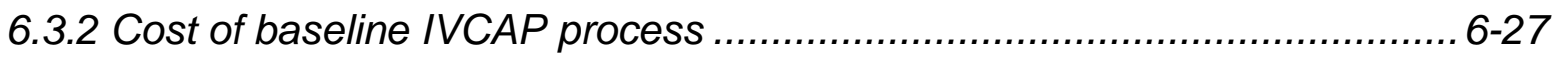

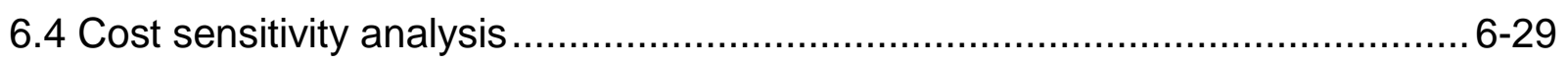

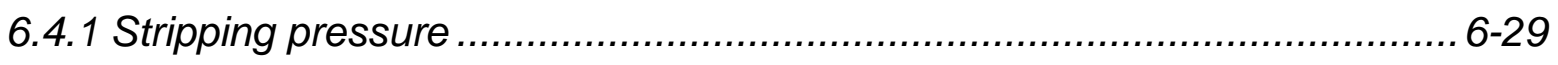

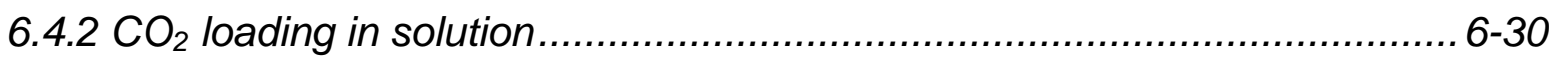

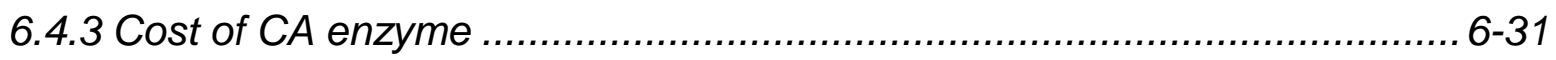

6.4.4 Use of additives to reduce water vapor saturation pressure..................... 6-32

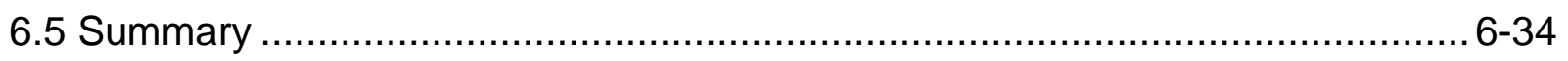

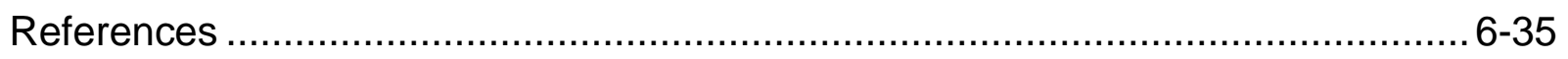

CHAPTER 7. EVALUATION OF OTHER MAJOR TECHNICAL RISKS ......................... 7-1

7.1 Corrosion risk, inhibition and effect.............................................................

7.1.1 Corrosion circumstances caused by PC solutions ................................... 7-1

7.1.2 Cause and mechanism of corrosion ....................................................... $7-2$ 
7.1.3 Inhibitors for corrosion mitigation ..................................................... 7-4

7.1.4 Discussion of corrosion inhibition in IVCAP ............................................ 7-5

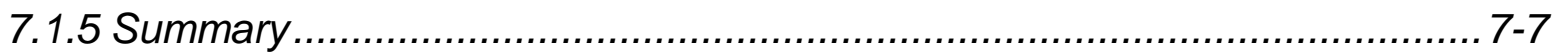

7.2 Effect of flue gas trace elements on CA enzyme activity and stability ............... 7-7

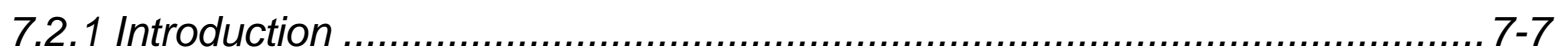

7.2.2 Effect of heavy metals on the activity and stability of CA enzymes ............. 7-9

7.2.3 Effect of anions on CA enzyme activity and stability ............................... 7-10

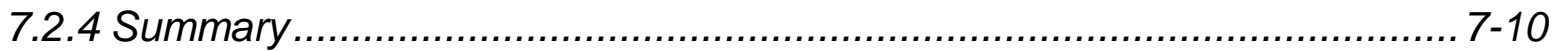

7.3 Treatment needed to use IVCAP condensate water as feedwater for power plant

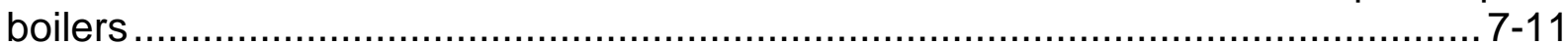

7.3.1 Recycled use of IVCAP condensate as feedwater in power plants ............ 7-11

7.3.2 Quality of water condensate from IVCAP stripper .................................. 7-12

7.3.3 Quality required for boiler feedwater ................................................... 7-13

7.3.4 Treatment options for IVCAP water condensate .................................. 7-13

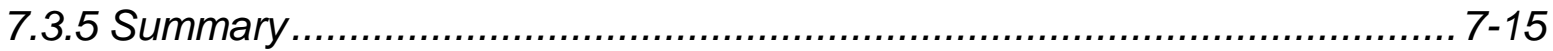

7.4 Potential for precipitation of potassium bicarbonate from PC solution .............. 7-15

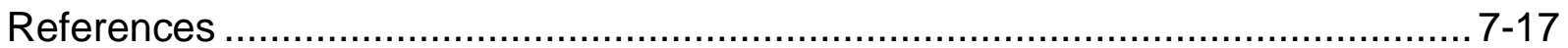

CHAPTER 8. CONCLUSIONS AND RECOMMENDATIONS ............................................... 8-1

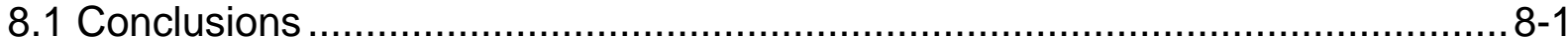

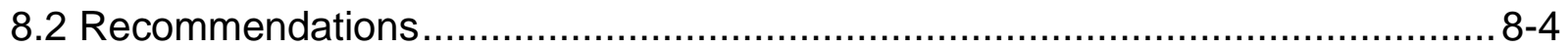

APPENDIX A. STATEMENT OF PROJECT OBJECTIVES ...............................................A-1

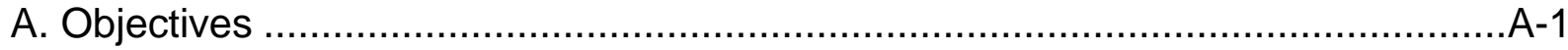

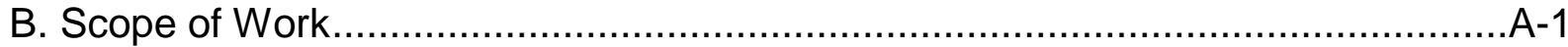

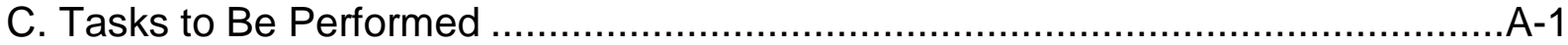

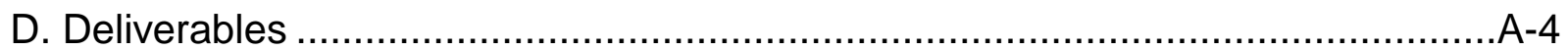

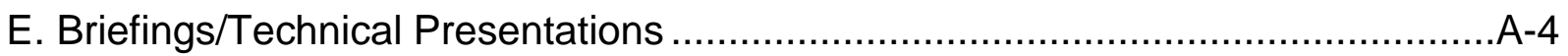




\section{LIST OF FIGURES}

Figure 1-1. Schematic diagram of a sub-critical steam cycle power plant ................................. 1-3

Figure 1-2. Steam properties during expansion in the IP and LP turbines ................................. 1-3

Figure 1-3. Schematic diagram of the proposed IVCAP ...................................................... 1-4

Figure 2-1. Schematic diagram and photos of the experimental setup for VLE measurement ... 2-3

Figure 2-2. Chromatographs of standard gases for GC calibration. ......................................... 2-5

Figure 2-3. Comparison of water vapor saturation pressure measured by the HMT 338 with those in the literature for pure water and two standard saturated salt solutions.......................... 2-6

Figure 2-4. Equilibrium vapor pressure of $\mathrm{CO}_{2}$ over the $20 \mathrm{wt} \% \mathrm{PC}$ obtained from this study, literature, and CHEMCAD modeling. ……………….................................................... 2-7

Figure 2-5. Equilibrium pressure of water vapor over the $20 \mathrm{wt} \%$ PC solution measured in this study and reported by Tosh et al. (1959). ................................................................. 2-7

Figure 2-6. Equilibrium water vapor pressure over the PC20-20 solution with different additives

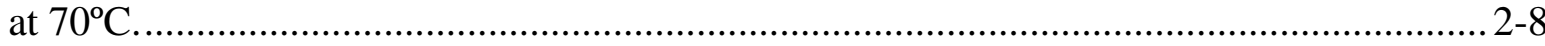

Figure 2-7. Equilibrium water vapor pressure over the $20 \mathrm{wt} \% \mathrm{PC}$ with additives at $50^{\circ} \mathrm{C}$ and $70^{\circ} \mathrm{C}$ $2-10$

Figure 2-8. Comparison of equilibrium water vapor pressures over the $20 \mathrm{wt} \% \mathrm{PC}$ with additives. 2-11

Figure 2-9. Equilibrium vapor pressure of $\mathrm{CO}_{2}$ over the $20 \mathrm{wt} \% \mathrm{PC}$ with additives............... 2-13

Figure 3A-1. Schematic diagram of a STR experimental setup. ............................................... 3-4

Figure 3A-2. Plots of $\operatorname{Ln}\left[\left(C_{1} P_{\mathrm{CO}, 0}+C_{2}\right) /\left(C_{1} P_{C O 2, t}+C_{2}\right)\right] v s$. $-C_{1} \Delta t$ using the data for absorption of $\mathrm{CO}_{2}$ into water at temperatures between 25 and $80^{\circ} \mathrm{C}$ and the corresponding linear regression for each data set ................................................................................... 3-8

Figure 3A-3. Plots of $\operatorname{Ln}\left[\left(P_{\mathrm{CO}, 0^{-}} C^{b} \mathrm{He}\right) /\left(P_{\mathrm{CO}, t^{-}} C^{b} \mathrm{He}\right)\right] v s . \mathrm{RTA} \Delta t /\left(V_{G} \mathrm{He}\right)$ using the data for absorption of $\mathrm{CO}_{2}$ into a $20 \mathrm{wt} \% \mathrm{PC}$ solution. ................................................................ 3-9

Figure 3A-4. $k_{O H}$ values determined for absorption of $\mathrm{CO}_{2}$ into $5 \%-40 \% \mathrm{PC}$ solutions at temperatures between 25 and $80^{\circ} \mathrm{C}$........................................................................ 3-10

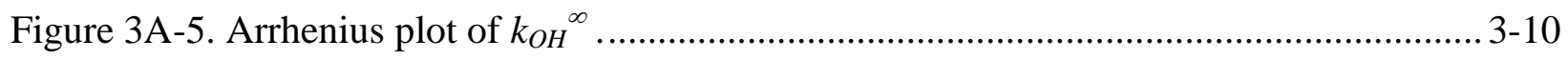

Figure 3A-6. Arrhenius plot of $k_{O H}$ values in 5 to $40 \%$ PC solutions......................................... 3-11

Figure 3A-7. Arrhenius plot of $\log k_{O H}$ values in $20 \mathrm{wt} \% \mathrm{PC}$ solutions with different $\mathrm{CO}_{2}$

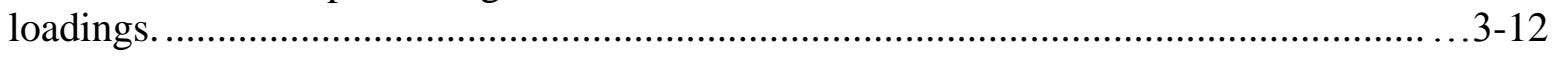

Figure 3A-8. Arrhenius plot of $\log k_{O H}$ values in $30 \mathrm{wt} \% \mathrm{PC}$ solutions with different $\mathrm{CO}_{2}$ loadings. 
Figure 3B-1. Rate of $\mathrm{CO}_{2}$ absorption into the PC20-20 solution promoted by additives at (a) $25^{\circ} \mathrm{C}$ and (b) $40^{\circ} \mathrm{C}$. 3-18

Figure 3B-2. Enhancement factors of selected additives for $\mathrm{CO}_{2}$ absorption into PC20-20.... 3-19

Figure 3C-1. Plot of $\operatorname{Ln}\left(P_{C O 2,0} P_{C O 2, t}\right)$ vs. RTA $\Delta t /\left(V_{G} H e\right)$ using data of $\mathrm{CO}_{2}$ absorption into the PC20-20 solution without and with various amounts of the CA enzyme at $40^{\circ} \mathrm{C}$. $3-23$

Figure $3 \mathrm{C}-2$. Determination of $k_{C A}$ at 25,40 , and $50^{\circ} \mathrm{C}$ in the $20 \mathrm{wt} \% \mathrm{PC}$ with CTB conversion rates ranging from 10 to $50 \%$.

Figure 3D-1. Rate of $\mathrm{CO}_{2}$ absorption into PC containing different concentrations of ACA1 enzyme and $\mathrm{E}$ values under different conditions.

Figure 3D-2. Rates of $\mathrm{CO}_{2}$ absorption into PC20-20 and PC20-40 solutions at $50^{\circ} \mathrm{C}$ without and with 50 and $300 \mathrm{mg} / \mathrm{L}$ ACA1 enzyme loadings.

Figure 3D-3. Effect of temperature on the rate of $\mathrm{CO}_{2}$ absorption into PC20-20 without and with 50 and $300 \mathrm{mg} / \mathrm{l} \mathrm{CA}$ enzyme.

Figure 3D-4. $\mathrm{CO}_{2}$ absorption rates into the lean and rich $20 \mathrm{wt} \% \mathrm{PC}+300 \mathrm{mg} / \mathrm{L} \mathrm{CA}$ and $5 \mathrm{M}$ MEA solutions at $50^{\circ} \mathrm{C}$.

Figure 3D-5. Effect of flue gas impurities on the $\mathrm{CO}_{2}$ absorption rate promoted by ACA and on $E_{C A}$ values.

Figure 3D-6. Rate of $\mathrm{CO}_{2}$ absorption into PC20-20 containing ACA1 enzyme with and without the presence of rate promoters at $25^{\circ} \mathrm{C}$ and $40^{\circ} \mathrm{C}$. 3-37

Figure 3D-7. Enhancement factor of ACA1 enzyme in PC20-20 with and without the presence of rate promoters at $25^{\circ} \mathrm{C}$ and $40^{\circ} \mathrm{C}$. 3-38

Figure 3D-8. Resistance of ACA enzyme to KAc, KA and EG in PC solution at $40^{\circ} \mathrm{C} \ldots \ldots \ldots . . .3-40$

Figure 3D-9. Long-term stability of ACA1 in $20 \mathrm{wt} \%$ PC solutions at $25^{\circ} \mathrm{C}$....................... 3-42

Figure 3D-10. Long-term stability of ACA1 in $20 \mathrm{wt} \%$ PC solutions at $40^{\circ} \mathrm{C}$....................... 3-43

Figure 3D-11. Long-term stability of ACA1 in a $20 \mathrm{wt} \% \mathrm{PC}$ solution at $50^{\circ} \mathrm{C}$ 3-43

Figure 3D-12. Enhancement factors (a) and activity loss (b) of ACA1 in $20 \mathrm{wt} \%$ PC at 25, 40, and $50^{\circ} \mathrm{C}$.

Figure 3D-13. Long-term stability of ACA2 in $20 \mathrm{wt} \% \mathrm{PC}$ solutions at $40^{\circ} \mathrm{C}$ 3-45

Figure 3D-14. Long-term stability of ACA2 in $20 \mathrm{wt} \% \mathrm{PC}$ solutions at $50^{\circ} \mathrm{C}$. 3-46

Figure 3D-15. Long-term stability of ACA2 in $20 \mathrm{wt} \% \mathrm{PC}$ solutions at $60^{\circ} \mathrm{C}$ $3-47$

Figure 3D-16. $E_{C A}$ and percentage activity loss of ACA2 in $20 \mathrm{wt} \% \mathrm{PC}$ at 40,50 , and $60^{\circ} \mathrm{C} . .3-48$

Figure 3D-17. Long-term stability of BCA1 enzyme for promoting $\mathrm{CO}_{2}$ absorption into PC20-20 solution at (a) 40 , (b) 50 , and (c) $60^{\circ} \mathrm{C}$. $3-50$

Figure $3 \mathrm{D}-18 . E_{C A}$ and activity loss of BCA1 in $20 \mathrm{wt} \% \mathrm{PC}$ at 40,50 , and $60^{\circ} \mathrm{C}$. 3-51 
Figure 3D-19. Comparison among ACA1, ACA2, and BCA1 for long-term thermal stability for promoting $\mathrm{CO}_{2}$ absorption into PC20-20 solutions at 40,50 , and $60^{\circ} \mathrm{C} \ldots \ldots \ldots \ldots \ldots \ldots \ldots . . . . . . . . . .3-53$

Figure 4A-1. Main reactions involved in CA immobilization on CPG support....................... 4-4

Figure 4A-2. Main reactions involved in CA immobilization on AC support. ......................... 4-4

Figure 4A-3. Main reactions involved in the CA immobilization on Eupergit C support.......... 4-5

Figure 4A-4. Schematic diagram of a stirred tank reactor (STR) apparatus for $\mathrm{CO}_{2}$ absorption.4-8

Figure 4A-5. Flow chart of the optimal procedure of enzyme immobilization on CPG support.4-9

Figure 4A-6. SEM images of as-received CPG100 at magnifications of 70K (a) and 35K (b); CPG100 surface activated with silanizing reagent at magnifications of $15 \mathrm{~K}$ (c) and $70 \mathrm{~K}(\mathrm{~d})$; and CPG100 immobilized with SCA enzyme at magnifications of $100 \mathrm{~K}$ (e) and 35K (f).

Figure 4A-7. Impact of immobilization pH on enzyme loading and activity of SCA-CPG100.

Figure 4A-8. Profile of the SCA enzyme concentration in the supernatant during the SCA and CPG100 coupling reaction at $\mathrm{pH} 8.0$ and room temperature. 4-13

Figure 4A-9. Impact of stirring speed on the measurement of the SCA-CPG100 activity for $p$ NPA hydrolysis.

Figure 4A-10. Relative $p$-NPA hydrolysis activities of free SCA and SCA-CPG100 at room temperature under various $\mathrm{pH}$ conditions.

Figure 4A-11. Relative $p$-NPA hydrolysis activities of free SCA and SCA-CPG100 at pH7.85 and at various temperatures.

Figure 4A-12. Kinetics of $p$-NPA hydrolysis catalyzed by SCA-CPG100. 4-16

Figure 4A-13. Pore size distribution of AC and CPG38 before and after enzyme immobilization based on BJH method.

Figure 4A-14. LSCM images of selected X-Y slices taken along the Z-axis for the three immobilized enzymes: (a) ACA1-CPG38, (b) ACA1-CPG100, and (c) ACA1-AC.

Figure 4A-15. Thermal stability of immobilized and free enzymes for $\mathrm{CO}_{2}$ hydration at (a) $50^{\circ} \mathrm{C}$ and (b) $60^{\circ} \mathrm{C}$. 4-22

Figure 4A-16. Comparison between $\mathrm{CO}_{2}$ hydration and $p$-NPA activity for free SCA enzyme and comparison of $p$-NPA activity between free SCA, SCA-CPG100, and SCA-CPG38 over 90 days at $50^{\circ} \mathrm{C}$.

Figure 4A-17. Flux of $\mathrm{CO}_{2}$ absorption with and without $\mathrm{CA}$ enzymes at $50^{\circ} \mathrm{C} \ldots \ldots \ldots \ldots \ldots \ldots \ldots . . . . . . . .25$

Figure 4B-1. Schematic of Flame Spray Pyrolysis experimental apparatus.......................... 4-31

Figure 4B-2. XRD patterns of the FSP-made nanoparticles............................................... 4-37

Figure 4B-3. $\mathrm{N}_{2}$ adsorption isotherms $\left(-196^{\circ} \mathrm{C}\right)$ of the FSP-made nanoparticles. ................. 4-38 
Figure 4B-4. Magnetic separation of $\mathrm{SiO}_{2}-\gamma-\mathrm{Fe}_{2} \mathrm{O}_{3}$ composite nanoparticles from a suspension in water: (a) SF1 and (b) SF2 nanoparticles.

Figure 4B-5. FTIR spectrum of the FSP silica nanoparticles.

Figure 4B-6. Profiles of the SCA enzyme's loading and relative activity over the immobilization time.

Figure 4B-7. Loadings and activities of the immobilized SCA enzymes prepared under various initial enzyme concentrations in the immobilization medium.

Figure 4B-8. Effect of $\mathrm{pH}$ on the activities of free and immobilized SCA enzymes at $4{ }^{\circ} \mathrm{C} \ldots \ldots . .4-43$

Figure 4B-9. Effect of temperature on the activities of free and immobilized SCA enzymes at $\mathrm{pH}$ 10.5 .

Figure 4B-10. Thermal stability of the immobilized SCA enzymes for $\mathrm{CO}_{2}$ hydration at $50^{\circ} \mathrm{C}$.

Figure 4B-11. Thermal stability of immobilized ACA1 enzymes for $\mathrm{CO}_{2}$ hydration at $50^{\circ} \mathrm{C}$.

Figure 4B-12. Relative activity of immobilized SCA enzymes in $\mathrm{KHCO}_{3} / \mathrm{K}_{2} \mathrm{CO}_{3}$ solution in the presence of $\mathrm{SO}_{4}{ }^{2-}, \mathrm{NO}_{3}{ }^{-}$, and $\mathrm{Cl}^{-}$at $50^{\circ} \mathrm{C}$ for 30 days.

Figure 4B-13. Relative activity of immobilized ACA1 enzymes in $\mathrm{KHCO}_{3} / \mathrm{K}_{2} \mathrm{CO}_{3}$ solution in the presence of $\mathrm{SO}_{4}{ }^{2-}, \mathrm{NO}_{3}{ }^{-}$, and $\mathrm{Cl}^{-}$at $50^{\circ} \mathrm{C}$ for 60 days.

Figure 5-1. Schematic of the modified IVCAP for combined $\mathrm{CO}_{2}$ capture and $\mathrm{SO}_{2}$ removal....5-1

Figure 5-2. Predicted equilibrium concentrations of carbonaceous and $\mathrm{H}^{+}$species in a $20 \mathrm{wt} \% \mathrm{PC}$ solution vs. $\mathrm{CO}_{2}$ partial pressure at $25^{\circ} \mathrm{C}$.

Figure 5-3. Schematic diagram of an experimental setup for measuring the reaction rate and equilibrium liquid concentration for the conversion of $\mathrm{K}_{2} \mathrm{CO}_{3}$ into $\mathrm{KHCO}_{3}$ using a highpressure $\mathrm{CO}_{2}$ gas stream.

Figure 5-4. Photographs of a Parr autoclave reactor used for PC solution treatment under highpressure $\mathrm{CO}_{2}$ gas.

Figure 5-5. Rates of $\mathrm{CO}_{2}$ absorption into $20 \mathrm{wt} \% \mathrm{PC}$ solution at room temperature and elevated $\mathrm{CO}_{2}$ pressures.

Figure 5-6. XRD patterns of precipitate particles from the $20 \%$ PC- $40 \%$ CTB- $0.1 \mathrm{M} \mathrm{K}_{2} \mathrm{SO}_{4}$ $+0.1 \mathrm{M} \mathrm{Ca}(\mathrm{OH})_{2}$ experiment..

Figure 5-7. XRD patterns of precipitates reclaimed in 0.2 M PC solutions.

Figure 5-8. XRD patterns of precipitates reclaimed from the $0.2 \mathrm{M}$ PC solution containing 300 $\mathrm{mg} / \mathrm{L} \mathrm{CA}$ enzyme or $1 \mathrm{wt} \% \mathrm{KVO}_{3}$.

Figure 5-9. Modified process concept I for combined $\mathrm{SO}_{2}$ removal and $\mathrm{CO}_{2}$ capture in the IVCAP. 
Figure 5-10. Modified process concept (II) for the combined $\mathrm{SO}_{2}$ removal and $\mathrm{CO}_{2}$ capture in the IVCAP. 5-14

Figure 6-1. Process flow diagram of the IVCAP for $\mathrm{CO}_{2}$ capture ...................................... 6-2

Figure 6-2. Process flow diagram of the power plant boiler and flue gas cleaning system....... 6-3

Figure 6-3. Process flow diagram of the power plant subcritical steam cycle. ........................ 6-4

Figure 6-4. Mass and energy balance of the reference pulverized coal-fired power plant. ......... 6-7

Figure 6-5. Mass and energy balances of the MEA process................................................ 6-8

Figure 6-6. Partial pressures of $\mathrm{CO}_{2}$ and water vapor over a $20 \mathrm{wt} \% \mathrm{~K}_{2} \mathrm{CO}_{3}$-equivalent PC solution predicted by CHEMCAD .................................................................... 6-10

Figure 6-7. Mass and energy balances of the IVCAP under a baseline condition................... 6-11

Figure 6-8. Electricity losses at different stripping pressures. (Flue gas: $130^{\circ} \mathrm{F}, 13.9 \% \mathrm{CO}_{2}$; solvent: 20 wt\% PC solution, $1 \% \mathrm{CO}_{2}$ lean loading; $\mathrm{L} / \mathrm{G}$ ratio: $1.2(\mathrm{~L} / \mathrm{G})_{\min }$; stripper

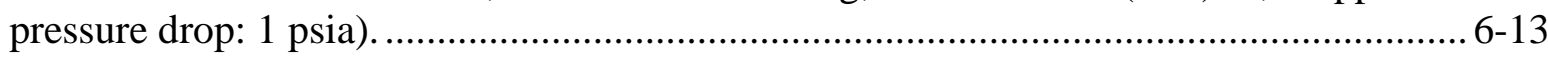

Figure 6-9. L/G ratios at different $\mathrm{CO}_{2}$ loadings (Flue gas: $130^{\circ} \mathrm{F}, 13.9 \% \mathrm{CO}_{2}$; Solvent: $20 \mathrm{wt} \%$ PC solution; L/G ratio: $1.2(\mathrm{~L} / \mathrm{G})_{\min }$; stripping pressure: 3 psia; stripper pressure drop: 1 psia).

Figure 6-10. Steam extraction losses at different $\mathrm{CO}_{2}$ loadings (Flue gas: $130^{\circ} \mathrm{F}, 13.9 \% \mathrm{CO}_{2}$; Solvent: $20 \mathrm{wt} \%$ PC solution; L/G ratio: $1.2(\mathrm{~L} / \mathrm{G})_{\min }$; Stripping pressure: 3 psia; Stripper pressure drop: 1 psia). 6-14

Figure 6-11. Steam extraction losses at different $\mathrm{L} / \mathrm{G}$ ratios (Flue Gas: $130^{\circ} \mathrm{F}, 13.9 \% \mathrm{CO}_{2}$; solvent: $20 \mathrm{wt} \%$ PC solution $\mathrm{K}_{2} \mathrm{CO}_{3}, 1 \% \mathrm{CO}_{2}$ lean loading).

Figure 6-12. Height of packed bed vs. dosage of CA enzyme (the packing with specific surface area of $350 \mathrm{~m}^{2} / \mathrm{m}^{3}$ was assumed in the calculation).

Figure 6-13. Sensitivity of costs of $\mathrm{CO}_{2}$ capture to the stripping pressure (Flue gas: $130^{\circ} \mathrm{F}, 13.9 \%$ $\mathrm{CO}_{2}$; solvent: $20 \mathrm{wt} \% \mathrm{PC}$; $1 \% \mathrm{CO}_{2}$ lean loading; L/G ratio: $1.2(\mathrm{~L} / \mathrm{G})_{\min }$; stripper pressure drop: 1 psia). 6-30

Figure 6-14. Sensitivity of costs of $\mathrm{CO}_{2}$ capture to $\mathrm{CO}_{2}$ loading in lean solution (Flue gas: $130^{\circ} \mathrm{F}$, $13.9 \% \mathrm{CO}_{2}$; Solvent: $20 \mathrm{wt} \% \mathrm{PC}$; L/G ratio: $1.2(\mathrm{~L} / \mathrm{G})_{\min }$; stripping pressure: 3 psia; stripper pressure drop: 1 psia).

Figure 6-15. Sensitivity of costs of $\mathrm{CO}_{2}$ capture to enzyme price (Flue gas: $130^{\circ} \mathrm{F}, 13.9 \% \mathrm{CO}_{2}$; solvent: $20 \mathrm{wt} \% \mathrm{PC} ; 1 \% \mathrm{CO}_{2}$ lean loading; $\mathrm{L} / \mathrm{G}$ ratio: $1.2(\mathrm{~L} / \mathrm{G})_{\min }$; stripping pressure: 3 psia, stripper pressure drop: 1 psia). 6-32

Figure 6-16. Sensitivity of costs of $\mathrm{CO}_{2}$ capture to water vapor saturation reduction by additives (Flue gas: $130^{\circ} \mathrm{F}, 13.9 \% \mathrm{CO}_{2}$; solvent: $20 \mathrm{wt} \% \mathrm{PC} ; 1 \% \mathrm{CO}_{2}$ lean loading; $\mathrm{L} / \mathrm{G}$ ratio: 1.2 $(\mathrm{L} / \mathrm{G})_{\min }$; stripping pressure: 3 psia, stripper pressure drop: 1 psia). 6-33

Figure 6-17. Comparison of costs of $\mathrm{CO}_{2}$ capture between MEA, baseline IVCAP, IVCAP with reduced O\&M cost (increased lean $\mathrm{CO}_{2}$ loading, lower enzyme price, and reduced water 
vapor pressure), and IVCAP with reduced capital cost (less expensive absorber, desorber, compressor and vacuum pump).

Figure 7-1. Corrosion rate of carbon steel in $25 \mathrm{wt} \% \mathrm{PC}$ solution at different temperatures under

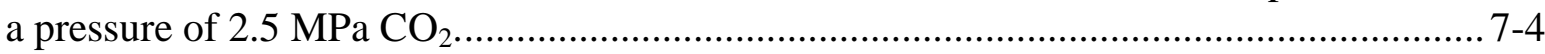

Figure 7-2. Effect of $4 \mathrm{wt} \% \mathrm{KVO}_{3}$ in the $20 \mathrm{wt} \% \mathrm{PC}$ solution with $20 \% \mathrm{CTB}$ conversion on the rates of $\mathrm{CO}_{2}$ absorption without and with the presence of the $\mathrm{CA}$ enzyme........................ 7-6

Figure 7-3. A schematic diagram of the structure of human CA enzyme II (Histidine residues (pink), hydroxide group (red), coordinating zinc ion (black)).

Figure 7-4. A schematic of use of water condensate from the IVCAP $\mathrm{CO}_{2}$-water vapor stream as boiler feed water in a coal-fired power plant.

Figure 7-5. A schematic of a forced draft degasifier. …………………………………..... 7-14

Figure 7-6. A schematic of a membrane contactor degasifier. ………………………............ 7-14

Figure 7-7. Vapor-liquid equilibrium of $\mathrm{CO}_{2}-\mathrm{K}_{2} \mathrm{CO}_{3} / \mathrm{KHCO}_{3}\left(20 \mathrm{wt} \% \mathrm{~K}_{2} \mathrm{CO}_{3}\right.$-equivalent) system (data generated using CHEMCAD software).................................................. 7-16

Figure 7-8. Solubility of bicarbonate in PC solution. ............................................................. 7-17 


\section{LIST OF TABLES}

Table 2-1. GC parameters and experimental conditions

Table 3A-1. Comparison of the experimental $E a$ and $\ln (A)$ with those reported in the literature

Table 3C-1. The obtained values of $k_{C A}$ in $20 \mathrm{wt} \% \mathrm{PC}$ solutions at 25,40 , and $50^{\circ} \mathrm{C}$.

Table 3C-2. Michaelis-Menten kinetic parameters for $\mathrm{CO}_{2}$ hydration catalyzed by the human $\mathrm{CA}$ II enzyme at $25^{\circ} \mathrm{C}$ (All buffer concentrations were maintained at $50 \mathrm{mM}$ and the ionic strength at $0.1 \mathrm{M}$ with $\mathrm{Na}_{2} \mathrm{SO}_{4}$ )

Table 3D-1. Test matrix for a long-term thermal stability study on the three CA enzymes ..... 3-29

Table 3D-2. Modeling of $\mathrm{CO}_{2}$ absorption into $20 \mathrm{wt} \% \mathrm{PC}+\mathrm{ACA} 1$ and 5M MEA solutions in a

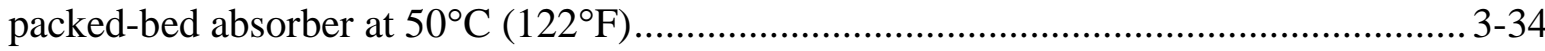

Table 3D-3. Test matrix for investigating the resistance of ACA1 to water vapor inhibitors... 3-39

Table 4A-1. Density of the $-\mathrm{NH}_{2}$ group on silanized CPG100 and resulting SCA-CPG100 activity

Table 4A-2. Activity of SCA-CPG100 prepared using the modified method. 4-12

Table 4A-3. Activities of SCA-CPG100 at different dosage levels for $p$-NPA hydrolysis ....... 4-15

Table 4A-4. Michaelis-Menten parameters of the free SCA and SCA-CPG100 for $p$-NPA hydrolysis....

Table 4A-5. Comparison of enzyme loading and activity between SCA-Eup and SCA-CPG100

Table 4A-6. Comparison of thermal stability between SCA-Eup and SCA-CPG100............. 4-18

Table 4A-7 Pore structure of AC, CPG38, CPG100, SCA-AC and SCA-CPG38.................. 4-19

Table 4A-8 Loadings and IFs of immobilized CA enzymes. .............................................. 4-19

Table 4A-9. Stability of immobilized and free CA in presence of $\mathrm{SO}_{4}{ }^{2-}, \mathrm{NO}_{3}{ }^{-}$, and $\mathrm{Cl}^{-}$anions at $50^{\circ} \mathrm{C}$

Table 4B-1. Test matrix for synthesis of silica nanoparticles

Table 4B-2. Loadings and activities of the immobilized SCA enzymes prepared at different $\mathrm{pH}$ conditions.

Table 4B-3. Enzyme loadings, kinetic parameters and IFs of the immobilized CA enzymes .. 4-43

Table 5-1. Test matrix for semi-continuous sulfate reclamation experiments..........................5-7

Table 5-2. Compositions of precipitate samples reclaimed from 0.2 M PC solution............... 5-10

Table 5-3. Solubility of pure chemicals in water, g/100 water ..........................................5-13

Table 6-1. Main operating conditions of the $528 \mathrm{MWe}$ (gross) power plant and the IVCAP, MEA assumed in process simulations

Table 6-2. Electricity use and output in the reference pulverized coal-fired plant with either the

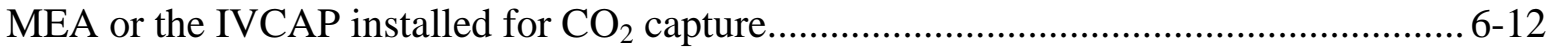

Table 6-3. Baseline operating conditions used in the absorber sizing calculation .................. 6-16 Table 6-4. Height of the packed-bed absorber with packing of 3 different specific surface areas (the CA concentration was assumed to be $3 \mathrm{~g} / \mathrm{L}$ in the calculation)..... 
Table 6-5. Height of packed bed using the PC20-20 vs. PC20-15 as the feed solution (the packing with surface area of $350 \mathrm{~m}^{2} / \mathrm{m}^{3}$ and the enzyme concentration of $3 \mathrm{~g} / \mathrm{L}$ were assumed)

Table 6-6. Baseline operating conditions used in the stripper sizing calculation

Table 6-7. Height and diameter of the packed-bed stripper under the baseline IVCAP condition (packing with surface area of $350 \mathrm{~m}^{2} / \mathrm{m}^{3}$ and void fraction of 0.98 )

Table 6-8. Height and diameter of the packed-bed stripper under various stripping pressure conditions (the packing with surface area of $350 \mathrm{~m}^{2} / \mathrm{m}^{3}$ and void fraction of 0.98 )

Table 6-9. Baseline operating conditions used in the steam extraction line sizing calculation. 6-22

Table 6-10. Pressure and temperature drops through the extraction steam lines to the stripper and reboiler under the baseline IVCAP condition (a pipe length of $50 \mathrm{~m}$ was assumed; 5 gate valves, 5 ball valves, 5 standard $90^{\circ}$ elbows, and 5 standard $45^{\circ}$ elbows were assumed in the piping system) 6-23

Table 6-11. Items of capital cost estimation.......................................6-24

Table 6-12. Process units and scaling parameters ................................................................ 6-24

Table 6-13. Estimation of the fixed O\&M cost .............................................................. 6-25

Table 6-14. Unit prices of consumables used for $\mathrm{CO}_{2}$ capture .......................................... 6-25

Table 6-15. Financial assumptions for the cost estimation................................................. 6-26

Table 6-16. Capital and O\&M costs for the IVCAP and MEA installed in a $528 \mathrm{MWe}$ (gross)

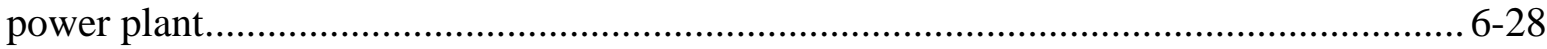

Table 6-17. Comparison of cost performance between IVCAP and MEA............................ 6-29

Table 7-1. Corrosion rates of different materials at various equipment sites .......................... 7-2

Table 7-2. Corrosion rates of carbon steel in $\mathrm{K}_{2} \mathrm{CO}_{3} / \mathrm{KHCO}_{3}$ solutions with and without using different inhibitors ....................................................................................... $7-5$

Table 7-3. Trace elements in FGD wastewater................................................................. 7-8

Table 7-4. Effect of heavy metals on the activity of the bovine CA II enzyme ....................... 7-9

Table 7-5. Calculated values of $\mathrm{pH}$ and alkalinity $\left(\left[\mathrm{CO}_{3}{ }^{2-}\right]+\left[\mathrm{HCO}_{3}{ }^{-}\right]\right)$of water condensate from

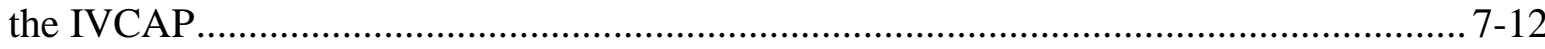

Table 7-6. Chemistry limits for boiler feed water....................................................... 7-13 


\section{ABBREVIATIONS AND NOMENCLATURE}

ABBREVIATIONS

A\&S

ABMA

$\mathrm{AC}$

ACA1, ACA2

APAVE

ATP

$\mathrm{Ba}_{2} \mathrm{CO}_{3}$

$\mathrm{BaCl}_{2}$

BCA1

BEC

BET

BJH desorption

Btu/lb

CA

$\mathrm{Ca}(\mathrm{OH})_{2}$

$\mathrm{CA}-\mathrm{AC}$

$\mathrm{CaCO}_{3}$

CA-CPG

CA-Eup

CA-SF

CA-SN

$\mathrm{CaSO}_{4} \cdot 2 \mathrm{H}_{2} \mathrm{O}$

CA-SZ

CHEMCAD

$-\mathrm{CHO}$

CLM

$\mathrm{CO}_{2}$

CPG

CSTR

CTB

DEG

DI water

DMF

DOE

EG

EM

EPRI

ESP

EWs

$\mathrm{Fe}_{2} \mathrm{O}_{3}$

$\mathrm{FeCO}_{3}$

FGD
Administrative \& Support

American Boiler Manufacturers Association

Activated carbon

Technical-grade CA enzymes \#1 and \#2 provided by enzyme manufacturing company A

Association of Electrical and Steam Unit Owners

2-aminothiophenol

Barium carbonate

Barium chloride

A CA enzyme provided by a university

Bare erected cost

Brunauer, Emmett and Teller theory

Barrett-Joyner-Halenda desorption method

Btu per pound

Carbonic anhydrase

Calcium hydroxide

CA enzyme immobilized onto AC support

Limestone

CA enzyme Immobilized onto CPG support

CA enzyme immobilized onto Eupergit $\mathrm{C}$ support

CA enzyme immobilized onto SF support

CA enzyme Immobilized onto SN support

Gypsum

CA enzyme immobilized onto SZ support

A process design/simulation software package

Aldehyde group

Contained-liquid membrane

Carbon dioxide

Controlled-pore glass

Continuous stirring tank reactor

Carbonate to bicarbonate

Diethylene glycol

Deionized water

Dimethylformamide

Department of Energy

Ethylene glycol

Enzyme

Electric Power Research Institute

Electrostatic precipitator

Equivalent weights

Maghemite

Ferrous carbonate

Flue gas desulphurization 


\begin{tabular}{|c|c|}
\hline FSP & Flame spray pyrolysis \\
\hline FTIR & Fourier Transform Infrared \\
\hline $\mathrm{GC}$ & Gas chromatography \\
\hline $\mathrm{H}_{2}$ & Hydrogen \\
\hline HA & Formic acid \\
\hline $\mathrm{HAC}$ & Acetic acid \\
\hline $\mathrm{H}_{4} \mathrm{BNa}$ & Sodium borohydride \\
\hline $\mathrm{HCl}$ & Hydrogen chloride \\
\hline HEDP & 1-(hydroxyethylidene)-1,1-diphosphonic acid \\
\hline $\mathrm{HF}$ & Hydrogen fluoride \\
\hline HHV & Higher heating value \\
\hline His & Histidine residues \\
\hline HMPTAM & Hexamethyl phosphoric triamide \\
\hline HMT & Humidity and temperature transducer \\
\hline $\mathrm{HNO}_{3}$ & Nitric acid \\
\hline HP & High pressure \\
\hline ID & Internal diameter \\
\hline IECM & Integrated Environmental Control Model \\
\hline IF & Immobilization factor \\
\hline IP & Intermediate pressure \\
\hline IVCAP & Integrated Vacuum Carbonate Absorption Process \\
\hline $\mathrm{K}_{2} \mathrm{Ca}\left(\mathrm{SO}_{4}\right)_{2} \cdot \mathrm{H}_{2} \mathrm{O}$ & Syngenite \\
\hline $\mathrm{K}_{2} \mathrm{CO}_{3}, \mathrm{PC}$ & Potassium carbonate \\
\hline $\mathrm{K}_{2} \mathrm{Cr}_{2} \mathrm{O}_{7}$ & Potassium dichromate \\
\hline $\mathrm{K}_{2} \mathrm{SO}_{4}$ & Potassium sulfate \\
\hline KA & Potassium formate \\
\hline KAc & Potassium acetate \\
\hline $\mathrm{KCl}$ & Potassium chloride \\
\hline $\mathrm{KH}_{2} \mathrm{PO}_{4}$ & Potassium dihydrogen phosphate \\
\hline $\mathrm{KHCO}_{3}$ & Potassium bicarbonate \\
\hline $\mathrm{KOH}$ & Potassium hydroxide \\
\hline $\mathrm{KVO}_{3}$ & Potassium Metavanadate \\
\hline $\mathrm{L} / \mathrm{G}$ & Liquid-to-gas ratio \\
\hline$(\mathrm{L} / \mathrm{G})_{\min }$ & Minimum liquid-to-gas ratio \\
\hline LCOE & Levelized cost of electricity \\
\hline LFOS & Limestone Forced Oxidation Scrubbing \\
\hline $\mathrm{LiCl}$ & Lithium Chloride \\
\hline LP & Lower pressure \\
\hline LPM & Liter per minute \\
\hline LSCM & Laser Scanning Confocal Microscope \\
\hline LSFO & Limestone slurry forced oxidation \\
\hline M & Molar per liter \\
\hline MEA & Monoethanolamine \\
\hline MF & Mass flow meter \\
\hline ML\&M & Annual maintenance labor and material \\
\hline $\mathrm{MW}_{\mathrm{e}}$ & Megawatt of electricity \\
\hline
\end{tabular}




\begin{tabular}{|c|c|}
\hline $\mathrm{MW}_{\text {th }}$ & Megawatt of thermal \\
\hline $\mathrm{N}=\mathrm{CH}$ & Schiff bond \\
\hline $\mathrm{N}_{2}$ & Nitrogen \\
\hline $\mathrm{N}_{2} \mathrm{O}$ & Nitrous oxide \\
\hline $\mathrm{Na}_{2} \mathrm{CO}_{3}$ & Sodium carbonate \\
\hline $\mathrm{Na}_{2} \mathrm{CrO}_{4}$ & Sodium chromate \\
\hline $\mathrm{Na}_{2} \mathrm{HPO}_{4}$ & Disodium hydrogen phosphate \\
\hline $\mathrm{Na}_{2} \mathrm{SO}_{3}$ & Sodium sulfite \\
\hline $\mathrm{NaCl}$ & Sodium chloride \\
\hline $\mathrm{NaOH}$ & Sodium hydroxide \\
\hline NETL & National Energy Technology laboratory \\
\hline NG & Natural gas \\
\hline$\left(\mathrm{NH}_{4}\right)_{2} \mathrm{SO}_{4}$ & Ammonium sulfate \\
\hline$-\mathrm{NH}_{2}$ & Amino-group \\
\hline $\mathrm{NO}_{\mathrm{x}}$ & Oxides of Nitrogen \\
\hline NRTL & Non-Randomness Two-Liquid \\
\hline $\mathrm{O} \& \mathrm{M}$ & Operating \& maintenance \\
\hline OL & Cost of operating labor \\
\hline OJ & Operating job \\
\hline OS & Daily operating shift \\
\hline $\mathrm{O}_{2}$ & Oxygen \\
\hline PC20-15 & $\begin{array}{l}20 \mathrm{wt} \%\left(\mathrm{~K}_{2} \mathrm{CO}_{3} \text {-equivalent) } \mathrm{K}_{2} \mathrm{CO}_{3} / \mathrm{KHCO}_{3} \text { solution with }\right. \\
15 \% \mathrm{CTB} \text { conversation }\end{array}$ \\
\hline PC20-20 & $\begin{array}{l}20 \mathrm{wt} \%\left(\mathrm{~K}_{2} \mathrm{CO}_{3} \text {-equivalent }\right) \mathrm{K}_{2} \mathrm{CO}_{3} / \mathrm{KHCO}_{3} \text { solution with } \\
20 \% \mathrm{CTB} \text { conversation }\end{array}$ \\
\hline PC20-40 & $\begin{array}{l}20 \mathrm{wt} \%\left(\mathrm{~K}_{2} \mathrm{CO}_{3} \text {-equivalent) } \mathrm{K}_{2} \mathrm{CO}_{3} / \mathrm{KHCO}_{3} \text { solution with }\right. \\
40 \% \text { CTB conversation }\end{array}$ \\
\hline PFD & Process flow diagram \\
\hline PIPE & Pipe Sizing and Rating \\
\hline$p$-NP & $p$-nitrophenol \\
\hline$p$-NPA & $p$-nitrophenyl acetate \\
\hline ppmv & Parts per million by volume \\
\hline psi & Pounds per square inch \\
\hline psia & Pounds per square inch pressure absolute \\
\hline PZ & Piperazine \\
\hline$R \& D$ & Research and development \\
\hline RA & Relative activity \\
\hline $\mathrm{RH}$ & Relative humidity \\
\hline $\mathrm{rpm}$ & Revolution per minute \\
\hline SCA & A CA enzyme purchased from Sigma-Aldrich Co. \\
\hline SCC & Stress corrosion cracking \\
\hline SCDS & Rigorous multi-stage vapor-liquid equilibrium mod \\
\hline SCR & Selective catalytic reduction \\
\hline SEM & Scanning Electron Microscopy \\
\hline $\mathrm{SF}$ & $\mathrm{SiO}_{2}-\mathrm{Fe}_{2} \mathrm{O}_{3}$ composite nanoparticles \\
\hline $\mathrm{SiO}_{2}$ & Silica \\
\hline
\end{tabular}




\begin{tabular}{|c|c|}
\hline $\mathrm{Si}-\mathrm{OH}$ & Silanol \\
\hline SN & Silica nanoparticles \\
\hline $\mathrm{SO}_{2}$ & Sulfur dioxide \\
\hline SRK & Soave-Redlich-Kwong \\
\hline STR & Stirred tank reactor \\
\hline SZ & $\mathrm{SiO}_{2}-\mathrm{ZrO}_{2}$ composite nanoparticles \\
\hline TCD & Thermal conductivity detector \\
\hline TCR & Total capital requirement \\
\hline TEG & Triethylene glycol \\
\hline TEOS & Tetraethylorthosilicate \\
\hline TPC & Total plant cost \\
\hline ton & Short ton (2,000 pounds) \\
\hline tonne & Long ton (1,000 kilograms) \\
\hline $\mathrm{V}_{2} \mathrm{O}_{5}$ & Vanadium pentoxide \\
\hline VLE & Vapor-liquid equilibrium \\
\hline wt & Weight fraction \\
\hline XRD & X-ray diffraction \\
\hline $\mathrm{ZrO}_{2}$ & Zirconia \\
\hline
\end{tabular}

\section{NOMENCLATURE}

$a_{e}$
$A$
$A_{\text {cross }}$
$b_{\text {ion }}$
$B E C_{\text {IVCAP }}$
$B E C_{M E A}$
$c_{0}$
$C^{*}$
$C^{b}$
$c_{G}$
$c_{G, 0}$
$[C A]$
$C s$
$D_{C O, P C}$
$D_{C O 2, \text { Water }}$
$E$
$E a$
$E_{C A}$
$E_{C A+P C}$
$E_{c a t}$
$E_{c a t+P C}$
$E_{P C}$
$G$
$h_{G, 0}$
$h_{G}$

Effective interfacial surface area, $m^{2}$

Interfacial area between the gas- and liquid-phase, $m^{2}$

Cross area of each absorber, $m^{2}$

Ion contribution parameter in Eq. (3A-6), $\mathrm{m}^{3} / \mathrm{kmol}$

$\mathrm{BEC}$ of an individual unit in IVCAP process

$\mathrm{BEC}$ of an individual unit in MEA process

Original concentration of potassium carbonate, $\mathrm{kmol} / \mathrm{m}^{3}$

Physical solubility of $\mathrm{CO}_{2}$ in liquid phase, $\mathrm{kmol} / \mathrm{m}^{3}$

Concentration of unreacted $\mathrm{CO}_{2}$ gas in the bulk liquid, $\mathrm{kmol} / \mathrm{m}^{3}$

Gas solubility in salt solution, $\mathrm{M} / \mathrm{Pa}$

Gas solubility in water, $\mathrm{M} / \mathrm{Pa}$

Concentration of CA enzyme, $M$

Capacity parameter of packed-bed column

Diffusivity of $\mathrm{CO}_{2}$ in PC solution, $\mathrm{m}^{2} / \mathrm{s}$

Diffusivity of $\mathrm{CO}_{2}$ in water, $\mathrm{m}^{2} / \mathrm{s}$

Enhancement factor

Experimental activation energy, $\mathrm{KJ} / \mathrm{mol}$

Enhancement factor for CA enzyme

Overall enhancement factor for PC solution with CA enzyme

Enhancement factor for a catalyst

Overall enhancement factor for PC solution with a catalyst

Overall enhancement factor for PC solution without a catalyst

Gas volumetric flow rate, $\mathrm{L} / \mathrm{hr}$

Gas-specific parameter in Schumpe's correlation at $25^{\circ} \mathrm{C}, \mathrm{m}^{3} / \mathrm{kmol}$

Gas-specific parameter in Schumpe's correlation, $\mathrm{m}^{3} / \mathrm{kmol}$ 


\begin{tabular}{|c|c|}
\hline $\begin{array}{l}h_{i} \\
h_{T}\end{array}$ & $\begin{array}{l}\text { Specific parameter of species i in Schumpe's correlation, } \mathrm{m}^{3} / \mathrm{kmol} \\
\text { Gas-specific temperature parameter in Schumpe's correlation, } \\
\mathrm{m}^{3} / \mathrm{kmol} \cdot \mathrm{K}\end{array}$ \\
\hline$H$ & Reciprocal of $\mathrm{He}$ \\
\hline $\mathrm{Ha}$ & Hatta number \\
\hline $\mathrm{He}$ & Henry's law coefficient of $\mathrm{CO}_{2}$ in PC solution, $\mathrm{kmol} / \mathrm{kPa} \cdot \mathrm{m}^{3}$ \\
\hline$I$ & Total ionic strength, $\mathrm{kmol} / \mathrm{m}^{3}$ \\
\hline$I_{i o n}$ & Individual ionic strength, $\mathrm{kmol} / \mathrm{m}^{3}$ \\
\hline$J_{i}$ & Rate of $\mathrm{CO}_{2}$ absorption, $\mathrm{mol} / \mathrm{m}^{2} \cdot \mathrm{s}$ \\
\hline$K_{1}$ & Equilibrium constant for Reaction (3A-R2), $\mathrm{kmol} / \mathrm{m}^{3}$ \\
\hline$K_{2}$ & Equilibrium constant for Reaction (3A-R3), $\mathrm{kmol} / \mathrm{m}^{3}$ \\
\hline$K_{G}$ & Overall gas-phase mass transfer coefficient, $\mathrm{kmol} / \mathrm{m}^{2} \cdot \mathrm{kpa} \cdot \mathrm{s}$ \\
\hline$K_{L}$ & Overall liquid-phase mass transfer coefficient, $\mathrm{m} / \mathrm{s}$ \\
\hline$K_{W}$ & Dissociation constant of water, $\mathrm{kmol}^{2} / \mathrm{m}^{6}$ \\
\hline$K_{m}$ & Michaelis constant, $M$ \\
\hline$K_{n}$ & Nucleation rate constant \\
\hline$K_{g}$ & Crystal growth rate constant \\
\hline$k_{11}^{\circ}$ & Forward reaction rate constant of Reaction (6-R1) \\
\hline$k_{12}$ & Backward reaction rate constant of Reaction (6-R1) \\
\hline$k_{21}$ & Forward reaction rate constant of Reaction (6-R2) \\
\hline$k_{22}$ & Backward reaction rate constant of Reaction (6-R2) \\
\hline$k_{C A}$ & Kinetic rate constant for CA enzyme $\left(k_{c a t} / K_{m}\right), M^{-1} s^{-1}$ \\
\hline$k_{\text {cat }}$ & Turnover number, $s^{-1}$ \\
\hline$k_{\mathrm{H}_{2} \mathrm{O}}$ & Rate constant for Reaction (3A-R2), $s^{-1}$ \\
\hline$k_{O H}$ & Rate constant for Reaction (3A-R4), $\mathrm{m}^{3} / \mathrm{kmol} \cdot \mathrm{s}$ \\
\hline$k_{\mathrm{OH}-}^{\infty}$ & Rate constant for Reaction (3A-R4) at infinite dilution, $\mathrm{m}^{3} / \mathrm{kmol} \cdot \mathrm{s}$ \\
\hline$k_{o v}$ & Overall first-order rate constant, $s^{-1}$ \\
\hline$k_{L}$ & Liquid-phase mass transfer coefficient, $\mathrm{m} / \mathrm{s}$ \\
\hline$k_{G}$ & Gas-phase mass transfer coefficient, $\mathrm{kmol} / \mathrm{m}^{2} \cdot \mathrm{kpa} \cdot \mathrm{s}$ \\
\hline$L$ & Volumetric flow rate of liquid, $\mathrm{m}^{3} / \mathrm{hr}$ \\
\hline$M_{\mathrm{K}^{2} \mathrm{CO}_{3}}$ & Molecular weight of $\mathrm{K}_{2} \mathrm{CO}_{3}, \mathrm{~g} / \mathrm{mol}$ \\
\hline$\left[\mathrm{OH}^{-}\right]$ & Concentration of hydroxide ions, $\mathrm{kmol} / \mathrm{m}^{3}$ \\
\hline $\mathrm{P}_{\mathrm{CO}_{2}}$ & Partial pressures of $\mathrm{CO}_{2}, p s i a$ \\
\hline$P_{\mathrm{CO} 2,0}$ & Initial partial pressure of $\mathrm{CO}_{2}, \mathrm{kPa}$ \\
\hline$P_{C_{2, t}}$ & Partial pressure of $\mathrm{CO}_{2}$ at the time $\mathrm{t}, \mathrm{kPa}$ \\
\hline$P_{\text {ini,CO2 }}$ & Initial equilibrium pressure of $\mathrm{CO}_{2}, p s i a$ \\
\hline$P_{i n i}$ & Initial equilibrium pressure, $p s i a$ \\
\hline$P_{t}$ & Total pressure, psia \\
\hline$P_{W}$ & Water vapor partial pressure, $p$ sia \\
\hline$Q_{\text {reaction }}$ & Reaction heat (for desorption), $\mathrm{kJ} / \mathrm{kg}$ \\
\hline$Q_{\text {sensible }}$ & Sensible heat (for heating liquid), $k J / k g$ \\
\hline$Q_{\text {stripping }}$ & Stripping heat (for water vaporization), $k J / k g$ \\
\hline$R_{\text {crystal }}$ & Rate of crystal growth \\
\hline$R_{\text {nucleation }}$ & Rate of nucleation \\
\hline$R_{\text {gas }}$ & Universal gas constant, $\mathrm{m}^{3} \mathrm{kPa} / \mathrm{K} \cdot \mathrm{kmol}$ \\
\hline$S_{I V C A P}$ & Cost scaling factor for IVCAP process \\
\hline
\end{tabular}




\begin{tabular}{|c|c|}
\hline$S_{M E A}$ & Cost scaling factor for MEA process \\
\hline$t$ & Time, $s$ \\
\hline$T$ & Temperature, $K$ \\
\hline$\left(\text { ton } \mathrm{CO}_{2} / \mathrm{kWh}\right)_{\text {capture }}$ & Amount of $\mathrm{CO}_{2}$ captured per net $\mathrm{kWh}$ generation \\
\hline$\left(\text { ton } \mathrm{CO}_{2} / \mathrm{kWh}\right)_{\text {reference, emi }}$ & $\mathrm{CO}_{2}$ emissions per net $\mathrm{kWh}$ generation without $\mathrm{CO}_{2}$ capture \\
\hline$\left(\text { ton } \mathrm{CO}_{2} / \mathrm{kWh}\right)_{\text {capture, emi }}$ & $\mathrm{CO}_{2}$ emissions per net $\mathrm{kWh}$ generation with $\mathrm{CO}_{2}$ capture \\
\hline$u_{G}$ & Operating gas velocity, $\mathrm{m} / \mathrm{s}$ \\
\hline$u_{G}$, & Flooding gas velocity, $\mathrm{m} / \mathrm{s}$ \\
\hline$V_{G}$ & Volume of gas,$m^{3}$ \\
\hline$V_{L}$ & Volume of liquid, $m^{3}$ \\
\hline$V_{M}$ & Molar volume of inert gas \\
\hline$x_{1}$ & CTB conversion level in fresh PC \\
\hline$x^{*}$ & $\begin{array}{l}\mathrm{CTB} \text { conversion level in solution in equilibrium with inlet } \mathrm{CO}_{2} \text { partial } \\
\text { pressure }\end{array}$ \\
\hline$Y_{1}$ & Molar ratio of $\mathrm{CO}_{2}$ to inert gas at the absorber bottom \\
\hline$Y_{2}$ & Molar ratio of $\mathrm{CO}_{2}$ to inert gas at the absorber top \\
\hline$(\$ / k W h)_{\text {capture }}$ & LCOE of power plant with $\mathrm{CO}_{2}$ capture \\
\hline$(\$ / k W h)_{\text {reference }}$ & LCOE of power plant without $\mathrm{CO}_{2}$ capture \\
\hline$\mu_{\text {Water }}$ & Dynamic viscosity of water, $\mathrm{kg} / \mathrm{m} \cdot \mathrm{s}$ \\
\hline$\mu_{P C}$ & Dynamic viscosity of PC solution, $\mathrm{kg} / \mathrm{m} \cdot \mathrm{s}$ \\
\hline$\rho_{G}$ & Gas density, $\mathrm{kg} / \mathrm{m}^{3}$ \\
\hline$\rho_{L}$ & Liquid density, $\mathrm{kg} / \mathrm{m}^{3}$ \\
\hline
\end{tabular}




\section{EXECUTIVE SUMMARY}

This project was aimed at obtaining process engineering and scale-up data through a laboratoryscale study necessary to determine the technical and economic feasibility of a patented postcombustion $\mathrm{CO}_{2}$ capture process-the Integrated Vacuum Carbonate Absorption Process (IVCAP). Unique features of the IVCAP include its ability to be fully-integrated with the power plant's steam cycle and the potential for combined sulfur dioxide $\left(\mathrm{SO}_{2}\right)$ removal and $\mathrm{CO}_{2}$ capture. Objectives of the project included: 1) performing an experimental study to test the proof-of-concept of the IVCAP process; 2) examining and identifying effective catalysts to accelerate the $\mathrm{CO}_{2}$ absorption rate and effective additives to reduce the stripping heat associated with water vaporization, and 3) evaluating a modified IVCAP process concept for combined $\mathrm{SO}_{2}$ and $\mathrm{CO}_{2}$ removal. The major work activities and the results of these studies are summarized as follows:

\section{Measurement of vapor-liquid equilibrium for $\mathrm{K}_{2} \mathrm{CO}_{3}$ solutions and screening of additives. \\ Using an additive to suppress the saturation pressure of water vapor over the potassium} carbonate (PC) solution used as a solvent in the IVCAP can reduce the heat use associated with water vaporization during $\mathrm{CO}_{2}$ stripping. A screening study identified potassium acetate (KAc), potassium formate (KA), and ethylene glycol (EG) as effective additives. Adding $20 \mathrm{wt} \%$ of the additives reduced the water vapor pressure by about $20 \%$ at 50 and $70^{\circ} \mathrm{C}\left(122\right.$ and $\left.158^{\circ} \mathrm{F}\right)$.

\section{Study of $\mathrm{CO}_{2}$ absorption kinetics and the role of catalysts to accelerate $\mathrm{CO}_{2}$ absorption.}

The carbonic anhydrase (CA) enzyme was identified as the most effective catalyst for enhancing $\mathrm{CO}_{2}$ absorption into the PC solution. The $\mathrm{CO}_{2}$ absorption rate into the $20 \mathrm{wt} \% \mathrm{PC}$ solution with $20 \%$ carbonate-to-bicarbonate $(\mathrm{CTB})$ conversion $\left(\mathrm{C}_{2}\right.$-lean solution) at 300 $\mathrm{mg} / \mathrm{L}$ ACA1 dosage, as measured in a stirred tank reactor (STR) apparatus, was several times lower than $5 \mathrm{M}$ monoethanolamine (MEA) of $0.2 \mathrm{~mol} / \mathrm{mol} \mathrm{CO}_{2}$ loading at $50^{\circ} \mathrm{C}\left(122^{\circ} \mathrm{F}\right)$, but the absorption rate into the $20 \mathrm{wt} \% \mathrm{PC}$ solution with $40 \% \mathrm{CTB}$ conversion $\left(\mathrm{CO}_{2}\right.$ rich) at the same ACA1 enzyme dosage was comparable to the $5 \mathrm{M}$ MEA of $0.45 \mathrm{~mol} / \mathrm{mol} \mathrm{CO}_{2}$ loading. Modeling predictions suggested that in a packed-bed column, where gas diffusion resistance is significant for fast reactions, the difference between the $\mathrm{CO}_{2}$ absorption rates into the MEA and PC+CA enzyme become less, especially when the $\mathrm{CO}_{2}$ loading of the solutions is high.

The ACA1 enzyme had satisfactory stability at $25^{\circ} \mathrm{C}$ (20\% activity loss after 6 months), but not at temperatures above $40^{\circ} \mathrm{C} / 104^{\circ} \mathrm{F}$ (at least $73 \%$ activity loss). The ACA2 enzyme (a thermophilic CA enzyme provided by enzyme-manufacturing company A) demonstrated excellent stability at $40^{\circ} \mathrm{C}\left(104^{\circ} \mathrm{F}\right)$; losing only $15 \%$ of its initial activity after 6 months. However, at $50^{\circ} \mathrm{C}\left(122^{\circ} \mathrm{F}\right)$, the ACA2 enzyme had a half-life of about two months. Both enzymes demonstrated excellent chemical stability against the most abundant flue gas impurities.

\section{Development of immobilized CA enzymes.}

Covalent bonding methods were developed to immobilize the CA enzymes (ACA1 and SCA from Sigma Aldrich) onto micron-sized, porous controlled pore glass (CPG) and activated carbon (AC) support materials. All of the immobilized CA enzymes exhibited significantly improved thermal stability. They retained 62 to $92 \%$ of their initial activities after 90 days at $50^{\circ} \mathrm{C}\left(122^{\circ} \mathrm{F}\right)$, compared to about $33 \%$ activity retention for their free counterparts. The 
immobilization also improved the chemical resistance of the CA enzymes to concentrations of sulfate, nitrate, and chloride impurities entrained in coal combustion flue gas.

To minimize the $\mathrm{CO}_{2}$ diffusion resistance in porous support materials and improve the activity of immobilized enzyme, a new class of nano-sized $(<100 \mathrm{~nm})$ support/carrier particles, including silica $(\mathrm{SN}), \mathrm{SiO}_{2}-\mathrm{ZrO}_{2}(\mathrm{SZ})$, and $\mathrm{SiO}_{2}-\mathrm{Fe}_{2} \mathrm{O}_{3}(\mathrm{SF})$, were synthesized by a flame spray pyrolysis (FSP) method. The immobilized enzymes maintained high activities at $\mathrm{pH}$ conditions typical of the IVCAP. Compared to the porous support materials, the FSP nanoparticles provided higher enzyme loading, higher activity, and better thermal stability.

\section{Evaluation of combined $\mathrm{SO}_{2}$ removal and $\mathrm{CO}_{2}$ capture in IVCAP.}

Results of semi-continuous tests for precipitating $\mathrm{CaSO}_{4}$ using hydrated lime and a highpressure (about 34 atm/500 psia) $\mathrm{CO}_{2}$ gas suggested that further modifications could improve the economic performance of $\mathrm{SO}_{2}$ removal in the IVCAP. One option would be to decouple the $\mathrm{SO}_{2}$ scrubbing and the $\mathrm{CO}_{2}$ absorption and use a different scrubbing $\mathrm{PC}$ solution with a low concentration $(\leq 0.2 \mathrm{M})$ and high CTB conversion level to obtain a high concentration ratio of $\mathrm{SO}_{4}{ }^{2-} / \mathrm{CO}_{3}{ }^{2}$. The other option would be to precipitate $\mathrm{K}_{2} \mathrm{SO}_{4}$ directly from the $\mathrm{PC}$ solution, because $\mathrm{K}_{2} \mathrm{SO}_{4}$ is less soluble than other potassium salts, followed by reclamation of the $\mathrm{K}_{2} \mathrm{SO}_{4}$ precipitate via reaction with lime.

\section{Techno-economic study of the IVCAP process.}

Process simulation studies were performed using CHEMCAD software. The IVCAP integrated with a $528 \mathrm{MWe}$ (gross) coal-fired, subcritical power plant at a baseline condition lowered parasitic power losses by $24 \%$ compared to a conventional MEA process. Equipment size modeling revealed that at the baseline condition, and with $2 \mathrm{~g} / \mathrm{L} \mathrm{CA}$ dosage, the dimensions of the IVCAP absorber were about 23 to $40 \%$ larger, and the vacuum stripper about 3.8 to 5.4 times larger, than the equivalent equipment for the MEA process.

The capital cost of the IVCAP was higher than that for the MEA process, but its O\&M cost was lower, due to its reduced parasitic power losses and low solvent cost. Results from the techno-economic study revealed that the cost of $\mathrm{CO}_{2}$ avoidance for the IVCAP integrated with the $528 \mathrm{MWe}$ (gross) power plant was about 30\% lower than a conventional MEA-based process. The levelized cost of electricity (LCOE) of the IVCAP ranged from $\$ 40$ to 46/MWh, an increase of 60 to $70 \%$ compared to a reference power plant without $\mathrm{CO}_{2}$ capture.

\section{Major conclusion.}

A major conclusion of the project is that the IVCAP is a technically feasible and economically more attractive process than MEA-based processes. A scale-up study using a slipstream of an actual coal-derived flue gas, and development of a more stable CA enzyme are recommended for future studies. 


\section{CHAPTER 1. INTRODUCTION}

\subsection{Background}

Absorption-based processes are the most mature option for post-combustion capture of carbon dioxide $\left(\mathrm{CO}_{2}\right)$ from coal combustion flue gases. Currently, monoethanolamine (MEA) absorption processes are considered state-of-the-art; however, they are very expensive, typically ranging from 50 to $70 \$$ tonne $\mathrm{CO}_{2}$ avoided. ${ }^{[1]}$ The major cost contributor, amounting to about $60 \%$, is parasitic power and steam consumption in the absorption process that results in a significant derating (about 30\%) of the power plant. ${ }^{[2,3]}$ Reducing energy consumption is key to lowering the $\mathrm{CO}_{2}$ capture cost for absorption-based processes.

In the MEA process, about $65 \%$ of the electricity loss is due to steam extraction from the power plant to supply the heat required for $\mathrm{CO}_{2}$ desorption in the stripper. Compression of the recovered $\mathrm{CO}_{2}$ to pipeline pressure $(136.1 \mathrm{~atm} / 2,000 \mathrm{psia})$ accounts for another $25 \%$, and gas blowers and liquid pumps are responsible for the remaining $10 \%{ }^{[4]}$ Obviously, minimizing the reboiler heat duty and/or lowering the quality of the extracted steam are the most viable ways to reduce energy use in the process.

The total heat consumption for the stripping reboiler in an absorption process consists of three components: the sensible heat (for heating liquid), reaction heat (for desorption), and stripping heat (for water vaporization):

$$
Q_{\text {total }}=Q_{\text {sensible }}+Q_{\text {reaction }}+Q_{\text {stripping }}
$$

Absorption and stripping columns in an MEA process typically operate at 55 and $120^{\circ} \mathrm{C}(131$ and $248^{\circ} \mathrm{F}$ ), respectively, and the $\mathrm{Q}_{\text {reaction, }} \mathrm{Q}_{\text {sensible, }}$ and $\mathrm{Q}_{\text {stripping }}$ contribute 50,36 , and $14 \%$, respectively, to the total energy demand (about $4,000 \mathrm{~kJ} / \mathrm{kg} / 1721 \mathrm{Btu} / \mathrm{lb} \mathrm{CO}_{2}$ in a typical process without heat integration). ${ }^{[5]}$ For a different solvent, the total stripper energy demand depends on two major properties-heat of absorption, and equilibrium capacity of the solvent. Based on thermodynamic considerations, a solvent with a higher heat of absorption requires a higher

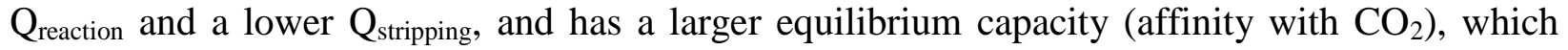
would result in a higher stripping temperature and a larger electricity loss due to steam extraction. Therefore, selection of a solvent should consider the combined impact of these factors on the overall energy performance of an absorption process.

It is often useful to describe heat energy by both its quantity and quality. Heat energy at a higher temperature will contain more exergy, a measure of the work potential at a certain state relative to the reference state $\left(\mathrm{T}_{0}=25^{\circ} \mathrm{C} / 77^{\circ} \mathrm{F}, \mathrm{P}_{0}=1\right.$ atm $\left./ 14.7 \mathrm{psia}\right)$, as compared to heat at a lower temperature. A typical MEA process operates at 93 to $121^{\circ} \mathrm{C} / 200$ to $250^{\circ} \mathrm{F}(1-2 \mathrm{~atm} / 14.7-29.4$ psia) for $\mathrm{CO}_{2}$ stripping. To maintain the required temperature difference, the driving force for heat transfer, the steam used in the reboiler of the stripper in an MEA process must be extracted from the power plant steam cycle at a pressure of about $4.1 \mathrm{~atm} / 60 \mathrm{psia}$ (saturation temperature of $145^{\circ} \mathrm{C} / 293^{\circ} \mathrm{F}$ ) ${ }^{[6]}$ This high temperature requirement increases the electricity loss due to steam extraction. If the heat energy consumed in a $\mathrm{CO}_{2}$ absorption process is of low quality (i.e., its $\mathrm{T}$ and $\mathrm{P}$ are close to $\mathrm{T}_{0}$ and $\mathrm{P}_{0}$ ), or even waste heat (whose $\mathrm{T}$ and $\mathrm{P}$ are virtually $\mathrm{T}_{0}$ and $\mathrm{P}_{0}$ ), then the 
total energy cost of the $\mathrm{CO}_{2}$ capture process will be low even though the amount of heat required is large.

\subsection{Introduction of Integrated Vacuum Carbonate Absorption Process}

Guided by the above analyses, a novel Integrated Vacuum Carbonate Absorption Process (IVCAP) has been proposed for post-combustion $\mathrm{CO}_{2}$ capture to reduce the quality and quantity of heat required for $\mathrm{CO}_{2}$ capture. A U.S. patent for the process was awarded in $2011 .^{[7]}$

The IVCAP process employs a potassium carbonate $\left(\mathrm{K}_{2} \mathrm{CO}_{3}, \mathrm{PC}\right)$ aqueous solution for $\mathrm{CO}_{2}$ absorption. The overall reaction for $\mathrm{CO}_{2}$ absorption is:

$$
\mathrm{CO}_{2}+\mathrm{H}_{2} \mathrm{O}+\mathrm{K}_{2} \mathrm{CO}_{3}=2 \mathrm{KHCO}_{3}
$$

The reaction of $\mathrm{CO}_{2}$ desorption occurs, of course, in the reverse direction.

Due to the low alkalinity of $\mathrm{K}_{2} \mathrm{CO}_{3}$, the heat of absorption of the $\mathrm{CO}_{2} / \mathrm{K}_{2} \mathrm{CO}_{3}$ system $(609 \mathrm{~kJ} / \mathrm{kg} /$ $262 \mathrm{Btu} / \mathrm{lb})$ is much less than that of the $\mathrm{CO}_{2} / \mathrm{MEA}$ system $(1919 \mathrm{~kJ} / \mathrm{kg} / 825 \mathrm{Btu} / \mathrm{lb})$. The weak affinity of $\mathrm{CO}_{2}$ with the $\mathrm{K}_{2} \mathrm{CO}_{3}$ solvent allows for $\mathrm{CO}_{2}$ stripping at a relatively low temperature and under vacuum pressure conditions. The steam condition required for $\mathrm{CO}_{2}$ capture is determined by the stripping temperature. One of the key advantages of the IVCAP is in its ability to use low quality steam from the power plant as a heat source. To better describe this key technical advantage of the IVCAP, a typical power plant steam cycle is described below.

In a sub-critical steam cycle power plant (see Figure 1-1), electricity is generated through three staged steam turbines, i.e., high pressure (HP) turbine, intermediate pressure (IP) turbine, and lower pressure (LP) turbine. The HP steam contains the highest exergy and the LP steam possesses the lowest exergy. The lower pressure exhaust steam from the LP turbine is at about $8.27 \mathrm{kPa}(1.2 \mathrm{psia})$ and $42^{\circ} \mathrm{C}\left(108^{\circ} \mathrm{F}\right)$. In general, about one-third of the coal heating value is converted to electricity through the steam turbines, about $10 \%$ is entrained in the flue gas leaving the air preheater, and the remaining exergy is contained in the LP exhaust steam, which is released to the environment through the cooling water in a power plant cooling system. ${ }^{[8]}$

The heat contained in steam through the steam cycle can vary in quality. Figure 1-2 shows the change of steam properties and its capability for generating electricity when it passes through the IP and LP turbines. In preparing the data presented in Figure 1-2, an adiabatic expansion process with an efficiency of $88.5 \%$ was assumed. During the expansion, the capability of the steam to generate electricity decreases logarithmically with decreasing steam pressure. At the IP inlet $\left(538^{\circ} \mathrm{C} / 1,000^{\circ} \mathrm{F}, 37.1 \mathrm{~atm} / 545.4 \mathrm{psia}\right)$, about $32 \%$ of the total heat contained in the steam can be converted to electricity, while little or no such heat can be converted to electricity at the outlet of the LP turbine $\left(42^{\circ} \mathrm{C} / 108^{\circ} \mathrm{F}, 8.27 \mathrm{kPa} / 1.2 \mathrm{psia}\right)$. The withdrawal of low quality steam for $\mathrm{CO}_{2}$ capture can significantly reduce the energy penalty for $\mathrm{CO}_{2}$ capture compared to the penalty for using the MEA process. 


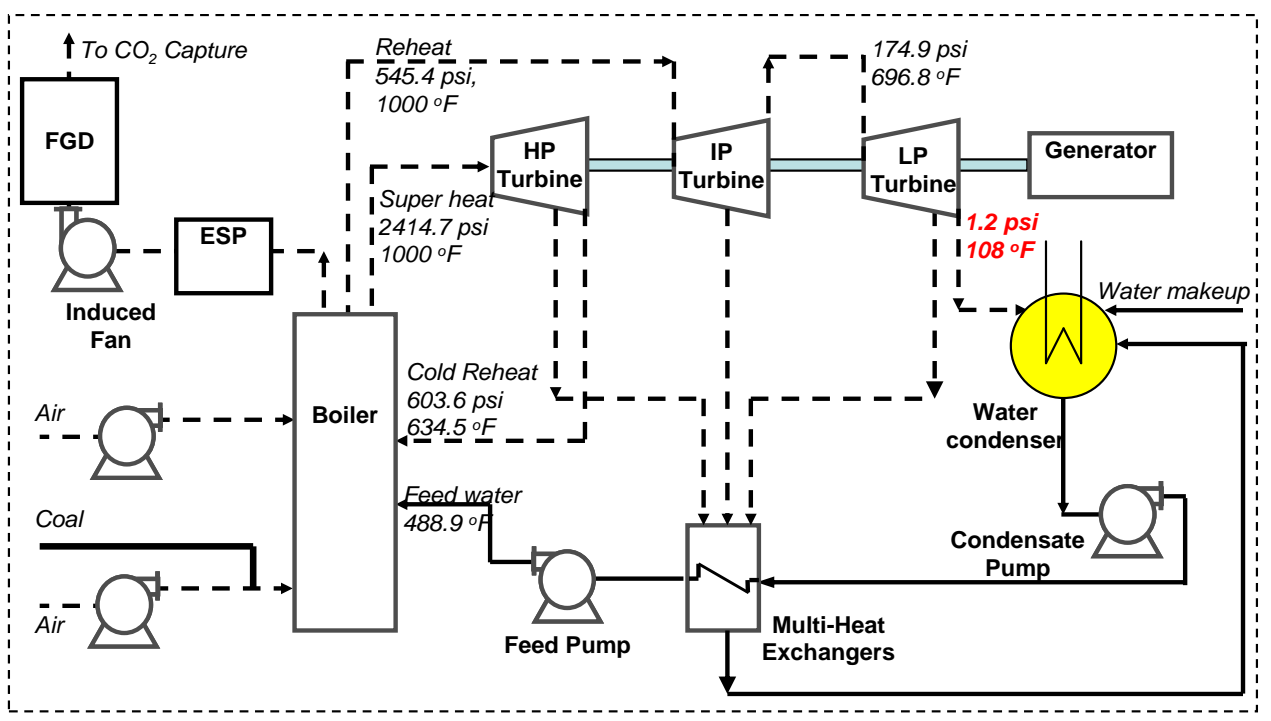

Figure 1-1. Schematic diagram of a sub-critical steam cycle power plant

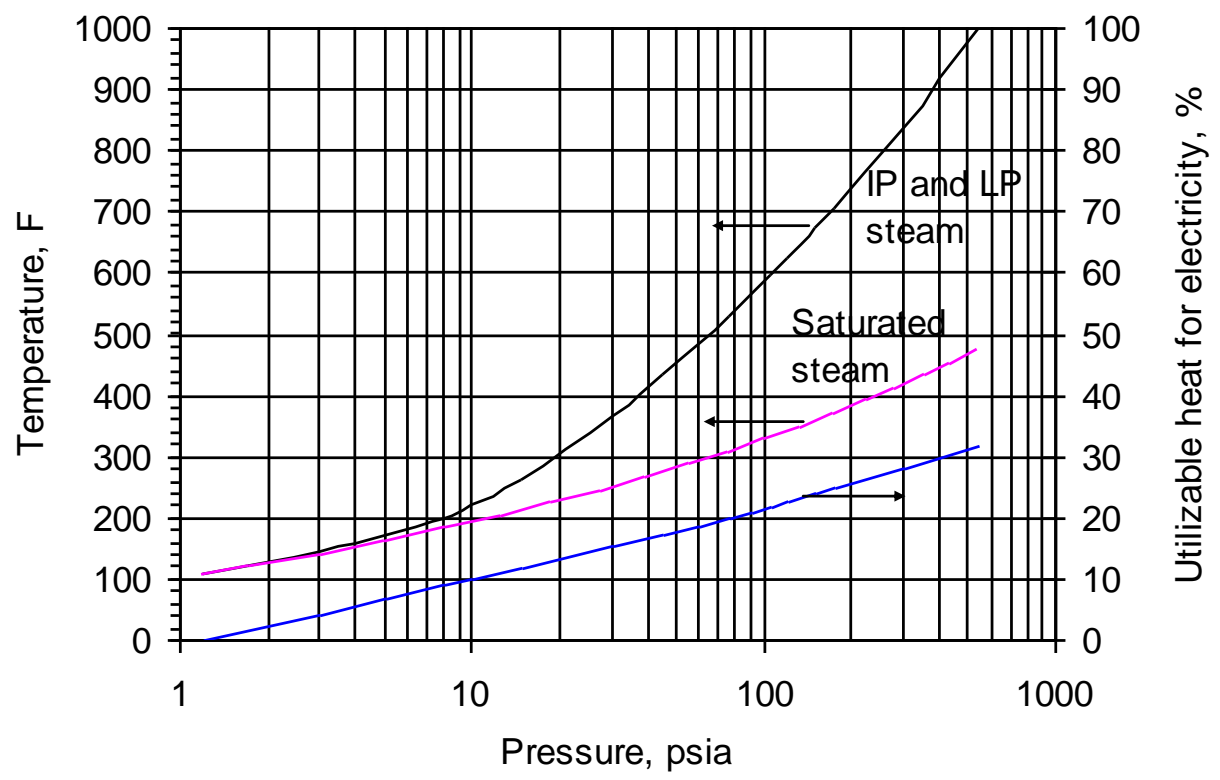

Figure 1-2. Steam properties during expansion in the IP and LP turbines

A schematic diagram of the IVCAP is shown in Figure 1-3. ${ }^{[7]}$ The LP steam used in the stripper is extracted from the LP turbine, typically at pressures ranging from 13.8 to $62.1 \mathrm{kPa}$ (2 to 9 psia). As aforementioned, $4.1 \mathrm{~atm}$ (60 psia) steam is required in the MEA process. The IVCAP thus uses a steam with lower quality than that of the MEA. In addition, in the IVCAP, a large part of the steam is directly introduced into the stripper for stripping and heating. Another part of the steam is used for indirect heating in the reboiler. This is very different from the MEA process, where all the steam is introduced to the reboiler at the bottom of the stripper for indirect heating. The product stream exiting the stripper in the IVCAP is a mixture of water vapor and $\mathrm{CO}_{2}$ and can either be sent directly to the condenser in the power plant (Figure 1-3), or optionally, can be condensed in a separate condenser and the condensate then can be recycled to the steam cycle (not shown in Figure 1-3). In the IVCAP, the vacuum condition is provided 
partly by water vapor condensation from the $\mathrm{CO}_{2}$ stream in the condenser, and partly from a vacuum pump.

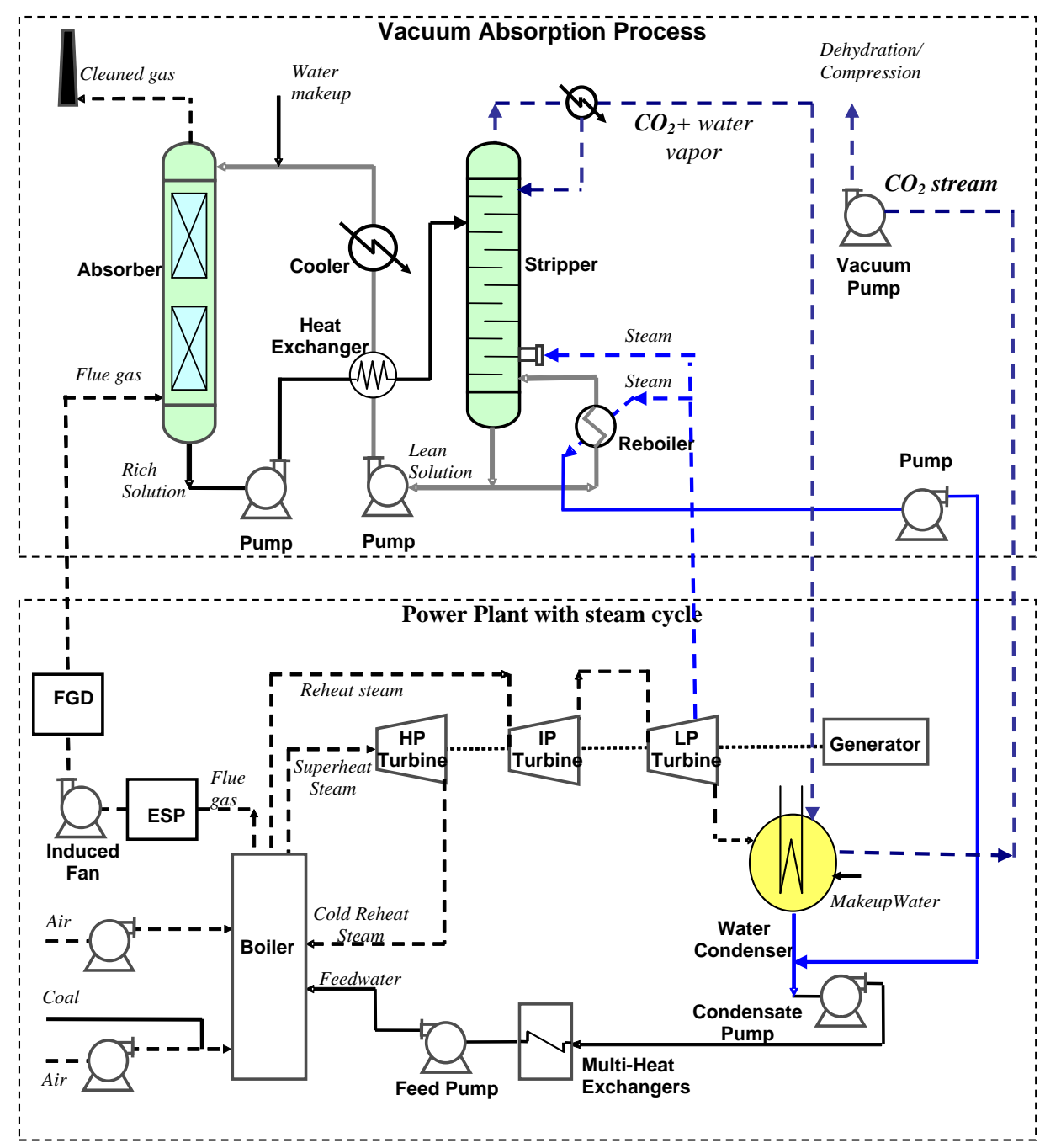

Figure 1-3. Schematic diagram of the proposed IVCAP

There are additional benefits of integrating the $\mathrm{CO}_{2}$ capture process with the steam cycle of the power plant. First, the two processes share the same condenser, so a large amount of capital cost can be saved. Second, the direct introduction of steam into the stripper will eliminate the temperature difference $(\Delta \mathrm{T})$ between the steam and the solution for heat transfer. A typical $\Delta \mathrm{T}$ of 10 to $20^{\circ} \mathrm{C}$ ( 18 to $36^{\circ} \mathrm{F}$ ) yields a thermal efficiency loss of about 1 to $3 \%$, especially when the steam temperature is low. Third, direct injection of steam into the stripper will significantly reduce the required size of the reboiler.

Use of low stripping pressure and direct introduction of the steam into the stripper reduces the quality and quantity of steam required for the striping process, both of which lower the parasitic power losses for a power plant equipped with the IVCAP system compared to the MEA system. A preliminary process evaluation showed that up to $30 \%$ of the total electricity loss (including 
$\mathrm{CO}_{2}$ capture and compression) can be saved in the IVCAP compared to conventional MEA processes.

Another advantage of the IVCAP is that an $\mathrm{SO}_{2}$ removal option may be integrated with the $\mathrm{CO}_{2}$ capture process, thus potentially eliminating the need for, or downsizing a separate wet FGD unit. In the MEA process, $\mathrm{SO}_{2}$ in the flue gas reacts with the solvent and produces a heat stable salt that is difficult to regenerate. This causes a permanent loss of the solvent. Therefore, a FGD unit must be installed upstream of the MEA unit to reduce the $\mathrm{SO}_{2}$ concentration in the flue gas to $<20 \mathrm{ppm}$ to reduce the potential loss of solvent. In the IVCAP, $\mathrm{SO}_{2}$ also strongly reacts with a $\mathrm{K}_{2} \mathrm{CO}_{3}$ solvent and produces potassium sulfate $\left(\mathrm{K}_{2} \mathrm{SO}_{4}\right)$. A high $\mathrm{SO}_{2}$ removal efficiency (>99\%) is expected due to a higher acidity of $\mathrm{SO}_{2}$ than $\mathrm{CO}_{2}$. The overall absorption reaction can be expressed as:

$$
\mathrm{SO}_{2}+1 / 2 \mathrm{O}_{2}+\mathrm{K}_{2} \mathrm{CO}_{3}=\mathrm{K}_{2} \mathrm{SO}_{4}+\mathrm{CO}_{2}
$$

$\mathrm{K}_{2} \mathrm{SO}_{4}$ is soluble in water (e.g., $120 \mathrm{~g} / \mathrm{L}$ water at $25^{\circ} \mathrm{C} / 77^{\circ} \mathrm{F}$ ), and exists as sulfate $\left(\mathrm{SO}_{4}{ }^{2-}\right.$ ) and potassium $\left(\mathrm{K}^{+}\right)$ions in the solution. Thus, the key to achieving combined $\mathrm{CO}_{2} / \mathrm{SO}_{2}$ removal is to be able to continuously reclaim the desulfurization product $\mathrm{K}_{2} \mathrm{SO}_{4}$. A reclamation process employing lime to precipitate the sulfate ions from the $\mathrm{K}_{2} \mathrm{CO}_{3} / \mathrm{KHCO}_{3}$ solution treated with a slipstream of high-pressure $\mathrm{CO}_{2}$ can potentially achieve this goal.

\subsection{Technical challenges to be addressed}

A major technical challenge with the IVCAP technology is the lower rate of absorption of $\mathrm{CO}_{2}$ into the PC solution when compared to the rate of absorption of $\mathrm{CO}_{2}$ into the MEA solution. Depending on properties of the carbonate solution, such as temperature, ion concentrations, ion strength, and $\mathrm{CO}_{2}$ loading, the intrinsic reaction rate can be 3-4 orders of magnitude slower and the overall rate of $\mathrm{CO}_{2}$ absorption with the consideration of mass transfer resistance one order of magnitude slower compared to that of a 7M MEA solution. ${ }^{[9]}$

This issue can be resolved by using a promoter/catalyst to enhance the rate of chemical reaction between $\mathrm{CO}_{2}$ and $\mathrm{K}_{2} \mathrm{CO}_{3}$, which is the limiting step in the absorption process. Different promoters and catalysts, including inorganic and organic materials, have been studied for this purpose and some of them are commercially-available. Recently, it has been demonstrated that a $20 \mathrm{wt} \% \mathrm{~K}_{2} \mathrm{CO}_{3}$ solution promoted with $0.6 \mathrm{M}$ piperazine (PZ) could achieve absorption rates comparable to those in $5 \mathrm{M}$ MEA at 40 to $80^{\circ} \mathrm{C}$ (104 to $\left.176^{\circ} \mathrm{F}\right) .{ }^{[9,10]}$ However, the heat of absorption in the PC-PZ mixture is much higher than the aqueous $\mathrm{K}_{2} \mathrm{CO}_{3}$ solution alone. Indicating more energy is required during desorption. Therefore, a need exists to develop a better promoter/activator to make the $\mathrm{CO}_{2}$ capture process more economically feasible. By far the most effective $\mathrm{CO}_{2}$ hydration catalyst known is the carbonic anhydrase (CA) enzyme, which is present in blood and speeds up the desorption of $\mathrm{CO}_{2}$ into the lungs. ${ }^{[11,12,13]}$ In this research, the role of a catalyst for the absorption of $\mathrm{CO}_{2}$ into the $\mathrm{K}_{2} \mathrm{CO}_{3} / \mathrm{KHCO}_{3}$ solution under the IVCAP condition was studied, with an emphasis on the CA enzyme biocatalyst.

A related technical issue to be considered is the thermal and chemical stability of the enzyme biocatalyst over time since it directly impacts the operating cost. The thermal stability is related to the operating temperature. A few researchers have shown that it is possible to provide an isozyme that will work well regardless of the operating temperature selected over the range of 20 
to $85^{\circ} \mathrm{C}\left(68\right.$ to $\left.185^{\circ} \mathrm{F}\right){ }^{[14]}$ However, additional research is required to investigate the thermal stability of the currently available enzymes for the IVCAP application and explore technical measures, such as enzyme immobilization, to improve the enzyme stability. In addition, a coal combustion flue gas contains many contaminants, such as $\mathrm{SO}_{2}, \mathrm{NOx}, \mathrm{HCl}, \mathrm{HF}$, and heavy metals, which may influence CA activity. A specific study is required to determine the inhibition effects of gas contaminants for the IVCAP.

Reclaiming the desulfurization product $\left(\mathrm{K}_{2} \mathrm{SO}_{4}\right)$ from the solution in the combined $\mathrm{CO}_{2}$ capture and $\mathrm{SO}_{2}$ removal process also presents significant technical challenges. No data are available in the literature regarding competitive crystallization between calcium sulfate and calcium carbonate at conditions similar to those in the IVCAP process. The feasibility of such a new concept has to be experimentally investigated via a crystallization kinetic study. If these studies are not successful, other process options for combined $\mathrm{CO}_{2}$ capture and $\mathrm{SO}_{2}$ removal in the IVCAP process need to be explored and evaluated.

While the vacuum stripping condition in the IVCAP process can reduce parasitic power losses in a power plant, the vacuum pump will lead to an increase in the capital cost. The vacuum in the stripper will significantly increase the gas stream volume, especially when the vacuum is high. For example, at $0.1 \mathrm{~atm}(1.47 \mathrm{psia})$, the total $\mathrm{CO}_{2}$ volume will be more than 2 million $\mathrm{m}^{3} /$ hour $(1.2$ million $\mathrm{cfm})$ for a $500 \mathrm{MWe}$ power plant. At a $5 \mathrm{~m} / \mathrm{s}(16.4 \mathrm{ft} / \mathrm{s})$ velocity, the total crosssection area of the vacuum pump inlet will be $111 \mathrm{~m}^{2}\left(1,194 \mathrm{ft}^{2}\right)$. The capital cost of the vacuum pump and the stripper required to treat such a large volume of gas could potentially be expensive. A techno-economic analysis is required to investigate the mass/energy balances, the overall cost of the process, and the cost sensitivity of the process operating conditions and material/equipment pricing.

Additional technical risks include the corrosion effect of $\mathrm{KCO}_{3} / \mathrm{KHCO}_{3}$ solution on the equipment, corrosion inhibition, needs of recycle water treatment, potential air ingress into the vacuum system, and the potential impact of trace flue gas components on the CA enzyme biocatalyst, etc. For example, a water treatment unit may be needed before the water is recycled to the steam cycle. A literature search was conducted to evaluate these technical risks.

\subsection{Project Objectives}

Experimental studies in this project addressed the major technical challenges and risks described above. The objectives of the project included: 1) performing an experimental study to test the proof-of-concept of the IVCAP process; 2) examining various catalysts to accelerate the $\mathrm{CO}_{2}$ absorption rate and effective additives to reduce the stripping heat, and 3) evaluating a modified IVCAP process for combined $\mathrm{SO}_{2}$ and $\mathrm{CO}_{2}$ removal.

Three criteria were considered to evaluate the success of the proposed project. They included: 1) successful development/identification of a catalyst and relevant process conditions to achieve an acceptable $\mathrm{CO}_{2}$ absorption rate into the potassium carbonate aqueous solution; 2) successful identification of an additive to suppress the rate of water vaporization during $\mathrm{CO}_{2}$ stripping to further reduce the stripping heat by $20 \%$ or more; and 3) successful proof of a modified IVCAP process option for combined removal of $\mathrm{SO}_{2}$ and $\mathrm{CO}_{2}$. 


\subsection{Scope of Work}

The rate of $\mathrm{CO}_{2}$ absorption into the $\mathrm{K}_{2} \mathrm{CO}_{3}$ solution is critical to the IVCAP process. CA enzyme biocatalysts and several other selected inorganic/organic catalysts were tested and the related process conditions were identified to accelerate the rate of $\mathrm{CO}_{2}$ absorption by 2- to 3- fold. Research focus was placed on the enzyme biocatalyst and its immobilization. Because the stripping heat associated with water vaporization contributes to about $70 \%$ of the heat used in the stripping process, the study of additives to suppress the saturation pressure of water vapor was also important. Vapor-liquid equilibrium (VLE) measurements were performed to evaluate the effectiveness of selected additives in lowering the water vapor pressure over the $\mathrm{K}_{2} \mathrm{CO}_{3}$ solution. Combined $\mathrm{SO}_{2}$ removal and $\mathrm{CO}_{2}$ capture in the IVCAP process can potentially eliminate the installation of a separate FGD system in the power plant. A kinetic study on the reclamation of the desulfurization byproduct was conducted to test the process concept proposed in this project. Finally, a techno-economic study based on process simulations and cost modeling was performed on a conceptual full-scale pulverized coal-fired power plant equipped with the IVCAP for $\mathrm{CO}_{2}$ capture. Four major research tasks were successfully completed.

In Task 1, activities of an enzyme biocatalyst (CA enzyme) and selected inorganic and organic catalysts for increasing the rate of $\mathrm{CO}_{2}$ absorption into the $\mathrm{K}_{2} \mathrm{CO}_{3}$ solution were measured under typical operating conditions of the IVCAP process. The catalyst study was focused on the CA biocatalyst, which has been applied to capture the $\mathrm{CO}_{2}$ from flue gases in other emerging technologies. Both the reaction rate and the mass transfer resistance were examined using a continuous stirring tank reactor (CSTR) system. Besides the activity, the thermal and chemical stability of the CA enzyme underwent extended testing (several months). The thermal stability test was conducted under selected conditions of temperature, $\mathrm{CA}$ dosage, and $\mathrm{CO}_{2}$ loading. The chemical stability test was conducted in the presence of $\mathrm{SO}_{4}{ }^{2-}, \mathrm{NO}_{3}{ }^{-}$, and $\mathrm{Cl}^{-}$ions to simulate typical impurities in scrubbing liquids.

Immobilization of the CA enzyme was also performed in this project. Immobilization can improve an enzyme's stability, but may also result in some loss of activity. The activity loss is related to both the coupling reaction between the enzyme and support, and the diffusion resistance of the substrate $\mathrm{CO}_{2}$ in the support. Various support/carrier materials with different sizes (in both micron and nanometer ranges) and different surface properties were employed for the CA enzyme immobilization. Such materials were either acquired and re-engineered, or were fabricated in this project. Various analysis techniques were employed to characterize their morphology, crystal structure, surface functionality, pore size, and BET surface area. Different strategies to immobilize the CA enzyme were developed and optimized for particular support/carrier materials. The activity and stability (thermal and chemical) of the immobilized enzymes were investigated using a manometric method and a CSTR setup.

In Task 2, additives were screened and investigated to reduce the saturation pressure of water vapor at temperatures typical to the IVCAP stripping column. For this purpose, VLE measurements were performed for the $\mathrm{K}_{2} \mathrm{CO}_{3}$ solution in the absence and presence of additives. A VLE experimental system was established and the related measurement approach has been verified using VLE data in the literature. Potassium sulfate, ethylene glycol (EG), and sodium 
chloride were initially tested as baseline additives. A literature search focusing on the potential additives was conducted and a screening study of the additives was carried out. Additives found to be effective for suppressing water vaporization were also investigated for their impact on CA enzyme activity.

In Task 3, a kinetics study on the reclamation of the $\mathrm{K}_{2} \mathrm{CO}_{3}$ solvent reacted with $\mathrm{SO}_{2}$ was conducted. One option for the reclamation is to precipitate the sulfate as $\mathrm{CaSO}_{4}$ and recover the potassium as $\mathrm{K}_{2} \mathrm{CO}_{3} / \mathrm{KHCO}_{3}$ using lime or hydrated lime as a regent. The rate of sulfate crystallization was measured using both a batch and a semi-continuous system. In the batch system, the reclamation process was simulated by directly mixing the $\mathrm{K}_{2} \mathrm{CO}_{3}$ solution (with the concentrations of major ions similar to those under equilibrium with high-pressure $\mathrm{CO}_{2}$ ) with the calcium ions under desired $\mathrm{pH}$ conditions. In the semi-continuous system, the liquid was under batch mode and the gas (high-pressure $\mathrm{CO}_{2}$ stream) under continuous mode. Kinetic tests were performed for both the conversion of carbonate ions to bicarbonate ions under high-pressure $\mathrm{CO}_{2}$ and the crystallization of $\mathrm{CaSO}_{4}$ through the reaction between the $\mathrm{CO}_{2}$-treated solution and the calcium hydrate reagent. In addition, the additives identified in Task 2 and inorganic catalysts in Task 1 might have an effect on the sulfate reclamation process. Therefore, crystallization reclamation tests were also performed in the presence of selected additives and catalysts.

The results of an initial feasibility study of the combined $\mathrm{CO}_{2}$ capture and $\mathrm{SO}_{2}$ removal revealed that other process options to reclaim the desulfurization product $\left(\mathrm{K}_{2} \mathrm{SO}_{4}\right)$ might be explored. Advantages and disadvantages of various process options were examined.

In Task 4, a techno-economic analysis was performed for the IVCAP process installed in a conceptual 500 MWe (gross) power plant. A process design/simulation software package, CHEMCAD, was used for the process simulation. The data obtained from Tasks 1-3 were used as input for this activity. A cost estimation study was then conducted based on the results of mass/energy balances from the process simulation. Three approaches have been combined to estimate the capital and operating \& maintenance (O\&M) costs: 1) DOE/EPRI techno-economic guideline documents; 2) related equipment vendors and manufacturers; and 3) application of the scaling factors from chemical process handbooks. The cost results included the capital cost, O\&M costs, levelized cost of electricity (LCOE), and $\mathrm{CO}_{2}$ avoidance cost.

More details of the research activities are described in the Statement of Project Objectives attached in Appendix A.

\section{References}

1. Ciferno, J. P., Fout, T. E., Jones, A. P., Murphy, J. T. Capturing Carbon from Existing Coal Fired Power Plants. Chem. Eng. Prog. 2009, 105, 33-41.

2. Singh, D., Croiset E., Douglas P. L., Douglas M. A. Techno-Economic Study of $\mathrm{CO}_{2} \mathrm{Capture}$ from An Existing Coal-Fired Power Plant: MEA Scrubbing vs. $\mathrm{O}_{2} / \mathrm{CO}_{2}$ Recycle Combustion. Energy Conversion and Management 2003, 44: 3073-3091.

3. Alie C., Backham L., Croiset E., Douglas P.L. Simulation of $\mathrm{CO}_{2}$ Capture Using MEA Scrubbing: A Flowsheet Decomposition Method. Energy Conversion and Management 2005, 46: 475-487. 
4. Research and Development Solutions, LLC, Cost and Performance Baseline for Fossil Energy Plants: Volume 1: Bituminous Coal and Natural Gas to Electricity, DOE/NETL2010/1397, November 2010.

http://www.netl.doe.gov/energy-analyses/pubs/Bituminous\%20Baseline_Final\%20Report.pdf

5. Ciferno J., Dipietro P., Tarka T. An Economic Scoping Study for $\mathrm{CO}_{2}$ Capture Using Aqueous Ammonia, February 2005.

6. ya Nsakala N., Marion J., Bozzuto C., Liljedahl G., Palkes M. Engineering Feasibility of $\mathrm{CO}_{2}$ Capture on An Existing US Coal-Fired Power Plant, First National Conference on Carbon Sequestration, Washington DC, May 15-17, 2001.

7. Chen S., Lu Y., Rostam-Abadi M. Integrated Vacuum Absorption Steam Cycle Gas Separation. Patent No. US 8,062,408, Nov. 2011.

8. Gilbert/Commonwealth Inc., 1995, Clean Coal Reference Plants: Pulverized Coal Boiler with Flue Gas Desulfurization, DE-AM21-94MC311 66, September 1995.

9. Cullinane T. J., Rochelle G. T. Carbon Dioxide Absorption with Aqueous Potassium Carbonate Promoted by Piperazine, Chemical Engineering Science 2004, 59: 3619-3630.

10. Cullinane T. J., Rochelle G. T. Kinetics of Carbon Dioxide Absorption into Aqueous Potassium Carbonate and Piperazine, Industrial and Engineering Chemistry Research 2006, 45: 2531-2545.

11. Silverman D.N., Lindskog S. The Catalytic Mechanism of Carbonic Anhydrase: Implications of A Rate-Limiting Protolysis of Water, Acc. Chem. Res. 1988, 21: 30-36.

12. Enns T. Facilitation by Carbonic Anhydrase of Carbon Dioxide Transport. Science 1967, 155: 44-47.

13. Alper E., Deckwer W. D. Kinetics of Absorption of $\mathrm{CO}_{2}$ into Buffer Solutions Containing Carbonic Anhydrase. Chemical Engineering Science 1980, 35: 549-557.

14. Trachtenberg M.C. Biomimetic Membrane for $\mathrm{CO}_{2}$ Capture from Flue Gas, Progressive Report from 05/10/06-03/19/07, DE FG26-06NT42824, August 29, 2007. 


\section{CHAPTER 2. VAPOR-LIQUID PHASE EQUILIBRIUM BEHAVIOR OF $\mathrm{K}_{2} \mathrm{CO}_{3}$ SOLUTIONS AND SCREENING OF ADDITIVES TO REDUCE ENERGY CONSUMPTION}

The stripping heat associated with water vaporization was estimated to consume about $70 \%$ of the total heat used in the IVCAP. We hypothesized that using an additive to suppress the saturation pressure of water vapor over the potassium carbonate (PC) solution in the IVCAP could reduce process energy use. Vapor-Liquid equilibrium (VLE) measurements for PCadditive systems were conducted to evaluate the selected additives for this purpose. VLE measurements at low temperatures (less than $70^{\circ} \mathrm{C} / 158^{\circ} \mathrm{F}$ ) were also required for the IVCAP design, because such data is lacking in the literature.

A screening study was conducted to identify the additives that would be most effective in lowering the water vapor saturation pressure over the PC solution. VLE measurements were then conducted for the $20 \mathrm{wt} \%$ PC solution mixed with the selected additives at 50 and $70^{\circ} \mathrm{C}(122$ and $\left.158^{\circ} \mathrm{F}\right)$.

\subsection{Experimental methodology}

\subsubsection{Materials}

Potassium carbonate (PC, Sigma Aldrich, ACS reagent, $\geq 99.0 \%$ ) and potassium bicarbonate (PBC, Sigma Aldrich, ACS reagent, $\geq 99.7 \%$ ) were used for preparing carbonate solutions of desired concentrations. Additives selected to reduce water vapor pressure of the PC solution included potassium acetate (Sigma Aldrich, ACS reagent, $\geq 99.0 \%$ ), potassium formate (Sigma Aldrich, assay >99\%), triethylene glycol (TCI, >98\%), diethylene glycol (Sigma Aldrich, ReagentPlus $^{\circledR}, \geq 99.0 \%$ ), ethylene glycol (Sigma Aldrich, ReagentPlus ${ }^{\circledR}, \geq 99.0 \%$ ), and sucrose (Sigma Aldrich, >99.5\%). As-received materials were used in all experiments.

\subsubsection{Apparatus}

A schematic diagram of the closed-loop system with a gas-phase pressure control used to measure the VLE of $\mathrm{CO}_{2}$ in the PC solution is shown in Figure 2-1. Figure 2-2 is a photograph of the actual system. The system consists of an equilibrium cell, a gas supply/control unit, and instrumentation for measuring gas/liquid compositions.

The equilibrium cell was a stainless steel vessel of $525 \mathrm{~cm}^{3}\left(32 \mathrm{inch}^{3}\right)$ internal volume (7.8 $\mathrm{cm} / 3.1$ inch in in ID and $11.0 \mathrm{~cm} / 4.3$ inch in height). A vacuum pump (Dekker, RVL002H-01) provided the required initial vacuum level for the system. The pressure of the gas stream into the equilibrium cell was controlled and monitored by a pressure transducer (PC-15PSIA-D/5P, Alicat Scientific). A mass flow meter (M-500SCCM-D/5, Alicat Scientific) was used to measure the gas flow rate. A single elevated-head micro-diaphragm pump (B161-BP-AA1-LV3, Air Dimensions Inc.) was installed to recycle the gas into the cell in order to accelerate the system toward an equilibrium state under the test conditions. A humidity and temperature transducer (HMT) (HMT330, Vaisala Inc.) measured the temperature and partial pressure of water vapor in the gas phase. A magnetic stirrer with a controller (Variomag Mobil 25, Thermo Scientific) 
capable of operating at temperatures up to $120^{\circ} \mathrm{C}\left(248^{\circ} \mathrm{F}\right)$ and $1000 \mathrm{rpm}$, along with a 4-cm $(1.6$ inch) Teflon stirrer, provided liquid mixing at controllable speeds. The temperature in the liquid phase was measured by a thermocouple (Omega, Type K, model KMQSS-125-G-6). The equilibrium cell, stirrer, gas circulation loop, HMT probe, and the head section of the gas pump were stored in an incubator (model $4 \# 31483$, GCA Corporation, Precision Scientific Group) with $\pm 0.5^{\circ} \mathrm{C}\left( \pm 0.9^{\circ} \mathrm{F}\right)$ precision temperature control. The pressure, gas flow rate, humidity/water vapor pressure, and temperature of the circulating gas stream were monitored and recorded with a computer through a data acquisition system. The compositions of the gas and liquid were analyzed by gas chromatography (Shimadzu GC-2014) and a titration method, respectively. Gas samples were obtained by inserting a $100 \mu 1$ syringe (cat. \#20162, Restek Corporation) through a $10 \mathrm{~mm}(0.39$ inch $)$ septum fitted onto a $6.35 \mathrm{~mm}(0.25$ inch $)$ diameter tee in the tubing between the equilibrium cell and the gas circulation pump (see Fig. 2-1). Liquid samples were discharged directly from the sample port located at the bottom of the equilibrium cell through a switching valve.

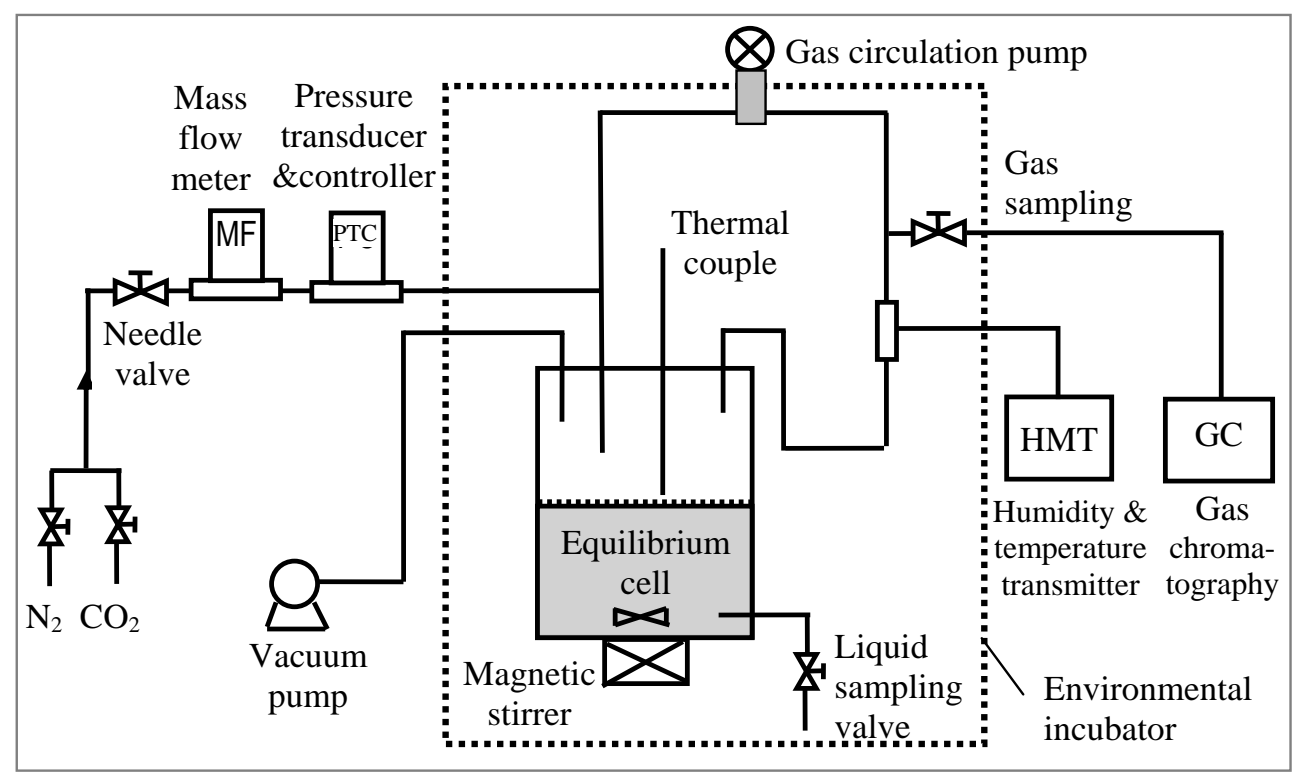




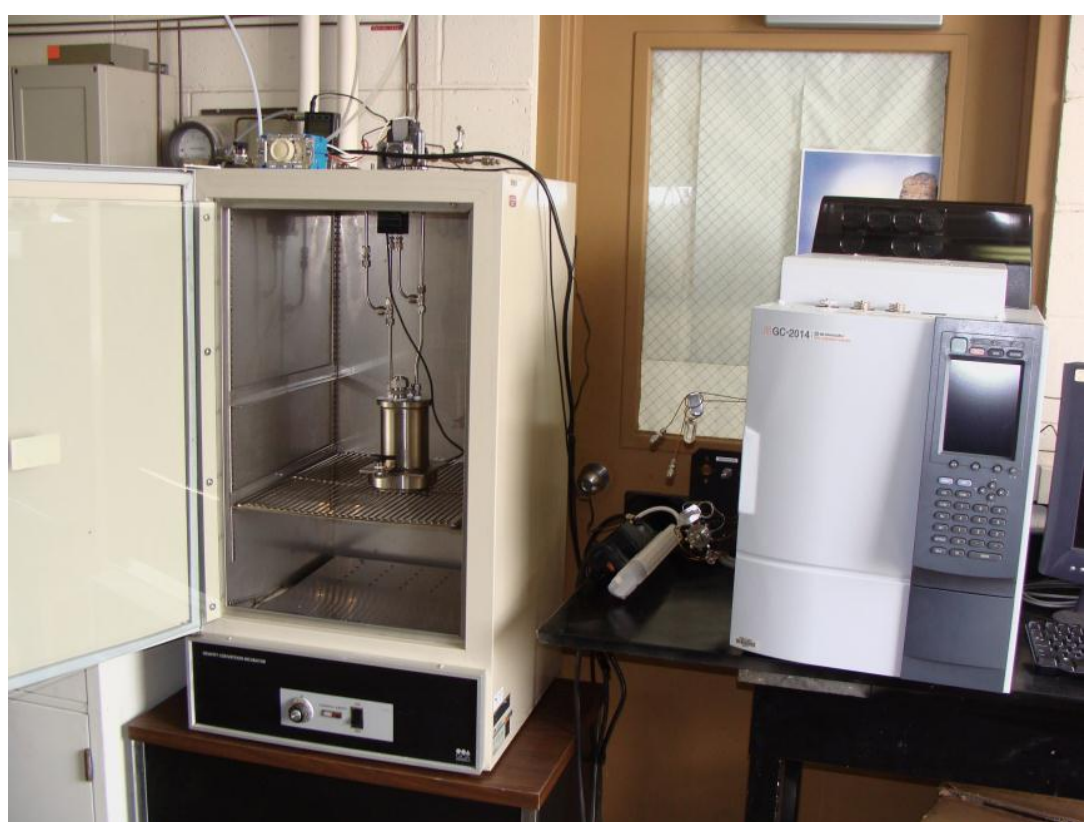

Figure 2-1. Schematic diagram and photos of the experimental setup for VLE measurement

\subsubsection{Experimental procedure}

VLE measurements of the $\mathrm{CO}_{2}$-PC systems were performed in a semi-continuous mode with respect to the gas phase. In a typical experiment, 350 grams of a PC solution with the desired composition was fed into the equilibrium cell. The system was initially evacuated to a required pressure at room temperature, and then the vacuum pump was turned off and the temperature of the incubator was raised to the desired set point for the experiment. When the temperature reading was stable, the pressure of the water vapor $\left(\mathrm{P}_{\mathrm{w}}\right)$ was recorded by both the pressure transducer and the HMT. The and the pure nitrogen $\left(\mathrm{N}_{2}\right)$ gas stream was introduced into the equilibrium cell to achieve a predetermined system pressure, and the stirrer in the liquid phase (700 rpm), and the gas circulation pump (1 LPM) were turned on. When the humidity/water vapor pressure values reported by the HMT had stabilized, the humidity/water vapor partial pressure $\left(\mathrm{P}_{\mathrm{w}}\right)$ was recorded. The gas supply line was then switched and pure $\mathrm{CO}_{2}$ entered the equilibrium cell until a set point pressure value was reached. As $\mathrm{CO}_{2}$ was consumed in the PC solution, the $\mathrm{CO}_{2}$ gas stream was intermittently, but automatically, supplied into the equilibrium cell to maintain the set point pressures. The total gas pressure was held constant during the experiment. An equilibrium state was defined when the flow of $\mathrm{CO}_{2}$ into the cell stopped as indicated by the mass flow meter. The system typically took 16 to 20 hours to reach this equilibrium state. Samples of the gas and liquid then were collected and analyzed to determine the equilibrium values.

\subsubsection{Analysis methods}

Liquid composition. A titration method was employed to determine the concentration of $\mathrm{KHCO}_{3}$ in the liquid mixture at equilibrium. ${ }^{[1]}$ The liquid sample was added to an excess amount of potassium hydroxide $(\mathrm{KOH})$ solution to convert any $\mathrm{KHCO}_{3}$ and free dissolved $\mathrm{CO}_{2}$ to $\mathrm{K}_{2} \mathrm{CO}_{3}$. Then, an excess amount of barium chloride $\left(\mathrm{BaCl}_{2}\right)$ was added to the solution to precipitate the 
carbonate in the form of barium carbonate $\left(\mathrm{Ba}_{2} \mathrm{CO}_{3}\right)$. The excess $\mathrm{KOH}$ was titrated with a standard hydrochloric acid $(\mathrm{HCl})$ solution $(0.1 \mathrm{M})$ using phenolphthalein as the indicator.

In a typical titration measurement, about four to five grams of liquid sample was withdrawn from the equilibrium cell and placed in a vessel containing an excess amount of $\mathrm{KOH}$ solution $(0.1 \mathrm{M})$. An excess amount of $\mathrm{BaCl}_{2}$ solution or solid (above five times more than the required equivalent molar amount) was added to the solution. The solution was stirred for 5 minutes, and then several drops of phenolphthalein were added to the solution as a color indicator. The titration was performed using standard $\mathrm{HCl}(0.1 \mathrm{M})$ until the color of the solution changed from fuchsia (red) to colorless. The volume of the added $\mathrm{HCl}$ was recorded and used for calculation of the concentration of $\mathrm{KHCO}_{3}$. The concentration of $\mathrm{K}_{2} \mathrm{CO}_{3}$ in the liquid sample at equilibrium was calculated from the known initial concentrations of $\mathrm{K}_{2} \mathrm{CO}_{3}$ and $\mathrm{KHCO}_{3}$ in the starting solution prior to the VLE test and the fact that two moles of $\mathrm{KHCO}_{3}$ form from one mole of $\mathrm{K}_{2} \mathrm{CO}_{3}$ during the $\mathrm{CO}_{2}$ absorption. The error of this method was estimated to be less than $2 \%$ according to experiments with standard solutions with known concentrations.

Analysis of gas composition. The pressure of water vapor was recorded by the HMT with accuracy of $\pm 1.0 \%$ relative humidity $(\mathrm{RH})$ at the measured temperatures.

The concentrations of the $\mathrm{CO}_{2}$ and $\mathrm{N}_{2}$ in the gas phase were analyzed by the GC equipped with a thermal conductivity detector (TCD). The GC parameters and experimental conditions used are listed in Table 2-1.

Table 2-1. GC parameters and experimental conditions

\begin{tabular}{|ll|}
\hline GC & Shimadzu GC-2014 \\
Column & $\mathrm{RT}^{\circledR}$-Q-Bond (fused Silica PLOT), $0.53 \mathrm{~mm} \times 30 \mathrm{~mm}$ with 20 \\
& $\mu \mathrm{m}$ film thickness \\
Carrier & Helium $5 \mathrm{ml} / \mathrm{min} @ 60^{\circ} \mathrm{C} / 140^{\circ} \mathrm{F}$, constant flow mode \\
Oven & $60^{\circ} \mathrm{C} / 140^{\circ} \mathrm{F}$ constant \\
Injection & $125^{\circ} \mathrm{C} / 257^{\circ} \mathrm{F}, 100 \mu 1$ syringe injection, direct mode \\
Detector & $\mathrm{TCD}$ and preheat at $150^{\circ} \mathrm{C} / 302^{\circ} \mathrm{F}$ \\
\hline
\end{tabular}

Three standard gas mixtures containing $98 \% / 2 \%, 90 \% / 10 \%$, and $50 \% / 50 \%$ (in volume) $\mathrm{N}_{2} / \mathrm{CO}_{2}$ were analyzed for GC calibration, as shown in Figure 2-2. 

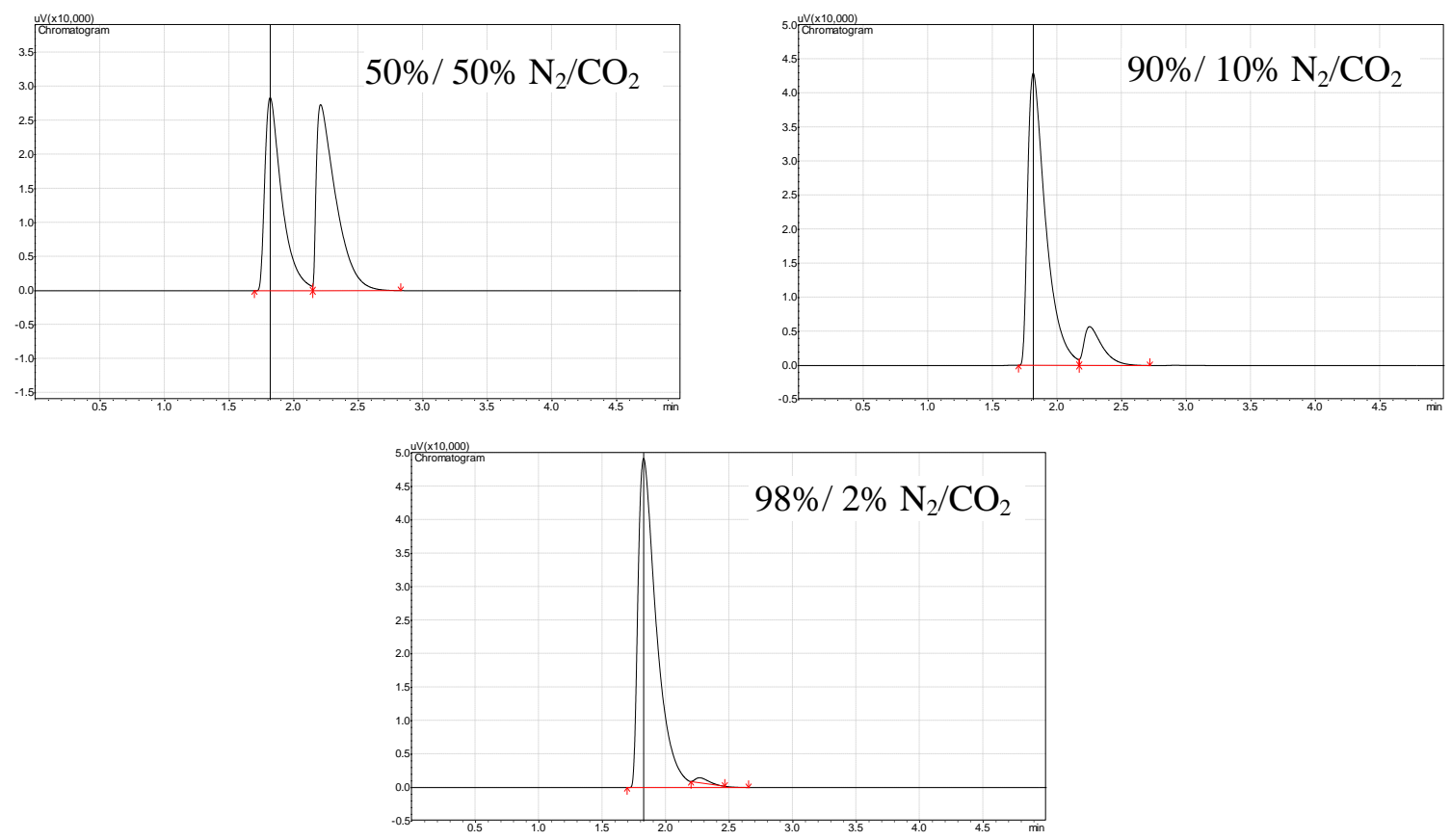

Figure 2-2. Chromatographs of standard gases for GC calibration.

The first and second peaks correspond to the $\mathrm{N}_{2}$ and $\mathrm{CO}_{2}$ gas components, respectively. The ratios of the peak areas of $\mathrm{N}_{2}$ and $\mathrm{CO}_{2}$ were calibrated with the standard $\mathrm{CO}_{2} / \mathrm{N}_{2}$ gases and were used to determine the concentrations of the $\mathrm{N}_{2}$ and $\mathrm{CO}_{2}$ gas components in the gas samples. The $\mathrm{GC}$ can measure the partial pressure of $\mathrm{CO}_{2}$ with an accuracy and reproducibility of $\pm 0.069 \mathrm{kPa}$ $( \pm 0.01$ psia).

Measurement of water vapor pressure. A humidity and temperature transducer (HMT338, Vaisala Inc.) was used to measure the water vapor pressure of the gas stream. The accuracy and reliability of the HMT instrument was validated by measuring the water vapor pressure of pure water and standard salt solutions, e.g., the saturated $\mathrm{K}_{2} \mathrm{CO}_{3}$ and $\mathrm{KCl}$ aqueous solutions with known relative humidity data at different temperatures. Pure nitrogen, circulated by a pump within the VLE cell at atmospheric pressure was used as a carrying gas. The water vapor pressures measured were in good agreement with those in the literature ${ }^{[2]}$ for the humidity calibration, as shown in Figure 2-3. The maximum relative error is less than $4 \%$. 


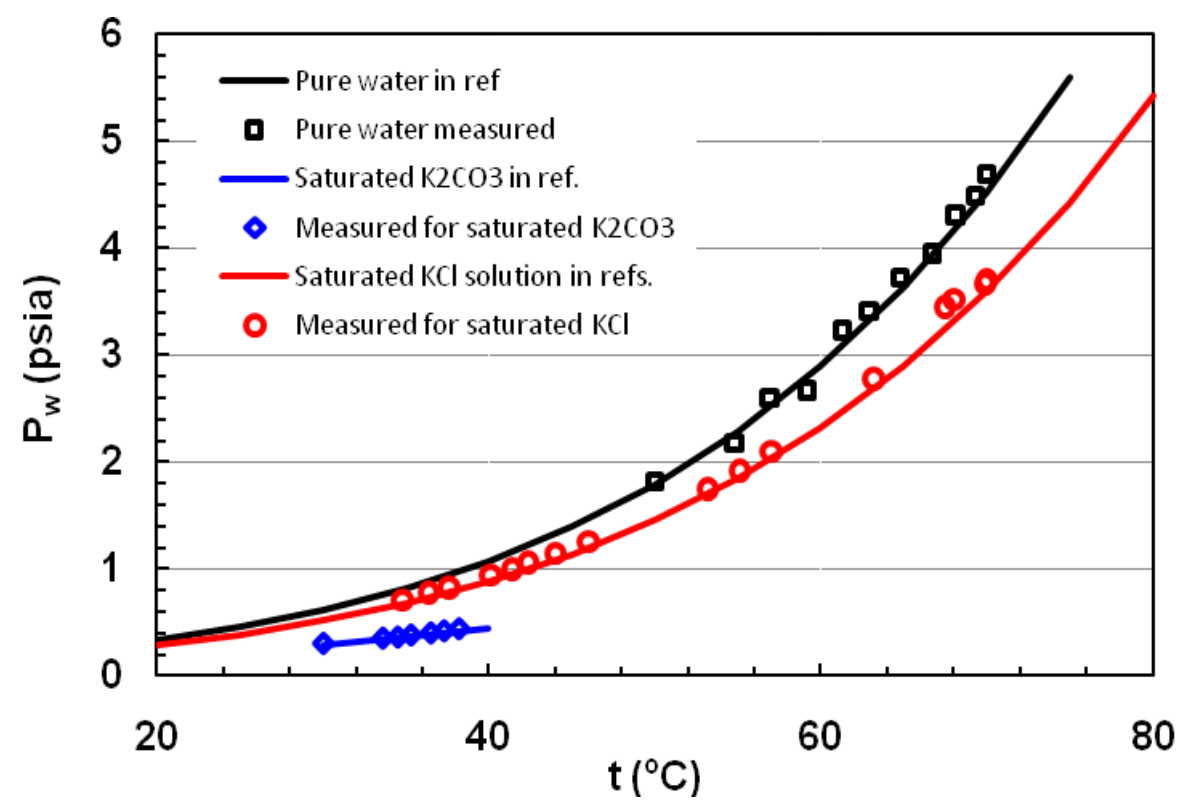

Figure 2-3. Comparison of water vapor saturation pressure measured by the HMT 338 with those in the literature for pure water and two standard saturated salt solutions.

\subsection{Results and discussion}

The VLE data for the $\mathrm{CO}_{2}-\mathrm{PC}$ and $\mathrm{CO}_{2}$-PC-additive systems are necessary for screening of additives and the design and optimization of the IVCAP. Previous research in the literature had reported VLE data for PC systems at temperatures above $70^{\circ} \mathrm{C}\left(158^{\circ} \mathrm{F}\right) .{ }^{[3]}$ However, VLE data for PC solutions at the low to moderate temperatures (less than $70^{\circ} \mathrm{C} / 158^{\circ} \mathrm{F}$ ) expected in the IVCAP were lacking. In particular, data for the $\mathrm{CO}_{2}$ in $\mathrm{PC}$ solutions with additives are seldom available in the literature.

\subsubsection{VLE measurements of $\mathrm{CO}_{2}$ in $\mathrm{PC}$ solutions without additives}

The measurements were performed for $\mathrm{CO}_{2}$ in the $20 \mathrm{wt} \% \mathrm{PC}$ solution. Figure 2-4 presents the $\mathrm{S}$-shaped VLE curves measured at 50 and $70^{\circ} \mathrm{C}\left(122\right.$ and $\left.158^{\circ} \mathrm{F}\right)$. The equilibrium $\mathrm{CO}_{2}$ pressures are plotted at various Carbonate To Bicarbonate (CTB) conversion rates for the $20 \mathrm{wt} \% \mathrm{PC}$ solution. The $\mathrm{CO}_{2}$ partial pressure approaches zero at a CTB conversion rate of zero and becomes very large at near $100 \%$ CTB. Experiments were performed in the range of CTB conversion rates between $10 \%$ and $70 \%$ considered applicable to the IVCAP.

Our VLE measurements were compared to those at $70^{\circ} \mathrm{C}\left(158^{\circ} \mathrm{F}\right)$ reported by Tosh et al..$^{[3]}$ and to the curves modeled at $50^{\circ} \mathrm{C}$ and $70^{\circ} \mathrm{C}\left(122\right.$ and $\left.158^{\circ} \mathrm{F}\right)$ using CHEMCAD. The modeled curves drawn by CHEMCAD at $50^{\circ} \mathrm{C}\left(122^{\circ} \mathrm{F}\right)$ were compared with our measured values, because such data are not available in the literature. There was good agreement between the curves drawn by the CHEMCAD model, the literature data and our measurements at $\geq 70^{\circ} \mathrm{C} / 158^{\circ} \mathrm{F}(< \pm 20 \%$ except one data point with the lowest $\mathrm{CO}_{2}$ partial pressure). It should be noted that when the level of $\mathrm{CO}_{2}$ partial pressure is low, a small difference between the measured and literature/modeled data could result in a very large relative error. The experimental system and 
test method were thus considered validated and were used for the VLE measurements for the $\mathrm{CO}_{2}$-PC-additve system.

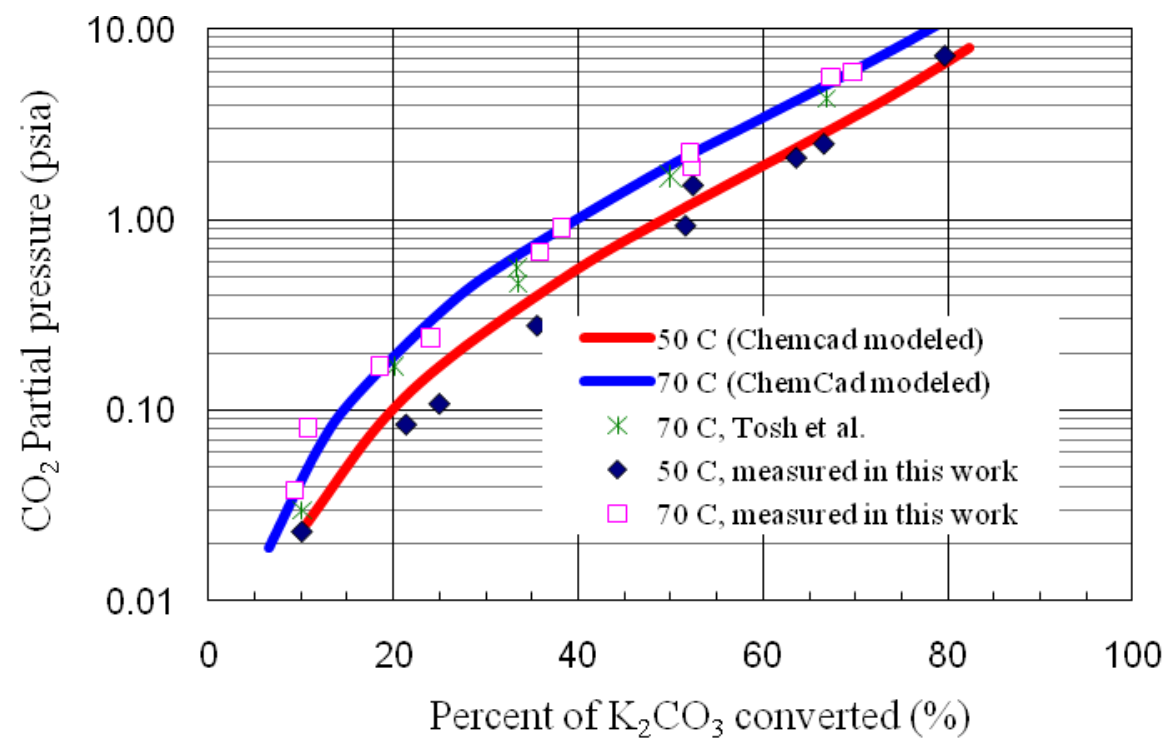

Figure 2-4. Equilibrium vapor pressure of $\mathrm{CO}_{2}$ over the $20 \mathrm{wt} \% \mathrm{PC}$ obtained from this study, literature, and CHEMCAD modeling.

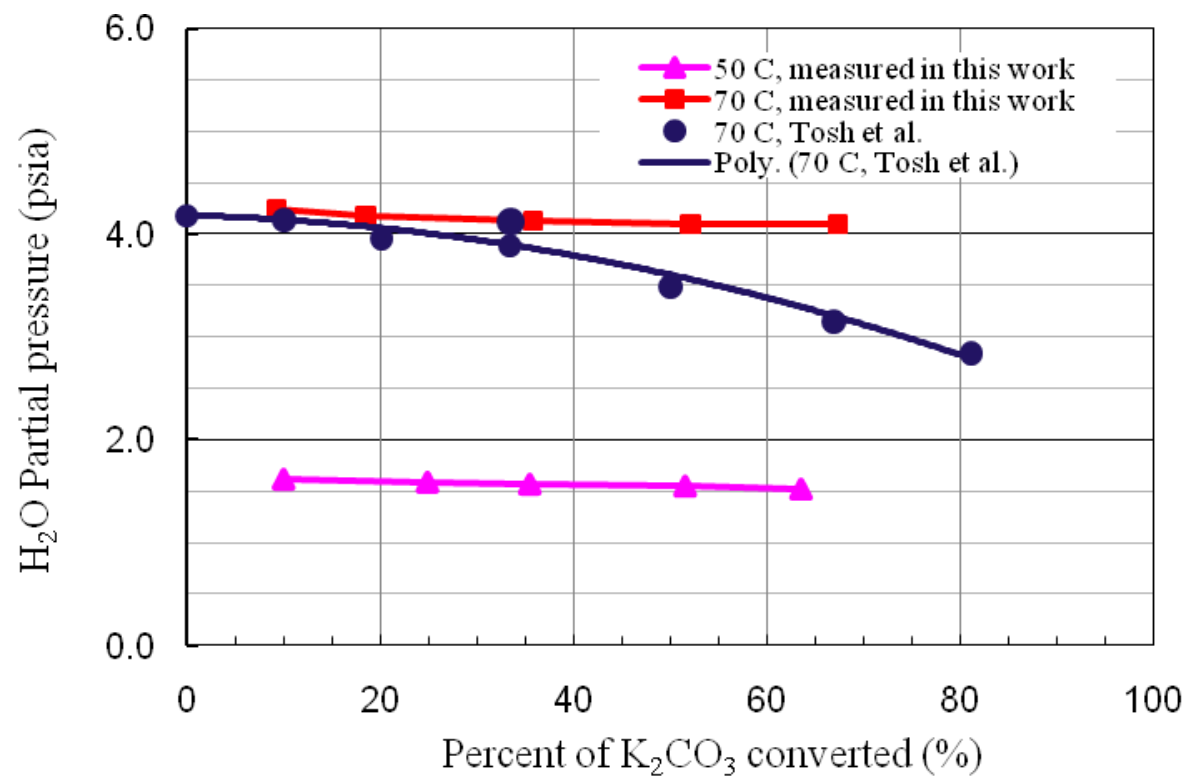

Figure 2-5. Equilibrium pressure of water vapor over the $20 \mathrm{wt} \%$ PC solution measured in this study and reported by Tosh et al. (1959).

The measured water vapor saturation pressures $\left(P_{w}\right)$ over the $20 \mathrm{wt} \%$ PC solution at various CTB conversion rates at 50 and $70^{\circ} \mathrm{C}\left(122\right.$ and $\left.158^{\circ} \mathrm{F}\right)$ are shown in Figure 2-5 along with those at $70^{\circ} \mathrm{C}\left(158^{\circ} \mathrm{F}\right)$ reported by Tosh et al ${ }^{[3]}$. At both temperatures, the water vapor pressure, $P_{w}$, slightly decreases with increasing CTB conversion rate. This tendency is similar to that reported by Tosh at $70^{\circ} \mathrm{C}\left(158^{\circ} \mathrm{F}\right)$ over the investigated CTB conversion range. However, the $P_{w}$ value 
decreases less significantly with increasing CTB conversion rate. Larger deviations were observed between our measured data and those obtained by Tosh et al. at conversion rates higher than $30 \%$.

\subsubsection{VLE measurements of $\mathrm{CO}_{2}$ in $\mathrm{PC}$ solutions with additives}

\subsubsection{Screening of additives}

Several additives, including inorganic salts and glycols, were examined to reduce the water vapor saturation pressure of the PC solution at $70^{\circ} \mathrm{C}\left(158^{\circ} \mathrm{F}\right)$. For these experiments, the stirred cell system was evacuated to a desired level and allowed to stabilize for equilibrium while the liquid phase was stirred at $450 \mathrm{rpm}$. The total equilibrium pressure $\left(P_{t}\right)$ was recorded, which represents the sum of the equilibrium vapor pressures of $\mathrm{CO}_{2}\left(P_{\mathrm{CO} 2}\right)$ and water $\left(P_{w}\right) . P_{w}$ was estimated by assuming $P_{\mathrm{CO}}$ is equal to that over the $20 \% \mathrm{PC}$ solution without an additive in the initial screening study.

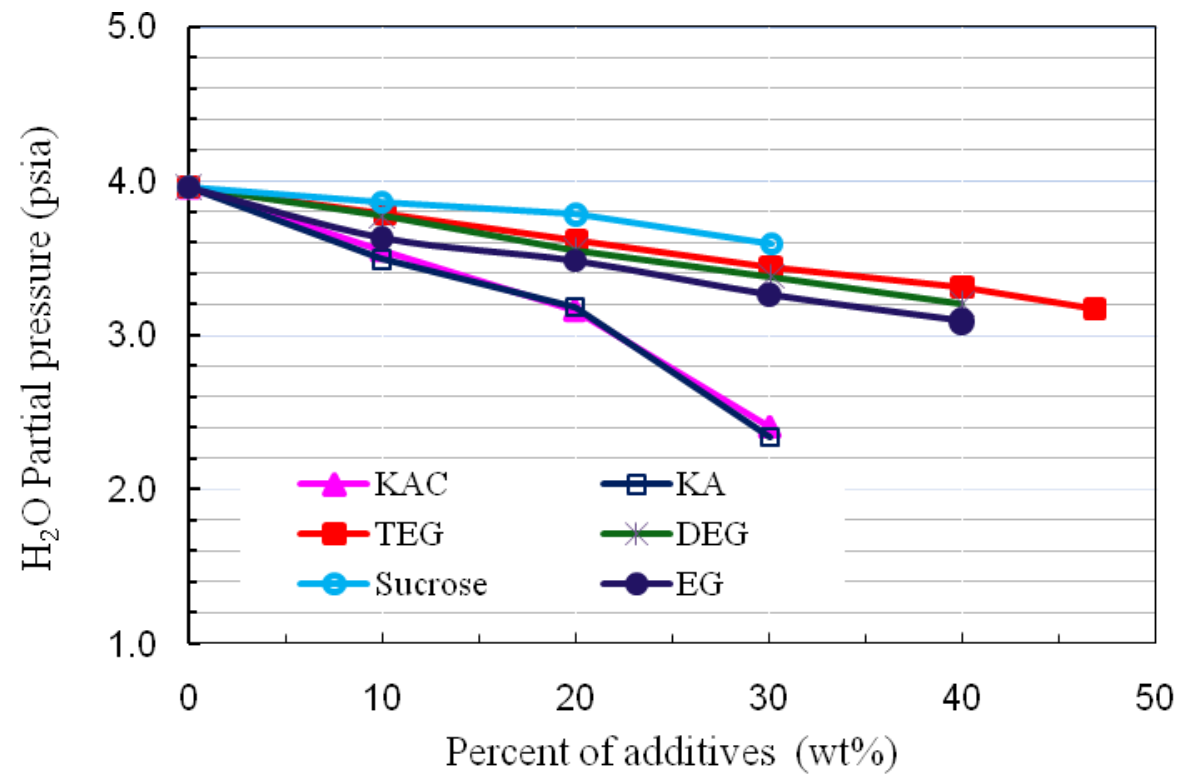

Figure 2-6. Equilibrium water vapor pressure over the PC20-20 solution with different additives at $70^{\circ} \mathrm{C}$.

The tested additives included potassium acetate (KAc), potassium formate (KA), triethylene glycol (TEG), diethylene glycol (DEG), ethylene glycol (EG), and sucrose. These additives not only potentially reduce the water vapor pressure, but also possess good chemical and thermal stability, high solubility, and low volatility under typical IVCAP operating conditions. Figure 2-6 shows the partial pressures of water vapor over the PC20-20 solution with the additives at various concentrations. Both KAc and KA substantially reduced the water vapor pressure over the PC solution. With $20 \mathrm{wt} \%$ of either KAc or KA present, the $P_{w}$ was lowered from 27.3 to $21.8 \mathrm{kPa}$ (3.96 to 3.16 psia, reduced by $20.2 \%$ ); with $30 \mathrm{wt} \%$ present, the $P_{w}$ dropped to $16.5 \mathrm{kPa}$ (2.4 psia, reduced by 39.4\%). Sucrose was not an effective additive. The various glycols only mildly reduced the water vapor pressure over the PC solution compared to KAc and KA. For example, at a $20 \mathrm{wt} \%$ concentration of EG in the PC solution, the $P_{w}$ was lowered from 27.3 to $21.8 \mathrm{kPa}$ (3.96 to $3.48 \mathrm{psia}$, reduced by $12.1 \%$ ); with a $30 \mathrm{wt} \%$ concentration, the $P_{w}$ dropped to 
$22.5 \mathrm{kPa}$ (3.26 psia, reduced by 17.7\%). The extent of lowering of the $P_{w}$ also depended on the CTB conversion rate of the PC solution.

From the screening studies, three additives were selected for further VLE measurements: KAc, $\mathrm{KA}$, and EG.

\subsubsection{VLE measurements of $\mathrm{CO}_{2}$-PC solutions with selected additives}

The measured water vapor pressures over the $20 \mathrm{wt} \%$ PC solution with KAc (20 wt $\%)$, KA (20 $\mathrm{wt} \%)$, and EG $(30 \mathrm{wt} \%)$ at 50 and $70^{\circ} \mathrm{C}\left(122\right.$ and $\left.158{ }^{\circ} \mathrm{F}\right)$ are shown in Figure 2-7. For the 20 wt $\%$ KAc-PC solution at $70^{\circ} \mathrm{C}\left(158^{\circ} \mathrm{F}\right)$, the $P_{w}$ increased slightly at 20 to $30 \% \mathrm{CTB}$ conversion and then decreased to a constant level. Addition of $20 \mathrm{wt} \% \mathrm{KAc}$ or $20 \mathrm{wt} \% \mathrm{KA}$ to the PC solution reduced the $P_{w}$ by about $20 \%$ at $70^{\circ} \mathrm{C} / 158^{\circ} \mathrm{F}$ (Figure 2-8). The $P_{w}$ decreased slightly with increasing CBT conversion rate for the $30 \mathrm{wt} \%$ EG-PC solution.

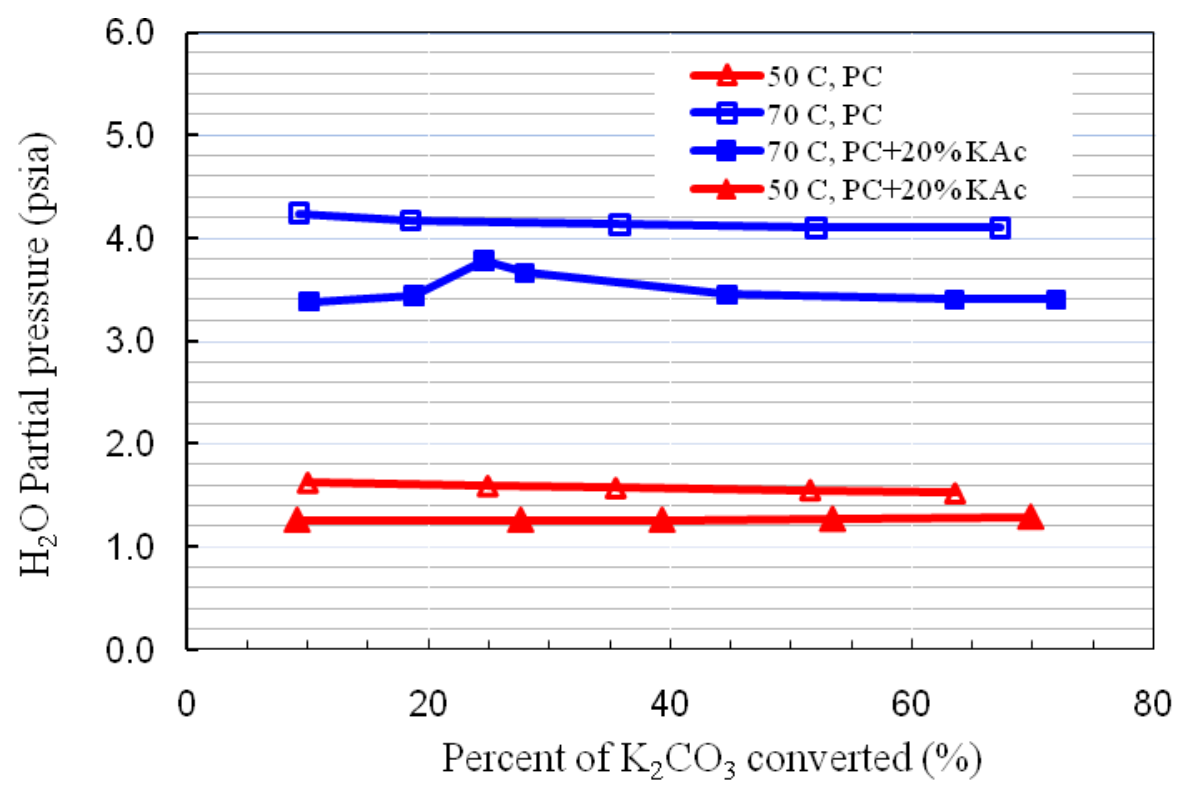

(a) $\mathrm{PC}+20 \% \mathrm{KAc}$ 


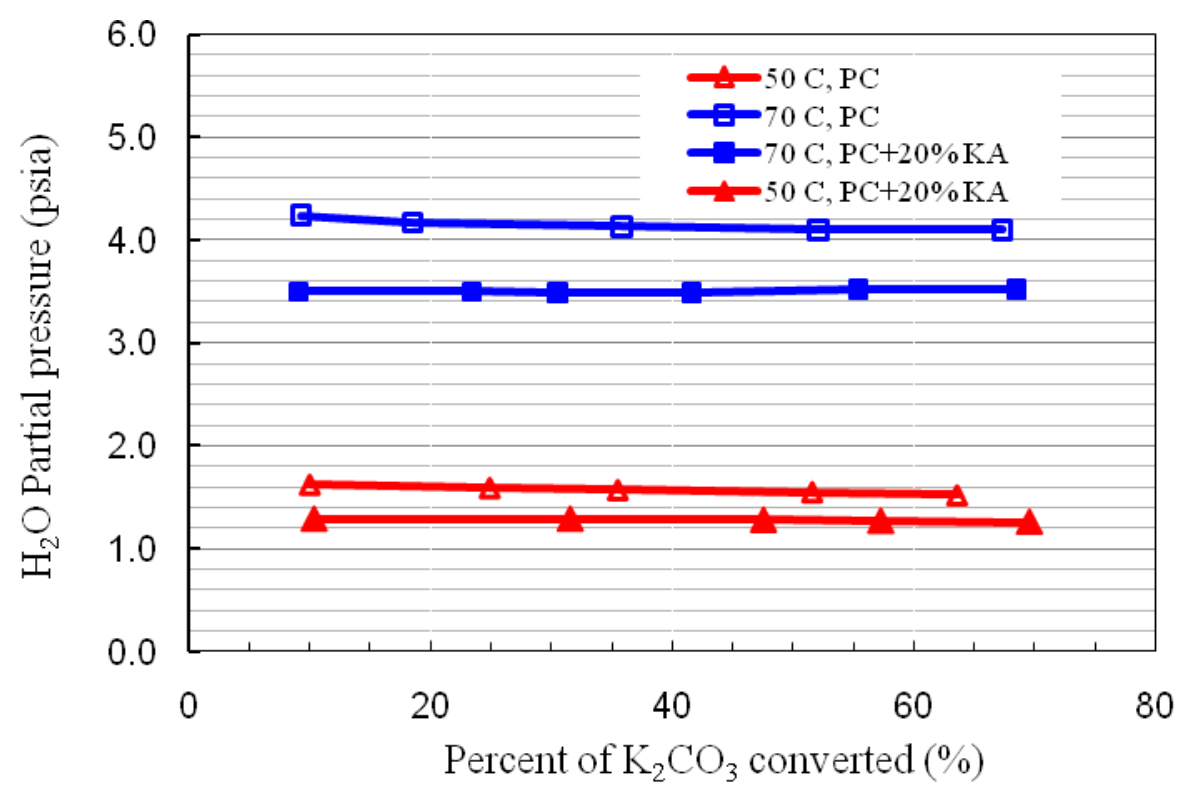

(b) $\mathrm{PC}+20 \% \mathrm{KA}$

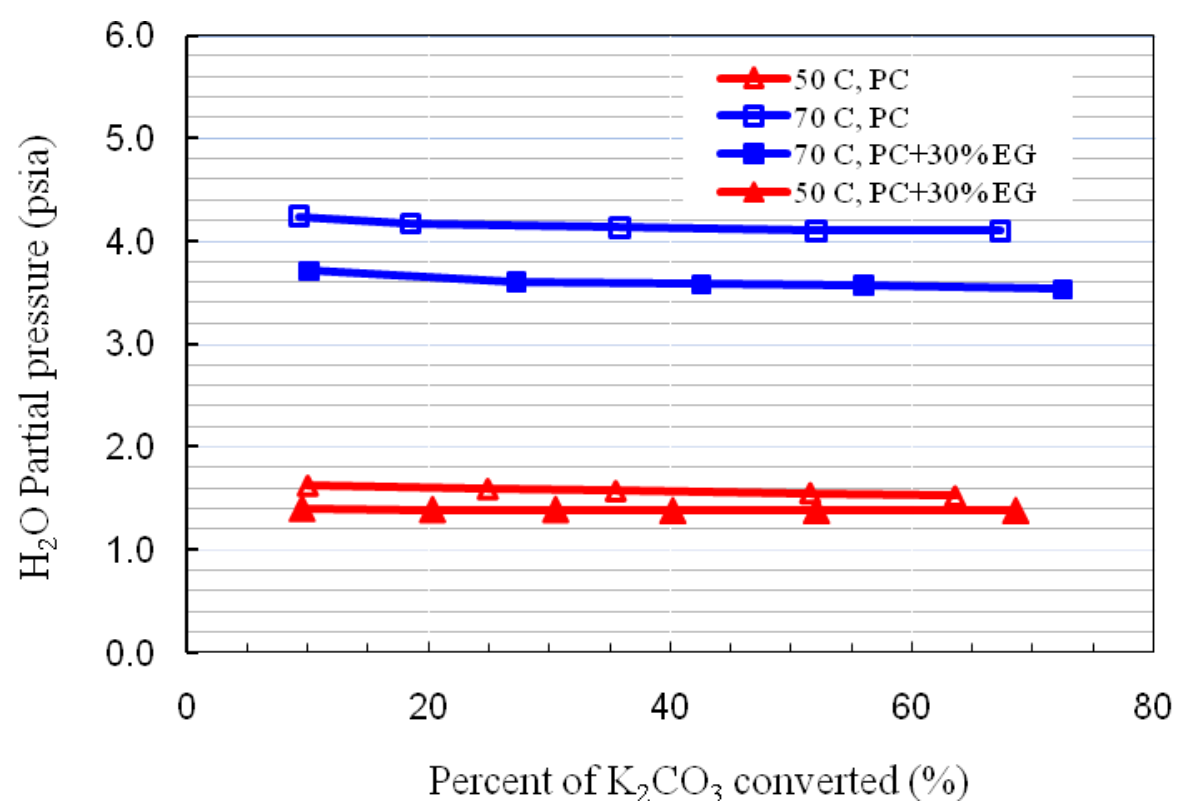

(c) $\mathrm{PC}+30 \% \mathrm{EG}$

Figure 2-7. Equilibrium water vapor pressure over the $20 \mathrm{wt} \% \mathrm{PC}$ with additives at $50^{\circ} \mathrm{C}$ and $70^{\circ} \mathrm{C}$. 


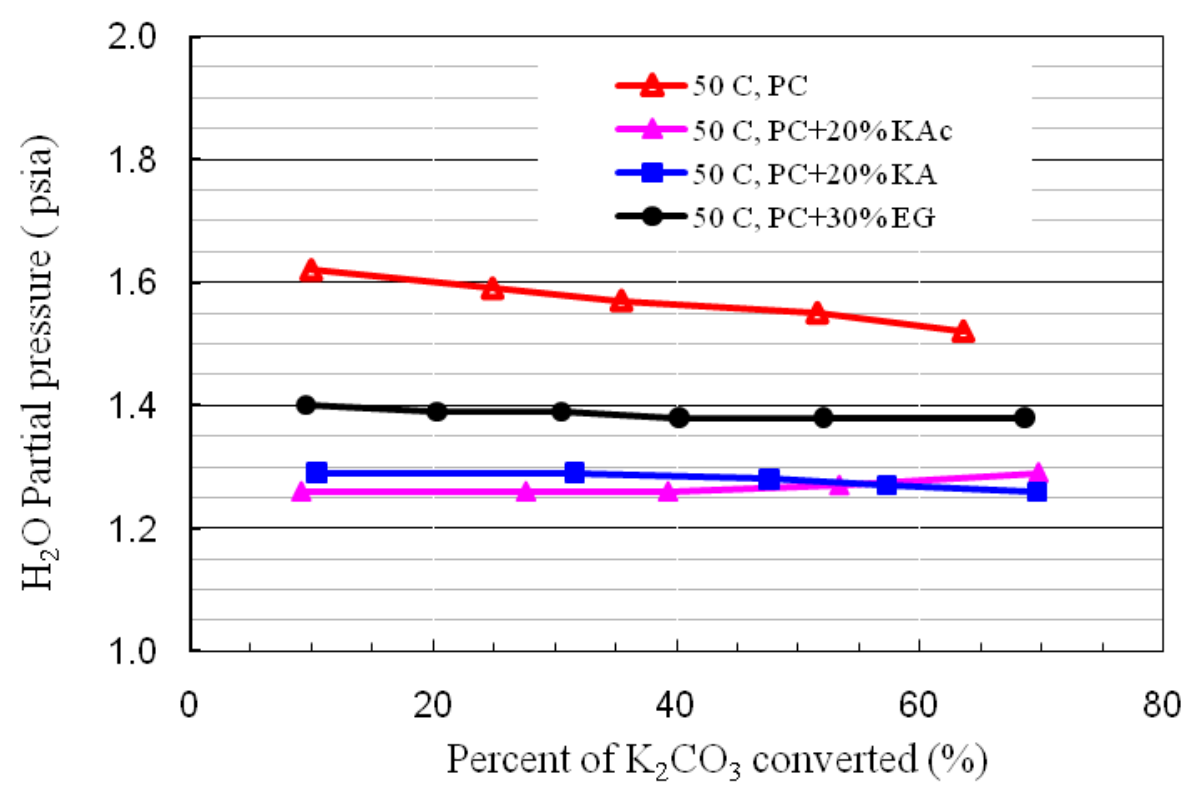

(a) At $50^{\circ} \mathrm{C}$

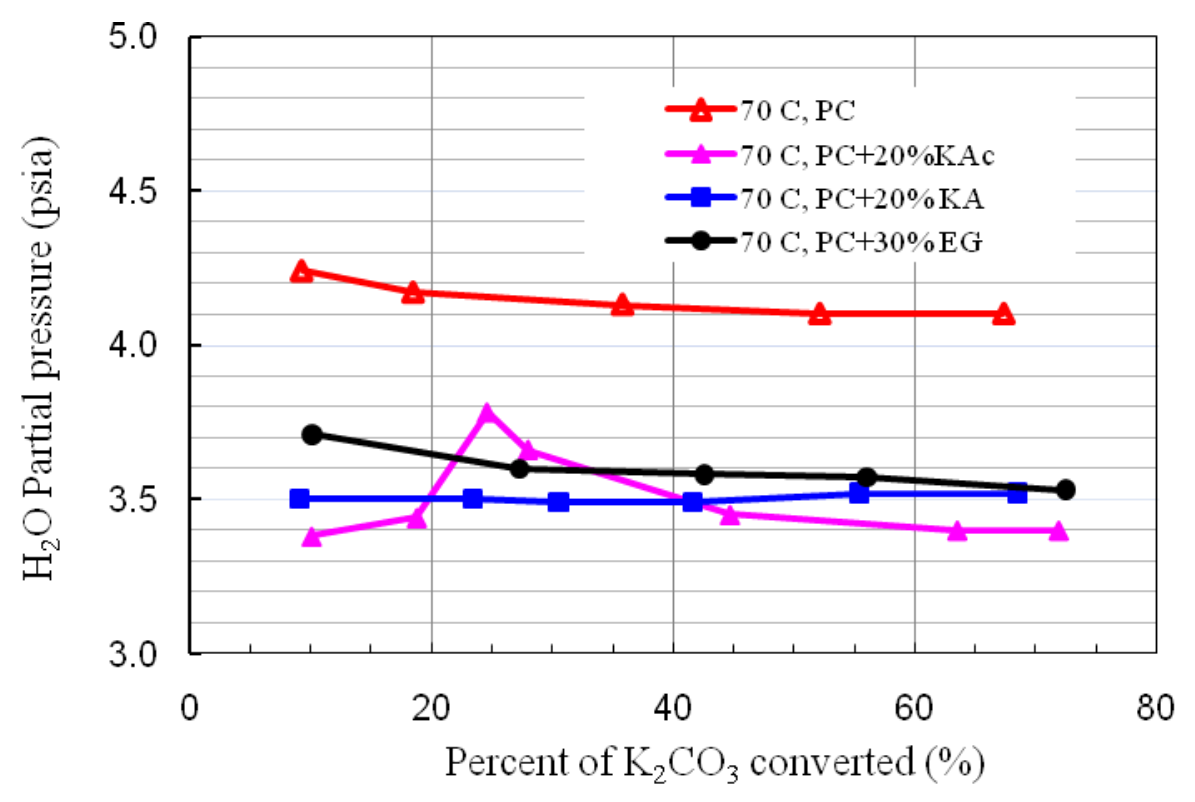

(b) At $70^{\circ} \mathrm{C}$

Figure 2-8. Comparison of equilibrium water vapor pressures over the $20 \mathrm{wt} \% \mathrm{PC}$ with additives.

The impacts of the additives in the PC solution on the equilibrium $\mathrm{CO}_{2}$ pressures are shown in Figure 2-9. In addition to lowering the equilibrium $P_{w}$, the three additives tested also increased the equilibrium solubility of $\mathrm{CO}_{2}$ into the $\mathrm{PC}$ solution to varying degrees. In the presence of the additives, at a given $\mathrm{CO}_{2}$ pressure level, a higher CTB conversion rate was observed; or, for a given $\mathrm{CTB}$ conversion rate, the equilibrium $\mathrm{CO}_{2}$ pressure was lowered. From a practical viewpoint, these results indicate that the selected additives can significantly reduce the water vapor pressures of the $\mathrm{PC}$ solutions and shift the $\mathrm{CO}_{2}-\mathrm{PC}$ equilibrium to higher CTB conversion rates, which favor $\mathrm{CO}_{2}$ absorption. In addition, a lower vacuum (or higher pressure) in the stripper could be favorably achieved due to this shift of the equilibrium CTB conversion rate. 
Because they both are salts of weak acids, $\mathrm{KAc}$ and $\mathrm{KA}$ promote the solubility of $\mathrm{CO}_{2}$ into the PC solution equally. EG may increase the solubility of $\mathrm{CO}_{2}$ into the PC solution as a physical solvent and thus it has a stronger effect on promoting $\mathrm{CO}_{2}$ solubility at $50^{\circ} \mathrm{C}\left(122^{\circ} \mathrm{F}\right)$ than at $70^{\circ} \mathrm{C}\left(158^{\circ} \mathrm{F}\right)$, because of its higher solubility at lower temperatures, as displayed in Figure 29(c).
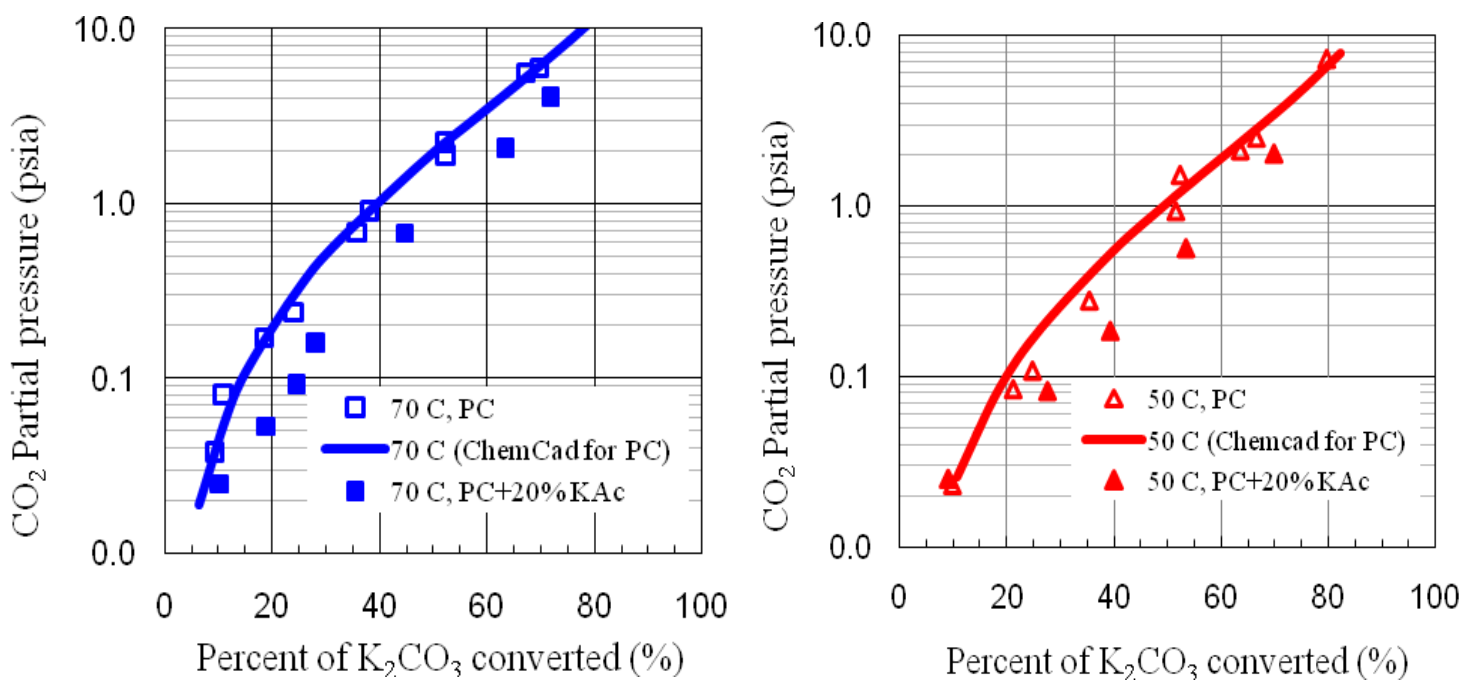

(a) $\mathrm{PC}+20 \mathrm{wt} \% \mathrm{KAc}$
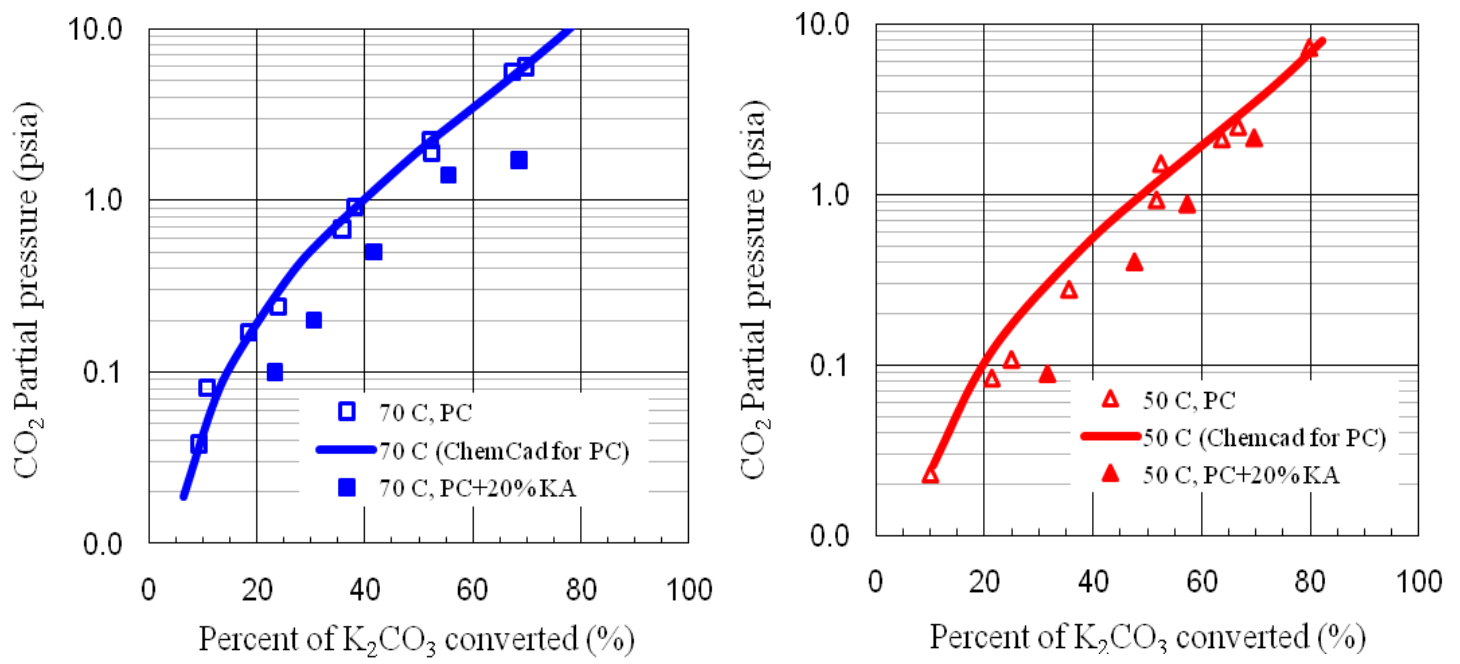

(b) $\mathrm{PC}+20 \mathrm{wt} \% \mathrm{KA}$ 

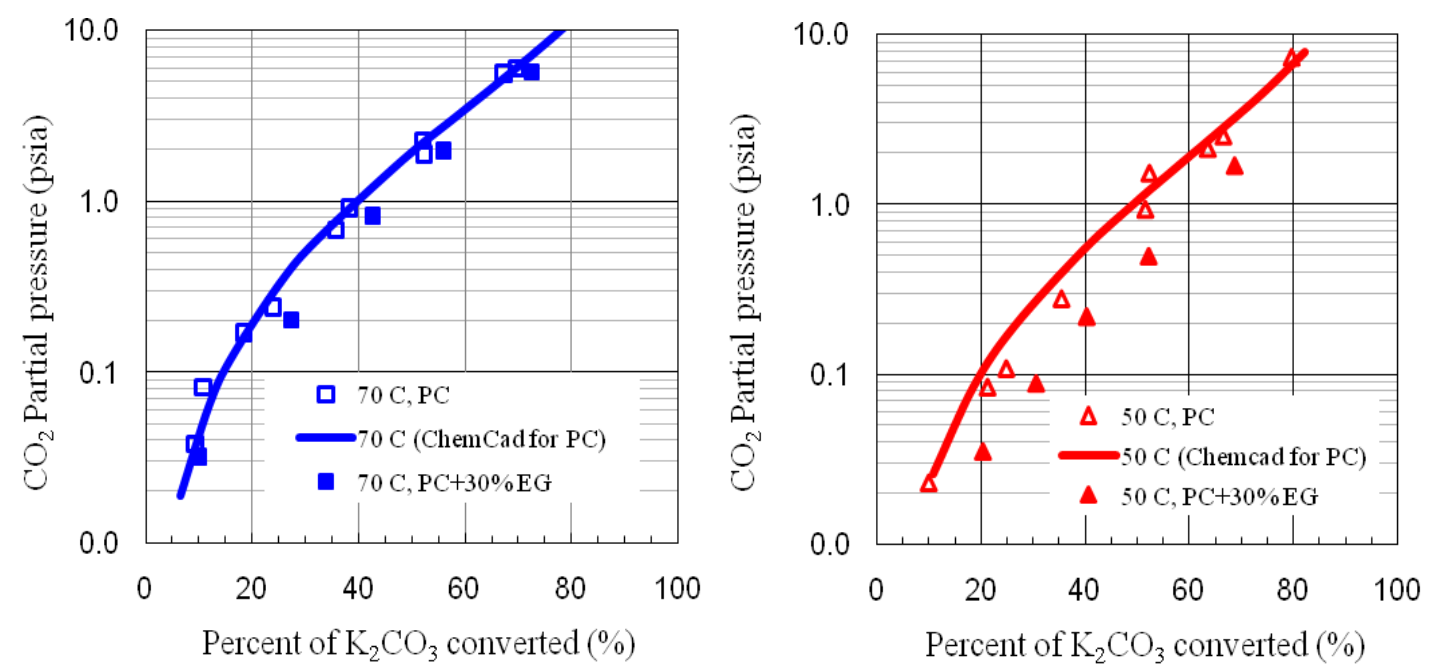

(c) $\mathrm{PC}+30 \mathrm{wt} \% \mathrm{EG}$

Figure 2-9. Equilibrium vapor pressure of $\mathrm{CO}_{2}$ over the $20 \mathrm{wt} \% \mathrm{PC}$ with additives.

\subsection{Summary}

VLE measurements were performed for $\mathrm{CO}_{2}$ in the $20 \mathrm{wt} \% \mathrm{PC}$ solution without an additive at 50 and $70^{\circ} \mathrm{C}\left(122\right.$ and $\left.158^{\circ} \mathrm{F}\right)$. The results were compared to those reported in the literature and modeled by CHEMCAD software. The comparison showed that our experimental data agreed well with those in the literature and the data modeled by CHEMCAD. Thus, our experimental system and test method were validated.

Through a series of screening tests, KAc, KA, and EG were identified as the additives best suited to reduce the water vapor pressure over the PC solution. VLE results showed that adding $20 \mathrm{wt} \%$ KAc or KA reduced the water vapor saturation pressure over the $20 \mathrm{wt} \% \mathrm{PC}$ by about $20 \%$ at $70^{\circ} \mathrm{C}\left(158^{\circ} \mathrm{F}\right)$ and by nearly $40 \%$ at $50^{\circ} \mathrm{C}\left(122^{\circ} \mathrm{F}\right)$. The three additives also enhanced the solubility of $\mathrm{CO}_{2}$ into the PC. A preliminary thermodynamic analysis showed that the volatilities of the acid forms (HAc and HA) of these additives in the $\mathrm{PC}$ are negligible ( $<1 \mathrm{ppmv}$ at $\left.70^{\circ} \mathrm{C} / 158^{\circ} \mathrm{F}\right)$.

\section{References}

1. Shen K.P, Li M.H. Solubility of carbon dioxide in aqueous mixtures of monoethanolamine with methyldiethanolamine, Journal of Chemical \& Engineering Data 1992; 37:96-100.

2. Vapor pressure of saturated salt solutions, in Section 6: Fluid properties, CRC Handbook of Chemistry and Physics, editors: W. M. "Mickey" Haynes et al., 91st Edition, Internet Version 2011.

3. Tosh J.S., Field J.H., Benson H.E., Haynes W.P.. Equilibrium study of the system potassium carbonate, potassium bicarbonate, carbon dioxide, and water. Bureau of Mines, Report of Investigations, 1959; No. 5484: pp.23. 


\section{CHAPTER 3. KINETICS OF $\mathrm{CO}_{2}$ ABSORPTION INTO $\mathrm{K}_{2} \mathrm{CO}_{3}$ SOLUTIONS}

\section{PART 3A. KINETICS OF $\mathrm{CO}_{2}$ ABSORPTION INTO $\mathrm{K}_{2} \mathrm{CO}_{3}$ SOLUTION WITHOUT A CATALYST}

\section{A.1 Introduction}

The IVCAP technology uses an aqueous potassium carbonate (PC) solution as a solvent for $\mathrm{CO}_{2}$ absorption. Knowledge of the kinetics of $\mathrm{CO}_{2}$ absorption into the PC solution is necessary to provide a basis for the design of absorption columns and for studies of promoter/catalysts.

$\mathrm{CO}_{2}$ absorption into a $\mathrm{PC}$ solution follows the overall reaction:

$$
\mathrm{CO}_{2}+\mathrm{H}_{2} \mathrm{O}+\mathrm{K}_{2} \mathrm{CO}_{3} \Leftrightarrow 2 \mathrm{KHCO}_{3}
$$

The reaction consists of a sequence of elementary steps: ${ }^{[1-6]}$

$$
\begin{aligned}
& \mathrm{CO}_{2}+\mathrm{H}_{2} \mathrm{O} \Leftrightarrow \mathrm{HCO}_{3}^{-}+H^{-} \\
& \mathrm{HCO}_{3}^{-} \stackrel{\mathrm{K}_{2}}{\Leftrightarrow} \mathrm{H}^{+}+\mathrm{CO}_{3}^{2-} \\
& \mathrm{CO}_{2}+\mathrm{OH}^{-} \Leftrightarrow \mathrm{HCO}_{3}^{-} \\
& \mathrm{H}_{2} \mathrm{O} \Leftrightarrow \mathrm{K}_{W}
\end{aligned}
$$

Under some process conditions, the overall reaction rate is a pseudo-first order with respect to $\mathrm{CO}_{2}$ :

$$
r=-d\left[\mathrm{CO}_{2}\right] / d t=k_{o v} \times\left[\mathrm{CO}_{2}\right]
$$

The overall rate constant is expressed: ${ }^{[1,3,7,8]}$

$$
k_{o v}=k_{\mathrm{H}_{2} \mathrm{O}}+k_{\mathrm{OH}}\left[\mathrm{OH}^{-}\right]
$$

where $r$ is the rate of absorption, $k_{o v}\left(s^{-1}\right)$ is the overall first order rate constant, and $k_{H 2 O}\left(s^{-1}\right)$ and $k_{O H}\left(m^{3} \mathrm{kmol}^{-1} \mathrm{~s}^{-1}\right)$ are the rate constants for reactions (3A-R2) and (3A-R4). The value of $k_{H 2 O}$ is negligible (ranging between 0.02 and $0.0375 s^{-1}$ at $25-50^{\circ} \mathrm{C} / 77-122^{\circ} \mathrm{F}$ ) compared with the second term. ${ }^{[8-10]}$

Numerous researchers have measured the values of $k_{O^{-}}$using various techniques, but most of the reported values are those measured in dilution, or in low concentrations of alkaline solutions at temperatures between 20 and $50^{\circ} \mathrm{C}\left(68\right.$ and $\left.122^{\circ} \mathrm{F}\right) .{ }^{[11-18]}$ Since some factors, including temperature and ionic type and strength in solutions, significantly affect the values of $k_{O H}$, the reported values vary between $2 \times 10^{3}$ and $3 \times 10^{5} \mathrm{~m}^{3} \mathrm{kmol}^{-1} \mathrm{~s}^{-1} .{ }^{[4,5,8]}$

Pinsent et al. ${ }^{[11]}$ measured $k_{\mathrm{OH}^{-}}$using a rapid thermal method by mixing $\mathrm{CO}_{2}$ with concentrations of $\mathrm{NaOH}$ solution ranging from 0.005 to $0.05 \mathrm{M}$ at temperatures between 0 and $40^{\circ} \mathrm{C}\left(32\right.$ and $\left.104^{\circ} \mathrm{F}\right)$. They reported the following relationship for dilute solutions:

$$
\log k_{O H^{-}}^{\infty}=13.635-2895 / T
$$

They also reported the values of $k_{O H^{-}}$in $\mathrm{NaOH}$ solutions at ionic strengths up to $3.0 \mathrm{M} \mathrm{KCl}, 3.6$ $\mathrm{M} \mathrm{NaNO}_{3}$, and $1.0 \mathrm{M} \mathrm{Na}_{2} \mathrm{SO}_{4}$. 
Nijsing et al. ${ }^{[12]}$ investigated the kinetics of $\mathrm{CO}_{2}$ absorption into $2 \mathrm{M}$ caustic solutions at $20^{\circ} \mathrm{C}$ $\left(68^{\circ} \mathrm{F}\right)$ by a laminar jet and laminar falling film method. They proposed the following formula to describe the effect of different ionic species such as $\mathrm{K}^{+}, \mathrm{Na}^{+}$, or $\mathrm{Li}^{+}$and strengths in the solutions on the $k_{O H^{-}}$value:

$$
\log k_{\mathrm{OH}^{-}}=\log k_{\mathrm{OH}^{-}}^{\infty}+a I
$$

Astarita et al. ${ }^{[13,14]}$ measured absorption and desorption rates of $\mathrm{CO}_{2}$-hot carbonate solutions and interpreted the data using a film-theory model. They suggested that Eq. (3A-5) could be used at all ionic strengths of interest at temperatures between 0 and $110^{\circ} \mathrm{C}\left(32\right.$ and $\left.230^{\circ} \mathrm{F}\right)$ :

$$
\log k_{\mathrm{OH}^{-}}=13.635-2895 / T+0.08 I
$$

However, some researchers questioned the validity of Eq. (3A-5), because it does not consider the influence of ion-type on the value of $k_{\mathrm{OH}^{-}}{ }^{[15,17]}$

Pohorecki and Moniuk ${ }^{[15]}$ studied the effect of ion type on the $k_{O H^{-}}$value by measuring the rate of $\mathrm{CO}_{2}$ absorption into different aqueous solutions of $\mathrm{KOH}, \mathrm{NaOH}$, and $\mathrm{LiOH}$ containing neutral electrolytes (carbonates, chlorides, bromides, nitrates, and sulphates) using the laminar-jet technique. They proposed the following general correlations:

$$
\log k_{\mathrm{OH}^{-}}=\log k_{O H^{-}}^{\infty}+\sum b_{\text {ion }} I_{\text {ion }}
$$

and

$$
\log k_{O H^{-}}^{\infty}=11.916-2382 / T
$$

for $k_{O H^{-}}$at temperatures between 18 and $41^{\circ} \mathrm{C}\left(64.4\right.$ and $\left.105.8^{\circ} \mathrm{F}\right)$ and total ionic strength up to $4.0 \mathrm{kmol} / \mathrm{m}^{3}$, where the value of $b_{\text {ion }}$ depends on the type of ion species present. However, only nine ion species have known $b_{\text {ion }}$ values. The $b_{\text {ion }}$ for the $\mathrm{HCO}_{3}{ }^{-}$ion, an important ion species in carbonate solutions, is not known.

Kucha et al. ${ }^{[17]}$ reported that the influence of the different cations present in solution on the $k_{O H^{-}}$ cannot be neglected. They measured the reaction rate of $\mathrm{CO}_{2}$ absorption into aqueous $\mathrm{KOH}$ and $\mathrm{NaOH}$ solutions and found that the $\mathrm{KOH}_{\mathrm{OH}^{-}}$values were larger in solutions containing $\mathrm{K}^{+}$than those in solutions containing $\mathrm{Na}^{+}$when the other conditions such as the temperature and total ionic strength were equal. They used Eq. (3A-5) to derive the following empirical relationship:

$$
\log k_{O H^{-}}^{\infty}=13.513-2871 / T
$$

They also reported the ionic constants for $\mathrm{KOH}$ and $\mathrm{NaOH}$ solutions with ionic strengths up to $0.85 \mathrm{kmol} / \mathrm{m}^{3}$ and at temperatures ranging from 20 to $50^{\circ} \mathrm{C}\left(68\right.$ to $\left.122^{\circ} \mathrm{F}\right)$.

Knuutila et al. ${ }^{[18]}$ studied the kinetics of $\mathrm{CO}_{2}$ absorption into solutions of 5-30 wt $\% \mathrm{Na}_{2} \mathrm{CO}_{3}$ and $5-50 \mathrm{wt} \% \mathrm{~K}_{2} \mathrm{CO}_{3}$ at temperatures up to $70^{\circ} \mathrm{C}$ in a string of discs apparatus and obtained

$$
\log k_{\mathrm{OH}^{-}}^{\infty}=13.667-2905 / T
$$

They found that the difference between the concentration- and activity-based kinetic constants were small at low concentrations, but became more significant at higher concentrations. 
Haubrock et al. ${ }^{[19]}$ investigated the applicability of using activity instead of concentration to obtain an intrinsic rate constant $\left(k_{\mathrm{OH}^{-}}\right)$for a series of experiments measuring $\mathrm{CO}_{2}$ absorption into different aqueous $\mathrm{NaOH}(1,1.5,2.0 \mathrm{M})$-salt $(0.5$ and $1.5 \mathrm{M} \mathrm{LiCl}, \mathrm{NaCl}$ or $\mathrm{KCl})$ solutions at $25^{\circ} \mathrm{C}\left(77^{\circ} \mathrm{F}\right)$. They found that the concentration-based $k_{O H^{-}}$depended on both the counter-ion and the ionic strength of the solution because of the strong non-ideal behavior of various components in the solution. They incorporated an activity coefficient in the reaction rate expression and obtained an activity-based $k_{O H^{-}}$that was between 10,000 and $15,000 \mathrm{kmol}^{-1} \mathrm{~m}^{3} \mathrm{~s}^{-1}$ compared with the concentration-based $k_{O H^{-}}$between 7,000 and $34,000 \mathrm{kmol}^{-1} \mathrm{~m}^{3} \mathrm{~s}^{-1}$. They found that the influence of the ionic species and strength on the activity-based $k_{O_{H}}$ value was considerably reduced. However, this approach requires an appropriate equilibrium model to calculate the activity coefficient and thus is not practical.

It should be noted that reported $k_{\mathrm{OH}^{-}}$values in concentrated solutions are lacking, particularly for those in concentrated $\mathrm{K}_{2} \mathrm{CO}_{3}(\mathrm{PC})$ solutions at temperatures above $50^{\circ} \mathrm{C}\left(122^{\circ} \mathrm{F}\right)$. Accurate calculation of $k_{\mathrm{OH}^{-}}$values depends on numerous factors, including calculation of the [ $\left.\mathrm{OH}^{-}\right]$ concentration, solubility, diffusion coefficient of the absorbed gas in the solution, and the equilibrium constants required to calculate the concentrations of the related ions. These factors are complicated by the effects of the different ionic species and ionic strengths of the solutions.

In this study, we experimentally determined the $k_{O H}$ values in PC solutions with concentrations between 5 and $50 \%$ and at temperatures between 25 and $80^{\circ} \mathrm{C}\left(77\right.$ and $\left.176^{\circ} \mathrm{F}\right)$ in a stirred tank reactor (STR) cell. The $k_{O H}^{\infty}$ values we obtained by the extrapolation method were compared with those reported in the literature in order to validate the method. We also investigated the effects of the $\mathrm{CO}_{2}$ loading of the $\mathrm{PC}$ solution (denoted by the conversion rate of $\mathrm{K}_{2} \mathrm{CO}_{3}$ into $\mathrm{KHCO}_{3}(\mathrm{CTB})$ by the absorption of $\mathrm{CO}_{2}$ ). This information is important for understanding the change in the $k_{O H}$ profile along an absorption column as the $\mathrm{CO}_{2}$ absorption reaction proceeds.

\section{A.2 Experimental method}

Materials. The reagents potassium carbonate (ACS reagent $\geq 99.0 \%$, Sigma-Aldrich), potassium bicarbonate ( $\geq 99.5 \%$, Sigma-Aldrich), and $\mathrm{CO}_{2}$ gas $(99.99 \%$ purity, S.J Smith) were used as received.

Experimental setup and procedure. A schematic diagram of the experimental apparatus used to measure the rate of $\mathrm{CO}_{2}$ absorption into the PC solutions is shown in Figure 3A-1. It consists of a stirred tank reactor (STR), a gas supply/control unit, and data acquisition instrumentation. The reactor was a Plexiglas vessel $10 \mathrm{~cm}$ (3.94 inch) in internal diameter and $17 \mathrm{~cm}$ (6.69 inch) in height. Four symmetrical baffles, each $1.25 \mathrm{~cm}(0.49 \mathrm{inch})$ in width, were attached inside the vessel to prevent a stirring vortex in the liquid phase. A magnetic stirrer (Isotemp, Fisher Scientific) with a $5 \mathrm{~cm}$ ( 2 inch) Telfon stir bar provided mixing at controllable speeds in the liquid phase. A stirrer driven by an external motor (Caframo, model BCD2002) via a magnetic coupling provided mixing at 0 to $3,000 \mathrm{rpm}$ in the gas-phase. The temperature of the reactor was controlled by a water jacket with water circulating through a temperature-controlled thermostatic water bath (Neslab, model RTE-110). The pressure of the gas stream in the reactor was controlled/measured by a pressure transducer (Alicat Scientific, PC-30PSIA-D/5P). The 
temperature in the liquid phase was measured by a thermocouple (Omega, Type K, model KMQSS-125-G-6). A vacuum pump (Dekker, RVL002H-01) provided the required initial vacuum level for the system. The pressure and temperature readouts were monitored and recorded by a computer.

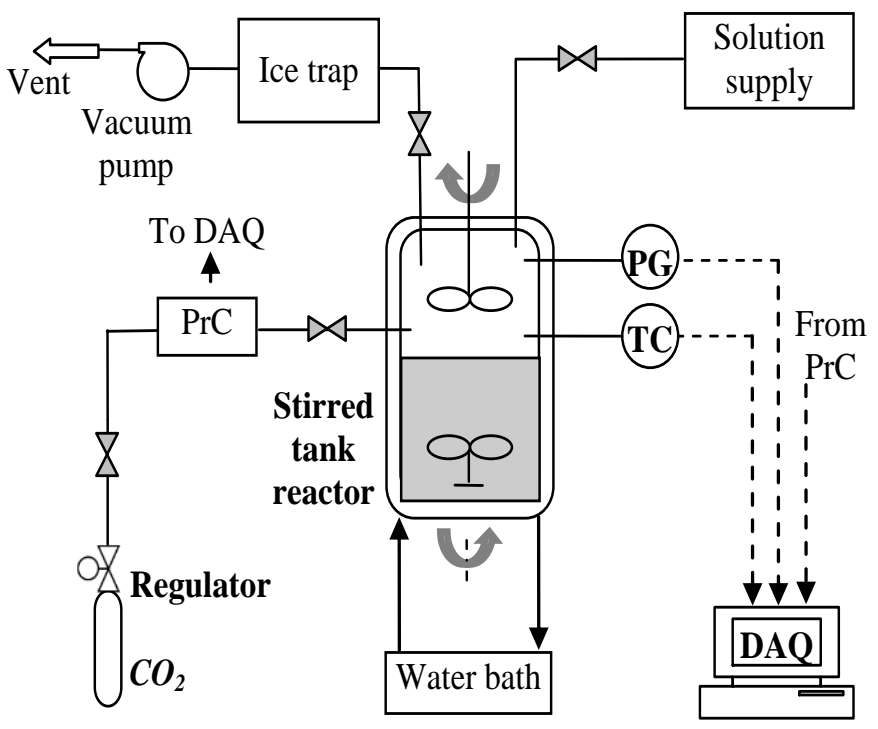

(PrC: Pressure controller; TC: Thermal couple; PG: pressure gauge DAQ: Data acquisition)

Figure 3A-1. Schematic diagram of a STR experimental setup.

The rates of $\mathrm{CO}_{2}$ absorption were measured in the batch mode with respect to both the gas- and liquid-phase. In a typical experiment, $800 \mathrm{ml}$ of the desired PC solution was fed into the reactor. The system was evacuated to a desired pressure level to purge residual air and other undesirable impurity gases, if any, and allowed to stabilize for an equilibrium state after the vacuum was turned off. The initial equilibrium pressure $\left(P_{i n i}\right)$ was recorded for calculation of the equilibrium water vapor pressure $\left(P_{w}\right)$ by deducting the $\mathrm{P}_{i n i, C O 2}$ term $\left(P_{w}=P_{i n i}-\mathrm{P}_{i n i, C O 2}\right)$. The $\mathrm{P}_{i n i, C O 2}$ value was obtained from the data in the literature. Then a pure $\mathrm{CO}_{2}$ gas stream was introduced to the reactor within a short time (about two seconds) to a predetermined pressure, and immediately the stirrer in the liquid phase $(450 \mathrm{rpm})$ and the propeller $(300 \mathrm{rpm})$ in the gas phase were turned on. The stirring speeds selected ensured homogeneous mixing in the liquid and gas phases and maintained a flat gas-liquid interface. The change in the total gas pressure was recorded, from which, the $\mathrm{CO}_{2}$ partial pressures were calculated by deducting the $P_{w}$ term $\left(\mathrm{P}_{\mathrm{CO}_{2}}=\mathrm{P}_{\mathrm{t}}-\mathrm{P}_{\mathrm{w}}\right)$.

\section{A.3 Theoretical analysis and data interpretation}

Under certain circumstances, the concentration of $\mathrm{OH}^{-}$ions near the gas-liquid surface is not significantly depleted by the absorbed $\mathrm{CO}_{2}$. The $\mathrm{CO}_{2}$ follows a pseudo-first order reaction, and the rate of absorption can be expressed as: ${ }^{[20]}$

$$
R=k_{L} \sqrt{\left(1+\frac{D_{C O_{2}, P C} k_{o v}}{k_{L}^{2}}\right)} \times\left(C^{*}-C^{b}\right)
$$


where $R$ is the rate of absorption based on unit interfacial area; $k_{L}$ is the physical mass transfer coefficient in the liquid phase; $D_{C O_{2}, P C}$ is the diffusivity of $\mathrm{CO}_{2}$ in the PC solution; $C^{*}$ is the physical solubility of $\mathrm{CO}_{2}$ in liquid phase (at the pressure prevailing at the interface); and $C^{b}$ is the concentration of unreacted $\mathrm{CO}_{2}$ gas.

Danckwerts and Sharma suggested a criterion for treating the absorption reaction as a pseudofirst order reaction by the following expression: ${ }^{[20]}$

$$
C^{*}\left(\frac{1}{a}+\frac{2}{b}\right)\left[\sqrt{\left(1+\frac{D_{\mathrm{CO}_{2}, P C} k_{o v}}{k_{L}^{2}}\right)}-1\right]<<1
$$

where $a$ and $\mathrm{b}$ are the concentrations of $\mathrm{CO}_{3}^{2-}$ and $\mathrm{HCO}_{3}^{-}$.

To reduce the error in calculating the absorption rates to less than $3 \%$, Cents et al. justified and confined the criterion by further reducing the value of the left term in Eq. (3A-11): ${ }^{[2]}$

$$
C^{*}\left(\frac{1}{a}+\frac{2}{b}\right)\left[\sqrt{\left(1+\frac{D_{C_{2}, P C} k_{o v}}{k_{L}^{2}}\right)}-1\right]<<0.1
$$

For the gas absorption taking place in a stirred cell reactor the following equations can be derived based on mass conservation principles, the ideal gas law, and Henry's law: ${ }^{[21]}$

$$
R=-\frac{V_{G}}{A \times R_{g a s} T} \frac{d P_{C_{2}, t}}{d t}=k_{L} \sqrt{\left(1+\frac{D_{C O_{2}, P C} k_{o v}}{k_{L}^{2}}\right)} \times\left(C^{*}-C^{b}\right)
$$

and

$$
C^{*}=\frac{P_{\mathrm{CO}_{2}, t}}{\mathrm{He}}
$$

where $V_{G}$ is the volume of the gas phase; $A$ is the interfacial area between the gas and the liquid phase; $R_{\text {gas }}$ is the gas constant; $T$ is the temperature; $P_{C O 2, t}$ is the partial pressure of the $\mathrm{CO}_{2}$ gas at the time, $t$; and $\mathrm{He}$ is the Henry's law coefficient of $\mathrm{CO}_{2}$ in the PC solution.

By combining Eq. (3A-13) and (3A-14) and integrating, we have

$$
\operatorname{Ln}\left(\frac{P_{\mathrm{CO}_{2}, 0}-C^{b} \mathrm{He}}{P_{\mathrm{CO}_{2}, t}-C^{b} \mathrm{He}}\right)=\sqrt{k_{L}^{2}+D_{\mathrm{CO}_{2}, P C} k_{o v}} \frac{R T A}{V_{G} \mathrm{He}} \Delta t
$$

where $P_{C_{2}, 0}$ is the initial partial pressure of the $\mathrm{CO}_{2}$.

The concentrations of $C^{b}$ and $\left[\mathrm{OH}^{-}\right]$in the PC solution are obtained by solving Eqs. 3A-16 to 3A20 simultaneously

$$
\left[\mathrm{C}^{b}\right]=\frac{\left[\mathrm{H}^{+}\right]\left[\mathrm{HCO}_{3}^{-}\right]}{K_{1}}
$$




$$
\begin{aligned}
& {[\mathrm{OH}]^{-}=\frac{K_{W}\left[\mathrm{CO}_{3}^{2-}\right]}{\mathrm{K}_{2}\left[\mathrm{HCO}_{3}^{-}\right]}} \\
& {\left[\mathrm{H}^{+}\right] \times\left[\mathrm{OH}^{-}\right]=K_{W}} \\
& {\left[\mathrm{~K}^{+}\right]+\left[\mathrm{H}^{+}\right]=2 \times\left[\mathrm{CO}_{3}^{2-}\right]+\left[\mathrm{HCO}_{3}^{-}\right]+\left[\mathrm{OH}^{-}\right] \text {(charge balance) }} \\
& {\left[\mathrm{CO}_{3}^{2-}\right]+\left[\mathrm{HCO}_{3}^{2-}\right]=c_{0}\left(1-x_{0}+2 x_{0}\right) \text { (materials balance) }}
\end{aligned}
$$

where $x_{0}$ and $c_{0}$ are the CTB conversion rates and the original concentration of potassium carbonate (assuming $x_{0}=0$ ), respectively.

Solving these equations requires reliable information about the equilibrium constants. However, the values of the equilibrium constants vary remarkably in the presence of various types of ions at different concentrations in the PC solution. Only limited data are available in the literature on concentration-based equilibrium constants in the concentrated carbonate-bicarbonate solutions applicable to the IVCAP. Correlations or the values of the concentration-based equilibrium constants at infinite dilutions were used, ${ }^{[14,22,23]}$, while considering the overall effects of the ions of different species and concentrations on the rate constants.

The value of $k_{o v}$ can be determined from the slope of the line by plotting $\operatorname{Ln}\left(\frac{P_{\mathrm{CO}_{2}, 0}-C^{b} \mathrm{He}}{P_{\mathrm{CO}_{2}, t}-C^{b} \mathrm{He}}\right)$ vs. $\frac{R T A}{V_{G} H e} \Delta t$ (3A-15) using the data from the pressure change profile obtained during our experiments on the absorption of $\mathrm{CO}_{2}$ into PC solutions. The values of $k_{O H}$ can thus be obtained from Eq. (3A-2) and the known $\left[\mathrm{OH}^{-}\right]$concentration. To obtain the $k_{O H}$ values, accurate calculations of $k_{L}$ and the physical properties of $\mathrm{CO}_{2}$ gas in PC solutions such as the values of $H_{e}$ and $D_{\mathrm{CO}_{2}, P C}$ are needed.

\section{A.4 Results and discussion}

\section{A.4.1 Estimation of physical properties of PC solutions}

To obtain reliable $k_{O H}$ values in the PC solution, it is important to have accurate density and viscosity of the $\mathrm{PC}$ solutions, and the solubility and diffusivity of $\mathrm{CO}_{2}$ in the solutions.

The densities of $\mathrm{K}_{2} \mathrm{CO}_{3}-\mathrm{KHCO}_{3}$ solutions were obtained by using correlations for ternary solution densities reported by Sohnel and Pereira ${ }^{[24,-25]}$. The values obtained from the two references were in good agreement, with relative errors of less than $2 \%$. Few reports on the viscosity of $\mathrm{K}_{2} \mathrm{CO}_{3}-\mathrm{KHCO}_{3}$ solutions at temperatures other than $20{ }^{\circ} \mathrm{C}\left(68^{\circ} \mathrm{F}\right)$ were available. At $20{ }^{\circ} \mathrm{C}\left(68^{\circ} \mathrm{F}\right)$, the viscosity of $\mathrm{K}_{2} \mathrm{CO}_{3}-\mathrm{KHCO}_{3}$ solutions with different $\mathrm{CTB}$ conversion rates were found to be close to that of a $\mathrm{K}_{2} \mathrm{CO}_{3}$ solution with the same equivalent weight, ${ }^{[26-28]}$ indicating that the viscosity of $\mathrm{K}_{2} \mathrm{CO}_{3}-\mathrm{KHCO}_{3}$ solutions does not change substantially with the CTB conversion rate. It is likely that this conclusion is valid at other temperatures. Therefore, the viscosity of $\mathrm{K}_{2} \mathrm{CO}_{3}-\mathrm{KHCO}_{3}$ mixture solution that we used was obtained from the viscosity of a $\mathrm{K}_{2} \mathrm{CO}_{3}$ solution with the same equivalent weight, which has been reported. ${ }^{[29-31]}$ 
The solubility of $\mathrm{CO}_{2}$ in the PC solution that we used was obtained from the results reported by Knuutila et al. ${ }^{[32]}$ and the so-called $\mathrm{N}_{2} \mathrm{O}$ analogy. ${ }^{[33]}$ The model of Weisenberger and Schumpe has been widely used to predict the solubility of gases in salt solutions, but for $\mathrm{CO}_{2}$ at temperatures below $313 \mathrm{~K}\left(103.7^{\circ} \mathrm{F}\right)$ and salt concentration less than $2 \mathrm{kmol} / \mathrm{m}^{3} \cdot{ }^{[34]}$ Knuutila et al. ${ }^{[32]}$ modified the model parameters and extended the application range to $353 \mathrm{~K}\left(175.7^{\circ} \mathrm{F}\right)$ and $50 \mathrm{wt} \%\left(5.5 \mathrm{kmol} / \mathrm{m}^{3}\right)$ aqueous $\mathrm{K}_{2} \mathrm{CO}_{3}-\mathrm{KHCO}_{3}$ solutions.

The diffusivity of $\mathrm{CO}_{2}$ in $\mathrm{PC}$ solutions was estimated from the solution's viscosity using a correlation of Joosten and Danckwerts based on a modified Stokes-Einstein equation: ${ }^{\text {[35] }}$

$$
\left(\frac{D_{\mathrm{CO}_{2}, \text { PC }}}{D_{\mathrm{CO}_{2}, \text { Water }}}\right)=\left(\frac{\mu_{\text {Waterr }}}{\mu_{P C}}\right)^{0.818}
$$

The diffusivity of $\mathrm{CO}_{2}$ in water was given by ${ }^{[33]}$

$$
D_{C O 2, \text { Water }}=2.35 \times 10^{-6} \exp \left(\frac{-2119}{T}\right) \mathrm{m}^{2} / \mathrm{s}
$$

\section{A.4.2 Determination of liquid-phase physical mass transfer coefficient}

The magnitude of liquid-phase physical mass transfer coefficient $k_{L}$ is controlled by the degree of fluid mixing in the liquid phase in the reactor. In the STR, $k_{L}$ was obtained by measuring the absorption of $\mathrm{CO}_{2}$ into pure water with the $\mathrm{pH}$ adjusted to between 5.5 and 6.5. At these conditions, the rate of chemical reaction between $\mathrm{CO}_{2}$ and $\left[\mathrm{OH}^{-}\right]$is negligible and the $\mathrm{CO}_{2}$ absorbed in the liquid mostly exists in a physically dissolved molecular form. To accelerate the rate of absorption, and to minimize the gas-phase mass transfer resistance, pure $\mathrm{CO}_{2}$ gas with an initial pressure up to about 0.99 atm (14.5 psia) was used. The absorption rate was measured at a $300 \mathrm{rpm}$ propeller speed in the gas phase and a $450 \mathrm{rpm}$ speed for the magnetic stirrer in the liquid phase, at temperatures between 25 and $80^{\circ} \mathrm{C}\left(77\right.$ and $\left.176^{\circ} \mathrm{F}\right)$.

The reaction rate for the physical absorption of $\mathrm{CO}_{2}$ into water is:

$$
R=-\frac{V_{G}}{A \times R_{\text {gas }} T} \frac{d P_{C O_{2}, t}}{d t}=k_{L} \times\left(\frac{P_{C O_{2}, t}}{H e}-C^{b}\right)
$$

and

$$
C^{b}=\frac{\left(P_{\mathrm{CO}_{2}, 0}-P_{\mathrm{CO}_{2}, t}\right) \times V_{G}}{V_{L} R T}
$$

where the parameters are defined as for equations 3A-13 and 3A-14.

By rearranging equations 3A-23 and 3A-24 and integrating, we have

$$
\operatorname{Ln}\left(\frac{C_{1} P_{C_{2}, 0}+C_{2}}{C_{1} P_{C_{2}, t}+C_{2}}\right)=-k_{L} C_{1} \Delta t
$$


where $C_{1}=-\frac{R T \times A}{V_{G}}\left(\frac{1}{H e}+\frac{V_{G}}{V_{L} R T}\right)$

and

$$
C_{2}=\frac{P_{\mathrm{CO}_{2}, 0} \times A}{V_{L}}
$$

The values of $k_{L}$ are obtained from the slopes of the lines by plotting $\operatorname{Ln}\left(\frac{C_{1} P_{\mathrm{CO}_{2}, 0}+C_{2}}{C_{1} P_{\mathrm{CO}_{2}, t}+C_{2}}\right) v s$. $-C_{1} \Delta t$ using the data for the absorption of $\mathrm{CO}_{2}$ into water at different temperatures, as shown in Figure 3A-2. Good linear relationships were obtained.

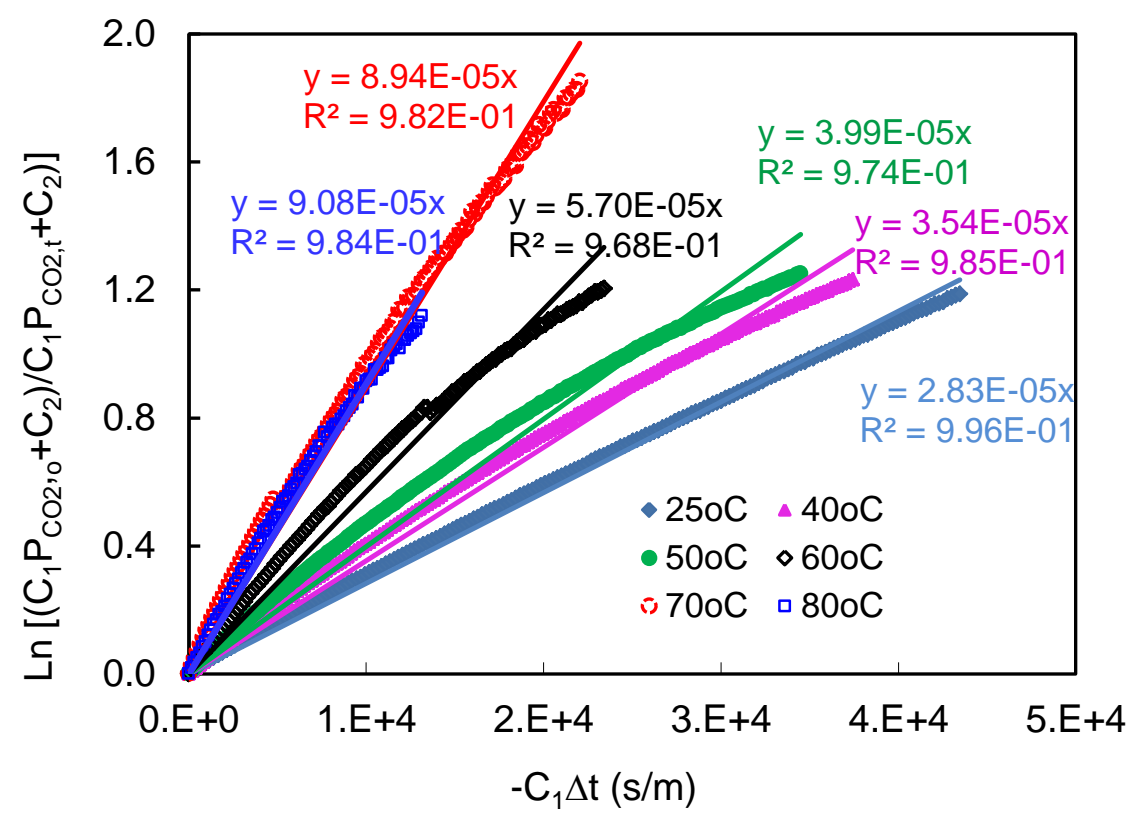

Figure 3A-2. Plots of $\operatorname{Ln}\left(\frac{C_{1} P_{C_{2}, 0}+C_{2}}{C_{1} P_{C_{2}, t}+C_{2}}\right) v s .-C_{1} \Delta t$ using the data for absorption of $\mathrm{CO}_{2}$ into water at temperatures between 25 and $80^{\circ} \mathrm{C}$ and the corresponding linear regression for each data set.

\section{A.4.3 Calculation of $k_{O H}$ in PC solutions}

The rates of $\mathrm{CO}_{2}$ absorption into $\mathrm{PC}$ solutions of selected equivalent weights (EWs) between 5 and $40 \mathrm{wt} \% \mathrm{PC}$ were measured at temperatures between 25 and $80^{\circ} \mathrm{C}\left(77\right.$ and $\left.176^{\circ} \mathrm{F}\right)$. One advantage of using the STR system is that the pressure change profile in the gas phase is measured without the need of knowing the liquid phase composition. The change in the liquid phase composition is negligible during the $\mathrm{CO}_{2}$ absorption process, because a small volume of $\mathrm{CO}_{2}$ gas is absorbed into a large volume of the PC solution. Therefore, the concentration and composition of the solution during the experimental time essentially remain unchanged.

The measurements were carried out under controlled conditions to satisfy the criterion of Eq. (3A-12) to ensure that the overall reaction can be treated as pseudo-first order with respect to 
$\mathrm{CO}_{2}$. Due to the effects of the concentrations of the $\mathrm{CO}_{3}{ }^{2-}$ and $\mathrm{HCO}_{3}{ }^{-}$ions on the concentration of $\mathrm{OH}^{-}$in the solution, the transport of these ions is not a limiting step through the interfacial reaction zone during the absorption process. When this criterion is satisfied, the concentrations of the reactant ions are uniform throughout the mass transfer zone.

The values of $k_{o v}$ are required for the criterion selected. A trial and error (shooting) method was used to circumvent the difficulty. The iteration steps included: 1) selecting an initial value of $k_{O H}$ comparable to those reported in the literature; 2) selecting the data satisfying the criterion (Eq. $3 \mathrm{~A}-12$ ); 3) calculating $k_{O H}$ using Eqs. (3A-15 and 3A-2); 4) calculating the $\left[\mathrm{OH}^{-}\right]$concentration; 5) re-checking the criterion using the calculated $k_{O H}$ value; and 6) if not satisfied, use the calculated $k_{O H}$ and return to Step 2 until the criterion is satisfied. It was found that $P_{\mathrm{CO} 2}$, the $\mathrm{CO}_{2}$ partial pressure in the gas phase, was a critical parameter for satisfying the criterion. A suitable range of $P_{\mathrm{CO} 2}$ between 6.9 and $103.4 \mathrm{kPa}$ (1.0 and $\left.15 \mathrm{psia}\right)$ was used. Figure 3A-3 shows a typical plot of $L n\left(\frac{P_{C 0_{2}, 0}-C^{b} H e}{P_{C 0_{2}, t}-C^{b} H e}\right) v s \cdot \frac{R T A}{V_{G} H e} \Delta t$ using the $\mathrm{CO}_{2}$ absorption data into a $20 \mathrm{wt} \% \mathrm{PC}$ solution at temperatures between 25 and $80^{\circ} \mathrm{C}\left(77\right.$ and $\left.176^{\circ} \mathrm{F}\right)$. Good linear relationships were obtained. The calculated $k_{O H}$ values are shown in Figure 3A-4 as a function of PC EW concentrations. The $k_{O H}$ values increased with increasing EW of PC solutions. Extrapolation of the isothermal lines to zero EW PC concentration provides the $k_{O H}^{\infty}$ values in an infinite dilution PC solution at the respective temperatures. Figure 3A-5 displays the Arrhenius plot of the $k_{O H}^{\infty}$ values, from which the following equation was obtained:

$$
\log k_{O H^{-}}^{\infty}=12.809-2779 / T
$$

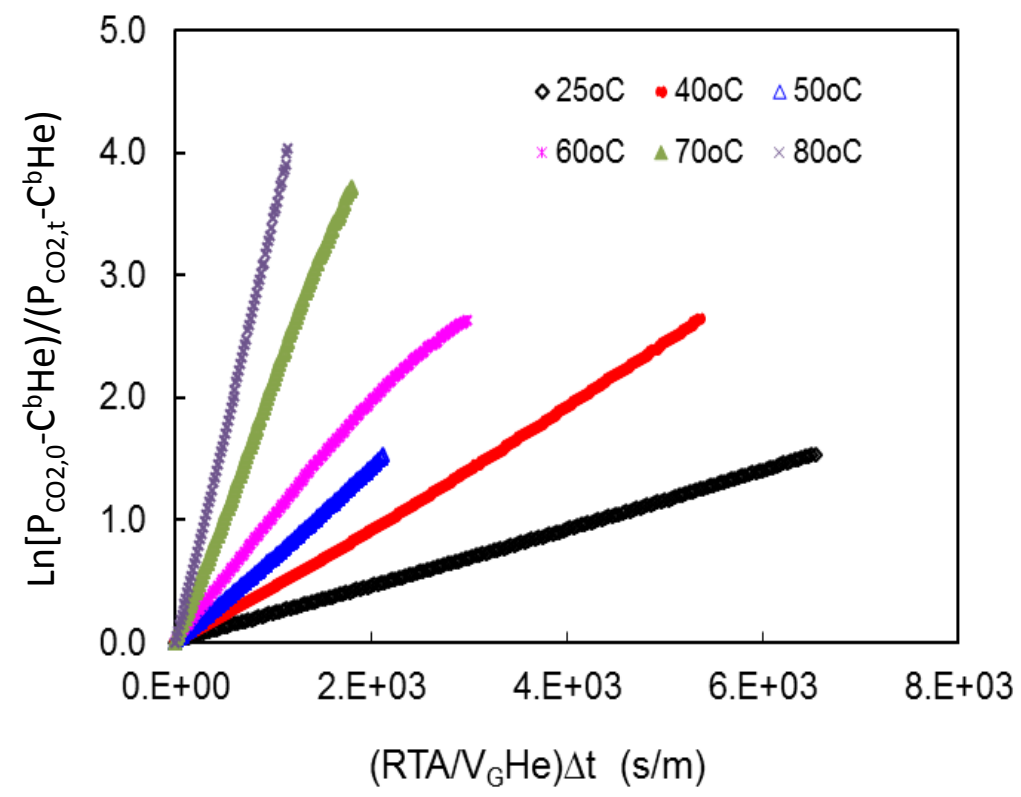

Figure 3A-3. Plots of $\operatorname{Ln}\left(\frac{P_{\mathrm{CO}_{2}, 0}-C^{b} \mathrm{He}}{P_{\mathrm{CO}_{2}, t}-C^{b} \mathrm{He}}\right) v s . \frac{R T A}{V_{G} \mathrm{He}} \Delta t$ using the data for absorption of $\mathrm{CO}_{2}$ into a $20 \mathrm{wt} \%$ PC solution. 


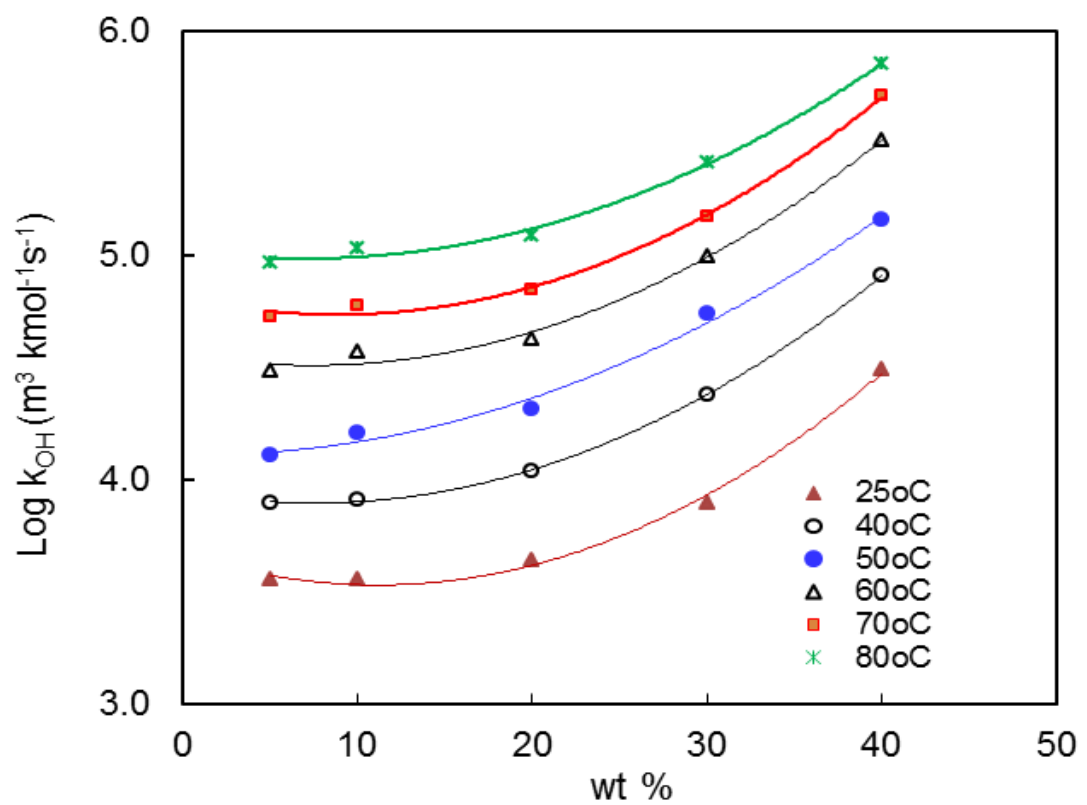

Figure 3A-4. $k_{O H}$ values determined for absorption of $\mathrm{CO}_{2}$ into $5 \%-40 \%$ PC solutions at temperatures between 25 and $80^{\circ} \mathrm{C}$.

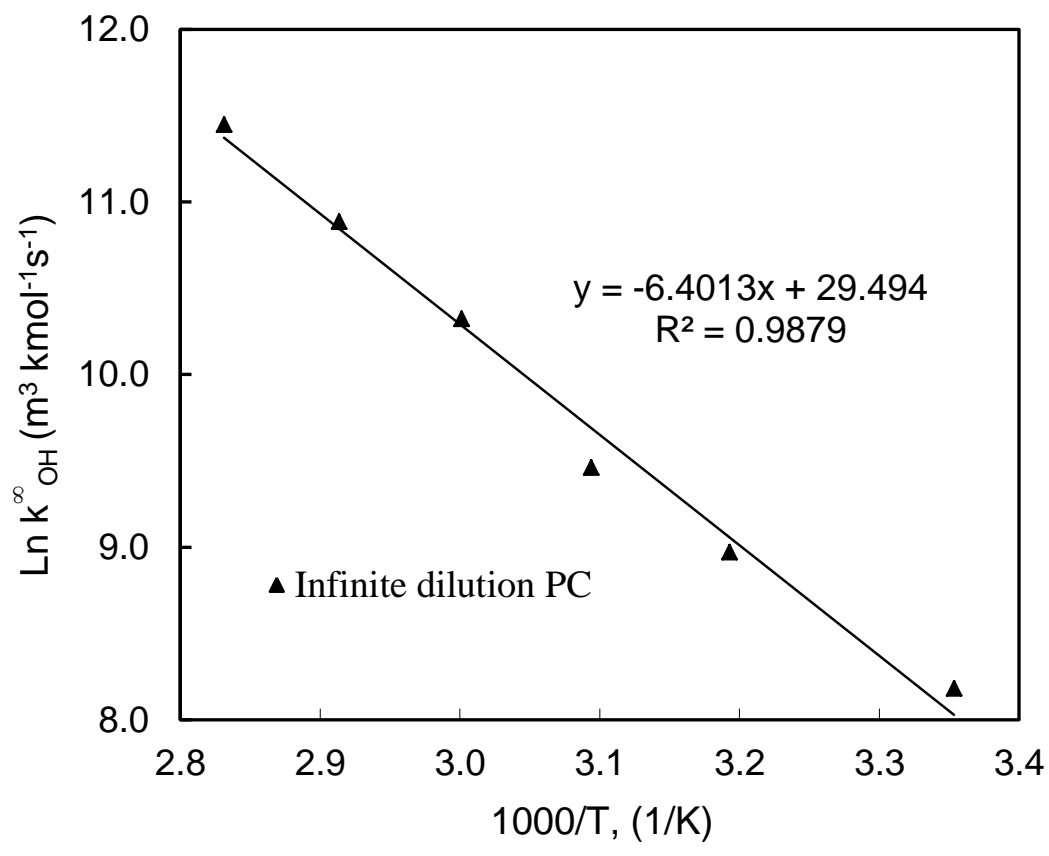

Figure 3A-5. Arrhenius plot of $k_{O H}^{\infty}$. 
Table 3A-1 compares the experimental activation energy, $E a$, and pre-exponential constant expressed by $\operatorname{Ln}(A)$ with those reported in the literature. Both the $E a$ and $\ln (A)$ values at temperatures between 25 and $80^{\circ} \mathrm{C}\left(77\right.$ and $\left.176^{\circ} \mathrm{F}\right)$ are comparable with those previously reported at temperatures below $50^{\circ} \mathrm{C}\left(122^{\circ} \mathrm{F}\right)$.

Table 3A-1. Comparison of the experimental $E a$ and $\ln (A)$ with those reported in the literature

\begin{tabular}{|l|c|c|}
\hline Researchers/references & $E a(\mathrm{~kJ} / \mathrm{mol})$ & $\ln (\mathrm{A})\left(\mathrm{m}^{3} \mathrm{kmol}^{-1} \mathrm{~s}^{-1}\right)$ \\
\hline Pinsent et al. ${ }^{[1]]}\left(0-40^{\circ} \mathrm{C} / 32-104^{\circ} \mathrm{F}\right)$ & 55.43 & 31.4 \\
\hline Pohorecki and Moniuk ${ }^{[15]}\left(13-41^{\circ} \mathrm{C} / 55.4-105.8^{\circ} \mathrm{F}\right)$ & 45.61 & 27.44 \\
\hline Kucha et al. ${ }^{[17]}\left(20-50^{\circ} \mathrm{C} / 68-122^{\circ} \mathrm{F}\right)$ & 54.97 & 31.12 \\
\hline Knuutila et al. ${ }^{[18]}\left(40-70^{\circ} \mathrm{C} / 104-158^{\circ} \mathrm{F}\right)$ & 49.33 & 29.2 \\
\hline This study $\left(25-80^{\circ} \mathrm{C} / 77-176^{\circ} \mathrm{F}\right)$ & 53.22 & 29.49 \\
\hline
\end{tabular}

Figure 3A-6 shows the Arrhenius plots of the $k_{O H}$ values measured in the 5\%-40\% PC solutions at temperatures between 25 and $80^{\circ} \mathrm{C}\left(77\right.$ and $\left.176^{\circ} \mathrm{F}\right)$. Good linear relationships were obtained with the straight lines nearly parallel to one another, indicating that the $E a$ values are comparable at concentrations between 5 and $40 \mathrm{wt}$ \% PC. In addition, at the same reaction temperature, the $\log k_{O H}$ value increases with increasing PC concentration. This tendency becomes more important when the PC concentration is greater than 20\%; at concentrations less than $20 \%$, the $k_{O H}$ value does not increase very much with increasing PC concentration. This result suggests that solutions containing greater than $20 \mathrm{wt} \%$ PC should be used to favor the kinetics of $\mathrm{CO}_{2}$ absorption.

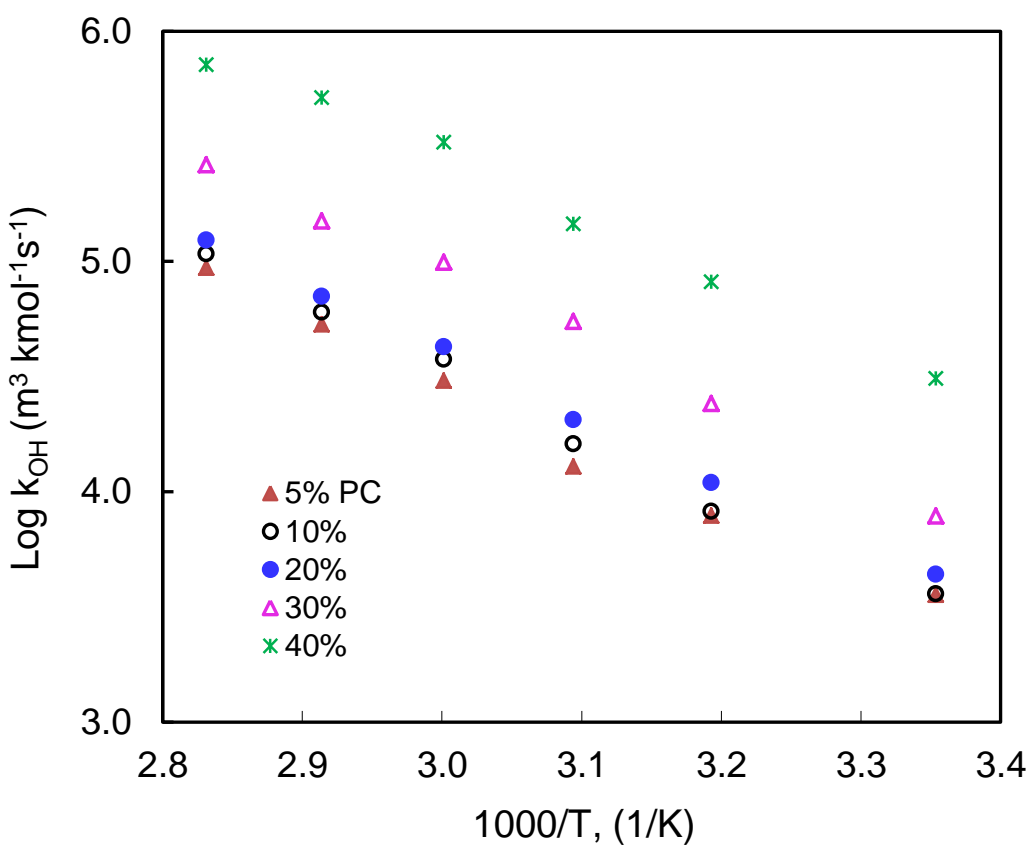

Figure 3A-6. Arrhenius plot of $k_{O H}$ values in 5 to $40 \%$ PC solutions.

To investigate the effect of $\mathrm{CO}_{2}$ loading in the PC solution on $k_{O H}$, the $k_{O H}$ values in the 20 and $30 \mathrm{wt} \%$ PC solutions with CTB conversion rates between zero and $50 \%$ were measured. Figures $3 \mathrm{~A}-7$ and $3 \mathrm{~A}-8$ show Arrhenius plots of the $k_{O H}$ values. At the same reaction temperature, the 
$\mathrm{k}_{O H}$ value increased with increasing CTB conversion rate for both the 20 and $30 \mathrm{wt} \% \mathrm{PC}$ solutions. When the CTB conversion rate of the PC solution increases, the $\mathrm{HCO}_{3}{ }^{-}$concentration increases and the total ionic strength decreases. This result demonstrates that both the ion type and strength affect the $k_{O H}$ values.

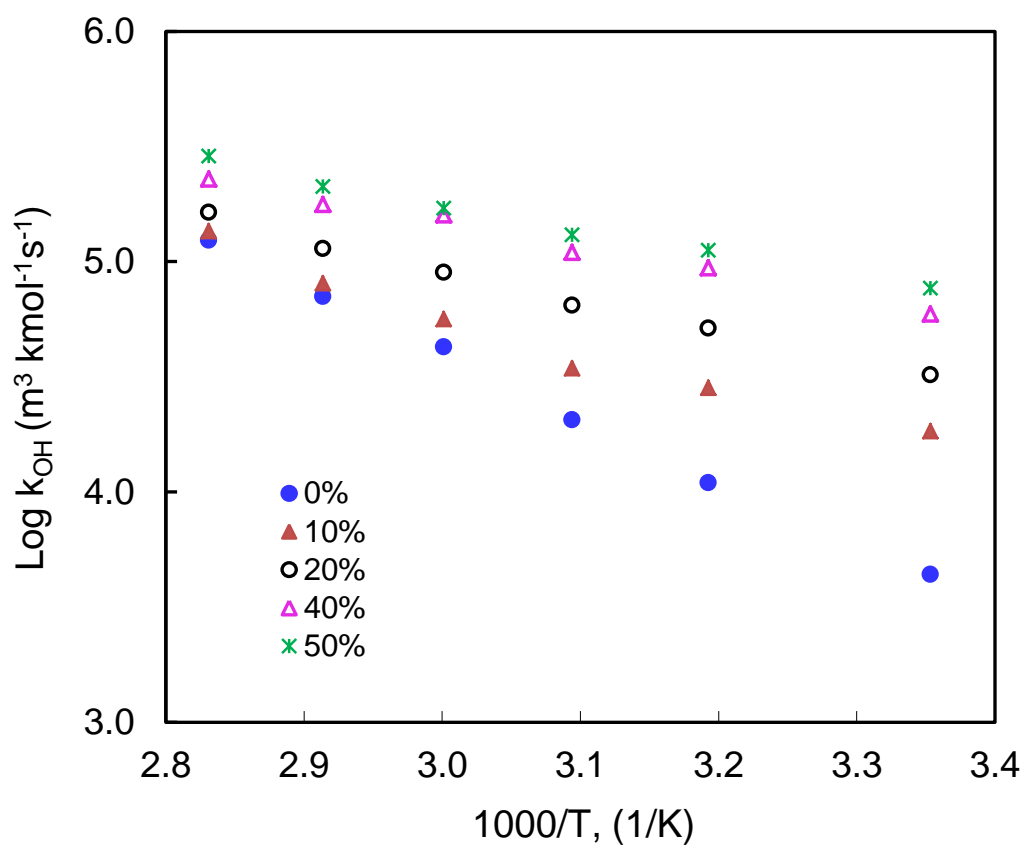

Figure 3A-7. Arrhenius plot of $\log k_{O H}$ values in $20 \mathrm{wt} \%$ PC solutions with different $\mathrm{CO}_{2}$ loadings.

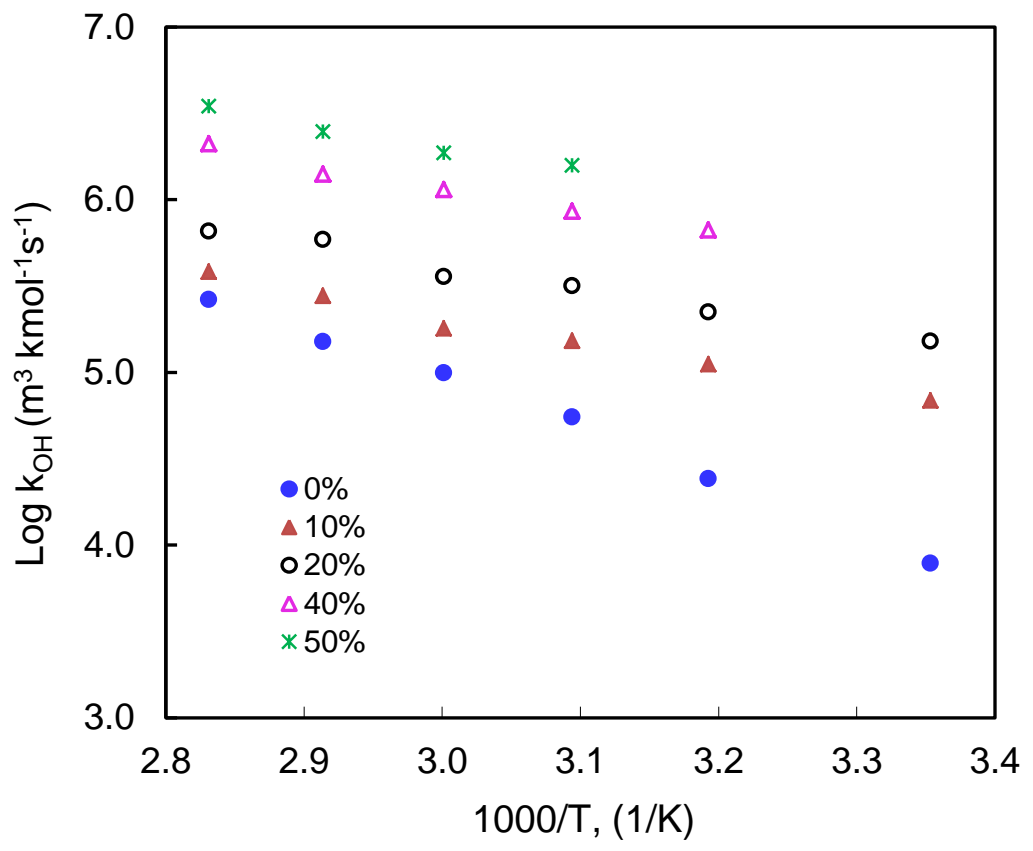

Figure $3 \mathrm{~A}-8$. Arrhenius plot of $\log k_{O H}$ values in $30 \mathrm{wt} \%$ PC solutions with different $\mathrm{CO}_{2}$ loadings.

In Figures 3A-7 and 3A-8, the slopes of the straight lines decrease with increasing CTB conversion rate at the same EW concentration of PC solution, indicating that the $E a$ value may 
decrease with increasing CTB conversion rate. This tendency becomes less noticeable for the 30 $\mathrm{wt} \% \mathrm{PC}$ than for the $20 \mathrm{wt} \% \mathrm{PC}$. It is inferred that increasing temperature may less effectively promote the kinetics in PC solutions at higher CTB conversion rates. For concentrated PC solutions at high CTB conversion rates, increasing temperature may still be an effective way to increase the kinetics.

\section{A.5 Summary}

The $\mathrm{CO}_{2}$ absorption rate constants $\left(k_{\mathrm{OH}}\right)$ into 5 to $40 \mathrm{wt} \% \mathrm{PC}$ solutions were experimentally determined. Additionally, the impact of $\mathrm{CO}_{2}$ loading (i.e., CTB conversion) on $k_{o h}{ }^{\infty}$ in 20 and $30 \% \mathrm{PC}$ solutions at temperatures between 25 and $80^{\circ} \mathrm{C}\left(77\right.$ and $\left.176^{\circ} \mathrm{F}\right)$ were measured. The Arrhenius equation for $k_{O H}^{\infty}$ and the values of both the $E a$ and $\ln (A)$ terms were comparable to those reported in the literature.

At a particular reaction temperature, the $k_{O H}$ increases with increasing PC concentration between 5 and $40 \mathrm{wt} \%$. The increase in $k_{O H}$ becomes greater when the PC concentration is greater than 20 wt $\%$; at concentrations between $5 \%$ and $20 \%$, the $k_{O H}$ does not increase much with increasing PC concentration. This result suggests that PC solutions with concentrations greater than $20 \mathrm{wt} \%$ favor the kinetics of $\mathrm{CO}_{2}$ absorption. PC solutions containing between 5 and $40 \mathrm{wt} \% \mathrm{PC}$ had comparable Ea values for absorption.

For both the 20 and $30 \mathrm{wt} \%$ PC solutions at CTB conversion rates less than $50 \%$, the $\mathrm{k}_{O H}$ values at the same reaction temperature increased while the $E a$ values decreased with increasing CTB conversion rate. This tendency becomes less noticeable in the $30 \mathrm{wt} \% \mathrm{PC}$ than in the $20 \mathrm{wt} \% \mathrm{PC}$. The results indicate that the ionic species and strengths in the solutions have complex effects on the $\mathrm{k}_{O H}$ values. It can be concluded that for the PC solutions at higher CTB conversion rate, increasing the reaction temperature may more efficiently promote the $\mathrm{CO}_{2}$ absorption kinetics when the PC concentration is higher than $20 \mathrm{wt} \%$.

\section{References}

1. Cents A.H.G., Brilman D.W.F., Versteeg G.F. Gas absorption in an agitated gas-liquid-liquid system. Chemical Engineering Science, 2001, 56: 1075-1083.

2. Cents A.H.G, Brilman D.W.F, Versteeg G.F. $\mathrm{CO}_{2}$ absorption in carbonate/bicarbonate solutions: The danckwerts-criterion revisited. Chemical Engineering Science, 2005, 60: 5830-5835.

3. Vazquez G., Chenlo F., Pereira G. Enhancement of the absorption of CO2 in alkaline buffers by organic solutes: Relation with degree of dissociation and molecular $\mathrm{OH}$ density. Industrial Engineering Chemical Research, 1997, 36: 2353-2358.

4. Augugliaro V., Rizzuti L. Kinetics of carbon dioxide absorption into catalysed potassium carbonate solutions. Chemical Engineering Science, 1987, 42: 2339-2343.

5. Pohorecki R., Moniuk W. Kinetics of reaction between carbon dioxide and hydroxyl ions in aqueous electrolyte solutions. Chemical Engineering Science, 1988, 43: 1677-1684. 
6. Ghosh U.K., Kentish S.E., Stevens G.W. Absorption of carbon dioxide into aqueous potassium carbonate promoted by boric acid. Energy Procedia, 2009, 1: 1075-1081.

7. Danckwerts P. V. Gas-liquid reactions. 1970. Mc-Graw-Hill, New York, p.276.

8. Alper E., Deckwer W. Kinetics of absorption of $\mathrm{CO}_{2}$ into buffer solutions containing carbonic anhydrase. Chemical Engineering Science, 1980, 35: 549-557.

9. Ho C., Sturtevant J.M. The kinetics of the hydration of carbon dioxide at $25^{\circ}$. Journal of Biological Chemistry, 1963, 238: 3499-3501.

10. Roughton F.J.W. Harvey lectures. 1943-1944. Science Press Printing Co., Lancaster, PA., p.96.

11. Pinsent B.R.W., Pearson L., Roughton F.J.W. Kinetics of combination of carbon dioxide with hydroxide ions. Transactions of the Faraday Society 1956, 52: 1512-1520.

12. Nijsing R.A.T.O., Hendriksz R.H., Kramers H. Absorption of $\mathrm{CO}_{2}$ in jets and falling films of electrolyte solutions, with and without chemical reaction. Chemical Engineering Science 1959, 10: 88-104.

13. Savage D.W., Astarita G., Joshi S. Chemical absorption and desorption of carbon dioxide from hot carbonate solutions. Chemical Engineering Science, 1980, 35: 1513-22.

14. Astarita, G., Savage D.W., Bisio A. Gas treating with chemical solvents. 1983. Wiley, New York.Pohorecki R, Moniuk W. Kinetics of reaction between carbon dioxide and hydroxyl ions in aqueous electrolyte solutions. Chemical Engineering Science, 1988, 43: 1677-84.

15. Pohorecki R., Kucharski E. Desorption with chemical reaction in the system carbon dioxideaqueous solution of potassium carbonate. Chemical Engineering Journal Lausanne, Switzerland, 1991, 46: 1-7.

16. Kucka L., Kenig E.Y., Gorak A. Kinetics of the gas-liquid reaction between carbon dioxide and hydroxide ions. Industrial Engineering and Chemical Research, 2002, 41: 5952-5957.

17. Knuutila H., Juliussen O., Svendsen H.F. Kinetics of the reaction of carbon dioxide with aqueous sodium and potassium carbonate solutions. Chemical Engineering Science, 2010, 65: 6077-6088.

18. Haubrock J., Hogendoorn J.A., Versteeg G.F. The applicability of activities in kinetic expressions: A more fundamental approach to represent the kinetics of the system $\mathrm{CO}_{2}-\mathrm{OH}-$ salt in terms of activities. Chemical Engineering Science, 2007, 62:5753-5769.

19. Danckwerts P. V., Sharma M. M. Absorption of carbon dioxide into solutions of alkalis and amines. Journal of Chemcial Engineering Reviews Series No 2, The Chemical Engineer, CE 1966, 244-280.

20. Kucka L., Richter J., Kenig E.Y., Górak A. Determination of gas-liquid reaction kinetics with a stirred cell reactor. Separation Purification Technology, 2003, 31:163-175.

21. Danckwerts P.V., Sharma M.M. Absorption of carbon dioxide into solutions of alkalies and amines. hydrogen sulfide and carbonyl sulfide. Chemical Engineering, (1904-20) 1966, No.202: CE244-CE280.

22. Tseng P.C., Ho W.S., Savage D.W. Carbon dioxide absorption into promoted carbonate solutions. Ameican Iinstitute of Chemical Engineers Journal, 1988, 34: 922-31 . 
23. Söhnel O., Novotný P. Densities of aqueous solutions of inorganic substances. 1985. Elsevier Publishers. Amsterdam. p.335.

24. Pereira G., Moreira R., Vázquez M.J., Chenlo F. Kinematic viscosity prediction for aqueous solutions with various solutes. Chemical Engineering Journal, 2001, 81:35-40.

25. Palaty Z. Viscosity of diluted aqueous potassium carbonate/potassium bicarbonate solutions. Collection of Czechoslovak Chemical Communications, 1992, 57: 1879-87.

26. Anonymous. - Viscosity of aqueous solutions of potassium carbonate/potassium bicarbonate $\left(\mathrm{K}_{2} \mathrm{CO}_{3} / \mathrm{KHCO}_{3}\right)$. - Chemical and Biochemical Engineering Quarterly - 155.

27. Haynes W.M., Lide, D.R. Concentrative properties of aqueous solutions: density, refractive index, freezing point depression, and viscosity. In: CRC Handbook of Chemistry and Physics (91st edition). Internet version 2011, p.8/65-8/66.

28. Riesenfeld FC., Kohl AL. Gas purification. 1985. Gulf Publishing Co., Houston: p.900.

29. Correia R.J., Kestin J., Khalifa H.E. Viscosity and density of aqueous sodium carbonate and potassium carbonate solutions in the temperature range 20-90.degree.C and the pressure range 0-30 MPa. Journal of Chemical \& Engineering Data, 1980, 25: 201-206 .

30. Gonçalves F.A., Kestin J. The viscosity of $\mathrm{Na}_{2} \mathrm{CO}_{3}$ and $\mathrm{K}_{2} \mathrm{CO}_{3}$ aqueous solutions in the range 20-60 ${ }^{\circ} \mathrm{C}$. International Journal of Thermophysics, 1981, 2: 315-322.

31. Knuutila H., Juliussen O., Svendsen H.F. Density and $\mathrm{N}_{2} \mathrm{O}$ solubility of sodium and potassium carbonate solutions in the temperature range $25{ }^{\circ} \mathrm{C}$ to $80{ }^{\circ} \mathrm{C}$. Chemical Engineering Science, 2010, 65: 2177-2182.

32. Versteeg G.F., Van Swaalj W. Solubility and diffusivity of acid gases (carbon dioxide, nitrous oxide) in aqueous alkanolamine solutions. Journal of Chemical \& Engineering Data, 1988, 33: 29-34.

33. Weisenberger S., Schumpe A. Estimation of gas solubilities in salt solutions at temperatures from $273 \mathrm{~K}$ to $363 \mathrm{~K}$. American Institute of Chemical Engineers Journal, 1996, 42: 298-300.

34. Joosten G.E.H, Danckwerts P.V. Solubility and diffusivity of nitrous oxide in equimolar potassium carbonate-potassium bicarbonate solutions at 25 degrees. and 1 atmosphere. Journal of Chemical \& Engineering Data, 1972,17: 452-454. 


\section{PART 3B. INVESTIGATION OF CATALYSTS FOR ENHANCING ABSORPTION OF $\mathrm{CO}_{2}$ INTO $\mathrm{K}_{2} \mathrm{CO}_{3}$ SOLUTIONS}

\section{B.1 Introduction}

Numerous chemical additives that were expected to accelerate the rate of $\mathrm{CO}_{2}$ absorption into PC solutions were investigated. These additives had been reported to either increase $\mathrm{CO}_{2}$ solubility into water and/or decrease the surface tension of PC solutions and thus increase the gas-liquid interfacial area and the mass transfer rate. ${ }^{[1,2]}$ Most of the additives tested also possessed good chemical and thermal stability, high solubility in water, and low water vapor saturation pressure in PC solutions.

\section{B.2 Experimental method}

The chemical additives investigated, and their suppliers, included the following: sucrose (>99.5\%, Sigma Aldrich); glucose (anhydrous, 96\%, Sigma Aldrich); glycine (>98.5\%, Sigma Aldrich); triethylene glycol (TEG, TCI); hexamethyl phosphoric triamide (HMPTAM, TCI); propylene carbonate (ACS specifications, TCI); and sodium metavanadate $\left(\mathrm{NaVO}_{3}\right.$, anhydrous 99.9\% metals, Sigma-Aldrich). All were used in their as-received forms. Potassium borate $\left(\mathrm{K}_{3} \mathrm{BO}_{3}\right)$ was produced from the reaction between equivalent molar amounts of potassium hydroxide (reagent grade, 90\%, flakes, Sigma-Aldrich) and boric acid (for molecular biology, $\geq$ $98.5 \%$, Sigma-Aldrich) in aqueous solutions. For most of the additives, an amount of $10 \mathrm{wt} \%$ in the PC solution (20 wt $\%$ PC solution with $20 \%$ carbonate to bicarbonate (CTB) conversion rate) was used. For the HMPTAM, $\mathrm{NaVO}_{3}$, and $\mathrm{K}_{3} \mathrm{BO}_{3}, 5 \mathrm{wt} \%$, $4 \mathrm{wt} \%$, and $5 \mathrm{wt} \%$, respectively, were used. Tests were performed at 25 and $40^{\circ} \mathrm{C}\left(77\right.$ and $\left.104^{\circ} \mathrm{F}\right)$ in the stirred cell reactor (STR) system.

Rates of $\mathrm{CO}_{2}$ absorption into the PC solutions with catalysts at various IVCAP conditions were measured using the same laboratory batch STR and procedure, as described previously in Section 3A.2.

\section{B.3 Results and discussion}

For absorption of a gas into a liquid phase that involves simultaneous chemical reactions, an enhancement factor, E, is typically introduced into the equation describing the physical absorption of the gas to describe the overall rate. ${ }^{[3,4]}$ For $\mathrm{CO}_{2}$ absorption, the rate can be expressed:

$$
J=E \times k_{L}\left(\frac{P_{\mathrm{CO}_{2}, t}}{\mathrm{He}}-C^{b}\right)
$$

where $J_{i}$ is the rate of absorption of the gas component $\left(\mathrm{mol} / \mathrm{m}^{2} \mathrm{~s}\right), k_{L}$ is physical mass transfer coefficient in the liquid-phase, $H e$ is the Henry's law constant of the gas component, $P_{c o 2, t}$ is the partial pressure of the gas component over the gas-liquid interface, and $C^{b}$ is the concentration of the freely dissolved gas (in molecular form) in the bulk liquid phase.

The rate of $\mathrm{CO}_{2}$ absorption into a PC solution can be determined from the measured gas phase 
pressure change profile in our stirred cell reactor during an experiment. According to the conservation principle and the ideal gas law, the $\mathrm{CO}_{2}$ flux, $J_{i}$, is:

$$
J=-\frac{V_{G}}{A R T} \frac{d P_{C O_{2}, t}}{d t}
$$

where $V_{G}$ is the volume of the gas phase, $A$ is the gas-liquid interfacial area, $R$ is the universal gas constant, $T$ is the temperature,. The value of $C^{b}$ in Eq. (3B.1) generally is negligibly small when a small amount of $\mathrm{CO}_{2}$ gas is absorbed into a large amount of $\mathrm{PC}$ solution with relatively low $\mathrm{CO}_{2}$ loading (not larger than $40 \%$ CTB conversion rate). By combining Equations $3 \mathrm{~B} .1$ and 3B.2 and integrating, we obtain

$$
\operatorname{Ln}\left(\frac{P_{\mathrm{CO}_{2}, 0}}{P_{\mathrm{CO}_{2}, t}}\right)=E k_{L} \frac{R T A}{V_{G} H_{e}} \Delta t
$$

where $p_{i, 0}$ is the initial $\mathrm{CO}_{2}$ partial pressure. The value of $E$ can thus be determined from the slope of the trend line for a plot of $L n\left(\frac{P_{\mathrm{CO}_{2}, 0}}{P_{\mathrm{CO}_{2}, t}}\right)$ vs. $k_{L} \frac{R T A}{V_{G} H_{e}} \Delta t$.

For $\mathrm{CO}_{2}$ absorption into a PC solution promoted by a catalyst or chemical additive, the overall catalytic activity of the catalyst is expressed by a relative enhancement factor, $E_{c a t}$, defined by:

$$
E_{c a t}=\frac{E_{c a t+P C}}{E_{P C}}
$$

where $E_{c a t+P C}$ and $E_{P C}$ are the enhancement factors of the PC solution with and without the catalyst. The value of $E_{c a t}$ describes how strongly a catalyst promotes the reactions compared with the PC solution without the catalyst.

The selected additives may be categorized into two types. The first type, such as propylene carbonate, increases the solubility of $\mathrm{CO}_{2}$ into water. ${ }^{[5,6]}$ The second type, such as $\mathrm{NaVO}_{3}$ and $\mathrm{K}_{3} \mathrm{BO}_{3}$, is a Lewis base that has a single, lone pair of electrons on the anion that neutralizes the Lewis acidity of the $\mathrm{CO}_{2}$ as it is being absorbed. In order for a "base" to act as a promoter, it must possess certain properties. A too-strong base may form a very stable $\mathrm{CO}_{2} \cdot$ base complex, or simply react with water to generate more $\mathrm{OH}^{-}$. On the other hand, a too- weak base will not interact with the $\mathrm{CO}_{2}$ effectively enough. A number of promoters of this type, such as arsenite, selenite, and sulfite have been examined by others. However, their toxicity, or their instability under typical industrial conditions limits their applications. In contrast, the $\mathrm{NaVO}_{3}$ and $\mathrm{K}_{3} \mathrm{BO}_{3}$ that we tested possess good chemical and thermal stability and high solubility in PC solutions.

The rates of $\mathrm{CO}_{2}$ absorption into the PC20-20 solutions promoted by these additives at 25 and $40^{\circ} \mathrm{C}\left(77\right.$ and $\left.104^{\circ} \mathrm{F}\right)$ are shown in Figure $3 \mathrm{~B}-1$. The enhancement factor for each additive was calculated using Eq. (3B-4) and is shown in Figure 3B-2. The absorption rate increase was limited to less than 1.75 times the absorption rate for pure PC for most additives. The values of $E_{c a t}$ did not significantly vary with the reaction temperature between 25 and $40^{\circ} \mathrm{C}$ (77 and $104^{\circ} \mathrm{F}$ ). It is noteworthy that using $4 \mathrm{wt} \% \mathrm{NaVO}_{3}$ improved the absorption rates by up to 3.8 times the rate for pure $\mathrm{PC}$ at $25^{\circ} \mathrm{C}\left(77^{\circ} \mathrm{F}\right)$, and 3.5 times at $40^{\circ} \mathrm{C}\left(104^{\circ} \mathrm{F}\right)$. The rates into the PC2020 promoted by the additives at $40^{\circ} \mathrm{C}\left(104^{\circ} \mathrm{F}\right)$ were also compared to that into a $5 \mathrm{M}$ MEA with $\mathrm{CO}_{2}$ loading of $0.2 \mathrm{~mol} / \mathrm{mol} \mathrm{MEA}$ at $50^{\circ} \mathrm{C} / 122^{\circ} \mathrm{F}$ (due to lack of experimental data for MEA at $40^{\circ} \mathrm{C} / 104^{\circ} \mathrm{F}$ in this study). The rates into the $\mathrm{PC}$ with the addition of $4 \mathrm{wt} \% \mathrm{NaVO}_{3}$ were still 5 to 
11 times slower than the 5M MEA within the $\mathrm{CO}_{2}$ partial pressure range between about 0.7 and $48.26 \mathrm{kPa}(0.1$ and $7 \mathrm{psia}$, see Figure 3B-1(b)).

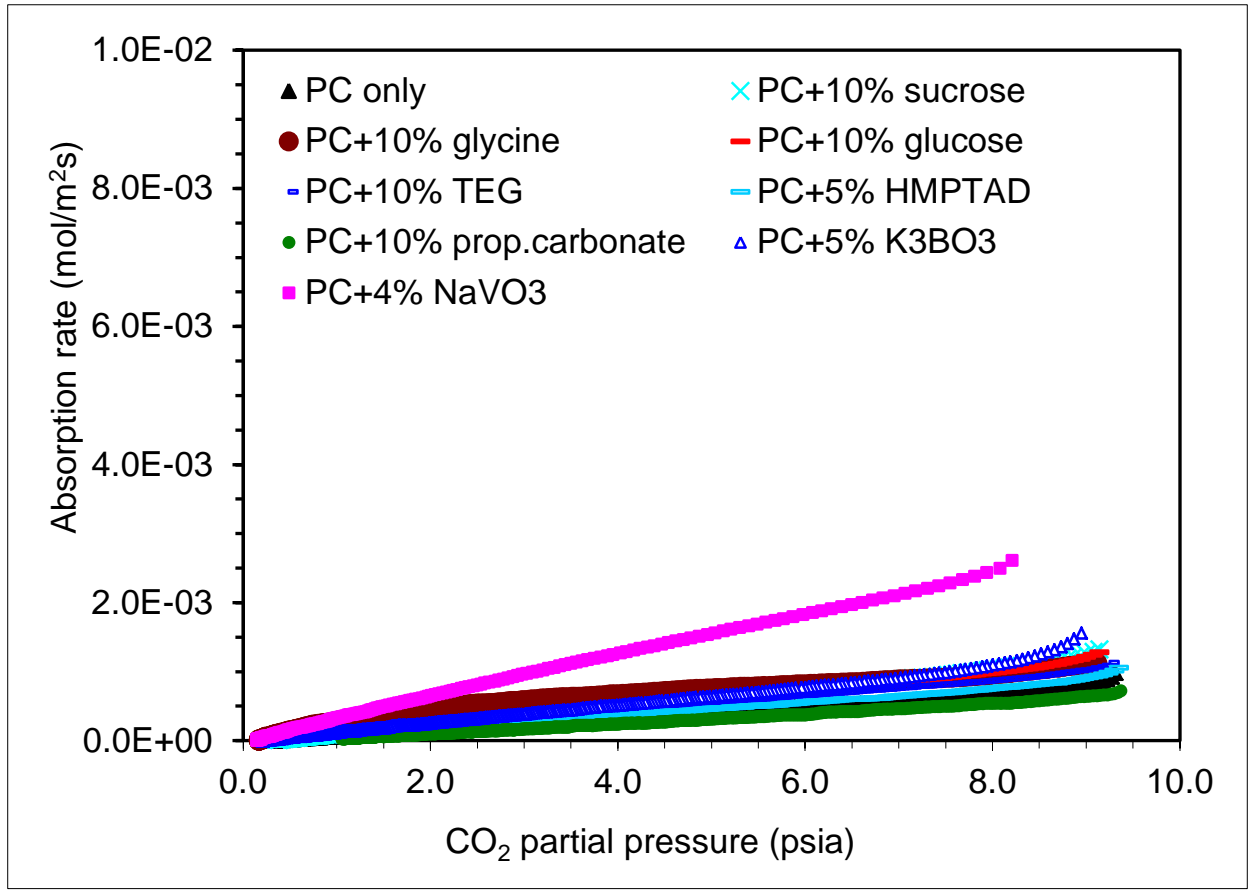

(a) at $25^{\circ} \mathrm{C}$.

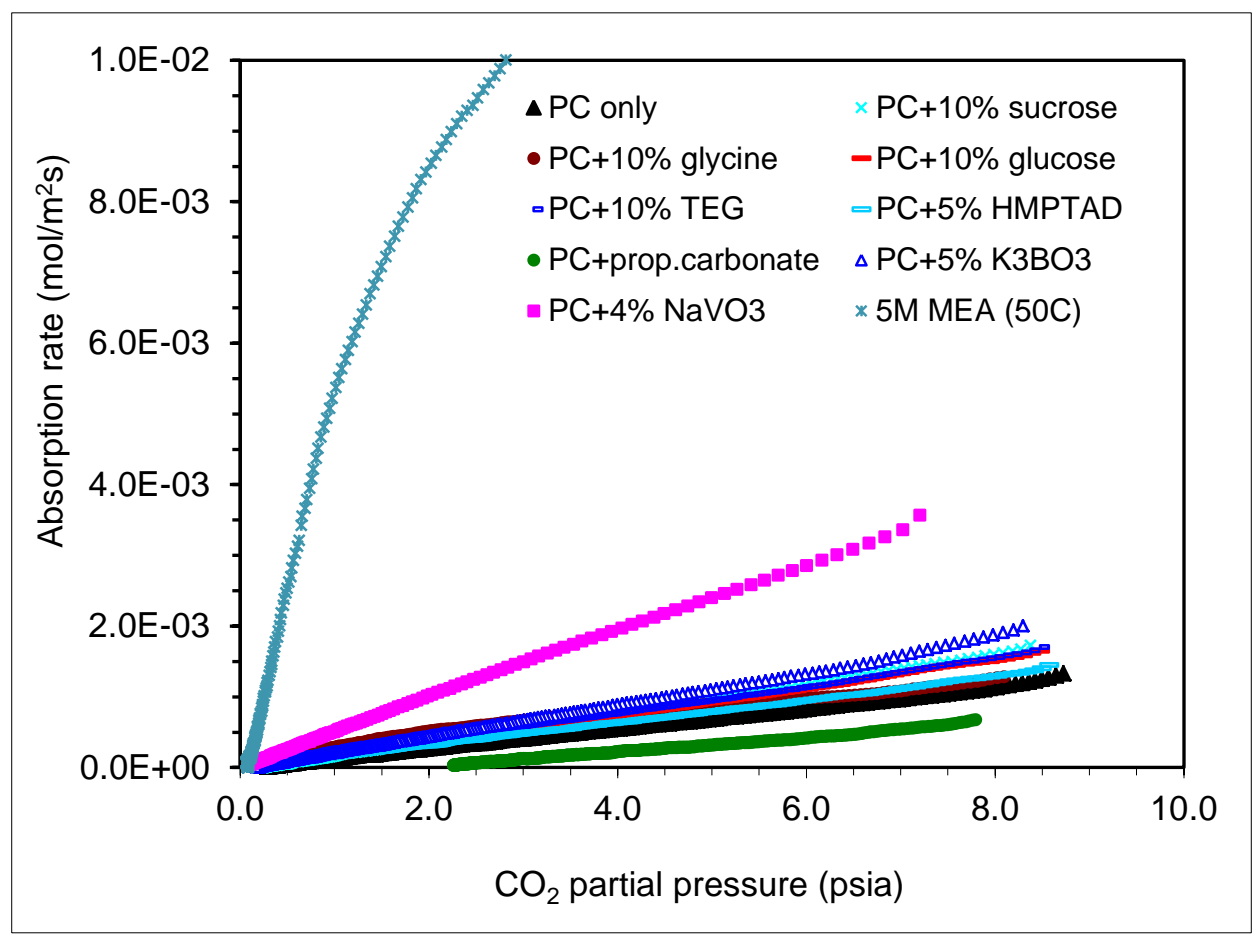

(b) at $40^{\circ} \mathrm{C}$.

Figure 3B-1. Rate of $\mathrm{CO}_{2}$ absorption into the PC20-20 solution promoted by additives at (a) $25^{\circ} \mathrm{C}$ and (b) $40^{\circ} \mathrm{C}$. 


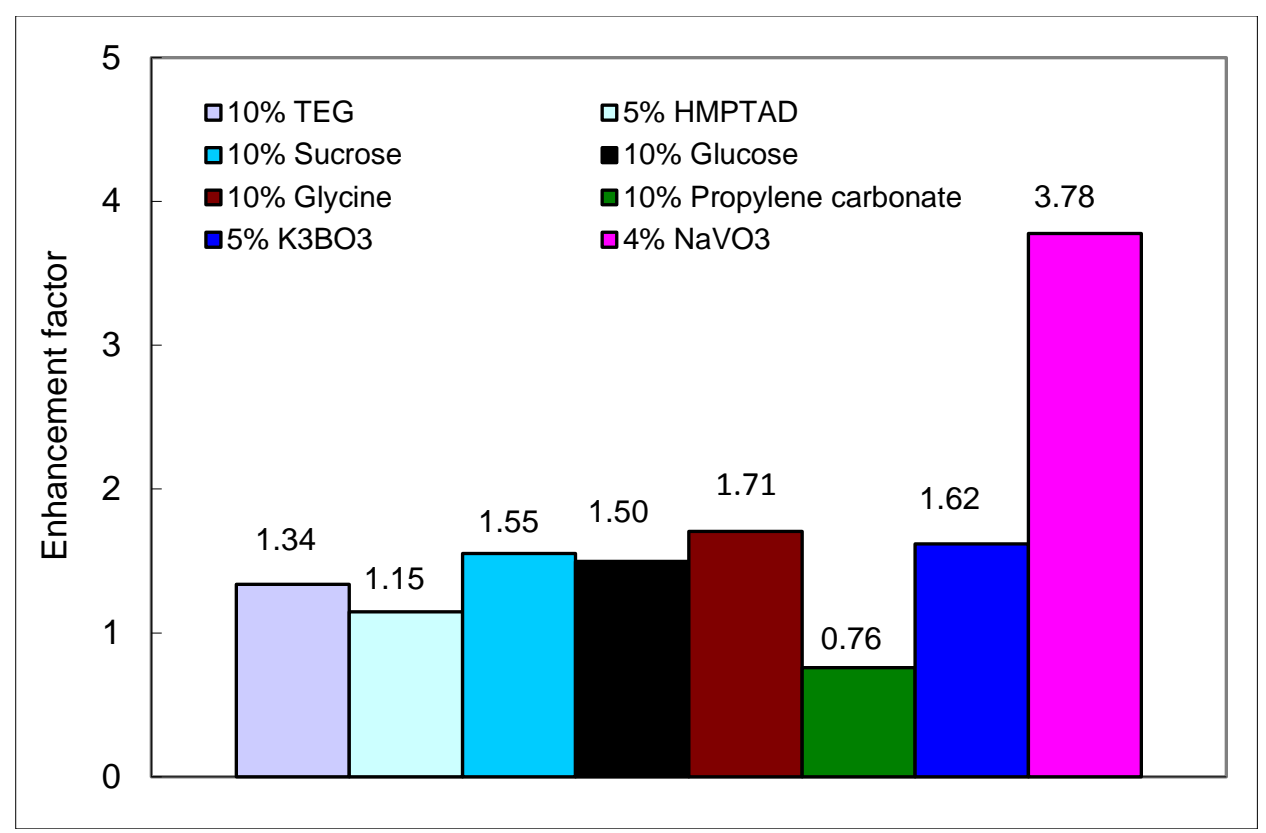

(a) at $25^{\circ} \mathrm{C}$

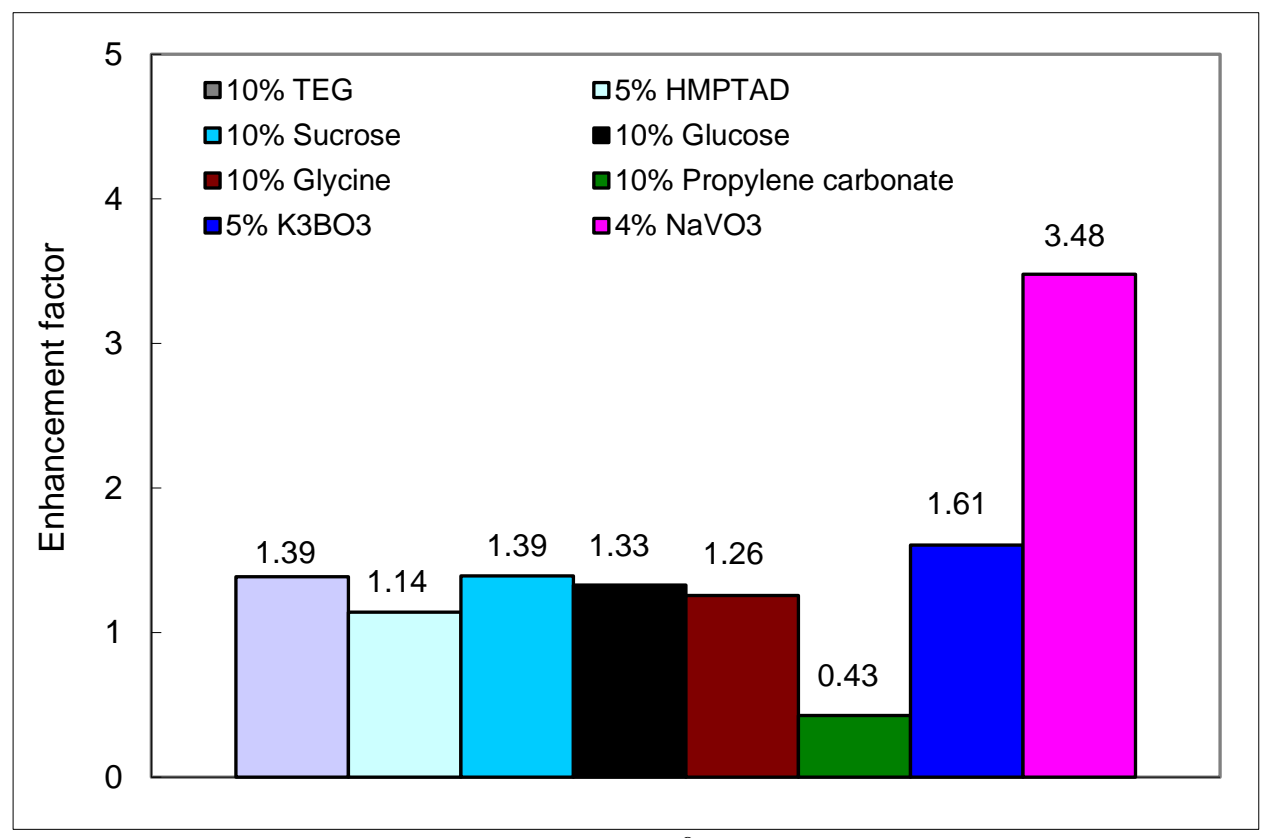

(b) at $40^{\circ} \mathrm{C}$

Figure 3B-2. Enhancement factors of selected additives for $\mathrm{CO}_{2}$ absorption into PC20-20.

\section{B.4 Summary}

Numerous additives expected to promote the rate of $\mathrm{CO}_{2}$ absorption into PC solutions were tested in our stirred reactor cell. The many type of additives that either increase $\mathrm{CO}_{2}$ solubility into water and/or decrease the surface tension of the PC solutions enhanced the $\mathrm{CO}_{2}$ absorption rate by less than 1.75 times the absorption rate for the pure PC solution without additives. In contrast, the addition of $4 \mathrm{wt} \%$ of $\mathrm{NaVO}_{3}$, a weak Lewis base-type additive accelerated the $\mathrm{CO}_{2}$ 
absorption rate by as much as 3.8 times the rate for pure $\mathrm{PC}$ at $25^{\circ} \mathrm{C}\left(77^{\circ} \mathrm{F}\right)$, and 3.5 times at $40^{\circ} \mathrm{C}\left(104^{\circ} \mathrm{F}\right)$.

\section{References}

1. Vazquez G., Chenlo F., Pereira G. Enhancement of the absorption of $\mathrm{CO}_{2}$ in alkaline buffers by organic solutes: relation with degree of dissociation and molecular $\mathrm{OH}$ density. Industrial Engineering and Chemical Research, 1997, 36: 2353-2358.

2. Lenoir J., Renault P., Renon H. Gas chromatographic determination of Henry's constants of 12 gases in 19 solvents, Journal of Chemical Engineering Data, 1971, 16: 340-342.

3. Danckwerts P. V. Gas-liquid reactions. 1970. Mc-Graw-Hill, New York, p. 276.

4. Cents A.H.G., Brilman D.W.F., Versteeg G.F. Gas absorption in an agitated gas-liquid-liquid system, Chemical Engineering Science, 2001, 56:1075-1083.

5. Vazquez G., Chenlo F., Pereira G. Enhancement of the absorption of $\mathrm{CO}_{2}$ in alkaline buffers by organic solutes: relation with degree of dissociation and molecular $\mathrm{OH}$ density. Industrial Engineering and Chemical Research, 1997, 36: 2353-2358.

6. Lenoir J., Renault P., Renon H. Gas chromatographic determination of Henry's constants of 12 gases in 19 solvents. Journal of Chemical Engineering Data, 1971, 16: 340-342. 


\section{PART 3C. KINETICS OF $\mathrm{CO}_{2}$ ABSORPTION INTO $\mathrm{K}_{2} \mathrm{CO}_{3}$ (PC) SOLUTIONS PROMOTED BY CA ENZYME}

\section{C.1 Introduction}

The IVCAP uses an aqueous PC solution as a solvent for $\mathrm{CO}_{2}$ absorption. The kinetics of $\mathrm{CO}_{2}$ absorption into PC are slow compared with that into MEA. One option for increasing the absorption rate is to mix the PC with another solvent or a mixture of solvents that have stronger affinity to $\mathrm{CO}_{2}$. This option, however, increases the heat of absorption of the solution ${ }^{[1]}$ and thus increases the energy consumption of the process. Using a catalyst to promote the absorption rate does not increase the heat of absorption. Several catalysts, including arsenate, sulfide, hypochlorite, sodium/potassium metavanadate, and formaldehyde have been found by others to accelerate the $\mathrm{CO}_{2}$ absorption rate by $2-5$ fold. ${ }^{[2-5]}$ However, some drawbacks of these promoters, including low catalytic activity, especially at low concentrations, toxicity, instability, or corrosiveness, limited their practical applications in the IVCAP. Studies by others indicate that the most effective catalyst for $\mathrm{CO}_{2}$ hydration in the IVCAP may be the carbonic anhydrase (CA) enzyme. The turnover number for a human $\mathrm{CA}$ is as high as $1.4 \times 10^{6} \mathrm{~s}^{-1} .{ }^{[6]}$

If a CA enzyme is to be used as a biocatalyst to accelerate the rate of $\mathrm{CO}_{2}$ absorption into the PC solution, knowledge of the kinetics of $\mathrm{CA}$ enzyme-promoted $\mathrm{CO}_{2}$ absorption is necessary for the design, scale-up, and economic evaluation of the absorption columns. In this part of our study, the reaction rate constant of the CA enzyme in promoting absorption of $\mathrm{CO}_{2}$ into a $20 \mathrm{wt} \% \mathrm{PC}$ solution with varying CTB conversion rates $(10$ to $50 \%)$ at 25,40 , and $50^{\circ} \mathrm{C}\left(77,104\right.$, and $\left.122^{\circ} \mathrm{F}\right)$ was measured using the STR cell reactor. These conditions are typical of $\mathrm{CO}_{2}$ absorption in IVCAP.

\section{C.2 Experimental method}

The CA enzyme (ACA1) was provided by a leading enzyme manufacturer as a technical-grade sample for research purposes (not for commercial sale). It is an extra-cellular enzyme of microbial origin with a molecular weight of approximate 25-30 kDa. The enzyme was produced by fermentation using a benign host organism, which was removed during recovery of the enzyme broth and thus not present in the CA samples. The ACAlenzyme was received in the form of concentrated solutions (about $3 \mathrm{~g} \mathrm{CA} / \mathrm{L}$ ) containing small amounts of impurities, such as low molecular weight fermentation residues, processing acids, salts, and other proteins. The asreceived enzyme samples were mixed with PC solutions to prepare solutions of various CA concentrations.

Potassium carbonate (ACS reagent $\geq 99.0 \%$, Sigma-Aldrich), potassium bicarbonate ( $\geq 99.5 \%$, Sigma-Aldrich), and $\mathrm{CO}_{2}$ gas (99.99\% purity, S.J Smith) were used as received.

The experimental setup and procedure used for these kinetic studies have been described in Section 3A.2 of this chapter.

\section{C.3 Theoretical analysis and data interpretation}


To promote $\mathrm{CO}_{2}$ absorption into a $\mathrm{PC}$ solution, the $\mathrm{CA}$ enzyme catalyzes the $\mathrm{CO}_{2}$ hydration reaction (3A-R2) according to the following mechanism: ${ }^{[7,8]}$

$$
\mathrm{CO}_{2}+\mathrm{H}_{2} \mathrm{O}+\mathrm{EM} \Leftrightarrow \mathrm{HCO}_{3}^{-}+\mathrm{H}^{+}+\mathrm{EM}
$$

Under some process conditions, the concentration of $\mathrm{OH}^{-}$ions near the gas-liquid surface is not significantly depleted by the absorbed $\mathrm{CO}_{2}$, and then the overall reaction rate is a pseudo-first order with respect to $\mathrm{CO}_{2}$ :

$$
r=-d\left[\mathrm{CO}_{2}\right] / d t=k_{o v} \times\left[\mathrm{CO}_{2}\right]
$$

The overall rate constant is a linear function of the total catalyst concentration expressed by the following equation: ${ }^{[9-12]}$

$$
k_{o v}=k_{\mathrm{H}_{2} \mathrm{O}}+k_{\mathrm{OH}}\left[\mathrm{OH}^{-}\right]+k_{\mathrm{CA}}[\mathrm{CA}]
$$

where $k_{C A}$ is the reaction rate constant, and [CA] is the concentration of the CA enzyme added into the PC solution.

Recall Eq. (3A.15) in Part A of this chapter

$$
\operatorname{Ln}\left(\frac{P_{\mathrm{CO}_{2}, 0}-C^{b} \mathrm{He}}{P_{\mathrm{CO}_{2}, t}-C^{b} \mathrm{He}}\right)=\sqrt{k_{L}^{2}+D_{\mathrm{CO}_{2}, P C} k_{o v}} \frac{R T A}{V_{G} \mathrm{He}} \Delta t
$$

By rearranging Eq. (3C-2) and (3A-15), the following equation can be obtained:

$$
\left(\frac{m_{C A}}{m_{0}}\right)^{2}=1+\frac{k_{C A} D_{C O_{2}, P C}[C A]}{m_{0}^{2}}
$$

where $m_{C A}$ and $m_{0}$ are the slopes of the lines obtained by plotting $L n\left(\frac{P_{\mathrm{CO}_{2}, 0}-C^{b} \mathrm{He}}{P_{\mathrm{CO}_{2}, \mathrm{t}}-\mathrm{C}^{b} \mathrm{He}}\right) v s$. $\frac{R T A}{V_{G} H e} \Delta t$ using the data from the pressure-change profile for the absorption of $\mathrm{CO}_{2}$ into $\mathrm{PC}$ solutions with and without the CA enzyme.

The value of $k_{C A}$ can thus be determined from the slope of the line formed by a plot of $\left(m_{C A} / m_{o}\right)^{2}$ vs. $D_{C O 2, P C}[C A] / m_{o}{ }^{2}$ when the intercept is set to be 1 . This method to obtain the value of $k_{C A}$ minimizes the errors, if any, associated with calculations/estimations of $k_{L}$ and the physical properties of the gas and liquid phase.

\section{C.4 Results and discussion}

The rates of $\mathrm{CO}_{2}$ absorption into a $20 \mathrm{wt} \% \mathrm{PC}$ solution with different $\mathrm{CTB}$ conversion rates (10 to $50 \%)$ at 25,40 , and $50^{\circ} \mathrm{C}\left(77,104\right.$, and $\left.122^{\circ} \mathrm{F}\right)$ were measured using the STR. One advantage of using the STR system to measure the $\mathrm{CO}_{2}$ absorption rates is that the pressure change profile in the gas phase is measured without knowledge of the liquid phase composition. The change in the liquid phase composition is assumed negligible during the $\mathrm{CO}_{2}$ absorption process, because only a small volume of $\mathrm{CO}_{2}$ gas is absorbed into a large volume of the PC solution and, 
therefore, the concentration and composition of the solution during the experimental time remain essentially unchanged.

The measurements were carried out under the conditions necessary to satisfy the requirement of the criterion equation $3 \mathrm{~A}-12$ to ensure that the overall reaction can be treated as pseudo-first order related to $\mathrm{CO}_{2}$. The $\mathrm{CO}_{2}$ partial pressure $\left(\mathrm{P}_{\mathrm{CO} 2}\right)$ in the gas phase, was a critical parameter to satisfy the requirement. A suitable range of $P_{C O 2}$ values, mostly falling between 6.9 and $69 \mathrm{kPa}$ (1.0 and $10 \mathrm{psia}$ ) in the measurements, was used.

Figure 3C-1 shows a typical plot of $\operatorname{Ln}\left(\frac{P_{\mathrm{CO}_{2}, 0}-C^{b} \mathrm{He}}{P_{\mathrm{CO}_{2}, t}-C^{b} \mathrm{He}}\right)$ vs. $\frac{R T A}{V_{G} \mathrm{He}} \Delta t$ using the data for $\mathrm{CO}_{2}$ absorption at $40^{\circ} \mathrm{C}\left(104^{\circ} \mathrm{F}\right)$ into $20 \mathrm{wt} \%$ PC solutions with a $20 \% \mathrm{CTB}$ conversion rate (PC2020) without and with various concentrations of the CA enzyme ranging between 10 and 200 $\mathrm{mg} / \mathrm{L}$. It can be seen that the data fit a linear relationship and the values of $m_{C A}$ and $m_{0}$, i.e., the slopes of the straight lines as dictated by Eq. (3C-3), thereby can be calculated by a simple linear regression.

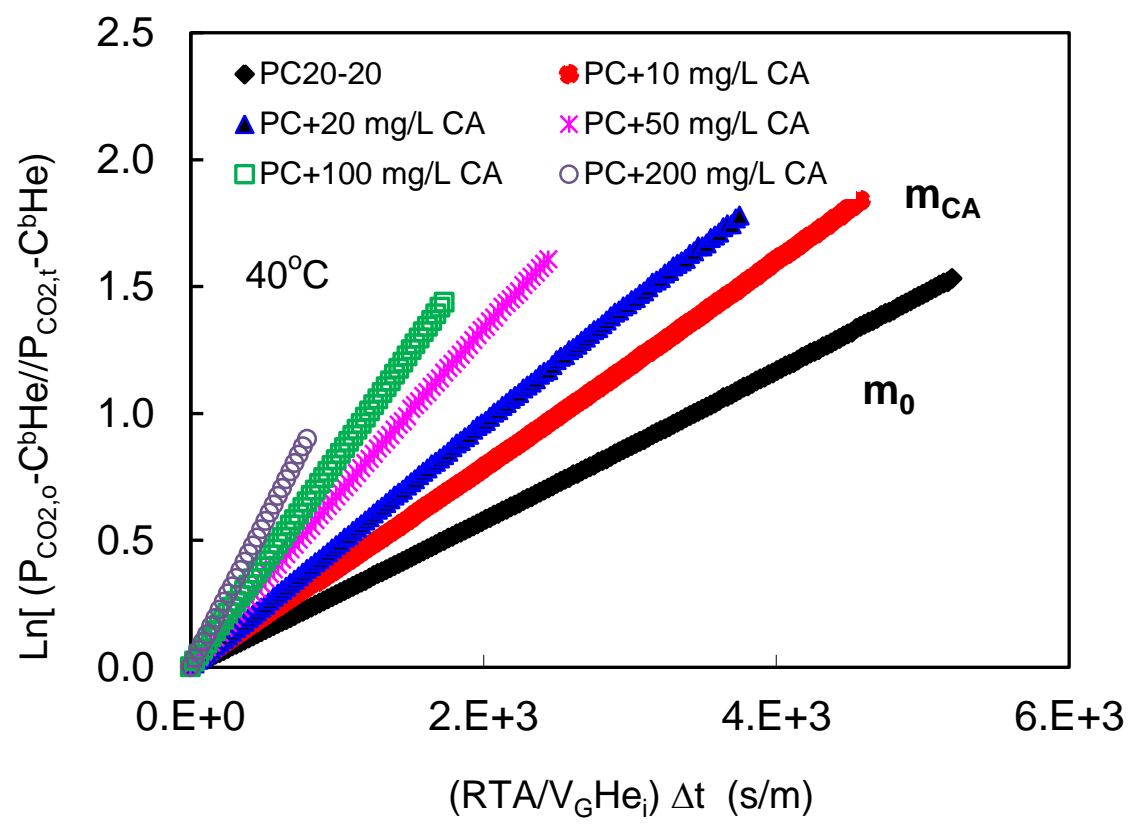

Figure 3C-1. Plot of $\operatorname{Ln}\left(\frac{P_{\mathrm{CO}_{2}, 0}}{P_{\mathrm{CO}_{2}, t}}\right)$ vs. $\frac{R T A}{V_{G} \mathrm{He}} \Delta t$ using data of $\mathrm{CO}_{2}$ absorption into the PC20-20 solution without and with various amounts of the CA enzyme at $40^{\circ} \mathrm{C}$.

In the same way, the values of $m_{C A}$ and $m_{0}$ for $\mathrm{CO}_{2}$ absorption with different $\mathrm{PC}$ compositions and temperatures were obtained (figures not shown). Figure 3C-2 shows a plot of $\left(m_{C A} / m_{o}\right)^{2}$ vs. $D[C A] / m_{o}{ }^{2}$ using the calculated values of $m_{C A}$ and $m_{0}$ from Figure 3C-1 and those calculated from similar plots at 25 and $50^{\circ} \mathrm{C}\left(77\right.$ and $\left.122^{\circ} \mathrm{F}\right)$. It can be noted that at each temperature, a good linear relationship was obtained, indicating that the values of $k_{C A}$ do not significantly depend on the CTB conversion rate (i.e., the $\mathrm{CO}_{2}$ loading of the $\mathrm{PC}$ solution). 


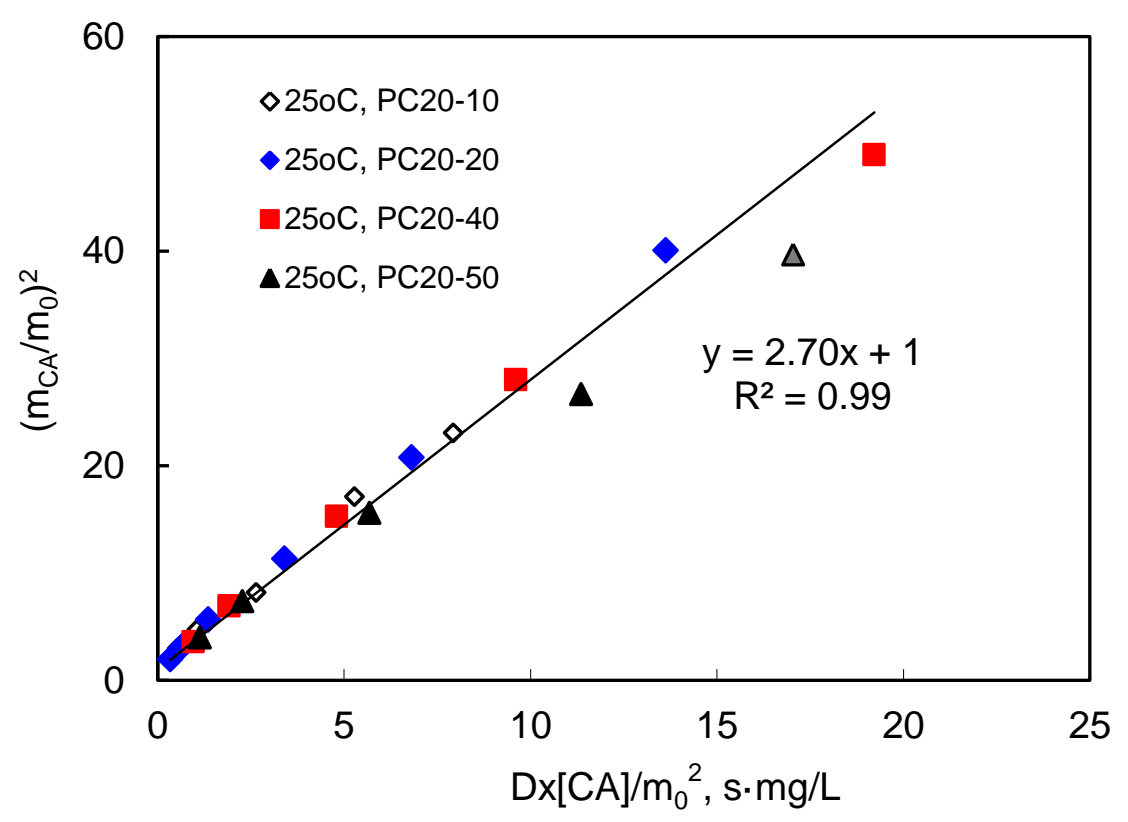

(a) at $25^{\circ} \mathrm{C}$

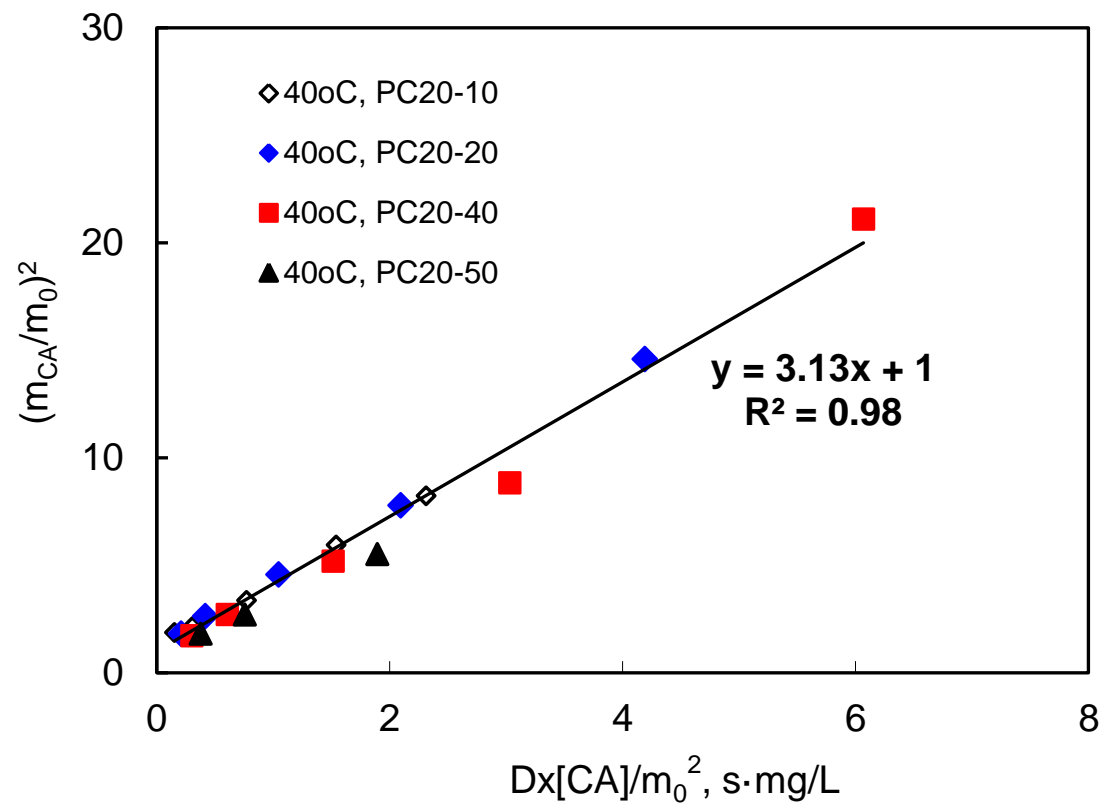

(b) at $40^{\circ} \mathrm{C}$ 


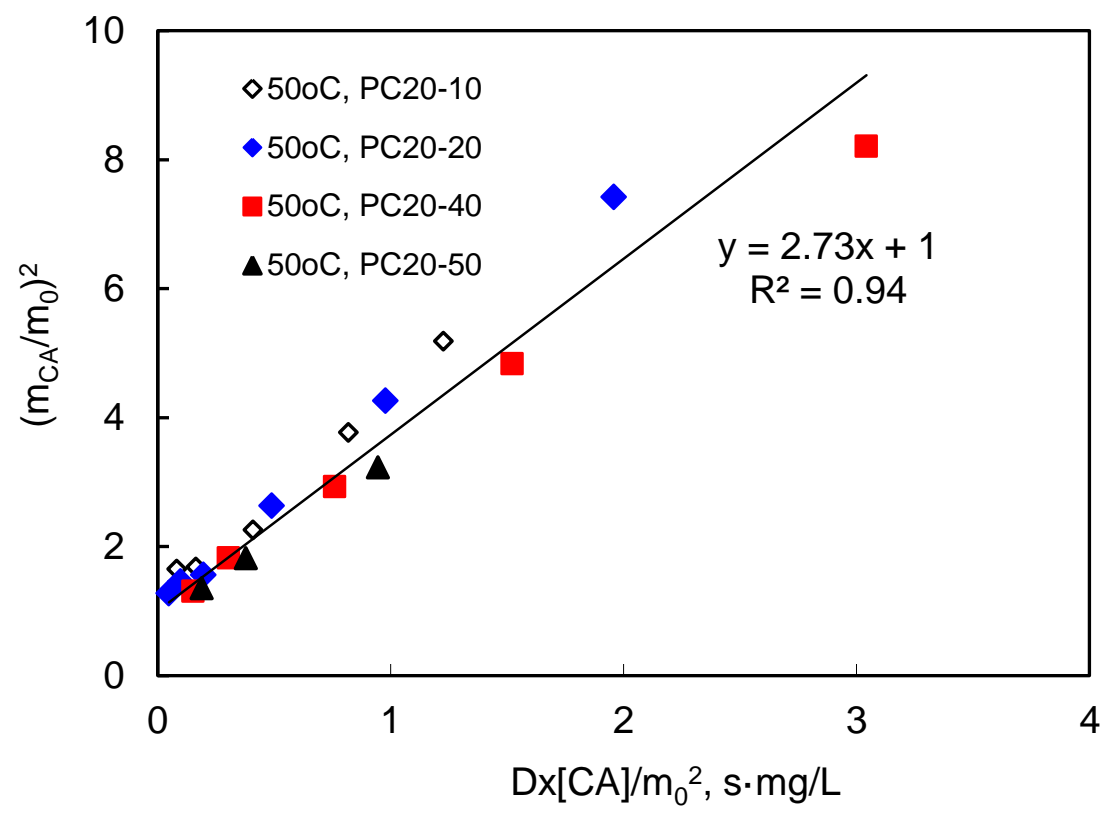

(c) at $50^{\circ} \mathrm{C}$

Figure $3 \mathrm{C}-2$. Determination of $k_{C A}$ at 25,40 , and $50^{\circ} \mathrm{C}$ in the $20 \mathrm{wt} \% \mathrm{PC}$ with $\mathrm{CTB}$ conversion rates ranging from 10 to $50 \%$.

The calculated values of $k_{C A}$ are summarized in Table $3 \mathrm{C}-1$. The value of $k_{C A}$ is slightly higher at $40^{\circ} \mathrm{C}$ than at 25 and $50^{\circ} \mathrm{C}\left(77\right.$ and $\left.122^{\circ} \mathrm{F}\right)$, but nearly comparable at 25 and $50^{\circ} \mathrm{C}\left(77\right.$ and $\left.122^{\circ} \mathrm{F}\right)$. It is expected that the $k_{C A}$ value increases with increasing temperature from 25 to $40^{\circ} \mathrm{C}$ (77 to $104^{\circ} \mathrm{F}$ ) since the kinetics are generally favored as the temperature increases. However, the $k_{C A}$ value at $50^{\circ} \mathrm{C}\left(122^{\circ} \mathrm{F}\right)$ is lower than that at $40^{\circ} \mathrm{C}\left(104^{\circ} \mathrm{F}\right)$, indicating that the enzyme activity was reduced when the temperature was further raised from 40 to $50^{\circ} \mathrm{C}\left(104\right.$ to $\left.122^{\circ} \mathrm{F}\right)$. These empirically obtained $k_{C A}$ values have minimized errors, if any, associated with the estimations of the physical properties based on measuring and comparing the absorption rates of $\mathrm{CO}_{2}$ into the PC solutions without and with different concentrations of the CA enzyme.

Table $3 \mathrm{C}-1$. The obtained values of $k_{C A}$ in $20 \mathrm{wt} \%$ PC solutions at 25,40 , and $50^{\circ} \mathrm{C}$

\begin{tabular}{|c|c|c|}
\hline Temperature $\left({ }^{\circ} \mathrm{C}\right)$ & $k_{C A}(\mathrm{~L} / \mathrm{mg} \cdot \mathrm{s})$ & $k_{C A}\left(\mathrm{M}^{-1} \cdot \mathrm{s}^{-1}\right)$ \\
\hline 25 & 2.70 & $8.1 \times 10^{7}$ \\
\hline 40 & 3.13 & $9.4 \times 10^{7}$ \\
\hline 50 & 2.73 & $8.2 \times 10^{7}$ \\
\hline
\end{tabular}

Among many naturally occurring CA isozymes, the human CA II enzyme is known as the fastest $\mathrm{CA}$ isozyme for $\mathrm{CO}_{2}$ hydration. It has been reported that the human CA II enzyme's activity increases with increasing $\mathrm{pH}$ from 6.2 to 8.9 , but drops when $\mathrm{pH}$ further increases. ${ }^{[13]} \mathrm{The} \mathrm{pH}$ value of the $20 \mathrm{wt} \%$ PC with the CTB conversation rates of 10 to $50 \%$ used in this study varied from 10 to 10.5 . From Table $3 \mathrm{C}-2$, the $k_{C A}$ value of the $\mathrm{CA}$ enzyme averaging from $\mathrm{pH} 10$ to 10.5 at $25^{\circ} \mathrm{C}\left(77^{\circ} \mathrm{F}\right)$ was estimated to be $8.1 \times 10^{7} \mathrm{M}^{-1} \cdot \mathrm{s}^{-1}$, which is comparable to, or only slightly higher than, those of the natural human CA II enzyme at similar $\mathrm{pH}$ conditions (Table 3C-2). 
Table 3C-2. Michaelis-Menten kinetic parameters for $\mathrm{CO}_{2}$ hydration catalyzed by the human CA II enzyme at $25^{\circ} \mathrm{C}$ (All buffer concentrations were maintained at $50 \mathrm{mM}$ and the ionic strength at $0.1 \mathrm{M}$ with $\left.\mathrm{Na}_{2} \mathrm{SO}_{4}\right)^{[13]}$

\begin{tabular}{|c|c|c|c|c|}
\hline Buffer & $\mathrm{pH}$ & $k_{\text {cat }}(1 / s)^{*}$ & $K_{m}(M)^{* *}$ & $k_{C A}=k_{\text {cat }} / K_{m}\left(\mathrm{M}^{-1} \cdot \mathrm{s}^{-1}\right)$ \\
\hline Ches & 9.4 & $1600 \times 10^{3}$ & $18 \times 10^{-3}$ & $9 \times 10^{7}$ \\
\hline Bicine & 8.9 & $1100 \times 10^{3}$ & $8.0 \times 10^{-3}$ & $14 \times 10^{7}$ \\
\hline Taps & 8.9 & $1000 \times 10^{3}$ & $9.7 \times 10^{-3}$ & $10 \times 10^{7}$ \\
\hline Mops & 7.2 & $350 \times 10^{3}$ & $6.8 \times 10^{-3}$ & $5.1 \times 10^{7}$ \\
\hline NMI & 7.2 & $430 \times 10^{3}$ & $9.9 \times 10^{-3}$ & $4.3 \times 10^{7}$ \\
\hline Phosphate & 7.1 & $570 \times 10^{3}$ & $9.0 \times 10^{-3}$ & $6.4 \times 10^{7}$ \\
\hline Mes & 6.2 & $84 \times 10^{3}$ & $8.1 \times 10^{-3}$ & $1.0 \times 10^{7}$ \\
\hline
\end{tabular}

$* k_{\text {cat }}$ is the turnover number. $* * K_{m}$ is the Michaelis constant.

\section{C.5 Summary}

The reaction rate constants of the CA enzyme in $20 \mathrm{wt} \% \mathrm{PC}$ solution at 25,40 and $50^{\circ} \mathrm{C}(77$, 104 , and $122^{\circ} \mathrm{F}$ ) were empirically determined using a STR reactor based on classic Danckwerts theory for absorption with chemical reactions.

The results show that the value of $k_{C A}$ was slightly higher at $40^{\circ} \mathrm{C}\left(104^{\circ} \mathrm{F}\right)$ than at $25^{\circ} \mathrm{C}\left(77^{\circ} \mathrm{F}\right)$, but comparable at 25 and $50^{\circ} \mathrm{C}\left(77\right.$ and $\left.122^{\circ} \mathrm{F}\right)$. The value of $k_{C A}$ did not significantly depend on the CTB conversion rate of the $20 \mathrm{wt} \% \mathrm{PC}$ solution. The value of $k_{C A}$ obtained in this study is comparable to, or slightly higher than, those reported for the natural human CA II enzyme in the literature under comparable $\mathrm{pH}$ conditions at $25^{\circ} \mathrm{C}\left(77^{\circ} \mathrm{F}\right)$.

\section{References}

1. Cullinane J. T., Rochelle G. T. Thermodynamics of aqueous potassium carbonate, piperazine, and carbon dioxide. Fluid Phase Equilibria, 2005, 227:197-213.

2. Kohl A. S., Nielsen R. B. Gas purification. 5th Edn, Houston: Gulf Publishing, 1997.

3. Augugliaro V., Rizzuti L. Kinetics of carbon dioxide absorption into catalysed potassium carbonate solutions. Chemical Engineering Science, 1987, 42:2339-2343.

4. Pohorecki R. The absorption of $\mathrm{CO}_{2}$ in carbonate - bicarbonate buffer solutions containing hypochlorite catalyst on a sieve plate. Chemical Engineering Science, 1968, 23:1447-1451.

5. Sharma M. M., Danckwerts P. V. Fast reactions of $\mathrm{CO}_{2}$ in alkaline solutions- (a) Carbonate buffers with arsenite, formaldehyde and hypochlorite as catalysts (b) Aqueous monoisopropanolamine (1-amino-2-propanol) solutions. Chemical Engineering Science 1963, 18:729-735.

6. Kjxalifah R. G. The Carbon Dioxide Hydration Activity of Carbonic Anhydrase I. StopFlow Kinetic Studies on the Native Human Isoenzymes B and C. The Journal of Biological Chemistry, 1971, 246:2561-2573.

7. Pandey A., Webb C., Soccol C.R., Larroche C. Enzyme technology. Springer; 2006. 
8. Mirjafari P., Asghari K., Mahinpey N. Investigating the application of enzyme carbonic anhydrase for $\mathrm{CO} 2$ sequestration purposes. Industrial Engineering and Chemical Research, 2007, 46:921-926.

9. Cents A.H.G., Brilman D.W.F. Versteeg GF. Gas absorption in an agitated gas-liquid-liquid system. Chemical Engineering Science, 2001, 56:1075-1083.

10. Vazquez G., Chenlo F., Pereira G.. Enhancement of the absorption of $\mathrm{CO} 2$ in alkaline buffers by organic solutes: Relation with degree of dissociation and molecular $\mathrm{OH}$ density. Industrial Engineering and Chemical Research, 1997, 36:2353-2358.

11. Danckwerts P. V. Gas-liquid reactions. Mc-Graw-Hill, New York, 1970.

12. Alper E., Deckwer W. Kinetics of absorption of $\mathrm{CO} 2$ into buffer solutions containing carbonic anhydrase. Chemical Engineering Science, 1980, 35:549-557.

13. Engstrand C., Forsman C., Liang Z., Lindskog S. Proton transfer roles of lysine 64 and glutamic acid 64 replacing histidine 64 in the active site of human carbonic anhydrase II, Biochimica et Biophysica Acta, 1992, 1122: 321-326. 


\section{PART 3D. ACTIVITY AND STABILITY OF CA ENZYME FOR ENHANCING $\mathrm{CO}_{2}$ ABSORPTION INTO $\mathrm{K}_{2} \mathrm{CO}_{3}$ SOLUTIONS}

\section{D.1 Introduction}

In this part of the study, the effectiveness of the CA enzyme as a biocatalyst to promote $\mathrm{CO}_{2}$ absorption into PC solutions was determined. The activity of the CA enzyme was investigated under different conditions, including $\mathrm{CO}_{2}$ loading of the $\mathrm{PC}$ solution (CTB conversion rates from 20 to $40 \%$ ), temperatures $\left(25,40\right.$, and $50^{\circ} \mathrm{C} / 77,104$, and $122^{\circ} \mathrm{F}$ ), and enzyme concentrations (between 10 and $600 \mathrm{mg} / \mathrm{L}$ ). In addition, the thermal stability of the CA enzyme was examined over a two- to six-month period at 40 to $60^{\circ} \mathrm{C}\left(104\right.$ to $\left.140^{\circ} \mathrm{F}\right)$, and its chemical stability was tested in the presence of flue gas contaminants and chemical additives under typical IVCAP operating conditions.

\section{D.2 Experimental method}

\section{D.2.1 Method and materials}

Three types of CA enzymes were used; one was a CA enzyme for general purpose (denoted as ACA1), and the second was a thermophilic CA enzyme engineered for higher temperature (up to $60^{\circ} \mathrm{C} / 140^{\circ} \mathrm{F}$ ) applications (denoted as ACA2). The two CA enzymes were provided by a leading enzyme manufacturer as technical-grade samples for research purposes (not for commercial application). These enzymes were produced by microbial fermentation using a benign host organism, which was removed during recovery of the enzyme broth and thus not present in the samples. The enzymes have a molecular weight ranging between 25 and $30 \mathrm{kDa}$. The ACA1 enzyme was received in the form of a concentrated solution (about $3 \mathrm{~g} \mathrm{CA} / \mathrm{L}$ ) containing small amounts of impurities, such as low molecular weight fermentation residues, processing acids, salts, and other proteins. The ACA2 enzyme contained $38 \mathrm{~g} / \mathrm{L}$ of CA enzyme protein.

A third enzyme (denoted as BCA1) was developed by a research organization for potential application in IVCAP at elevated temperatures up to $60^{\circ} \mathrm{C}\left(140^{\circ} \mathrm{F}\right)$. The as-received samples were used for preparing PC solutions with desired concentrations of the various enzymes.

Potassium carbonate (ACS reagent $\geq 99.0 \%$, Sigma-Aldrich), potassium bicarbonate $(\geq 99.5 \%$, Sigma-Aldrich), potassium sulfate $(\geq 99.0 \%$, Sigma-Aldrich), potassium nitrate $(\geq 99.0 \%$, Sigma-Aldrich), potassium chloride ( $\geq 99.0 \%$, Sigma-Aldrich), and $\mathrm{CO}_{2}$ gas $(99.99 \%$ purity, S.J Smith) were used in their as-received form to prepare the various solutions used in the experiments.

Rates of $\mathrm{CO}_{2}$ absorption into the PC solutions containing the $\mathrm{CA}$ enzymes were measured using the same batch STR setup and procedure described in Section 3A.2.

\section{D.2.2 Experimental conditions}

The three enzymes were investigated for their long-term thermal stabilities in PC solutions with $300 \mathrm{mg} / \mathrm{L}$ of the various CA enzymes at the respective temperatures. The testing periods varied 
with the temperature and ranged from two to six months (Table 3D-1). During the testing intervals, the PC-CA solutions were stored in a thermostatic incubator at the desired temperatures without stirring.

Table 3D-1. Test matrix for a long-term thermal stability study on the three CA enzymes

\begin{tabular}{|l|c|c|c|}
\hline Conditions & ACA1 enzyme & ACA2 enzyme & BCA1 enzyme \\
\hline Temperatures $\left({ }^{\circ} \mathrm{C}\right)$ & $25,40,50$ & $40,50,60$ & $40,50,60$ \\
\hline PC solutions and CTB \% & PC20-20\& PC20-40 & PC20-20\& PC20-40 & PC20-20 \\
\hline & 6 months at $25 \&$ & 6 months at $40^{\circ} \mathrm{C}$, & 4 months at $40^{\circ} \mathrm{C}$, \\
Testing period (months) & $40^{\circ} \mathrm{C} ; 2$ months at $50^{\circ} \mathrm{C}$ & 4 months at $50^{\circ} \mathrm{C} ;$ & 3 months at $50^{\circ} \mathrm{C} ;$ \\
& 3 months at $60^{\circ} \mathrm{C}$ & 2 months at $60^{\circ} \mathrm{C}$ \\
\hline
\end{tabular}

Enzyme ACA1 was further tested for its activity and chemical stability. The activity of the ACA1 enzyme was investigated at concentrations ranging from 10 to $600 \mathrm{mg} / \mathrm{L}$ in PC20-20 and PC20-40 solutions at 25,40 and $50^{\circ} \mathrm{C}\left(77,104\right.$, and $\left.122^{\circ} \mathrm{F}\right)$. The chemical stability of the ACA1 enzyme was examined in the presence of flue gas contaminants and chemical additives, including reaction rate promoters $\left(\mathrm{NaVO}_{3}\right)$ and water vapor pressure inhibitors (KAC) under typical IVCAP operating conditions. All of these tests were performed in the STR cell described in Section 3A.2.

\section{D.3 Theoretical analysis and data interpretation}

The stability of the CA enzyme in the PC solution was calculated by the changing rate of $E_{C A}$ or by the activity loss of the enzyme $\left(\eta_{C A}\right)$ defined by

$$
\eta_{C A}=\frac{E_{C A, 0}-E_{C A}}{E_{C A, 0}-1} \times 100 \%
$$

$E_{C A}$ was defined the same as $E_{c a t}$ in Section 3B.3 for CA enzyme used as a catalyst. $E_{C A, 0}$ was the initial value of $\mathrm{E}_{\mathrm{CA}}$ before any degradation.

\section{D.4 Results and discussion}

\section{D.4.1 Activity of free ACA1 enzyme}

Impact of CA enzyme concentration. The ACA1 enzyme's activity was tested in $20 \mathrm{wt} \% \mathrm{PC}$ solutions with $20 \%$ and $40 \%$ CTB conversion rates (denoted as PC20-20 and PC20-40) at 25, 40 , and $50^{\circ} \mathrm{C}\left(77,104\right.$, and $\left.122^{\circ} \mathrm{F}\right)$. Figure $3 \mathrm{D}-1(\mathrm{a})$ is a representative plot showing the rates of $\mathrm{CO}_{2}$ absorption at $40^{\circ} \mathrm{C}\left(104^{\circ} \mathrm{F}\right)$ into $\mathrm{PC} 20-20$ solution containing dosage levels of ACA1 enzyme between 20 and $600 \mathrm{mg} / \mathrm{L}$. The $\mathrm{CO}_{2}$ absorption rate significantly increased as the CA enzyme dosage increased up to $600 \mathrm{mg} / \mathrm{L}$. This suggests that further improvement may be anticipated at even higher ACA1 dosage levels.

The enhancement factors of the CA enzyme, $E_{C A}$, obtained under various conditions are shown in Figure 3D-1(b). $E_{C A}$ values are smaller at higher temperatures. The $E_{C A}$ is about 8.2 at $25^{\circ} \mathrm{C}$ $\left(77^{\circ} \mathrm{F}\right)$, but decreased to 5.3 at $40^{\circ} \mathrm{C}\left(104^{\circ} \mathrm{F}\right)$ and 3.2 at $50^{\circ} \mathrm{C}\left(122^{\circ} \mathrm{F}\right)$ with $300 \mathrm{mg} / \mathrm{l} \mathrm{ACA} 1$ in a PC20-20 solution. At the same temperature, the $E_{C A}$ value increased, but not proportionally with 
increasing CA dosage level within the investigated range. For instance, in the PC20-20 solution at $40^{\circ} \mathrm{C}\left(104^{\circ} \mathrm{F}\right)$, the $E_{C A}$ increased from about 2.2 to 2.9 and 5.3 as the CA dosage level increased from 50 to 100 to $300 \mathrm{mg} / \mathrm{l}$. The ACA1 enzyme demonstrated larger $E_{C A}$ values in the PC solution at higher $\mathrm{CO}_{2}$ loadings. The value of $\mathrm{E}_{\mathrm{CA}}$ is calculated relative to a reference PC solution without the CA enzyme. It is desirable to comprehend how the actual promoted $\mathrm{CO}_{2}$ absorption rates are affected by the operational parameters.

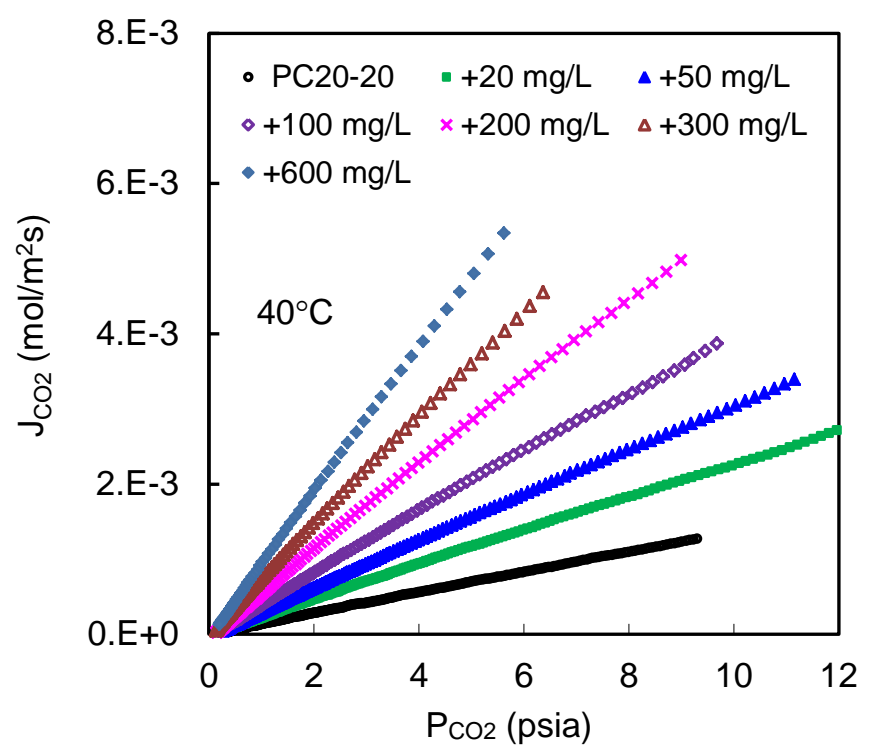

(a) Effect of CA dosage

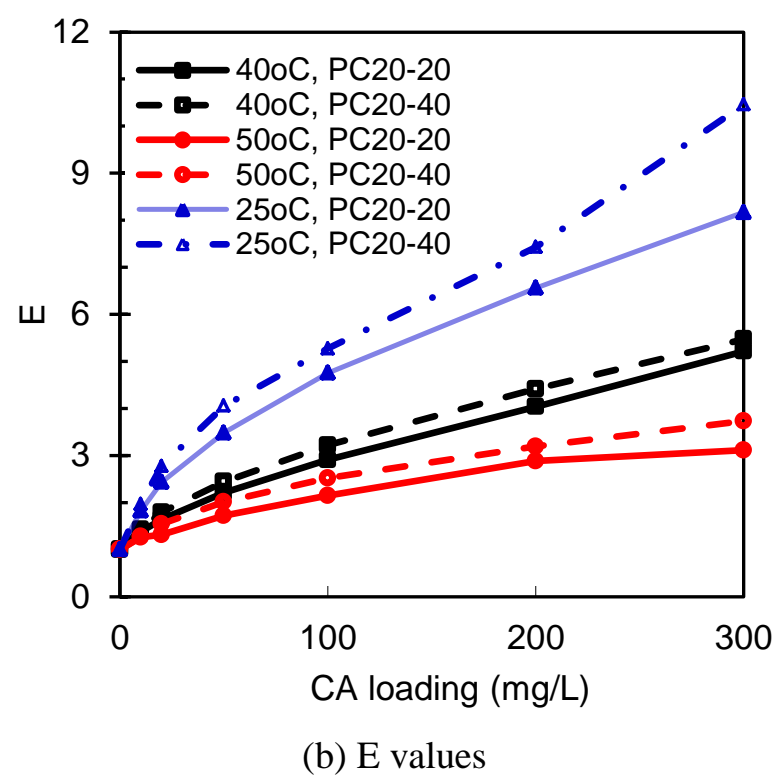

Figure 3D-1. Rate of $\mathrm{CO}_{2}$ absorption into PC containing different concentrations of ACA1 enzyme and E values under different conditions.

Effect of $\mathrm{CO}_{2}$ loading of $P C$ solution on activity of CA enzyme. Figure 3D-2 shows the rate of $\mathrm{CO}_{2}$ absorption at $50^{\circ} \mathrm{C}\left(122^{\circ} \mathrm{F}\right)$ into the PC $20-20$ and PC20-40 solutions without the enzyme and at 50 and $300 \mathrm{mg} / \mathrm{L}$ ACA1 loadings. Without the CA enzyme, the PC20-40 had a lower $\mathrm{CO}_{2}$ 
absorption rate than the PC20-20. No appreciable increase in $\mathrm{CO}_{2}$ absorption rate was observed at $50 \mathrm{mg} / \mathrm{l} \mathrm{CA}$ loading. However, when the CA dosage was increased to $300 \mathrm{mg} / \mathrm{L}$, the $\mathrm{CO}_{2}$ absorption rate into the PC20-40 became comparable with the rate absorbed into the PC20-20 solution. This result indicates that the $\mathrm{CA}$ activity does not noticeably depend on the $\mathrm{CO}_{2}$ loading of the PC solution. This observation can be explained well by the kinetics for $\mathrm{CO}_{2}$ absorption into a PC solution promoted by a catalyst. It is well known that under certain conditions the overall reaction rate is pseudo-first-order with respect to $\mathrm{CO}_{2}$. The rate constant is a linear function of the total catalyst concentration given by: ${ }^{1]}$

$$
r=-d\left[\mathrm{CO}_{2}\right] / d t=k_{o v} \times\left[\mathrm{CO}_{2}\right]
$$

and

$$
k_{o v}=k_{\mathrm{H}_{2} \mathrm{O}}+k_{\mathrm{OH}}\left[\mathrm{OH}^{-}\right]+k_{C A}[\mathrm{CA}]
$$

where $k_{O v}\left(s^{-1}\right)$ is the overall first order rate constant, and $k_{H 2 O}\left(s^{-1}\right), k_{O H}\left(m^{3} \mathrm{kmol}^{-1} \mathrm{~s}^{-1}\right)$, and $k_{C A}$ $\left(M^{-1} s^{-1}\right)$ are the kinetic rate constants for hydration, reaction with $\left[\mathrm{OH}^{-}\right]$, and the reaction promoted by the catalyst, respectively. When no or a small amount of the CA enzyme is applied, the term $k_{O H}\left[\mathrm{OH}^{-}\right]$dominates the overall $\mathrm{CO}_{2}$ absorption. A PC solution with a smaller CTB conversion rate corresponds to a higher $\left[\mathrm{OH}^{-}\right]$concentration, resulting in a higher $\mathrm{CO}_{2}$ absorption rate. At higher $\mathrm{CA}$ dosages, the catalyzed reaction becomes dominant, leading to a smaller difference between the $\mathrm{CO}_{2}$ absorption rates in the $20 \mathrm{wt} \%$ PC solution with different CTB conversion rates. This result indicates that the $\mathrm{CA}$ enzyme can retain its catalytic activity even when the $\mathrm{CO}_{2}$ loading of the solvent is large in an absorption column.

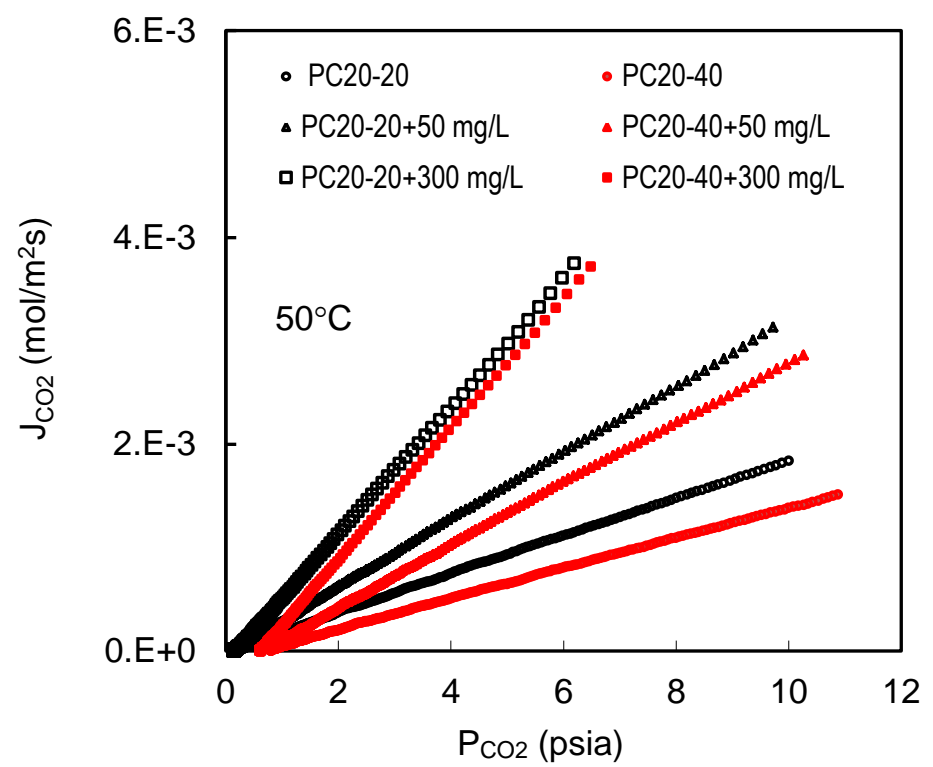

Figure 3D-2. Rates of $\mathrm{CO}_{2}$ absorption into PC20-20 and PC20-40 solutions at $50^{\circ} \mathrm{C}$ without and with 50 and $300 \mathrm{mg} / \mathrm{L}$ ACA1 enzyme loadings.

Effect of temperature on the activity of CA enzyme. Figure 3D-3 displays the effect of temperature on the rate of $\mathrm{CO}_{2}$ absorption into the PC20-20 solution without and with 50 and $300 \mathrm{mg} / \mathrm{l}$ ACA1 enzyme loadings at 25,40 , and $50^{\circ} \mathrm{C}\left(77,104\right.$, and $\left.122^{\circ} \mathrm{F}\right)$. For the $\mathrm{PC}$ solution without the $\mathrm{CA}$ enzyme, the $\mathrm{CO}_{2}$ absorption rate increased with increasing reaction temperature. 
When $50 \mathrm{mg} / \mathrm{L}$ of the ACA1 enzyme was added, the difference among the absorption rates caused by temperature became less evident. When $300 \mathrm{mg} / \mathrm{l}$ ACA1 was added, the $\mathrm{CO}_{2}$ absorption rates at 25 and $40^{\circ} \mathrm{C}\left(77\right.$ and $\left.104^{\circ} \mathrm{F}\right)$ were comparable and slightly higher than at $50^{\circ} \mathrm{C}$ $\left(122^{\circ} \mathrm{F}\right)$. This phenomenon can be explained by the dependency of $\mathrm{CO}_{2}$ solubility (Henry's constant) and reaction kinetics on the reaction temperature. The $\mathrm{CO}_{2}$ solubility decreases while the reaction kinetics increase with increasing temperature. Because the $\mathrm{CA}$ enzyme reduces the activation energy of the $\mathrm{CO}_{2}$ hydration, the kinetics becomes less dependent on temperature. At the CA dosage of $300 \mathrm{mg} / \mathrm{l}$, as the temperature was increased from 25 to $50^{\circ} \mathrm{C}\left(77\right.$ to $\left.122^{\circ} \mathrm{F}\right)$, the absorption rate reduced by the decreased $\mathrm{CO}_{2}$ solubility term was more than that increased by the kinetics term. At $40^{\circ} \mathrm{C}\left(104^{\circ} \mathrm{F}\right)$, these two effects almost exactly offset each other, and the $\mathrm{CO}_{2}$ absorption rate was comparable to that measured at $25^{\circ} \mathrm{C}\left(77^{\circ} \mathrm{F}\right)$.

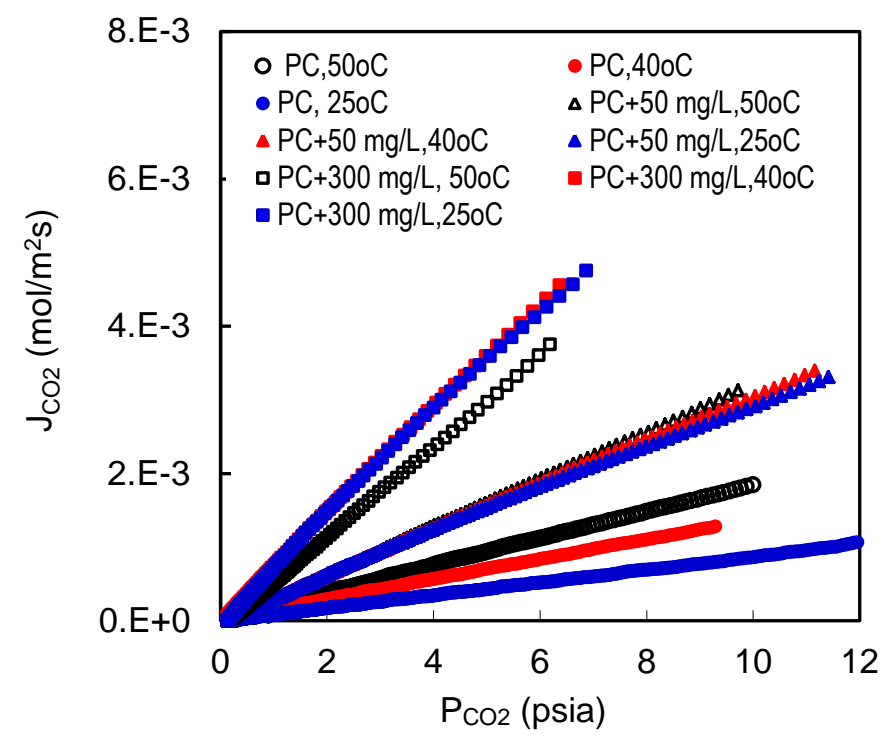

Figure 3D-3. Effect of temperature on the rate of $\mathrm{CO}_{2}$ absorption into PC20-20 without and with 50 and $300 \mathrm{mg} / \mathrm{l} \mathrm{CA}$ enzyme.

\section{D.4.2 Comparison of $\mathrm{CO}_{2}$ absorption rates into PC+ACA1 and MEA}

Rates of $\mathrm{CO}_{2}$ absorption into $5 \mathrm{M}$ MEA also were measured at $50^{\circ} \mathrm{C}\left(122^{\circ} \mathrm{F}\right)$ using the STR setup. Two MEA solutions were used: one is a 5M MEA loaded with $0.2 \mathrm{~mol} \mathrm{CO}_{2} / \mathrm{mol} \mathrm{MEA} \mathrm{or} 40 \%$

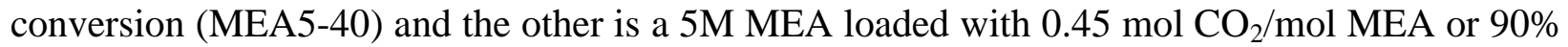
conversion (MEA5-90). The MEA5-40 and MEA5-90 correspond to the $\mathrm{CO}_{2}$ lean and rich condition employed in a typical MEA absorber. As expected, the rates for MEA solutions with different conversion rates differ substantially. ${ }^{[2]}$

The $\mathrm{CO}_{2}$ absorption rates into the 5M MEA solutions are compared with the rates into the 20 wt $\%$ PC solutions with $20 \%$ and $40 \%$ CTB conversion mixed with $300 \mathrm{mg} / \mathrm{l}$ ACA1 (PC20$20+\mathrm{CA}^{*}$ and $\left.\mathrm{PC} 20-40+\mathrm{CA}^{*}\right)$ in Figure 3D-4. The PC20-40+CA* solution represents the $\mathrm{CO}_{2}$ lean condition and the PC20-40+CA* is close to the one at the rich condition in the IVCAP. Results revealed that the $\mathrm{CO}_{2}$ absorption rates into the lean PC20-20+CA* are 4 to 9 times lower than those into the lean MEA5-40 at $50^{\circ} \mathrm{C}\left(122^{\circ} \mathrm{F}\right)$. However, because the rates of $\mathrm{CO}_{2}$ absorption into the $\mathrm{PC}+\mathrm{CA}$ did not decrease with increasing $\mathrm{CTB}$ conversion or $\mathrm{CO}_{2}$ loading, the 
rates into the rich $\mathrm{PC} 20-40+\mathrm{CA}^{*}$ and MEA5-90 are comparable at $50^{\circ} \mathrm{C}\left(122^{\circ} \mathrm{F}\right)$. Thus, the rate difference between the MEA and PC is less significant when the $\mathrm{CO}_{2}$ loading level increases.

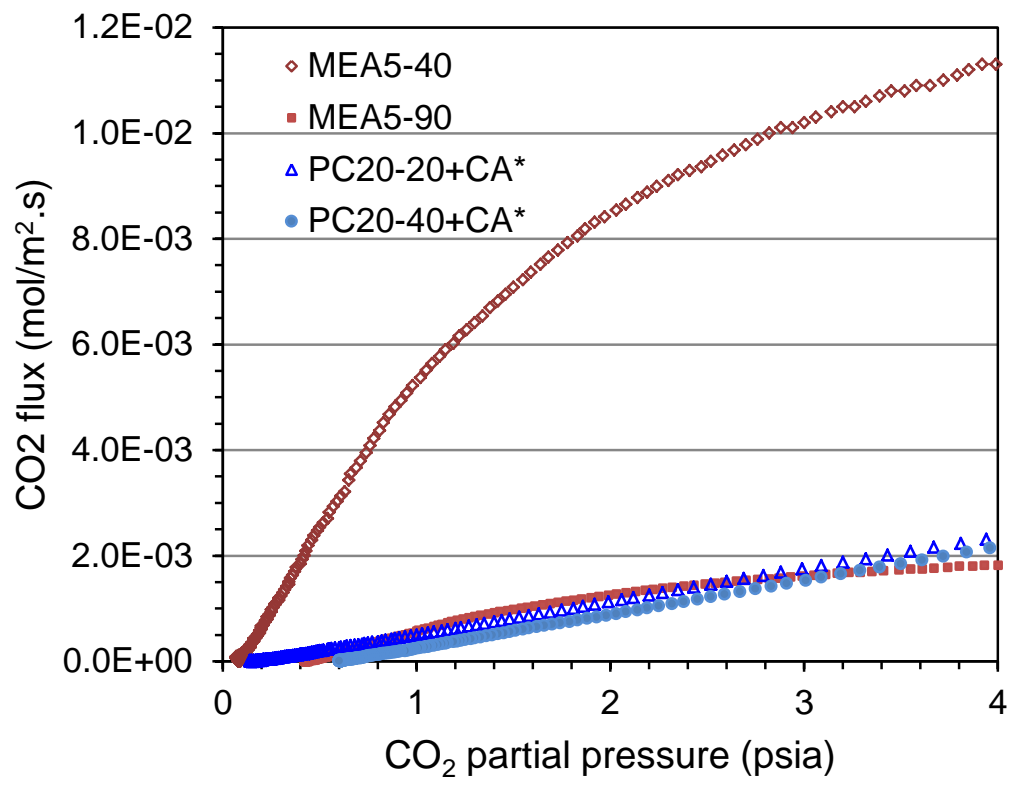

Figure 3D-4. $\mathrm{CO}_{2}$ absorption rates into the lean and rich $20 \mathrm{wt} \% \mathrm{PC}+300 \mathrm{mg} / \mathrm{L} \mathrm{CA}$ and $5 \mathrm{M}$ MEA solutions at $50^{\circ} \mathrm{C}$.

The STR experiments were performed under conditions such that the absorption rate of $\mathrm{CO}_{2}$ into the solvent was not limited by the gas-phase mass transfer resistance. However, in a packed-bed absorption column, the gas-phase mass transfer resistance could become important. Consequently, the difference between the overall $\mathrm{CO}_{2}$ absorption rates into the MEA and $\mathrm{PC}+\mathrm{CA}$ solutions in a packed bed are expected to be less extreme than in the STR system.

The $\mathrm{CO}_{2}$ absorption rate based on the overall gas-phase mass transfer coefficient can be described as follows, assuming the $\mathrm{CO}_{2}$ concentration in the bulk liquid phase is negligible:

$$
\begin{aligned}
& J=K_{G} \frac{p_{C O 2, t}}{R T} \\
& \frac{1}{K_{G}}=\frac{1}{k_{G}}+\frac{1}{H E k_{L}}
\end{aligned}
$$

where $K_{G}$ is the overall gas-side mass transfer coefficient; $k_{G}$ is the gas-phase mass transfer coefficient; $\mathrm{H}$ is the dimensionless Henry's constant (liquid phase/gas phase concentration). Note that $1 / k_{G}$ and $1 / H \cdot E \cdot k_{L}$ represent the gas- and the liquid-phase mass transfer resistances, respectively.

In the STR test, $1 / k_{G}$ was negligible, because pure $\mathrm{CO}_{2}$ gas and vacuum conditions were employed. The coefficient $k_{L}$ in the STR was measured for water. This value was adjusted to be applied to different solvents at different temperatures by considering the related physical property changes. ${ }^{[3]}$ The values of $H \cdot E$ at various conditions were estimated from the 
measurements of the rates into the PC and MEA solutions according to Eq. (3D-5) (by noting $H$ $\propto 1 / \mathrm{He})$.

In calculating rates in the packed-bed absorption column, ceramic Raschig rings with a diameter of $50 \mathrm{~mm}$ were used as packing materials. The value of $k_{L}$ was estimated using the Billet and Schultes ${ }^{[4]}$ method and that of $k_{g}$ using the Bravo et al. method ${ }^{[5]}$. The superficial gas and liquid velocities were assumed to be 1.0 and $0.007 \mathrm{~m} / \mathrm{s}(3.3$ and $0.023 \mathrm{ft} / \mathrm{s})$ to ensure that the operating condition selected was below the loading point of the absorption column. As an approximate calculation, the values of $H \cdot E$ in the packed bed were assumed to be the same as those obtained from the STR measurements for the same solvents at the same temperatures. The physical properties (Henry's constant, viscosity, diffusivity, etc) of the $20 \mathrm{wt} \% \mathrm{PC}$ and 5M MEA solutions, and water at $50^{\circ} \mathrm{C}\left(122^{\circ} \mathrm{F}\right)$ were the ones used in a recent study. ${ }^{[3]}$

The estimated mass transfer resistances for $\mathrm{CO}_{2}$ absorption into the $20 \mathrm{wt} \% \mathrm{PC}$ with $300 \mathrm{mg} / \mathrm{L}$ ACA1 and 5M MEA solutions in a packed-bed column at $50^{\circ} \mathrm{C}\left(122^{\circ} \mathrm{F}\right)$ are listed in Table 3D-2. For both the PC20-20+CA* and PC 20-40+CA* solution, the liquid-phase mass transfer (including the reactions) is a limiting factor in the overall absorption rate (about $90 \%$ of the total absorption resistance). Results also indicate that the overall rate of $\mathrm{CO}_{2}$ absorption into the $\mathrm{PC}+\mathrm{CA}$ would be improved by increasing the reaction rate (such as increasing $\mathrm{CA}$ dosage above $300 \mathrm{mg} / \mathrm{L}$ ) and liquid-phase mass transfer rate. For the MEA5-40 solution, the gas- (about 50\%) and liquid-phase (about 50\%) resistances are comparable to each other. When the MEA solution becomes rich (MEA5-90) during $\mathrm{CO}_{2}$ absorption, the rate decreases significantly; as a result, the gas-phase mass transfer resistance (about 12\%) becomes less important.

Table 3D-2. Modeling of $\mathrm{CO}_{2}$ absorption into $20 \mathrm{wt} \% \mathrm{PC}+\mathrm{ACA} 1$ and 5M MEA solutions in a packed-bed absorber at $50^{\circ} \mathrm{C}\left(122^{\circ} \mathrm{F}\right)$

\begin{tabular}{|l|c|c|c|c|c|}
\hline & STR & \multicolumn{4}{c|}{ Packed-bed column } \\
\hline \multicolumn{1}{|c|}{ Column top } & $\begin{array}{c}\text { Rate ratio to } \\
\text { water }\end{array}$ & $\begin{array}{c}\text { Total resist. } \\
1 / \mathrm{K}_{\mathrm{G}}(\mathrm{s} / \mathrm{m})\end{array}$ & $\begin{array}{c}\text { Gas phase } \\
\text { resist. }(\%)\end{array}$ & $\begin{array}{c}\text { liquid phase } \\
\text { resist. }(\%)\end{array}$ & $\begin{array}{c}\text { Rate ratio to } \\
\text { water }\end{array}$ \\
\hline MEA5-40 & 74.20 & 215 & 49.51 & 50.49 & 35.23 \\
\hline PC20-20+CA* & 8.49 & 1,023 & 10.41 & 89.59 & 7.39 \\
\hline PC20-20 & 3.03 & 2,680 & 3.98 & 96.02 & 2.82 \\
\hline \multicolumn{1}{|c|}{ Column bottom } & & & & & \\
\hline MEA5-90 & 10.45 & 877 & 12.11 & 87.89 & 8.62 \\
\hline PC20-40+CA* & 6.26 & 1,350 & 7.90 & 92.10 & 5.60 \\
\hline PC20-40 & 1.38 & 5,749 & 1.85 & 98.15 & 1.32 \\
\hline
\end{tabular}

Because the gas-phase mass transfer resistance is larger for the MEA than for the $\mathrm{PC}+\mathrm{CA}$ in the packed-bed column, especially at the $\mathrm{CO}_{2}$ lean condition, the difference in absorption rate into the PC+CA and MEA solution in the packed-bed absorber becomes smaller than that in the STR. For example, the absorption rate (indicated as the rate ratio to water) into the lean PC20-20+CA* in the packed-bed column is 4.8 times lower than the lean MEA5-40, as compared to 8.7 times slower in the STR (see Table 3D-2). The rate difference between the PC20-40+CA* and MEA590 , which represent the $\mathrm{CO}_{2}$ rich condition (at the bottom of the column), is only 1.5 times.

Less difference in absorption rate between the PC+CA and MEA in a packed-bed column than in a STR is beneficial for the IVCAP, because the height of a column is mostly affected by the zone 
with the slowest absorption rates. A more detailed comparison of the absorption rates into the $\mathrm{PC}+\mathrm{CA}$ and MEA solution in a packed-bed column is presented in the absorber sizing modeling in Chapter 6.

\section{D.4.3 Chemical stability of free ACA1 enzyme}

Resistance of free ACA1 enzyme to flue gas impurities. Chemical contaminants, such as $\mathrm{SO}_{2}$, $\mathrm{NO}_{\mathrm{x}}, \mathrm{HCl}$, etc., exist in coal combustion flue gases. These gaseous components may enter into the absorption column and affect the activity and/or stability of the CA enzyme. The concentrations of the major contaminant anions in the wastewater from a wet flue gas desulfurization (FGD) unit ranges between 0.03 and $0.05 \mathrm{M}$ for $\mathrm{SO}_{4}{ }^{2-}, 0.005$ and $0.02 \mathrm{M}$ for

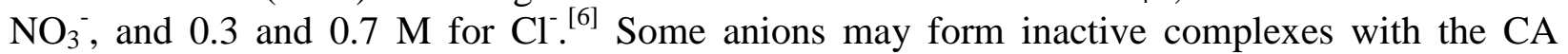
enzyme by binding at a site that is linked to the ionizing group. The dissociation of $\mathrm{H}^{+}$from the ionizing group can reduce, but may not eliminate, the binding of anions. ${ }^{[7]}$

Various impurity concentrations, up to $0.9 \mathrm{M} \mathrm{SO}_{4}{ }^{2-}, 0.7 \mathrm{M} \mathrm{Cl}^{-}$, and $0.2 \mathrm{M} \mathrm{NO}_{3}{ }^{-}$either alone or in combination $\left(0.4 \mathrm{M} \mathrm{SO}_{4}{ }^{2-}, 0.3 \mathrm{M} \mathrm{Cl}^{-}\right.$, and $\left.0.05 \mathrm{M} \mathrm{NO}_{3}{ }^{-}\right)$, were examined in a PC20-20 solution containing $300 \mathrm{mg} / \mathrm{l}$ ACA1 enzyme at $50^{\circ} \mathrm{C}\left(122^{\circ} \mathrm{F}\right)$. Potassium salts containing these corresponding anions were used to control the contaminant concentrations such that no new cations would be introduced into the solutions. These selected contaminant levels were 30 times, 40 times, and 1 times the levels present in typical waste water from a wet FGD scrubber, . The use of such a high concentration of $\mathrm{SO}_{4}{ }^{2-}$ is based on the concept that the $\mathrm{SO}_{2}$ removal may be combined with the $\mathrm{CO}_{2}$ capture in the IVCAP without using a separate FGD unit. The tests were conducted at $50^{\circ} \mathrm{C}\left(122^{\circ} \mathrm{F}\right)$, because this temperature is close to that of the flue gas exiting from a wet FGD unit.

Figure 3D-5(a) shows the $\mathrm{CO}_{2}$ absorption rates into the PC solutions promoted by the ACA1 enzyme without and with the presence of the impurities under the specified concentrations. The presence of the impurities at such high concentrations in the PC solution, either alone or as a mixture, did not significantly reduce the $\mathrm{CO}_{2}$ absorption rate.

The effect of the impurities on the long-term stability of the CA enzyme also was investigated at $50^{\circ} \mathrm{C}\left(122^{\circ} \mathrm{F}\right)$ in a PC20-20 solution containing $300 \mathrm{mg} / \mathrm{L}$ ACA enzyme in the presence of $0.4 \mathrm{M}$ $\mathrm{K}_{2} \mathrm{SO}_{4}, 0.3 \mathrm{M} \mathrm{KCl}$, and $0.05 \mathrm{M} \mathrm{KNO}_{3}$, either alone or combined together. Figure 3D-5(b) compares the value of $E_{C A}$ over the two-month period with and without these impurities. The value of $E_{C A}$ slightly decreased in the presence of the impurities, but this effect did not become greater with time. Based on the change of the $E_{C A}$ value, the activity loss of the ACA1 enzyme caused by the impurities, either alone or combined together, was less than $12 \%$ and it did not increase with time. This observation indicates that these impurities at the investigated concentrations did not significantly affect the activity and long- term stability of the ACA1 enzyme. 


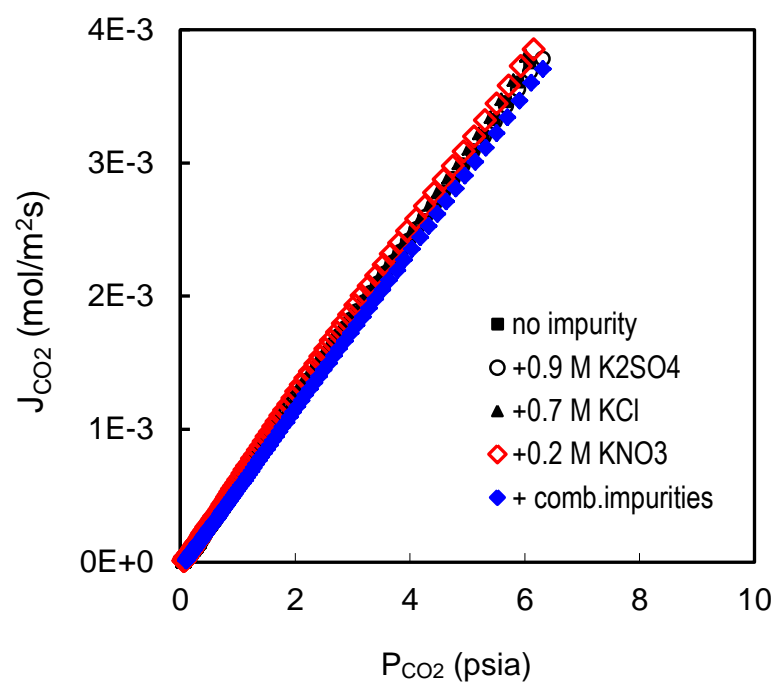

(a) $\mathrm{CO}_{2}$ absorption rate

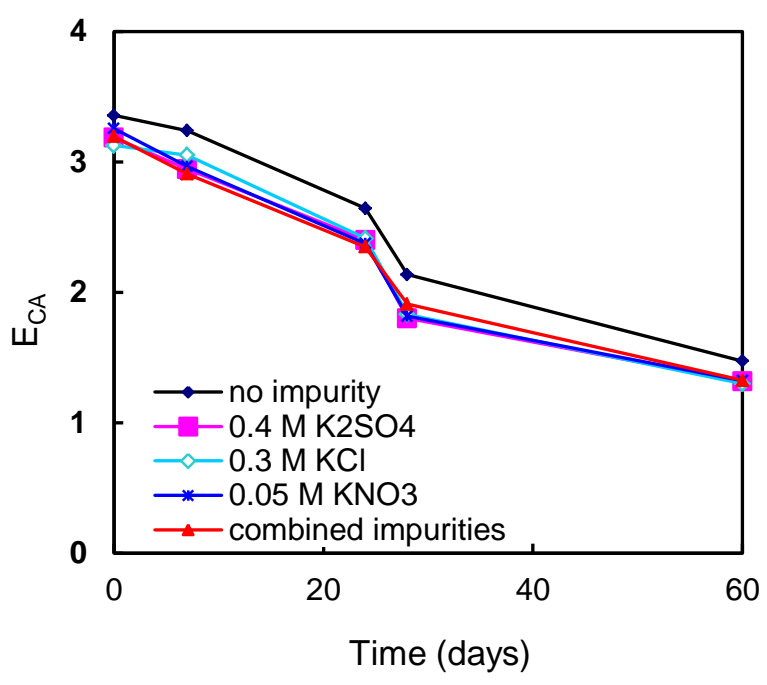

(b) $E_{C A}$ value

Figure 3D-5. Effect of flue gas impurities on the $\mathrm{CO}_{2}$ absorption rate promoted by ACA enzyme and on $E_{C A}$ values.

Resistance of free ACA1 enzyme to chemical additives as a rate promoter. As previously described (Part 3B.3), adding $4 \% \mathrm{NaVO}_{3}$ increased the $\mathrm{CO}_{2}$ absorption rate into the $\mathrm{PC}$ solutions by more than three times, which was about equal to one-half of the catalytic effect of adding 300 $\mathrm{mg} / \mathrm{L}$ of the ACA1 enzyme. The promotion effect of the $\mathrm{NaVO}_{3}$ increased with increasing temperature from 25 to $40^{\circ} \mathrm{C}$ ( 77 to $104^{\circ} \mathrm{F}$ ). Another additive, $10 \%$ sucrose, increased the $\mathrm{CO}_{2}$ absorption rate by about 55\%. Unlike $\mathrm{NaVO}_{3}$, however, this additive is plentiful in supply, environmentally-benign, and inexpensive.

The resistance of the ACA1 enzyme to $\mathrm{NaVO}_{3}$ and sucrose and their synergistic effects with the $\mathrm{CA}$ enzyme for promoting the $\mathrm{CO}_{2}$ absorption rate into the $\mathrm{PC}$ solution were investigated. Figure 3D-6 show the rate of $\mathrm{CO}_{2}$ absorption into PC20-20 containing ACA1 with and without the presence of $10 \%$ sucrose and $4 \% \mathrm{NaVO}_{3}$ at 25 and $40^{\circ} \mathrm{C}\left(77\right.$ and $\left.104^{\circ} \mathrm{F}\right)$. The rates of $\mathrm{CO}_{2}$ absorption into the PC20-20 promoted with $300 \mathrm{mg} / \mathrm{l}$ ACA enzyme and either of the two additives was lower than those with the enzyme alone. It seems that these two additives reduced the activity of the ACA1 enzyme; however, this effect became less significant when the temperature was increased from 25 to $40^{\circ} \mathrm{C}$ ( 77 to $104^{\circ} \mathrm{F}$ ). This observation could be explained by the effect of sucrose on the $\mathrm{CO}_{2}$ solubility of the PC solution. In the presence of sucrose, the $\mathrm{CO}_{2}$ solubility in the PC solution increases, ${ }^{[8]}$ whereas the $\mathrm{CO}_{2}$ diffusivity decreases, because the solution becomes more viscous. ${ }^{[9]}$ Although sucrose promoted the $\mathrm{CO}_{2}$ absorption rate (Figure 3D-6), its negative impact on the $\mathrm{CO}_{2}$ diffusivity became more important in the presence of the enzyme when the $\mathrm{CO}_{2}$ reaction with $\mathrm{PC}$ was fast. As a net effect, the addition of sucrose to the ACA1-promoted PC solution decreased the $\mathrm{CO}_{2}$ absorption rate. When the temperature was increased from 25 to $40^{\circ} \mathrm{C}$ ( 77 to $104^{\circ} \mathrm{F}$ ), this net effect became smaller because the impact on the $\mathrm{CO}_{2}$ diffusivity term was more pronounced than the solubility term. 


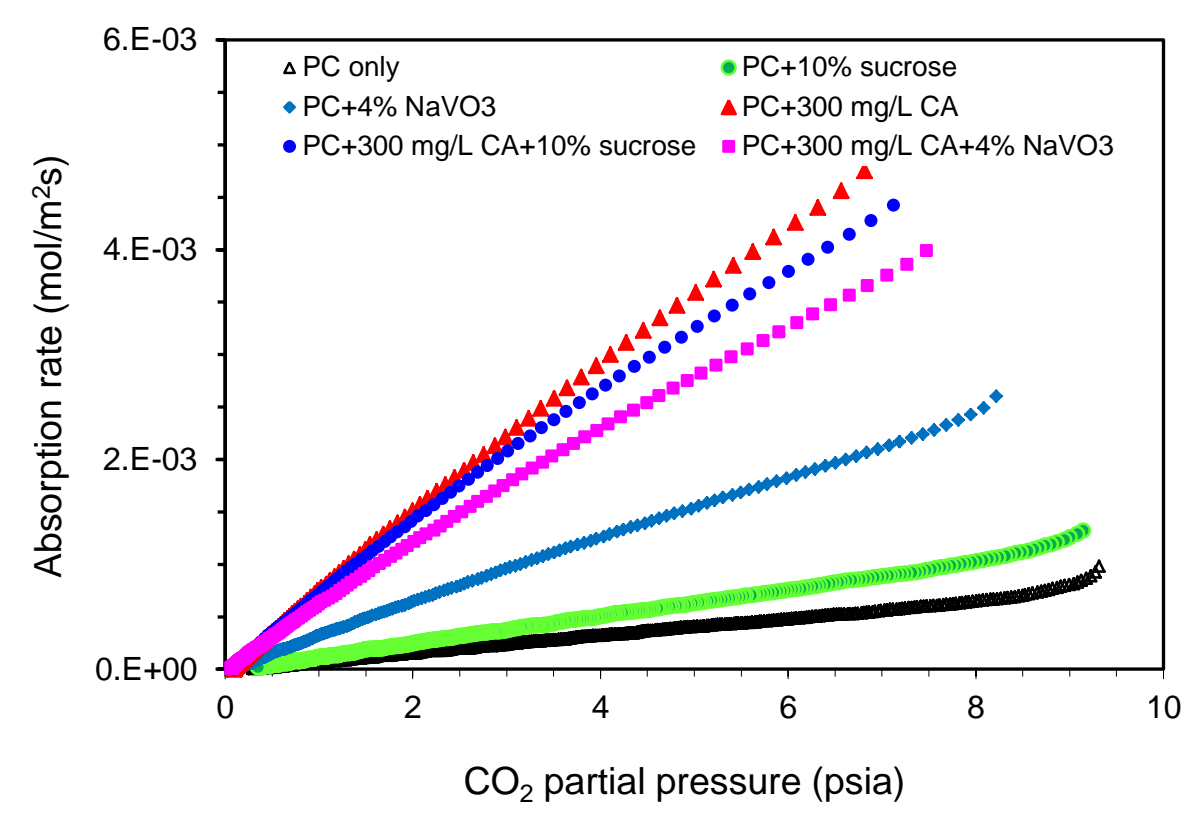

(a) at $25^{\circ} \mathrm{C}$

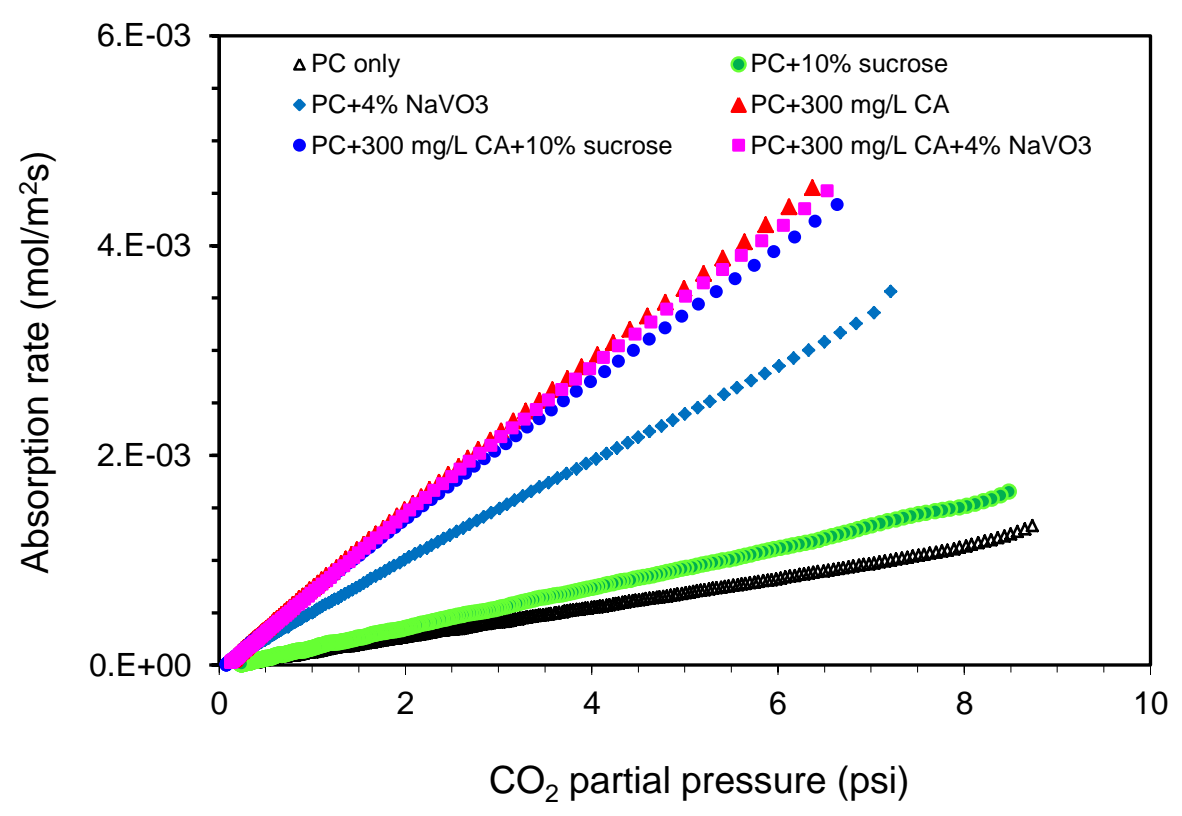

(b) at $40^{\circ} \mathrm{C}$

Figure 3D-6. Rate of $\mathrm{CO}_{2}$ absorption into PC20-20 containing ACA1 enzyme with and without the presence of rate promoters at $25^{\circ} \mathrm{C}$ and $40^{\circ} \mathrm{C}$.

The impact on the $\mathrm{CO}_{2}$ absorption rate by the addition of $4 \% \mathrm{NaVO}_{3}$ to the PC20-20 containing $300 \mathrm{mg} / \mathrm{l} \mathrm{ACA} 1$ enzyme was greater than that for sucrose. Based on the concentrations (4 wt\% vs. $300 \mathrm{mg} / \mathrm{l})$ and molecular weight of $\mathrm{NaVO}_{3}$ and ACA1 (122 vs. 30,000), the molar concentration of the $\mathrm{NaVO}_{3}$ was much higher than that of the ACA by four orders of magnitude. Therefore, the absorption of $\mathrm{CO}_{2}$ molecules in the solution was preferentially promoted by the $\mathrm{NaVO}_{3}$ molecules before they reached the ACA sites. Although the ACA1 enzyme has a higher 
catalytic activity than $\mathrm{NaVO}_{3}$, the overall $\mathrm{CO}_{2}$ absorption rate into the ACA-promoted PC solution decreased when $\mathrm{NaVO}_{3}$ was present. However, this effect became less marked when the temperature was increased from 25 to $40^{\circ} \mathrm{C}$ ( 77 to $104^{\circ} \mathrm{F}$ ), because the catalytic activity of $\mathrm{NaVO}_{3}$ (having a higher activation energy than the ACA1 enzyme) increased more with increasing temperature than that of ACA.

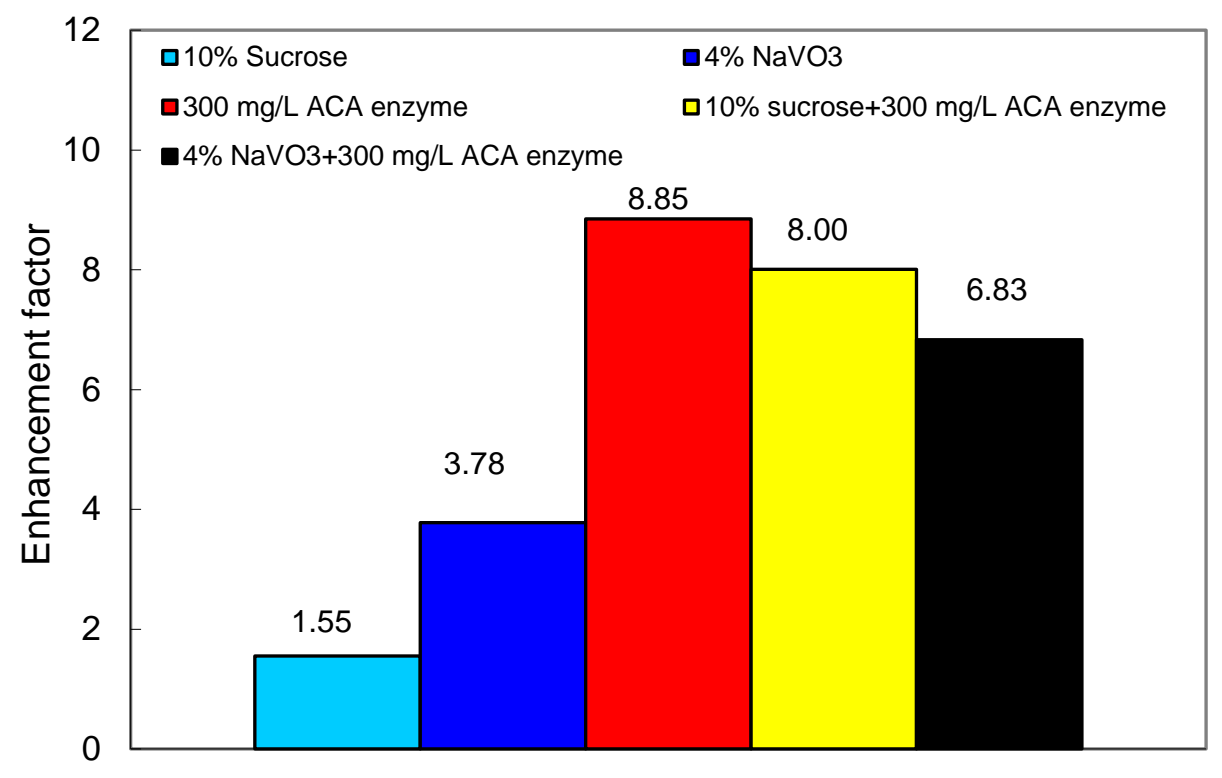

(a) at $25^{\circ} \mathrm{C}$

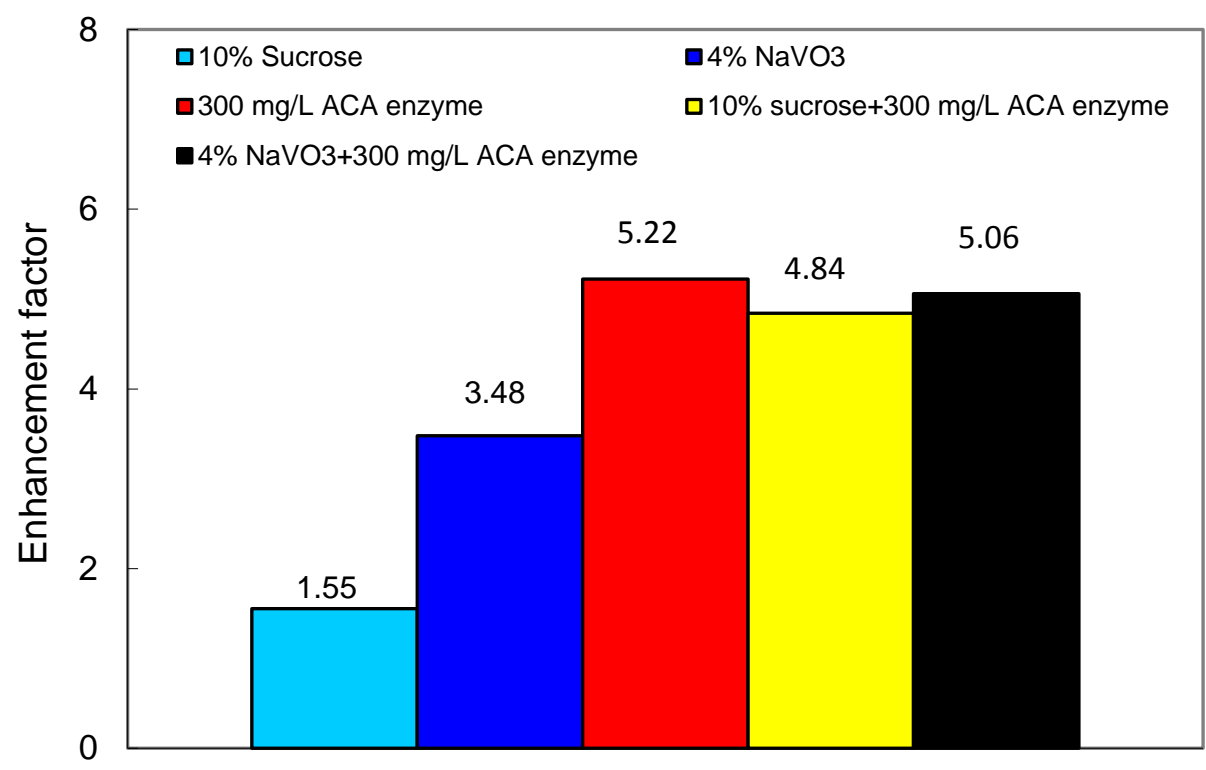

(b) at $40^{\circ} \mathrm{C}$

Figure 3D-7. Enhancement factor of ACA1 enzyme in PC20-20 with and without the presence of rate promoters at $25^{\circ} \mathrm{C}$ and $40^{\circ} \mathrm{C}$. 
The enhancement factor values for the ACA enzyme, used alone or together with either $4 \%$ $\mathrm{NaVO}_{3}$ or $10 \%$ sucrose, at 25 and $40^{\circ} \mathrm{C}\left(77\right.$ and $\left.104^{\circ} \mathrm{F}\right)$ are shown in Figure 3D-7. It reveals that using $300 \mathrm{mg} / \mathrm{L}$ ACA1 enzyme, the E value was 8.85 and 5.22 at 25 and $40^{\circ} \mathrm{C}\left(77\right.$ and $\left.104^{\circ} \mathrm{F}\right)$, respectively. Using the same concentration of ACA1 enzyme together with either $4 \mathrm{wt} \% \mathrm{NaVO}_{3}$ or $10 \%$ sucrose, the $\mathrm{E}$ value became 6.83 or 8.00 and 5.06 or 4.84 at 25 and $40^{\circ} \mathrm{C}\left(77\right.$ and $\left.104^{\circ} \mathrm{F}\right)$, respectively. The chemical promoters reduced the $\mathrm{E}$ value of the ACA1 enzyme; this effect became smaller when the temperature increased from 25 to $40^{\circ} \mathrm{C}\left(77\right.$ and $\left.104^{\circ} \mathrm{F}\right)$.

Resistance of free ACA1 enzyme to chemical additives as a water vaporization inhibitor. In this study, three chemical additives - potassium acetate (KAc), potassium formate (KA), and ethylene glycol (EG) - were identified to reduce the saturation pressure of water vapor. Therefore, the resistance of the CA enzyme to these additives was investigated.

In separate STR tests performed at $40^{\circ} \mathrm{C}\left(104^{\circ} \mathrm{F}\right)$, the addition of 5, 10 and $20 \mathrm{wt} \% \mathrm{KAC} ; 10$ and $20 \mathrm{wt} \% \mathrm{KA}$; and 15 and $30 \mathrm{wt} \%$ EG to PC20-20 solution containing $300 \mathrm{mg} / \mathrm{L}$ ACA enzyme was investigated. An additional test was performed using $10 \mathrm{wt} \% \mathrm{KAC}$ added to a PC20-40 solution containing $300 \mathrm{mg} / \mathrm{L}$ ACA enzyme. The test matrix is shown in Table 3D-2.

Table 3D-3. Test matrix for investigating the resistance of ACA1 to water vapor inhibitors

\begin{tabular}{|c|c|c|}
\hline Chemical reagents & Amount (wt\%) & PC solutions \\
\hline \multirow{3}{*}{ KAc } & 5 & \multirow{2}{*}{ PC20-20 solution $+300 \mathrm{mg} / \mathrm{L}$ ACA } \\
\cline { 2 - 2 } & 10 & \\
\cline { 2 - 2 } KA & 20 & \multirow{2}{*}{ PC20-20 solution $+300 \mathrm{mg} / \mathrm{L}$ ACA } \\
\cline { 2 - 2 } EG & 10 & PC20-20 solution $+300 \mathrm{mg} / \mathrm{L}$ ACA \\
\cline { 2 - 2 } & 15 & PC20-40 solution $+300 \mathrm{mg} / \mathrm{L}$ ACA \\
\hline KAc & 30 & \\
\hline
\end{tabular}

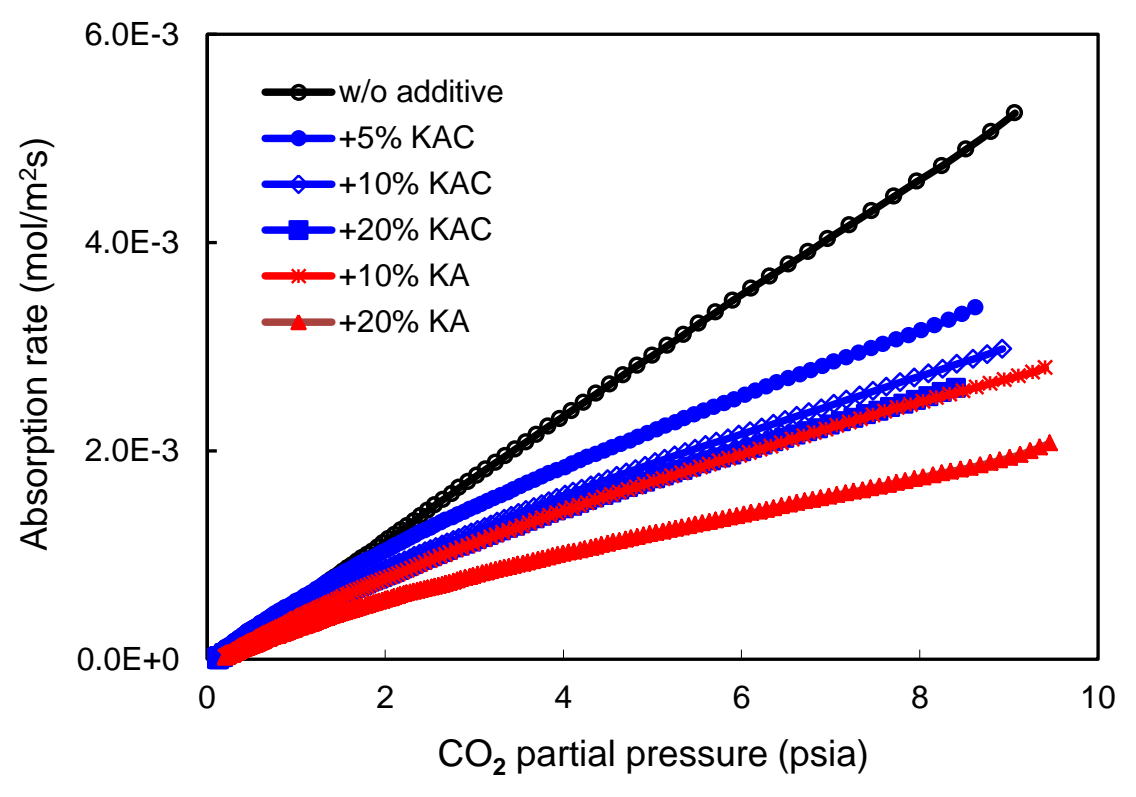

(a) With various amounts of KAC or KA additive in the PC20-20 solution 


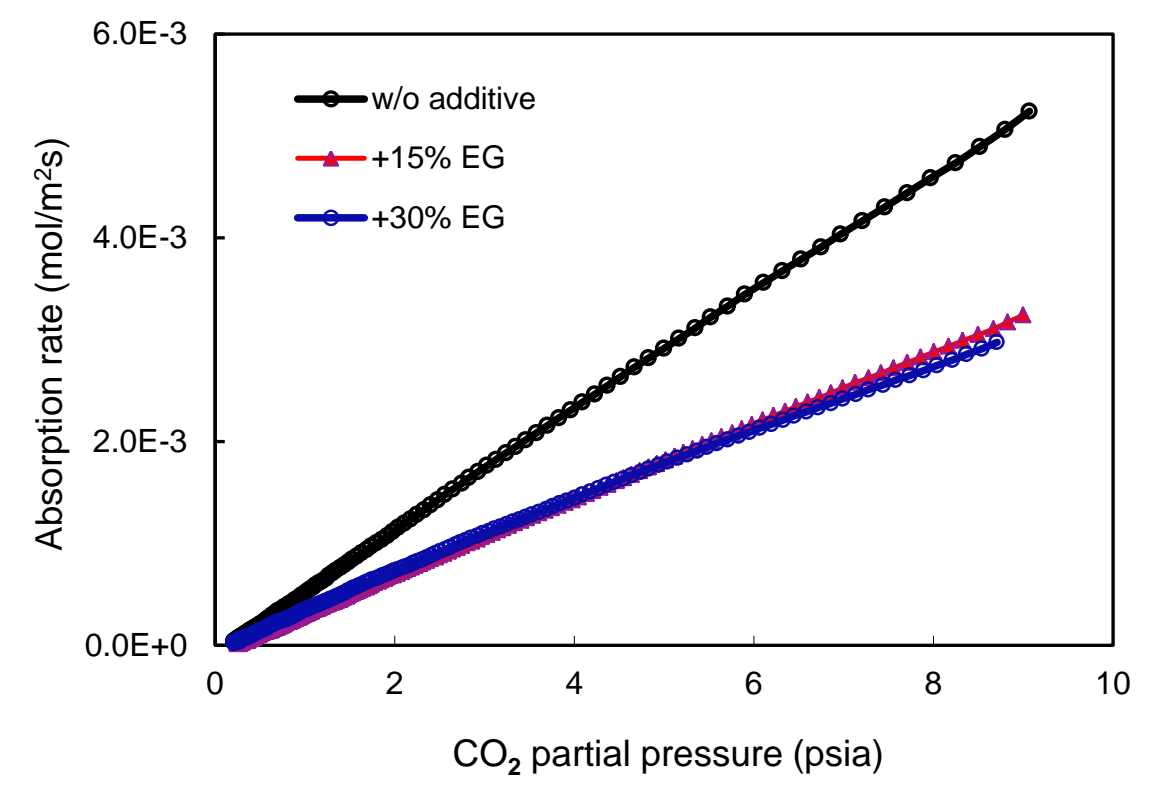

(b) With $15 \mathrm{wt} \%$ and $30 \mathrm{wt} \%$ EG in the PC-20-20 solution

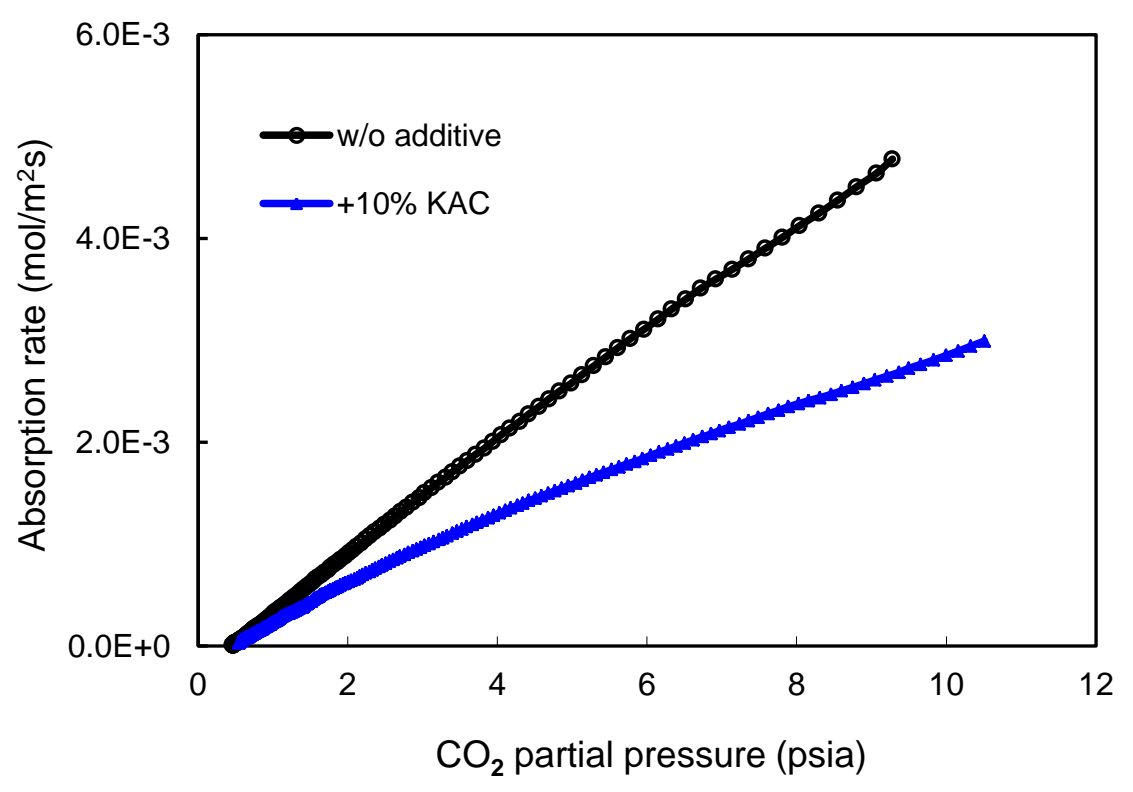

(c) With $10 \mathrm{wt} \% \mathrm{KAC}$ in the PC-20-40 solution

Figure 3D-8. Resistance of ACA enzyme to KAc, KA and EG in PC solution at $40^{\circ} \mathrm{C}$.

Figure 3D-8 compares the rate of $\mathrm{CO}_{2}$ absorption into the PC solutions containing $300 \mathrm{mg} / \mathrm{L}$ ACA1 enzyme without and with the additives of different concentrations at $40^{\circ} \mathrm{C}\left(104^{\circ} \mathrm{F}\right)$. Addition of 5 and 20 wt\% KAc lowered the $\mathrm{CO}_{2}$ absorption rate by about 30 and $40 \%$, respectively (Figure 3D-8(a) and (b)). A similar tendency was observed for $\mathrm{KA}_{\mathrm{C}}$ added to the PC20-40 solution (Figure 3D-8(c)). Compared to $\mathrm{KA}_{\mathrm{C}}$ and EG, the KA additive affected the $\mathrm{CO}_{2}$ absorption rate more severely (Figure 3D-8(a)). 
Lowering the water vapor pressure in the IVCAP vacuum stripper can lower the heat of stripping (heat for water vaporization) and thus lower the parasitic power loss in a power plant. Although these additives were effective for lowering the water vapor pressure over the PC solution, they had an adverse impact on the activity of the CA enzyme. It remains a tradeoff between the benefit of lower energy consumption and the adverse impact on absorption rate when using the additives.

\section{D.4.4 Long-term thermal stability of free CA enzymes}

ACA1 enzyme. The long-term thermal stability of the ACA1 enzyme was investigated at 25, 40, and $50^{\circ} \mathrm{C}\left(77,104\right.$, and $\left.122^{\circ} \mathrm{F}\right)$ at a concentration of $300 \mathrm{mg} / \mathrm{L}$ in PC20-20 and PC20-40 solutions. Figures 3D-9 to 3D-11 show that the $\mathrm{CO}_{2}$ absorption rate changed with time under the test conditions. The values of enhancement factors and the percentage activity loss over time are shown in Figure 3D-12. At $25^{\circ} \mathrm{C}\left(77^{\circ} \mathrm{F}\right)$, the $E_{C A}$ of the ACA1 enzyme in the PC20-20 solution decreased slightly from 8.8 to 7.3 (about a $20 \%$ activity loss) after six months, and from 11.8 to 9.2 (25\% activity loss) in the PC20-40 solution. At $40^{\circ} \mathrm{C}\left(104^{\circ} \mathrm{F}\right)$, the $E_{C A}$ in the PC20-20 solution decreased more rapidly from 5.1 to 2.1 (73\% activity loss), and from 5.8 to 2.2 (76\% activity loss) in the PC20-40 solution over the same testing period. In comparison, after only two months, the $E_{C A}$ value of the PC20-20 decreased sharply from 3.2 to 1.4 at $50^{\circ} \mathrm{C}\left(122^{\circ} \mathrm{F}\right)$. The greater CTB conversion rate of the PC20-40 did not greatly affect the long-term thermal stability of the ACA enzyme over the investigated range between 20 and $40 \%$. These results indicate that the activity loss of the enzyme was comparable in the PC20-20 and PC20-40 solutions.

Enzyme stability will determine the makeup rate of the enzyme and thus the operating cost in practical applications. One option to maintain the long-term stability of the enzyme is to lower the flue gas temperature to below $40^{\circ} \mathrm{C}\left(104^{\circ} \mathrm{F}\right)$ by flue gas cooling, but this option increases the operating cost. The results from the stability tests have provided useful information for optimizing the process.

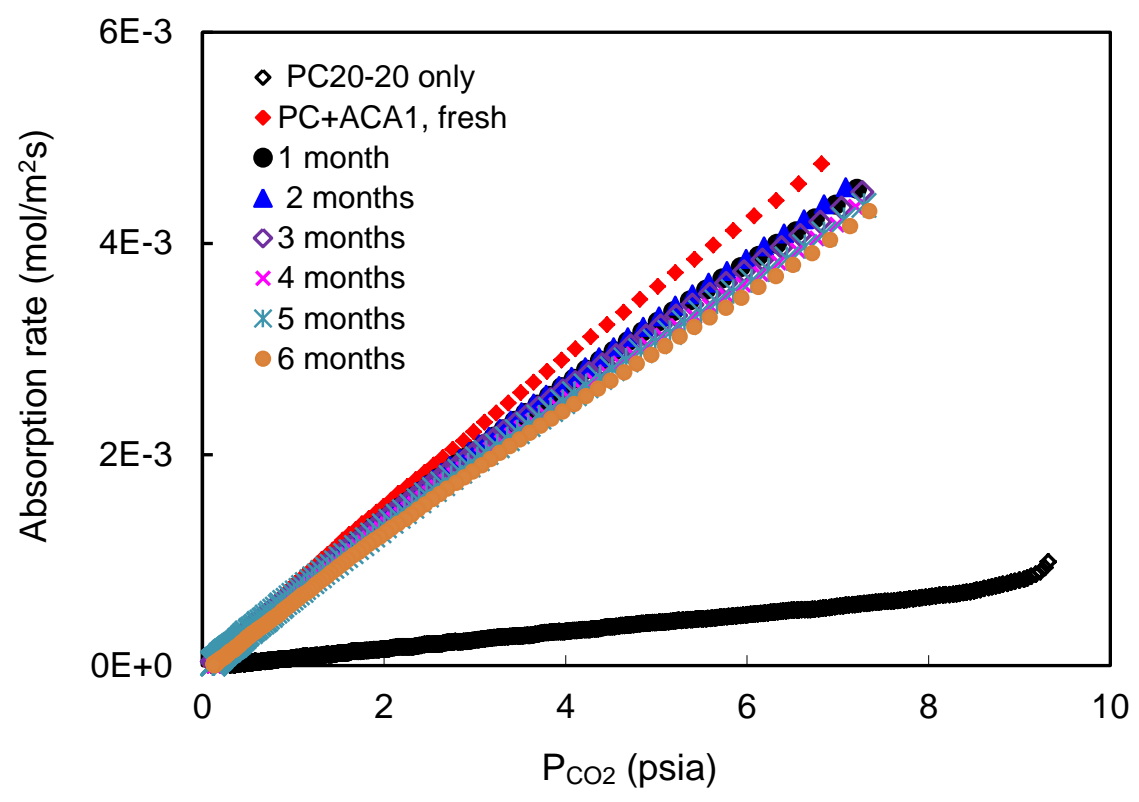

(a) $300 \mathrm{mg} / \mathrm{L}$ ACA1 in a PC20-20 solution 


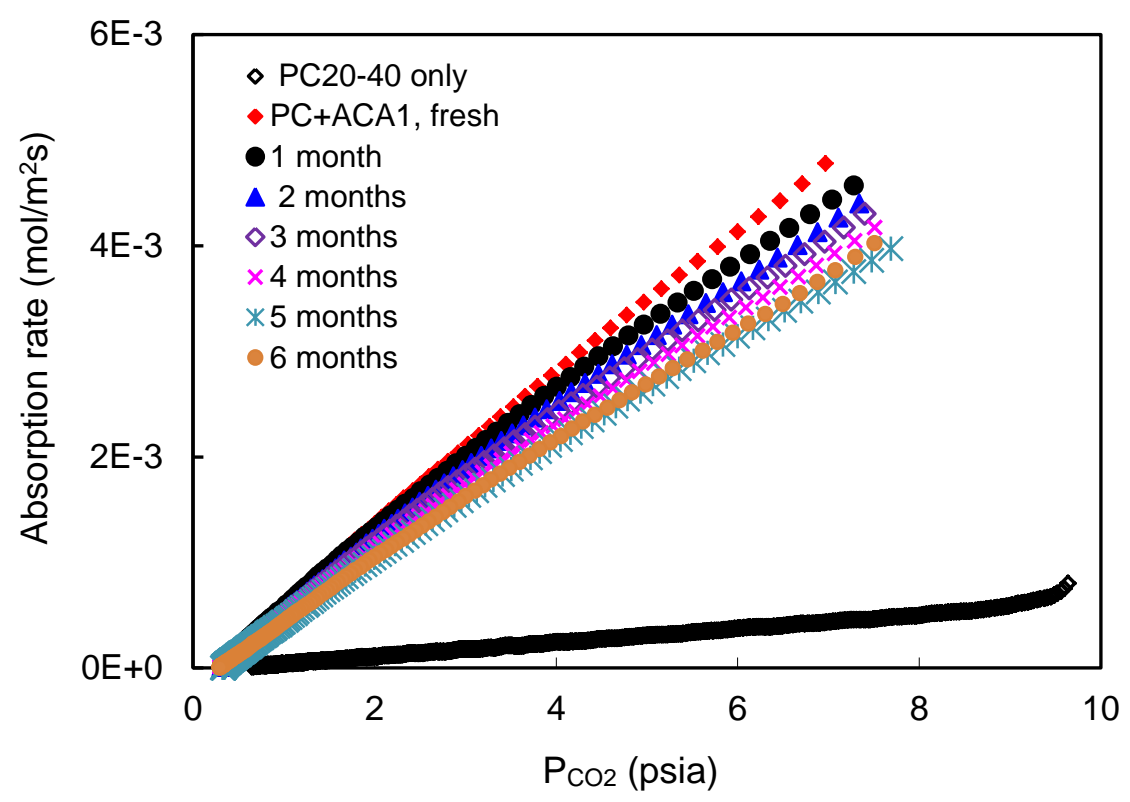

(b) $300 \mathrm{mg} / \mathrm{L}$ ACA1 in a PC20-40 solution

Figure 3D-9. Long-term stability of ACA1 in $20 \mathrm{wt} \%$ PC solutions at $25^{\circ} \mathrm{C}$.

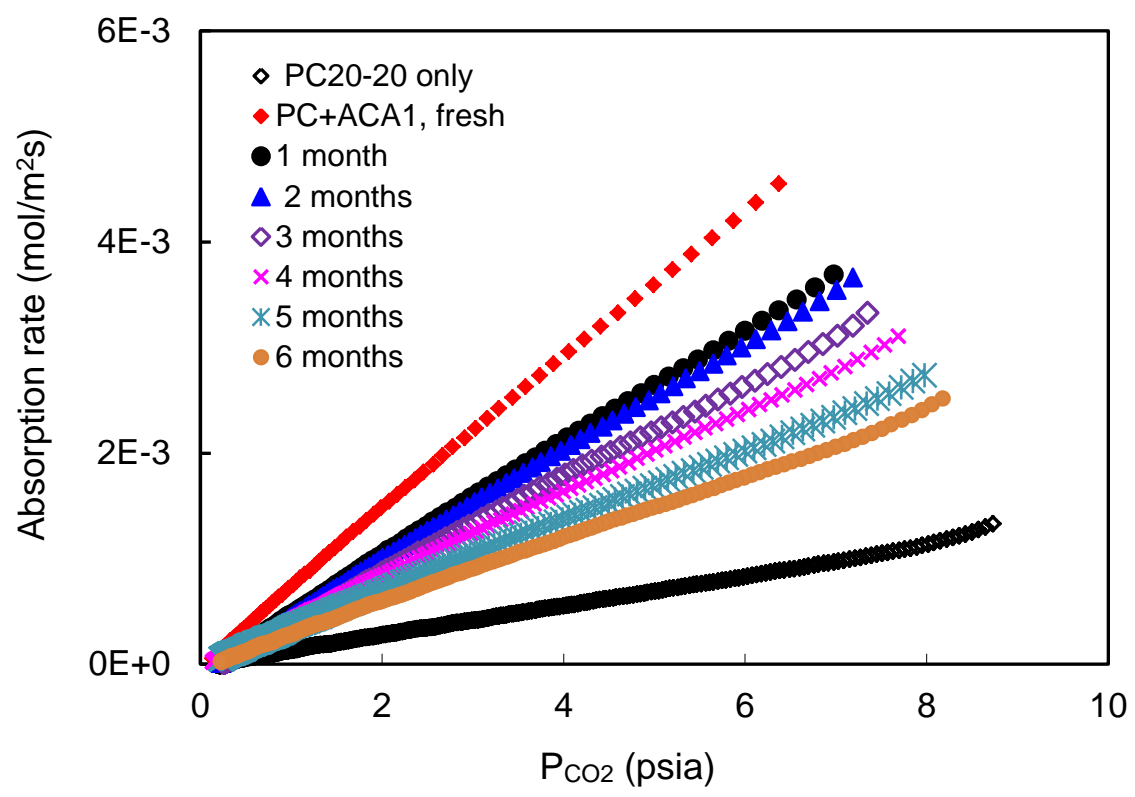

(a) $300 \mathrm{mg} / \mathrm{L}$ ACA1 in a PC20-20 solution 


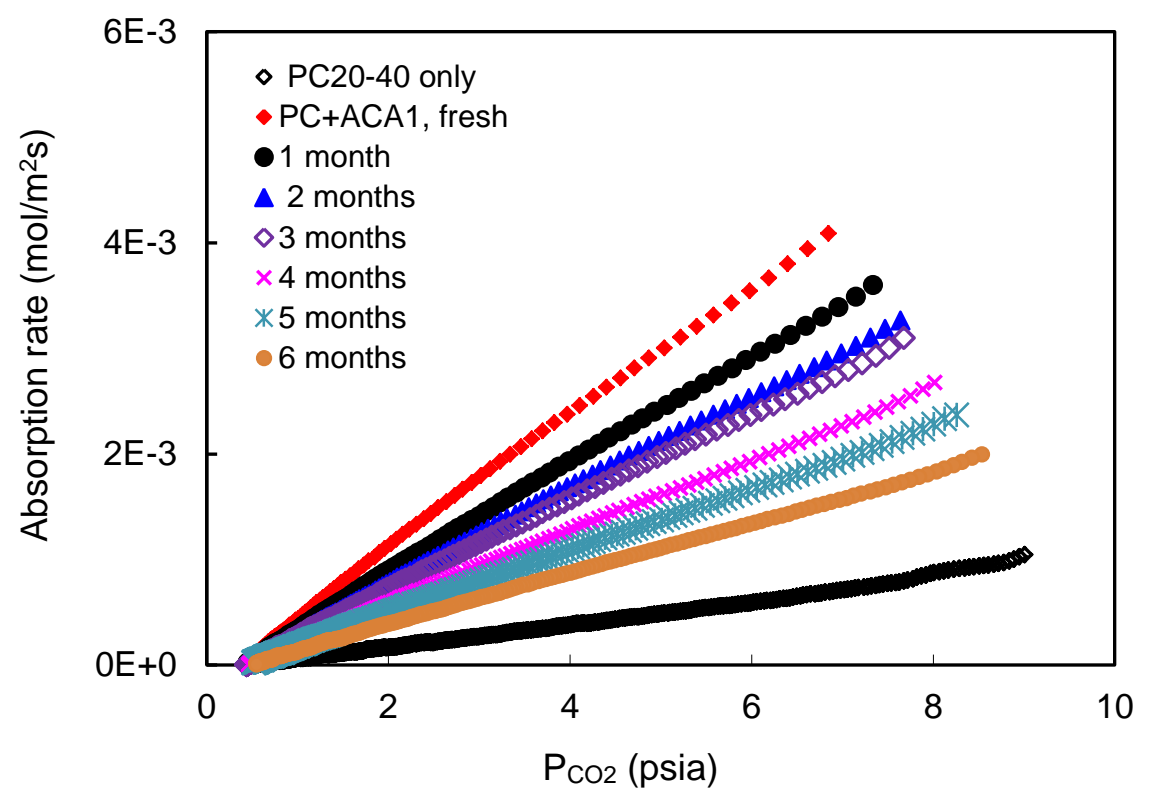

(b) $300 \mathrm{mg} / \mathrm{L}$ ACA1 in a PC20-40 solution

Figure 3D-10. Long-term stability of ACA1 in $20 \mathrm{wt} \%$ PC solutions at $40^{\circ} \mathrm{C}$.

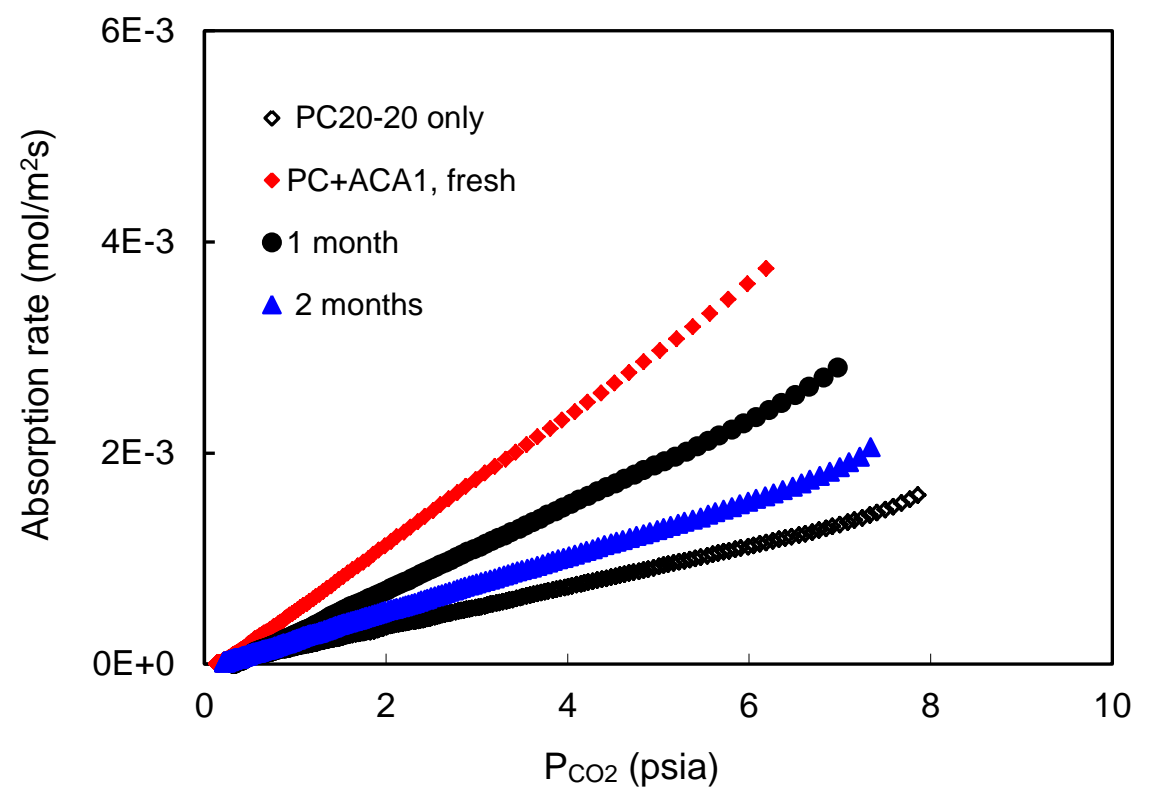

$300 \mathrm{mg} / \mathrm{L}$ ACA1 in PC20-20

Figure 3D-11. Long-term stability of ACA1 in a $20 \mathrm{wt} \% \mathrm{PC}$ solution at $50^{\circ} \mathrm{C}$ 


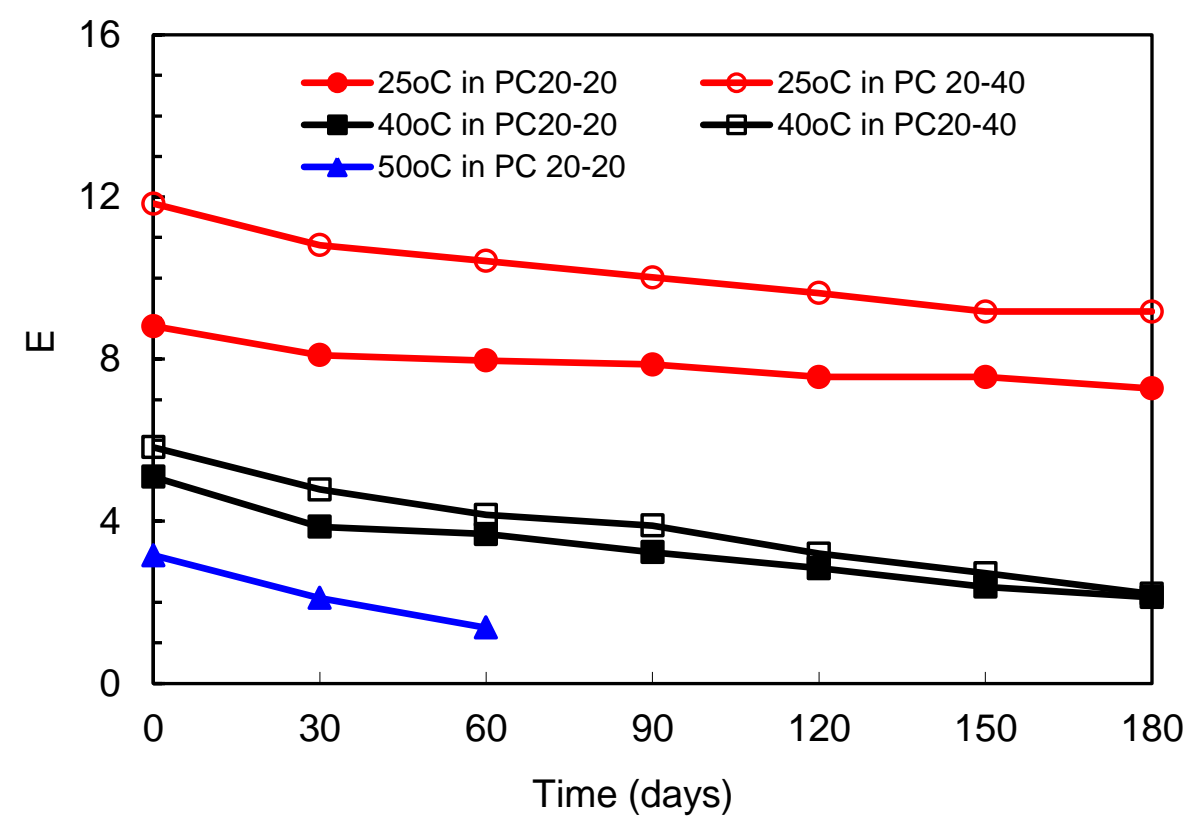

(a) Enhancement factors

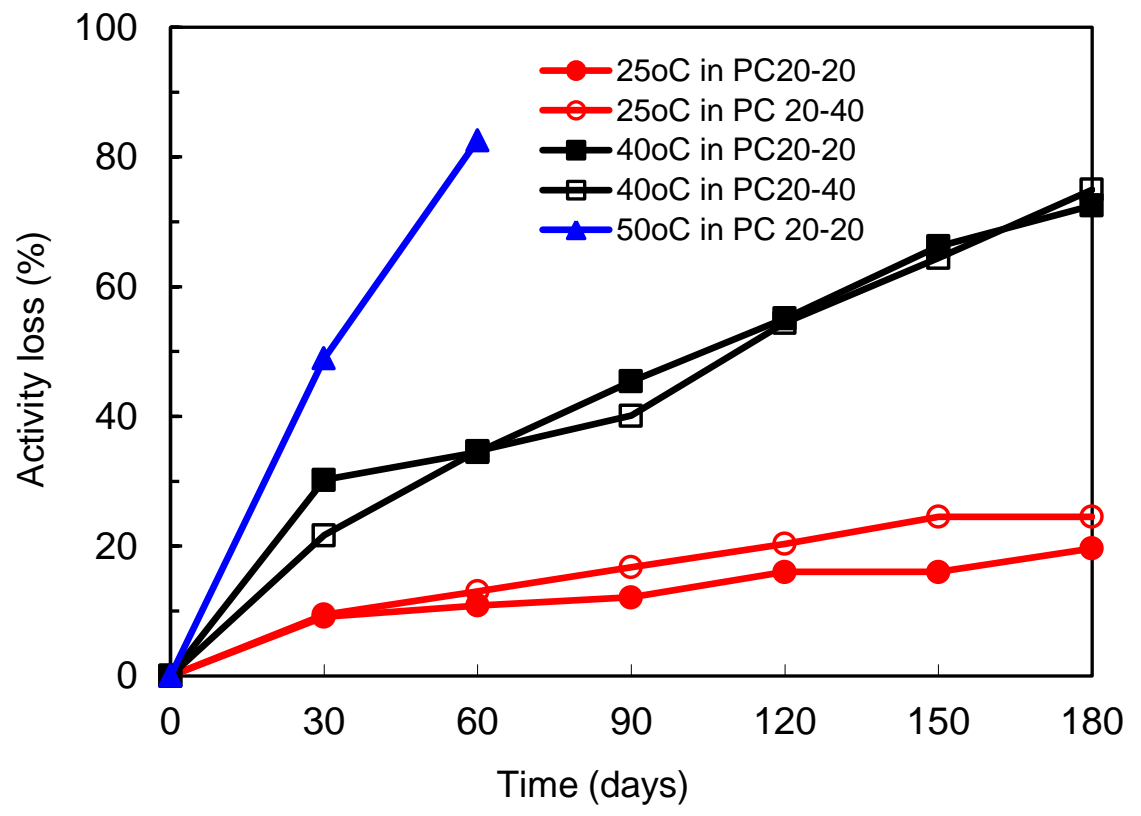

(b) Activity loss

Figure 3D-12. Enhancement factors (a) and activity loss (b) of ACA1 in $20 \mathrm{wt} \% \mathrm{PC}$ at 25, 40, and 50 ${ }^{\circ} \mathrm{C}$.

ACA2 enzyme. The thermophilic ACA2 enzyme has been engineered for higher temperature (up to $60^{\circ} \mathrm{C} / 140^{\circ} \mathrm{F}$ ) applications. Its long-term thermal stability was investigated at $300 \mathrm{mg} / \mathrm{L}$ in PC20-20 and PC20-40 solutions at 40, 50, and $60{ }^{\circ} \mathrm{C}\left(104,122\right.$, and $\left.140^{\circ} \mathrm{F}\right)$ over test periods of 6,4 , and 3 months, respectively. Figures $3 \mathrm{D}-13$ to $3 \mathrm{D}-15$ show the rates of $\mathrm{CO}_{2}$ absorption at various times under these conditions. Figure 3D-16 displays the evolution of the enhancement factor and the corresponding activity loss over time. 
The ACA2 enzyme demonstrated excellent stability; at $40^{\circ} \mathrm{C}\left(104^{\circ} \mathrm{F}\right)$ it had lost only about $15 \%$ of its initial activity after 6 months. The activity loss at $50^{\circ} \mathrm{C}\left(122^{\circ} \mathrm{F}\right)$ became more substantial, with about $60 \%$ of its original activity lost after 2 months and $80 \%$ after 3 months. At $60^{\circ} \mathrm{C}$ $\left(140^{\circ} \mathrm{F}\right)$, the thermal stability was rather poor; after just 1 month, the ACA2 enzyme had lost about $60 \%$ of its initial activity and, after 2 months, about $80 \%$. No difference was observed for the activity loss of the ACA2 enzyme in the PC20-20 and PC20-40 solutions, indicating that the $\mathrm{CO}_{2}$ loading of the $\mathrm{PC}$ solution did not significantly affect the thermal stability of the enzyme.

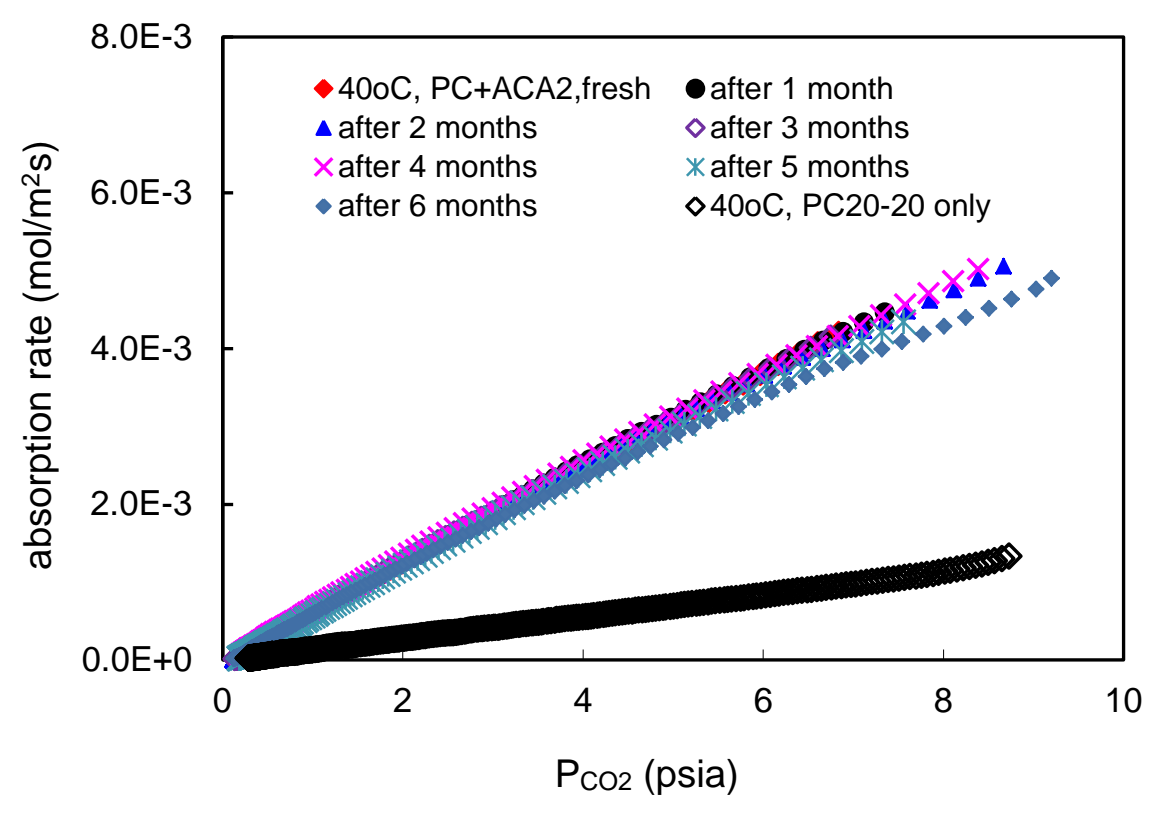

(a) $300 \mathrm{mg} / \mathrm{L}$ ACA2 in PC20-20

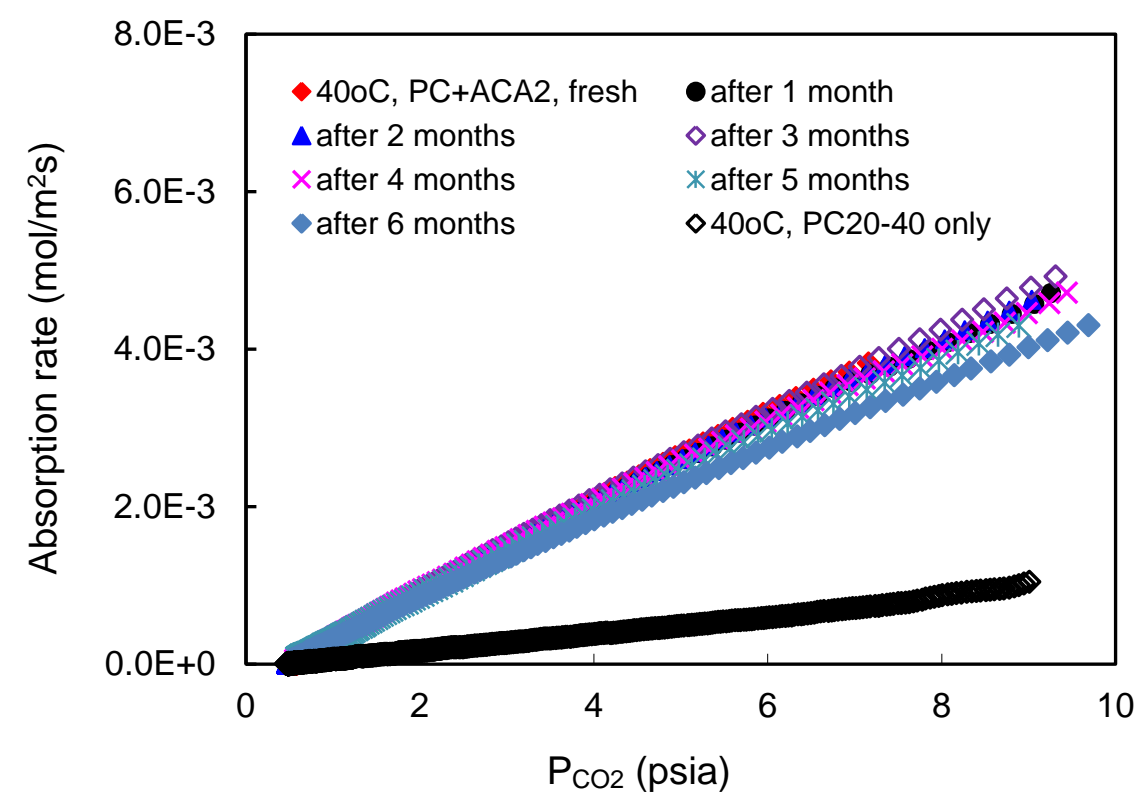

(b) $300 \mathrm{mg} / \mathrm{L}$ ACA2 in PC20-40

Figure 3D-13. Long-term stability of ACA2 in $20 \mathrm{wt} \%$ PC solutions at $40^{\circ} \mathrm{C}$. 


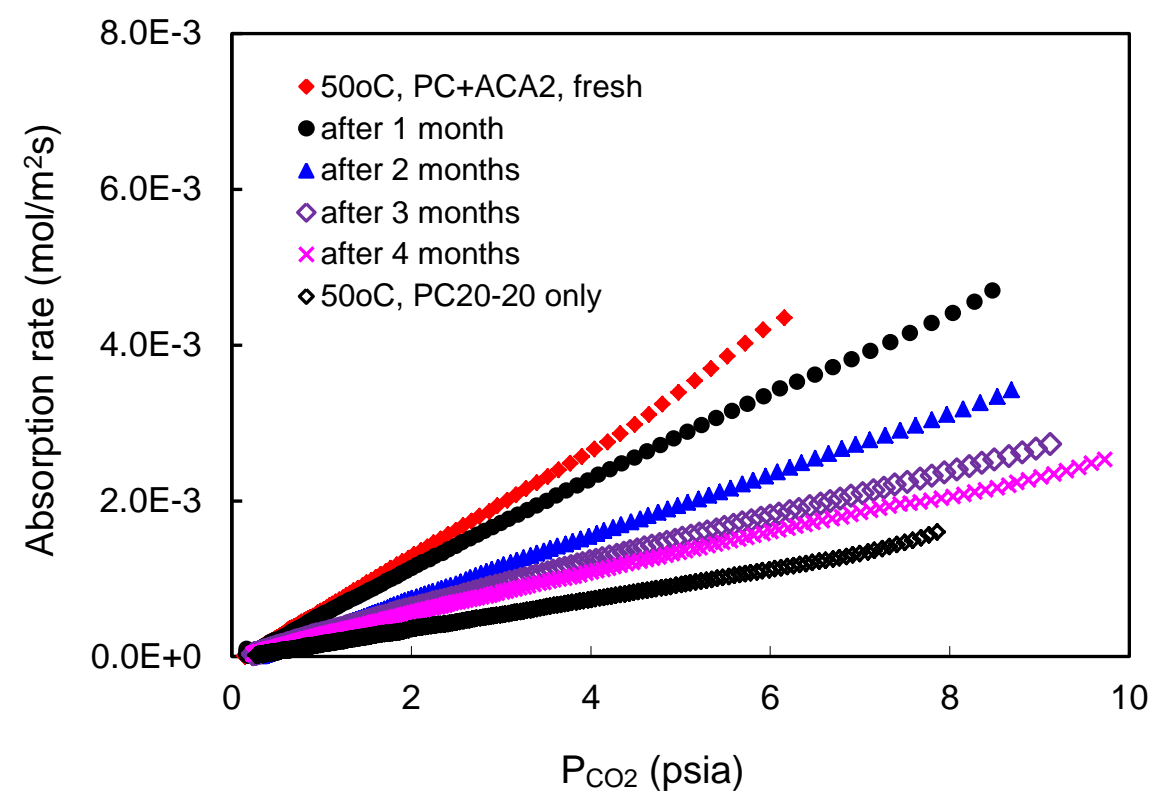

(a) $300 \mathrm{mg} / \mathrm{L}$ ACA2 in PC20-20

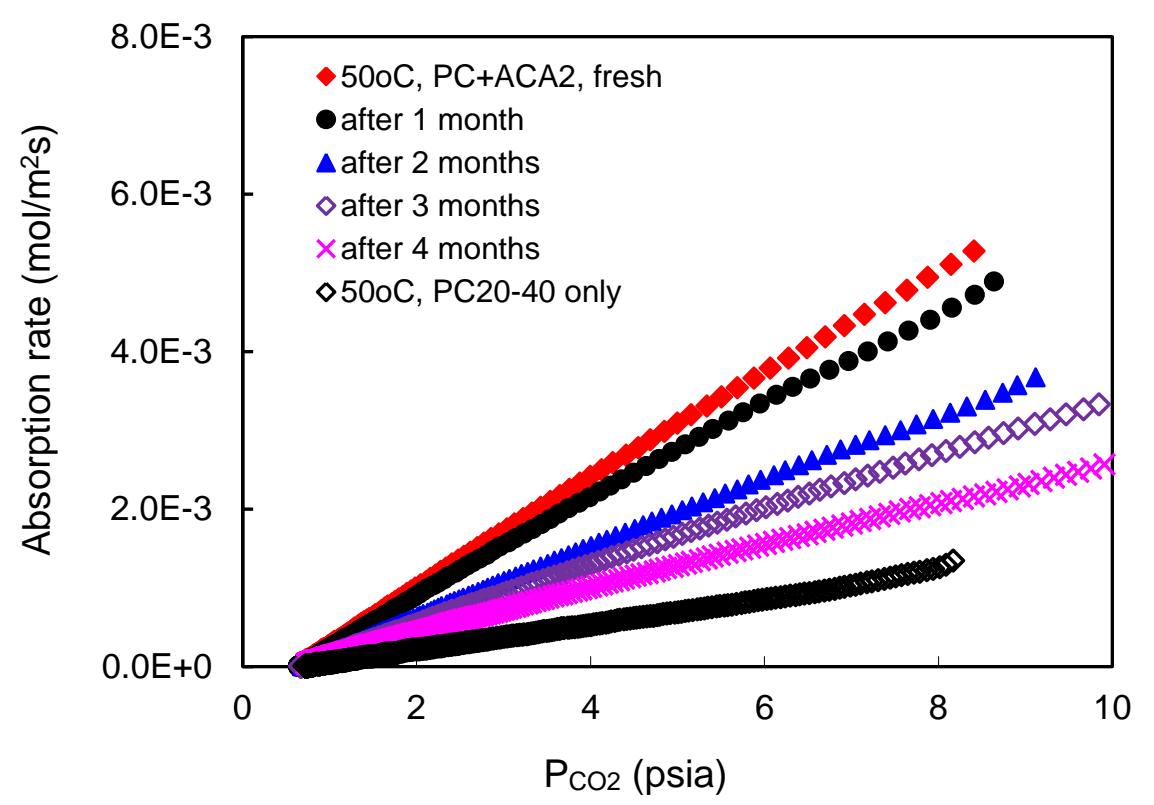

(b) $300 \mathrm{mg} / \mathrm{L}$ ACA2 in PC20-40

Figure 3D-14. Long-term stability of ACA2 in $20 \mathrm{wt} \% \mathrm{PC}$ solutions at $50^{\circ} \mathrm{C}$. 


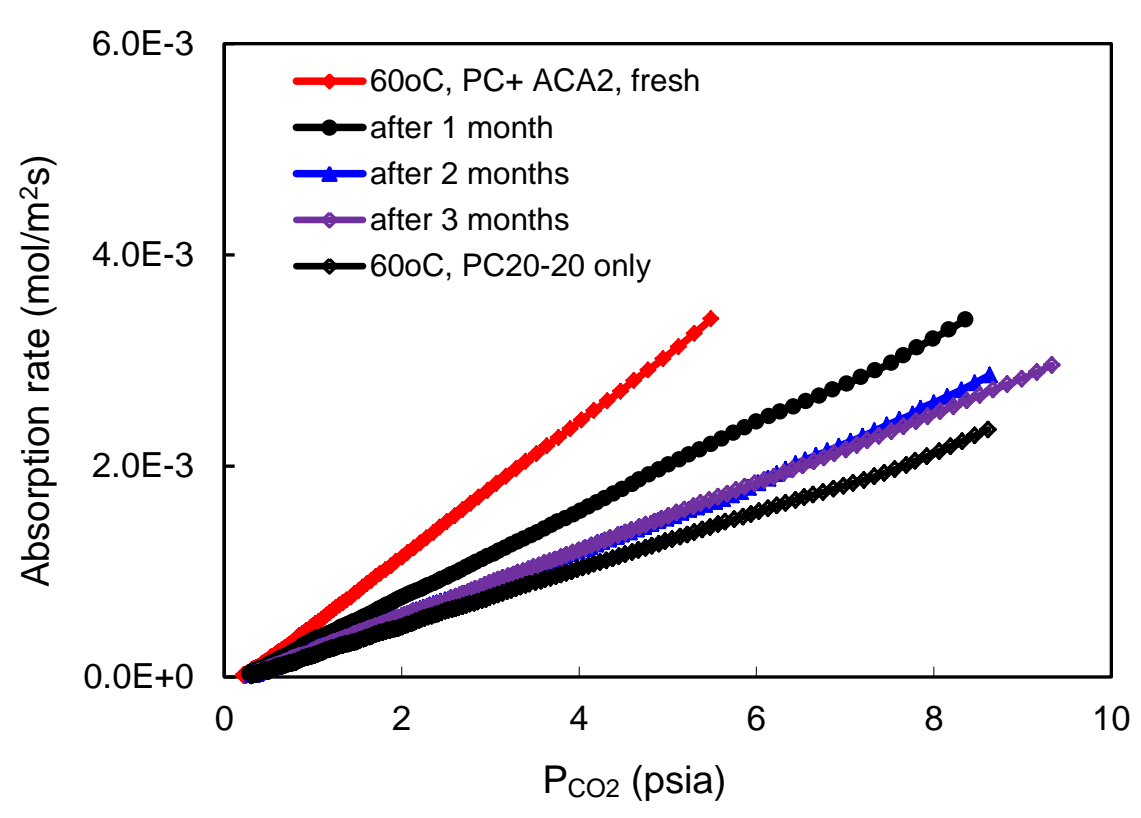

(a) $300 \mathrm{mg} / \mathrm{L}$ ACA2 in PC20-20

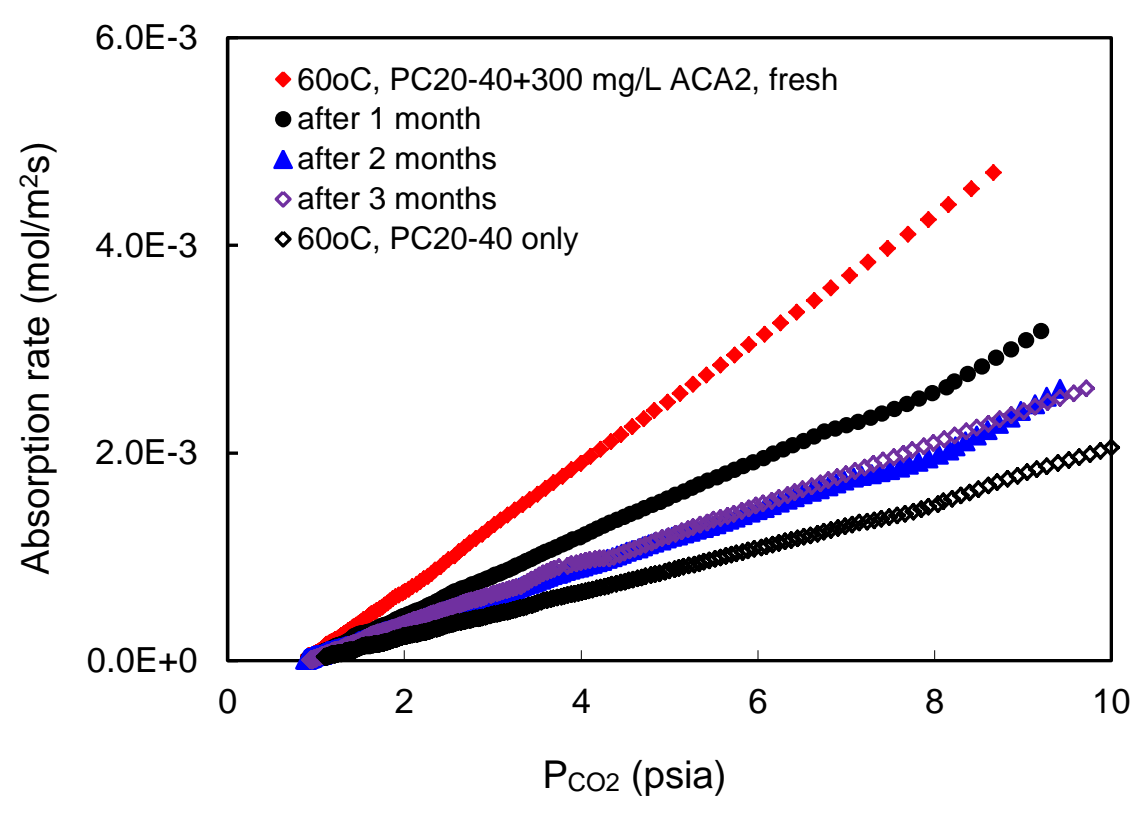

(b) $300 \mathrm{mg} / \mathrm{L}$ ACA2 in PC20-40

Figure 3D-15. Long-term stability of ACA2 in $20 \mathrm{wt} \%$ PC solutions at $60^{\circ} \mathrm{C}$. 


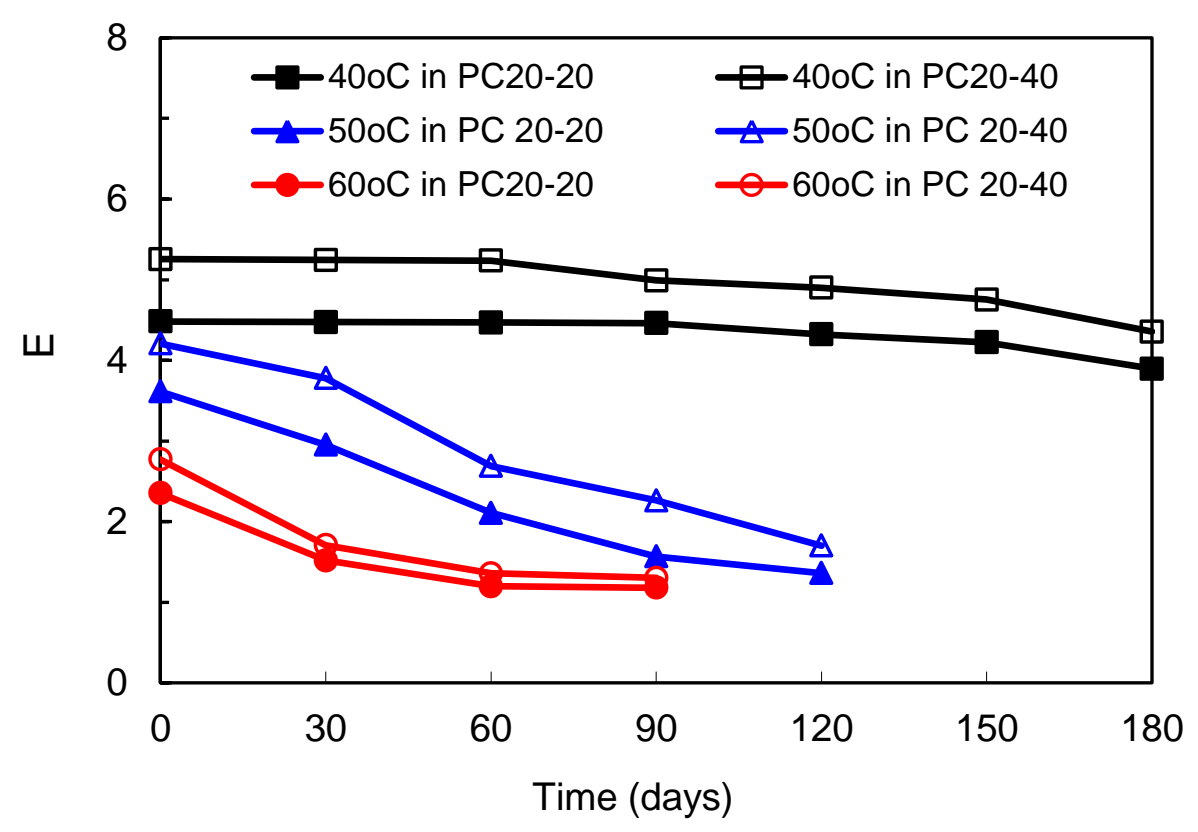

(a) $E_{C A}$

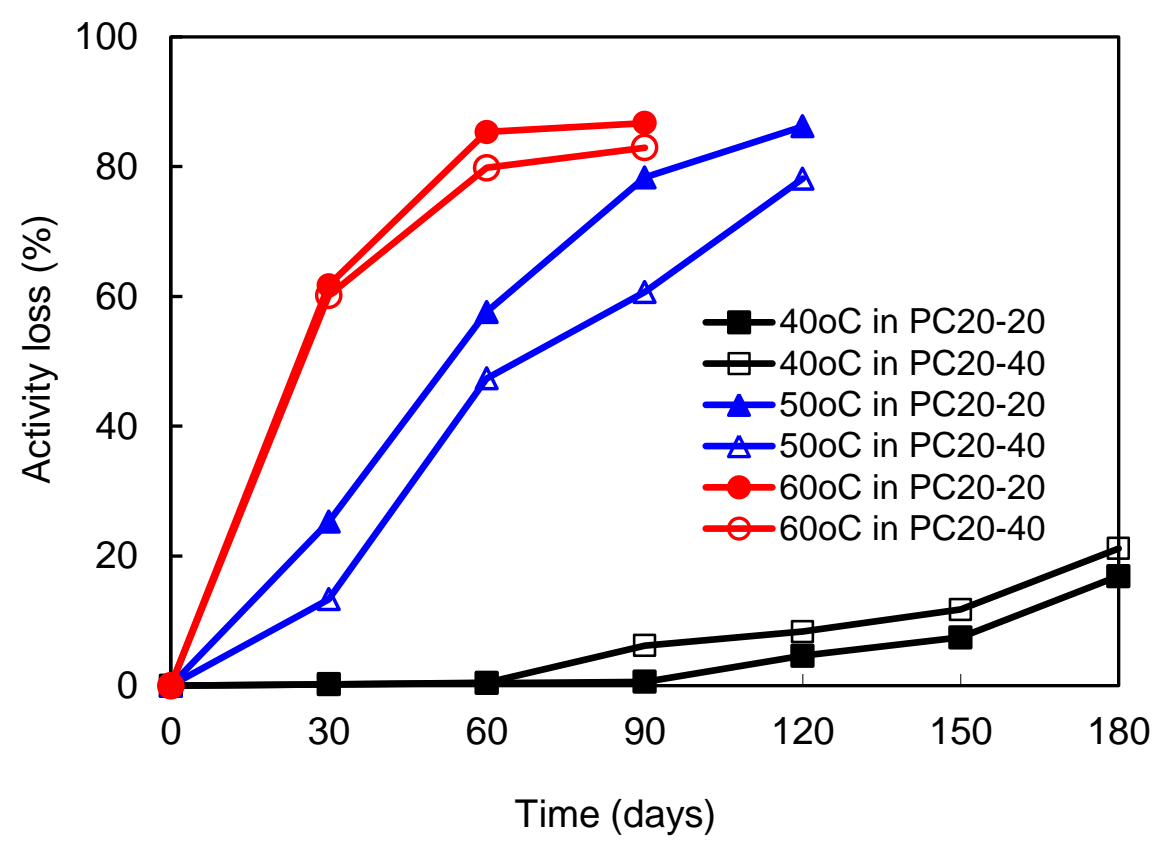

(b) Activity loss

Figure 3D-16. $E_{C A}$ and percentage activity loss of ACA2 in $20 \mathrm{wt} \% \mathrm{PC}$ at 40,50 , and $60^{\circ} \mathrm{C}$.

BCA1 enzyme. The BCA1 thermophilic CA enzyme was obtained from a research group at Ohio State University. This enzyme was designed for potential application in the IVCAP at temperatures up to $60^{\circ} \mathrm{C}\left(140^{\circ} \mathrm{F}\right)$. Its long-term thermal stability was investigated at 40, 50, and $60^{\circ} \mathrm{C}\left(104,122\right.$, and $\left.140^{\circ} \mathrm{F}\right)$ by loading a PC20-20 solution with $300 \mathrm{mg} / \mathrm{L}$ of BCA1. 
Figure 3D-17 shows the rates of $\mathrm{CO}_{2}$ absorption into the PC20-20 solution promoted by the BCA1 enzyme at various periods. Figure 3D-18 displays the corresponding $E_{C A}$ values and activity loss. The stability of the BCA1 enzyme at $40^{\circ} \mathrm{C}\left(104^{\circ} \mathrm{F}\right)$ was good; about 30 and $45 \%$ of the initial activity was lost after 1 and 4 months, respectively. The activity loss at $50^{\circ} \mathrm{C}\left(122^{\circ} \mathrm{F}\right)$ became worse with about 56 and $82 \%$ of the initial activity lost after 1 and 2 months, respectively (Figure 3D-18 (b)). The thermal stability of the BCA1 enzyme at $60^{\circ} \mathrm{C}\left(140^{\circ} \mathrm{F}\right)$ was quite poor; after just 2 months the BCA enzyme had completely lost its initial activity and the $\mathrm{CO}_{2}$ absorption rate was nearly the same as that of $\mathrm{PC}$ solution without the addition of the BCA1 enzyme, as shown in Figure 3D-18(b).

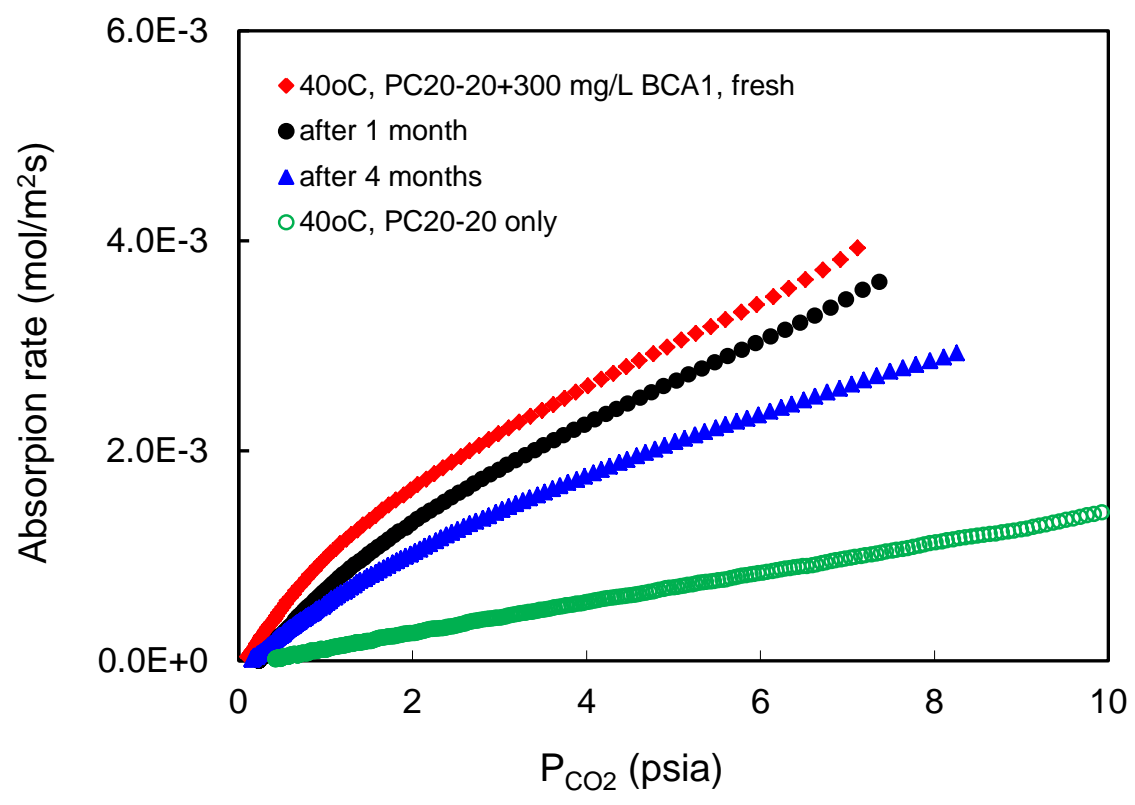

(a) At $40^{\circ} \mathrm{C}$

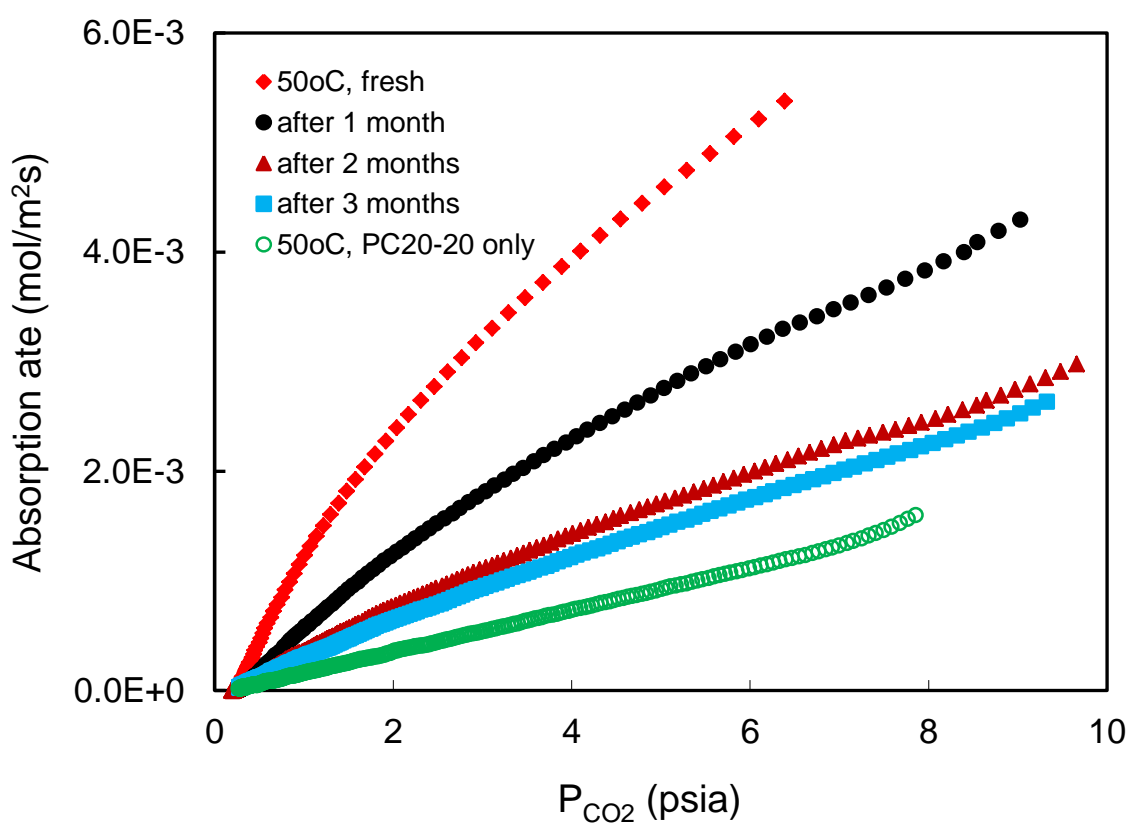

(b) At $50^{\circ} \mathrm{C}$ 


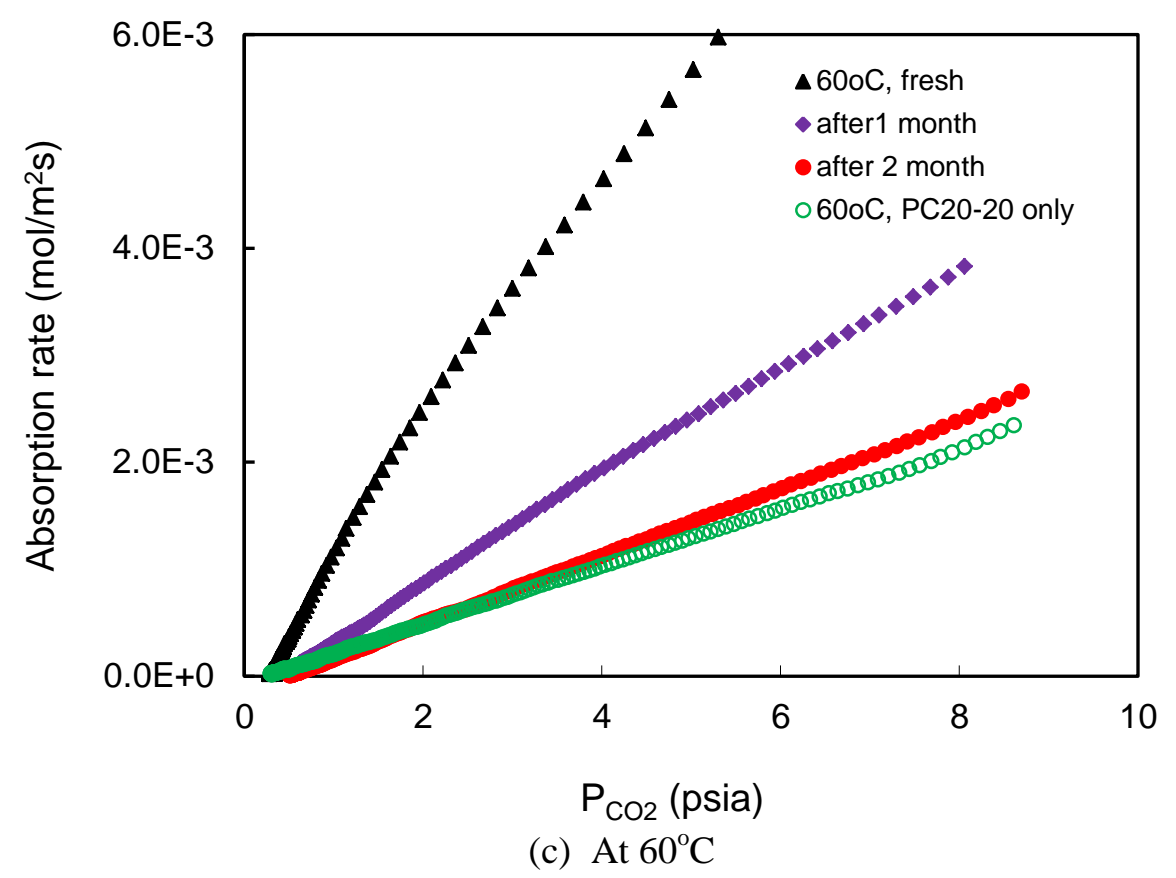

Figure 3D-17. Long-term stability of BCA1 enzyme for promoting $\mathrm{CO}_{2}$ absorption into PC20-20 solution at (a) 40, (b) 50, and (c) $60^{\circ} \mathrm{C}$.

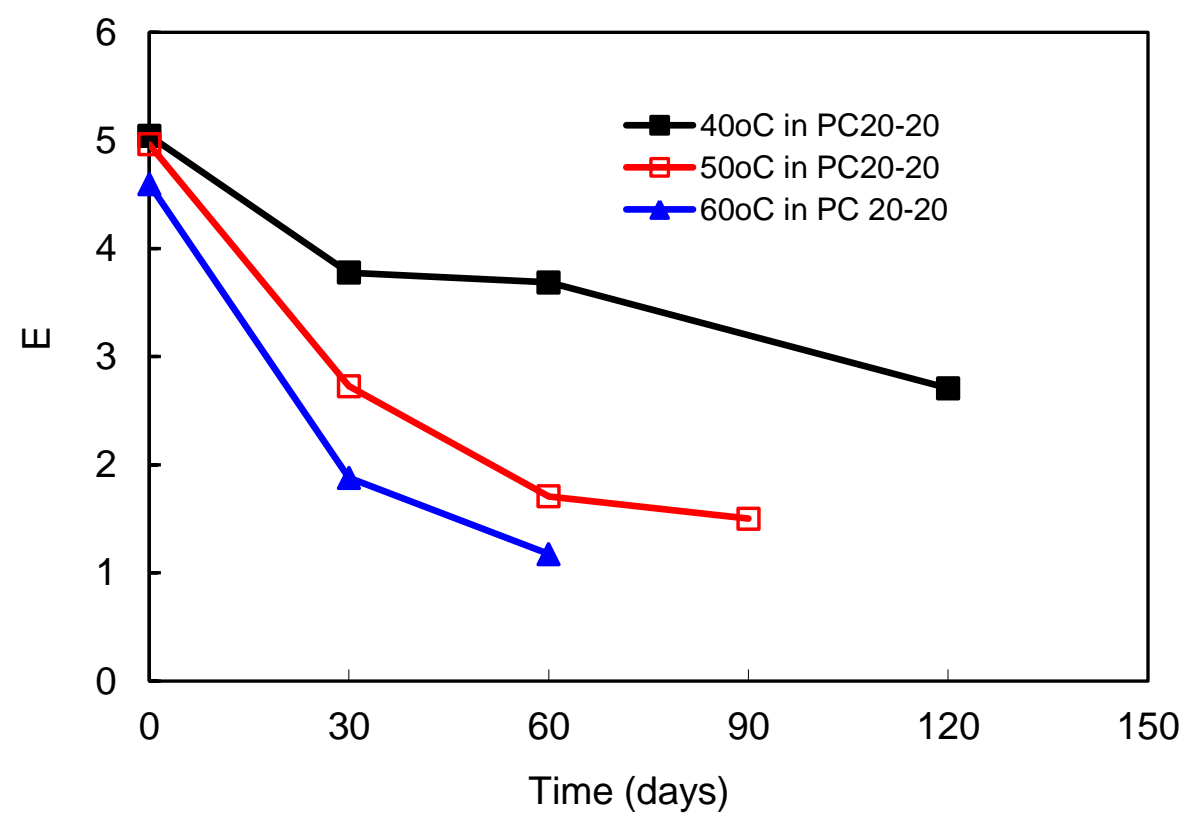

(a) $E_{C A}$ value 


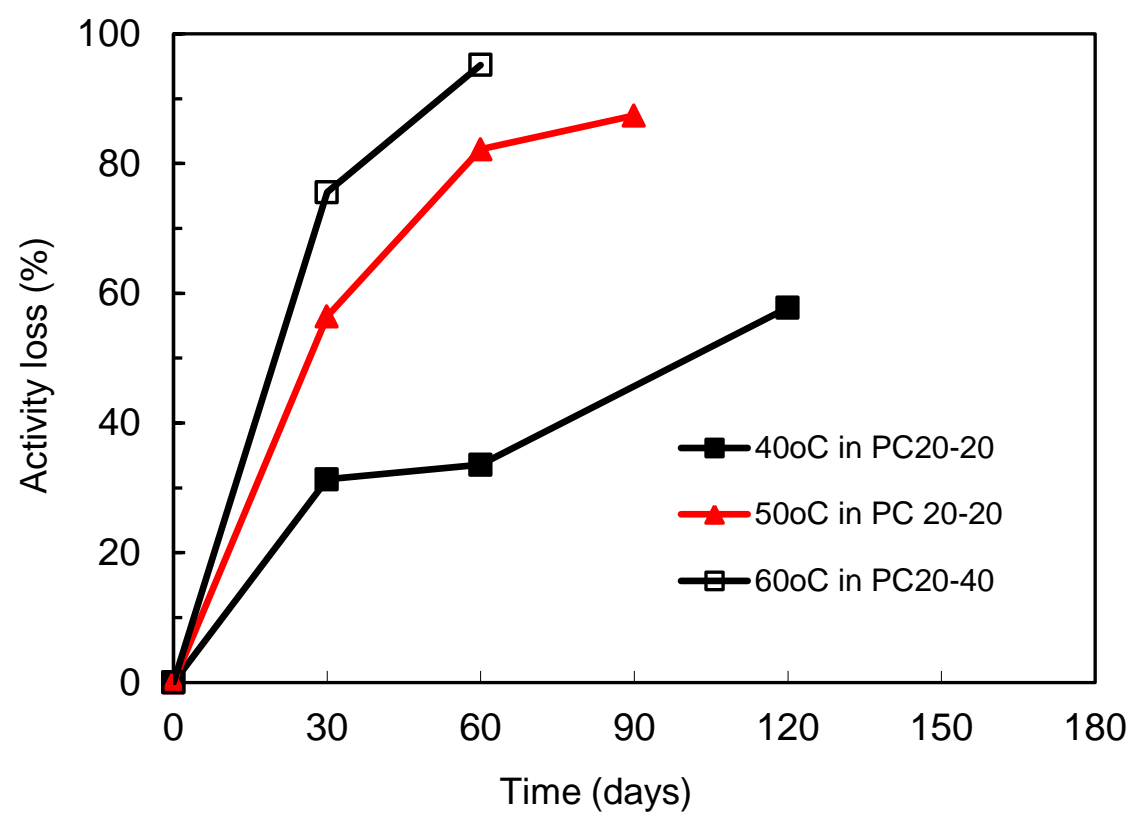

(b) Activity loss

Figure $3 \mathrm{D}-18 . E_{C A}$ and activity loss of BCA1 in $20 \mathrm{wt} \% \mathrm{PC}$ at 40,50 , and $60^{\circ} \mathrm{C}$.

Comparison of long-term thermal stability among the three free CA enzymes. The values of $E_{C A}$ and activity of the three free CA enzymes (ACA1, ACA2, and BCA1) to promote $\mathrm{CO}_{2}$ absorption into PC20-20 solution at 40,50 , and $60^{\circ} \mathrm{C}\left(104,122\right.$, and $\left.140^{\circ} \mathrm{F}\right)$ are compared in Figure 3D-19. The thermal stability of the ACA2 enzyme at $40^{\circ} \mathrm{C}\left(104^{\circ} \mathrm{F}\right)$ was superior; its activity loss was much lower (about 15\%) than that of ACA1 and BCA1 (about 70\%) during the six-month test; although the initial E value of ACA2 was lower. The ACA1 and BCA1 enzyme demonstrated comparable thermal stability at $40^{\circ} \mathrm{C} / 104^{\circ} \mathrm{F}$ (see Figure $3 \mathrm{D}-19(\mathrm{~b})$ ).

At 50 and $60^{\circ} \mathrm{C}\left(122\right.$ and $\left.140^{\circ} \mathrm{F}\right)$, the BCA1 enzyme demonstrated higher initial $E_{C A}$ values, but its $E_{C A}$ value dropped more sharply over time than those of the ACA enzymes, as shown in Figure 3D-19(c). The ACA2 enzyme showed better thermal stability at 50 and $60^{\circ} \mathrm{C}(122$ and $140^{\circ} \mathrm{F}$ ) than the other two enzymes. For example, the activity loss of the ACA2 was about $50 \%$ after two months at $50{ }^{\circ} \mathrm{C}\left(122^{\circ} \mathrm{F}\right)$, while that of ACA1 and BCA1 enzymes was about $80 \%$. At $60^{\circ} \mathrm{C}\left(140^{\circ} \mathrm{F}\right)$, the activity loss of ACA2 after one month was $60 \%$, slightly lower than that of BCA1 (80\%), as shown in Figure 3D-19(d). The ACA1 enzyme had completely lost its initial activity after just a few hours at $60^{\circ} \mathrm{C} / 140^{\circ} \mathrm{F}$ (data not shown). 


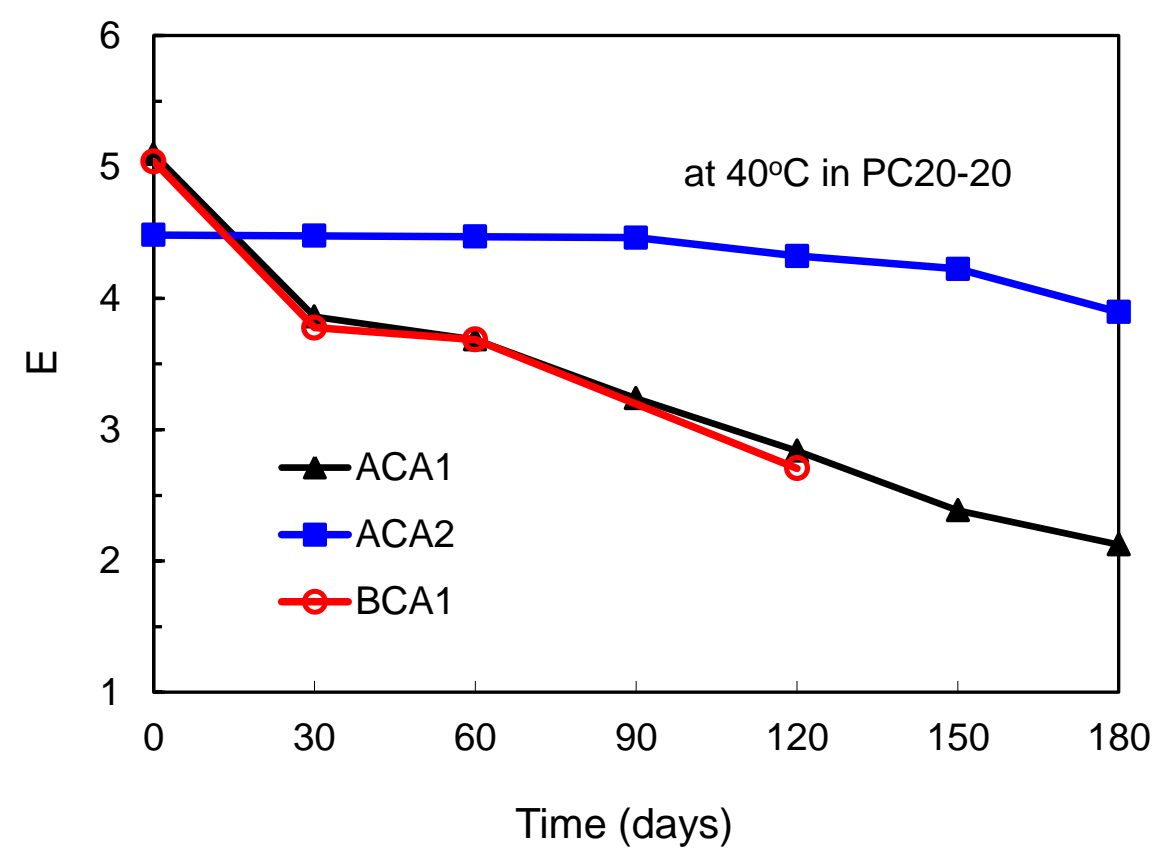

(a) Change of $\mathrm{E}$ values in PC20-20 at $40^{\circ} \mathrm{C}$

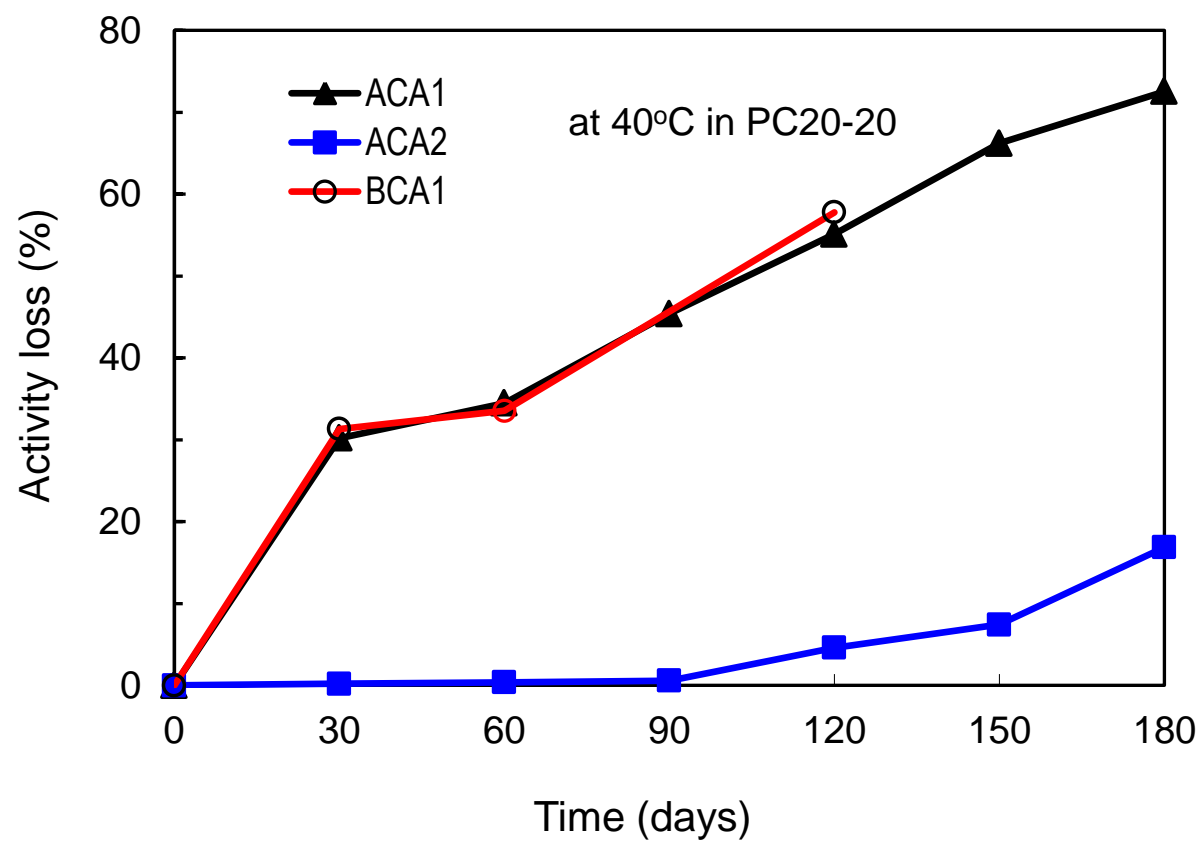

(b) Activity loss over time in PC20-20 at $40^{\circ} \mathrm{C}$ 


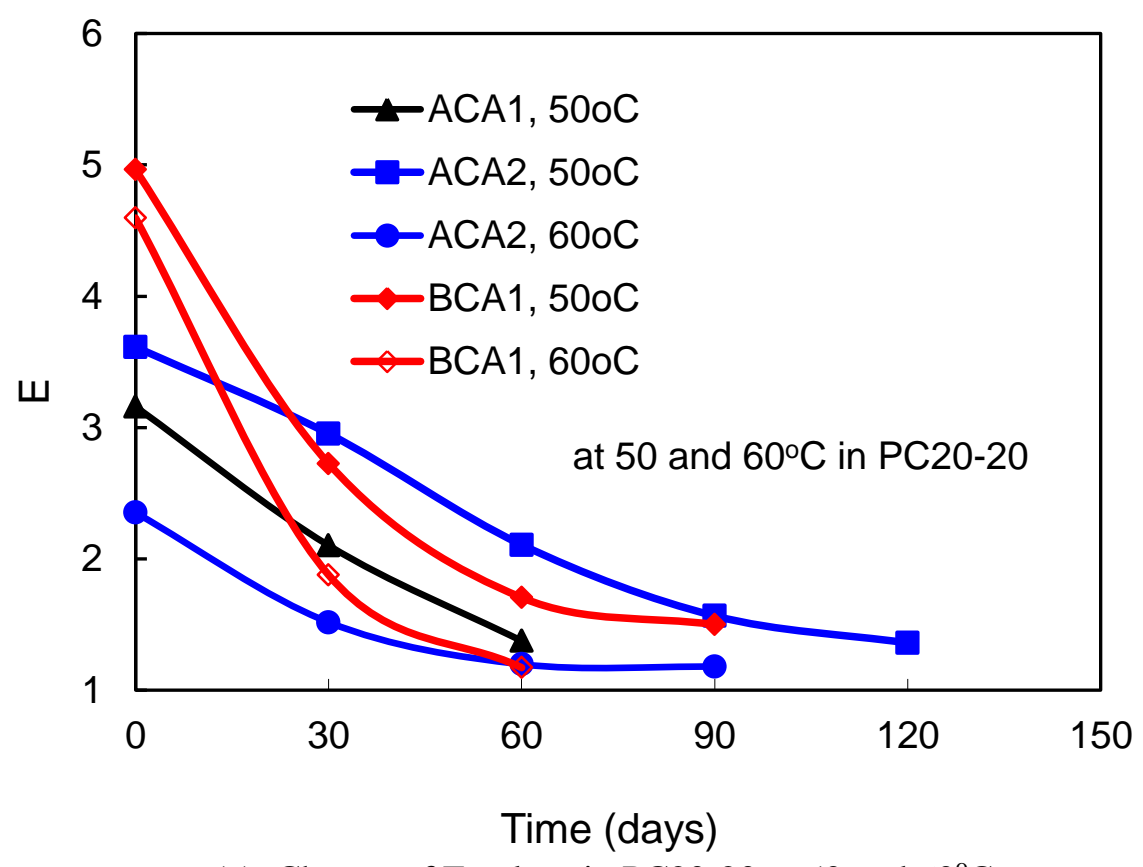

(c) Change of E values in PC20-20 at 50 and $60^{\circ} \mathrm{C}$

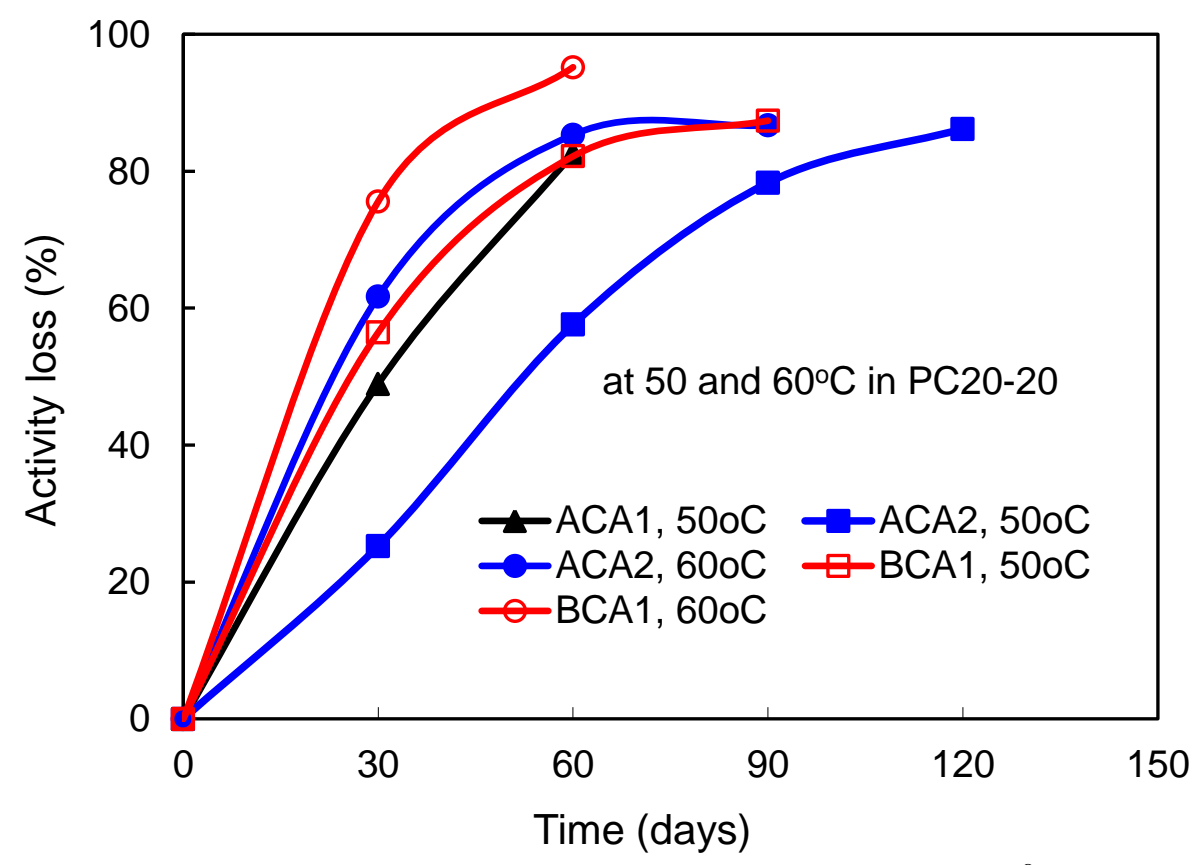

(d) Activity loss over time in PC20-20 at 50 and $60^{\circ} \mathrm{C}$

Figure 3D-19. Comparison among ACA1, ACA2, and BCA1 for long-term thermal stability for promoting $\mathrm{CO}_{2}$ absorption into PC20-20 solutions at 40,50 , and $60^{\circ} \mathrm{C}$. 


\section{D.5 Summary}

\section{Activity of free ACA1 enzyme}

The $\mathrm{CO}_{2}$ absorption rate was significantly increased with increasing CA enzyme concentration up to $600 \mathrm{mg} / \mathrm{L}$. Further improvement may be anticipated at even higher CA concentrations.

The CA activity showed little dependence on the $\mathrm{CO}_{2}$ loading of the PC solution, indicating that the $\mathrm{CA}$ enzyme can maintain its catalytic activity along the entire absorption column regardless of the $\mathrm{CO}_{2}$ loading of the solvent.

The CA enzyme's catalytic activities at 25 and $40^{\circ} \mathrm{C}\left(77\right.$ and $\left.104^{\circ} \mathrm{F}\right)$ were comparable and slightly higher than at $50^{\circ} \mathrm{C}\left(122^{\circ} \mathrm{F}\right)$.

The $\mathrm{CO}_{2}$ absorption rate into the PC20-20 ( $\mathrm{CO}_{2}$ lean) at $300 \mathrm{mg} / \mathrm{l}$ ACA1 dosage was several times lower than the MEA5-40 in the STR at $50^{\circ} \mathrm{C}\left(122^{\circ} \mathrm{F}\right)$, while the rate into the PC20-40 $\left(\mathrm{CO}_{2}\right.$ rich) at the same ACA1 dosage was comparable to the MEA5-90. Furthermore, modeling predictions suggest that in a packed-bed absorption column, where the gas diffusion resistance is significant for fast reactions, the differences between the $\mathrm{CO}_{2}$ absorption rates into the MEA and $\mathrm{PC}+\mathrm{CA}$ are expected to be less, especially when the $\mathrm{CO}_{2}$ loading of the solutions is high.

\section{Chemical stability of free ACA1 enzyme}

The ACA1 enzyme demonstrated excellent chemical stability in resisting typical flue gas impurities containing $\mathrm{Cl}^{-}, \mathrm{NO}_{3}{ }^{-}$, and $\mathrm{SO}_{4}{ }^{2-}$. The activity loss of the $\mathrm{CA}$ enzyme was less than $12 \%$ and did not change over two months.

The activity of the CA enzyme may not be affected by the tested rate promoters. Tested promoters (sucrose and $\mathrm{NaVO}_{3}$ ) reduced the $\mathrm{E}$ value of the ACA1 enzyme. The net effect of the chemical rate promoters on the $\mathrm{E}$ value became less when the reaction temperature was increased from 25 to $40^{\circ} \mathrm{C}\left(77\right.$ to $\left.104^{\circ} \mathrm{F}\right)$.

The $\mathrm{CO}_{2}$ absorption activity of the CA enzyme was adversely affected by the chemical additives tested as water vaporization inhibitors (KAc, KA and EG). This leads to a tradeoff between the benefit of reduced energy consumption by inhibiting water vaporization and the adverse impact on the absorption rate from using these additives.

\section{$\underline{\text { Long-term thermal stability of free CA enzyme }}$}

Temperature was a critical factor affecting the long-term stability of the CA enzymes. For CTB conversion rates between 20 and $40 \%$, the $\mathrm{CO}_{2}$ loading of the PC solution did not affect the thermal stability of the enzymes.

The ACA1 enzyme had satisfactory stability at $25^{\circ} \mathrm{C}\left(77^{\circ} \mathrm{F}\right)$, but not at $40^{\circ} \mathrm{C}\left(104^{\circ} \mathrm{F}\right)$ or higher temperatures. At $25^{\circ} \mathrm{C}\left(77^{\circ} \mathrm{F}\right)$, the activity of the ACA1 enzyme in the PC20-20 solution was 
about $20 \%$ less than the initial value after six months. At $40^{\circ} \mathrm{C}\left(104^{\circ} \mathrm{F}\right)$, the activity loss reached $73 \%$ after six months.

The thermophilic ACA2 enzyme demonstrated excellent stability at $40^{\circ} \mathrm{C}\left(104^{\circ} \mathrm{F}\right)$; after 6 months, it had lost only about $15 \%$ of its initial activity. Compared with the ACA1 and BCA1 enzymes, the ACA2 enzyme showed better thermal stability at 50 and $60^{\circ} \mathrm{C}\left(122\right.$ and $\left.140^{\circ} \mathrm{F}\right)$; the activity loss of the ACA2 enzyme at $50^{\circ} \mathrm{C}\left(122^{\circ} \mathrm{F}\right)$ was about $50 \%$ after two months, while the ACA 1 and BCA1 enzymes had lost about $80 \%$ of their initial activity after two months at $50^{\circ} \mathrm{C}$ $\left(122^{\circ} \mathrm{F}\right)$.

The ACA1 and BCA1 enzymes demonstrated comparable thermal stabilities at 40 to $50^{\circ} \mathrm{C}(104$ to $122^{\circ} \mathrm{F}$ ), although the BCA1 enzyme was engineered to be stable to $60^{\circ} \mathrm{C}$.

The thermal stability of the CA enzymes needs to be further improved for operating temperatures above $50^{\circ} \mathrm{C}\left(122^{\circ} \mathrm{F}\right)$.

\section{References}

1. Danckwerts P. V. Gas-liquid reactions. Mc-Graw-Hill, New York; 1970.

2. Hikita H., Asai S., Katsu Y., Ikuno S. Absorption of carbon dioxide into aqueous monoethanolamine solutions. American Institute of Chemical Engineering Journal, 1979, 25(5): 793-800.

3. Khodayari A. Experimental and theoretical study of $\mathrm{CO}_{2}$ absorption into potassium carbonate solution promoted with enzyme. Master Thesis, University of Illinois at Urbana-Champaign, July 2010.

4. Billet R., Schultes M. Prediction of mass transfer columns with dumped and arranged packings. Transactions of the American Imstitute of Chemical Engineering, 1999, 77(A):498504.

5. Bravo J. L., Rocha J. A. Mass transfer in gauze packings. Fair J. R. Hydrocarbon Processing, 1985, 64: 91-95.

6. Pudvay, M. Operating Experience on the Treatment on FGD Scrubber Blowdown from Existing Generating Stations. http://www.degremont-technologies.com/, as of Feb. 26, 2010.

7. Kernohan, J.C. The pH-Activity Curve of Bovine Carbonic Anhydrase and Its Relationship to the Inhibition of the Enzyme by Anions. Biochimica et Biophysica Acta, 1965, 96: 304317.

8. Lenoir J., Renault P., Renon H. Gas chromatographic determination of Henry's constants of 12 gases in 19 solvents. Journal of Chemical Engineering Data, 1971, 16 (3): 340-342.

9. Chenlo F., Moreira R., Pereira G. and Ampudia A. Viscosities of aqueous solutions of sucrose and sodium chloride of interest in osmotic dehydration processes. Journal of Food Engineering, 2002, 54(4): 347-352. 


\section{CHAPTER 4. CARBONIC ANHYDRASE ENZYME IMMOBILIZATION}

\section{PART 4A. CA ENZYME IMMOBILIZATION ONTO POROUS MATERIALS}

\section{A.1 Introduction}

A carbonic anhydrase (CA) enzyme was employed as a biocatalyst to accelerate the $\mathrm{CO}_{2}$ absorption rate in the IVCAP system without changing the heat of absorption and phase equilibrium of the system. CA is a zinc metalloenzyme that can efficiently catalyze the hydration of $\mathrm{CO}_{2}$ to form bicarbonate. The turnover rate of the CA enzyme can be as great as $10^{6} \mathrm{~s}^{-1}$. [1] Enzymes are natural biocatalysts which offer mild reaction conditions (physiological $\mathrm{pH}$ and temperature), high activity, and high selectivity. However, for industrial applications, such enzymes commonly are hampered by a lack of long-term operational stability, and difficulties in their recovery and re-use. Enzymes undergo a variety of denaturation reactions under the harsh conditions typically found in industrial applications. Denaturation is the unfolding of the enzyme's tertiary structure to a disordered polypeptide in which key amino acid residues are no longer aligned closely enough for continued participation in functional or structure-stabilizing interactions. The denaturation can be reversed if the denaturing factor is removed. An enzyme is also subject to chemical changes leading to an irreversible loss of activity or inactivation, particularly following unfolding. Degradation of the CA enzyme due to heat denaturation or thermodynamic instability over time would require replacement of CA enzyme and hence raise the overall cost of the use of the CA enzyme in the process. The maximum catalytic rate for most enzymes typically lies within a relatively narrow temperature range. In order to use CA enzymes in the industrial setting of the IVCAP system, the stability and the optimal operating temperature of the enzyme must be altered to conform to the IVCAP's operating conditions.

Immobilization of enzymes on solid carriers is perhaps the most commonly used strategy for improving the operational stability of biocatalysts and increasing the flexibility of reactor design. The thermal stability of the immobilized enzyme generally is improved by the molecular rigidity introduced by attachment to a rigid support and creation of a protected micro-environment. A free CA enzyme homogeneously dissolves in a solution and, therefore, offers a greater specific activity compared to an immobilized enzyme. However, immobilization can improve the stability of the enzyme, which is important for the $\mathrm{CO}_{2}$-capture application in a power plant. The enzyme can either be immobilized onto packing materials, or onto fine particle carriers that are suspended in the solvent; if the carrier is not stable at the elevated stripping temperature, the carrier can be separated from the solvent prior to stripping. The CA enzyme commonly has been immobilized using covalent coupling methods, ${ }^{[2,3]}$ which have the advantage that enzyme leaching from the surface is minimal. Other methods have included enzyme entrapment in capsules ${ }^{[4,5]}$ and enzyme adsorption. ${ }^{[6]}$ A variety of support materials, such as iron filings, methacylic acid polymer, silica, graphite, controlled-pore glass, alginate, and polyurethane foam have been investigated for CA enzyme immobilization. ${ }^{[2,4,5,7]}$ The reported studies showed that immobilization generally resulted in an activity reduction, but increased the stability of the CA enzyme over time. For example, one study showed that the initial activity of a bovine CA immobilized on silica materials was $30 \%$ less, and on graphite materials $60 \%$ less than its free counterpart. However, the immobilizations resulted in the CA enzyme's retaining more than 70\%

of its initial activity levels during 500 days of storage at $4^{\circ} \mathrm{C}\left(39^{\circ} \mathrm{F}\right) .{ }^{[2]}$ Another study showed 
that the enzyme unfolding temperature of a single CA molecule encapsulated onto a spherical nano-gel increased from 64 to $81^{\circ} \mathrm{C}\left(147\right.$ to $\left.178^{\circ} \mathrm{F}\right){ }^{[8]}$ Several processes employing immobilized $\mathrm{CA}$ enzyme as a catalyst for $\mathrm{CO}_{2}$ capture from flue gases also have been reported, including a spray reactor process employing the $\mathrm{CA}$ enzyme immobilized onto iron filing matrices, ${ }^{[3]} \mathrm{a}$ hollow fiber contained liquid membrane (CLM) system with the CA immobilized in a liquid membrane ${ }^{[9]}$ and a packed-bed reactor with the CA immobilized onto inorganic or organic supports. ${ }^{[10]}$

The above-mentioned studies demonstrate that CA enzyme immobilization could effectively improve the enzyme's stability and promote $\mathrm{CO}_{2}$ absorption into various solvents. However, most of these studies were performed at low or room temperatures and at solution conditions ( $\mathrm{pH}$, composition, etc.) much different from those proposed in the IVCAP. In addition, the flue gases emitted by coal combustion contain significant amounts of $\mathrm{SO}_{2}, \mathrm{NO}_{\mathrm{x}}, \mathrm{HCl}$, and other impurities. As a result, sulfates, nitrates, and chlorides tend to be major impurities found in the scrubbing liquids at power plants. In the IVCAP, the immobilized CA would be subjected to temperatures ranging from 40 to $60^{\circ} \mathrm{C}\left(104\right.$ to $\left.140^{\circ} \mathrm{F}\right), \mathrm{pH}$ ranging from 9 to 12 , and the flue gas impurities. It should also be noted that the enzymes used in the previous studies represented almost exclusively the type of bovine CA enzymes produced in a laboratory environment at a small-scale only suitable for research purposes.

For this study, a new CA enzyme manufactured by a leading enzyme company in a pilot-scale unit that is scalable for large-scale capture applications was employed. A commercially available bovine CA enzyme was used as a reference for comparison. The two CA enzymes were covalently immobilized onto four different materials: two different controlled-pore glass (CPG) materials, an activated carbon, and Eupergit C. The CPG was selected as a support material because: 1) it has a uniform physical structure (pore size and surface) and thus is ideal for the immobilization study, and 2) the results can be applied to less expensive ceramic materials that possess similar surface functionalities. The activated carbon support material was selected, because it is widely available and its surface chemistry and pore structure can be easily tailored for enzyme immobilization. Eupergit $\mathrm{C}$ was selected, because it provides high-density oxirane groups for multi-point immobilization of the enzyme. We hypothesized that this "multi-pointattachment" might result in a high operational stability of enzymes bound to Eupergit C. The activities of the immobilized CA enzymes were tested and compared with the activities of their free counterparts. The thermal stability and resistance to chemical impurities of the immobilized enzymes were investigated over a three-month period under the temperature and solution conditions expected in the IVCAP.

\section{A.2 Experimental methods}

\section{A.2.1 Materials}

A leading enzyme manufacturer supplied a technical-grade CA enzyme (ACA1) that had been produced in a pilot-scale manufacturing unit. The as-received sample was in the form of concentrated enzyme $(\sim 3 \mathrm{~g} / \mathrm{L})$ in an aqueous solution. According to the manufacturer, the liquid sample contained small amounts of impurities, such as low molecular weight fermentation 
residues, processing aids, salts, and other proteins. The reference CA enzyme (SCA), a bovine CA enzyme, was purchased from Sigma-Aldrich Co.

Two CPG materials with pore sizes of $38 \mathrm{~nm}$ (CPG38) and $100 \mathrm{~nm}$ (CPG100) were purchased from Sigma-Aldrich. The CPG samples had a particle size of 200-400 mesh (38-75 $\mu \mathrm{m})$. The activated carbon (AC), CAL-AC was supplied by Calgon Carbon Corporation. The AC had a particle size of 40-60 mesh $(250-400 \mu \mathrm{m})$. The Eupergit C 250L (Sigma-Aldrich) is a commercial copolymer made by copolymerization of methacrylamide, methylene-bismethacrylamide, glycidyl-methacrylate and allyl-glycidyl-ether. It has a pore size of $100 \mathrm{~nm}$ and a particle size of $250 \mu \mathrm{m}$. The following chemicals used in the experiments were purchased from Sigma-Aldrich Co.: $\gamma$-Aminopropyl triethoxysilane $(\geq 98 \%)$; glutaraldehyde solution $(25 \%$, w/w); N-hydroxy succinimide ( $\geq 97 \%) ; \quad \mathrm{N}$-Cyclohexyl-N-(2-morpholinoethyl) carbodiimide metho-p-toluenesulfonate $(\geq 95 \%)$; 1,4-dioxane ( $\geq 99.8 \%)$; methanol $(\geq 99.8 \%)$ and $\mathrm{H}_{4} \mathrm{BNa}$ $\left(\geq 98 \%\right.$ ). The reagents $\mathrm{HNO}_{3}, \mathrm{KH}_{2} \mathrm{PO}_{4}, \mathrm{Na}_{2} \mathrm{HPO}_{4}, \mathrm{KHCO}_{3}, \mathrm{~K}_{2} \mathrm{CO}_{3}$, Tris-hydroxymethyl aminomethane, toluene, and acetone needed for the experiments were obtained from Fisher Scientific, Inc.

\section{A.2.2 Enzyme purification}

The ACA1 enzyme was purified before immobilization. The as-received ACA1 solution was first mixed with $\left(\mathrm{NH}_{4}\right)_{2} \mathrm{SO}_{4}$ to $80 \%$ saturation of the sulfate and then refrigerated $\left(4^{\circ} \mathrm{C} / 39^{\circ} \mathrm{F}\right)$ overnight to precipitate the protein content. The solution was then centrifuged and the ACA1 precipitant was dissolved in a $\mathrm{Na}_{2} \mathrm{HPO}_{4}-\mathrm{KH}_{2} \mathrm{PO}_{4}$ buffer $(30 \mathrm{mM}, \mathrm{pH} 8.05)$. The resulting solution was dialyzed twice against $10 \mathrm{mM} \mathrm{K}_{2} \mathrm{CO}_{3}$ solution for 8 hours with Fisher brand regenerated cellulose dialysis tubing (flat width: $33 \mathrm{~mm}$ ). No purification process was applied to the SCA reference enzyme, because it was pure in its as-received condition.

\section{A.2.3 Enzyme immobilization}

Enzyme immobilization on CPG support. A covalent coupling method based on the one developed by Weetall and Lee ${ }^{[1]]}$ was used for immobilization of the CA onto the CPG support (CA-CPG). It involved activation of the CPG surface with a silane and an aldehyde, followed by covalent coupling between the CA enzyme and the activated CPG. The main reactions that occur in the enzyme immobilization process are shown in Figure 4A-1.

The immobilization procedure on the CPG support was optimized. The optimal procedure involved cleaning the CPG by boiling it in a $5 \%$ nitric acid solution for 45 minutes; washing with deionized (DI) water; mixing 0.1-0.2 gram of the cleaned CPG material with $10 \mathrm{~mL}$ of $10 \%$ (v/v) $\gamma$-aminopropyl triethoxysilane dissolved in toluene; stirring the mixture mildly for 24 hours at room temperature; filtering and washing the material in the filter with toluene and acetone, and air drying the filter at $110^{\circ} \mathrm{C}\left(230^{\circ} \mathrm{F}\right)$ for 4 hours. For immobilization, the silanized CPG was mixed with $10 \mathrm{~mL}$ of $2.5 \mathrm{wt} \%$ glutaraldehyde in a $0.1 \mathrm{M}$ phosphate buffer $(\mathrm{pH} 7.0)$ and stirred mildly for 1 hour at room temperature. The resulting CPG then was washed with a $0.05 \mathrm{M}$ phosphate buffer ( $\mathrm{pH} 8.05)$ solution, stirred in $10-20 \mathrm{~mL}$ of CA solution $(400 \mathrm{mg} / \mathrm{l})$ in a $0.1 \mathrm{M}$ phosphate buffer $(\mathrm{pH} 8.05)$ for 3 hours at room temperature, and washed thoroughly with the same phosphate buffer ( $\mathrm{pH} 8.05)$ to remove unbound enzyme. The extra aldehyde on the CPG 
was quenched by immersing the CPG in a $0.1 \mathrm{M}$ Tris- $\mathrm{H}_{2} \mathrm{SO}_{4}(\mathrm{pH}$ 8.1) solution for 1 hour. The current immobilized CA-CPG was further mixed in $0.2 \% \mathrm{NaBH}_{4}$ in a $\mathrm{Na}_{2} \mathrm{HPO}_{4}-\mathrm{KH}_{2} \mathrm{PO}_{4}$ buffer $(0.1 \mathrm{M}, \mathrm{pH} 8.05)$ for 30 minutes to reduce the Schiff-base formed during the coupling reaction between the CA and aldehyde. The resultant CA-CPG sample was washed with the $\mathrm{Na}_{2} \mathrm{HPO}_{4}$ $\mathrm{KH}_{2} \mathrm{PO}_{4}$ buffer $(0.1 \mathrm{M}, \mathrm{pH} 8.05)$ solution. The product was stored in the $0.1 \mathrm{M}$ phosphate buffer $(\mathrm{pH} 8.05)$ at $4^{\circ} \mathrm{C}\left(39^{\circ} \mathrm{F}\right)$ before the activity and stability measurements. Using this method, four immobilized enzyme samples were prepared: 1) ACA1 immobilized on CPG100 (ACA1CPG100); 2) ACA1 on CPG38 (ACA1-CPG38); 3) SCA on CPG100 (SCA-CPG100); and 4) SCA on CPG38 (SCA-CPG38).

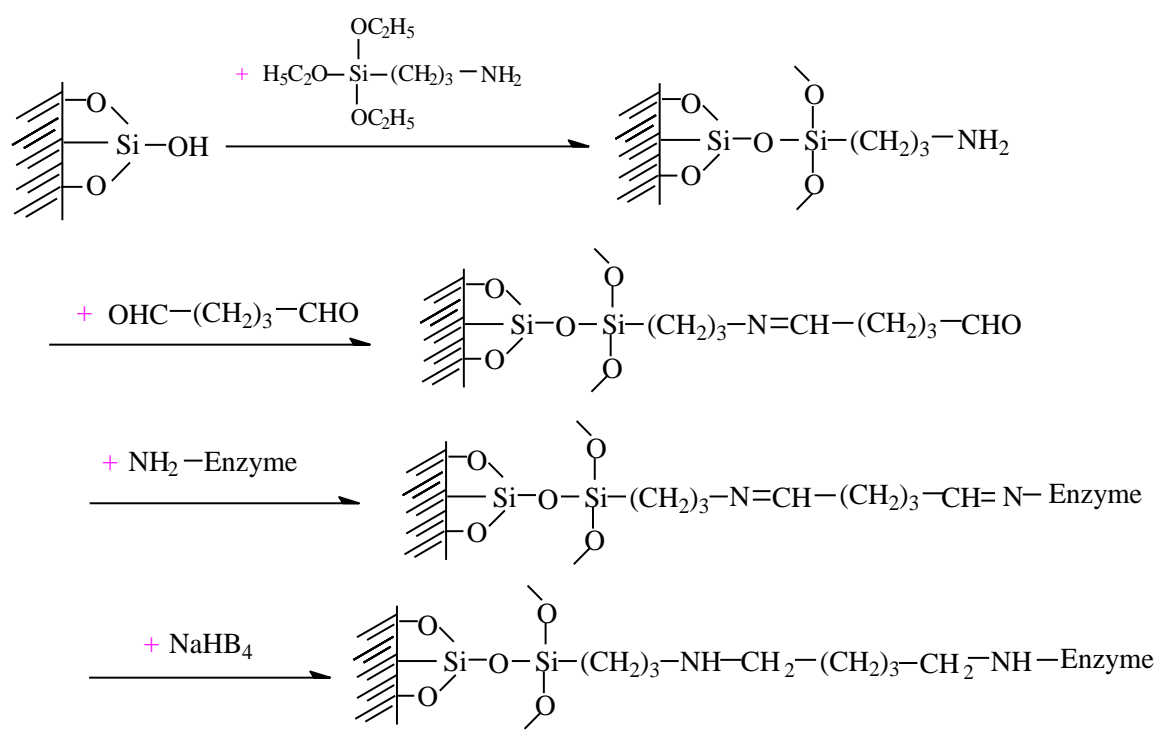

Figure 4A-1. Main reactions involved in CA immobilization on CPG support.

Enzyme immobilization on $\boldsymbol{A C}$ support. The method employed to covalently immobilize CA enzyme onto the AC support (CA-AC) was developed based on the Carbodiimide method. ${ }^{[12]}$ The primary enzyme immobilization reactions are shown in Figure 4A-2.

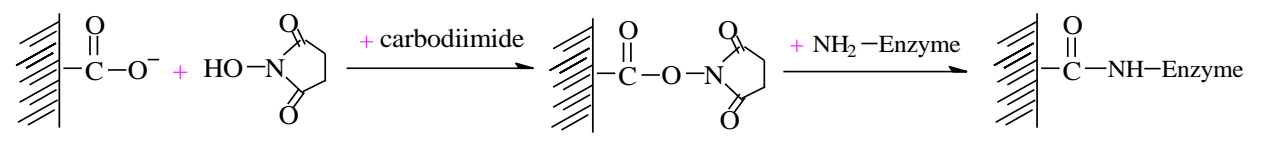

Figure 4A-2. Main reactions involved in CA immobilization on AC support.

The immobilization process included AC cleaning, AC surface treatment, and CA immobilization. For cleaning, about $20 \mathrm{~g}$ of AC was washed with warm DI water; soaked and stirred in one liter of a $6 \mathrm{~N} \mathrm{HCl}$ solution for 24 hours; filtered; washed with DI water until the $\mathrm{pH}$ approached 7 , and dried in air at $105^{\circ} \mathrm{C}\left(221^{\circ} \mathrm{F}\right)$ overnight. For activation, the cleaned AC was suspended in a dioxane solvent and solid N-hydroxy succinimide was added to the stirred suspension to obtain a $0.05 \mathrm{M}$ solution. Solid N-Cyclohexyl-N-(2-morpholinoethyl) carbodiimide metho-p-toluenesulfonate was added to make a $0.05 \mathrm{M}$ solution, followed by mild stirring for 70 minutes at room temperature. The AC thus prepared was filtered and washed in sequence with dioxane, methanol (to remove the precipitated dicyclohexylurea), and dioxane. After drying for 1 to 2 minutes under vacuum, the slightly moist AC was weighed and added to a 
$\mathrm{Na}_{2} \mathrm{HPO}_{4}-\mathrm{KH}_{2} \mathrm{PO}_{4}$ buffer $(30 \mathrm{mM}, \mathrm{pH}$ 8.05) solution containing a predetermined amount of the CA enzyme. The coupling reaction was carried out with gentle stirring for 2 hours at room temperature. The CA-AC sample was filtered and washed with a Tris- $\mathrm{H}_{2} \mathrm{SO}_{4}$ buffer $(0.1 \mathrm{M}, \mathrm{pH}$ 8.1). The immobilized enzyme was stored in a $0.1 \mathrm{M}$ phosphate buffer $(\mathrm{pH} 8.05)$ at $4^{\circ} \mathrm{C}\left(39^{\circ} \mathrm{F}\right)$. Two CA-AC samples were prepared using this method: ACA1 immobilized on AC (ACA1-AC), and SCA on AC (SCA-AC).

Enzyme immobilization on Eupergit $\boldsymbol{C}$ support. The method for immobilizing the CA enzyme onto the Eupergit $\mathrm{C}$ support (SCA-Eup) was a modification of a method reported in the literature. ${ }^{[13,14]}$ The main reactions involved in the enzyme immobilization are shown in Figure 4A-3. The immobilization process involved three steps: 1) the epoxy groups in Eupergit are acidized to form diol; 2) the diol is further oxidized by sodium periodate to produce the aldehyde groups; and 3) the enzyme is coupled through bonding with the aldehyde group in support.

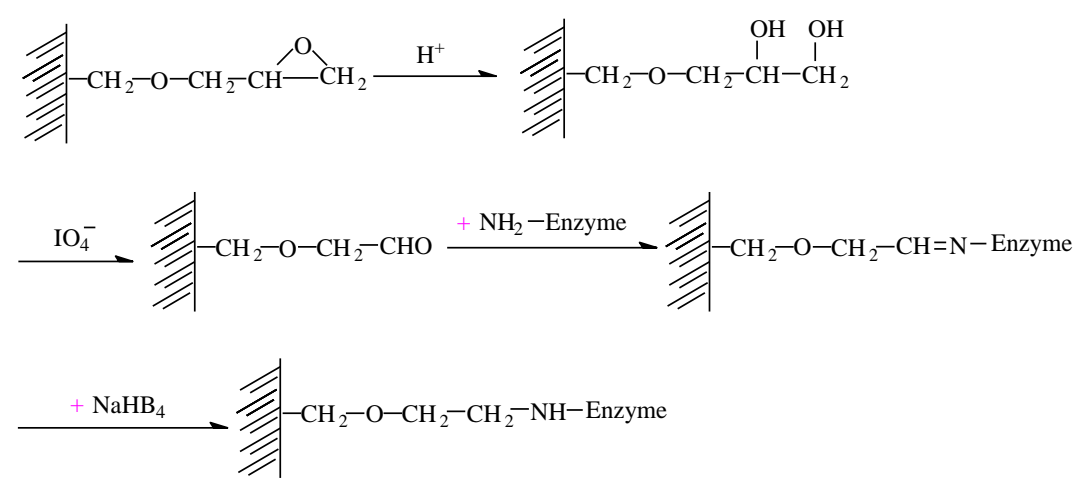

Figure 4A-3. Main reactions involved in the CA immobilization on Eupergit C support.

During the immobilized enzyme preparation, $0.3 \mathrm{~g}$ Eupergit C sample was mixed with $5 \mathrm{ml}$ of DI water and $2 \mathrm{ml}$ of glacial aceticacid. The mixture was stirred at 82 to $85^{\circ} \mathrm{C}$ (180 to $185^{\circ} \mathrm{F}$ ) for 1 hour. The acid-treated Eupergit $\mathrm{C}$ was thoroughly washed with DI water. It was then suspended in $10 \mathrm{ml}$ of $20 \mathrm{mM}$ sodium periodate $\left(\mathrm{NaIO}_{4}\right)$ solution $\left(\mathrm{NaIO}_{4}\right.$ dissolved in $0.1 \mathrm{M}$, pH 5.5 HAc$\mathrm{NaAc}$ buffer). The suspension was stirred in darkness at room temperature for 1 hour. The oxidized Eupergit was washed with $50 \mathrm{mM}$ of $\mathrm{Na}_{2} \mathrm{HPO}_{4}-\mathrm{KH}_{2} \mathrm{PO}_{4}$ buffer solution ( $\mathrm{pH} 7.0$ ), and then added to $10 \mathrm{ml}$ of $1 \mathrm{~g} / \mathrm{CA}$ solution (CA dissolved in $50 \mathrm{mM}$, pH $9.5 \mathrm{KHCO}_{3}-\mathrm{K}_{2} \mathrm{CO}_{3}$ buffer). The coupling reaction between the enzyme and the activated support lasted for 3 hours under stirring at room temperature. The support was washed thoroughly with the $\mathrm{Na}_{2} \mathrm{HPO}_{4}$ $\mathrm{KH}_{2} \mathrm{PO}_{4}$ buffer ( $\mathrm{pH}$ 8.05) to remove the unbound enzyme. The extra aldehyde groups on the support were quenched by $0.1 \mathrm{M}$ Tris- $\mathrm{H}_{2} \mathrm{SO}_{4}(\mathrm{pH}$ 8.10) solution for 1 hour. The Schiff-base formed during the coupling reaction was reduced using $0.2 \% \mathrm{NaBH}_{4}$ in $50 \mathrm{mM} \mathrm{KHCO}-\mathrm{K}_{2} \mathrm{CO}_{3}$ buffer ( $\mathrm{pH} 9.5$ ) for 40 minutes. After washing with $50 \mathrm{mM} \mathrm{Na} 2 \mathrm{HPO}_{4}-\mathrm{KH}_{2} \mathrm{PO}_{4}$ buffer ( $\mathrm{pH} 8.05$ ), the resulting immobilized CA (SCA-Eup) was stored in the buffer $(\mathrm{pH} 8.05)$ solution at $4{ }^{\circ} \mathrm{C}$ $\left(39^{\circ} \mathrm{F}\right)$ prior to activity and stability testing. One CA-Eup sample was prepared using this method: SCA on Eupergit C (SCA-Eup). The SCA-Eup exhibited a lower enzyme activity and loading level compared to those of the SCA-CGP100. Thus, immobilization of the ACA1 enzyme onto Eupergit C was not investigated. 


\section{A.2.4 Analysis of $\mathrm{NH}_{2}$ functional group density}

The density of the amine $\left(-\mathrm{NH}_{2}\right)$ functional group on the CPG100 surface was determined by the Aldehyde test method. ${ }^{[15]}$ About $36 \mathrm{~g}$ of silanized CPG100 was immersed in $5 \mathrm{ml}$ of $0.2 \mathrm{M}$ aldehyde (2-hydroxy-1-naphthaldehyde) in dimethylformamide (DMF) for 14 hours, and washed with methylene chloride, DMF (two $5 \mathrm{ml}$ portions), and $40 \mathrm{ml}$ of $95 \%$ ethanol. The treated CPG100 was added to $10 \mathrm{ml}$ of $0.4 \mathrm{M}$ benzylamine in ethanol solvent for 1 hour and then washed with ethanol. The solution collected during the washing step was diluted to $250 \mathrm{ml}$ and measured for absorbance at the $420 \mathrm{~nm}$ wavelength. The extinction coefficient of the Schiff base formed by the benzylamine and the aldehyde was determined to be 10,900 at $420 \mathrm{~nm}$.

\section{A.2.5 Characterization of support materials and immobilized enzymes}

The pore structures of the $\mathrm{CPG}$ and $\mathrm{AC}$ support materials before and after enzyme immobilization were characterized using nitrogen adsorption-desorption isotherms at $-196^{\circ} \mathrm{C}(-$ $321^{\circ} \mathrm{F}$ ) (Micromeritics ASAP 2020 analyzer). Prior to each measurement, the samples were evacuated at $100^{\circ} \mathrm{C}$ under vacuum ( $\mathrm{p}$ (total pressure) $<0.01 \mathrm{mmHg} / 1.93 \times 10^{-4} \mathrm{psia}$ ) and then held at $100^{\circ} \mathrm{C}\left(212^{\circ} \mathrm{F}\right)$ under vacuum $\left(\mathrm{p}<1 \mathrm{mmHg} / 1.93 \times 10^{-2} \mathrm{psia}\right)$ for 4 hours to degas. The specific surface area of the sample was determined from the linear part of the BET equation. The pore volume was derived from the amount of adsorption at a relative pressure of $\mathrm{P} / \mathrm{P}_{0}=0.985$. The pore size distribution was estimated using the Barrett-Joyner-Halenda (BJH) desorption method.

Three samples - raw CPG100, activated CPG100, and CPG100 immobilized with SCA - were selected for the Scanning Electron Microscopy (SEM) analysis. Prior to the SEM analysis, each sample was air-dried at room temperature overnight. The sample was coated with palladium (Pd) in a sputter coater (Emitech K575) to increase the conductivity of its surface. The coated material was analyzed using a Hitachi SEM (Hitachi S4700).

A Laser Scanning Confocal Microscope (LSCM, Leica Microsystems, TCS SP2 RBB) was employed to map the distribution of the ACA1 enzyme inside the CPG and AC support particles. Fluorescamine, a non-fluorescent reagent itself, was employed to react with the primary amines of the ACA1 enzyme to form a fluorescent product, Flourescamine-CA, which is detectable by the LSCM. To make the fluorescent ACA1, $1 \mathrm{ml}$ of Fluorescamine solution dissolved in acetone $(3 \mathrm{mg} / \mathrm{ml}$ ) was reacted with $0.3 \mathrm{mg}$ of the immobilized enzyme sample for 10 minutes. Microscope slides of the now fluorescent immobilized enzyme samples were prepared with the use of mowiol coverslip mounting solution. After drying overnight, the sample was excited at $458 \mathrm{~nm}$ wavelength and the fluorescent images were taken at 460 to $503 \mathrm{~nm}$ wavelengths using a DD 458/514 beam splitter. A series of 30 cross-sectional X-Y slices along the Z-axis from the top to the bottom of the support particles were scanned.

\section{A.2.6 Enzyme loading}

The amount of CA enzyme loaded onto a support material was determined by measuring the concentrations of the free CA enzyme before and after the immobilization treatment. The measurement method is referred to the Bradford method for protein quantitation. ${ }^{[16]}$ The Bradford reagent was prepared by dissolving $100 \mathrm{mg}$ Coomassie Brilliant Blue G-250 in 50ml of 
a $95 \%$ ethanol, adding $100 \mathrm{ml}$ of $85 \%$ phosphoric acid, and diluting with DI water to make 1 liter of the solution. The resulting reagent was filtered with a Whatman No.1 filter and stored in an amber bottle at room temperature.

A calibration curve of the CA concentration vs. absorbance was prepared on a daily basis. The measurement of $\mathrm{CA}$ concentration in the solution involved diluting the CA solution with a $\mathrm{Na}_{2} \mathrm{HPO}_{4}-\mathrm{KH}_{2} \mathrm{PO}_{4}$ buffer to an estimated concentration of about $0.1 \mathrm{mg} / \mathrm{ml}$, and mixing $0.3 \mathrm{ml}$ of the diluted solution with $0.7 \mathrm{ml}$ of $0.15 \mathrm{M} \mathrm{NaCl}$ and $5 \mathrm{ml}$ of Bradford reagent. After 2 minutes of incubation, the CA enzyme concentration in solution was measured with the spectrophotometer at the absorbance wavelength of $595 \mathrm{~nm}$.

\section{A.2.7 Enzyme activity assay}

Two CA activity assays, the $p$-nitrophenyl acetate ( $p$-NPA) hydrolysis assay, and a manometric assay, were employed to evaluate the activity of the immobilized CA enzymes.

The $p$-NPA hydrolysis assay measures the CA enzyme's activity for hydrolysis of $p$-NPA to form $p$-nitrophenol $(p-\mathrm{NP})$. It is a modification of an assay proposed by Pocker and Stone. ${ }^{[17]}$ For the free CA enzyme, $0.2 \mathrm{ml}$ of enzyme sample was added to a solution containing $4.6 \mathrm{ml}$ of $\mathrm{Na}_{2} \mathrm{HPO}_{4}-\mathrm{KH}_{2} \mathrm{PO}_{4}$ buffer solution $(0.1 \mathrm{M}, \mathrm{pH} 8.0)$ and $0.2 \mathrm{ml}$ of $p$-NPA $\left(2.2 \times 10^{-4} \mathrm{M}\right)$. The free CA enzyme's activity was determined by measuring the $p$-NP concentration in the hydrolysis solution in a $5 \mathrm{ml} \mathrm{UV}$ cuvette at $25^{\circ} \mathrm{C}\left(77^{\circ} \mathrm{F}\right)$ for 3 minutes, using a UV-visible spectrophotometer (Shimadzu UV-1800) at $400 \mathrm{~nm}$ wavelength. To assay the activity of an immobilized CA enzyme, about $0.5 \mathrm{ml}$ of immobilized CA sample was added to a solution containing $4.3 \mathrm{ml}$ of $\mathrm{Na}_{2} \mathrm{HPO} 4-\mathrm{KH}_{2} \mathrm{PO}_{4}$ buffer $(0.1 \mathrm{M}, \mathrm{pH} 8.0)$ and $0.2 \mathrm{ml}$ of $p$-NPA $\left(2.2 \times 10^{-4}\right.$ $\mathrm{M})$. The $p$-NPA hydrolysis was carried out in a rotary incubator under a mild stirring condition for 10 minutes. The solution was then transferred to a $5 \mathrm{ml} \mathrm{UV}$ cuvette to determine the $p$-NP concentration.

The manometric method directly measures the $\mathrm{CA}$ enzyme's activity for $\mathrm{CO}_{2}$ hydration. The method was proposed by Roughton and Booth. ${ }^{[18]}$ A batch stirred tank reactor (STR) was used to measure the activities of the free and immobilized enzymes (Figure 4A-4). The STR is a waterjacketed glass vessel with an internal diameter of $4.0 \mathrm{~cm}$ (1.58 inch) and a height of $4.2 \mathrm{~cm}(1.65$ inch). Three symmetric baffles, each $0.6 \mathrm{~cm}(0.24 \mathrm{inch})$ wide, were attached to the inside of the reactor wall to ensure better mixing. A stainless steel flange with a rubber O-ring gasket was placed on the top to seal the reactor. A magnetic stirrer (Corning, PC-320) with a $2.54 \mathrm{~cm}$ (1 inch) Telfon-coated stir bar provided mixing at 60 to $1100 \mathrm{rpm}$ in the liquid-phase. The temperature of the reactor was controlled at $4^{\circ} \mathrm{C}\left(39^{\circ} \mathrm{F}\right)$ by circulating ice water through a thermostatic water bath (Neslab, RTE-110). Pure $\mathrm{CO}_{2}$ gas was supplied to the reactor from the gas cylinder and the pressure during the absorption was measured by a vacuum pressure transducer (Omegadyne, PX429-015AUSB) and recorded by a computer. A vacuum pump (Dekker, RVL002H-01) provided the initial vacuum prior to each experiment. In a typical manometric test, a free or immobilized enzyme sample at a desired dosage level was mixed with $15 \mathrm{ml}$ of a $0.1 \mathrm{M} \mathrm{Na}_{2} \mathrm{HPO}_{4}-\mathrm{NaH}_{2} \mathrm{PO}_{4}$ buffer solution ( $\mathrm{pH} 7.4$ ). The $\mathrm{CO}_{2}$ absorption experiments were performed at an initial $\mathrm{CO}_{2}$ partial pressure of $5.8 \mathrm{kPa}(0.84 \mathrm{psia}), 4^{\circ} \mathrm{C}\left(39^{\circ} \mathrm{F}\right)$, and 300 
rpm. The profile of the $\mathrm{CO}_{2}$ pressure change recorded during the test was used to estimate the instant rate of $\mathrm{CO}_{2}$ absorption according to the following equation:

$$
J=\frac{d P_{\mathrm{CO}_{2}, t}}{d t} \frac{V_{G}}{R T A}
$$

where $J$ is the $\mathrm{CO}_{2}$ flux into the liquid phase; $P_{\mathrm{CO} 2, \mathrm{t}}$ is the $\mathrm{CO}_{2}$ partial pressure; $t$ is time; $V_{\mathrm{G}}$ is the gas volume in the reactor; $R$ is the universal gas constant; $T$ is temperature; and $A$ is the gasliquid interface area. The $\mathrm{CO}_{2}$ partial pressure was obtained by subtracting the solution's water vapor pressure, which is constant during the experiment, from the total pressure. Under the experimental conditions employed, the impact of gas-phase diffusion is negligible, because the pressure of water vapor at $4^{\circ} \mathrm{C}\left(39^{\circ} \mathrm{F}\right)$ is much smaller than that of the $\mathrm{CO}_{2}$ employed. The instant rate of $\mathrm{CO}_{2}$ absorption into the solution was used as an indication of the $\mathrm{CO}_{2}$ hydration activity for either an immobilized or a free CA enzyme.

In this work, immobilization factor (IF), defined as a ratio of the activity of an immobilized CA to its free counterpart, was employed to compare the enzyme activity for different immobilized enzymes.

$$
I F=\frac{\text { Specific activity of immobilized enzyme }}{\text { Specific activity of free enzyme }}
$$

Relative activity (RA), defined as the ratio of the retained activity of an immobilized CA or free enzyme to its initial activity, was employed to compare stability (activity change over the time) for the immobilized and free enzymes.

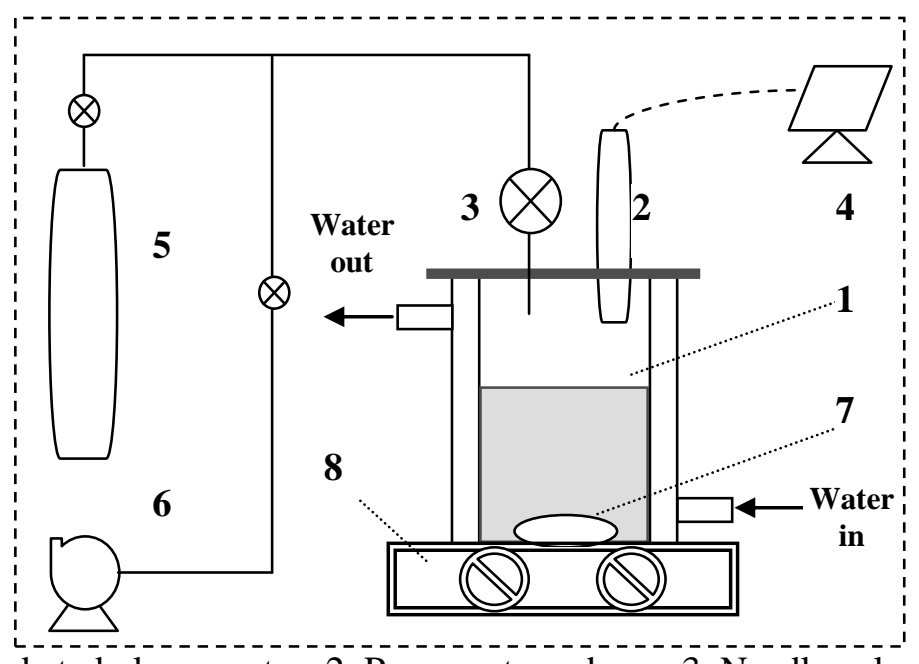

(1. Water-jacketed glass reactor; 2. Pressure transducer; 3 . Needle valve; 4. Computer;

5. $\mathrm{CO}_{2}$ cylinder; 6. Vacuum pump; 7. Stir bar; 8. Magnetic stirrer)

Figure 4A-4. Schematic diagram of a stirred tank reactor (STR) apparatus for $\mathrm{CO}_{2}$ absorption.

\section{A.2.8 Chemical and thermal stability assays}

The activities of the immobilized enzymes were measured periodically to assess their thermal stability during this period. Both the $p$-NPA and manometric assays were employed for these 
enzyme activity determinations. During the testing period, the immobilized enzymes were stored in a $30 \mathrm{mM} \mathrm{KHCO} 3-\mathrm{K}_{2} \mathrm{CO}_{3}$ buffer solution ( $\mathrm{pH} \mathrm{10)}$ at specified test temperatures. The stabilities of immobilized CA samples (SCA-CPG38, SCA-AC, ACA1-CPG38, ACA1-CPG100, and ACA1-AC) were tested at $50^{\circ} \mathrm{C}\left(122^{\circ} \mathrm{F}\right)$. The ACA1-CPG38 sample was also investigated for its stability at $60^{\circ} \mathrm{C}\left(140^{\circ} \mathrm{F}\right)$. The thermal stability of SCA-Eup was tested at $40^{\circ} \mathrm{C}\left(104^{\circ} \mathrm{F}\right)$. The SCA-CPG100 sample was tested for its stability at 40 and $50^{\circ} \mathrm{C}\left(104^{\circ} \mathrm{F}\right)$. The thermal stabilities of the two free enzymes were investigated under the same conditions and served as the baselines for the thermal stability tests.

The ACA1-CPG38 sample was further investigated for its stability with respect to the three chemical impurities (sulfate, nitrate, and chloride) that are typically found in the combustion flue gas from a high-sulfur coal. During the test, the immobilized ACA1-CPG38 enzyme was stored in a $30 \mathrm{mM} \mathrm{KHCO}{ }_{3}-\mathrm{K}_{2} \mathrm{CO}_{3}$ buffer solution ( $\mathrm{pH} \mathrm{10)} \mathrm{mixed} \mathrm{with} \mathrm{SO}_{4}{ }^{2-}(0.4 \mathrm{M}), \mathrm{NO}_{3}{ }^{-}(0.05 \mathrm{M})$, and $\mathrm{Cl}^{-}(0.3 \mathrm{M})$ anions at $50^{\circ} \mathrm{C}$. The activity of the ACA1-CPG38 was measured every 10 days for 30 days using the manometric assay. The activity of an ACA1-CPG38 sample held in the same buffer solution without the addition of any anion impurities was also assayed for comparison.

\section{A.3 Results and discussion}

\section{A.3.1 Optimization of enzyme immobilization onto CPG}

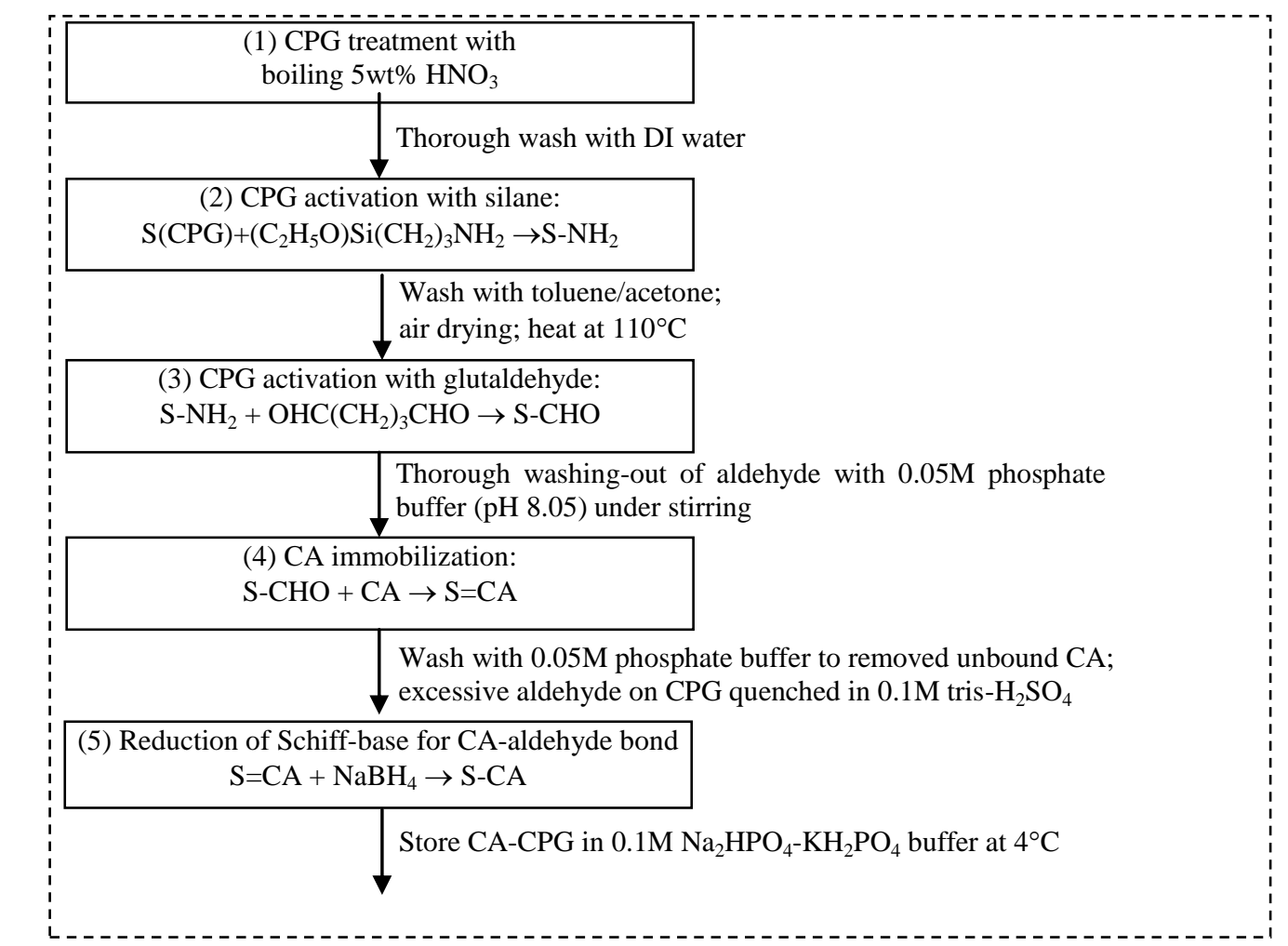

Figure 4A-5. Flow chart of the optimal procedure of enzyme immobilization on CPG support.

CPG100 and SCA were selected to optimize the immobilization condition onto CPG material. For the purposes of this optimization, the activities of the free and immobilized SCA enzyme 
were determined by the $p$-NPA assay. The optimal procedure of enzyme immobilization onto CPG materials in this study is shown in Figure 4A-5.

As shown in the figure, the $-\mathrm{NH}_{2}$ group formed during the activation of the CPG100 surface (containing silanol $\mathrm{Si}-\mathrm{OH}$ ) with the silane was further treated with glutaldehyde to introduce the - CHO group, by which SCA molecules could be immobilized via Schiff bond $(\mathrm{N}=\mathrm{CH})$. The $\mathrm{NH}_{2}$ group is an important intermediate for immobilization of the CA enzyme. Dissolving the silane in different solvents could impact the density of the $-\mathrm{NH}_{2}$ group formed during the silanization treatment of the CPG100 surface. A non-aqueous solvent, toluene, and an aqueous solvent, alcohol/water, were selected for this comparison. The results showed that the density of the surface $-\mathrm{NH}_{2}$ group formed in toluene was 10 times greater than that formed in the alcohol/water solvent, as shown in Table 4A-1. This is mainly because the siloxane group (Si-O$\mathrm{Si}$ ) formed from the silanization reaction between the silanol on the CPG100 surface and the silane reagent is hydrolyzed in the presence of water. The treated CPG100 with a higher surface $-\mathrm{NH}_{2}$ density can therefore be loaded with a larger amount of enzyme and this results in an SCA-CPG100 with a higher activity (on the basis of per unit mass of SCA-CPG100). Thus, the toluene was used as the solvent to dissolve silane agent during the surface activation step with the silane agent.

Table 4A-1. Density of the $-\mathrm{NH}_{2}$ group on silanized CPG100 and resulting SCA-CPG100 activity*

\begin{tabular}{|c|c|c|}
\hline Solvent used for silanizing treatment & $\begin{array}{c}-\mathrm{NH}_{2} \text { density } \\
(\mu \mathrm{mol} / \mathrm{g} \text { CPG100) }\end{array}$ & $\begin{array}{c}\text { Activity of immobilized CA } \\
(\mathrm{U} / \mathrm{g} \text { support)** }\end{array}$ \\
\hline Alcohol/water $(50: 50, \mathrm{v} / \mathrm{v})$ & 5.66 & 0.058 \\
\hline Toluene & 65.8 & 0.199 \\
\hline
\end{tabular}

* $10 \%$ ( $\gamma$-Aminopropyl) triethoxysilane ( $\gamma$-APTES) used as the silanizing reagent.

$* * 1 \mathrm{U}$ (enzyme activity unit) is defined in this table as the quantity of CA-support for $1 \mu \mathrm{mol} / \mathrm{min} p$-NPA conversion or $p$-NP production.

Figure 4A-6 shows the SEM images of the as-received CPG100 material (Figure 4A-6a and 6b), CPG100 activated with the silane agent $\gamma$-aminopropyl triethoxysilane (Figure 4A-6c and 6d), and the SCA-CPG100 (Figure 4A-6e and 6f). From the images, the untreated CPG100 surface was clean and smooth. The CPG100 matrix had a pore diameter of about $100 \mathrm{~nm}$ and its voids were strongly interconnected. After the CPG100 was activated by the silane agent, it was observed that the CPG100 surface was covered with a thick layer of the silane agent in some places, but not all (Figure 4A-6c and d), indicating that at some sites on the surface, the silane agent was not completely washed out and some residuals were deposited on the surface after drying. This observation suggested that a thorough washing with buffer solution after the silanization treatment was needed to reduce the presence of residual silanization reagent on the surface and improve the accessibility of CPG100 surface/porosity for enzyme immobilization. After attachment with the SCA enzyme, the CPG100 surface became rough and coarse with visible deposits at some surface sites (Figure 4A-6e and 6f). Such a change in morphology resulted either from the treatment of CPG100 (activation using a silane agent) and/or enzyme coupling reaction on the CPG100 surface (the CA enzyme is $\sim 6 \mathrm{~nm}$ in diameter).

Removing glutaldehyde residue thoroughly after the step of activation with the glutaldehyde also was important for successful enzyme immobilization. Results revealed that the activity of the SCA-CPG100 prepared with a thorough removal of glutaldehyde residue was $106 \mathrm{U} / \mathrm{g}$ SCA on 
support compared to $46.9 \mathrm{U} / \mathrm{g}$ SCA on support for the sample without a thorough washing. While the specific activity increased by more than two-fold, the SCA enzyme loading on the CPG100 with a thorough washing increased from 10.7 to $18.3 \mathrm{~g} \mathrm{CA} / \mathrm{g}$ support.
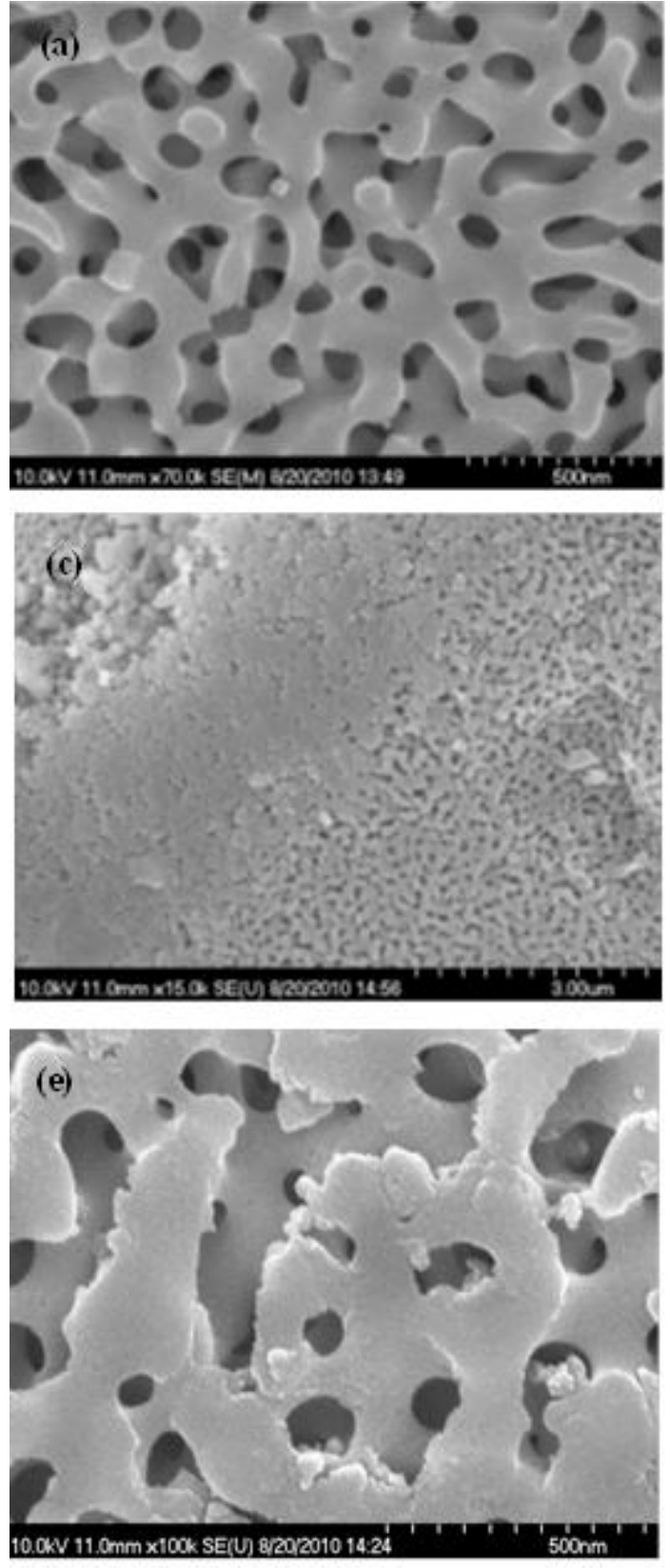
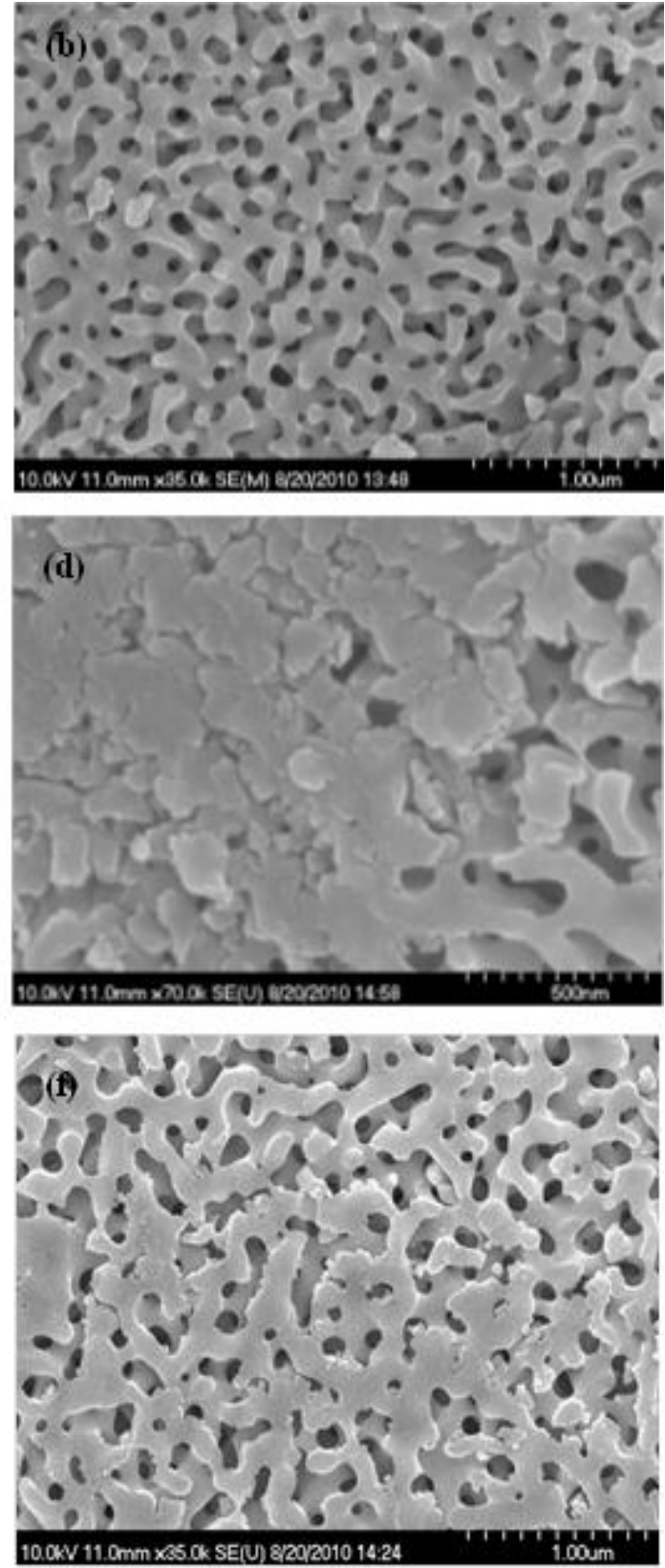

Figure 4A-6. SEM images of as-received CPG100 at magnifications of 70K (a) and 35K (b); CPG100 surface activated with silanizing reagent at magnifications of $15 \mathrm{~K}$ (c) and $70 \mathrm{~K}(\mathrm{~d})$; and CPG100 immobilized with SCA enzyme at magnifications of 100K (e) and 35K (f).

The resulting SCA-CPG100 can either be kept in a solution or air-dried for storage. Results indicated that the SCA-CPG100 prepared with air drying was less active than the samples kept in solution (Table 4A-2). The specific activity of the wet SCA-CPG100 reached 46.9 U/g CA compared to $9.06 \mathrm{U} / \mathrm{g}$ CA for the air-dried sample. Under the same measurement conditions, the specific activity of the free enzyme was $277 \mathrm{U} / \mathrm{g}$ CA. The immobilized enzyme tends to be less 
active compared to its dissolved form due to structure transformation of the enzyme during the immobilization and the presence of intra-particle diffusion resistance for the substrate. A comparison between the three SCA-CPG100 samples showed that the IF values of two CA samples prepared using the modified immobilization procedure increased 12 and 5 times, respectively, compared to the one prepared without a thorough washing and stored under airdried condition (0.383 and 0.169 vs. 0.033$)$.

Table 4A-2. Activity of SCA-CPG100 prepared using the modified method ${ }^{*}$

\begin{tabular}{|l|c|c|c|c|}
\hline & $\begin{array}{c}\text { Activity } \\
\text { (U/g SCA-CPG100, } \\
\text { dry basis) }\end{array}$ & $\begin{array}{c}\text { SCA loading on } \\
\text { dry CPG100 } \\
\text { (mg/g) }\end{array}$ & $\begin{array}{c}\text { Specific } \\
\text { activity } \\
\text { (U/g SCA) }\end{array}$ & IF \\
\hline SCA-CPG100 air-dried & 0.097 & 10.7 & 9.06 & 0.033 \\
\hline $\begin{array}{l}\text { SCA-CPG100 without air } \\
\text { drying }\end{array}$ & 0.438 & 10.7 & 46.9 & 0.169 \\
\hline $\begin{array}{l}\text { SCA-CPG100 with } \\
\text { aldehyde removal + } \\
\text { without air drying }\end{array}$ & 1.939 & 18.3 & 106 & 0.383 \\
\hline
\end{tabular}

* $1 \mathrm{U}$ (enzyme activity unit) is defined in this table as the quantity of CA or CA-CPG for $1 \mu \mathrm{mol} / \mathrm{min} p$ NPA conversion or $p$-NP production.

Crumbliss et al. ${ }^{[2]}$ reported that the apparent second-order rate constant for the hydrolysis of $p$ NPA catalyzed by a bovine CA immobilized on CPG beads was $2.6 \times 10^{2} \mathrm{M}^{-1} \mathrm{~s}^{-1}$ while that for the free CA enzyme was $9.1 \times 10^{2} \mathrm{M}^{-1} \mathrm{~s}^{-1}$. The IF value of the immobilized enzyme was thus estimated to be 0.286 , which was lower than the one acquired in this work (0.383). However, the enzyme loading in the literature reached $32.5 \mathrm{mg} / \mathrm{g} \mathrm{CPG}$, compared to $18.3 \mathrm{mg} / \mathrm{g}$ CPG in this work. It should also be noted that the CPG support in the literature was obtained from Pierce Chemical Company with aniline derivatives covalently attached to the silica surface. In this study, untreated CPG was purchased from Sigma-Aldrich and treated using silane to introduce $\mathrm{NH}_{2}$ groups. The difference of CA loading on support was also due to the difference of pore size between the two CPG materials. The CPG used by Crumbliss et al. ${ }^{[2]}$ had a smaller pore diameter as indicated from its higher surface area $\left(70 \mathrm{~m}^{2} / \mathrm{g}\right)$ compared to the CPG100 used in this study $\left(100 \mathrm{~nm}\right.$ and $\left.25 \mathrm{~m}^{2} / \mathrm{g}\right)$. It is therefore believed that a higher CA loading on CPG is possible if a smaller pore size is used. The effect of pore size on the enzyme loading and activity is further discussed in Section 4A.3.4.

Figure 4A-7 exhibits the impact of the $\mathrm{pH}$ of the coupling reaction between the SCA and CPG100 on the loading and activity of the immobilized SCA. Five SCA-CPG100 samples were prepared under different immobilization $\mathrm{pH}$ conditions. The enzyme activity measurement was conducted at the baseline condition $\left(\mathrm{pH} 8.05\right.$, room temperature, and $0.04 \mathrm{~g} / \mathrm{l}$ or $2.2 \times 10^{-4} \mathrm{M} p$ NPA substrate in mixture solution). The results showed that increasing the immobilization $\mathrm{pH}$ increased the SCA loading on the CPG100 and generally decreased the SCA activity. It is also noted that the SCA activity was the lowest at $\mathrm{pH} 6.5$, while the overall trend of the SCA loading was not disturbed. It is believed that the isoelectric point of SCA enzyme is close to $\mathrm{pH}$ 6.5. Below this $\mathrm{pH}$ value the protein tended to congregate. The congregated enzyme loaded on support was less active than the loaded enzyme well-dispersed. The activity of SCA-CPG100 in terms of activity per gram of CPG100 prepared at $\mathrm{pH} 8.0$ was the highest. Therefore, $\mathrm{pH} 8.0$ is 
believed to be optimal for SCA immobilization. Note that the specific activity of the free SCA was $277 \mathrm{U} / \mathrm{g}$ SCA under the same measurement condition.

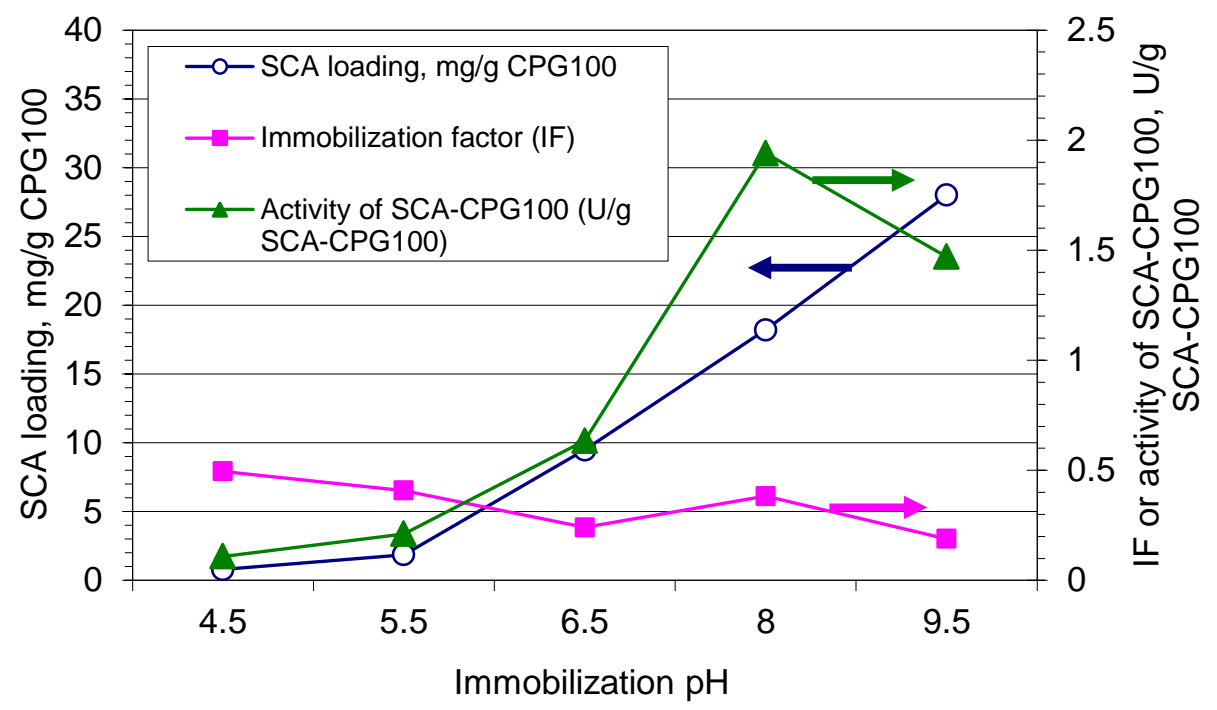

Figure 4A-7. Impact of immobilization pH on enzyme loading and activity of SCA-CPG100.

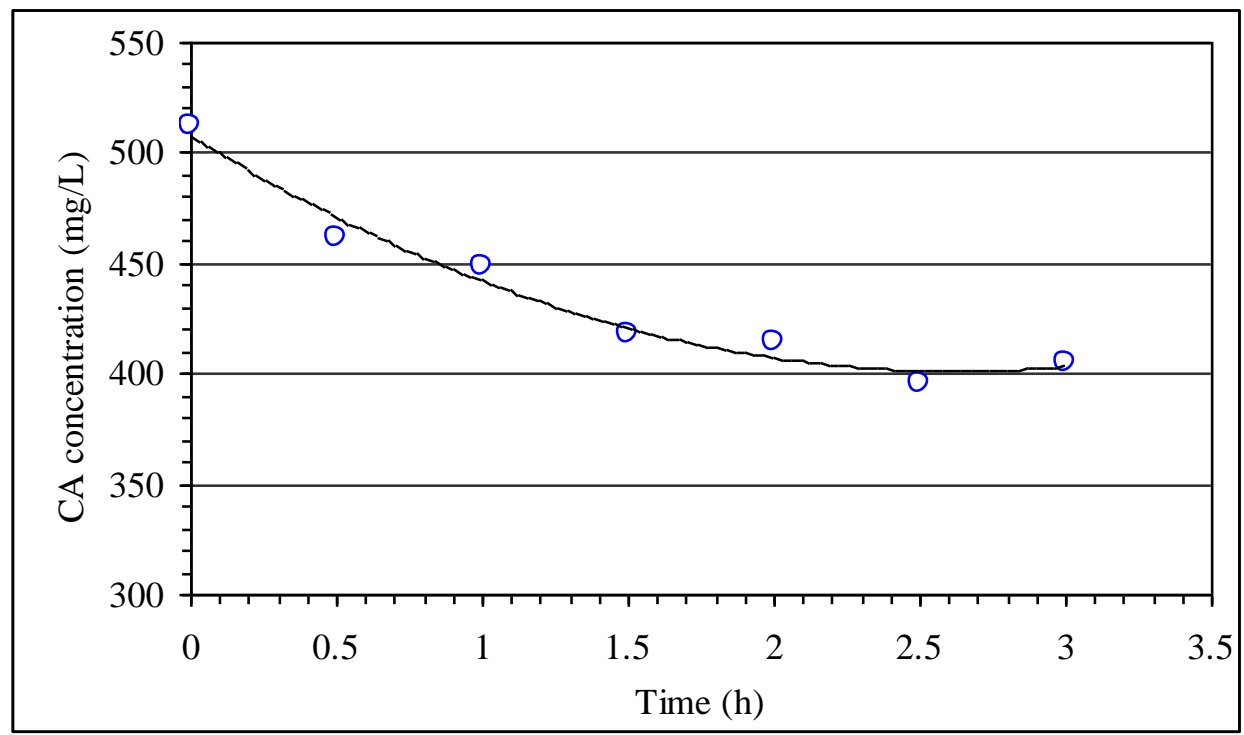

Figure 4A-8. Profile of the SCA enzyme concentration in the supernatant during the SCA and CPG100 coupling reaction at $\mathrm{pH} 8.0$ and room temperature.

The progress of the coupling reaction between the SCA enzyme and the CPG100 support was monitored by measuring the change of the SCA concentration in the supernatant over time (Figure 4A-8). During the coupling reaction, the activated CPG100 support with -CHO surface functional groups was suspended in the CA enzyme solution. It can be seen that the SCA enzyme concentration decreased in the first 2.5 hours. Afterward, it remained unchanged, indicating that 
the coupling reaction was completed in 2.5 hours. Thus, the enzyme immobilization time was set to 2.5 hours.

\section{A.3.2 Activity of SCA-CPG}

The SCA-CPG100 used in this section was prepared under the optimal condition, as described above. The $p$-NPA analysis was employed to determine the activity of SCA-CPG100. The impact of the stirring speed on the specific activity of the SCA-CPG100 for $p$-NPA hydrolysis is displayed in Figure 4A-9. With no stirring, a low activity was observed, because the apparent reaction rate was significantly limited by the mass transfer resistance in the bulk liquid. When the stirrer's speed control knob was turned to "slow" position, the specific activity rose greatly (from 22 to $110 \mathrm{U} / \mathrm{g} \mathrm{CA}$ ). It only slightly increased when the stirring speed was further adjusted from "slow" to "fast" position. A higher stirring speed resulted in a large vortex in the liquid center and the SCA-CPG100 particles concentrated at its bottom. Therefore, a mild stirring rate (the " 3 " position) was selected for measurements of the activity of the SCA-CPG100.

The $p$-NPA hydrolysis reaction was also studied at different dosage levels of the SCA-CPG100 (Table 4A-3). The concentration of the $p$-NP product during the hydrolysis reaction was determined by measuring the absorbance of the reacting solution at $400 \mathrm{~nm}$ wavelength. The changes of absorbance during the first 15 min was used to calculate the average rate of the hydrolysis reaction. The results showed that the rate of $p$-NPA hydrolysis increased proportionally with increasing dosage level of the SCA-CPG100, as shown in Table 4A-3. In accordance, the measured specific SCA activity was comparable between the different SCACPG100 dosages used. This indicates that the absorption of the $p$-NP product on the CPG100 surface is negligible during the hydrolysis reaction. It was thus confirmed that there was no impact of $p$-NP adsorption on the measurement of absorbance.

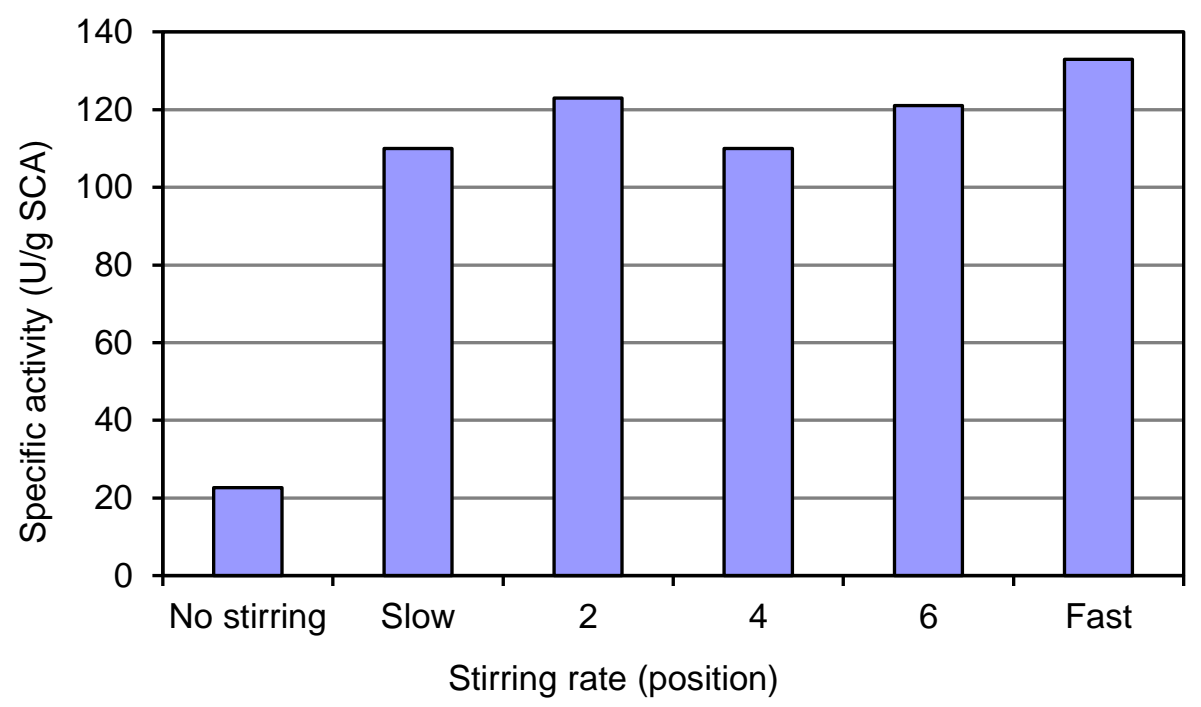

Figure 4A-9. Impact of stirring speed on the measurement of the SCA-CPG100 activity for $p$-NPA hydrolysis. 
Table 4A-3. Activities of SCA-CPG100 at different dosage levels for $p$-NPA hydrolysis

\begin{tabular}{|c|c|c|c|}
\hline $\begin{array}{c}\text { Dosage of SCA-CPG100 } \\
(\mathrm{mg} / \mathrm{ml})\end{array}$ & $\begin{array}{c}\text { Average formation rate } \\
\text { of } p \text {-NP }(\mu \mathrm{mol} / \mathrm{L} \cdot \mathrm{min})\end{array}$ & $\begin{array}{c}\text { Immobilized SCA } \\
\text { activity } \\
(\mathrm{U} / \mathrm{g} \text { support })\end{array}$ & $\begin{array}{c}\text { Specific activity } \\
(\mathrm{U} / \mathrm{g} \text { SCA on } \\
\text { support })\end{array}$ \\
\hline 3.5 & 0.696 & 0.199 & 6.19 \\
\hline 1.6 & 0.309 & 0.193 & 6.00 \\
\hline 0.7 & 0.135 & 0.195 & 6.06 \\
\hline
\end{tabular}

Figure 4A-10 displayed the relative $p$-NPA hydrolysis activities of the free SCA and SCACPG100 as a function of $\mathrm{pH}$ at room temperature. The relative activity (RA) is defined here as the ratio of the enzyme's activity at a specific $\mathrm{pH}$ to that at $\mathrm{pH} 7.85$. Therefore, the $\mathrm{RA}$ is $100 \%$ at $\mathrm{pH} 7.85$ both for the free SCA and SCA-CPG100 although their absolute activities at this $\mathrm{pH}$ were different. The RA of the SCA-CPG100 exhibited a similar trend to that of the free SCA at $\mathrm{pH} 6.0$ to 7.85; both increased substantially with increasing $\mathrm{pH}$. However, at $\mathrm{pH}$ higher than 7.85 , they displayed different trends of change with $\mathrm{pH}$. The RA of the SCA-CPG100 kept increasing (but not as rapidly) with increasing $\mathrm{pH}$, while that of the free SCA remained nearly constant. Since the $\mathrm{CO}_{2}$ absorption in the IVCAP operates at basic conditions, it is expected that the activity of the immobilized SCA will be more favorable than the free SCA at the high $\mathrm{pH}$ range of the IVCAP.

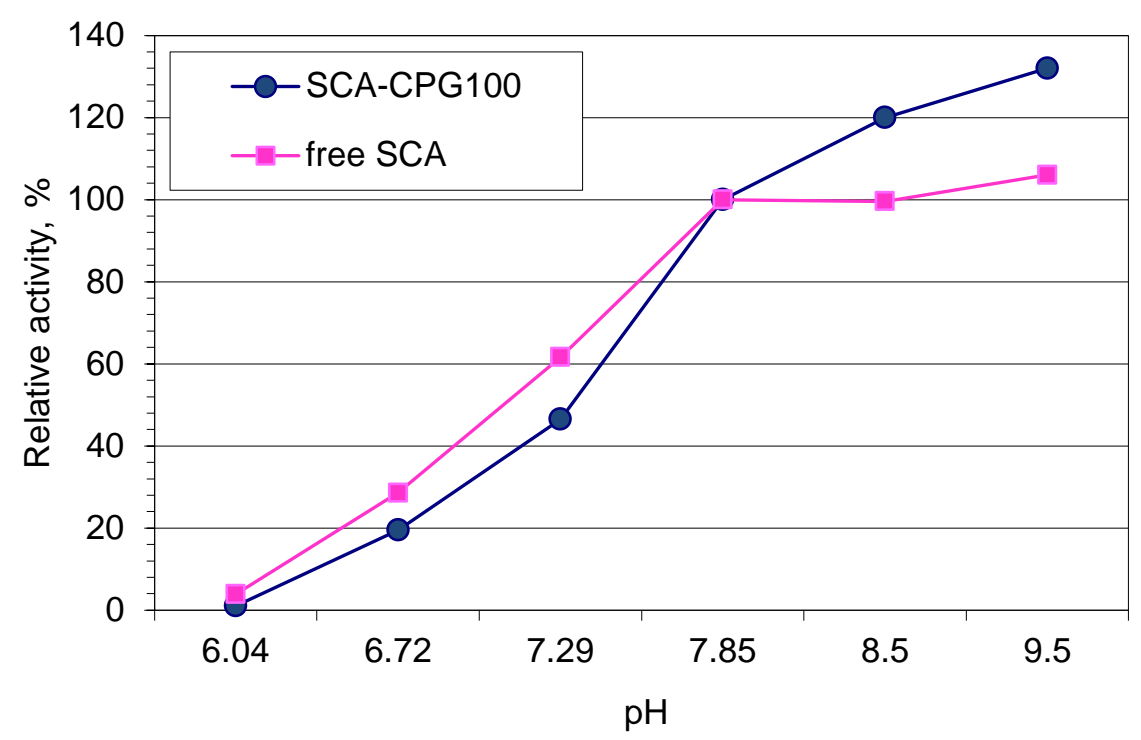

Figure 4A-10. Relative $p$-NPA hydrolysis activities of free SCA and SCA-CPG100 at room temperature under various $\mathrm{pH}$ conditions.

The temperature dependence of the RA of the free and immobilized SCA enzymes is shown in Figure 4A-11. A similar trend of the temperature dependence was observed for the free and the SCA-CPG100 at temperatures ranging from 7 to $50^{\circ} \mathrm{C}\left(44.6\right.$ to $\left.122^{\circ} \mathrm{F}\right)$. At temperatures below $40^{\circ} \mathrm{C}\left(104^{\circ} \mathrm{F}\right)$, the RA of the free and immobilized SCA both increased rapidly with an increase in temperature. However, at temperatures above $40^{\circ} \mathrm{C}\left(104^{\circ} \mathrm{F}\right)$, the change in RA with increasing temperature leveled off and barely varied with the temperature. The results also indicated that the relative activity of the SCA-CPG100 was slightly greater than the free SCA and, therefore, more resistant to higher temperatures. 


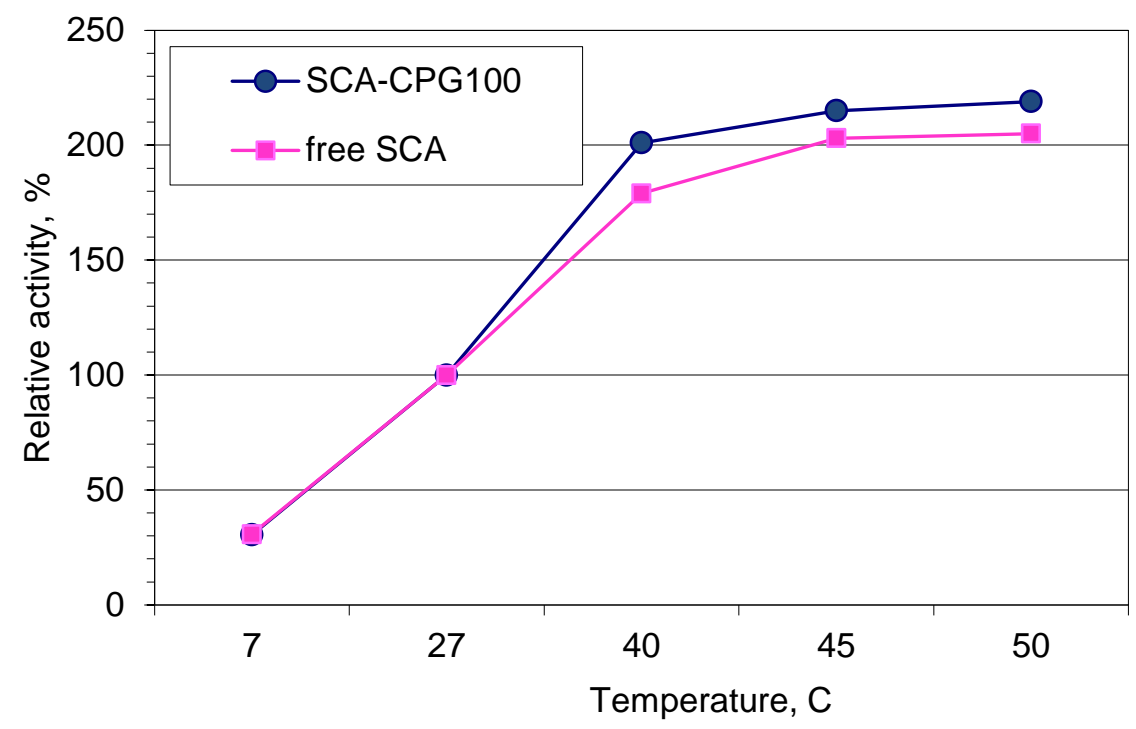

Figure 4A-11. Relative $p$-NPA hydrolysis activities of free SCA and SCA-CPG100 at pH7.85 and at various temperatures.

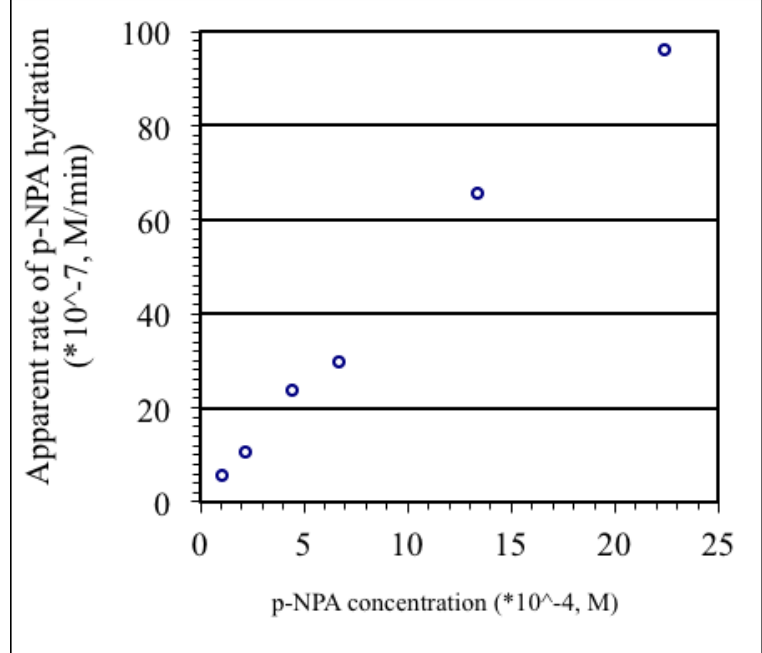

(a) Hydrolysis rate of p-NPA

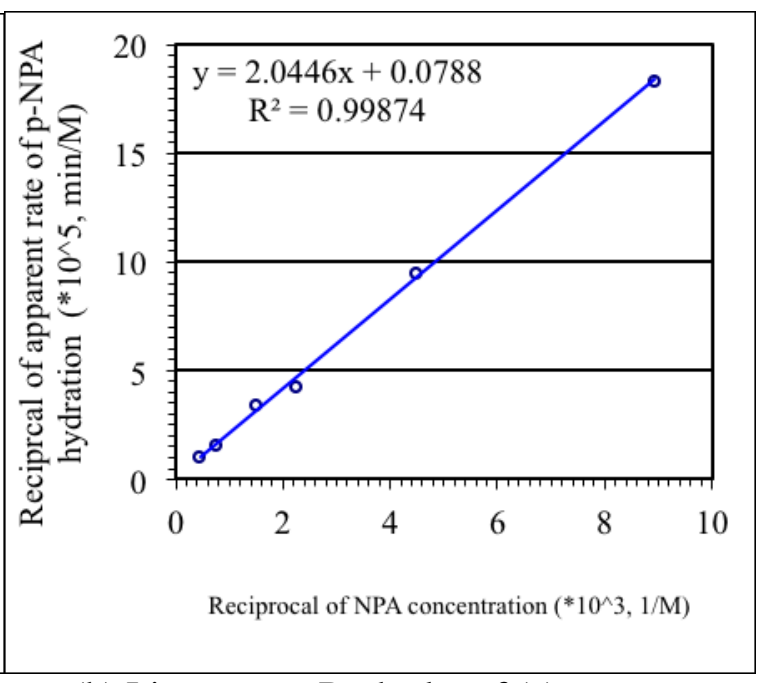

(b) Lineweaver-Burk plot of (a)

Figure 4A-12. Kinetics of $p$-NPA hydrolysis catalyzed by SCA-CPG100.

The $p$-NPA activity of the SCA-CPG100 at various substrate concentrations was measured to evaluate the kinetic parameters for the immobilized enzyme. The results in Figure 4A-12(a) exhibited that the rate of $p$-NPA hydrolysis catalyzed by the SCA-CPG100 increased almost linearly with increasing concentration of the $p$-NPA substrate. From the Lineweaver-Burk plot (Figure 4A-12(b)), the related Michaelis-Menten kinetic parameters were obtained. As shown in Table 4A-4, the enzyme's turnover number $\left(k_{\text {cat }}\right)$ to Michaelis constant $\left(K_{\mathrm{m}}\right)$ for the SCACPG100 were 61.7 and $223 \%$ of those of the free CA, respectively. It should be noted that the value of $1 / K_{\mathrm{m}}$ could be used to reflect the affinity of enzymes and substrate. A higher value of $K_{\mathrm{m}}$ of SCA-CPG100 was considered as an indication of a weaker enzyme affinity with the substrate, 
which may be due to the diffusion limitations in the pores of CPG100. The concentration of the $p$-NPA substrate used in the test was not greater than $2.5 \times 10^{-3} \mathrm{M}$, far less than $K_{\mathrm{m}}(25.9 \mathrm{mM})$. That explained why the relationship between the rate and the substrate concentration was nearly linear. In this case, higher $p$-NPA concentrations should not be employed in the measurement of the $p$-NPA hydrolysis rate, because otherwise the rate in the control solution (the hydrolysis rate without the enzyme) would be very high and the catalysis effect by the CA would thus be difficult to measure accurately.

Table 4A-4. Michaelis-Menten parameters of the free SCA and SCA-CPG100 for $p$-NPA hydrolysis

\begin{tabular}{|c|c|c|c|c|}
\hline & $\begin{array}{c}K_{m} \\
(\mathrm{mM})\end{array}$ & $\begin{array}{c}k_{c a t} \\
\left(\mathrm{~s}^{-1}\right)\end{array}$ & $\begin{array}{c}k_{c a t} / K_{m} \\
\left(\mathrm{M}^{-1} \mathrm{~s}^{-1}\right)\end{array}$ & Test conditions \\
\hline Free SCA & 11.6 & 6.9 & 595 & $\mathrm{pH} 8.0,25^{\circ} \mathrm{C}\left(77^{\circ} \mathrm{F}\right), 3.2 \times 10^{-7} \mathrm{M}$ free SCA \\
\hline SCA-CPG100 & 25.9 & 4.3 & 166 & $\mathrm{pH} 8.0,25^{\circ} \mathrm{C}\left(77^{\circ} \mathrm{F}\right), 4.9 \times 10^{-7} \mathrm{M}$ immobilized SCA \\
\hline
\end{tabular}

\section{A.3.3 Immobilization of SCA onto Eupergit support}

It has been reported that multipoint immobilization of enzymes, which may prevent subunit dissociation by inter-subunit cross-linking while simultaneously reducing conformational inactivation by intra-subunit crosslinking, exhibited a high thermal stability. ${ }^{[19]}$ Eupergit $\mathrm{C}$ is widely used as a support for multipoint-attachment enzyme immobilization. In order to compare the performance of the SCA when subjected to multi-point attachment, Eupergit C 250L, with the same pore size as the CPG100 support, was used. The material is a highly hydrophilic support with a water uptake capacity of $6 \mathrm{ml} / \mathrm{g}$ (dry). This polymer material bears greater than $200 \mu \mathrm{mol}$ epoxy group/g (dry). Due to the high density of oxirane groups on the surface of the beads, enzymes are immobilized at various sites of their structure. This "multipoint-attachment" may result in the high operational stability of enzymes bound to Eupergit $\mathrm{C}$.

A comparison of the enzyme loading and activity between the SCA-Eup and SCA-CPG100 is given in Table 4A-5. The spacer arm formed between the Eupergit C 250L and SCA is shorter than the one between the CPG100 and SCA. Since the SCA-CPG100 contains a longer methylene chain, it is more hydrophobic than SCA-Eup. However, the direct bond linking SCA to either of the two supports is the same. The $-\mathrm{NH}_{2}$ group on the surface of the SCA enzyme reacts with the aldehyde group on either support to form a Schiff-base. The enzyme loading of the SCA-Eup was $9.84 \mathrm{mg} / \mathrm{g}$ Eup, about $46.2 \%$ less than that of SCA-CPG100 (18.3 mg/g CPG100). The density of the functional group (epoxy group) of Eupergit $\mathrm{C}$ is 2 to 3 times greater than that of the silanol group of CPG100. The average pore size of CPG100 and Eupergit C was the same. The lower enzyme loading level found for the SCA-Eup could thus be related to the multipoint-attachment of the enzyme and the $\mathrm{IO}_{4}{ }^{-}$oxidation step. Both insufficient and excessive oxidation of the epoxy groups would produce a low-density aldehyde group. The aldehyde group provides the sites for enzyme bonding in the next step. The IF values for SCA-Eup and SCACPG100 were about equal. A comparison of thermal stability between SCA-Eup and SCACPG100 was carried out at $40^{\circ} \mathrm{C}\left(104^{\circ} \mathrm{F}\right)$ and $\mathrm{pH} 10$. As shown in Table 4A-6, the thermal stability of the SCA-Eup was slightly inferior to the SCA-CPG100. Based on activity, enzyme loading, thermal stability, and cost, the CPG100 is a better carrier for CA enzyme immobilization than Eupergit $\mathrm{C}$ for the IVCAP. 
Table 4A-5. Comparison of enzyme loading and activity between SCA-Eup and SCA-CPG100

\begin{tabular}{|l|c|c|c|}
\hline & $\begin{array}{c}\text { Enzyme loading on CPG100 } \\
\text { (mg CA/g support) }\end{array}$ & $\begin{array}{c}\text { Specific activity of SCA* } \\
\text { (U/g CA on support) }\end{array}$ & $\begin{array}{c}\text { Immobilization } \\
\text { factor, IF }\end{array}$ \\
\hline SCA-Eup & 9.84 & 104 & 0.375 \\
\hline SCA-CPG100 & 18.3 & 106 & 0.383 \\
\hline
\end{tabular}

* NPA hydrolysis activity.

Table 4A-6. Comparison of thermal stability between SCA-Eup and SCA-CPG100

\begin{tabular}{|c|c|c|}
\hline \multirow{2}{*}{ Time, day } & \multicolumn{2}{|c|}{ Relative activity } \\
\cline { 2 - 3 } & SCA-CPG100 & SCA-Eup \\
\hline 0 & $100 \%$ & $100 \%$ \\
\hline 7 & $37 \%$ & $35 \%$ \\
\hline
\end{tabular}

* NPA hydrolysis activity.

\section{A.3.4 Pore size of support material vs. loading and activity of immobilized CA}

Enzyme loading onto a support material depends on the pore size, pore volume, and specific surface area of the support material. As shown in Figure 4A-13, the activated carbon (AC) support is dominated by micropores $(<2 \mathrm{~nm}, 70 \%$ of total volume) and small mesopores (220nm, $20 \%$ of total volume), the CPG38 by mesopores, and the CPG100 by macropores. Results of the pore structure measurements are summarized in Table 4A-7. As expected, support materials with smaller pore size tended to have a larger surface area and pore volume. The average pore sizes are 3.8, 38.1 and $100 \mathrm{~nm}$ for the AC, CPG38 and CGP100 support materials, respectively. The average pore sizes of the CPG38 and AC materials were estimated based on the $\mathrm{BJH}$ method, which did not include the contributions from macropores and micropores. The pore size and surface area of the CPG100 were cited from the sample specification provided by Sigma-Aldrich, because the ASAP2020 instrument is not suitable for measuring the pore structure of macroporous materials.

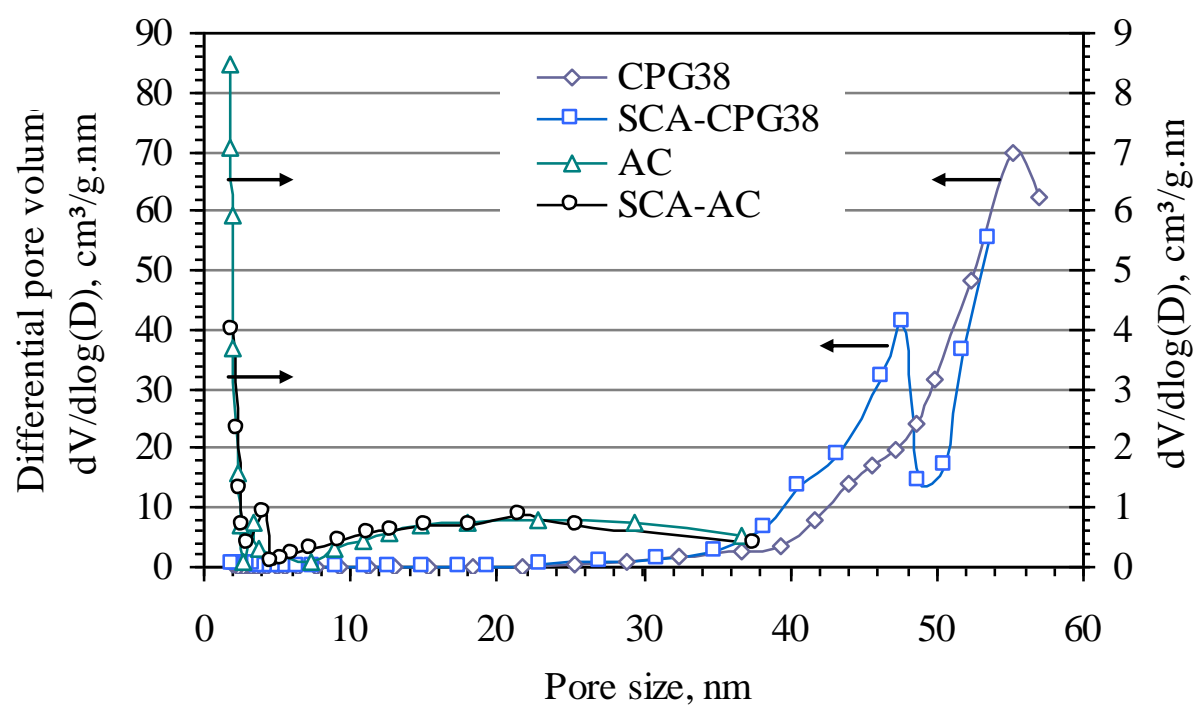

Figure 4A-13. Pore size distribution of AC and CPG38 before and after enzyme immobilization based on BJH method. 
As shown in Table 4A-8, the CA loading onto the AC was the lowest of all the immobilizing materials studied even though it had the highest BET surface area $\left(1,007 \mathrm{~m}^{2} / \mathrm{g}\right)$. The CPG38 that possessed larger pores exhibited a CA loading about three times greater than onto the AC. The CA loadings onto the SCA-CPG38 and SCA-AC samples were 32.6 and $10.7 \mathrm{mg} \mathrm{SCA} / \mathrm{g}$ support, respectively. After enzyme immobilization, the pore volume of the AC slightly decreased from 0.50 to $0.42 \mathrm{~cm}^{3} / \mathrm{g}$ and that of the CPG38 material decreased from 1.06 to $0.92 \mathrm{~cm}^{3} / \mathrm{g}$, as shown in Table 4A-7. It is well known that a CA molecule is nearly spherical with approximate dimensions of $5 \times 4 \times 4 \mathrm{~nm} .{ }^{[20]}$ In general, pores of a support material that are 3 to 9 times greater than the molecular diameter of an enzyme are most suitable for enzyme immobilization. ${ }^{[21]}$ It is thus likely that only pores greater than $20 \mathrm{~nm}$ in diameter were available for CA immobilization. Although the pore volume of the AC was the greatest of the three support materials tested, more than $90 \%$ of its pore volume was contributed by pores less than $20 \mathrm{~nm}$ in diameter, as shown in Figure 4A-13. As a result, the CA-AC exhibited the lowest CA loading. It was also observed for the $\mathrm{AC}$ that the total volume of pores less than $5 \mathrm{~nm}$ in diameter decreased after enzyme immobilization. This could be due to plugging of the small pores with CA molecules. Enzyme immobilization resulted in shifting the pore size distribution of the SCA-CPG38 material to a smaller size range. As shown in Table 4A-7, the CPG100 had the largest mean pore size (100 $\mathrm{nm}$ ) amongst the three support materials. However, the CA loading onto the CPG100 material was lower than that of the CPG38, because its pore volume $\left(0.79 \mathrm{~cm}^{3} / \mathrm{g}\right)$ and surface area $(22$ $\mathrm{m}^{2} / \mathrm{g}$ ) were relatively limited. It can also be seen from Table $4 \mathrm{~A}-8$ that there were only slight differences between the loadings of SCA and ACA1 onto the same support materials.

Table 4A-7 Pore structure of AC, CPG38, CPG100, SCA-AC and SCA-CPG38.

\begin{tabular}{|c|c|c|c|}
\hline Samples & Average pore size, $\mathrm{nm}$ & Surface area, $\mathrm{m}^{2} / \mathrm{g}$ & Total pore volume, $\mathrm{cm}^{3} / \mathrm{g}$ \\
\hline AC & 3.8 & 1007.0 & 0.50 \\
\hline CPG38 & 38.1 & 64.5 & 1.06 \\
\hline CPG100 & 100 & 21.8 & 0.79 \\
\hline SCA-AC & 4.8 & 889.8 & 0.42 \\
\hline SCA-CPG38 & 29.8 & 60.5 & 0.92 \\
\hline
\end{tabular}

*The average pore size and surface area are provided by Sigma-Aldrich.

Table 4A-8 Loadings and IFs of immobilized CA enzymes.

\begin{tabular}{|c|c|c|c|}
\hline Sample & $\begin{array}{l}\text { Enzyme loading } \\
\text { (mg CA/g support) }\end{array}$ & $\begin{array}{l}\text { Immobilization factor, } \\
\text { IF }\end{array}$ & CA activity assay \\
\hline \multirow{2}{*}{ SCA-CPG100 } & \multirow{2}{*}{18.3} & 0.383 & $p$-NPA hydrolysis \\
\hline & & 0.159 & Manometric \\
\hline \multirow{2}{*}{ SCA-CPG38 } & \multirow{2}{*}{32.6} & 0.351 & $p$-NPA hydrolysis \\
\hline & & 0.209 & Manometric \\
\hline SCA-AC & 10.7 & 0.229 & Manometric \\
\hline ACA1-CPG100 & 14.2 & 0.279 & Manometric \\
\hline ACA1-CPG38 & 27.1 & 0.345 & Manometric \\
\hline ACA1-AC & 9.6 & 0.217 & Manometric \\
\hline
\end{tabular}

Figure 4A-14 displays the LSCM images of the ACA1 enzyme on selected cross-sectional slices of the ACA1-CPG100, ACA1-CPG38, and ACA1-AC particles. These measurements suggested that the CA distribution inside a support particle depended on the pore size of the support 
material. For the mesoporous CPG38 and macroporous CPG100 particles, more CA molecules were distributed near the external surface (1/6 depth of the particles) than near the center $(1 / 2$ depth), although the differences between the different slices were not great. This observation indicated that CA molecules penetrated deeply inside the mesoporous and macroporous particles. For the AC particle, with its finer pores, the CA molecules were mainly seen near the external surface and hardly seen at all deeper inside the particle, which could be due to the limited accessibility for the $\mathrm{CA}$ into the small pores. Comparisons between the cross-sectional images of the different support materials also confirmed that the CA loading in the AC particle was much smaller than the CPG particles. This result is consistent with the pore structures and CA loading measurements described previously.

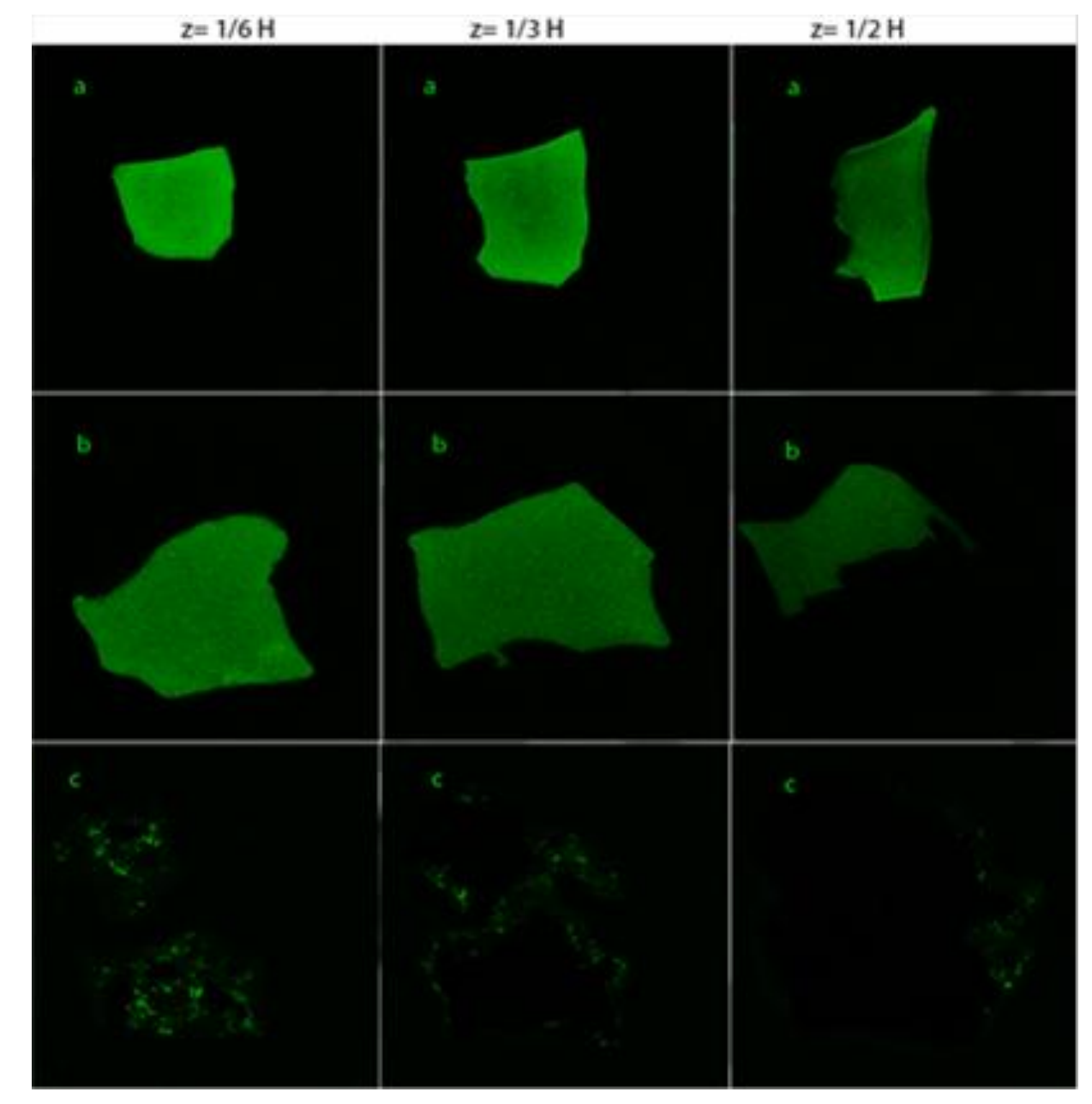

Figure 4A-14. LSCM images of selected X-Y slices taken along the Z-axis for the three immobilized enzymes: (a) ACA1-CPG38, (b) ACA1-CPG100, and (c) ACA1-AC.

$* \mathrm{H}$ is the depth of the immobilized enzyme particles along the $\mathrm{Z}$ axis.

Compared to the CA-CPG100, the CA-CPG38 had a higher IF value for $\mathrm{CO}_{2}$ hydration, as measured by the manometric method (see Table 4A-8). Such a trend is true for both the SCA and ACA1 enzymes. However, no such trend was observed for the activities of the CA-AC immobilized enzymes when compared to their CA-CPG counterparts. This may be due to the different enzyme immobilization methods used for the different support materials. It should be 
noted that the activity of the immobilized CA measured using the manometric method is not an intrinsic activity, because it includes an intra-particle diffusion resistance. For this reason, the IF of the CA-AC could become greater if the particle size of the AC were reduced to a size comparable to the $\mathrm{CPG}$.

The activity of the immobilized CA for catalyzing $p$-NPA hydrolysis was only measured for samples SCA-CPG100 and SCA-CPG38, because the as-received ACA1 possessed no $p$-NPA hydrolysis activity. The IF of an individual SCA-CPG sample based on $p$-NPA hydrolysis activity was higher than that based on $\mathrm{CO}_{2}$ hydration activity, as shown in Table 4A-8. It was expected that in the presence of the $\mathrm{CA}$ enzyme, the $\mathrm{CO}_{2}$ hydration reaction would be much faster than the $p$-NPA hydrolysis reaction. As a result, the diffusion of the $\mathrm{CO}_{2}$ substrate within the pore structure of a support particle becomes more important in the $\mathrm{CO}_{2}$ hydration system, resulting in a lower apparent CA activity being measured by the manometric method than by the p-NPA hydrolysis method.

Among the three support materials tested, the CPG38 achieved the highest CA loading and the CA immobilized onto this support retained the highest activity relative to its free counterpart. This indicates that a support material with abundant pores in the mesopore range should be better for CA immobilization. A mesoporous material provides pores large enough to be accessible for CA molecules and a large enough pore volume for a high CA loading during enzyme immobilization. The relatively large pores in the mesoporous support material also facilitate the transport of substrate and product during a catalytic reaction. ${ }^{[22]} \mathrm{A}$ similar study by Gomez et al. [23] showed that glucosidase immobilized onto a mesoporous silica material led to a high selectivity and activity for its enzymatic reactions.

\section{A.3.5 Thermal stability of immobilized $\mathrm{CA}$ for $\mathrm{CO}_{2}$ hydration}

The thermal stability results of the immobilized and free CA enzymes at $50^{\circ} \mathrm{C}\left(122^{\circ} \mathrm{F}\right)$ are shown in Figure 4A-15a. At $50^{\circ} \mathrm{C}\left(122^{\circ} \mathrm{F}\right)$, the free SCA retained 57 and $34 \%$ of its original activity for $\mathrm{CO}_{2}$ hydration after 30 and 90 days, respectively. The stability of the free ACA1 was similar to the free SCA. Compared to the two free CA enzymes, the thermal stabilities of all the immobilized enzymes for $\mathrm{CO}_{2}$ hydration were significantly improved. After 30 days at $50^{\circ} \mathrm{C}$ $\left(122^{\circ} \mathrm{F}\right)$, three of the immobilized enzymes (SCA-CPG100, ACA1-CPG100 and ACA1-CPG38) had not lost any activity. After 90 days at $50^{\circ} \mathrm{C}\left(122^{\circ} \mathrm{F}\right)$, the immobilized enzymes all retained at least $60 \%$ of their initial activities. In particular, the two CPG100-based immobilized enzymes appeared to be the most stable for $\mathrm{CO}_{2}$ hydration; both retained greater than $90 \%$ of their initial activities throughout the 90-day testing period. 

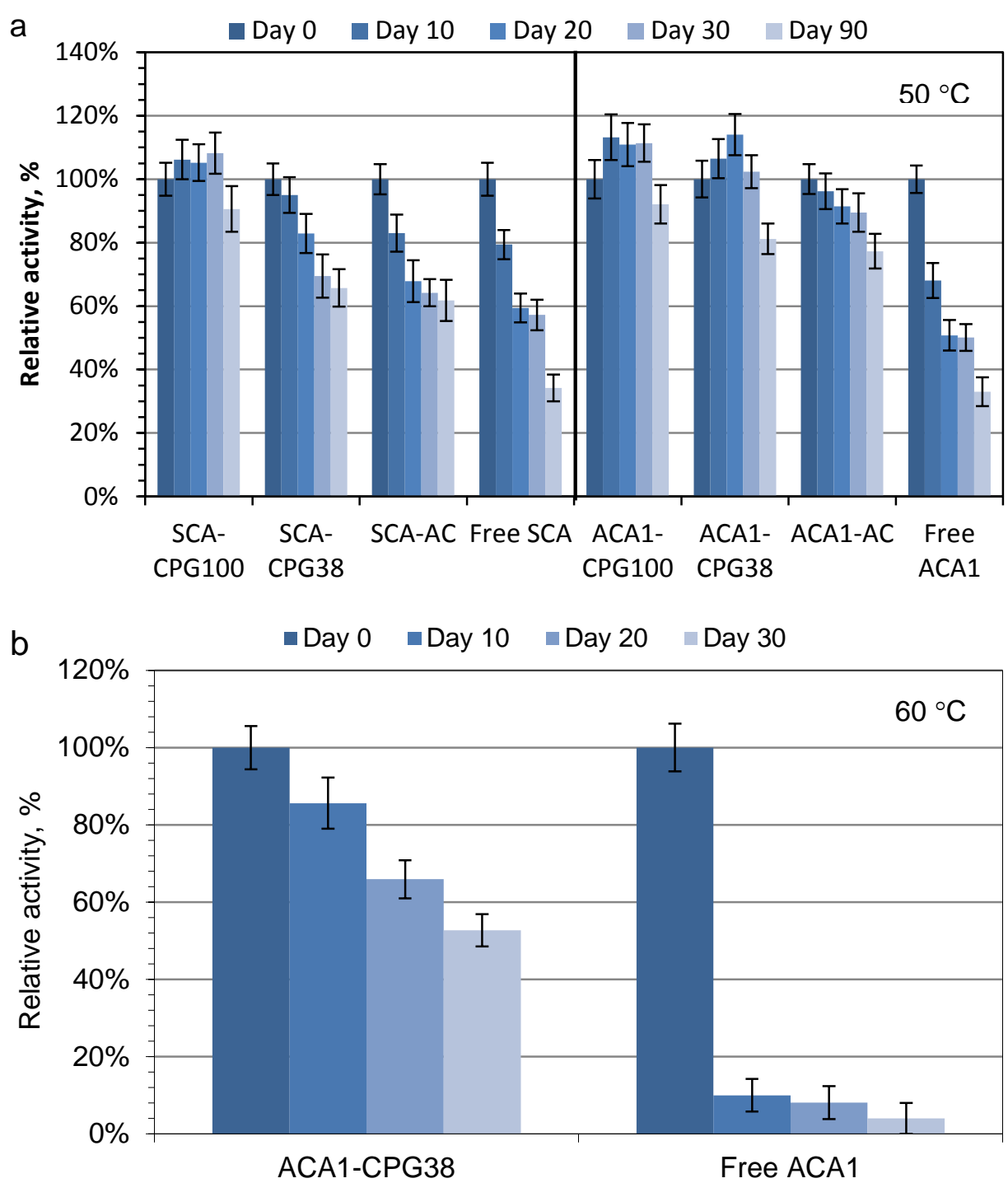

Figure 4A-15. Thermal stability of immobilized and free enzymes for $\mathrm{CO}_{2}$ hydration at (a) $50^{\circ} \mathrm{C}$ and (b) $60^{\circ} \mathrm{C}$.

It is interesting to note that the stability of the immobilized CA enzymes varied with the pore size of the support material. The average pore sizes are $100 \mathrm{~nm}$ for the CPG100 material, 38.1 $\mathrm{nm}$ for the CPG38 material, and $3.8 \mathrm{~nm}$ for the AC material. The stability of the immobilized CA slightly decreased from CA-CPG100 to CA-CPG38 and CA-AC. This decrease in thermal stability could be related to the distribution of the CA enzyme within the support particles, as shown in Figure 4A-14. The CA enzymes in the highly microporous AC support were mainly immobilized near the external surface and thus were not well protected from the environment by the particle. In contrast, the CA molecules were more evenly distributed in the macroporous (CPG100) and mesoporous (CPG38) particles, affording better protection against thermal, ionic, and shear stresses. 
Since the immobilized ACA1 samples exhibited good stability for $\mathrm{CO}_{2}$ hydration at $50^{\circ} \mathrm{C}\left(122^{\circ} \mathrm{F}\right.$, see Figure 4A-15a), the stability of sample ACA1-CPG38 also was investigated at $60^{\circ} \mathrm{C}\left(140^{\circ} \mathrm{F}\right)$. As described above, the ACA1-CPG38 had both the highest enzyme loading and IF value of all the immobilized enzyme samples. Results of the test at $60^{\circ} \mathrm{C}\left(140^{\circ} \mathrm{F}\right)$ showed a reduction in activity to 86,66 , and $53 \%$ of the initial $\mathrm{CO}_{2}$ hydration activity after 10, 20, and 30 days, respectively (see Figure 4A-15b). In comparison, the activity of the free ACA1 decreased rather rapidly, falling to just $4 \%$ of the original activity after 30 days at $60^{\circ} \mathrm{C}\left(140^{\circ} \mathrm{F}\right)$. Clearly, the thermal stabilities of the two CA enzymes were significantly improved by immobilization. In the IVCAP, the absorption column would operate at about 40 to $60^{\circ} \mathrm{C}\left(104\right.$ to $\left.140^{\circ} \mathrm{F}\right)$. The observed improvement in the thermal stability of the immobilized enzyme could result in a lower need for enzyme replenishment and more flexibility in operating temperatures for the IVCAP.

\section{A.3.6 Thermal stability based on p-NPA hydrolysis assay vs. $\mathrm{CO}_{2}$ hydration assay}

Since the $p$-NPA assay has been widely used in the literature, the thermal stability performances of the CA enzymes based on the $p$-NPA hydrolysis activity and $\mathrm{CO}_{2}$ hydration activity were compared. The $p$-NPA hydrolysis activity was measured only for the SCA enzyme samples, because the ACA1 enzyme sample exhibited no such activity. Results of the experiments showed that at $50^{\circ} \mathrm{C}\left(122^{\circ} \mathrm{F}\right)$, the activity of the free SCA for $p$-NPA hydrolysis decreased more rapidly than that for $\mathrm{CO}_{2}$ hydration over the same time period (see Figure 4A-16). Nevertheless, the $p$ NPA hydrolysis activity of the free SCA exhibited a high level of correlation with the $\mathrm{CO}_{2}$ hydration activity (R square of $>99 \%$ for the two groups of activity data shown in Figure 4A-16).

Surprisingly, the activity of the immobilized SCA for $p$-NPA hydrolysis at $50^{\circ} \mathrm{C}$ degraded more rapidly than that of the free SCA (see Figure 4A-16). For example, the SCA-CPG100 and SCACPG38 lost 88 and $67 \%$ of their initial activities after 30 days, respectively, whereas the free SCA lost only $63 \%$ of its initial activity over the same time period. The immobilized SCA was less stable for catalyzing $p$-NPA hydrolysis than the free SCA, indicating that the thermal stability of the CA activity for $p$-NPA hydrolysis actually decreased following enzyme immobilization.

A further comparison between the free SCA and SCA-CPG100 showed that the $\mathrm{CO}_{2}$ hydration activity of the free $\mathrm{SCA}$ rapidly degraded at $50^{\circ} \mathrm{C}\left(122^{\circ} \mathrm{F}\right)$ over the 90 day testing period, whereas no significant degradation in the hydration activity was observed for the SCA-CPG100, as shown in Figure 4A-15a. Such results reveal that the activity of the immobilized $\mathrm{CA}$ for $\mathrm{CO}_{2}$ hydration did not correlate to its activity for $p$-NPA hydrolysis. For the SCA-CPG100, the R square for the correlation between its $p$-NPA hydrolysis activity (data shown in Figure 4A-16) and $\mathrm{CO}_{2}$ hydration activity (data shown in Figure 4A-15a) was less than $13 \%$. One reason for this could be that the active sites of the CA enzyme are more sensitive to temperature for catalyzing $p$-NPA hydrolysis than for $\mathrm{CO}_{2}$ hydration, given that some degree of structure difference exists between the $p$-NPA and $\mathrm{CO}_{2}$ substrates. Another reason could be that after the CA was immobilized, the conformation of the enzyme's active site might slightly change because the molecular structure of the enzyme was affected by the additional chemical and physical forces aroused from the support material and the spacer arm. A small transformation of the active site could result in the observed changes in the activity and thermal sensitivity of the CA. Our results also indicate that the activity of an immobilized enzyme in applications for $\mathrm{CO}_{2}$ absorption should be determined 
using a $\mathrm{CO}_{2}$ hydration-based assay instead of the $p$-NPA assay that has been widely adopted in the literature.

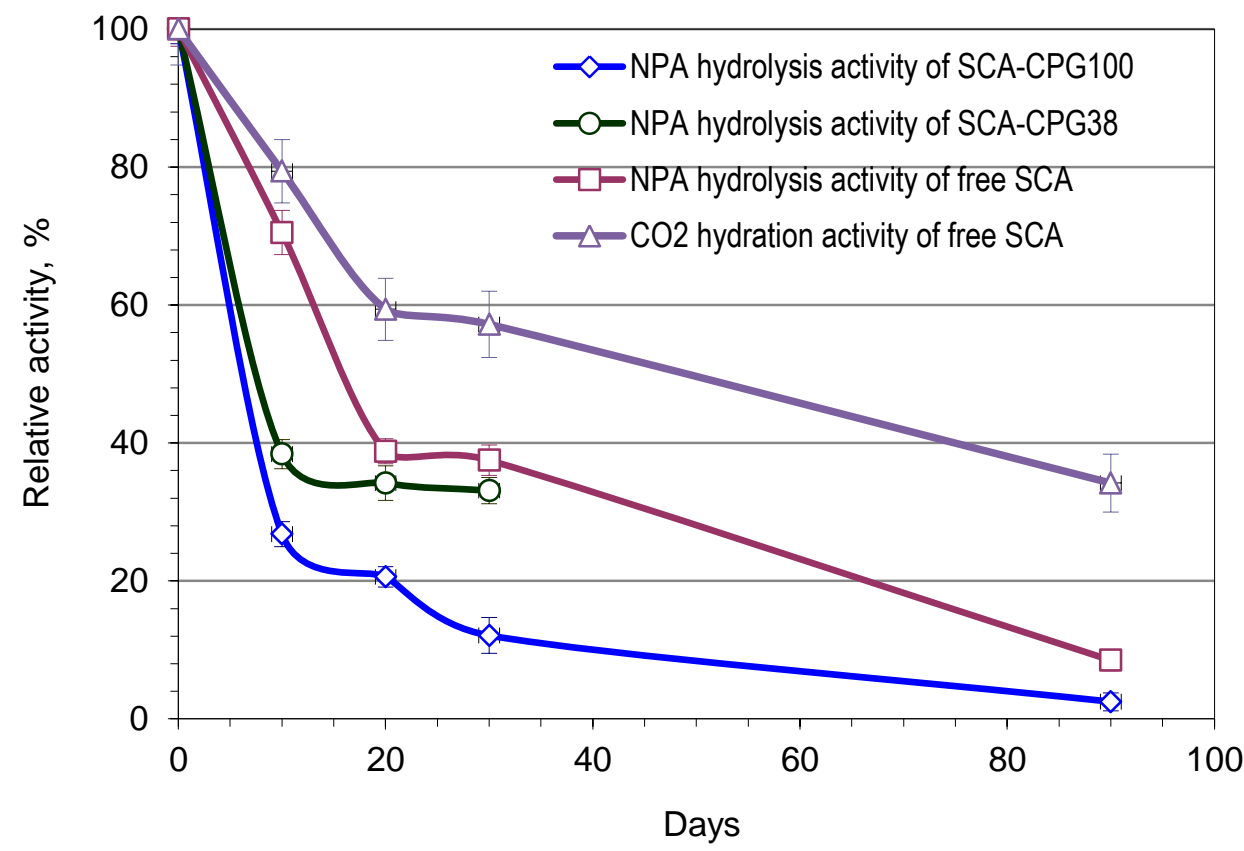

Figure 4A-16. Comparison between $\mathrm{CO}_{2}$ hydration and $p$-NPA activity for free SCA enzyme and comparison of $p$-NPA activity between free SCA, SCA-CPG100, and SCA-CPG38 over 90 days at $50^{\circ} \mathrm{C}$.

\section{A.3.7 Resistance to chemical impurities}

In a typical wet FGD blowdown stream, the concentrations of $\mathrm{SO}_{4}{ }^{2-}$ range from 0.03 to $0.05 \mathrm{M}$, of $\mathrm{NO}_{3}{ }^{-}$from 0.005 to $0.02 \mathrm{M}$, and of $\mathrm{Cl}^{-}$from 0.3 to $0.7 \mathrm{M}^{\left[{ }^{[24]}\right.}$ Concentration levels selected for this study were comparable to, or exceeded typical values reported for high-sulfur, high-chlorine coal. It has been reported that divalent anions, such as $\mathrm{SO}_{4}{ }^{2-}$, do not inhibit CA activity or only act as very weak inhibitors. ${ }^{[25]}$ It is also known that monovalent anions may inhibit CA activity, because they tend to bind to the $\mathrm{Zn}$ active site on the enzyme and prevent the formation of the coordinated $\mathrm{OH}^{-}$ion, which is an essential participant in the catalytic $\mathrm{CO}_{2}$ hydration. ${ }^{\text {[26] }}$ However, potential inhibition effects of these anions depend on many factors, such as the property of an individual CA enzyme and the solution conditions applied.

As shown in Table 4A-9, testing revealed no noticeable difference in the activity of the immobilized ACA1-CPG38 sample stored at $50^{\circ} \mathrm{C}\left(122^{\circ} \mathrm{F}\right)$ for 20 days in the solution with or without the addition of the three anions. In both cases, the activity of the ACA1-CPG38 was stable over the 20-day test period. It seems reasonable to conclude that the immobilized enzyme is largely unaffected by the presence of $0.4 \mathrm{M} \mathrm{SO}_{4}{ }^{2-}, 0.05 \mathrm{M} \mathrm{NO}_{3}{ }^{-}$, and $0.3 \mathrm{M} \mathrm{Cl}^{-}$anion impurities.

For comparison, the effect of the impurities on the free ACA1 enzyme was also investigated. In the presence of the $\mathrm{SO}_{4}{ }^{2-}, \mathrm{NO}_{3}{ }^{-}$, and $\mathrm{Cl}^{-}$anions, the free ACA1 retained only about $37 \%$ of its initial activity after 20 days at $50^{\circ} \mathrm{C}\left(122^{\circ} \mathrm{F}\right)$, whereas without the addition of the anion impurities 
the activity was still at $51 \%$ of the original level after 20 days at $50^{\circ} \mathrm{C} / 122^{\circ} \mathrm{F}$ (see Table $4 \mathrm{~A}-9$ ). Therefore, the activity loss of the free ACA1 increased by 39\% in the presence of the anions, indicating that immobilization improved the CA enzyme's chemical resistance to $\mathrm{SO}_{4}{ }^{2-}, \mathrm{NO}_{3}{ }^{-}$, and $\mathrm{Cl}^{-}$impurities.

Table 4A-9. Stability of immobilized and free $\mathrm{CA}$ in presence of $\mathrm{SO}_{4}{ }^{2-}, \mathrm{NO}_{3}{ }^{-}$, and $\mathrm{Cl}^{-}$anions at $50^{\circ} \mathrm{C}$

\begin{tabular}{|c|c|c|c|c|}
\hline \multirow{2}{*}{ Time, day } & \multicolumn{2}{|c|}{ Relative activity, with impurities } & \multicolumn{2}{c|}{ Relative activity, without impurities } \\
\cline { 2 - 5 } & ACA1-CPG38 & Free ACA1 & ACA1-CPG38 & Free ACA1 \\
\hline 0 & $100 \%$ & $100 \%$ & $100 \%$ & $100 \%$ \\
\hline 10 & $106 \%$ & $62 \%$ & $107 \%$ & $68 \%$ \\
\hline 20 & $102 \%$ & $37 \%$ & $114 \%$ & $51 \%$ \\
\hline
\end{tabular}

\section{A.3.8 $\mathrm{CO}_{2}$ absorption into carbonate solution promoted with immobilized $\mathrm{CA}$}

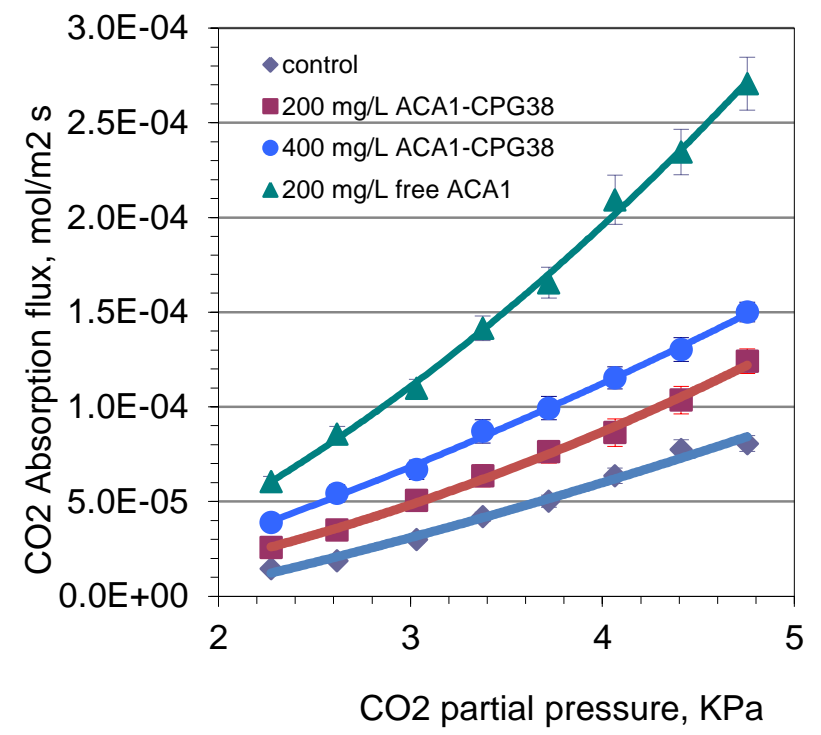

Figure 4A-17. Flux of $\mathrm{CO}_{2}$ absorption with and without $\mathrm{CA}$ enzymes at $50^{\circ} \mathrm{C}$.

The ACA1-CPG38, with the highest enzyme loading and IF, was selected for $\mathrm{CO}_{2}$ absorption experiments in a $30 \mathrm{mM}$ solution of $\mathrm{KHCO}_{3}-\mathrm{K}_{2} \mathrm{CO}_{3}(\mathrm{pH} 10.0)$. It was obvious from the results that the rate of $\mathrm{CO}_{2}$ absorption into the carbonate solution was significantly promoted by the addition of the immobilized ACA1. At $50^{\circ} \mathrm{C}\left(122^{\circ} \mathrm{F}\right)$, the rates of $\mathrm{CO}_{2}$ absorption into the solutions mixed with 200 and $400 \mathrm{mg} / \mathrm{l}$ ACA1-CPG38 were about 50 and 100\% greater, respectively, than the rate for the control solution without the addition of CA (see Figure 4A-17). At the same CA dosage $(200 \mathrm{mg} / \mathrm{L})$, the $\mathrm{CO}_{2}$ absorption rate increase with the ACA1-CGP38 ( $50 \%)$ compared to the control was only $20-30 \%$ of the rate increase provided by the free ACA1 ( 200-250\%). The ratio of the rate increase with the ACA1-CGP38 to that with the free ACA1 was slightly lower than, but consistent with, the IF value for ACA1-CPG38 given in Table 4A-8.

It should be noted that the comparison of the measured absorption rates into the carbonate solution promoted with the ACA1-CPG38 and into the control is only a qualitative indicator of 
the activity of the immobilized enzyme in the carbonate solution. Although the impact of gasphase diffusion was eliminated in the STR, the rate of $\mathrm{CO}_{2}$ absorption was impacted by both the intrinsic activity of the immobilized CA and the transport of the substrate as well as products in liquid bulk and intra-particle. Quantitative analyses on the intrinsic activity of the immobilized $\mathrm{CA}$ and the impact of liquid-bulk and intraparticle diffusion on that activity were investigated in Part 4B. However, the current work demonstrated that the immobilized CA enzyme effectively promoted the absorption of $\mathrm{CO}_{2}$ into the potassium carbonate solution, which is the solvent used in the IVCAP.

\section{A.4 Summary}

The covalent method for immobilization of the SCA enzyme onto the CPG100 support particle was optimized through several experiments. The $p$-NPA hydrolysis assay was used to measure and compare the activities of the free and immobilized SCA enzymes. The optimization studies showed that the glutaldehyde used in the immobilization process should be completely removed from the CPG100 after the activation, and the SCA-CPG100 product should be stored in solution instead of dry to preserve its activity. The activity of the SCA-CPG100 stored in solution was 5 times greater than its air-dried counterpart. The activity of the SCA-CPG100 prepared with thorough removal of glutaldehyde from the CPG and stored in solution was 12 times greater than the unmodified SCA sample. Enzyme loading increased, while its specific activity decreased, as the immobilization reaction was conducted at successively higher $\mathrm{pH}$ values. The $\mathrm{pH}$ value of 8.0 was identified to be optimal for achieving a maximum product of enzyme loading and specific activity.

The effects of stirring rate, dosage levels of the SCA-CPG100, $\mathrm{pH}$, and temperature on the activity of SCA-CPG100 were investigated. It was found that mild stirring was necessary during the activity assays. The dosage level of SCA-CPG100 had no influence on the activity of immobilized enzyme, which indicated that there was no impact of $p$-NP adsorption on the measurement of absorbance. Results also indicated that the activity of the SCA-CPG100 continued to increase with increasing $\mathrm{pH}$, while that of the free SCA leveled off at $\mathrm{pH}$ higher than 7.85. This indicated that the activity of the immobilized enzyme is favored at the high $\mathrm{pH}$ condition encountered in the IVCAP. The activity for both the free and immobilized SCA also increased with increasing temperature from 7 to $40^{\circ} \mathrm{C}\left(45\right.$ to $\left.104^{\circ} \mathrm{F}\right)$, and remained largely unchanged at temperatures from 40 to $50^{\circ} \mathrm{C}\left(104\right.$ to $\left.122^{\circ} \mathrm{F}\right)$. In general, the SCA-CPG showed slightly more resistance to high temperatures (higher than $40^{\circ} \mathrm{C} / 104^{\circ} \mathrm{F}$ ) than the free $\mathrm{SCA}$. Compared to the free SCA, the Michaelis-Menten kinetic parameter $k_{c a t}$ for the immobilized SCA decreased from 6.9 to $4.3 \mathrm{~s}^{-1}$, and $K_{m}$ increased from 11.6 to $25.9 \mathrm{mM}$ for $p$-NPA hydrolysis.

The SCA enzyme was also successfully immobilized onto the Eupergit C 250L support and the activity, enzyme loading, and stability of SCA-CPG100 and SCA-Eup were compared. Although the measured IF values were 0.375 and 0.383 for the SCA-Eup and SCA-CPG100, respectively, the enzyme loading of the SCA-Eup was only $9.84 \mathrm{mg} / \mathrm{g}$ Eup, about $46.2 \%$ less than the loading of the SCA-CPG100 (18.2 mg/g CPG100). The SCA-CPG100 immobilized enzyme exhibited a better thermal stability at $40^{\circ} \mathrm{C}\left(104^{\circ} \mathrm{F}\right)$ than the SCA-Eup enzyme. Overall, CPG100 was found to be a better carrier for SCA enzyme than Eupergit $\mathrm{C}$. 
ACA1, manufactured by a leading enzyme maker in a pilot-scale reactor, had no activity for $p$ NPA hydrolysis. Thus, a manometric method was developed to measure the activities of immobilized and free ACA enzymes for $\mathrm{CO}_{2}$ hydration. The SCA and ACA1 enzymes were immobilized onto the three support materials (CPG100 and CPG38 porous glass, and activated carbon- AC) in order to explore the effect of carrier pore size on activity and enzyme loading. The CPG38 carrier achieved the highest level of CA loading $(32.6 \mathrm{mg} \mathrm{SCA} / \mathrm{g}$ and $27.1 \mathrm{mg}$ ACA1/g), followed by the CPG100 glass and AC. The immobilized samples all exhibited high activities for $\mathrm{CO}_{2}$ hydration (IF higher than 0.2 for all the samples). Among the three support materials, the CAs immobilized on the CPG38 support exhibited the highest activity for $\mathrm{CO}_{2}$ hydration (IF= 0.209 for SCA-CPG38 and 0.345 for ACA1-CPG38). The distribution of the immobilized enzyme on the three micron-sized porous support materials was visually mapped using Laser Scanning Confocal Microscopy. The LSCM technique showed that the CA molecules penetrated deeply inside the mesoporous and macroporous CPG particles. For the AC particles, with their much finer pore size distribution, the CA molecules were mainly seen near the external surface and hardly seen at all deeper inside the particles. The LSCM results were consistent with the observed differences in loading and activity of the immobilized enzymes on the three support materials.

The six immobilized CA enzymes (SCA-CPG38, SCA-CPG100, SCA-AC, ACA1-CPG38, ACA1-CPG100, and ACA1-AC) developed in this study exhibited significantly greater thermal stability for $\mathrm{CO}_{2}$ hydration at 50 and $60^{\circ} \mathrm{C}\left(122\right.$ to $\left.140^{\circ} \mathrm{F}\right)$ than their free counterparts. The immobilized enzymes retained 62 to $92 \%$ of their initial activities at $50^{\circ} \mathrm{C}\left(122^{\circ} \mathrm{F}\right)$ after 90 days, compared to about $33 \%$ activity retention for their free counterparts. The ACA1-CPG38 retained $53 \%$ of its initial activity after 30 days at $60^{\circ} \mathrm{C}\left(122^{\circ} \mathrm{F}\right)$, whereas the free ACA1 enzyme was almost completely deactivated over the same period.

To investigate the stability of the immobilized enzymes when exposed to concentrations of $\mathrm{SO}_{4}{ }^{2-}, \mathrm{NO}_{3}{ }^{-}$and $\mathrm{Cl}^{-}$typically found in flue gas desulfurization fluids, samples of the ACA1CPG38 enzyme and its free counterpart both were stored for 20 days in solutions that contained and did not contain the anions. Little difference was observed in the activity of the immobilized enzyme stored in the two solutions over the test period. The immobilized enzyme, therefore, was stable in the presence of these anions at the concentration levels typical for, or higher than, those in a scrubbing liquid. In comparison, the activity of the free enzyme was inhibited by these impurities, further indicating that the immobilization improved the enzyme's resistance to the impurities. Overall, the results from the enzyme immobilization studies and the initial stability tests indicated that the immobilization methods developed in this study can effectively improve stability of CA enzymes for $\mathrm{CO}_{2}$ hydration in the IVCAP.

Our studies showed that the $p$-NPA hydrolysis assay, which is widely used for determining the activity of $\mathrm{CA}$ enzymes in $\mathrm{CO}_{2}$ absorption applications, is less accurate for immobilized enzymes than direct manometric measurement of the rate of $\mathrm{CO}_{2}$ absorption. Although a good correlation was found between the $p$-NPA hydrolysis activity and the $\mathrm{CO}_{2}$ hydration activity for the free SCA enzyme, such a correlation was not obtained for the immobilized CA enzymes. The $\mathrm{CO}_{2}$ hydration activity of the immobilized enzymes decreased much more slowly than their $p$-NPA hydrolysis activity over the same test period under typical IVCAP operating conditions. Such 
results indicate that the activity of an immobilized enzyme to be used for $\mathrm{CO}_{2}$ absorption needs to be evaluated using a $\mathrm{CO}_{2}$ hydration-based assay instead of the $p$-NPA assay.

\section{References}

1. Kernohan J.C. pH-activity curve of bovine carbonic anhydrase and its relationship to inhibition of enzyme by anions. Biochimica et Biophysica Acta, 1965, 96:304-317.

2. Crumbliss A.L., Mclachlan K.L., Odaly J.P., Henkens R.W. Preparation and activity of carbonic anhydrase immobilized on porous silica beads and graphite rods. Biotechnology and Bioengineering, 1988, 31:796-801.

3. Bhattacharya S., Nayak A., Schiavone M., Bhattacharya S.K. Solubilization and concentration of carbon dioxide: Novel spray reactors with immobilized carbonic anhydrase. Biotechnology and Bioenginering, 2004, 86: 37-46.

4. Drevon G.F., Urbanke C., Russell A.J. Enzyme-containing Michael-adduct-based coatings. Biomacromolecules, 2003, 4:675-682.

5. Ozdemir E. Biomimetic $\mathrm{CO}_{2}$ sequestration: 1. Immobilization of carbonic anhydrase within polyurethane foam. Energy Fuels, 2009, 23:5725-5730.

6. Azari F., Nemat-Gorgani M. Reversible denaturation of carbonic anhydrase provides a method for its adsorptive immobilization. Biotechnology and Bioengineering, 1999, 62:193-199.

7. Bhattacharya S., Schiavone M., Chakrabarti S., Bhattacharya S.K. $\mathrm{CO}_{2}$ hydration by immobilized carbonic anhydrase. Biotechnology and Applied Biochemistry, 2003, 38: 111-117.

8. Badjic J.D., Kostic N.M. Effects of encapsulation in sol-gel silica glass on esterase activity, conformational stability, and unfolding of bovine carbonic anhydrase II. Chemical Materials, 1999, 11: 3671-3679.

9. Bao L., Trachtenberg M.C. Facilitated transport of $\mathrm{CO}_{2}$ across a liquid membrane: Comparing enzyme, amine, and alkaline. Journal of Membrane Science, 2006, 280: 330-334.

10. Blais R., Peter R. 2003. Process and apparatus for the treatment of carbon dioxide with carbonic anhydrase, US Patent No. 6524843.

11. Weetall H.H., Lee M.J. Antibodies immobilized on inorganic supports. Applied Biochemistry and Biotechnology, 1989, 22: 311-330.

12. Cuatreca. P Parikh I. Adsorbents for affinity chromatography-use of N-hydroxysuccinimide esters of agarose, Biochemistry, 1972, 11: 2291-2299.

13. Ohlson S., Hansson L., Larsson P.O., Mosbach K. High-performance liquid affinity chromatography (Hplac) and its application to separation of enzymes and antigens. FEBS Letters, 1978, 93:5-9.

14. Shaw S.E., Russo T., Solomon D.H., Qiao G.G. An alternative pathway for the hydrolysis of epoxy ester compounds. Polymer, 2006, 47:8247-8252.

15. Lee C.C.Y., Loudon. G.M. Quantitative Determination of Amino Groups on Derivatized Controlled Pore Glass: A Comparison of Methods. Analytical Biochemistry, 1979, 94:60-64. 
16. Bradford M.M. Rapid and sensitive method for quantitation of microgram quantities of protein utilizing principle of protein-dye binding. Analytical Biochemistry, 1976, 72:248-254.

17. Pocker Y., Stone J.T. Catalytic versatility of erythrocyte carbonic anhydrase .3. kinetic studies of enzyme-catalyzed hydrolysis of p-nitrophenyl acetate. Biochemistry, 1967, 6:668-678.

18. Roughton F.J.W., Booth V.H. The manometric determination of the activity of carbonic anhydrase under varied conditions. Biochemical Journal, 1946, 40:309-319.

19. Iyer P.V., Ananthanarayan, L. 2008. Enzyme stability and stabilization-Aqueous and nonaqueous environment. Process Biochemistry, 43, 1019-1032.

20. Lindskog S. Structure and mechanism of carbonic anhydrase. Pharmacological Thermodynamics, 1997, 74:1-20.

21. Cao L. 2006. Carrier-bound immobilized enzymes: principles, applications and design, Wiley, New York.

22. Chong A.S.M., Zhao X.S. Design of large-pore mesoporous materials for immobilization of penicillin G acylase biocatalyst. Catalysis Today, 2004, 93-5, 293-299.

23. Gomez J.M., Romero M.D., Fernandez T.M., Garcia S. Immobilization and enzymatic activity of beta-glucosidase on mesoporous SBA-15 silica. Journal of Porous Materials, 2010, 17, 657-662.

24. Pudvay M., Operating experience on the treatment on FGD scrubber blowdown from existing generating stations. http://www.degremont-technologies.com/, as of May 26, 2011.

25. Simonsson I., Lindskog S. The interaction of sulfate with carbonic anhydrase. European Journal of Biochemistry, 1982, 123:29-36.

26. Bertini I., Luchinat C. Cobalt(ii) as a probe of the structure and function of carbonicanhydrase. Accounts of Chemical Research, 1983, 16: 272-279. 


\section{PART 4B. CA ENZYME IMMOBILIZATION ONTO NON-POROUS NANOPARTICLES}

\section{B.1 Introduction}

Enzyme immobilization can improve the stability of the enzyme and inhibit denaturation by heat, chemical impurities, or autolysis. Immobilized enzymes also exhibit improved performance under harsh conditions, such as high $\mathrm{pH}$ and ionic strength, as compared with free enzymes. ${ }^{[1,2]}$ In this study, a covalent binding method, which is the most effective in terms of thermal stabilization, ${ }^{[3]}$ was employed for CA enzyme immobilization. In the work described in Part 4A, porous materials that provided a high surface area were used as carriers for enzyme immobilization. The CA enzyme was immobilized onto three micron-size porous materials - a macroporous Controlled Pore Glass (CPG), a mesoporous CPG, and a micro/mesoporous Activated Carbon (AC) support material. The obtained immobilized CA enzymes exhibited improved thermal and chemical stability, but lower enzyme activity compared with their free counterparts. Immobilized enzymes using porous materials as carriers always suffer a great intraparticle diffusion limitation, which results in much lower activity. Improvements of biocatalytic efficiency can be achieved by manipulating the structure of carrier materials used for enzyme immobilization ${ }^{[4]}$.

Enzymes which are attached to the surfaces of nonporous materials are subject to minimal intraparticle diffusion effects, but enzyme loading per unit mass of support material generally is low. Reducing the particle size of the enzyme-carrier materials commonly can improve the efficiency of immobilized enzymes ${ }^{[4]}$. In the case of surface attachment, smaller particles can provide a larger surface area for the attachment of enzymes, leading to higher enzyme loading per unit mass of particles. Recently, a growing interest has been shown in using nanoparticles as carriers for enzyme immobilization. Nonporous nanosized (less than $100 \mathrm{~nm}$ ) support/carrier particles offer a large external surface area and incur a minimal intra-particle diffusion impact. These factors improve CA enzyme loading on the support, while maintaining a high overall activity (including mass transfer impact) of the immobilized enzyme. ${ }^{[5]}$

In the studies reported here, silica-based nanoparticles were employed for enzyme immobilization due to their excellent bio-compatibility and hydrophilicity. If necessary, this material can be further tailored to possess desired surface properties. A liquid-fed flame spray pyrolysis (FSP) technique was employed for the synthesis of the nanoparticles. The FSP technology is easy to scale-up, suitable for massive production of materials, and is waste-free. ${ }^{[6]}$ It also offers controllable particle size and controllable product composition at low cost. Three silica nanoparticles with different sizes, two silica- $\mathrm{Fe}_{2} \mathrm{O}_{3}$ composite nanoparticles with different ratios of silica-to- $\mathrm{Fe}_{2} \mathrm{O}_{3}$, and two silica-zirconia composite nanoparticles with different ratios of silica-to-zirconia were synthesized via the FSP technique. The physical properties of the silicabased nanoparticles were characterized by X-ray diffraction (XRD), Fourier Transform Infrared (FTIR) analysis, and a Micromeritics surface-area analyzer. A commercially-available bovine CA enzyme (SCA) was employed to explore the optimal enzyme immobilization condition, such as $\mathrm{pH}$, initial CA enzyme concentration, and immobilization time. The effect of $\mathrm{pH}$ and temperature on the immobilized SCA enzyme's activity was also investigated. The thermal stability and resistance to chemical impurities of the immobilized SCA and of another CA 
enzyme (ACA1) were investigated for about one month under the temperature and solution conditions expected in the IVCAP. A classic Danckwerts absorption theory with reaction was developed to estimate intrinsic kinetic parameters of the free and immobilized enzymes.

\section{B.2 Experimental methods}

\section{B.2.1 Materials}

A leading enzyme manufacturer supplied a technical-grade CA enzyme (ACA1). The bovine CA enzyme (SCA) used as a reference material was purchased from Sigma-Aldrich Co. The following chemicals also were purchased from Sigma-Aldrich Co.: $\gamma$-Aminopropyl triethoxysilane $(\geq 98 \%)$; glutaraldehyde solution $(25 \%$, w/w); Tetraethylorthosilicate (TEOS, $99 \%$ ), Zirconyl 2-ethylhexanoate in mineral spirits ( 6\%wt $\mathrm{Zr}$ ), iron naphthenate in mineral spirits $(\sim 12 \% \mathrm{Fe})$, xylene $(99 \%), \mathrm{H}_{4} \mathrm{BNa}(\geq 98 \%)$ and $\mathrm{KBr}$ (FTIR grade, $\left.\geq 99 \%\right)$. The reagents $\mathrm{HNO}_{3}, \mathrm{NaH}_{2} \mathrm{PO}_{4}, \mathrm{Na}_{2} \mathrm{HPO}_{4}, \mathrm{KHCO}_{3}, \mathrm{~K}_{2} \mathrm{CO}_{3}$, tris-hydroxymethyl aminomethane, toluene, and acetone used in the experiments were obtained from Fisher Scientific, Inc.

\section{B.2.2 Flame spray pyrolysis method for synthesis of nanoparticles}

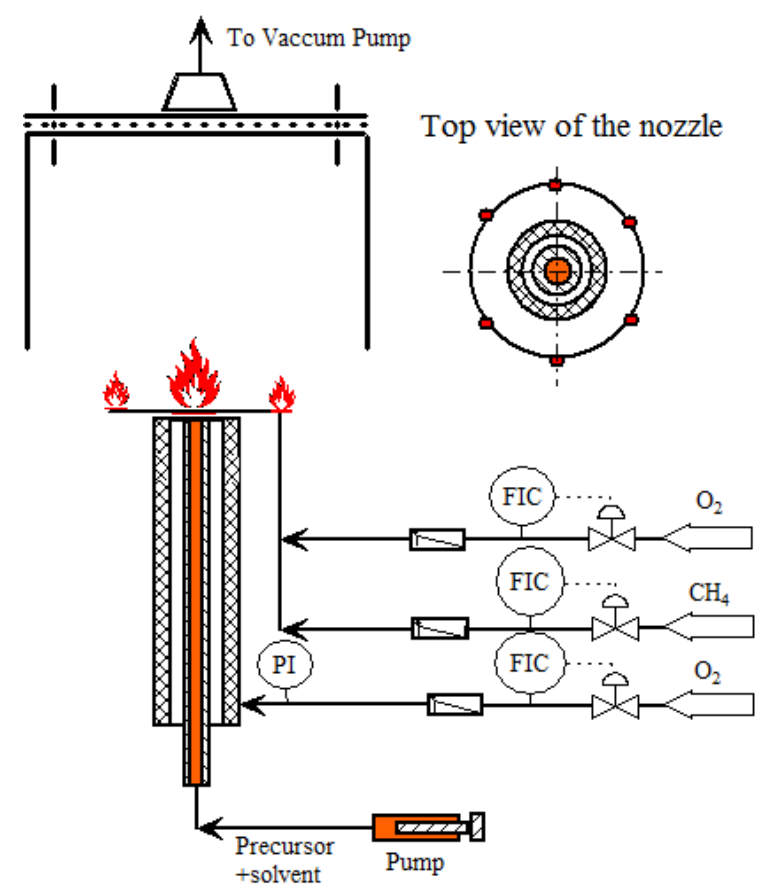

Figure 4B-1. Schematic of Flame Spray Pyrolysis experimental apparatus.

Figure 4B-1 shows a schematic diagram of the FSP experimental set-up. The system consists of a syringe pump to feed the liquid to be pyrolyzed, a spray nozzle, a natural gas (NG) line, two oxygen lines and a liquid line, and a mini-hood equipped with a vacuum particulate filter. The liquid feed was a mixture of a precursor and solvent. The nozzle consists of two coaxial stainless tubes: an inner tube with an inner diameter of $0.52 \mathrm{~mm}(0.02 \mathrm{inch})$ and a thickness of $0.15 \mathrm{~mm}$ (0.006 inch), and an outer tube with an inner diameter of $1.02 \mathrm{~mm}(0.04 \mathrm{inch})$. The liquid 
supplied through the inner tube was atomized by the oxygen passed through the external shell. A fuel-rich premixed oxygen and methane stream was supplied through six fine holes uniformly distributed on a circular tube of $12 \mathrm{~mm}(0.5 \mathrm{inch})$ radius that was centered at the nozzle to pyrolysize atomized droplets from the nozzle. A mini-hood attached to a vacuum pump was placed $18 \mathrm{~cm}$ (7 inch) above the nozzle. The FSP products were collected on a vacuum filter before they could reach the vacuum pump.

Tetraethylorthosilicate (TEOS) and xylene were chosen as the precursor and solvent, respectively, for the synthesis of silica nanoparticles $\left(\mathrm{SiO}_{2}\right)$. The silica nanoparticles $(\mathrm{SN} 1, \mathrm{SN} 2$, and SN3) were synthesized under three different conditions, as shown in Table 4B-1. Syntheses of $\mathrm{SiO}_{2}-\mathrm{ZrO}_{2}$ and $\mathrm{SiO}_{2}-\mathrm{Fe}_{2} \mathrm{O}_{3}$ composite nanoparticles were conducted using a one-step FSP method. Zirconyl 2-ethylhexanoate in mineral spirits, iron naphthenate in mineral spirits, and TEOS were used as precursors for the zirconia, $\mathrm{Fe}_{2} \mathrm{O}_{3}$, and silica, respectively. For synthesis of $\mathrm{SiO}_{2}-\mathrm{ZrO}_{2}$, the two precursors were dissolved in xylene until the total concentration reached 0.5 $\mathrm{M}$, among which the concentration of the zirconia precursor varied from $0.1 \mathrm{M}$ to $0.25 \mathrm{M}$. Two $\mathrm{SiO}_{2}-\mathrm{ZrO}_{2}$ composite nanoparticle supports, with a $\mathrm{Zr}: \mathrm{Si}$ molar ratio of 1:4 (SZ1) and 1:1 (SZ2), were synthesized. For the $\mathrm{SiO}_{2}-\mathrm{Fe}_{2} \mathrm{O}_{3}$ synthesis, a predetermined amount of TEOS was added to obtain the desired Fe:Si ratios (1:4 for SF1 and 1:8 for SF2). The iron naphthenate concentration was maintained at $0.4 \mathrm{M}$. The other synthesis conditions are shown in Table 4B-1.

Table 4B-1. Test matrix for synthesis of silica nanoparticles

\begin{tabular}{|c|c|c|c|c|c|}
\hline \multirow{2}{*}{$\begin{array}{c}\text { Sample } \\
\text { No. }\end{array}$} & \multicolumn{2}{|c|}{ Liquid feed } & \multicolumn{2}{|c|}{ Premixed combustion gas } & \multirow{2}{*}{$\begin{array}{c}\text { Flow rate of } \mathrm{O}_{2} \\
\text { dispersion gas, } \\
1 / \mathrm{min}\end{array}$} \\
\hline & $\begin{array}{c}\text { Volume Ratio of } \\
\text { precursor to solvent }\end{array}$ & $\begin{array}{c}\text { Flow rate, } \\
\mathrm{ml} / \mathrm{min}\end{array}$ & $\begin{array}{c}\text { Flow rate of } \\
\text { oxygen, } 1 / \mathrm{min}\end{array}$ & $\begin{array}{c}\text { Flow rate of } \\
\text { Methane, } 1 / \mathrm{min}\end{array}$ & \\
\hline SN1 & $1: 1$ & 2 & 0.42 & 0.41 & 3.48 \\
\hline SN2 & $1: 1$ & 1 & 0.42 & 0.41 & 4.46 \\
\hline SN3 & $1: 7$ & 2 & 0.42 & 0.41 & 3.48 \\
\hline SZ1 & - & 2 & 0.42 & 0.41 & 3.48 \\
\hline SZ2 & - & 2 & 0.42 & 0.41 & 3.48 \\
\hline SF1 & - & 3 & 0.42 & 0.41 & 3.48 \\
\hline SF2 & - & 3 & 0.42 & 0.41 & 3.48 \\
\hline
\end{tabular}

\section{B.2.3 Characterization of nanoparticles}

Specific surface area of the FSP-made nanoparticles was measured by $\mathrm{N}_{2}$ adsorption at $-196^{\circ} \mathrm{C}$ ($303^{\circ} \mathrm{F}$ ) using the BET method (Micromeritics ASAP 2020 analyzer). Prior to each measurement, the samples were evacuated at $100^{\circ} \mathrm{C}\left(212{ }^{\circ} \mathrm{F}\right.$ ) under vacuum (p (total pressure) $<0.01$ $\left.\mathrm{mmHg} / 1.93 \times 10^{-4} \mathrm{psia}\right)$, and then held at $100^{\circ} \mathrm{C}\left(212^{\circ} \mathrm{F}\right)$ under vacuum $\left(\mathrm{p}<1 \mathrm{mmHg} / 1.93 \times 10^{-2}\right.$ psia) for 4 hours to degas. The specific surface area of the samples was determined from the linear part of the BET equation. Crystalline phases of the nanoparticles were characterized using XRD (Siemens-Bruker D5000) utilizing $\mathrm{Cu} \mathrm{K \alpha}$ radiation scanned at $2 \theta=10-60^{\circ}$ with a step size of $0.05^{\circ}$ and a scan speed of $1 \%$ min. FTIR spectroscopy analysis was also performed on the silica nanoparticles at room temperature on a Nicolet EXUS 670 FTIR spectrophotometer using pure $\mathrm{KBr}$ as the medium.

\section{B.2.4 Enzyme immobilization onto nanoparticles}


The ACA1 enzyme was purified before immobilization. An ammonia sulfate precipitation method was used for the ACA1 enzyme purification. The detailed procedure of the ACA1 enzyme purification can be found in Section 4A.2.2 No purification process was applied to the SCA enzyme, because it was pure in its as-received condition.

A covalent coupling method, similar to the one developed for enzyme immobilization onto the CPG materials, was used for CA enzyme immobilization onto the FSP-made nanoparticles. It involved activation of the nanoparticles' surface with a silane and an aldehyde, followed by covalent coupling between the CA enzyme and the activated nanoparticles. A detailed description of the immobilization procedure can be found in Section 4A.2.3.

The SN2 support and SCA enzyme were selected to optimize the immobilization conditions for the silica-based nanoparticles. The SCA was immobilized onto SN2 under several pH conditions to identify the optimal $\mathrm{pH}$ for the coupling reaction between the SCA enzyme and the FSP silicabased support particles. Four buffer solutions were employed for this purpose, including two 0.1 $\mathrm{M}$ phosphate buffer solutions of $\mathrm{pH} 7$ and 8 , a $0.1 \mathrm{M}$ citrate buffer of $\mathrm{pH} 5$, and a $0.03 \mathrm{M}$ carbonate buffer of $\mathrm{pH} 10$. The effects of the initial CA enzyme concentration $(100-800 \mathrm{mg} / \mathrm{L})$ and reaction time $(0.5-2.5 \mathrm{hr})$ on enzyme immobilization were also investigated to identify the optimal condition for immobilization. Under the optimal immobilization conditions determined by these experiments, eight immobilized enzyme samples were prepared: SCA immobilized on SN1 (SCA-SN1), SCA on SN2 (SCA-SN2), SCA on SN3 (SCA-SN3), ACA1 immobilized on SN1 (ACA1-SN1), ACA1 on SZ1 (ACA1-SZ1), ACA1 on SZ2 (ACA1-SZ2), ACA1 on SF1 (ACA1-SF1), and ACA1 on SF2 (ACA1-SF2).

CA enzyme loadings onto the support materials were determined by measuring the concentrations of the free CA enzyme in the solution before and after the immobilization treatment. The measurement method is referred to the Bradford method for protein quantitation. $^{[7]}$

\section{B.2.5 Enzyme activity assay}

A modified manometric method was employed to measure the CA enzyme's activity for $\mathrm{CO}_{2}$ hydration. A batch STR was used to measure the activities of the free and immobilized enzymes. The details of the STR and the manometric assay method are described in Section 4A2.7. In a typical test, $15 \mathrm{ml}$ of a $0.1 \mathrm{M} \mathrm{KHCO}_{3}-\mathrm{K}_{2} \mathrm{CO}_{3}$ solution ( $\left.\mathrm{pH} 10.5\right)$ with a desired enzyme dosage level was added to the reactor. The system was evacuated using a vacuum pump prior to each test. The reactor was initially pressurized with pure $\mathrm{CO}_{2}$ to obtain a $\mathrm{CO}_{2}$ partial pressure of 0.76 $\mathrm{kPa}(0.11 \mathrm{psia})$. The reactor was continually stirred at $300 \mathrm{rpm}$ and held at a desired temperature with the help of a thermostatic water bath. The profile of the $\mathrm{CO}_{2}$ pressure change was measured by a vacuum pressure transducer (Omegadyne, PX429-015AUSB) during the test. A Classic Danckwerts absorption theory with reaction was applied to estimate intrinsic kinetic parameters of the free and immobilized enzymes, as described in Section 4B.3.

\section{B.2.6 Effect of pH and temperature on activity of immobilized enzymes}


The impact of $\mathrm{pH}$ and temperature on the activity of several of the immobilized enzymes (SCA$\mathrm{SN} 1, \mathrm{SCA}-\mathrm{SN} 2$, and SCA-SN3) activity was evaluated. Isothermal testing at $4^{\circ} \mathrm{C}\left(39^{\circ} \mathrm{F}\right)$ investigated the effect of $\mathrm{pH}$ values ranging from 6.0 to 10.5 on the immobilized enzymes' $\mathrm{CO}_{2}$ activity. The effect of temperature on the activity of the immobilized enzymes was also examined at temperatures between 4 and $50^{\circ} \mathrm{C}\left(39\right.$ to $\left.122^{\circ} \mathrm{F}\right)$ under $\mathrm{pH} 10.5\left(0.1 \mathrm{M} \mathrm{KHCO}_{3}\right.$ $\mathrm{K}_{2} \mathrm{CO}_{3}$ ). The effects of $\mathrm{pH}$ and temperature on the activity of the free SCA enzyme were also tested to provide a basis for comparison.

\section{B.2.7 Enzyme stability assay}

The activities of six of the immobilized enzymes (SCA-SN1, SCA-SN2, SCA-SN3, ACA1-SN1, ACA1-SZ1 and ACA1-SZ2) were measured periodically for 30 to 60 days to assess their thermal stability. During the testing period, the immobilized enzymes were stored in a $0.1 \mathrm{M} \mathrm{KHCO}_{3}$ $\mathrm{K}_{2} \mathrm{CO}_{3}$ buffer solution $(\mathrm{pH} 10.5)$ at $50^{\circ} \mathrm{C}\left(122^{\circ} \mathrm{F}\right)$.

The immobilized enzymes were also investigated for their chemical stability with respect to the three chemical impurities - sulfate, nitrate, and chloride - typically found in the combustion flue gas from a high-sulfur coal-fired power plant. During the test, the immobilized enzymes were stored in a $0.1 \mathrm{M} \mathrm{KHCO}_{3}-\mathrm{K}_{2} \mathrm{CO}_{3}$ buffer solution $(\mathrm{pH} 10.5)$ mixed with $\mathrm{SO}_{4}{ }^{2-}(0.4 \mathrm{M}), \mathrm{NO}_{3}{ }^{-}(0.05$ $\mathrm{M})$, and $\mathrm{Cl}^{-}(0.3 \mathrm{M})$ anions at $50^{\circ} \mathrm{C}\left(122^{\circ} \mathrm{F}\right)$. The activities of the immobilized enzymes were measured periodically for 30 to 60 days. The thermal and chemical stabilities of the two free enzymes were also investigated under the same conditions and served as a baseline.

\section{B.3 Theoretical analysis of enzymatic kinetics for $\mathrm{CO}_{2}$ absorption}

A classic Danckwerts absorption theory with reaction was applied to estimate kinetic parameters of the free and immobilized enzymes. Under certain circumstances, the concentration of a liquidphase reactant near the gas-liquid interface is not significantly depleted by the reaction with absorbed $\mathrm{CO}_{2}$. The $\mathrm{CO}_{2}$ thus undergoes a pseudo-first order reaction and the rate of $\mathrm{CO}_{2}$ absorption can be given according to the following equation: ${ }^{[8]}$

$$
R=k_{L} \sqrt{\left(1+\frac{D_{\mathrm{CO}_{2}, P C} k_{o v}}{k_{L}^{2}}\right)} \times\left(C^{*}-C^{b}\right)
$$

and

$$
C^{*}=\frac{P_{\mathrm{CO}_{2}, t}}{\mathrm{He}}
$$

where $R$ is the rate of absorption per unit interfacial area, $\mathrm{kmol} / \mathrm{m}^{2} . \mathrm{s} ; k_{o v}$ is the overall first order rate constant, $s^{-1} ; k_{L}$ is the physical mass transfer coefficient in liquid phase, $m / s ; D_{\mathrm{CO}_{2} / P C}$ is the diffusivity of $\mathrm{CO}_{2}, \mathrm{~m}^{2} / \mathrm{s} ; \mathrm{P}_{\mathrm{CO}, t}$ is the partial pressure of $\mathrm{CO}_{2}$ at the gas-liquid interface at time $\mathrm{t}$, $\mathrm{Pa}$; $\mathrm{He}$ is the Henry's law coefficient, $\mathrm{kmol} / \mathrm{kPa} \cdot \mathrm{m}^{3} ; C^{*}$ and $C^{b}$ are the physical solubility (at the pressure prevailing at the interface) and the concentration of unreacted molecular $\mathrm{CO}_{2}$ in liquid phase, respectively, $\mathrm{kmol} / \mathrm{m}^{3}$.

Danckwerts and Sharma ${ }^{[8]}$ have given the criterion to determine whether an absorption reaction can be regarded as pseudo-first order based on the following expression: 


$$
C^{*}\left(\frac{1}{a}+\frac{2}{b}\right)\left[\sqrt{\left(1+\frac{D_{\mathrm{CO}_{2}, P C} k_{o v}}{k_{L}^{2}}\right)}-1\right]<<1
$$

where, $a$ and $b$ are the concentrations of basic and acidic salts, respectively, mol $l^{-1}$.

This criterion has been further justified and confined to

$$
C^{*}\left(\frac{1}{a}+\frac{2}{b}\right)\left[\sqrt{\left(1+\frac{D_{\mathrm{CO}_{2}, P C} k_{o v}}{k_{L}^{2}}\right)}-1\right]<<0.1
$$

in order to reduce the possible error in the flux calculation to less than $3 \%$ when a pseudo-first order reaction is assumed. ${ }^{[9]}$

For $\mathrm{CO}_{2}$ absorption into a buffer solution in the presence of $\mathrm{CA}$ enzyme, the overall rate constant for the reactions involved in the absorption can be written as:

$$
k_{o v}=k_{\mathrm{H}_{2} \mathrm{O}}+k_{\mathrm{OH}}\left[\mathrm{OH}^{-}\right]+k_{\mathrm{CA}}[\mathrm{CA}]
$$

where $k_{H 2 O}\left(s^{-1}\right), k_{O H}\left(m^{3} / \mathrm{kmol} \cdot s\right)$, and $k_{C A}\left(M^{-1} s^{-1}\right)$ are the kinetic rate constants for the reaction of $\mathrm{CO}_{2}$ with $\mathrm{H}_{2} \mathrm{O}, \mathrm{OH}^{-}$and $\mathrm{CA}$ enzyme, respectively. [CA] is the concentration of CA enzyme. Compared to the other two terms, the value of $k_{\mathrm{H} 2 \mathrm{O}}$ is negligible (ranging between 0.02 and $0.0375 s^{-1}$ at 25 to $50^{\circ} \mathrm{C} / 77$ to $\left.122{ }^{\circ} \mathrm{F}\right) .{ }^{[10,11]}$

Based on Michaelis-Menton kinetics for enzymes, $k_{E}$ can be expressed as follows.

$$
k_{C A}=\frac{k_{c a t}}{K_{m}+C^{b}}
$$

When $K_{\mathrm{m}}>C^{\mathrm{b}}$, Equation (6) can be simplified as:

$$
k_{C A}=\frac{k_{c a t}}{K_{m}}
$$

where $k_{\text {cat }}$ is the turnover rate of the enzyme, $s^{-1} ; K_{\mathrm{m}}$ is the Michaelis constant, i.e., the substrate concentration at which the reaction rate is half of the maximum rate achieved by the system, $M$.

For gas absorption taking place in a stirred cell reactor, the following equation can be derived based on the conservation principle, ideal gas law, and Henry's law: ${ }^{[12]}$

$$
R=-\frac{V_{G}}{A \times R_{g a s} T} \frac{d P_{C O_{2}, t}}{d t}=k_{L} \sqrt{\left(1+\frac{D_{C O_{2}, P C} k_{o v}}{k_{L}^{2}}\right)} \times\left(C^{*}-C^{b}\right)
$$

where $V_{G}$ is the volume of the gas phase, $m^{3} ; A$ is the interfacial area between the gas and liquid phase, $\mathrm{m}^{2} ; R_{\text {gas }}$ is the universal gas constant, $\mathrm{kPa} \mathrm{m} / \mathrm{kmol} \cdot \mathrm{K}$; $T$ is the temperature, $K ; t$ is the time, $s$.

When $C^{b}$ is negligible, by combining Eq. (4B-2) and (4B-8) and integration we obtain: 


$$
L n\left(\frac{P_{C O_{2}, 0}}{P_{C O_{2}, t}}\right)=\sqrt{k_{L}^{2}+D_{C O_{2}, P C} k_{o v}} \frac{R T A}{V_{G} H e} \Delta t
$$

where, $P_{\mathrm{CO} 2,0}$ is the initial partial pressure of $\mathrm{CO}_{2}$ in the gas phase, $P a$.

By arranging Eq. (4B-5) and (4B-9), we can obtain the following equation:

$$
k_{C A}=\frac{m_{C A}^{2}-m_{0}^{2}}{D_{C O_{2}, P C}[C A]}
$$

where $m_{\mathrm{CA}}$ and $m_{0}$ are, respectively, the slopes of the lines obtained by plotting $\operatorname{Ln}\left(\frac{P_{\mathrm{CO}_{2}, 0}}{P_{\mathrm{CO}_{2}, t}}\right) v s$. $\frac{R T A}{V_{G} H e} \Delta t$ with the data from the pressure change profiles for the absorption of $\mathrm{CO}_{2}$ into $\mathrm{PC}$ solutions with and without the CA enzyme. The value of $k_{\mathrm{E}}$ can thus be determined when $D_{\mathrm{CO}_{2}, P C}$ and $[\mathrm{CA}]$ are known.

A dilute buffer solution $\left(0.1 \mathrm{M} \mathrm{KHCO}-\mathrm{K}_{2} \mathrm{CO}_{3}\right)$ will not have a significant difference of viscosity from pure water. Thus, the diffusivity of $\mathrm{CO}_{2}$ in the buffer solution is almost the same as that in water. The diffusivity of $\mathrm{CO}_{2}$ in water was given by Versteeg and van Swaaij as: ${ }^{[13]}$

$$
D_{\text {CO2/water }}=2.35 \times 10^{-6} \exp \left(\frac{-2119}{T}\right) \mathrm{m}^{2} / \mathrm{s}
$$

The correlations of Weisenberger and Schumpe were employed to estimate the Henry's law constant $(\mathrm{He})$ for $\mathrm{CO}_{2}$ in a salt solution: ${ }^{[14]}$

$$
\log \left(c_{G, o} / c_{G}\right)=\sum\left(h_{i}+h_{G}\right) c_{i}
$$

and

$$
h_{G}=h_{G, 0}+h_{T}(T-298.15 K)
$$

where $\mathrm{c}_{\mathrm{G}, 0}$ and $\mathrm{c}_{\mathrm{G}}$ denote the gas solubilities (the reciprocal of $H e$ ) in pure water and the salt solution at the concentration $c_{i}$, respectively, $\mathrm{kmol} / \mathrm{l} \cdot \mathrm{kPa} ; h_{i}, h_{G, 0}$, and $h_{T}$ are the model parameters for specific ions and gas components, which can be obtained from the literature. ${ }^{[14]}$

The solubility of $\mathrm{CO}_{2}$ in pure water was also obtained from the correlation proposed by Versteeg and van Swaaij: ${ }^{[13]}$

$$
c_{G, o}=3.54 \times 10^{-7} \exp \left(\frac{2044}{T}\right)
$$

In this work, IF is a ratio of the activity (expressed by $k_{c a} / K_{m}$ ) of an immobilized CA with respect to that of its free counterpart, which is an indication of the retention rate of the CA enzyme's activity during immobilization.

\section{B.4 Results and discussion}




\section{B.4.1 Characterization of nanoparticle support materials}

The silica nanoparticles were selected as the carriers for enzyme immobilization, because they are hydrophilic and suitable for enzyme immobilization. If necessary, this material can be further tailored to possess desired surface properties. The $\mathrm{SiO}_{2}$-magnetic $\mathrm{Fe}_{2} \mathrm{O}_{3}$ composite nanoparticles were synthesized for enzyme immobilization since they could be easily separated from liquid. Silica may gradually dissolve in the alkaline solution. Budd and Frackiewicz ${ }^{[15]}$ suggested an electrophilic/nucleophilic reaction mechanism for the attack of alkali on silica-based materials. The attack by $\mathrm{OH}^{-}$results in the destruction of Si-O-Si bonds on the silica surface. Resistance of $\mathrm{Si}-\mathrm{O}-\mathrm{Si}$ to $\mathrm{OH}^{-}$is thus critical to the chemical durability of silica nanoparticles. Since hydration of $\mathrm{ZrO}_{2}$ is more favorable than that of $\mathrm{SiO}_{2}$, a thin layer of hydrated $\mathrm{ZrO}_{2}$ can be formed on the surface to prevent the attack of $\mathrm{OH}^{-}$against the silica network. The hydrated $\mathrm{ZrO}_{2}$ layer is not soluble in the $\mathrm{pH}$ range of 0 to $17 .^{[16]}$ Thus, two $\mathrm{SiO}_{2}-\mathrm{ZrO}_{2}$ composite nanoparticles were also synthesized for enzyme immobilization.

The FSP silica nanoparticles (SN1, SN2 and SN3) derived from the TEOS precursor were white. The FSP $\mathrm{SiO}_{2}-\mathrm{ZrO}_{2}$ composite nanoparticles ( $\mathrm{SZ1}$ and SZ2) were yellow and brown. The FSP $\mathrm{SiO}_{2}$-magnetic $\mathrm{Fe}_{2} \mathrm{O}_{3}$ composite nanoparticles (SF1 and SF2) were dark brownish. XRD patterns of the particles are shown in Figure 4B-2. The peak with an equivalent Bragg angle at $2 \theta=23.6^{\circ}$, representative of amorphous silica structure, was observed for all of the five FSP products. XRD of silica nanoparticles displayed no sharp diffraction peaks, indicating the silica nanoparticles are amorphous silica nanoparticles. Such an observation is similar to the one reported by Martinez et al. for a similar material. ${ }^{[17]}$ The XRD pattern of the magnetic $\mathrm{Fe}_{2} \mathrm{O}_{3}$ matched closely with crystalline maghemite $\left(\gamma-\mathrm{Fe}_{2} \mathrm{O}_{3}\right.$, PDF: 004-0755), although the presence of the magnetite $\left(\mathrm{Fe}_{3} \mathrm{O}_{4}\right.$, PDF: 019-0629) phase could not be entirely ruled out due to the similarity in Bragg peaks. Superparamagnetic particles $\left(\gamma-\mathrm{Fe}_{2} \mathrm{O}_{3}\right)$ do not retain any permanent magnetization after removal of an applied magnetic field, thus facilitating their stability and dispersion. For the two $\mathrm{SiO}_{2}$ $\mathrm{ZrO}_{2}$ samples, zirconia was present as a tetragonal crystalline phase (PDF: 80-784).

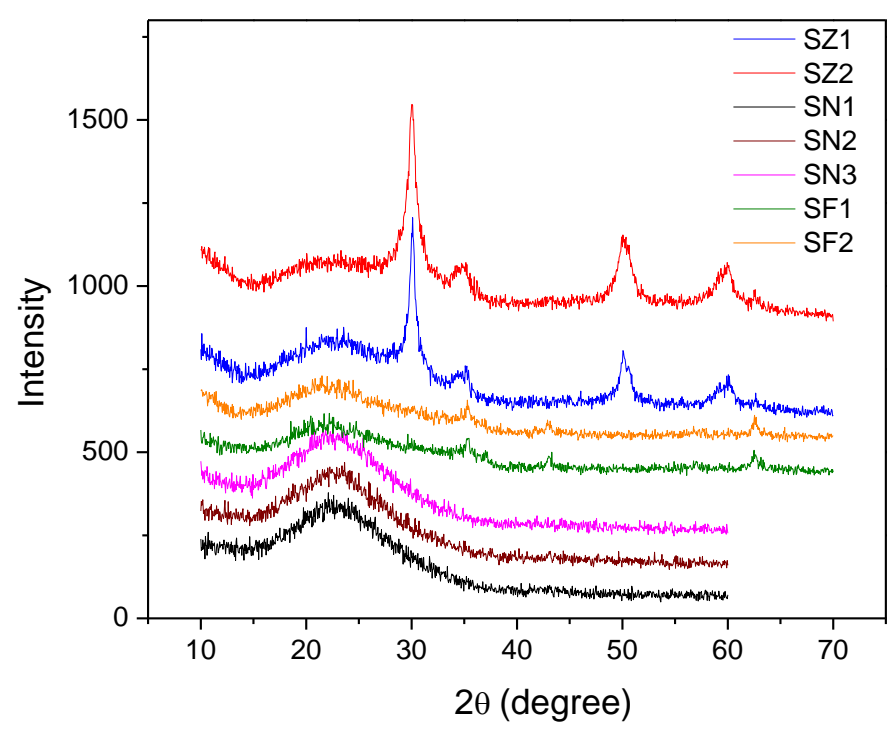

Figure 4B-2. XRD patterns of the FSP-made nanoparticles. 


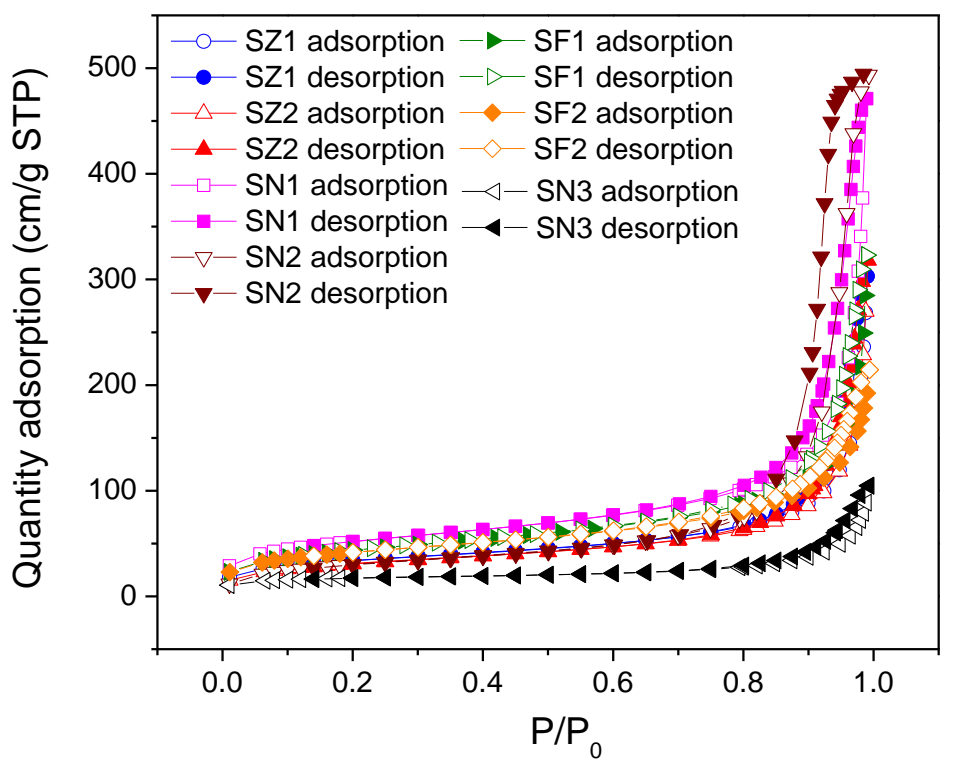

Figure 4B-3. $\mathrm{N}_{2}$ adsorption isotherms $\left(-196^{\circ} \mathrm{C}\right)$ of the FSP-made nanoparticles.

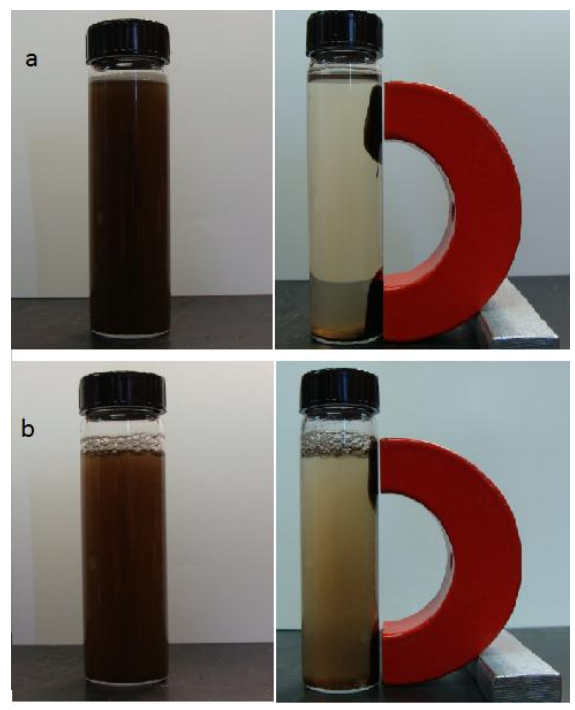

Figure 4B-4. Magnetic separation of $\mathrm{SiO}_{2}-\gamma-\mathrm{Fe}_{2} \mathrm{O}_{3}$ composite nanoparticles from a suspension in water: (a) SF1 and (b) SF2 nanoparticles.

The $\mathrm{N}_{2}$ adsorption-desorption isotherms of the FSP-made nanoparticles are of type IV, as shown in Figure 4B-3. These isotherms indicate multi-layer formation after completion of the monolayer at a relative pressure of about $0.2,0.2$, and 0.07 for silica nanoparticles, $\mathrm{SiO}_{2}-\gamma-\mathrm{Fe}_{2} \mathrm{O}_{3}$, and $\mathrm{SiO}_{2}-\mathrm{ZrO}_{2}$ composite nanoparticles, respectively. Results revealed that the FSP nanoparticles were nonporous, and the $\mathrm{N}_{2}$ adsorption occurred on the external surfaces of the particles and in the voids between the particles. The isotherms also exhibited a weak adsorption-desorption 
hysteresis arising from the voids between the nanoparticles. The BET surface areas of SN1, SN2, $\mathrm{SN} 3, \mathrm{SF} 1$, and SF2 were $184,115,88,148$, and $150 \mathrm{~m}^{2} / \mathrm{g}$, respectively. The BET surface areas of SZ1 and SZ2 were almost the same (about $120 \mathrm{~m}^{2} / \mathrm{g}$ ). The diameters of SN1, SN2, SN3, SF1, SF2, SZ1, and SZ2, based on their BET surface areas and assuming spherical particles, were estimated to be about $15,25,35,7,8,20$, and $15 \mathrm{~nm}$, respectively. Our previous studies were focused on enzyme immobilization onto porous, micron-sized support materials, such as CPG and AC. The activity of the immobilized enzyme was found to be much lower than that of its free counterpart due to the loss of intrinsic activity during the immobilization and the impact of intra-particle $\mathrm{CO}_{2}$ diffusion. The nano-sized nonporous FSP particles can minimize the adverse impact of intra-particle diffusion and thus may improve the overall activity of the immobilized enzyme. The synthesized $\mathrm{SiO}_{2}-\gamma-\mathrm{Fe}_{2} \mathrm{O}_{3}$ composite nanoparticles are strongly attracted to a magnet and can thereby be separated from water, as we demonstrated using a large magnet placed beside the vial (see Figure 4B-4).

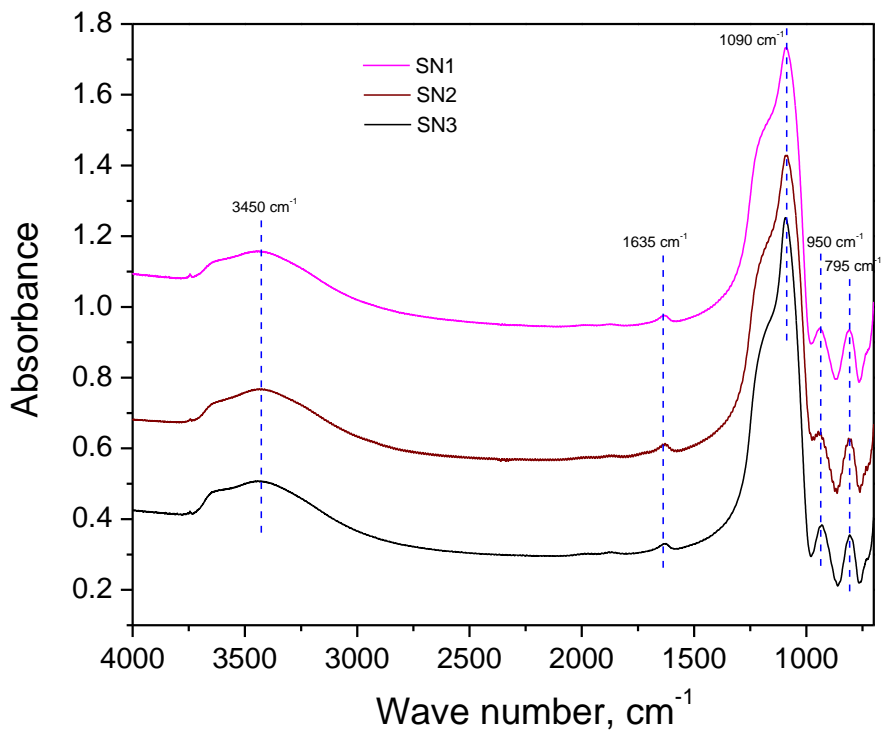

Figure 4B-5. FTIR spectrum of the FSP silica nanoparticles.

The FTIR spectra of the three silica nanoparticles shows the absorption bands arising from asymmetric vibrations of $\mathrm{Si}-\mathrm{O}\left(1,090 \mathrm{~cm}^{-1}\right), \mathrm{Si}-\mathrm{OH}\left(950 \mathrm{~cm}^{-1}\right)$, and $\mathrm{Si}-\mathrm{O}\left(795 \mathrm{~cm}^{-1}\right)$ bonds, as shown in Figure 4B-5. The absorption spectrum between 800 and $1260 \mathrm{~cm}^{-1}$ is believed to be a superposition of various spectral peaks associated with $\mathrm{SiO}_{2}, \mathrm{Si}-\mathrm{OH}$, and impurities due to the presence of residual organic groups on the surface of the particles. $\mathrm{Si}-\mathrm{OH}$, which is a required functionality for activation of SN to covalently bond with enzymes, was formed, as indicated by its characteristic peak. The intensive characteristic absorption band between $3300 \mathrm{~cm}^{-1}$ and 3500 $\mathrm{cm}^{-1}$ can be assigned to $\mathrm{O}-\mathrm{H}$ stretching in $\mathrm{H}$-bonded water. The presence of water is also confirmed by the band at $1635 \mathrm{~cm}^{-1}$ due to the bending vibration of molecular water.

\section{B.4.2 Optimization of enzyme immobilization conditions}

The CA enzyme immobilization conditions were optimized using the SN2 silica nanoparticles as the support material and the SCA enzyme. The activities of the immobilized enzymes were 
evaluated by measuring the absorption rate of pure $\mathrm{CO}_{2}$ (with an initial partial pressure of 0.76 $\mathrm{kPa} / 0.11$ psia) into a $0.1 \mathrm{M}$ carbonate/bicarbonate buffer solution $(\mathrm{pH} 10.5)$ at $4{ }^{\circ} \mathrm{C}\left(39^{\circ} \mathrm{F}\right)$.

The reaction time for $\mathrm{CA}$ enzyme immobilization onto the support is critical, because denaturation or conformational changes in the CA enzyme's secondary and tertiary structure may occur during the covalent binding reaction and thus impact the activity of the immobilized enzyme. A series of immobilization tests with immobilization times varying from 0.5 to 2.5 hours were carried out at $\mathrm{pH} 8.0$ and room temperature. The initial concentration of the CA enzyme was kept at $500 \mathrm{mg} / \mathrm{L}$ in these tests. The activities of the resulting immobilized enzymes were compared to that prepared from the medium with an immobilization time of 1.5 hours (its relative activity designated as 100\%). The effects of the immobilization reaction time on the loading and activity of the immobilized enzyme are shown in Figure 4B-6. It can be seen that the enzyme concentration decreased rapidly in the first half-hour, indicating that most of the enzyme coupling reaction occurred within that short time period. After 1.5 hours, the immobilization process was nearly completed. A longer time for the coupling reaction did not further increase the enzyme loading onto the support. In comparison, it took 3 hours or longer to reach the maximum loading for the enzyme immobilized onto the CPG100, CPG38, or AC support materials due to the limitation of intra-particle diffusion of the enzyme molecules. For the similar reason, it is expected that the intra-particle diffusion of the $\mathrm{CO}_{2}$ substrate would be eliminated or minimized when the SCA-FSP silica is used for promoting the $\mathrm{CO}_{2}$ absorption rate. Meanwhile, the test results also revealed that a longer immobilization time (more than 1.5 hours) would result in a decrease in the activity of the immobilized enzyme. Therefore, an immobilization time of 1.5 hours was deemed to be optimal with respect to both the loading and activity of the immobilized enzyme.

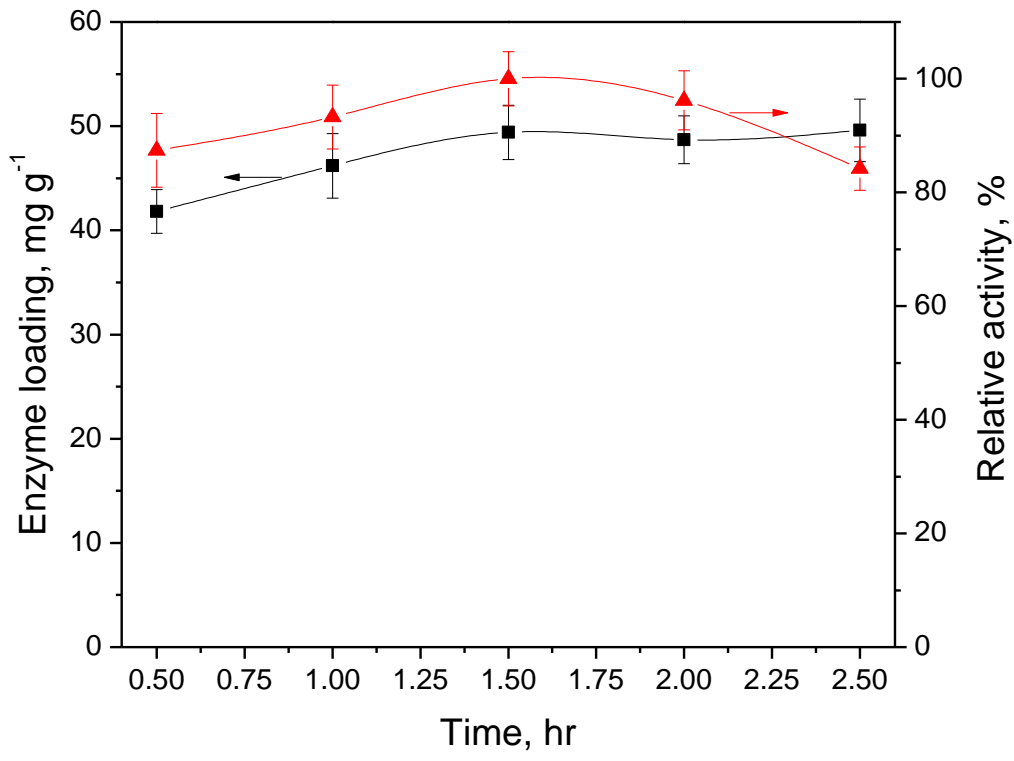

Figure 4B-6. Profiles of the SCA enzyme's loading and relative activity over the immobilization time.

Table 4B-2 shows the enzyme loading and catalytic activity of the immobilized SCA enzyme on the SN2 under different $\mathrm{pH}$ conditions with an initial CA concentration of $500 \mathrm{mg} / \mathrm{L}$ and an 
immobilization time of 1.5 hours. The activities of the resulting immobilized enzymes were compared to that prepared from the medium of $\mathrm{pH} 8.0$ (its relative activity designated as $100 \%$ ). The loading and activity retention of the SCA enzyme were the highest at $\mathrm{pH} 8$, followed by those at $\mathrm{pH} 7, \mathrm{pH} \mathrm{10}$, and $\mathrm{pH}$ 5. Thus, $\mathrm{pH} 8$ was demonstrated to be the optimal condition for enzyme immobilization.

Table 4B-2. Loadings and activities of the immobilized SCA enzymes prepared at different $\mathrm{pH}$ conditions

\begin{tabular}{|c|c|c|}
\hline $\mathrm{pH}$ & Enzyme loading, $\mathrm{mg} / \mathrm{g}$ & Relative activity,\% \\
\hline 10 & 22.3 & 82.5 \\
\hline 8 & 49.4 & 100 \\
\hline 7 & 33.2 & 84.2 \\
\hline 5 & 22.6 & 80.8 \\
\hline
\end{tabular}

The SCA enzyme was also immobilized onto SN2 silica nanoparticles with varying initial concentrations of the CA enzyme $(100-800 \mathrm{mg} / \mathrm{L})$ in the immobilization solution medium. The immobilization time was kept at 1.5 hours, the $\mathrm{pH}$ at 8.0 and room temperature. The activities of the resulting immobilized enzymes were compared to that prepared from the medium with an initial CA concentration of $500 \mathrm{mg} / \mathrm{L}$ (its relative activity designated as 100\%). Results showed that increasing the initial CA enzyme concentration in the immobilization medium resulted in an increase in enzyme loading onto the support (see Figure 4B-7). However, this also resulted in a decrease in the activity of the immobilized enzyme. It has been suggested in the literature that lateral interactions between the immobilized enzyme molecules could contribute to the deactivation of the enzyme immobilized onto a nano-sized support material. ${ }^{[18]}$ If such unfavorable lateral interactions are significant, the rate of enzymatic deactivation will increase with increasing coverage of the CA enzyme on the support particle surface. Among the various immobilized enzymes obtained, the one derived from the initial $500 \mathrm{mg} / \mathrm{L} \mathrm{CA}$ solution exhibited the best tradeoff between enzyme activity and loading.

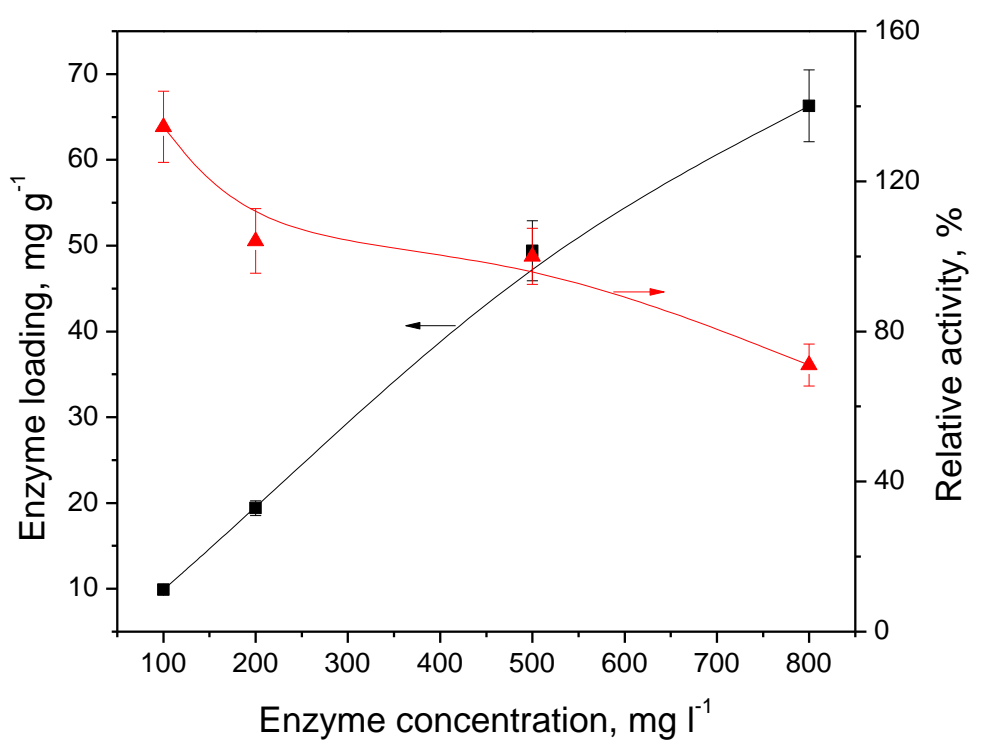

Figure 4B-7. Loadings and activities of the immobilized SCA enzymes prepared under various initial enzyme concentrations in the immobilization medium. 


\section{B.4.3 Enzyme loading and activity of immobilized enzymes}

The CA enzyme was immobilized onto the seven FSP-made nanoparticles. The optimal conditions identified from the above tests (immobilization for 1.5 hours, an initial dissolved CA concentration of $500 \mathrm{mg} / \mathrm{L}$ in the medium, and $\mathrm{pH}$ value of 8.0 in the solution) were employed. The activities of the free and immobilized enzymes were evaluated by measuring the absorption rate of pure $\mathrm{CO}_{2}$ (with an initial partial pressure of $0.76 \mathrm{kPa} / 0.11$ psia) into a $0.1 \mathrm{M}$ carbonate/bicarbonate buffer solution $(\mathrm{pH} 10.5)$ at $4^{\circ} \mathrm{C}\left(39^{\circ} \mathrm{F}\right)$. Kinetic parameters were calculated according to the principle described in Section 4B.3. Since the value of $k_{o v}$ is prerequired in the criteria formula (Eq.4B-4), a trial-and-error (shooting) process was followed to ensure the criterion was met. The value of $k_{\mathrm{cat}} / K_{\mathrm{m}}\left(k_{\mathrm{E}}\right)$ was determined by Eq. $4 \mathrm{~B}-10$.

In general, the enzyme loading onto a support material depends on the pore size, pore volume, and specific surface area of the support. For non-porous nanoparticles, the enzyme loading only depends on the specific surface area (completely contributed by the external surface). Silicabased nanoparticles possess a large number of hydroxyl groups on the surface and are highly biocompatible with enzymes. The enzyme loading levels of immobilized SCA and ACA1 on the same support (SN1) were comparable. As expected, the silica nanoparticles with a higher specific surface area tended to obtain a higher enzyme loading. The SN1, SN2, and SN3 support materials had $\mathrm{N}_{2}$-BET specific surface areas of 184,115 , and $88 \mathrm{~m}^{2} / \mathrm{g}$, while their SCA enzyme loadings reached 54.9, 49.4, and $45.1 \mathrm{mg} / \mathrm{g}$, respectively (see Table 4B-3). After zirconia was doped into the silica, the enzyme loading decreased with increasing zirconia content in the support particles (SN1<SZ1<SZ2). The ACA1 enzyme loading levels on the SN1, SZ1, and SZ2 supports reached 50.2, 35.9, and $22.7 \mathrm{mg} / \mathrm{g}$, respectively. Doping $\gamma-\mathrm{Fe}_{2} \mathrm{O}_{3}$ into the silica didn't result in a significant change in enzyme loading. The ACA1 enzyme loadings onto SF1 and SF2 were 47.3 and $52.5 \mathrm{mg} / \mathrm{g}$. The estimated values of $k_{\text {cat }} / K_{\mathrm{m}}$ of the immobilized enzymes at $4^{\circ} \mathrm{C}$ $\left(39^{\circ} \mathrm{F}\right)$ and their corresponding IF values are also displayed in Table 4B-3. For the free SCA and ACA1, the values of $k_{\mathrm{cat}} / K_{\mathrm{m}}$ were determined to be $0.597 \times 10^{7}$ and $0.795 \times 10^{7} \mathrm{M}^{-1} \mathrm{~s}^{-1}$ at $4^{\circ} \mathrm{C}$ $\left(39^{\circ} \mathrm{F}\right)$, respectively. Results indicated that the activity of the immobilized SCA enzymes (SCASN1, SCA-SN2, and SCA-SN3) increased with decreasing support particle size. Such a trend was also true for the immobilized ACA1 enzyme. This could be related to the difference in surface curvature for particles with different sizes. It has been reported that nanoparticle curvature strongly affects the amount of the enzyme's secondary structure (alpha helix and beta strand/sheet) that is perturbed. Using larger nanoparticles as a support material allows the formation of larger particle-protein interaction surfaces, which would result in larger perturbations of the enzyme's secondary structure upon the interaction and thus impair the enzyme activity. ${ }^{[19]}$ It can also be seen in Table 4B-3 that the ACA1-SZ1 exhibited a higher activity retention compared with the ACA1-SN1 and ACA1-SZ2. Since the sizes of the SN1 and SZ1 based on the BET method were comparable, higher ACA1 enzyme loading on the SN1 resulted in a higher enzyme coverage ratio on SN1. Protein-protein interaction is one of the important factors that induce protein denaturation under harsh conditions. At higher surface coverage, protein molecules are closer together, thereby leading to a greater likelihood of unfavorable protein-protein interactions that would enhance the rate of protein deactivation. ${ }^{[18,19]}$ The enzyme immobilized onto SF2 retained the highest activity $(\mathrm{IF}=0.468)$. 
Table 4B-3. Enzyme loadings, kinetic parameters and IFs of the immobilized CA enzymes

\begin{tabular}{|c|c|c|c|}
\hline Samples & Enzyme loading, $\mathrm{mg} / \mathrm{g}$ & $k_{\mathrm{cat}} / K_{\mathrm{m}} \times 10^{-7}, \mathrm{M}^{-1} \mathrm{~s}^{-1}$ & $\mathrm{IF}, \%$ \\
\hline SCA & - & 0.597 & - \\
\hline ACA1 & - & 0.795 & - \\
\hline SCA-SN1 & 54.9 & 0.281 & 47.0 \\
\hline SCA-SN2 & 49.4 & 0.266 & 34.6 \\
\hline SCA-SN3 & 45.1 & 0.216 & 37.3 \\
\hline ACA1-SN1 & 50.2 & 0.297 & 41.2 \\
\hline ACA1-SZ1 & 35.9 & 0.328 & 32.5 \\
\hline ACA1-SZ2 & 22.7 & 0.259 & 40.3 \\
\hline ACA1-SF1 & 47.3 & 0.321 & 46.8 \\
\hline ACA1-SF2 & 52.5 & 0.372 & \\
\hline
\end{tabular}

\section{B.4.4 Effect of pH and temperature on activity of immobilized enzymes}

The effect of $\mathrm{pH}$ on the free and immobilized SCA enzyme activity for $\mathrm{CO}_{2}$ hydration was investigated at $4^{\circ} \mathrm{C}\left(39^{\circ} \mathrm{F}\right)$ under $\mathrm{pH}$ values ranging between 6.0 and 10.5 , as shown in Figure 4B-8. It was observed that the activities of both the free and immobilized enzymes varied with the applied $\mathrm{pH}$ conditions. The immobilized enzymes exhibited the highest activity at $\mathrm{pH} 9.2$, whereas the free enzyme activity peaked at $\mathrm{pH}$ 8.0. The immobilized enzymes exhibited good response to basic environments given the fact that they could retain more than $80 \%$ of their highest activities even at $\mathrm{pH} 10.5$. In comparison, the free enzyme retained only about $63 \%$ of its highest activity at $\mathrm{pH} 10.5$. The improved stability in basic environments for the immobilized enzymes would be beneficial for their application in the IVCAP where the absorption operates within a $\mathrm{pH}$ range from about 9 (bottom of the absorber) to 11 (top of the absorber).

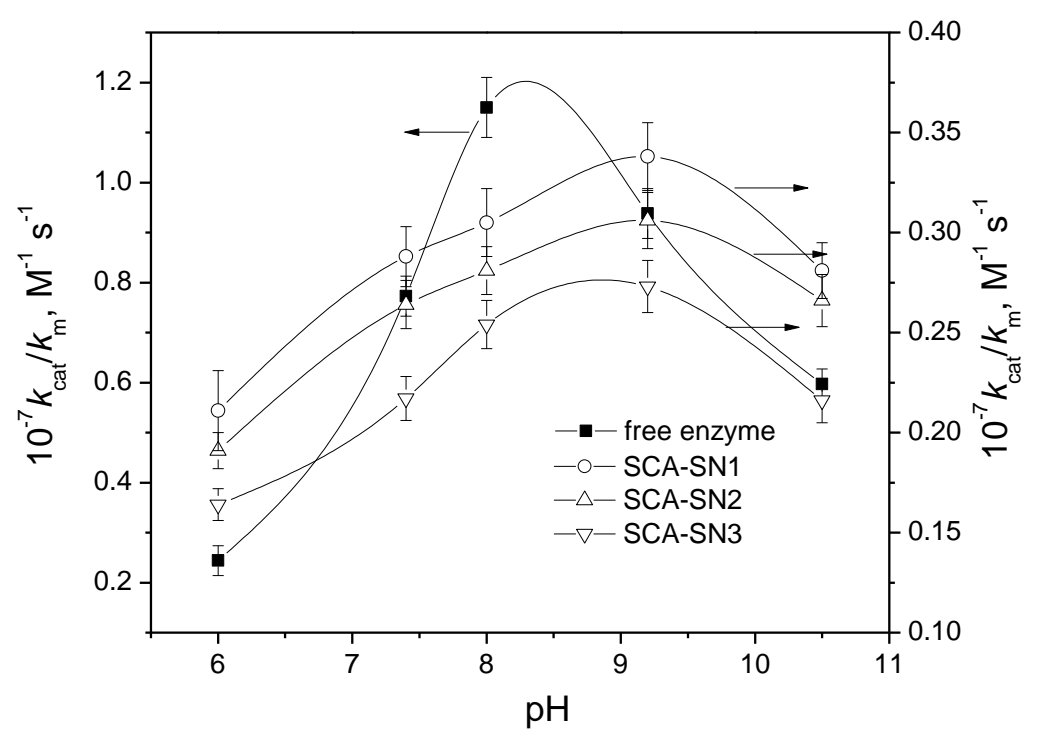

Figure 4B-8. Effect of $\mathrm{pH}$ on the activities of free and immobilized SCA enzymes at $4^{\circ} \mathrm{C}$.

The activities of the free and immobilized enzymes for $\mathrm{CO}_{2}$ hydration were also investigated at 4, 20, 40, and $50^{\circ} \mathrm{C}\left(39,68,104\right.$, and $\left.122^{\circ} \mathrm{F}\right)$ under $\mathrm{pH} 10.5$, as shown in Figure 4B-9. Temperatures higher than $50^{\circ} \mathrm{C}\left(122^{\circ} \mathrm{F}\right)$ were not employed due to the stability concern (see 
Section 4A.3.5). The immobilized enzymes demonstrated much higher activities than the free enzyme at $50^{\circ} \mathrm{C}\left(122^{\circ} \mathrm{F}\right)$, which is a typical absorption temperature in the IVCAP. At this temperature, the activities of the three immobilized enzymes were about three times higher than that of the free enzyme. In addition, the optimal temperature for the enzyme activity changed after the immobilization. The highest activity for the free enzyme occurred at $40^{\circ} \mathrm{C}\left(104^{\circ} \mathrm{F}\right)$, while the activities of the three immobilized enzymes were highest at $50^{\circ} \mathrm{C}\left(122^{\circ} \mathrm{F}\right)$. The activities of the immobilized enzymes increased with temperature. This suggests that the covalent attachment of the enzyme to the nanoparticles might have reduced the conformational flexibility of the enzyme molecules, which could result in enhanced enzyme activity at higher temperatures.

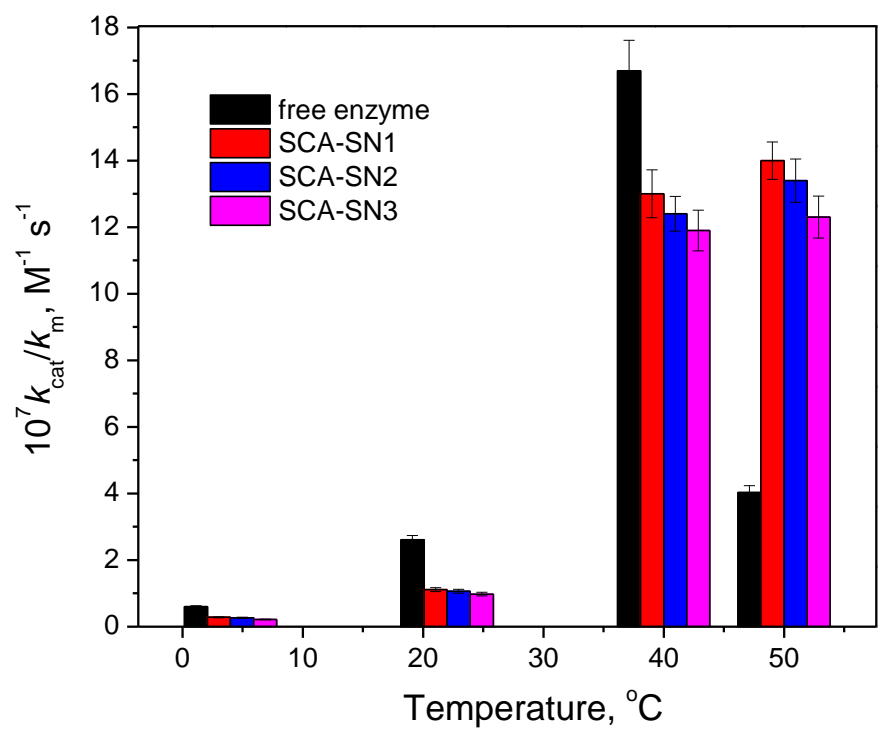

Figure 4B-9. Effect of temperature on the activities of free and immobilized SCA enzymes at $\mathrm{pH} 10.5$

\section{B.4.5 Thermal and chemical stability of immobilized enzymes}

The thermal stabilities of the immobilized and free SCA enzymes were determined at $50^{\circ} \mathrm{C}$ $\left(122^{\circ} \mathrm{F}\right)$ for 30 days. The activities of the enzyme samples stored at $50^{\circ} \mathrm{C}\left(122^{\circ} \mathrm{F}\right)$ were periodically measured at $4^{\circ} \mathrm{C}\left(39^{\circ} \mathrm{F}\right)$ and $\mathrm{pH} 10.5$. Results for the immobilized and free SCA enzymes are shown in Figure 4B-10. The activity of the free SCA decreased rather rapidly, only $3 \%$ of the original activity remained after 30 days at $50^{\circ} \mathrm{C}\left(122^{\circ} \mathrm{F}\right)$. In comparison, the immobilized enzymes on the silica support materials (SCA-SN1, SCA-SN2, and SCA-SN3) retained 38,27 , and $20 \%$ of their original activity after 30 days at $50^{\circ} \mathrm{C}\left(122^{\circ} \mathrm{F}\right)$, respectively. In addition, the SCA-SN1 and SCA-SN2 had not lost any activity at $50^{\circ} \mathrm{C}\left(122^{\circ} \mathrm{F}\right)$ for the first 12 days. It appeared that the immobilized enzyme onto the silica support with a smaller particle size $(\mathrm{SN} 1<\mathrm{SN} 2<\mathrm{SN} 3)$ retained a higher enzyme activity over the same period. The thermal stabilities of the SCA enzymes were obviously improved by the immobilization onto the nanoparticles. 


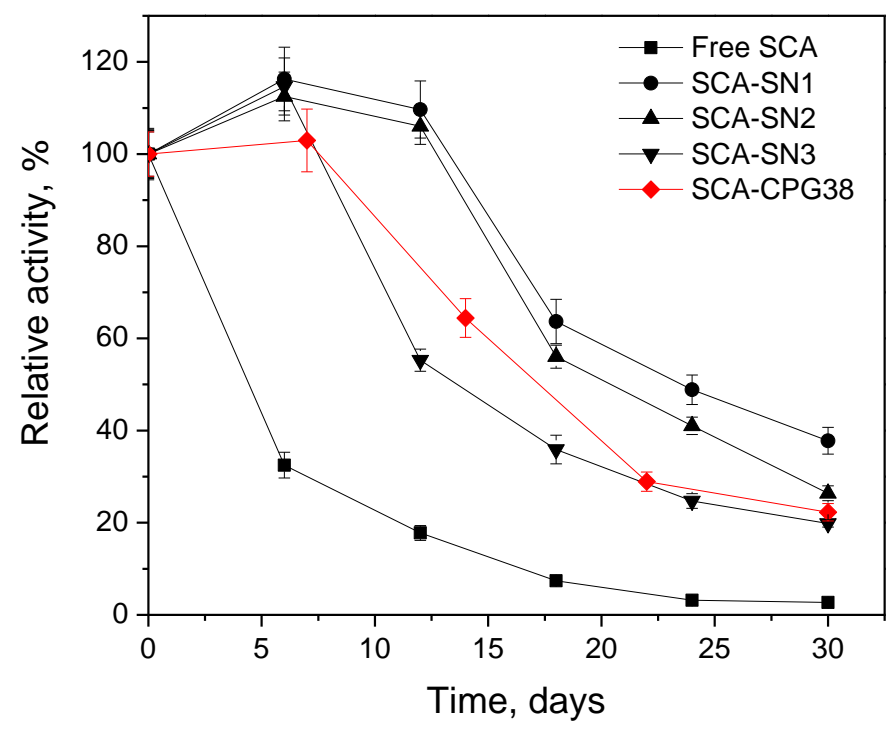

Figure 4B-10. Thermal stability of the immobilized SCA enzymes for $\mathrm{CO}_{2}$ hydration at $50^{\circ} \mathrm{C}$.

The thermal stability of the SCA enzyme immobilized onto a CPG material with a pore size of $38 \mathrm{~nm}$ (SCA-CPG38) and a particle size of 200-400 mesh was tested in Section 4A. Compared to the SCA-CPG38, the SCA immobilized onto the silica nanoparticles appeared to lose more activity over the same period of time. This is because the activity and stability assays and test conditions used for the SCA-SN and SCA-CPG38 are different. In the activity assay for the SCA-SN, $\mathrm{CO}_{2}$ absorption was performed in a $0.1 \mathrm{M} \mathrm{K}_{2} \mathrm{CO}_{3} / \mathrm{KHCO}_{3}$ buffer solution ( $\mathrm{pH} 10.5$ ) at $4^{\circ} \mathrm{C}\left(39^{\circ} \mathrm{F}\right)$ and estimated intrinsic kinetic constants were used to indicate the enzymatic activity; in the SCA-CPG38 tests, the $\mathrm{CO}_{2}$ absorption test was performed in a $0.1 \mathrm{M}$ phosphate buffer solution $\left(\mathrm{pH} \mathrm{7.4)}\right.$ at $4{ }^{\circ} \mathrm{C}\left(39^{\circ} \mathrm{F}\right)$ and apparent $\mathrm{CO}_{2}$ absorption rates were used to determine the enzymatic activity. Based on the data we have collected, it is expected that the $\mathrm{pH}$ condition of an absorbing solution would significantly affect the rate of $\mathrm{CO}_{2}$ absorption. The intrinsic enzyme activity also tended to be inhibited at higher $\mathrm{pH}$. Therefore, the results of thermal stability for the SCA-SN (see Figure 4B-10) and SCA-CPG38 (see Figure 4A-15) were not comparable. Considering these facts, the thermal stability of the SCA-CPG38 was also measured using the same activity assay employed for SCA-SN. As shown in Figure 4B-10, the thermal stability of the SCA-CPG38 showed a trend in activity similar to that of the SCA-SN. After 30 days, the SCA-CPG38 retained $22 \%$ of its original activity. The SCA-SN1 and SCA-SN2 samples exhibited better thermal stabilities than the SCA-CPG38 sample under the same conditions.

Thermal stability tests on the immobilized ACA1 enzymes were performed for 60 days at $50^{\circ} \mathrm{C}$ $\left(122^{\circ} \mathrm{F}\right)$. Results for the immobilized and free ACA1 enzymes are shown in Figure 4B-11. The ACA1 enzyme showed a better thermal stability compared with SCA enzyme. As shown in Figure 4b-10, the free SCA enzyme lost almost all its original activity after just 30 days at $50^{\circ} \mathrm{C}$ $\left(122^{\circ} \mathrm{F}\right)$. In comparison, the free ACA1 retained about $60 \%$ of its original activity after 30 days at $50^{\circ} \mathrm{C}\left(122^{\circ} \mathrm{F}\right)$, and about $30 \%$ after 60 days. The thermal stability of the ACA1 enzyme was substantially improved via immobilization. The ACA1 enzymes immobilized onto the nanoparticle support materials (ACA1-SZ1, ACA1-SZ2, and ACA1-SN1) retained 88, 70, and 
$56 \%$, respectively, of their original activity after 60 days at $50^{\circ} \mathrm{C}\left(122^{\circ} \mathrm{F}\right)$. In particular, the ACA1-SZ1 showed no decrease in activity during the first 30 days at $50^{\circ} \mathrm{C}\left(122^{\circ} \mathrm{F}\right)$. It also appeared that the ACA1 enzyme immobilized onto the $\mathrm{SiO}_{2}-\mathrm{ZrO}_{2}$ composite nanoparticles was more stable than the enzyme immobilized on the pure silica nanoparticles (ACA1-SN1). Two factors may contribute to the better thermal stability of the enzyme immobilized on the $\mathrm{SiO}_{2}$ $\mathrm{ZrO}_{2}$ nanoparticles: 1) Zirconium (IV) could play a role as a protein stabilizer, ${ }^{[20]}$ and 2) the doping of $\mathrm{ZrO}_{2}$ prevented the dissolution of $\mathrm{SiO}_{2}$ in the alkaline solution, which reduced the loss of enzyme from the nanoparticles over time. The results also indicated that an optimal content of $\mathrm{ZrO}_{2}$ in the composite material may exist, based on the fact that the ACA1 immobilized on the SZ2 support (ACA1-SZ2), containing more $\mathrm{ZrO}_{2}$ than the $\mathrm{SZ1}$ support, showed a lower thermal stability than the ACA1-SZ1. This may be because electrostatic repulsion occurs between the CA enzyme's active zinc site and the $\mathrm{ZrO}_{2}$, which impairs the activity and stability of the enzyme if the amount of $\mathrm{ZrO}_{2}$ in the support particle is too great.

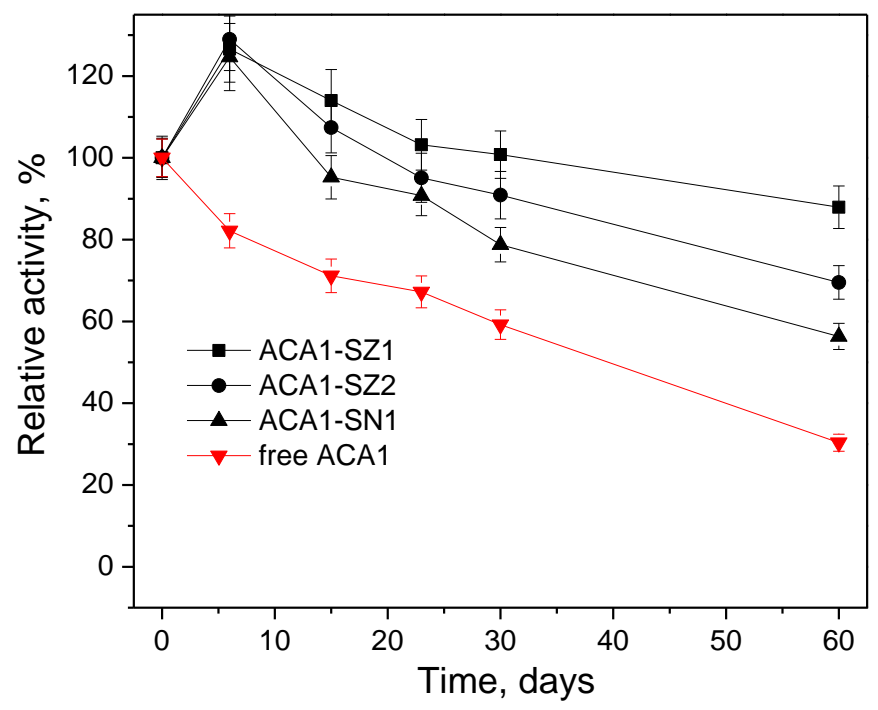

Figure 4B-11. Thermal stability of immobilized ACA1 enzymes for $\mathrm{CO}_{2}$ hydration at $50^{\circ} \mathrm{C}$.

In the typical blowdown from a FGD unit, the concentrations of $\mathrm{SO}_{4}{ }^{2-}$ range from 0.03 to $0.05 \mathrm{M}$, of $\mathrm{NO}_{3}^{-}$from 0.005 to $0.02 \mathrm{M}$, and of $\mathrm{Cl}^{-}$from 0.3 to $0.7 \mathrm{M}$. ${ }^{[21]}$ Thus, the stabilities of the immobilized (SCA-SN1, SCA-SN2 and SCA-SN3) and free SCA enzymes in the presence of $\mathrm{SO}_{4}{ }^{2-}, \mathrm{NO}_{3}{ }^{-}$, and $\mathrm{Cl}^{-}$impurities were determined at $50^{\circ} \mathrm{C}\left(122^{\circ} \mathrm{F}\right)$ over a 30 day period. The stock solution employed in the stability test was a $0.1 \mathrm{M} \mathrm{KHCO}_{3}-\mathrm{K}_{2} \mathrm{CO}_{3}$ buffer solution (pH 10) mixed with $\mathrm{SO}_{4}{ }^{2-}(0.4 \mathrm{M}), \mathrm{NO}_{3}{ }^{-}(0.05 \mathrm{M})$, and $\mathrm{Cl}^{-}(0.3 \mathrm{M})$ anions. While the free SCA enzyme lost nearly all of its initial activity for $\mathrm{CO}_{2}$ absorption after 30 days, the SCA-SN1, SCA-SN2 and SCA-SN3 enzymes retained 27, 23, and 9\% of their initial activities, respectively (see Figure 4B12). In comparison, the SCA-SN1, SCA-SN2, and SCA-SN3 in the absence of these anion impurities retained 38, 27, and $20 \%$ of their original activities (Figure 4B-10), respectively, indicating that the stabilities of the immobilized SCA enzymes were slightly reduced in the presence of these anion impurities. 


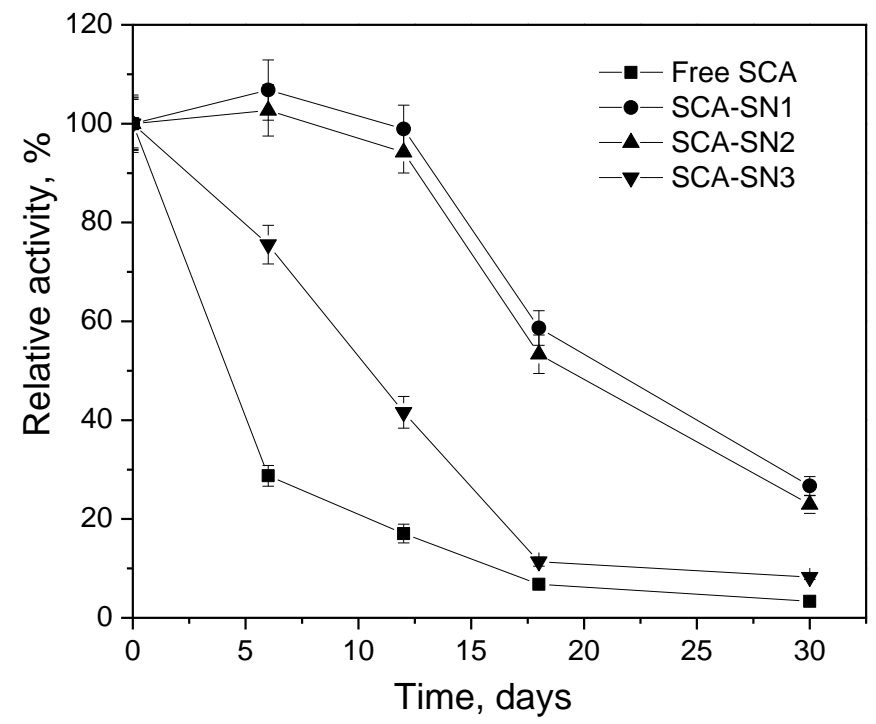

Figure 4B-12. Relative activity of immobilized SCA enzymes in $\mathrm{KHCO}_{3} / \mathrm{K}_{2} \mathrm{CO}_{3}$ solution in the presence of $\mathrm{SO}_{4}{ }^{2-}, \mathrm{NO}_{3}{ }^{-}$, and $\mathrm{Cl}^{-}$at $50^{\circ} \mathrm{C}$ for 30 days.

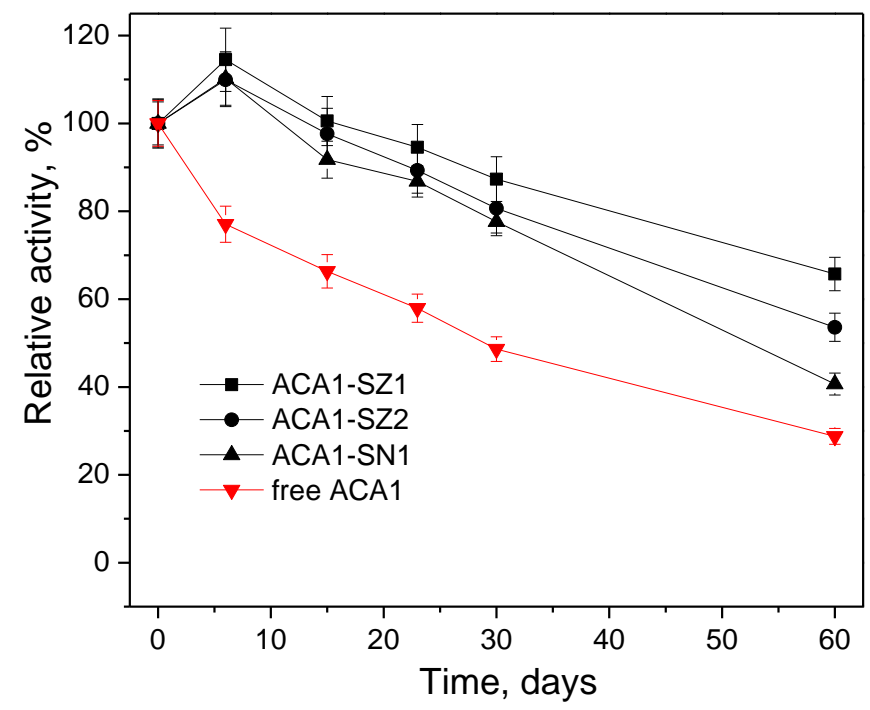

Figure 4B-13. Relative activity of immobilized ACA1 enzymes in $\mathrm{KHCO}_{3} / \mathrm{K}_{2} \mathrm{CO}_{3}$ solution in the presence of $\mathrm{SO}_{4}{ }^{2-}, \mathrm{NO}_{3}^{-}$, and $\mathrm{Cl}^{-}$at $50^{\circ} \mathrm{C}$ for 60 days.

Tests of the relative $\mathrm{CO}_{2}$ hydration activity of the free and immobilized ACA1 enzymes (ACA1$\mathrm{SZ1}$, ACA1-SZ2, and ACA1-SN1) in the presence of $0.4 \mathrm{M} \mathrm{SO}_{4}{ }^{2-}, 0.05 \mathrm{M} \mathrm{NO}_{3}{ }^{-}$, and $0.3 \mathrm{M} \mathrm{Cl}^{-}$ impurities were continued at $50^{\circ} \mathrm{C}\left(122^{\circ} \mathrm{F}\right)$ over a 60 days period. While the free ACA1 enzyme lost about $72 \%$ of its initial activity for $\mathrm{CO}_{2}$ absorption after 60 days, the ACA1-SZ1, ACA1SZ2, and ACA1-SN1 enzymes retained 66,54 , and $41 \%$ of their initial activities, respectively (see Figure 4B-13). In comparison, the ACA1-SZ1, ACA1-SZ2, and ACA1-SN1 in the absence of these anion impurities retained 88,70 , and $56 \%$ of their original activities (see Figure 4B-11), 
respectively, indicating that the relative activity of the immobilized ACA1 enzymes was adversely affected (by 22 to $27 \%$ over 60 days) in the presence of these anion impurities. However, compared with the free ACA1 enzyme, the stability of ACA1 enzyme was improved via immobilization.

\section{B.5 Summary}

Three nonporous, amorphous silica nanoparticles, two $\mathrm{SiO}_{2}-\mathrm{ZrO}_{2}$, and two $\mathrm{SiO}_{2}-\gamma-\mathrm{Fe}_{2} \mathrm{O}_{3}$ composite nanoparticles for enzyme immobilization were synthesized using a Flame Spray Pyrolysis method. Classic Danckwerts theory for absorption was successfully applied to estimate kinetic parameters $\left(k_{\mathrm{cat}} / K_{\mathrm{m}}\right)$ of the free and immobilized enzymes under different conditions.

An immobilization reaction time of 1.5 hours and an initial concentration of $500 \mathrm{mg} / \mathrm{L}$ of dissolved CA enzyme in the solution medium were identified to be optimal for enzyme immobilization. At these conditions, the immobilized CA enzymes exhibited both a high enzyme loading and a high retention rate of enzyme activity. The immobilized enzymes exhibited better response to basic environments than the free enzyme. The immobilized enzymes exhibited their highest activity at $\mathrm{pH} 8.0$ to 9.2 , but could maintain a high activity (more than $80 \%$ ) at $\mathrm{pH} 10.5$, which is a typical $\mathrm{pH}$ condition in the IVCAP. In comparison, the free enzyme's $\mathrm{CO}_{2}$ adsorption activity at $\mathrm{pH} 10.5$ was presented only $63 \%$ of its activity at $\mathrm{pH} 8.0$. In addition, the activities of the immobilized enzymes increased substantially as the temperature increased from 4 to $40^{\circ} \mathrm{C}$ (39 to $104^{\circ} \mathrm{F}$ ) and increased slightly with increasing temperature up to $50^{\circ} \mathrm{C}\left(122^{\circ} \mathrm{F}\right)$. The activity of the free SCA enzyme, by contrast, peaked at $40^{\circ} \mathrm{C}$, but dramatically dropped at $50^{\circ} \mathrm{C}\left(122^{\circ} \mathrm{F}\right)$. At $50^{\circ} \mathrm{C}\left(122^{\circ} \mathrm{F}\right)$, the apparent activities of the immobilized enzymes (including the mass transfer impact) were higher than the activity of the free enzyme.

The activity and loading of the immobilized CA enzyme increased with decreasing size of the supporting nanoparticles. With increasing zirconia content in the composite nanoparticles, the enzyme loading level decreased. Among the five ACA1 immobilized enzymes, the ACA1-SF2 exhibited the highest activity retention following immobilization. The immobilized CA enzymes exhibited improved thermal and chemical stabilities for $\mathrm{CO}_{2}$ hydration at $50^{\circ} \mathrm{C}\left(122^{\circ} \mathrm{F}\right)$ than their free counterparts. Among the three pure silica nanoparticles, the SCA enzyme immobilized onto the smallest particles (SN1) demonstrated the greatest thermal and chemical stability. The thermal and chemical stabilities of the ACA1 enzyme immobilized onto $\mathrm{SiO}_{2}-\mathrm{ZrO}_{2}$ composite nanoparticles were more improved than those of the same enzyme immobilized onto a pure silica nanoparticle.

The CA enzymes immobilized onto the non-porous nanoparticles exhibited higher enzyme activity and loading than the enzymes immobilized on controlled-pore glass materials. The activity of SCA-SN1 was almost 1.5 times higher than that of the SCA-CPG38. The enzyme loading of SCA-SN1 was about double that for SCA-CPG38. Furthermore, SCA-SN1 also exhibited a better thermal stability compared with the SCA-CPG38. The non-porous nanoparticles are better supports for CA enzyme immobilization because they can provide high enzyme activity, loading levels, and thermal stability. 


\section{References}

1. Iyer P.V., Ananthanarayan L. Enzyme stability and stabilization - Aqueous and non-aqueous environment. Process Biochemistry, 2008, 43:1019-1032.

2. Mateo C., Palomo J.M., Fernandez-Lorente G., Guisan J.M., Fernandez-Lafuente R. Improvement of enzyme activity, stability and selectivity via immobilization techniques. Enzyme and Microbial Technology, 2007, 40:1451-1463.

3. Guisan J.M., Fernandez-Lafuente R., Rodriguez V., Bastida A., Alvaro G. 1993. Enzyme stabilization by multipoint covalent attachment to activated pre-existing supports. In: Stability and Stabilization of Enzymes. van der Tweel W., Harder A., Buitelar R. (Editors), Amsterdam, Elsevier, 55-62.

4. Goddard J.M., Talbert J.N. Enzymes on materials surfaces. Colloids and surfaces B: Biointerfaces, 2012, 93:8-19.

5. Wang P. Nanoscale biocatalyst systems. Curr. Opin. Biotech, 2006, 17:574-579.

6. Mueller R., Madler L., Pratsinis S.E. Nanoparticle synthesis at high production rates by flame spray pyrolysis. Chemical Engineering Science, 2003, 58:1969-1976.

7. Pocker Y., Stone J.T. Catalytic versatility of erythrocyte Carbonic Anhydrase. 3. kinetic studies of enzyme-catalyzed hydrolysis of p-nitrophenyl acetate. Biochemistry, 1967, 6:668678.

8. Danckwerts P.V., Sharma. M.M. Absorption of carbon dioxide into solutions of alkalis and amines. J. Chem. Eng. Rev. Series No. 2, The Chemical Engineer 1966, CE 244-280.

9. Cents A.H.G., Brilman D.W.F., Versteeg G.F. $\mathrm{CO}_{2}$ absorption in carbonate/bicarbonate solutions: The danckwerts-criterion revisited. Chemical Engineering Science, 2005, 60:58305835.

10. Alper E., Deckwer W.D. Kinetics of absorption of $\mathrm{CO}_{2}$ into buffer solutions containing carbonic anhydrase. Chemical Engineering Science, 1980, 35:549-557.

11. Ho C., Sturtevant J.M. The kinetics of the hydration of carbon dioxide at $25^{\circ}$. Journal of Biological Chemistry, 1963, 238:3499-3501.

12. Kucka L., Richter J., Kenig E.Y., Górak A. Determination of gas-liquid reaction kinetics with a stirred cell reactor. Separation and Purification Technology, 2003, 31:163-175.

13. Versteeg G.F., Van Swaalj W. Solubility and diffusivity of acid gases (carbon dioxide, nitrous oxide) in aqueous alkanolamine solutions. Journal of Chemical and Engineering Data, 1988, 33:29-34.

14. Weisenberger S., Schumpe A. Estimation of gas solubilities in salt solutions at temperatures from $273 \mathrm{~K}$ to $363 \mathrm{~K}$. AICHE J., 1996, 42:298-300.

15. Budd S.M., Frackiewicz J. The mechanism reaction between silicate glass and attacking agents. Part 2. Chemical equilibria at glass-solution interfaces. Physics and Chemistry of Glasses., 1961, 2:115-118.

16. Paul A. Chemical durability of glasses: a thermodynamic approach. Journal of Materials Science, 1977, 2:2246-2268. 
17. Martinez J. R., Palomares S., Ortega-Zarzosa G., Ruiz, F., Chumakov Y. Rietveld refinement of amorphous $\mathrm{SiO}_{2}$ prepared via sol-gel method. Materials Letters, 2006, 60:3526-3529.

18. Asuri P., Karajanagi S.S., Yang H., Yim T., Kane R.S., Dordick J. S. Increasing Protein Stability through Control of the Nanoscale Environment. Langmiur, 2006, 22:5833-5836.

19. Lundqvist M., Sethson I., Jonsson B. Protein adsorption onto silica nanoparticles: Conformational Cchanges cepend on the particles' curvature and the protein stability. Langmuir, 2004, 20:10639-10647.

20. Fathima N.N, Balaraman M., Rao J.R., Nair B.U. Effect of zirconium(IV) complexes on the thermal and enzymatic stability of type I collagen. Journal of Inorganic Biochemistry, 2003, 95:47-54.

21. Pudvay M. Operating experience on the treatment on FGD scrubber blowdown from existing generating stations. http://www.degremont-technologies.com/, as of May 26, 2011. 


\section{CHAPTER 5. RECLAMATION OF SULFATE DESULFURIZATION PRODUCT IN IVCAP PROCESS}

\subsection{Introduction}

One important advantage of the IVCAP is that $\mathrm{SO}_{2}$ scrubbing can potentially be combined with the $\mathrm{CO}_{2}$ capture process. This could eliminate the need for a separate wet FGD unit, or permit the installation of a smaller polishing FGD unit. It is known that $\mathrm{SO}_{2}$ strongly reacts with a $\mathrm{K}_{2} \mathrm{CO}_{3}$ solvent to produce potassium sulfate $\left(\mathrm{K}_{2} \mathrm{SO}_{4}\right)$. A high $\mathrm{SO}_{2}$ removal efficiency is expected in a system designed for $90 \% \mathrm{CO}_{2}$ capture due to the higher acidity of $\mathrm{SO}_{2}$ than $\mathrm{CO}_{2}$. The overall absorption reaction for $\mathrm{SO}_{2}$ scrubbing is described as:

$$
\mathrm{SO}_{2}+1 / 2 \mathrm{O}_{2}+\mathrm{K}_{2} \mathrm{CO}_{3}=\mathrm{K}_{2} \mathrm{SO}_{4}+\mathrm{CO}_{2}
$$

$\mathrm{K}_{2} \mathrm{SO}_{4}$ exists as sulfate $\left(\mathrm{SO}_{4}{ }^{2-}\right)$ and potassium $\left(\mathrm{K}^{+}\right)$ions in the solution when the $\mathrm{K}_{2} \mathrm{SO}_{4}$ concentration is lower than its solubility (e.g., solubility of $120 \mathrm{~g} / \mathrm{L}$ at $25^{\circ} \mathrm{C} / 77^{\circ} \mathrm{F}$ ).

Figure 5-1 is a schematic diagram of the modified IVCAP proposed for the combined $\mathrm{SO}_{2}$ removal and $\mathrm{CO}_{2}$ capture. The $\mathrm{K}_{2} \mathrm{SO}_{4}$ product is formed in the absorption column during $\mathrm{CO}_{2}$ capture. A portion of the $\mathrm{SO}_{2}$ - and $\mathrm{CO}_{2}$-rich solution is extracted for sulfate reclamation. In the reclaimer, hydrated lime is added to convert $\mathrm{K}_{2} \mathrm{SO}_{4}$ into $\mathrm{KHCO}_{3}$ and form $\mathrm{CaSO}_{4}$. A small stream of pressurized $\mathrm{CO}_{2}$ from a multi-stage compressor is used to balance the solution's composition to preferentially favor the precipitation of $\mathrm{CaSO}_{4}$ over $\mathrm{CaCO}_{3}$ in a reclaiming reactor. The overall reaction in the reclaimer is:

$$
\mathrm{Ca}(\mathrm{OH})_{2}+\mathrm{K}_{2} \mathrm{SO}_{4}+2 \mathrm{CO}_{2}=\mathrm{CaSO}_{4}+2 \mathrm{KHCO}_{3}
$$

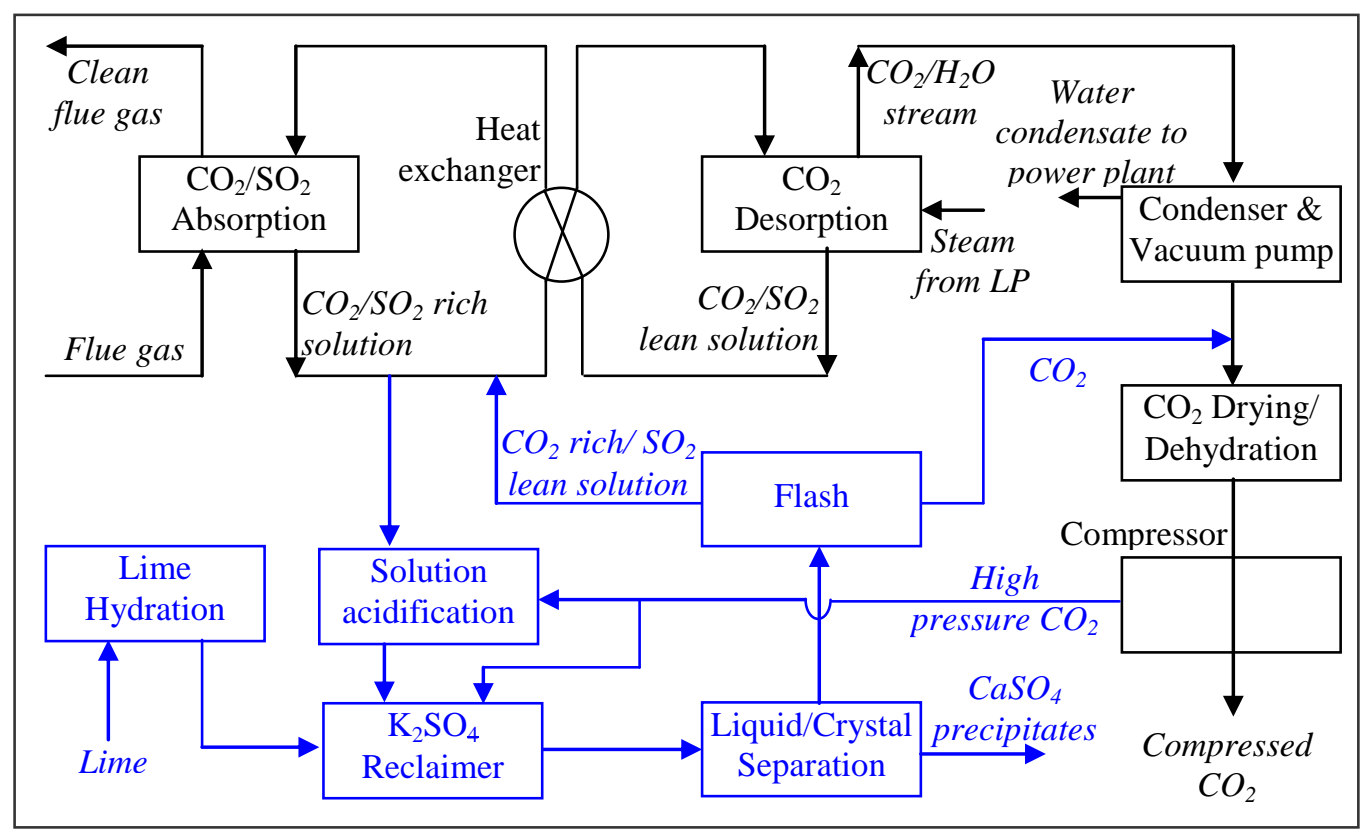

Figure 5-1. Schematic of the modified IVCAP for combined $\mathrm{CO}_{2}$ capture and $\mathrm{SO}_{2}$ removal.

The $\mathrm{CaSO}_{4}$ precipitate is recovered by filtration and the reclaimed solution passes through a flash process where $\mathrm{CO}_{2}$ is recovered and returned to the $\mathrm{CO}_{2}$ drying and compression units. The 
solution recovered in the flash unit is mixed with the spent solvent from the absorber and enters the $\mathrm{CO}_{2}$ stripping column.

The process concept is based on the chemistry of the reclaiming process. The $\mathrm{SO}_{2}$ - and $\mathrm{CO}_{2}$-rich solution exiting from the absorber contains both $\mathrm{SO}_{4}{ }^{2-}$ and $\mathrm{CO}_{3}{ }^{2-}$. In the reclaimer, these ions react with $\mathrm{Ca}^{2+}$ to form $\mathrm{CaSO}_{4}$ and $\mathrm{CaCO}_{3}$ precipitates according to the following reactions:

$$
\begin{aligned}
& \mathrm{Ca}(\mathrm{OH})_{2}=\mathrm{Ca}^{2+}+\mathrm{OH}^{-} \\
& \mathrm{Ca}^{2+}+\mathrm{SO}_{4}^{2-}=\mathrm{CaSO}_{4} \\
& \mathrm{Ca}^{2+}+\mathrm{CO}_{3}{ }^{2-}=\mathrm{CaCO}_{3}
\end{aligned}
$$

The solubility product of $\mathrm{CaCO}_{3}$ is about four orders of magnitude lower than that of $\mathrm{CaSO}_{4}$. For example at $25^{\circ} \mathrm{C}:{ }^{[1]}$

$$
\begin{aligned}
& {\left[\mathrm{SO}_{4}{ }^{2-}\right]\left[\mathrm{Ca}^{2+}\right]=2.4 \times 10^{-5}(\mathrm{~mol} / \mathrm{L})^{2}} \\
& {\left[\mathrm{CO}_{3}{ }^{2-}\right]\left[\mathrm{Ca}^{2+}\right]=3.8 \times 10^{-9}(\mathrm{~mol} / \mathrm{L})^{2}}
\end{aligned}
$$

Therefore, when the concentrations of $\mathrm{SO}_{4}{ }^{2-}$ and $\mathrm{CO}_{3}{ }^{2-}$ are comparable, $\mathrm{CaCO}_{3}$ rather than $\mathrm{CaSO}_{4}$ will preferentially precipitate from the solution.

However, the crystallization process is controlled not only by equilibrium considerations, but also by the kinetics of the competing precipitation reactions of $\mathrm{CaCO}_{3}$ and $\mathrm{CaSO}_{4}$. A typical crystallization process consists of two stages-a relatively slow nucleation stage and a fast crystal growth stage. Existence of a supersaturated solution is essential in both the nucleation and growth stages.

When solid impurities or seed crystals are present, the rate of nucleation is correlated to the degree of supersaturation according to: ${ }^{[2]}$

$$
R_{\text {nucleation }}=K_{n}(\Delta C)^{m}
$$

where $K_{n}$ is the rate constant, $m$ is the order constant depending on the properties and hydrodynamics of the system $(m=2-9), \Delta C$ is the relative supersaturation defined as $\Delta C=C_{i^{-}}$ $\mathrm{C}^{e}, C_{i}$ is the concentration of $\mathrm{SO}_{4}{ }^{2-}$ or $\mathrm{CO}_{3}{ }^{2-}$, and $C^{e}$ is the corresponding equilibrium saturation concentration. Similarly, the rate of crystal growth, $R_{\text {crystal }}$, is expressed by an empirical relationship: ${ }^{[2]}$

$$
R_{\text {crystal }}=K_{g}(\Delta C)^{g}
$$

where $K_{g}$ is the growth rate constant and $g$ is the order of growth process $(g=1-2$, dimensionless). According to Eq. (5-3) and (5-4), both rates of nucleation and crystal growth are proportional to $\Delta C$, the driving force between the actual and equilibrium concentration.

Based on the solubility product data in Eqs. (5-1 and 5-2), $\Delta C$ in Eqs. (5-3 and 5-4) can be approximated by $C$, because the equilibrium $C^{*}$ is much smaller than $C$ for both the $\mathrm{SO}_{4}{ }^{2-}$ and $\mathrm{CO}_{3}{ }^{2-}$ ions. Therefore, if the concentration of $\mathrm{CO}_{3}{ }^{2-}$ is much smaller than that of $\mathrm{SO}_{4}{ }^{2-}, \mathrm{CaSO}_{4}$ may be a dominant precipitate from the solution. It is for this reason that a small stream of highpressure $\mathrm{CO}_{2}$ is used to lower the $\mathrm{CO}_{3}{ }^{2-}$ concentration of the solution in the reclaimer, according to the following reactions. 


$$
\begin{aligned}
& \mathrm{H}_{2} \mathrm{O}+\mathrm{CO}_{2}=\mathrm{H}_{2} \mathrm{CO}_{3}=\mathrm{HCO}_{3}{ }^{-}+\mathrm{H}^{+} \\
& \mathrm{CO}_{3}{ }^{2-}+\mathrm{H}^{+}=\mathrm{HCO}_{3}{ }^{-}
\end{aligned}
$$

The concentration of $\mathrm{SO}_{4}{ }^{2-}$ in the $\mathrm{PC}$ solution may be adjusted by controlling the ratio between the rich solution withdrawal for reclaiming the sulfate and the main flow to the stripper. The concentration of $\mathrm{SO}_{4}{ }^{2-}$ in the solution typically ranges between 0.1 and $1 \mathrm{~mol} / \mathrm{L}$. The concentration of $\mathrm{CO}_{3}{ }^{2-}$ highly depends on the solution conditions, such as the $\mathrm{pH}$ and the total $\mathrm{K}_{2} \mathrm{CO}_{3}$ concentration.

Data presented in Figure 5-2 are the calculated equilibrium $\mathrm{CO}_{3}{ }^{2-}$ concentrations of a $20 \mathrm{wt} \% \mathrm{PC}$ $\left(\mathrm{K}_{2} \mathrm{CO}_{3}\right.$-equivalent) solution at various $\mathrm{CO}_{2}$ pressures and $25^{\circ} \mathrm{C}\left(77^{\circ} \mathrm{F}\right)$. Increasing the $\mathrm{CO}_{2}$ pressure from 1 to $40 \mathrm{~atm}$ ( 14.7 to $588 \mathrm{psia}$ ) theoretically decreases the $\mathrm{CO}_{3}{ }^{2-}$ concentration by two orders of magnitude (from 0.1 to $0.001 \mathrm{~mol} / \mathrm{L}$ ). If the concentration of $\mathrm{SO}_{4}{ }^{2-}$ can be maintained at $0.5-1.0 \mathrm{~mol} / \mathrm{L}$ and that of $\mathrm{CO}_{3}{ }^{2-}$ at $0.01 \mathrm{~mol} / \mathrm{L}$, the supersaturation $\Delta C$ for $\mathrm{SO}_{4}{ }^{2-}$ is 50-100 times larger than that of $\mathrm{CO}_{3}{ }^{2-}$ and the nucleation kinetics and growth rates of $\mathrm{CaSO}_{4}$ may be much faster than those for $\mathrm{CaCO}_{3}$. Therefore, $\mathrm{CaSO}_{4}$ can be the primary precipitate.

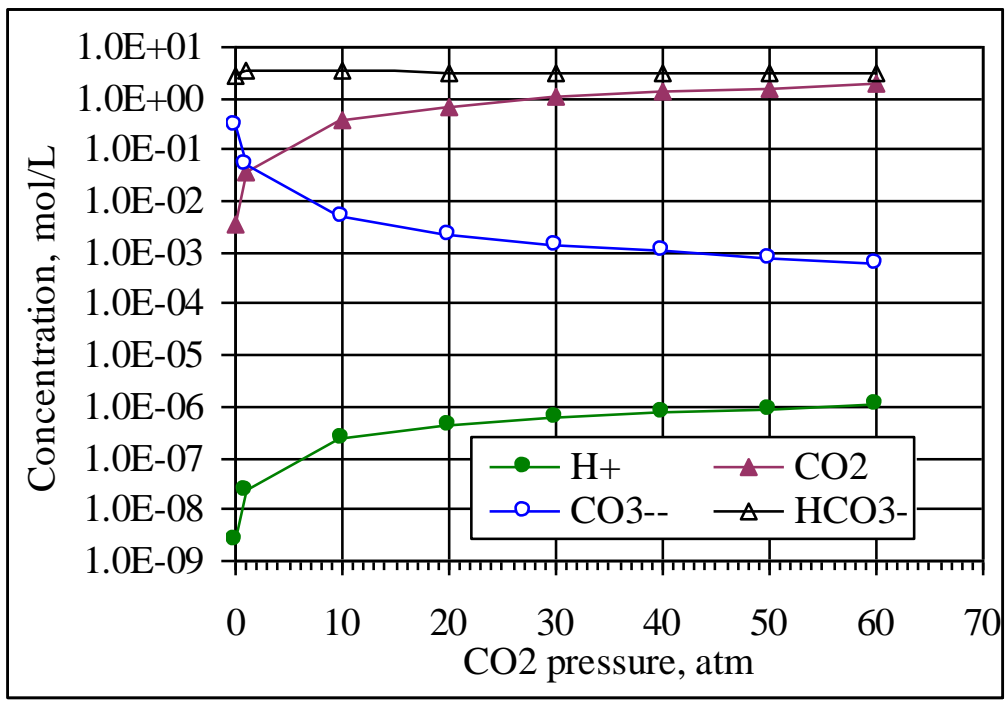

Figure 5-2. Predicted equilibrium concentrations of carbonaceous and $\mathrm{H}^{+}$species in a $20 \mathrm{wt} \% \mathrm{PC}$ solution vs. $\mathrm{CO}_{2}$ partial pressure at $25^{\circ} \mathrm{C}$.

Preliminary batch experiments at atmospheric pressure revealed that competitive precipitation of $\mathrm{CaSO}_{4}$ and $\mathrm{CaCO}_{3}$ strongly depended on the $\mathrm{SO}_{4}{ }^{2-} / \mathrm{CO}_{3}{ }^{2-}$ ratio in the solution, and a high $\mathrm{SO}_{4}{ }^{2-}$ $/ \mathrm{CO}_{3}{ }^{2-}$ ratio (>21) would kinetically favor the precipitation of $\mathrm{CaSO}_{4}$.

The reclamation process may have two steps. The first step is to lower the $\mathrm{pH}$ and $\mathrm{CO}_{3}{ }^{2-}$ concentration by introducing the pressurized $\mathrm{CO}_{2}$ gas to the reclaimer solution. The second step is to convert $\mathrm{K}_{2} \mathrm{SO}_{4}$ into $\mathrm{CaSO}_{4}$ by adding hydrated lime to the solution formed in the first step under a high $\mathrm{CO}_{2}$-pressure environment. In the following sections, experiments carried out to evaluate the feasibility of the two individual process steps are discussed.

\subsection{Measurement of $\mathrm{K}_{2} \mathrm{CO}_{3}$ conversion rate and extent under high-pressure $\mathrm{CO}_{2}$ gas}




\subsubsection{Experimental setup and apparatus}

Figure 5-3 shows a schematic diagram of the experimental setup for measuring the reaction rate and equilibrium liquid composition for the conversion of $\mathrm{K}_{2} \mathrm{CO}_{3}$ to $\mathrm{KHCO}_{3}$ at $\mathrm{CO}_{2}$ pressures up to about 3,447kpa (500psia). The apparatus consists of a high-pressure stirred tank reactor (STR, Parr Instrument Company, model 4531), a gas supply/control unit, a temperature control unit, and data acquisition instrumentation. The Parr autoclave reactor is a 1 liter $\left(0.035 \mathrm{ft}^{3}\right)$ cylinder, with an inner diameter of $10.1 \mathrm{~cm}(4.0 \mathrm{inch})$ and a depth of $13.7 \mathrm{~cm}(5.4 \mathrm{inch})$. It is furnished with a self-sealing FFKM O-ring closure suitable for operation at temperatures up to $275^{\circ} \mathrm{C}$ $\left(527^{\circ} \mathrm{F}\right)$ and pressures up to $131 \mathrm{~atm}(1900 \mathrm{psia})$. The pressure inside the reactor is measured by a pressure transducer (Omega, PX409-1.0KAUSB) and monitored/recorded by a computer. The reactor is equipped with a DC variable-speed magnetic stirrer with a maximum torque of 18.4 $\mathrm{kg}-\mathrm{cm}$ (16 inch-pounds) and controlled by the Parr Series 4840 controller to provide stirring speeds up to $600 \mathrm{rpm}$ for both the gas and liquid phases. The reactor is equipped with a gas inlet valve, a gas release valve, a liquid sampling valve, a pressure gauge, and a safety rupture disc for emergency ventilation. An external furnace and a separate Parr Series 4840 Temperature Controller controlled the reactor temperature. A cooling coil, in a serpentine configuration, can be installed inside the reactor to carry a controlled flow of cold water for test conditions below $150^{\circ} \mathrm{C}\left(302^{\circ} \mathrm{F}\right)$. Photographs of the Parr reactor system are displayed in Figure 5-4.

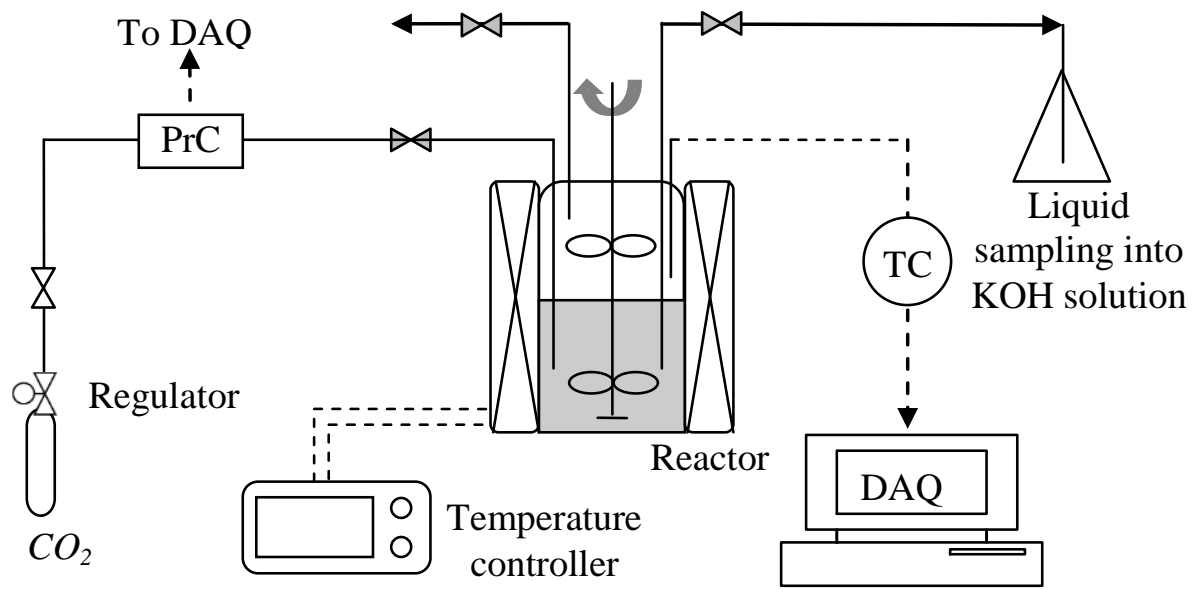

(PrC: Pressure transducer; TC: Thermal couple; DAQ: Data acquisition)

Figure 5-3. Schematic diagram of an experimental setup for measuring the reaction rate and equilibrium liquid concentration for the conversion of $\mathrm{K}_{2} \mathrm{CO}_{3}$ into $\mathrm{KHCO}_{3}$ using a high-pressure $\mathrm{CO}_{2}$ gas stream. 

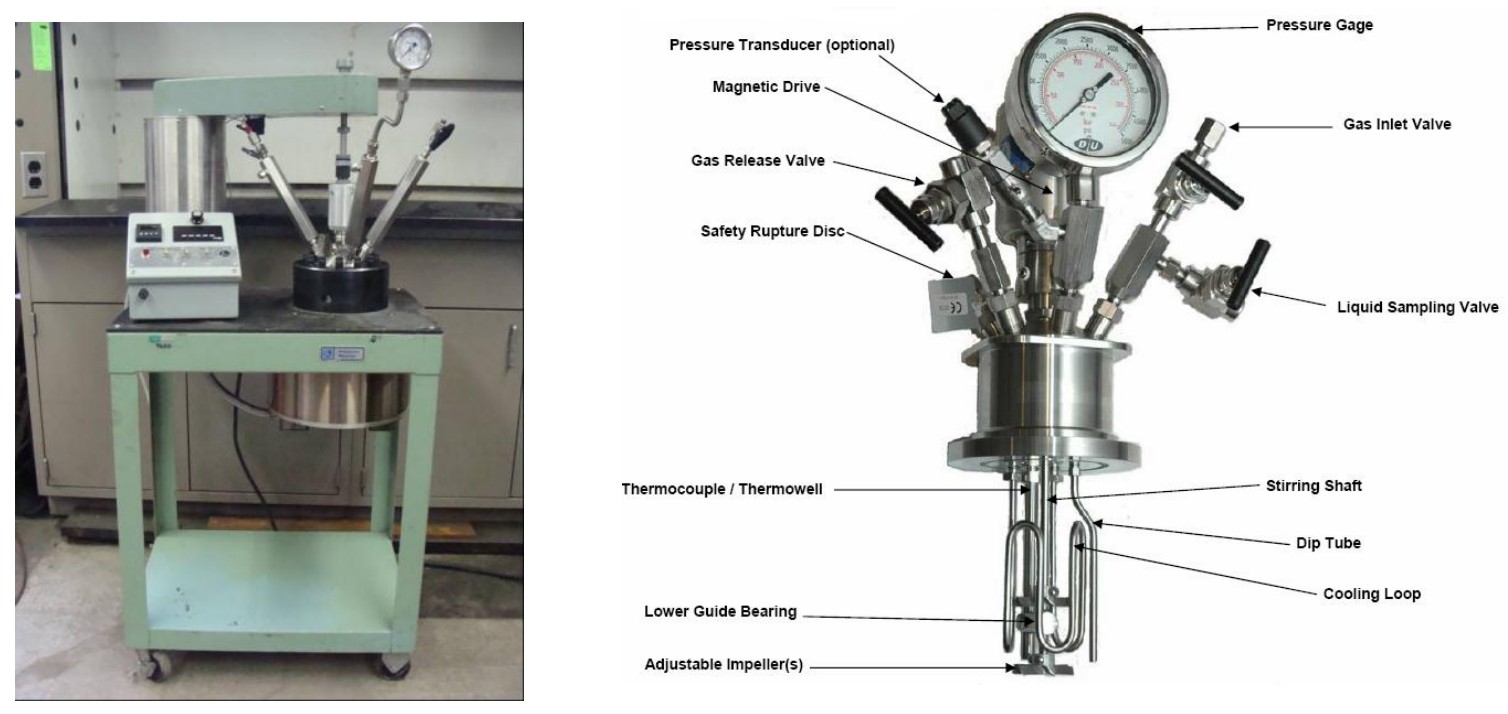

Figure 5-4. Photographs of a Parr autoclave reactor used for PC solution treatment under high-pressure $\mathrm{CO}_{2}$ gas.

\subsubsection{Experimental procedure}

Measurements of the reaction rates and equilibrium liquid compositions for the conversion of $\mathrm{K}_{2} \mathrm{CO}_{3}$ to $\mathrm{KHCO}_{3}$ were performed in a batch mode with respect to both the gas- and liquid-phase. In a typical experiment, $500 \mathrm{ml}$ of a $20 \mathrm{wt} \% \mathrm{~K}_{2} \mathrm{CO}_{3}$ solution with a CTB conversion ratio of $40 \%$ (PC20-40) was fed into the reactor. A pure $\mathrm{CO}_{2}$ gas stream was quickly introduced to the reactor at a desired pressure between 30.6 and $37.4 \mathrm{~atm}$ (between 450 and 550 psia). The stirrers (both at $350 \mathrm{rpm}$ ) were turned on, and the decrease in system's total pressure was recorded for 120 minutes. The experiment was repeated with PC solutions of different CTB conversion ratios.

When the system's pressure change was very small over long successive time intervals, a liquid sample of about 4 to $6 \mathrm{~mL}$ was extracted and added to an excess amount of $\mathrm{KOH}$ solution to convert $\mathrm{KHCO}_{3}$ and dissolved free $\mathrm{CO}_{2}$ in the bulk liquid sample into $\mathrm{K}_{2} \mathrm{CO}_{3}$. The titration method previously reported in Section 2.1.4) was employed to determine the total concentration of $\mathrm{KHCO}_{3}$ and dissolved free $\mathrm{CO}_{2}$ in the liquid mixture. The relative error of the titration method was estimated to be less than $2 \%$, as determined by analysis of standard solutions.

\subsubsection{Results and discussion}

The pressure change profiles recorded during the Parr reactor tests were used to calculate the rates of $\mathrm{CO}_{2}$ absorption into the $\mathrm{PC}$ solution using the following equation:

$$
J=\frac{d P_{C O_{2}, t}}{d t} \frac{V_{G}}{R T A}
$$

When $\mathrm{CO}_{2}$ is absorbed into the $\mathrm{PC}$ solution, the composition of the liquid changes. The ideal gas law and the principle of mass conservation between the gas and liquid phases were used to calculate the $\mathrm{CO}_{2}$ loading (indicated by the $\mathrm{CTB}$ conversion rate) of the PC solution. 
Rates of CTB conversion in the PC solutions at room temperature and elevated $\mathrm{CO}_{2}$ pressures are shown in Figure 5-5. The CTB conversion rate of the PC solution in the legend was an average value estimated over the pressure-changing process. For example, the $47 \%$ legend corresponds to the average $\mathrm{CTB}$ conversion rate ranging from 44 to $50 \%$. It can be seen that the reaction rates were rapid (between $6 \times 10^{-3}$ and $1 \times 10^{-2} \mathrm{~mole} / \mathrm{m}^{2} \mathrm{~s}$ ) when the CTB conversion rates were lower than $71 \%$. At higher CTB conversion levels, the reactions rates were significantly lowered. That tendency became more significant when the average CTB conversion rate reached $89 \%$.

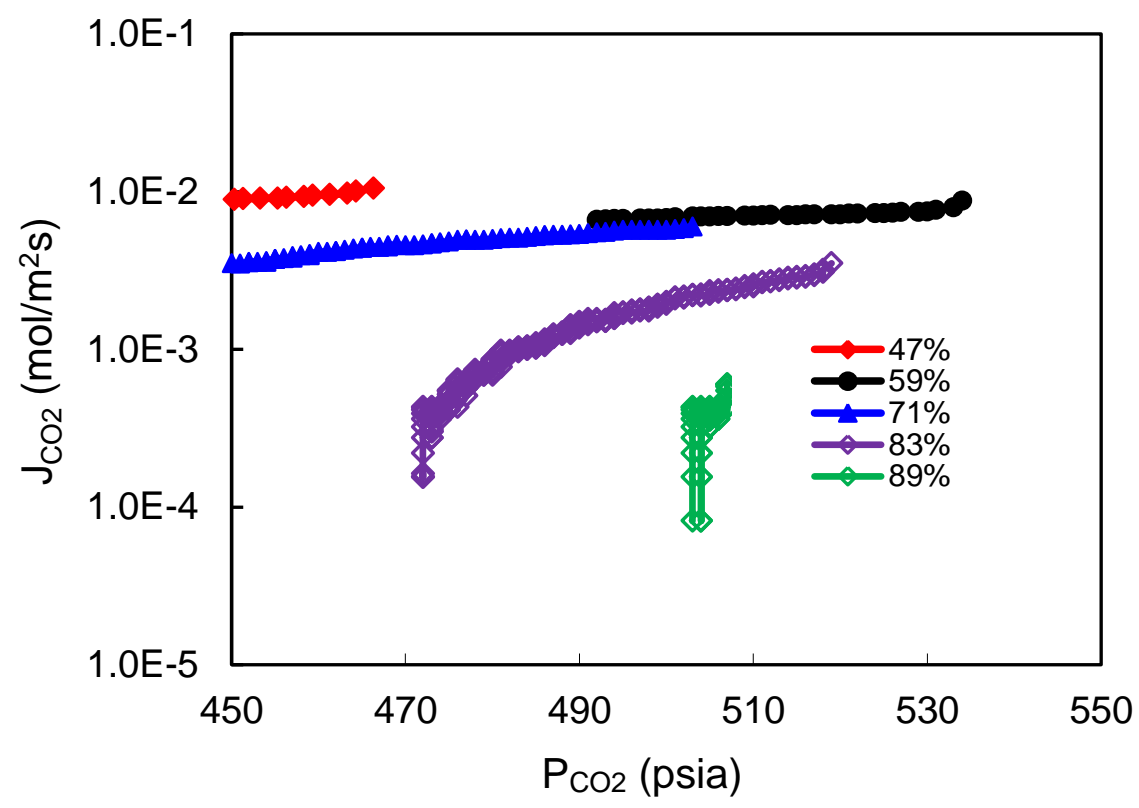

Figure 5-5. Rates of $\mathrm{CO}_{2}$ absorption into $20 \mathrm{wt} \%$ PC solution at room temperature and elevated $\mathrm{CO}_{2}$ pressures.

After the system reached the equilibrium state at about 34 atm (500psia), a liquid sample was withdrawn and added to an excess amount of $\mathrm{KOH}$ solution for titration to determine the liquid composition. The $\mathrm{CO}_{3}{ }^{2-}$ concentration was determined as $0.025 \mathrm{~mol} / \mathrm{L}$ based on the measured sum of the concentrations of $\mathrm{KHCO}_{3}$ and free dissolved $\mathrm{CO}_{2}$ in the liquid sample, and the assumption that carbonaceous species in the liquid were at equilibrium concentrations. In comparison, the initial $20 \mathrm{wt} \% \mathrm{PC}$ solution contained $1.69 \mathrm{~mol} / \mathrm{L} \mathrm{K}_{2} \mathrm{CO}_{3}$ (equivalent). The final liquid composition was thus equivalent to a $98.5 \%$ CTB conversion rate. It should be noted that two uncertainties may be associated with the sampling process. One is that the liquid composition in the reactor vessel might change when equilibrium is disturbed by lowering the pressure during sample withdrawal; the other is that the dissolved $\mathrm{CO}_{2}$ gas in the liquid sample might release and thus not completely react with the $\mathrm{KOH}$ solution when exposed to ambient atmospheric pressure. However, these two possible concerns would lead to a more conservative estimate on the CTB conversion rate. The actual CTB conversion rate, thus, could not be lower than the value obtained by the titration $(98.5 \%)$.

The fact that more than $98.5 \%$ of the $\mathrm{K}_{2} \mathrm{CO}_{3}$ in the initial PC solution was converted to $\mathrm{KHCO}_{3}$ at room temperature and about $34 \mathrm{~atm}(500 \mathrm{psia}) \mathrm{CO}_{2}$ pressure indicated that applying highpressure $\mathrm{CO}_{2}$ reduced the $\mathrm{CO}_{3}{ }^{2-}$ concentration in the $\mathrm{PC}$ solution. Batch experiments at 
atmospheric pressure revealed that competitive precipitations of $\mathrm{CaSO}_{4}$ and $\mathrm{CaCO}_{3}$ strongly depended on the $\mathrm{SO}_{4}{ }^{2-} / \mathrm{CO}_{3}{ }^{2}$ ratio in the solution, and a high $\mathrm{SO}_{4}{ }^{2-} / \mathrm{CO}_{3}{ }^{2-}$ ratio would kinetically favor the precipitation of $\mathrm{CaSO}_{4}$. It is expected that the ratio of $\mathrm{SO}_{4}{ }^{2-} / \mathrm{CO}_{3}{ }^{2-}$ can be significantly increased by using a high-pressure $\mathrm{CO}_{2}$ stream to lower $\mathrm{CO}_{3}{ }^{2-}$ concentration in the $\mathrm{PC}$ solution.

\subsection{Semi-continuous test for reclaiming $\mathrm{K}_{2} \mathrm{SO}_{4}$ from simulated absorption solutions}

\subsubsection{Experimental procedure}

The high-pressure Parr stirred reactor described earlier was used in this series of experiments. The reactor was operated in a semi-continuous mode: continuous with respect to the $\mathrm{CO}_{2}$ gas flow and batch with respect to the liquid phase. In a typical experiment, $500 \mathrm{ml}$ of the PC solution with the desired composition of $\mathrm{K}_{2} \mathrm{CO}_{3}, \mathrm{KHCO}_{3}$, and $\mathrm{K}_{2} \mathrm{SO}_{4}$ was fed to the reactor. The stirrers for the gas and liquid phase (both at $350 \mathrm{rpm}$ ) were turned on and a pure $\mathrm{CO}_{2}$ gas stream at 37.4 atm (550 psia) was introduced to the reactor. When the pressure inside the reactor reached $37.4 \mathrm{~atm}$ (550 psia), the system was allowed to reach an equilibrium state, which usually took about 5 hours. Once equilibrium was reached, a known amount of $\mathrm{CaCl}_{2}$ or $\mathrm{Ca}(\mathrm{OH})_{2}$ solution was added to the reactor, while the $\mathrm{CO}_{2}$ gas purged the reactor. After about 1 hour reaction time, a liquid sample of 100-200 $\mathrm{mL}$ was extracted and immediately filtered using a 0.2 $\mu \mathrm{m}$ Whatman nylon membrane filter. The solid retentate was collected, air-dried at $80^{\circ} \mathrm{C}$ $\left(176^{\circ} \mathrm{F}\right)$, and analyzed for composition using powder X-Ray Diffraction (XRD) (Siemens-Bruker D5000).

\subsubsection{Experiment conditions}

Table 5-1. Test matrix for semi-continuous sulfate reclamation experiments

\begin{tabular}{|c|c|c|c|c|}
\hline \multirow[b]{2}{*}{ Group } & \multicolumn{3}{|c|}{ Initial PC solution } & \multirow[b]{2}{*}{$\begin{array}{l}\mathrm{Ca}^{2+} \text { containing } \\
\text { reactant }\end{array}$} \\
\hline & $\begin{array}{l}\text { Weight or molar } \\
\text { conc. (\%wt or } \mathrm{M} \text {, } \\
\mathrm{K}_{2} \mathrm{CO}_{3} \text {-equvalent) }\end{array}$ & $\begin{array}{c}\text { Initial CTB } \\
\text { conv. rate }(\%)\end{array}$ & $\mathrm{K}_{2} \mathrm{SO}_{4}(\mathrm{M})$ & \\
\hline \multirow{3}{*}{ I. High concentration PC } & $20 \%(1.8 \mathrm{M})$ & $40 \%$ & $0.1 \mathrm{M}$ & $0.1 \mathrm{M} \mathrm{Ca}(\mathrm{OH})_{2}$ \\
\hline & $20 \%(1.8 \mathrm{M})$ & $40 \%$ & $0.1 \mathrm{M}$ & $0.1 \mathrm{M} \mathrm{CaCl}_{2}$ \\
\hline & $20 \%(1.8 \mathrm{M})$ & $90 \%$ & $0.3 \mathrm{M}$ & $0.3 \mathrm{M} \mathrm{Ca}(\mathrm{OH})_{2}$ \\
\hline \multirow{3}{*}{$\begin{array}{l}\text { II. Moderate } \\
\text { concentration PC }\end{array}$} & $10 \%(0.9 \mathrm{M})$ & $80 \%$ & $0.25 \mathrm{M}$ & $0.25 \mathrm{M} \mathrm{CaCl}_{2}$ \\
\hline & $5.4 \%(0.49 \mathrm{M})$ & $90 \%$ & $0.4 \mathrm{M}$ & $0.4 \mathrm{M} \mathrm{CaCl}_{2}$ \\
\hline & $5 \%(0.45 \mathrm{M})$ & $100 \%$ & $0.4 \mathrm{M}$ & $0.4 \mathrm{M} \mathrm{CaCl}_{2}$ \\
\hline \multirow{5}{*}{$\begin{array}{l}\text { III. Low concentration } \\
\text { PC }\end{array}$} & $2.7 \%(0.2 \mathrm{M})$ & $100 \%$ & $0.4 \mathrm{M}$ & $0.2 \mathrm{M} \mathrm{CaCl}_{2}$ \\
\hline & $2.7 \%(0.2 \mathrm{M})$ & $100 \%$ & $0.4 \mathrm{M}$ & $0.2 \mathrm{M} \mathrm{Ca}(\mathrm{OH})_{2}$ \\
\hline & $2.7 \%(0.2 \mathrm{M})$ & $80 \%$ & $0.4 \mathrm{M}$ & $0.2 \mathrm{M} \mathrm{CaCl}_{2}$ \\
\hline & $2.7 \%(0.2 \mathrm{M})$ & $80 \%$ & $0.4 \mathrm{M}$ & $0.2 \mathrm{M} \mathrm{Ca}(\mathrm{OH})_{2}$ \\
\hline & $2.7 \%(0.2 \mathrm{M})$ & $80 \%$ & $0.2 \mathrm{M}$ & $0.2 \mathrm{M} \mathrm{Ca}(\mathrm{OH})_{2}$ \\
\hline IV. PC+ $300 \mathrm{mg} / \mathrm{L}$ ACA1 & $2.7 \%(0.2 \mathrm{M})$ & $80 \%$ & $0.4 \mathrm{M}$ & $0.2 \mathrm{M} \mathrm{Ca}(\mathrm{OH})_{2}$ \\
\hline IV. $\mathrm{PC}+1 \% \mathrm{~K}_{2} \mathrm{VO}_{3}$ & $2.7 \%(0.2 \mathrm{M})$ & $80 \%$ & $0.4 \mathrm{M}$ & $0.2 \mathrm{M} \mathrm{Ca}(\mathrm{OH})_{2}$ \\
\hline
\end{tabular}

Four groups of experiments were carried out to identify the impact of solution conditions on the competitive precipitation of $\mathrm{CaSO}_{4}$ and $\mathrm{CaCO}_{3}$, as shown in Table 5-1. All of the experiments were performed at ambient temperatures using a stoichiometric amount of $\mathrm{CaCl}_{2}$ or $\mathrm{Ca}(\mathrm{OH})_{2}$ to 
$\mathrm{K}_{2} \mathrm{SO}_{4}$. Group I experiments employed $20 \mathrm{wt} \%$ PC solutions with different initial CTB conversion levels (40 and $90 \%)$ and $\mathrm{K}_{2} \mathrm{SO}_{4}$ concentrations $(0.1$ and $0.3 \mathrm{M})$. Group II experiments were conducted using PC solutions with concentrations of 5 to $10 \mathrm{wt} \%$, initial CTB conversion levels of greater than $80 \%$, and $\mathrm{K}_{2} \mathrm{SO}_{4}$ concentration of $0.4 \mathrm{M}$.

In Group III experiments, $2.7 \mathrm{wt} \%(0.2 \mathrm{M}) \mathrm{PC}$ solutions with 80 and $100 \%$ initial CTB conversion rates and containing 0.2 or $0.4 \mathrm{M} \mathrm{K}_{2} \mathrm{SO}_{4}$ were used. In Group IV, two catalysts/additives (i.e., $300 \mathrm{mg} / \mathrm{L}$ ACA1 enzyme or $1 \mathrm{wt} \% \mathrm{~K}_{2} \mathrm{VO}_{3}$ ) were also added to the $0.2 \mathrm{M}$ PC solution with the $80 \%$ initial CTB conversion rate containing $0.4 \mathrm{M} \mathrm{K}_{2} \mathrm{SO}_{4}$, because these two catalysts/additives were identified to be efficient in promoting the absorption of $\mathrm{CO}_{2}$ into $\mathrm{PC}$ solutions.

\subsubsection{Results and discussion}

\subsubsection{Sulfate reclamation from simulated PC solutions without additives}

As previously described, a high $\mathrm{SO}_{4}{ }^{2-} / \mathrm{CO}_{3}{ }^{2-}$ ratio would kinetically favor the competitive precipitation of $\mathrm{CaSO}_{4}$ over $\mathrm{CaCO}_{3}$ in the presence of $\mathrm{Ca}^{2+}$. In principle, the bulk of $\mathrm{CO}_{3}{ }^{2-}$ ions in the $\mathrm{PC}$ solution should be converted to $\mathrm{HCO}_{3}{ }^{-}$under high-pressure $\mathrm{CO}_{2}$ conditions, resulting in a reduced $\mathrm{CO}_{3}{ }^{2-}$ concentration. In the IVCAP, the concentration level of $\mathrm{SO}_{4}{ }^{2-}$ in the $\mathrm{CO}_{2}$-rich solution could be maintained at a level ranging between 0.1 and $1 \mathrm{~mol} / \mathrm{L}$ by controlling the ratio of the liquid flow withdrawn for sulfate reclamation to the main flow. The concentration of $\mathrm{CO}_{3}{ }^{2-}$ highly depends on the equilibrated $\mathrm{CTB}$ conversion level and the total $\mathrm{K}_{2} \mathrm{CO}_{3} / \mathrm{KHCO}_{3}$ concentration. Thus, the total PC concentration, initial CTB conversion rate, and $\mathrm{K}_{2} \mathrm{SO}_{4}$ concentration were chosen as key parameters for the competitive precipitation study. The objective was to seek the optimal solution composition for producing a precipitate with a high $\mathrm{CaSO}_{4}$ yield.

Group I experiments employed a $20 \mathrm{wt} \% \mathrm{PC}-40 \%$ initial CTB conversion $+0.1 \mathrm{M} \mathrm{K}_{2} \mathrm{SO}_{4}+$ $0.1 \mathrm{M} \mathrm{Ca}(\mathrm{OH})_{2}$ system (denoted as $20 \% \mathrm{PC}-40 \%$ CTB-0.1M K $\mathrm{K}_{2} \mathrm{SO}_{4}+0.1 \mathrm{M} \mathrm{Ca}(\mathrm{OH})_{2}$ and so forth). The XRD pattern of the precipitate sample obtained from this experiment showed that the precipitate contained both vaterite (a less stable $\mathrm{CaCO}_{3}$ phase than calcite) as the predominant form, and a lesser amount of calcite; crystalline $\mathrm{CaSO}_{4}$ was not observed (see Figure 5-6). Even when the initial CTB conversion level was increased to $90 \%$ and the concentration of $\mathrm{K}_{2} \mathrm{SO}_{4}$ was increased from 0.1 to $0.3 \mathrm{M}$, no $\mathrm{CaSO}_{4}$ phase was detected based on the XRD analysis of the precipitates from the Group I experiments (XRD data not shown).

To further increase the $\mathrm{SO}_{4}{ }^{2-} / \mathrm{CO}_{3}{ }^{2-}$ concentration ratio in the Group II experiments, the overall PC solution concentrations were lowered to 10, 5.4, and 5\%, while the $100 \%$ initial CTB conversion level and $0.4 \mathrm{M} \mathrm{K}_{2} \mathrm{SO}_{4}$ were employed. $\mathrm{A} \mathrm{CaCl}_{2}$ solution instead of $\mathrm{Ca}(\mathrm{OH})_{2}$ was used, because $\mathrm{Ca}(\mathrm{OH})_{2}$ might cause some of the $\mathrm{HCO}_{3}{ }^{-}$to revert to $\mathrm{CO}_{3}{ }^{2-}$. However, the XRD patterns of all the precipitate samples from the Group II experiments showed that forms of $\mathrm{CaCO}_{3}$ were still the dominant crystal phase (XRD data not shown). These results indicated that the overall PC concentration might be a critical factor preventing the precipitation of $\mathrm{CaSO}_{4}$ over $\mathrm{CaCO}_{3}$, because the equilibrated $\mathrm{CO}_{3}{ }^{2-}$ concentration in the $\mathrm{PC}$ solution increases with increasing PC concentration. 


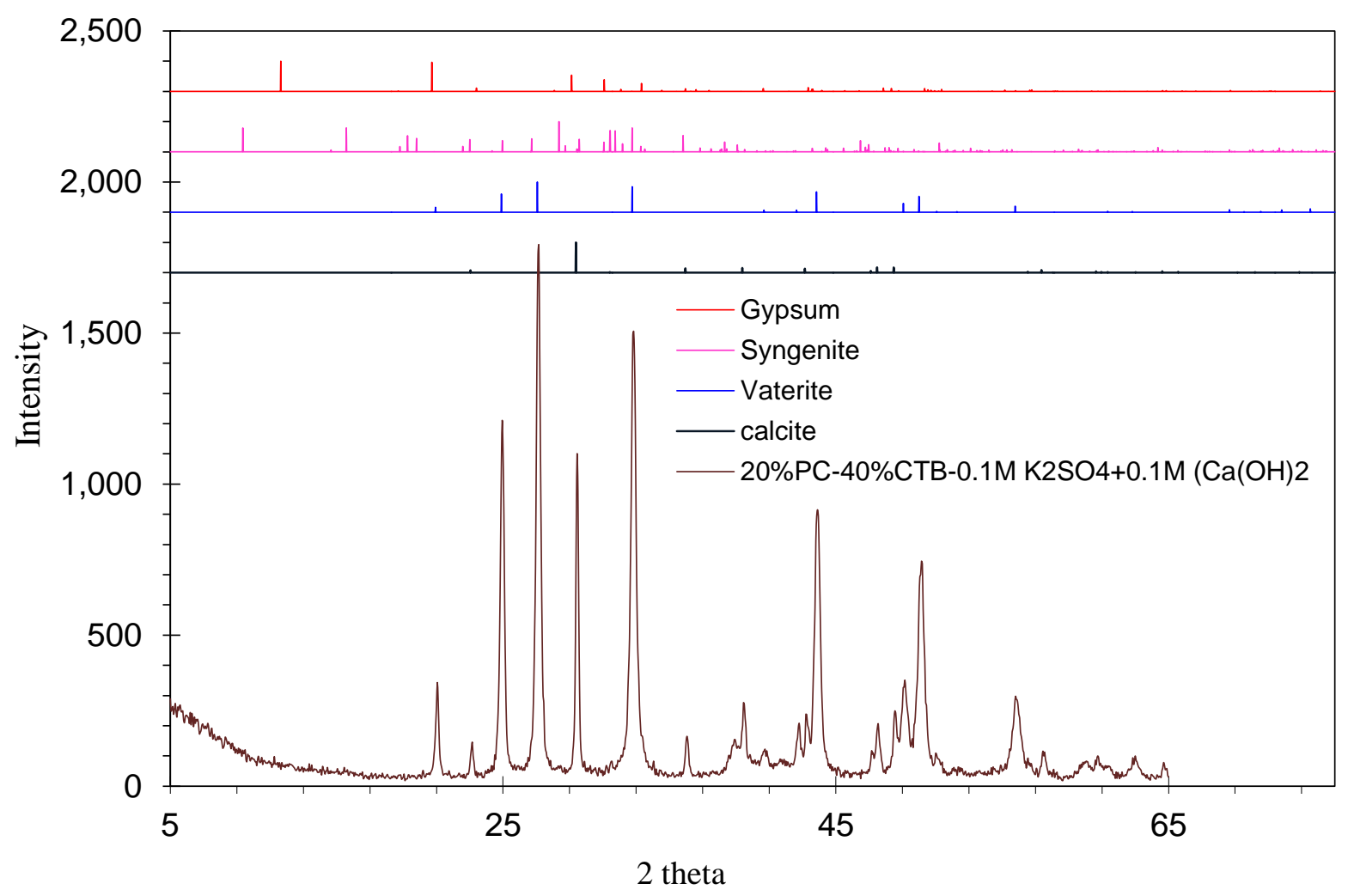

Figure 5-6. XRD patterns of precipitate particles from the $20 \%$ PC- $40 \%$ CTB- $0.1 \mathrm{M} \mathrm{K}_{2} \mathrm{SO}_{4}+0.1 \mathrm{M}$ $\mathrm{Ca}(\mathrm{OH})_{2}$ experiment.

Based on the results from the Group II experiments, the PC concentration in the Group III experiments was lowered to $0.2 \mathrm{M}$ while the concentration of $\mathrm{K}_{2} \mathrm{SO}_{4}$ was kept at $0.4 \mathrm{M}$. Figure 5-7 shows the XRD patterns of the precipitate samples produced in the $0.2 \mathrm{M}$ PC solutions. The XRD patterns demonstrated the presence of syngenite $\left(\mathrm{K}_{2} \mathrm{Ca}\left(\mathrm{SO}_{4}\right)_{2} \cdot \mathrm{H}_{2} \mathrm{O}\right)$ and gypsum $\left(\mathrm{CaSO}_{4} \cdot 2 \mathrm{H}_{2} \mathrm{O}\right)$ phases. The composition of the precipitate particles was estimated based on a quantitative XRD analysis method, as shown in Table 5-2. When $0.2 \mathrm{M} \mathrm{CaCl}_{2}$ or $0.2 \mathrm{M} \mathrm{Ca}(\mathrm{OH})_{2}$ was used with the $0.2 \mathrm{M} \mathrm{PC}$ and $0.4 \mathrm{M} \mathrm{K}_{2} \mathrm{SO}_{4}$ mixture solution with $100 \%$ initial CTB conversion (denoted as $0.2 \mathrm{M}$ PC- $100 \%$ CTB- $0.4 \mathrm{M} \mathrm{K}_{2} \mathrm{SO}_{4}+0.2 \mathrm{M} \mathrm{CaCl}_{2}$ and $0.2 \mathrm{M}$ PC- $100 \%$ CTB-0.4M K $\left.\mathrm{K}_{2} \mathrm{SO}_{4}+0.2 \mathrm{M} \mathrm{Ca}(\mathrm{OH})_{2}\right)$, the content of syngenite in the precipitate products was about 45.2 and $38.8 \%$, respectively; the balance of the precipitate was $\mathrm{CaCO}_{3}$ ). It is concluded that employing $\mathrm{Ca}(\mathrm{OH})_{2}$ solution did not significantly reduce the content of syngenite in the precipitate relative to the amount formed using $\mathrm{CaCl}_{2}$ as a source of calcium in the solution. 


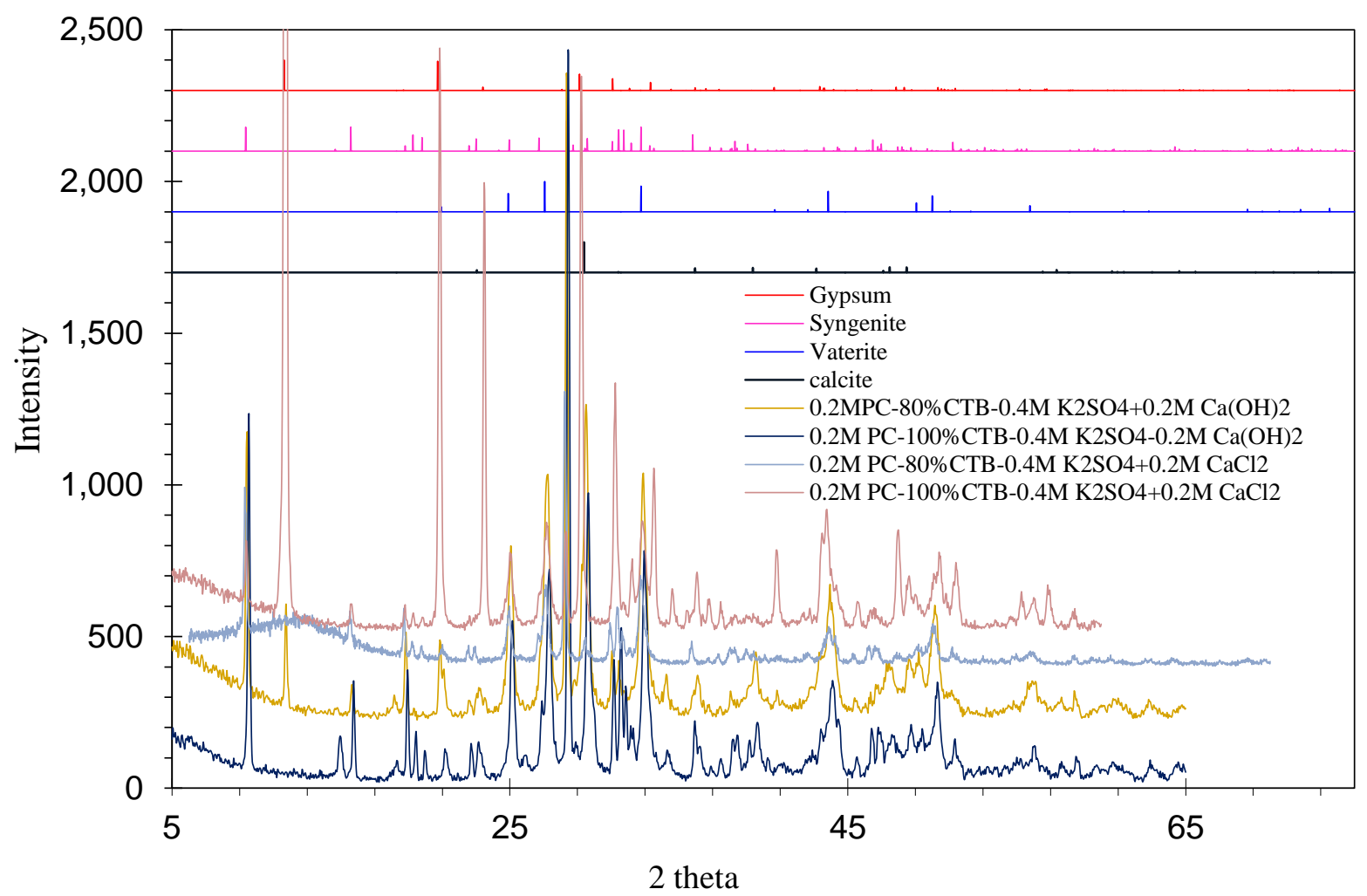

Figure 5-7. XRD patterns of precipitates reclaimed in $0.2 \mathrm{M}$ PC solutions.

To investigate the impact of the initial CTB conversion level of the PC solution, an $80 \%$ initial CTB level was used instead of $100 \%$ in some of the Group III experiments. It was found that the amount of syngenite in the precipitates was comparable, as shown in Table 5-2. These results demonstrated that the initial CTB conversion rate of the PC solution was not an important factor for the competitive precipitation of $\mathrm{CaSO}_{4} \cdot 2 \mathrm{H}_{2} \mathrm{O}$ since the equilibrated $\mathrm{CO}_{3}{ }^{2-}$ concentration would be attained by the high-pressure $\mathrm{CO}_{2}$ gas stream, regardless of the initial $\mathrm{CO}_{3}{ }^{2-}$ concentration. To reduce the time to reach an equilibrium state, the $80 \%$ initial CTB conversion level was used in all the following experiments. It is anticipated that similar results will be achieved when a lower initial CTB conversion level, such as $40 \%$, is used.

Table 5-2. Compositions of precipitate samples reclaimed from 0.2 M PC solution

\begin{tabular}{|c|c|c|c|c|c|}
\hline \multirow[b]{2}{*}{ Group } & \multicolumn{3}{|c|}{ Initial PC solution } & \multirow[b]{2}{*}{$\begin{array}{c}\mathrm{Ca}^{2+} \text {-containing } \\
\text { reactant }\end{array}$} & \multirow[b]{2}{*}{ Product composition } \\
\hline & $\begin{array}{c}\mathrm{K}_{2} \mathrm{CO}_{3} \text {-equv. } \\
\text { concentration } \\
(\mathrm{M})\end{array}$ & $\begin{array}{c}\text { Initial CTB } \\
\text { conv. rate } \\
(\%)\end{array}$ & $\mathrm{K}_{2} \mathrm{SO}_{4}(\mathrm{M})$ & & \\
\hline \multirow{4}{*}{$\begin{array}{l}\text { III: low conc. } \\
\text { PC }\end{array}$} & $0.2 \mathrm{M}$ & $100 \%$ & $0.4 \mathrm{M}$ & $0.2 \mathrm{M} \mathrm{CaCl}_{2}$ & $45.2 \%$ syngenite \\
\hline & $0.2 \mathrm{M}$ & $100 \%$ & $0.4 \mathrm{M}$ & $0.2 \mathrm{M} \mathrm{Ca}(\mathrm{OH})_{2}$ & $38.8 \mathrm{wt} \%$ syngenite \\
\hline & $0.2 \mathrm{M}$ & $80 \%$ & $0.4 \mathrm{M}$ & $0.2 \mathrm{M} \mathrm{CaCl}_{2}$ & $46.9 \%$ syngenite \\
\hline & $0.2 \mathrm{M}$ & $80 \%$ & $0.4 \mathrm{M}$ & $0.2 \mathrm{M} \mathrm{Ca}(\mathrm{OH})_{2}$ & $\begin{array}{l}4.3 \% \text { gypsum }+ \\
15.2 \% \text { syngenite }\end{array}$ \\
\hline $\begin{array}{l}\mathrm{IV}: \mathrm{PC}+300 \\
\mathrm{mg} / \mathrm{L} \mathrm{CA}\end{array}$ & $0.2 \mathrm{M}$ & $80 \%$ & $0.4 \mathrm{M}$ & $0.2 \mathrm{M} \mathrm{Ca}(\mathrm{OH})_{2}$ & $45 w t \%$ syngenite \\
\hline $\begin{array}{l}\text { IV: } \mathrm{PC}+1 \% \\
\mathrm{KVO}_{3}\end{array}$ & $0.2 \mathrm{M}$ & $80 \%$ & $0.4 \mathrm{M}$ & $0.2 \mathrm{M} \mathrm{Ca}(\mathrm{OH})_{2}$ & $\begin{array}{l}11.8 \mathrm{wt} \% \text { gypsum + } \\
26.6 \mathrm{wt} \% \text { syngenite }\end{array}$ \\
\hline
\end{tabular}




\subsubsection{Impact of catalysts and additives on sulfate reclamation}

The CA enzyme and $\mathrm{KVO}_{3}$ were previously identified as efficient catalysts to promote the absorption of $\mathrm{CO}_{2}$ into $\mathrm{PC}$ solution. Employing these catalysts/additives may significantly reduce the time to attain the equilibrium state desired for minimizing the $\mathrm{CO}_{3}{ }^{2-}$ concentration under a high-pressure $\mathrm{CO}_{2}$ gas stream. To investigate the impact of these two catalysts/additives on sulfate reclamation, either $300 \mathrm{mg} / \mathrm{L}$ of the ACA1 enzyme or $1 \mathrm{wt} \% \mathrm{KVO}_{3}$ was added to the 0.2 M PC $+0.4 \mathrm{M} \mathrm{K}_{2} \mathrm{SO}_{4}$ solution with the $80 \%$ initial CTB conversion level. The XRD patterns of the precipitate samples from these two solution systems are shown in Figure 5-8. As shown in Table 5-2, the quantitative interpretations of the XRD patterns revealed that the precipitate from the solution containing the CA enzyme contained $45 \mathrm{wt} \%$ syngenite, while that containing $1 \mathrm{wt} \%$ $\mathrm{KVO}_{3}$ contained $11.8 \mathrm{wt} \%$ gypsum and $26.6 \mathrm{wt} \%$ syngenite. Without a catalyst present, the contents of gypsum and syngenite in the precipitates produced by otherwise similar solutions were slightly lower, indicating that the presence of either $300 \mathrm{mg} / \mathrm{L} \mathrm{CA}$ enzyme or $1 \% \mathrm{KVO}_{3}$ catalyst slightly favored the sulfate reclamation.

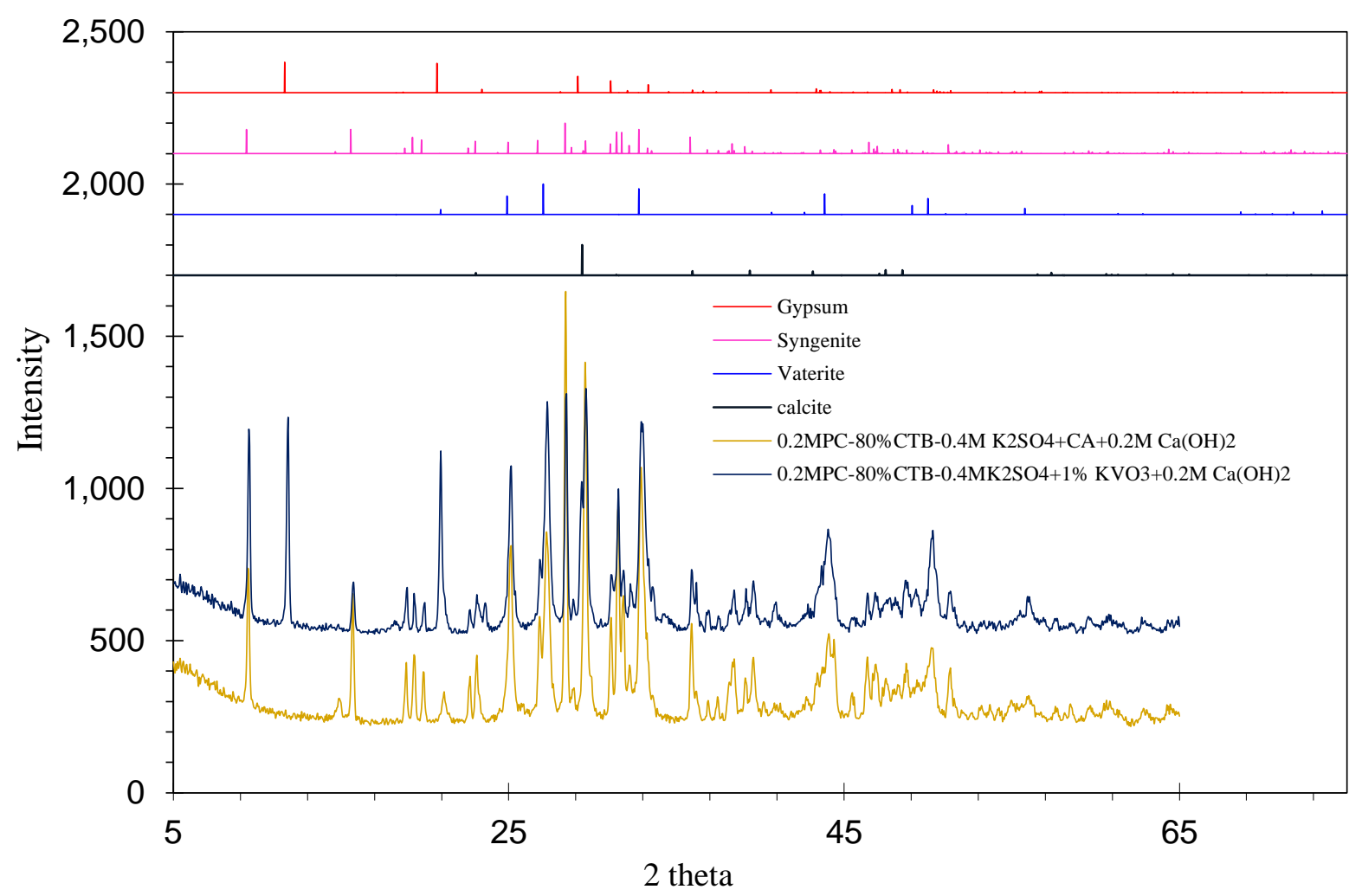

Figure 5-8. XRD patterns of precipitates reclaimed from the $0.2 \mathrm{M} \mathrm{PC}$ solution containing $300 \mathrm{mg} / \mathrm{L} \mathrm{CA}$ enzyme or $1 \mathrm{wt} \% \mathrm{KVO}_{3}$.

\subsection{Process modifications}

Modification (I) for combining $\mathrm{SO}_{2}$ removal in IVCAP. The originally proposed process concept (Figure 5-1) was intended to achieve a high $\mathrm{SO}_{4}{ }^{2-} / \mathrm{CO}_{3}{ }^{2-}$ ratio by reducing the $\mathrm{CO}_{3}{ }^{2-}$ concentration in the solution using a high-pressure $\mathrm{CO}_{2}$ gas stream to kinetically favor the 
competitive precipitation of $\mathrm{CaSO}_{4}$ over $\mathrm{CaCO}_{3}$. However, results from the semi-continuous tests showed that vaterite, instead of gypsum or syngenite, was the only crystal phase in the precipitates from the 5 to $20 \mathrm{wt} \%$ PC solutions. However, in the IVCAP, the $20 \mathrm{wt} \%$ PC solution is the one most favored as a solvent for $\mathrm{CO}_{2}$ absorption.

Therefore, as shown in Figure 5-9, a modified process concept (I) was proposed to remove $\mathrm{SO}_{2}$. The $\mathrm{SO}_{2}$ absorption and sulfate reclamation follow the same principle as described in Reactions (R7-R9). However, here the $\mathrm{SO}_{2}$ is absorbed into a different PC solution in a separate absorber prior to $\mathrm{CO}_{2}$ capture. After $\mathrm{SO}_{2}$ absorption, if necessary, the $\mathrm{SO}_{2}$-rich solution is treated with a high-pressure $\mathrm{CO}_{2}$ stream to convert $\mathrm{CO}_{3}{ }^{2-}$ to $\mathrm{HCO}_{3}{ }^{-}$. The solution with the minimal $\mathrm{CO}_{3}{ }^{2-}$ concentration then reacts with lime to precipitate $\mathrm{CaSO}_{4}$ and regenerate the solution. Since potassium losses are incurred due to losses in the precipitate cake and reactions with $\mathrm{SO}_{2}$, the scrubbing solution is made up by introducing a small slipstream of $\mathrm{CO}_{2}$-rich solution from the IVCAP.

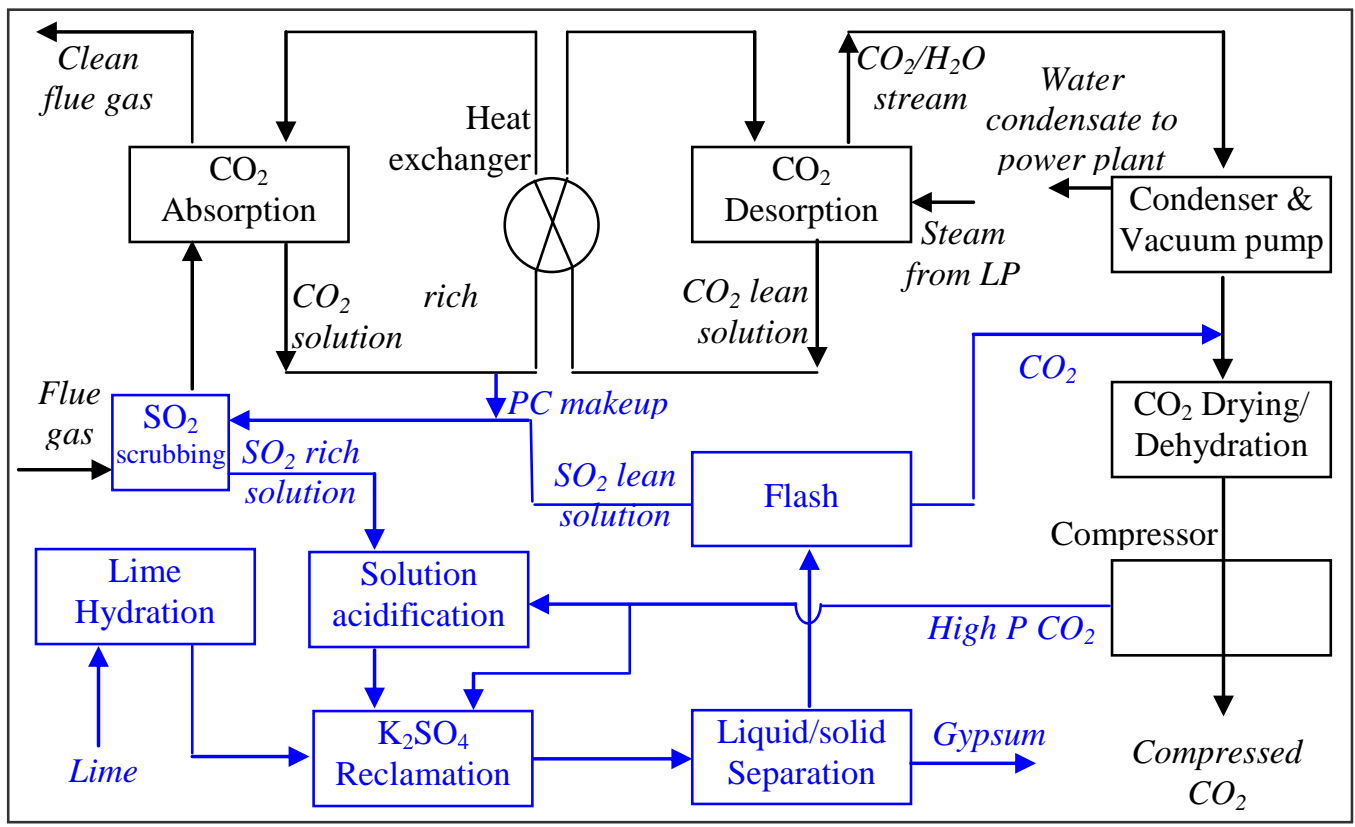

Figure 5-9. Modified process concept I for combined $\mathrm{SO}_{2}$ removal and $\mathrm{CO}_{2}$ capture in the IVCAP.

The $\mathrm{SO}_{2}$ scrubbing in the modified process (I) is partly decoupled from $\mathrm{CO}_{2}$ absorption, allowing the use of a different PC solution with a concentration lower than $0.2 \mathrm{M} \mathrm{PC}$ (less than 3 wt\%) and a high CTB conversion level (much higher than $40 \% \mathrm{CTB}$ conversion as in the $\mathrm{CO}_{2}$-rich solution). Based on the above experimental results, for the low-concentration PC solution, a precipitate containing a significant portion of syngenite and gypsum can potentially be obtained. On the other hand, the concentration of $\mathrm{CO}_{3}{ }^{2-}$ may not need to be further reduced using a highpressure $\mathrm{CO}_{2}$ gas stream for the PC solution with a high CTB conversion rate.

In a commercial Limestone Forced Oxidation Scrubbing (LFOS) process, the $\mathrm{pH}$ of the limestone slurry ranges within 5 to 6 . Therefore, the PC solution at a low concentration and high CTB conversion employed in the modified process (I) can be used for $\mathrm{SO}_{2}$ absorption with a high efficiency, because such a solution still has great alkalinity $(\mathrm{pH}>8.0)$. 
The modified process employs dual-alkali for $\mathrm{SO}_{2}$ removal. The $\mathrm{PC}$ solution $\left(\mathrm{KHCO}_{3}\right.$ and $\mathrm{K}_{2} \mathrm{CO}_{3}$ ) absorbs $\mathrm{SO}_{2}$ and lime is used to regenerate the spent solution. The modification is comparable in principle to the dual-alkali FGD process commercially deployed, but operates under different conditions. The commercial dual-alkali FGD process uses sodium, instead of potassium salts to only remove $\mathrm{SO}_{2}$ in flue gas. $\mathrm{SO}_{2}$ is removed by reactions with sodium sulfite $\left(\mathrm{Na}_{2} \mathrm{SO}_{3}\right)$ and bicarbonate $\left(\mathrm{NaHCO}_{3}\right)$ in the scrubber at a bleed $\mathrm{pH}$ of 5.7 to $6.0:{ }^{[3,4]}$

$$
\begin{aligned}
& \mathrm{NaHCO}_{3}+\mathrm{SO}_{2} \rightarrow \mathrm{NaHSO}_{3}+\mathrm{CO}_{2} \\
& \mathrm{Na}_{2} \mathrm{SO}_{3}+\mathrm{SO}_{2}+\mathrm{H}_{2} \mathrm{O} \rightarrow 2 \mathrm{NaHSO}_{3}
\end{aligned}
$$

The spent scrubbing solution is regenerated by reactions with lime or limestone at $\mathrm{pH}$ from 6.0 to 6.4. The precipitate includes mixed calcium sulfite and sulfate solids. The regeneration process involves the following overall reactions:

$$
\begin{aligned}
& 2 \mathrm{NaHSO}_{3}+\mathrm{Ca}(\mathrm{OH})_{2} \rightarrow \mathrm{Na}_{2} \mathrm{SO}_{3}+\mathrm{CaSO}_{3} \cdot 1 / 2 \mathrm{H}_{2} \mathrm{O}_{\downarrow}+3 / 2 \mathrm{H}_{2} \mathrm{O} \\
& \mathrm{Ca}^{2+}+\mathrm{SO}_{4}^{2-}+x \mathrm{H}_{2} \mathrm{O} \rightarrow \mathrm{CaSO}_{4} \cdot \mathrm{HH}_{2} \mathrm{O}_{\downarrow}
\end{aligned}
$$

In this modified process, $\mathrm{SO}_{2}$ scrubbing can operate at a $\mathrm{pH}$ higher than that in the commercial dual-alkali FGD process. As a result, a higher efficiency can be achieved for $\mathrm{SO}_{2}$ removal. In addition, if necessary, the modified process can use high-pressure $\mathrm{CO}_{2}$ to facilitate the sulfate regeneration process. However, a more detailed analysis is needed to investigate its economic feasibility compared to the LSFO and dual-alkali FGD processes when $\mathrm{CO}_{2}$ capture is applied.

Modification (II) for combining $\mathrm{SO}_{2}$ removal in IVCAP. A second alternative process concept is also proposed to include $\mathrm{SO}_{2}$ removal in the IVCAP by taking advantaging of the solubility differences amongst different potassium salts present in the absorbing solution. The published solubility limits of the three potassium salts $-\mathrm{K}_{2} \mathrm{CO}_{3}, \mathrm{KHCO}_{3}$, and $\mathrm{K}_{2} \mathrm{SO}_{4}$ - in water are listed in Table 5-3. The solubility of $\mathrm{K}_{2} \mathrm{SO}_{3}$ is not available in the literature, but is much higher than that of $\mathrm{K}_{2} \mathrm{SO}_{4}$. From the table, the solubility of $\mathrm{K}_{2} \mathrm{SO}_{4}$ is the smallest. The concentrations of $\mathrm{K}_{2} \mathrm{CO}_{3}$ and $\mathrm{KHCO}_{3}$ in the $\mathrm{CO}_{2}$-rich PC solution (such as $\mathrm{PC} 20-40$ ) are much lower than their solubility limits even at room temperatures. Although the absolute solubility limits of these salts in their combined solution will be different from the individual component solutions due to the impact of liquid activity change, their relative order in solubility is expected to remain the same.

Table 5-3. Solubility of pure chemicals in water, g/100 water ${ }^{[5]}$

\begin{tabular}{|l|c|c|c|c|}
\hline & $20^{\circ} \mathrm{C} / 68^{\circ} \mathrm{F}$ & $30^{\circ} \mathrm{C} / 86^{\circ} \mathrm{F}$ & $40^{\circ} \mathrm{C} / 104^{\circ} \mathrm{F}$ & $60^{\circ} \mathrm{C} / 140^{\circ} \mathrm{F}$ \\
\hline Potassium carbonate $\left(\mathrm{K}_{2} \mathrm{CO}_{3}\right)$ & 111 & 114 & 117 & 127 \\
\hline Potassium bicarbonate $\left(\mathrm{KHCO}_{3}\right)$ & 33.7 & 39.9 & 47.5 & 65.6 \\
\hline Potassium sulfate $\left(\mathrm{K}_{2} \mathrm{SO}_{4}\right)$ & 11.1 & 13 & 14.8 & 18.2 \\
\hline
\end{tabular}

A flow diagram for the modified process concept (II) is shown in Figure 5-10. In the scrubber, $\mathrm{SO}_{2}$ is absorbed into the $\mathrm{PC}$ solution to form potassium sulfite $\left(\mathrm{K}_{2} \mathrm{SO}_{3}\right)$ according to the following overall reaction:

$$
2 \mathrm{~K}_{2} \mathrm{CO}_{3}+\mathrm{SO}_{2}+\mathrm{H}_{2} \mathrm{O} \rightarrow \mathrm{K}_{2} \mathrm{SO}_{3}+\mathrm{H}_{2} \mathrm{CO}_{3}
$$


The concentration of $\mathrm{SO}_{3}{ }^{2-}$ can be adjusted to be above $0.85 \mathrm{M}$ (around the $\mathrm{K}_{2} \mathrm{SO}_{4}$ molar solubility at $40^{\circ} \mathrm{C} / 104^{\circ} \mathrm{F}$ ) by simply controlling the portion of the slipstream of $\mathrm{CO}_{2}$-rich solution withdrawn to the $\mathrm{SO}_{2}$ scrubber. The $\mathrm{SO}_{2}$ scrubber can be a stand-alone device (such as a spray tower or tray column), or integrated with the $\mathrm{CO}_{2}$ absorber.

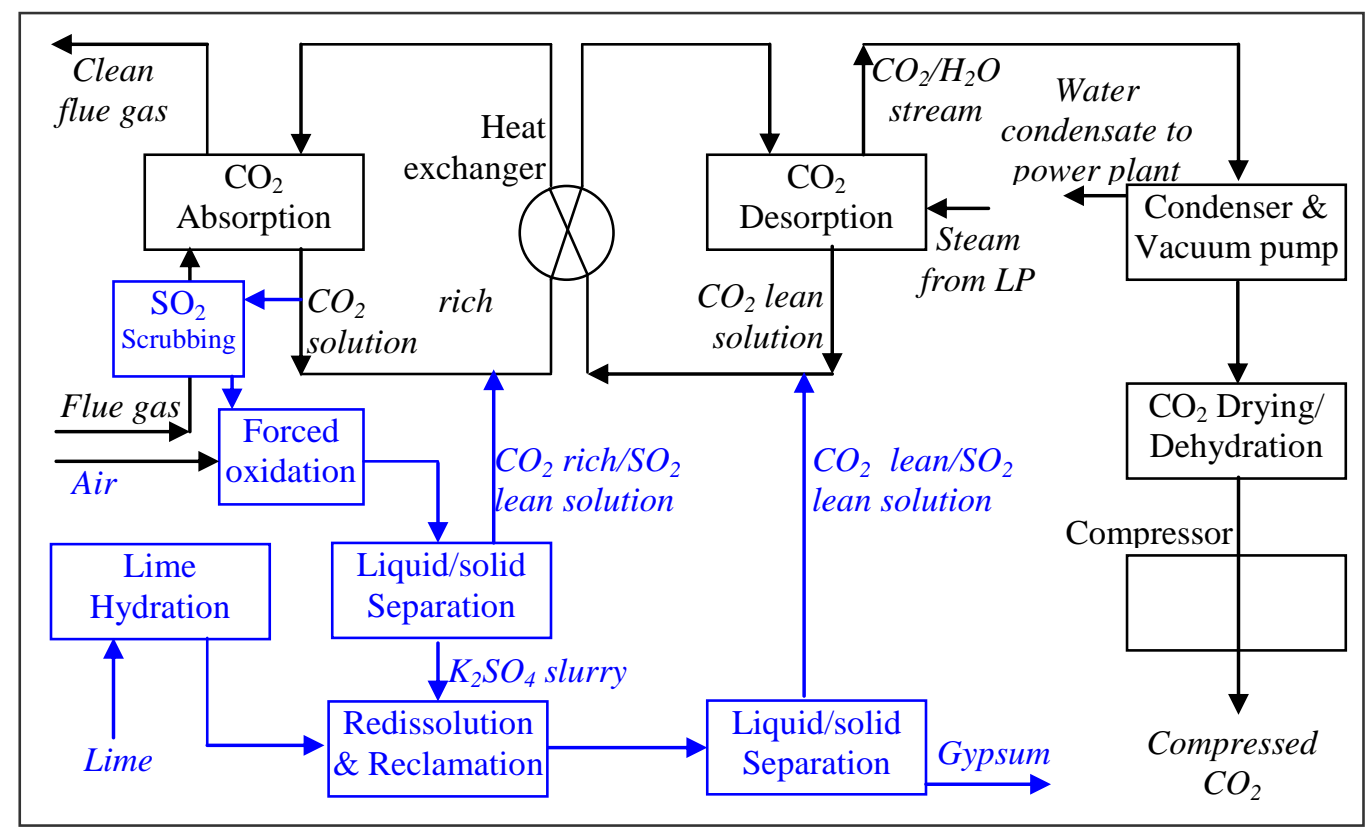

Figure 5-10. Modified process concept (II) for the combined $\mathrm{SO}_{2}$ removal and $\mathrm{CO}_{2}$ capture in the IVCAP.

The sulfite in the spent solution is oxidized to sulfate in a forced air oxidation unit:

$$
\mathrm{K}_{2} \mathrm{SO}_{3}+1 / 2 \mathrm{O}_{2} \rightarrow \mathrm{K}_{2} \mathrm{SO}_{4 \downarrow}
$$

Because $\mathrm{K}_{2} \mathrm{SO}_{4}$ has lower solubility than $\mathrm{K}_{2} \mathrm{SO}_{3}$, the level of sulfite oxidation can be controlled so that $\mathrm{K}_{2} \mathrm{SO}_{4}$ reaches its solubility limit and precipitates from the solution. The regenerated solution $\left(\mathrm{SO}_{2}\right.$-lean) is fed to the $\mathrm{CO}_{2}$-rich solution stream prior to the stripper, and the obtained $\mathrm{K}_{2} \mathrm{SO}_{4}$ slurry is subjected to further regeneration with lime:

$$
\mathrm{K}_{2} \mathrm{SO}_{4}+\mathrm{Ca}(\mathrm{OH})_{2}+2 \mathrm{H}_{2} \mathrm{O} \rightarrow \mathrm{CaSO}_{4} \cdot 2 \mathrm{H}_{2} \mathrm{O}_{\downarrow}+2 \mathrm{KOH}
$$

The regenerated solution containing $\mathrm{KOH}$ returns to the $\mathrm{CO}_{2}$-lean solution from the stripper.

In this modified process, the $\mathrm{SO}_{2}$ removal is integrated with the $\mathrm{CO}_{2}$ capture process, and the use of a high-pressure $\mathrm{CO}_{2}$ stream is not required. In addition, the process only involves the $\mathrm{SO}_{2}$ scrubber, forced oxidation vessel, and solid/liquid separation unit (such as hydro-cyclone and thickener). Because these devices are commercially-available for many FGD applications, the process appears to be technically and economically feasible.

\subsection{Summary}

The feasibility of a two-step process concept for reclaiming the potassium sulfate produced from combined $\mathrm{SO}_{2}$ removal and $\mathrm{CO}_{2}$ capture with the IVCAP was investigated. The first step in the process is the use of a high-pressure $\mathrm{CO}_{2}$ gas stream to reduce the $\mathrm{CO}_{3}{ }^{2-}$ concentration in the PC 
solution, and the second step is precipitation of calcium sulfate from the solution by adding lime to the solution while it remains under a high-pressure $\mathrm{CO}_{2}$ atmosphere.

Reaction rates and equilibrium liquid compositions for CTB conversion using a high-pressure $\mathrm{CO}_{2}$ gas stream (about $34 \mathrm{~atm} / 500 \mathrm{psia}$ ) were investigated to simulate the first process step. The reaction rates were rapid (between $6 \times 10^{-3}$ and $1 \times 10^{-2}$ mole $/ \mathrm{m}^{2} \mathrm{~s}$ ) when the CTB conversion levels of the PC solution were lower than $71 \%$. At higher CTB conversion levels, the reaction rates were significantly reduced, especially at a CTB conversion level above $89 \%$. However, more than $98.5 \%$ of the $\mathrm{K}_{2} \mathrm{CO}_{3}$ in the initial PC solution was converted to $\mathrm{KHCO}_{3}$ at room temperature and about $34 \mathrm{~atm}$ (500 psia) $\mathrm{CO}_{2}$, indicating that applying high-pressure $\mathrm{CO}_{2}$ could effectively reduce the $\mathrm{CO}_{3}{ }^{2-}$ concentration and thus raise the ratio of $\mathrm{SO}_{4}{ }^{2-} / \mathrm{CO}_{3}{ }^{2}$ in the solution to a sufficiently high level to greatly favor preferential precipitation of gypsum.

Semi-continuous tests for the reclamation of potassium sulfate from the PC solutions without and with catalysts/additives were performed under a $37.4 \mathrm{~atm}(550 \mathrm{psia}) \mathrm{CO}_{2}$ gas stream using a highpressure Parr stirred tank reactor. Precipitate samples collected under various conditions were characterized using XRD analysis. Results indicated that the overall PC concentration was a critical factor for the regeneration of the sulfate from the $\mathrm{SO}_{2}-$ rich $\mathrm{PC}$ solution. For PC solutions with concentrations ranging between 5 and $20 \mathrm{wt} \%$, vaterite (an unstable polymorph of $\mathrm{CaCO}_{3}$ ) was the only crystal phase present in the precipitate. For the $0.2 \mathrm{M}$ PC solution containing $0.4 \mathrm{M}$ $\mathrm{K}_{2} \mathrm{SO}_{4}$, up to $47 \mathrm{wt} \%$ syngenite $\left.\left[\mathrm{K}_{2} \mathrm{Ca}\left(\mathrm{SO}_{4}\right)_{2} \cdot \mathrm{H}_{2} \mathrm{O}\right)\right]$ was precipitated, with or without lesser amounts of gypsum $\left[\mathrm{CaSO}_{4} \cdot 2 \mathrm{H}_{2} \mathrm{O}\right]$ were detected in the precipitate. The presence of $300 \mathrm{mg} / \mathrm{L}$ of the ACA1 enzyme, or $1 \mathrm{wt} \%$ of the $\mathrm{KVO}_{3}$ additive in the $\mathrm{SO}_{2}$-rich $\mathrm{PC}$ solution favored the reclamation of sulfate to a small degree.

Based on the experimental results, the technical performance of the IVCAP for combining $\mathrm{SO}_{2}$ removal and $\mathrm{CO}_{2}$ capture could be improved with two modifications for the $\mathrm{SO}_{2}$ removal process. One proposed modification is based on decoupling the $\mathrm{SO}_{2}$ scrubbing from the $\mathrm{CO}_{2}$ absorption, which allows the use of a different solution with a low PC concentration (less than $0.2 \mathrm{M}$ ) and high CTB conversion for $\mathrm{SO}_{2}$ absorption. With such solution conditions, precipitates containing significant amounts of gypsum and syngenite crystals can be formed by reactions between sulfate ions using a high-pressure $\mathrm{CO}_{2}$ stream to remove carbonate ions and, if necessary, hydrated lime to boost the $\mathrm{Ca}$ concentration and thereby favor precipitation of gypsum. The other option is to precipitate $\mathrm{K}_{2} \mathrm{SO}_{4}$ directly from the PC solution, because it is relatively less soluble in the $\mathrm{PC}$ solution than other potassium salts. The $\mathrm{K}_{2} \mathrm{SO}_{4}$ precipitate can be further reclaimed by re-dissolution and reaction with lime. Both processes are technically feasible and can be integrated with $\mathrm{CO}_{2}$ capture in the IVCAP. However, additional process engineering data and techno-economic studies are needed to fully assess the modified IVCAP for combined $\mathrm{SO}_{2}$ removal and $\mathrm{CO}_{2}$ capture.

\section{References}

1. http://www.csudh.edu/oliver/chemdata/data-ksp.htm, as of Oct.23. 2011.

2. Pamplin, B. R. Crystal Growth. 2nd Edn. Pergamon Press Ltd., Oxford. 1980.

3. Valencia J. A. The Limestone Dual Alkali Process for Flue Gas Desulfurization. In Flue Gas Desulfurization, Hudson J., et al. (eds), ACS Symposium Series; American Chemical 
Society: Washington, DC, 1982. pp.325-347.

4. Chang J. C. S., Kaplan N. $\mathrm{SO}_{2}$ removal by limestone dual alkali. Environmental Progress, 1984, 3: 267-274.

5. Solubility table, wikipedia, http://en.wikipedia.org/wiki/Solubility_table, as of January 9, 2012. 


\section{CHAPTER 6 TECHNO-ECONOMIC ANALYSIS OF IVCAP PROCESS}

The objective of our techno-economic study was to evaluate the energy efficiency and cost performance of the IVCAP process integrated with a coal-fired power plant for large-scale $\mathrm{CO}_{2}$ capture. The IVCAP process is still at its conceptual stage and performing a techno-economic analysis is an important step in evaluating its economic competitiveness compared to the conventional MEA technology. Kinetic and phase equilibrium data presented in the previous chapters enabled a reasonably detailed study on the techno-economics of the process.

For the techno-economic study, the process flow diagrams of an integrated power plant-IVCAP system were developed and mass/energy balance simulations were performed. Equipment modeling then was conducted to determine the dimensions of major unit operations. With the mass/energy balances and equipment sizing results completed, a cost analysis was performed to determine the cost for $\mathrm{CO}_{2}$ capture and the sensitivity of the cost to operating conditions and material/equipment pricing. The potential benefit associated with combining $\mathrm{SO}_{2}$ removal in the IVCAP was not considered in this techno-economic analysis.

\subsection{Process simulation}

\subsubsection{Process flow charting}

\subsubsection{Description of IVCAP process}

The process flow diagram (PFD) of the IVCAP process is presented in Figure 6-1. The flue gas from a wet FGD unit, if required, flows counter-currently to the PC solution in a packed-bed absorption column (1). The cleaned flue gas (103) containing nitrogen and water vapor exits the absorber (1) to the stack. The $\mathrm{CO}_{2}$-rich PC solution (104) exits the bottom of the absorber (1) and passes through a cross-over heat exchanger (7) to exchange heat with the hot $\mathrm{CO}_{2}$-lean solution (109) from the stripper column (2). This $\mathrm{CO}_{2}$-rich solution (107) is fed to the stripper (2) where low-pressure steam (108) is injected to supply the required process heat to desorb $\mathrm{CO}_{2}$ from the solution. The regenerated $\mathrm{CO}_{2}$-lean solution (114) is cooled through the cross-over heat exchanger and recirculates (102) to the absorber (1). The $\mathrm{CO}_{2}$ stream (110) exits the stripper and is cooled in a reflux condenser to reduce its water vapor content. A vacuum pump downstream provides the vacuum for the partially-dried $\mathrm{CO}_{2}$ stream.

The $\mathrm{CO}_{2}$ stream (115) exits the vacuum pump (3) and passes through a four-stage compressor with inter-stage coolers (10-20). After each inter-stage cooler, the condensed water from the $\mathrm{CO}_{2}$ stream is removed with a knock-out unit. The high-pressure $\mathrm{CO}_{2}$ product stream (126) from the compressor is liquefied by cooling to ambient temperature. Residual trace gases are further flashed off in a gas separator prior to pipeline transportation (not shown in the figure). The $\mathrm{CO}_{2}$ stream (127) is finally compressed to 136 atm (2,000 psia).

It should be noted that the $\mathrm{PC}$ solution has strong affinity with $\mathrm{SO}_{2}$. Therefore, $\mathrm{SO}_{2}$ removal and $\mathrm{CO}_{2}$ capture can potentially be combined in the IVCAP. However, in the simulation study, $\mathrm{SO}_{2}$ is removed in a separate wet FGD scrubber upstream of $\mathrm{CO}_{2}$ capture. The potential benefit 
associated with combining $\mathrm{SO}_{2}$ removal in the IVCAP was not considered in the technoeconomic study described below, as suggested by a DOE peer review board for this project.

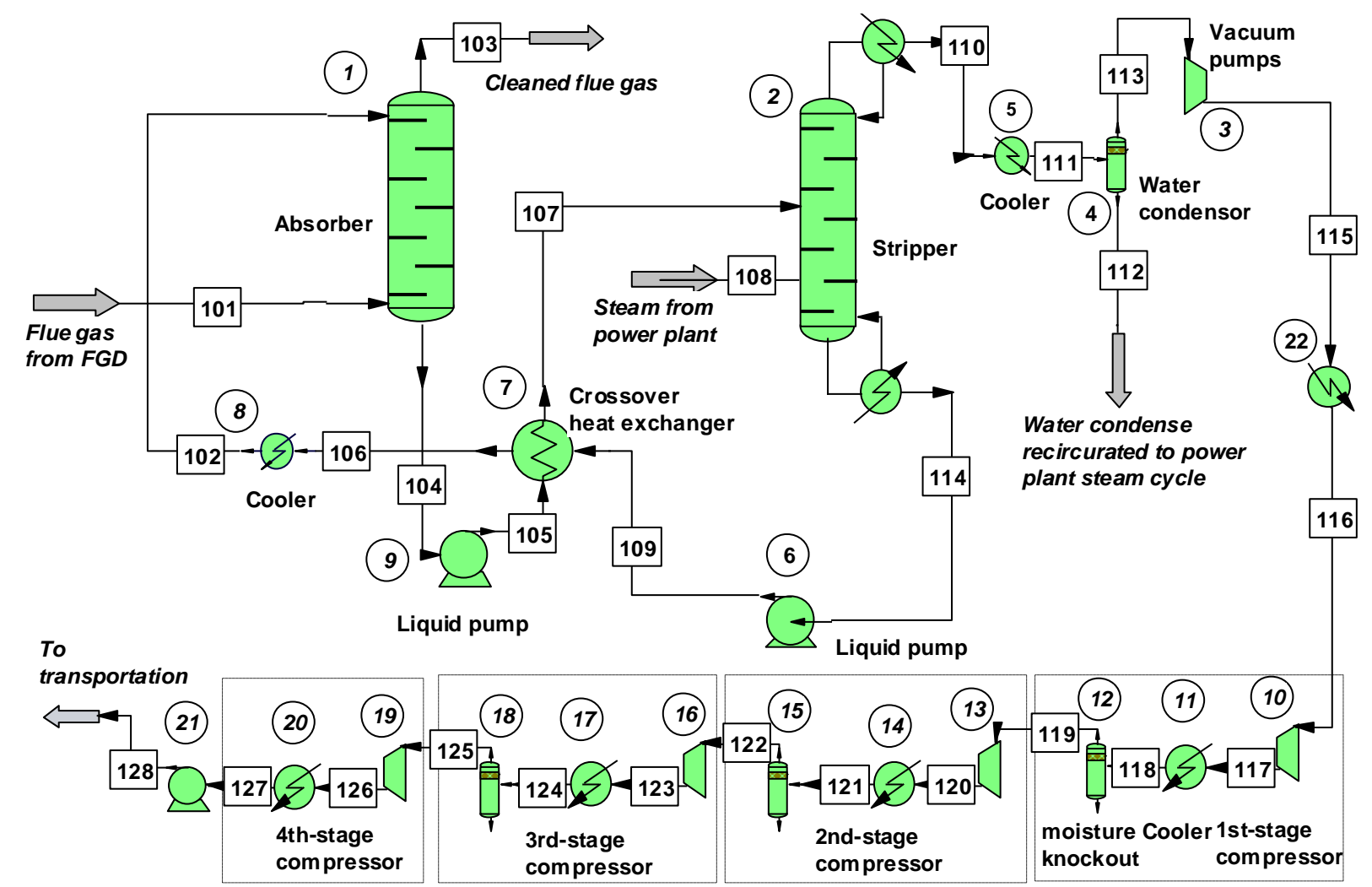

Figure 6-1. Process flow diagram of the IVCAP for $\mathrm{CO}_{2}$ capture.

\subsubsection{Integration with power plant}

The IVCAP process is integrated with a $528 \mathrm{MWe}$ sub-critical, pulverized coal-fired power plant to capture the $\mathrm{CO}_{2}$ from the flue gas. The power plant consists of a boiler, a super-heater, a reheater, an economizer, and an air pre-heater.

The NOx, fly ash, and $\mathrm{SO}_{2}$ entrained in the flue gas exiting the boiler are removed in a selective catalytic reduction (SCR) unit, an electrostatic precipitator (ESP) unit, and a limestone slurry forced oxidation (LSFO) FGD unit. A 90\% NOx removal efficiency is assumed in the SCR and a $99 \%$ fly ash removal efficiency in the ESP. ${ }^{[1]}$ The LSFO is assumed to be applied to an Illinois high-sulfur coal combustion flue gas with a $\mathrm{SO}_{2}$ removal efficiency of $98 \%$, which produces a flue gas containing about $34 \mathrm{ppmv} \mathrm{SO}_{2}$ entering the IVCAP.

The power plant employs a typical single reheat sub-critical steam power cycle. The performance of the steam power cycle is based on the nominal 164 atm $(2,415$ psia) throttle steam conditions. The nominal steam conditions for the main and reheat steams are assumed as follows:

- Main steam to high pressure (HP) turbine : $164 \mathrm{~atm} / 538^{\circ} \mathrm{C}\left(2,415 \mathrm{psia} / 1000^{\circ} \mathrm{F}\right)$;

- Reheat steam to intermediate pressure (IP) turbine: $37 \mathrm{~atm} / 538^{\circ} \mathrm{C}\left(545 \mathrm{psia} / 1000^{\circ} \mathrm{F}\right)$. 
The PFD of the power plant's boiler and flue gas cleaning system and steam cycle integrated with the IVCAP are shown in Figures 6-2 and 6-3. As shown in Figure 6-1, two low-pressure (LP) steam flows are used in the IVCAP stripper for regenerating the $\mathrm{CO}_{2}$-rich PC solution: 1) LP steam (108 in Figure 6-1 or 386 in Figure 6-3) is introduced to the stripping column for direct heat exchange; and 2) LP steam is also directed to the stripper reboiler for indirect heat exchange (not numbered in Figure 6-1, 385 in Figure 6-3). The two streams of LP steam are withdrawn from the LP turbine of the power plant's steam cycle at the respective conditions, which are determined by the stripping condition employed in the IVCAP and vary in the simulation case studies for comparison purposes. The condensed water from the condenser downstream of the stripper (112) is returned to the power plant steam condenser, and that from the reboiler (356 in Figure 6-3) is sent to a heat exchanger in the power plant feed-water cycle. The IVCAP process is thus highly heat-integrated with the power plant's steam turbine system.

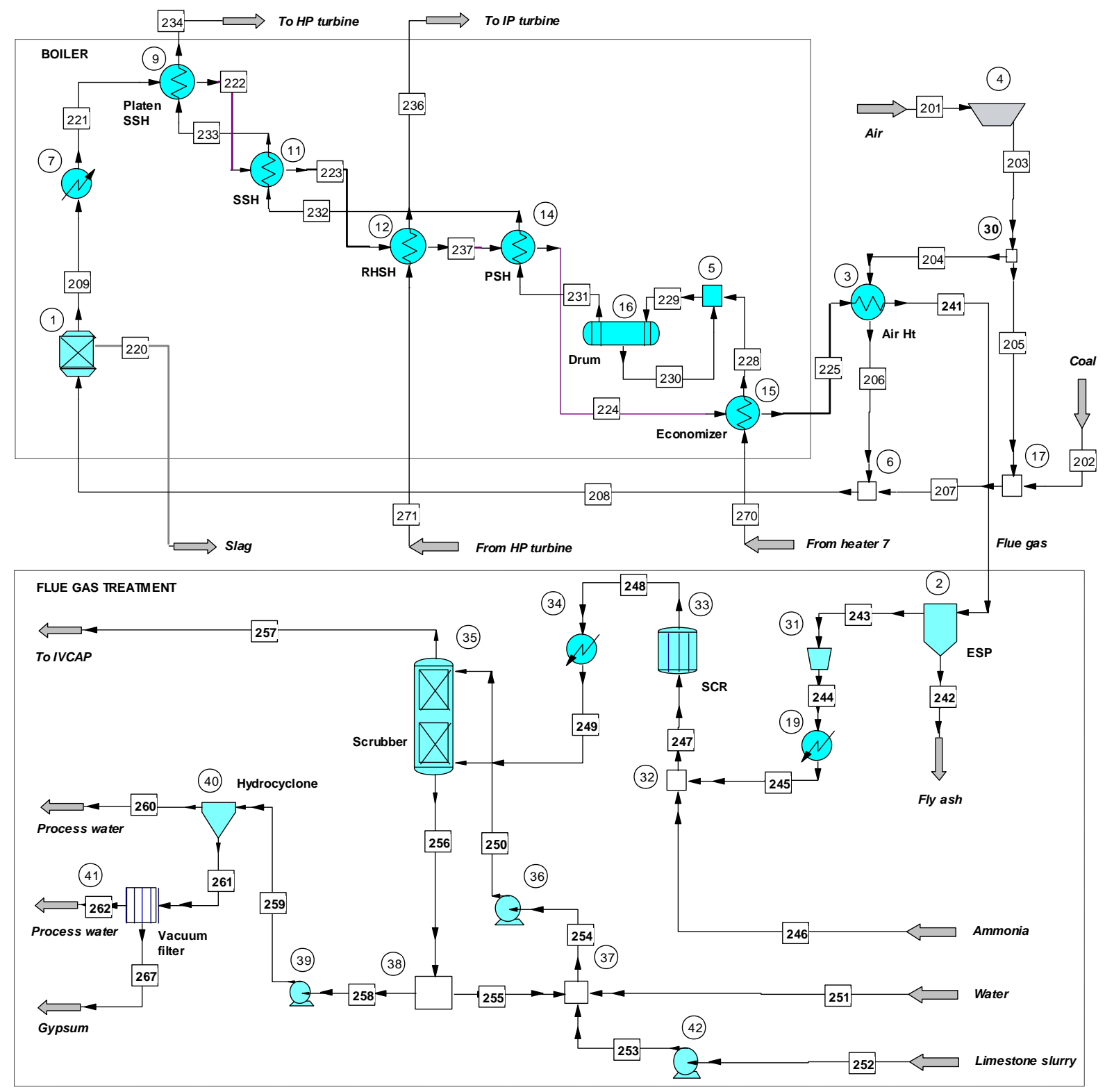

Figure 6-2. Process flow diagram of the power plant boiler and flue gas cleaning system. 


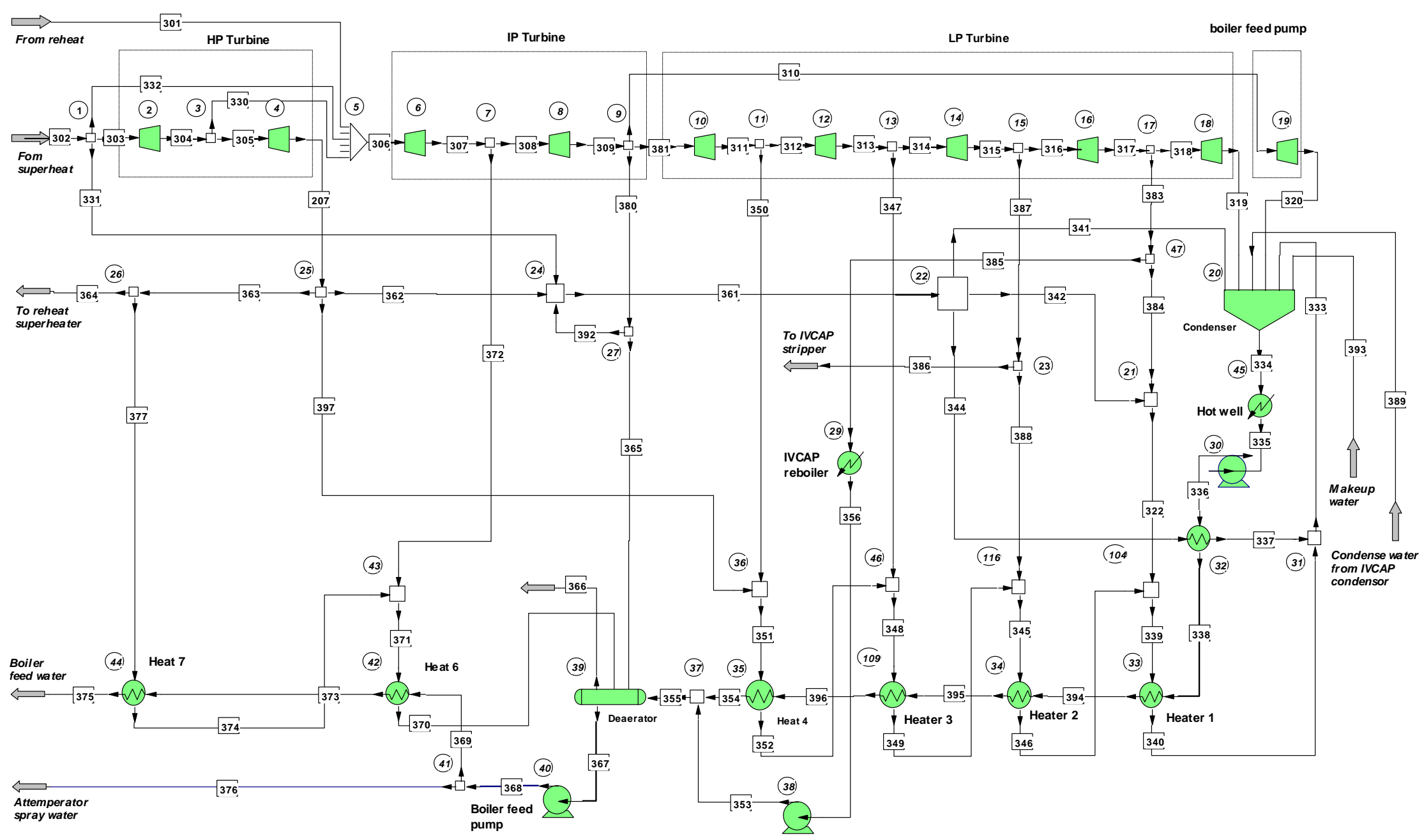

Figure 6-3. Process flow diagram of the power plant subcritical steam cycle. 


\subsubsection{Simulation method and assumptions}

A process simulation software, CHEMCAD (version 6.4.1), developed by Chemstations Inc., ${ }^{[2]}$ was used to perform steady state process simulations for the IVCAP process, a reference MEA process, and a reference subcritical power plant. The major operating conditions employed in these processes are listed in Table 6-1. Other process parameters, such as stripping temperature, heat duty of the reboiler, and steam extraction pressure were determined from the process simulations.

Table 6-1. Main operating conditions of the $528 \mathrm{MWe}$ (gross) power plant and the IVCAP, MEA assumed in process simulations

\begin{tabular}{|c|c|c|}
\hline \multicolumn{3}{|c|}{ Pulverized coal-fired power plant } \\
\hline Gross output, MWe & \multicolumn{2}{|c|}{528} \\
\hline Unit type & \multicolumn{2}{|c|}{ Sub-critical } \\
\hline Coal & \multicolumn{2}{|c|}{ IL bituminous \#6 } \\
\hline Excess Air, \% & \multicolumn{2}{|c|}{$15 \%$} \\
\hline Gas temperature exiting air preheater & \multicolumn{2}{|c|}{$146^{\circ} \mathrm{C}\left(295^{\circ} \mathrm{F}\right)$} \\
\hline Main steam condition & \multicolumn{2}{|c|}{$164 \mathrm{~atm} / 538^{\circ} \mathrm{C}\left(2,415 \mathrm{psia} / 1000^{\circ} \mathrm{F}\right)$} \\
\hline Reheat steam condition & \multicolumn{2}{|c|}{$37 \mathrm{~atm} / 538^{\circ} \mathrm{C}\left(545 \mathrm{psia} / 1000^{\circ} \mathrm{F}\right)$. } \\
\hline Turbine efficiency, $\%$ & \multicolumn{2}{|c|}{$88.5 \%$} \\
\hline $\mathrm{SO}_{2}$ removal in wet FGD, $\%$ & \multicolumn{2}{|c|}{$98 \%$} \\
\hline NOx removal in SCR, \% & \multicolumn{2}{|c|}{$90 \%$} \\
\hline Particle removal in ESP, $\%$ & \multicolumn{2}{|c|}{$99 \%$} \\
\hline $\mathrm{CO}_{2}$ capture and compression & MEA process & IVCAP process \\
\hline Solvent concentration, $\% \mathrm{wt}$ & $30 \%$ MEA & $\begin{array}{c}20 \% \mathrm{wt} \mathrm{K}_{2} \mathrm{CO}_{3^{-}} \\
\text {equivalent }(15-30 \% \mathrm{wt})\end{array}$ \\
\hline Pressure drop in absorber, psia & 2 & 2 (to be modeled) \\
\hline Temp. of flue gas entering absorber, ${ }^{\circ} \mathrm{F}$ & 129 & 129 \\
\hline Temp. of solvent entering absorber, ${ }^{\circ} \mathrm{F}$ & 104 & $122(104-140)$ \\
\hline Liquid to gas ratio, $\mathrm{lb} / \mathrm{lb}$ & 3.86 & $1.2(\mathrm{~L} / \mathrm{G})_{\min }(1-1.5)$ \\
\hline Lean $\mathrm{CO}_{2}$ loading, \%wt & $5.5 \%$ & $1 \%(0.5 \%-2 \%)$ \\
\hline Pressure at the top of stripper, psia & 25 & $3(2-8)$ \\
\hline Pressure drop in stripper, psia & 2 & 1 (to be modeled) \\
\hline Vacuum pump efficiency, $\%$ & - & $85 \%$ \\
\hline $\mathrm{CO}_{2}$ removal, $\%$ & $90 \%$ & $90 \%$ \\
\hline Compressor efficiency, $\%$ & $82 \%, 4-$ stag & ter-stage cooling \\
\hline Inter-stage cooling temperature, ${ }^{\circ} \mathrm{F}$ & & \\
\hline Compression end pressure, psia & & \\
\hline
\end{tabular}

$*$ Numbers in the brackets were ranges investigated. Others were used in a baseline case scenario.

The reference plant is a standard air-blown sub-critical power plant with a 528 MWe gross output. The design and configuration of the reference plant were based on a standard plant developed in a DOE-funded study. ${ }^{[3]}$ The operating conditions of the power plant used in the simulation are summarized in Table 6-1. A typical Illinois Herrin (\#6) bituminous coal was 
selected as the fuel. This coal has a moisture content of $6.08 \%$, an ash content of $8.90 \%$, and a higher heating value $(\mathrm{HHV})$ of $29,017 \mathrm{~kJ} / \mathrm{kg}(12,475 \mathrm{Btu} / \mathrm{lb}) .{ }^{[4]}$ The coal is expressed with an equivalent chemical formula of $\mathrm{C}_{164} \mathrm{H}_{134} \mathrm{O}_{11} \mathrm{~N}_{3} \mathrm{~S}_{2}$ on a dry ash-free basis. The coal is burned with air at a 15 vol\% excess to the stoichiometry. The combustion in the boiler was modeled by the Gibbs free energy reactor module, which determines the equilibrium state through minimization of the Gibbs free energy of the reaction system. The expander module was used to simulate the steam turbines. The expansion was assumed to be adiabatic. The heat exchanger module was applied to heat exchanges in the boiler.

The $\mathrm{CO}_{2}$ absorption and stripping columns in the IVCAP were modeled by the rigorous multistage vapor-liquid equilibrium module (SCDS). The VLE calculation was selected in the SCDS module. Fifteen stages were assumed for both the absorption and stripping columns. While the level of $\mathrm{CO}_{2}$ removal was fixed in absorption, the liquid-to-gas ratio (L/G) was adjustable by varying the stage equilibrium efficiency. The thermodynamic equilibrium constants ( $\mathrm{K}$ values) were calculated using the electrolyte Non-Randomness Two-Liquid (NRTL) model for the liquid phase and the ideal vapor model for the gas phase. The binary interaction parameters for the species in the $\mathrm{H}_{2} \mathrm{O}-\mathrm{CO}_{2}-\mathrm{K}_{2} \mathrm{CO}_{3}$ solution were adopted from the CHEMCAD database. The enthalpy and entropy models were based on the latent heat method. The chemical reaction equilibrium constants and transport properties of the simulation system, both of which are temperature-dependent, were based on the regression equations incorporated in CHEMCAD.

The SCDS module was also used to model the MEA process. The procedure of the VLE calculation was similar to that for the IVCAP process. The thermodynamic equilibrium $\mathrm{K}$ values were calculated by the amine K-value model, which is based on the Soave-Redlich-Kwong (SRK) equation of state. The chemical reaction equilibrium constants of the $\mathrm{CO}_{2}$-MEA aqueous solution were built into the CHEMCAD package. The enthalpies of chemical components were estimated by the amine enthalpy model, which employs the SRK equation for the vapor enthalpy and the method of Crynes and Maddox for the liquid enthalpy.

\subsubsection{Results and discussion}

\subsubsection{Reference power plant without $\mathrm{CO}_{2}$ capture}

The results of the energy and mass balance calculation for the reference power plant without $\mathrm{CO}_{2}$ capture are shown in Figure 6-4. Complete combustion of coal was assumed in the simulation. The plant operating at the full capacity demanded a heat input of 4,747 GJ/hr/ 4,499 MMBtu/hr (about 164 tonne/hr/ 180 ton/hr as-received coal).

In the steam cycle, the main steam $\left(538^{\circ} \mathrm{C} / 1000^{\circ} \mathrm{F}, 164 \mathrm{~atm} / 2415\right.$ psia) was fed to the HP turbine. The cold steam exiting the $\mathrm{HP}$ turbine $\left(335^{\circ} \mathrm{C} / 635^{\circ} \mathrm{F}, 41 \mathrm{~atm} / 604\right.$ psia) was reheated to $538^{\circ} \mathrm{C} / 1000^{\circ} \mathrm{F}(37 \mathrm{~atm} / 545 \mathrm{psia})$ and entered the IP and LP turbines in series. The exhaust steam from the LP turbine $\left(42.2^{\circ} \mathrm{C} / 108^{\circ} \mathrm{F}, 8.3 \mathrm{kPa} / 1.2 \mathrm{psia}\right)$ was condensed in the water condenser, preheated through seven consecutive heat exchangers, and fed to the boiler. For clarity, the calculated results for the seven heat exchangers were combined into one unit in Figure 6-4. A gross electricity output of 527.6 MWe was generated in the steam cycle, of which, 150.6 MWe was generated in the HP turbine, 124.7 MWe in IP turbine, and 252.3 MWe in the LP turbine. 
Due to the in-plant electricity consumption by equipment, such as pumps, blowers and fans, the net electricity output decreased to 492.9 MWe. In accordance, the net thermal efficiency, i.e., the conversion of the total heat input to the net electricity output, was $37.4 \%$.

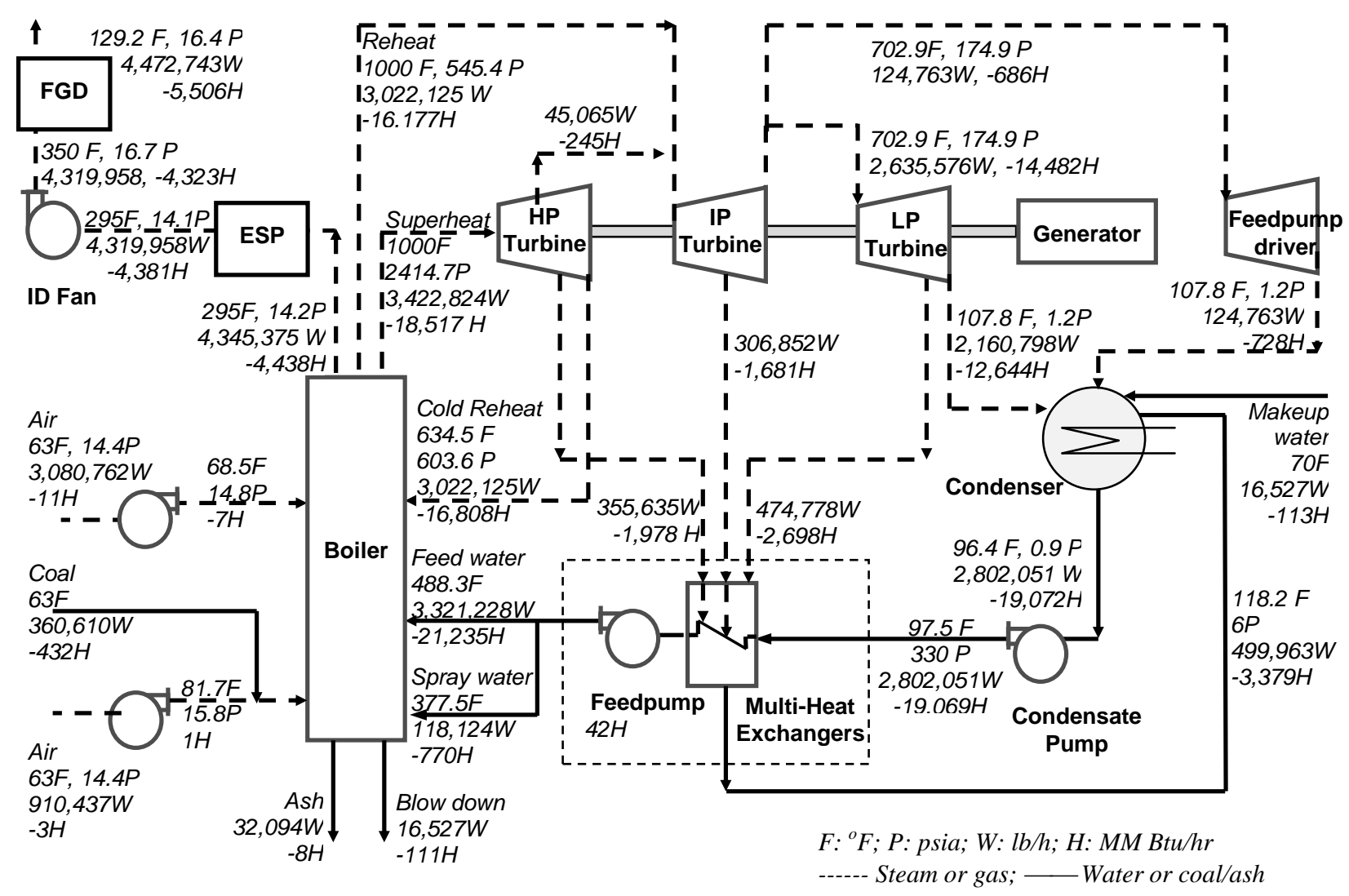

Figure 6-4. Mass and energy balance of the reference pulverized coal-fired power plant.

The flue gas exited the boiler at a flow rate of 0.143 million $\mathrm{Nm}^{3} / \mathrm{hr}$ (5.04 million scfh), contained 14.6 vol\% $\mathrm{CO}_{2}, 75.7 \% \mathrm{~N}_{2}, 2.7 \% \mathrm{O}_{2}, 6.8 \%$ water vapor, $1,774 \mathrm{ppm} \mathrm{SO}$, $325 \mathrm{ppm} \mathrm{NO}$, and $5.2 \mathrm{~g} / \mathrm{m}^{3}$ fly ash. Most of the ash and $\mathrm{SO}_{2}$ were removed in the ESP and FGD devices, respectively. The clean gas leaving the FGD had a slightly increased volume $(0.151$ million $\mathrm{Nm}^{3} / \mathrm{hr} / 5.34$ million scfh) due to water evaporation in the FGD absorber. This gas stream, which contained 13.9 vol\% of $\mathrm{CO}_{2}, 71.4 \% \mathrm{~N}_{2}, 2.5 \% \mathrm{O}_{2}, 12.2 \%$ water vapor, $34 \mathrm{ppm} \mathrm{SO}_{2}$, and $31 \mathrm{ppm}$ $\mathrm{NO}$, was sent to the $\mathrm{CO}_{2}$ capture process (either the MEA or the IVCAP).

The energy performance result of the reference plant above is comparable to Case 9 in a recent DOE/NETL study. The Case 9 plant is a subcritical design, employing a single reheat cycle $\left(566^{\circ} \mathrm{C} / 1050^{\circ} \mathrm{F}, 164 \mathrm{~atm} / 2400 \mathrm{psig}\right)$ similar to that used in this study. The plant produces a net output of $550 \mathrm{MWe}$ at a net generation efficiency of $36.8 \%$ (HHV basis). ${ }^{[5]}$

\subsubsection{MEA process}


Simulation of the MEA process was based on the flue gas leaving the wet FGD from the reference plant. Because the flue gas was cooled to $54^{\circ} \mathrm{C}\left(129^{\circ} \mathrm{F}\right)$ through the FGD absorber, no further cooling was assumed for the flue gas prior to entering the MEA process in this study.

The results of the process mass and energy balance calculation are shown in Figure 6-5. Nominally $90 \%$ of the $\mathrm{CO}_{2}$ in the flue gas was removed in the absorption column. The cleaned flue gas contained 74.1 vol\% $\mathrm{N}_{2}, 21.7 \%$ water vapor, $2.6 \% \mathrm{O}_{2}$, and $1.6 \% \mathrm{CO}_{2}$. MEA regeneration from the rich solution required a heat duty of about 1,477 GJ/hr $(1,400 \mathrm{MMBtu} / \mathrm{hr})$ in the stripper reboiler, which is equivalent to $3,908 \mathrm{~kJ} / \mathrm{kg}(1,680 \mathrm{Btu} / \mathrm{lb}) \mathrm{CO}_{2}$ removed. Note that this study did not intend to simulate the most advanced amine system and therefore, such a heat duty level does not represent the best energy efficiency reported up to the date. The gas stream from the stripper contained $58.7 \mathrm{vol} \% \mathrm{CO}_{2}$ and $41.3 \% \mathrm{H}_{2} \mathrm{O}$. The $\mathrm{CO}_{2}$ stream was cooled to $104^{\circ} \mathrm{F}$ to condense the water vapor and concentrate the stream to 95.7 vol\% $\mathrm{CO}_{2}$ and $4.3 \% \mathrm{H}_{2} \mathrm{O}$.

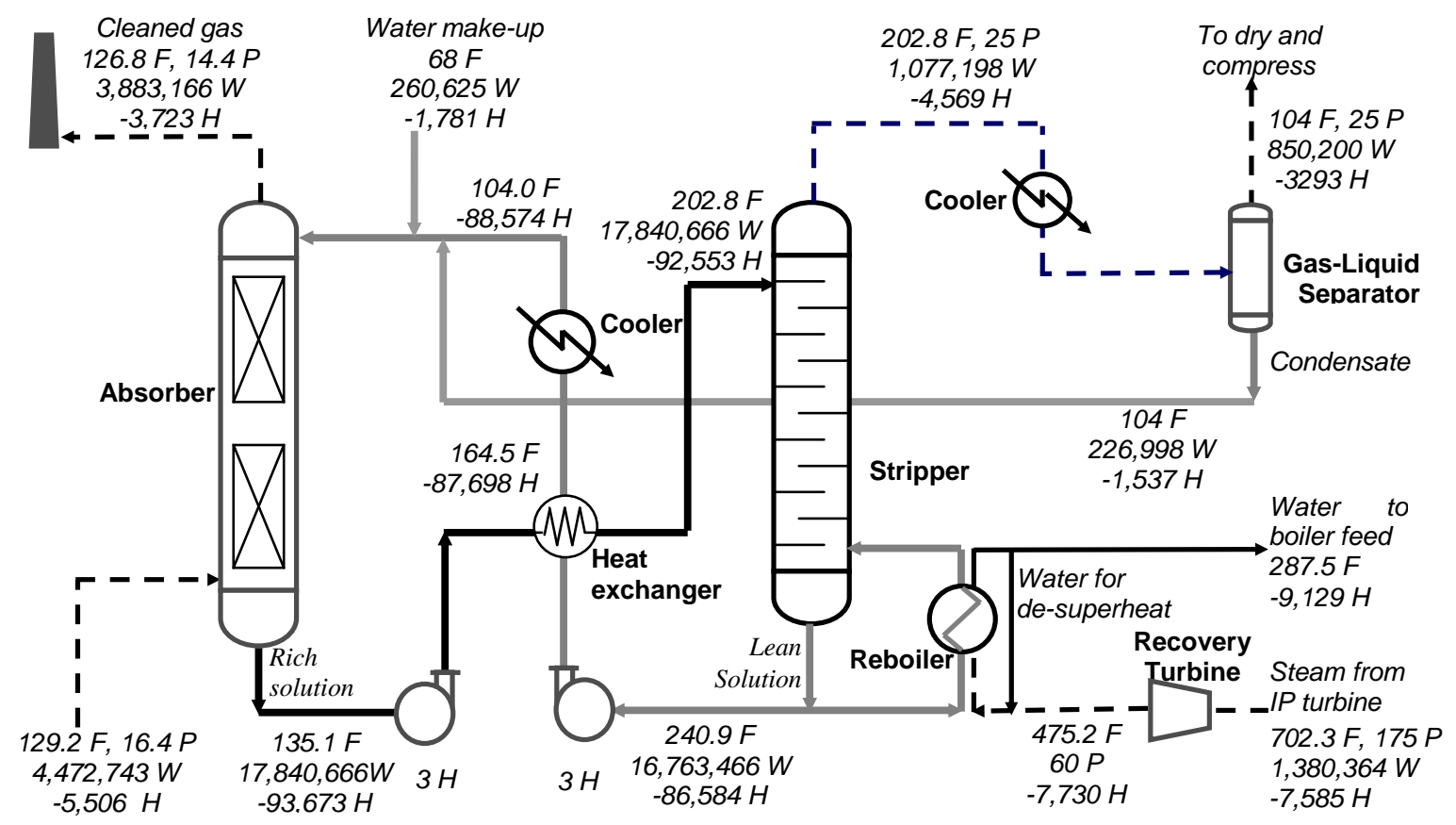

Figure 6-5. Mass and energy balances of the MEA process.

The steam used for MEA regeneration was extracted from the power plant. The steam condition was determined based on the required temperature for the stripper. As most of the heat from steam was stored as the latent heat that would be released during condensation, the saturation temperature of the steam was kept above the solution temperature at the bottom of the stripping tower. Also, a temperature difference of 22 to $28^{\circ} \mathrm{C}\left(40\right.$ to $\left.50^{\circ} \mathrm{F}\right)$ is typical in a stripper reboiler in the MEA process. As a result, steam with a saturation temperature of about $143^{\circ} \mathrm{C}\left(290^{\circ} \mathrm{F}\right)$ and pressure of about $4.1 \mathrm{~atm}$ (60 psia) was needed for the reboiler. The steam extracted from the IP turbine was at 11.9 atm (175 psia) and was expanded, through a separate expansion turbine, to $4.1 \mathrm{~atm} / 60 \mathrm{psia}\left(246^{\circ} \mathrm{C} / 475^{\circ} \mathrm{F}\right)$. It was further de-superheated prior to entering the reboiler. Part of the electricity was recovered during steam expansion. All of the steam was then directly introduced to the reboiler to heat the MEA solution through condensation. The condensate from the reboiler was returned to the feed water system in the power plant steam cycle. 
The extraction of steam resulted in a large reduction in electricity generation. With more than half of the total steam extracted from the exit of the IP turbine, gross electricity generation was reduced by $89.4 \mathrm{MW}$ (power recovery was considered). Another large electricity loss was caused by $\mathrm{CO}_{2}$ compression. The four-stage inter-stage cooling compressor consumed a total of 35.4 MW of electricity to compress all the captured $\mathrm{CO}_{2}$ from 1.7 to 136.1 atm (25 to 2,000 psia). In addition, about $10 \mathrm{MW}$ was required for the flue gas fan to overcome a pressure drop of 0.136 $\operatorname{atm}(2 \mathrm{psia})$ in the MEA absorber, and 1.8 MW for the MEA solution pumps. The other auxiliary power use in the PC+MEA plant (32 MW) was slightly less than the reference plant (34.7 MW). This is because the steam extraction demanded by the MEA process reduced the loading of the exhaust steam condenser and cooling tower in the power plant, which in turn, lowered the electricity usage. The results of the electricity use/loss are summarized in Table 6-2. Overall, the net electricity output in the PC+MEA power plant was reduced by $134 \mathrm{MW}$, equivalent to a loss of $27.2 \%$ of the net electricity output from the reference PC plant.

The net generation efficiency of the power plant equipped with the MEA process in this study was $27.4 \%$, which is higher than the $26.2 \%$ net efficiency for a similar power plant (Case 10) in a recent DOE /NETL study. ${ }^{[5]}$ The main reason for the difference is that a higher $\mathrm{CO}_{2}$-lean loading in the MEA solution ( 0.28 vs. about $0.2 \mathrm{~mol} / \mathrm{mol} \mathrm{MEA})$ was assumed and the resulting $\mathrm{CO}_{2}$-rich loading became higher in the current simulation. This resulted in less energy use required for $\mathrm{CO}_{2}$ stripping, although a conservative approach temperature $\left(21^{\circ} \mathrm{C} / 38^{\circ} \mathrm{F}\right)$ was assumed for the cross-over heat exchanger. Overall, the difference in energy performance between the two studies is not significant.

\subsubsection{Baseline IVCAP process}

\section{(1) Verification of VLE data in CHEMCAD}

The VLE data of the PC solution are critical for the energy and mass balance simulations for the IVCAP. The equilibrium partial pressures of $\mathrm{CO}_{2}$ and water vapor over the $20 \mathrm{wt} \% \mathrm{~K}_{2} \mathrm{CO}_{3^{-}}$ equivalent PC solution were predicted using CHEMCAD (see Figure 6-6). The predicted data agreed well with the literature data at 70 and $90^{\circ} \mathrm{C}\left(158\right.$ and $\left.194^{\circ} \mathrm{F}\right)$, the lowest temperatures employed in the VLE measurements by Tosh et al. ${ }^{[6]}$, while the predicted water vapor pressure was slightly overestimated at high $\mathrm{CO}_{2}$ loadings. The equilibrium data showed that at a temperature range of 40 to $90^{\circ} \mathrm{C}\left(104\right.$ to $\left.194^{\circ} \mathrm{F}\right)$, the total pressure of $\mathrm{CO}_{2}$ and water vapor changed between 6.9 and $62.1 \mathrm{kPa}\left(1\right.$ and 9 psia) when the $\mathrm{CO}_{2}$ loading was kept at $1 \mathrm{wt} \%$ at the stripper outlet. 

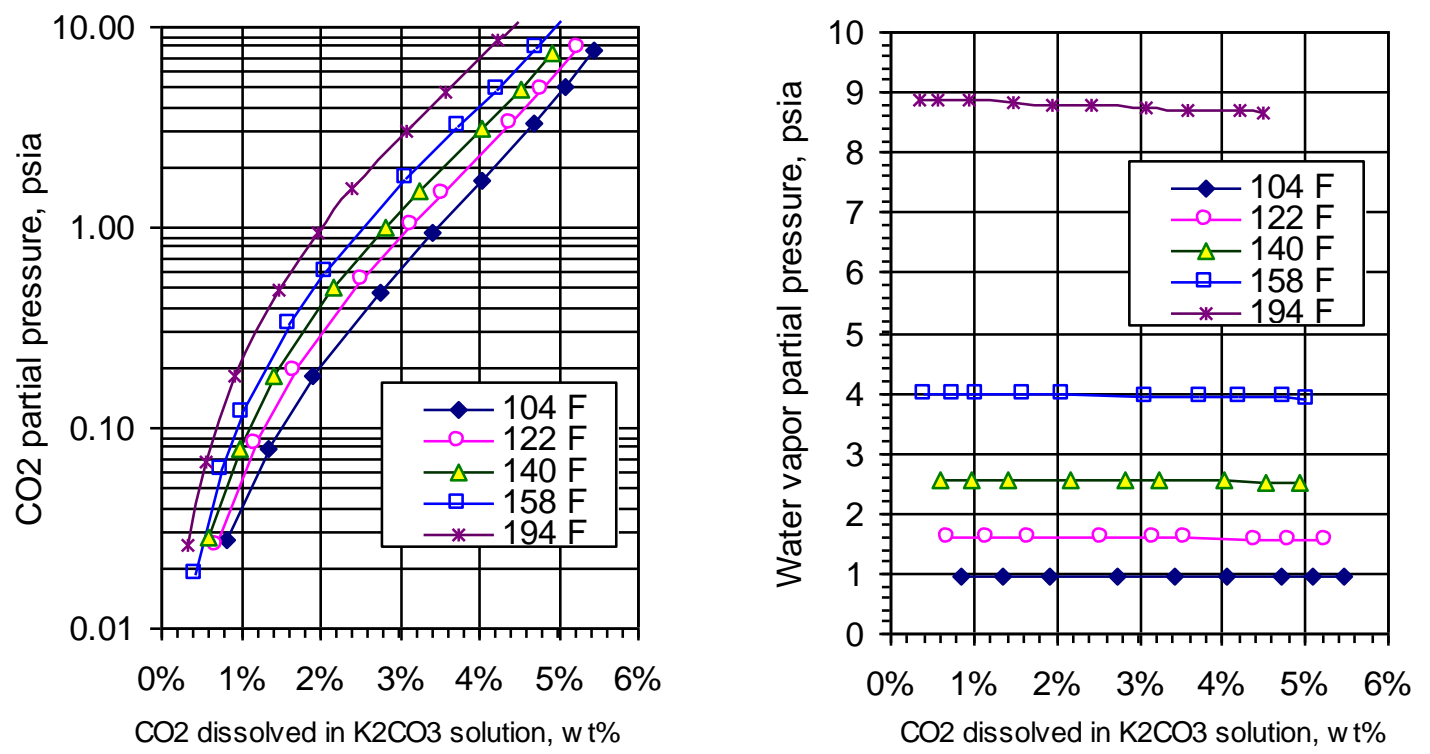

Figure 6-6. Partial pressures of $\mathrm{CO}_{2}$ and water vapor over a $20 \mathrm{wt} \% \mathrm{~K}_{2} \mathrm{CO}_{3}$-equivalent PC solution predicted by CHEMCAD.

Based on the VLE data, when the absorption operates at around atmospheric pressure, the $\mathrm{CO}_{2}$ partial pressure decreases from about 13.8 to $1.38 \mathrm{kPa}$ (2 to 0.2 psia) to achieve $90 \% \mathrm{CO}_{2}$ removal efficiency. Assuming that the $\mathrm{CO}_{2}$ in the gas phase is at equilibrium with the absorption solution at the bottom of the column, the $\mathrm{CO}_{2}$ loading in the $\mathrm{CO}_{2}$-rich solution ranged between 2.6 and $4.2 \mathrm{wt} \%$ in the temperature range of 90 to $40^{\circ} \mathrm{C}\left(194\right.$ to $104^{\circ} \mathrm{F}$, see Figure 6-6).

\section{(2) Baseline IVCAP case}

The low-pressure steam used in the stripper was extracted from the LP turbine, typically at pressures between 0.2 and 0.6 atm (between 3 and 9 psia). These pressures are much lower than the steam used in the MEA process (4.1 atm/60 psia). In the IVCAP, a portion of the steam was introduced directly into the stripper and the other portion was used for indirect heating in the reboiler. This is very different from the MEA process where the majority of the steam was introduced to the reboiler at the bottom of the stripper for indirect heating.

The IVCAP operating at a selected set of baseline conditions was developed to verify the simulation method and provide a reference for further modeling and sensitivity analysis of parameters. In the baseline case, the following major operating conditions were employed:

- $\quad$ PC concentration: $20 \mathrm{wt} \% \mathrm{~K}_{2} \mathrm{CO}_{3}$-equivalent

- $\quad \mathrm{CO}_{2}$-lean loading: $1 \mathrm{wt} \%$

- $\quad$ Liquid-to-gas $(\mathrm{L} / \mathrm{G})$ ratio: 1.2 times the minimum $\mathrm{L} / \mathrm{G}$ ratio $\left((\mathrm{L} / \mathrm{G})_{\min }\right.$

- $\quad$ Temperature difference for heat transfer in the reboiler: $11^{\circ} \mathrm{C}\left(20^{\circ} \mathrm{F}\right)$

- $\quad$ Stripping pressure: 0.2 atm (3 psia) at the top of the stripper

Results of the mass and heat balance calculations for the baseline IVCAP are listed in Figure 6-7. About 0.73 million $\mathrm{kg} / \mathrm{hr}(1.6 \mathrm{million} \mathrm{lb} / \mathrm{hr})$ of low quality steam $(0.27 \mathrm{~atm} / 4 \mathrm{psia})$ were 
consumed for $\mathrm{CO}_{2}$ regeneration, of which, $62 \%$ was directly introduced to the stripper and $38 \%$ to the reboiler. A temperature difference $(\Delta \mathrm{T})$ of $11^{\circ} \mathrm{C}\left(20^{\circ} \mathrm{F}\right)$ was adopted for heat transfer in the reboiler, because the lower heat duty $\left(662 \mathrm{GJ} / \mathrm{hr} / 627 \mathrm{MMBtu} / \mathrm{hr}\right.$ or $1,726 \mathrm{~kJ} / \mathrm{kg} / 742 \mathrm{Btu} / \mathrm{lb} \mathrm{CO}_{2}$ captured) of the IVCAP process provides flexibility for $\Delta \mathrm{T}$ in the reboiler. Different from the MEA process, the temperature swings only within a $13^{\circ} \mathrm{C}\left(24^{\circ} \mathrm{F}\right)$ range between the absorption and desorption in the IVCAP. Therefore, a temperature difference of $6^{\circ} \mathrm{C}\left(10^{\circ} \mathrm{F}\right)$ was believed to be reasonable for the cross-over heat exchanger and thus was adopted in the simulation.

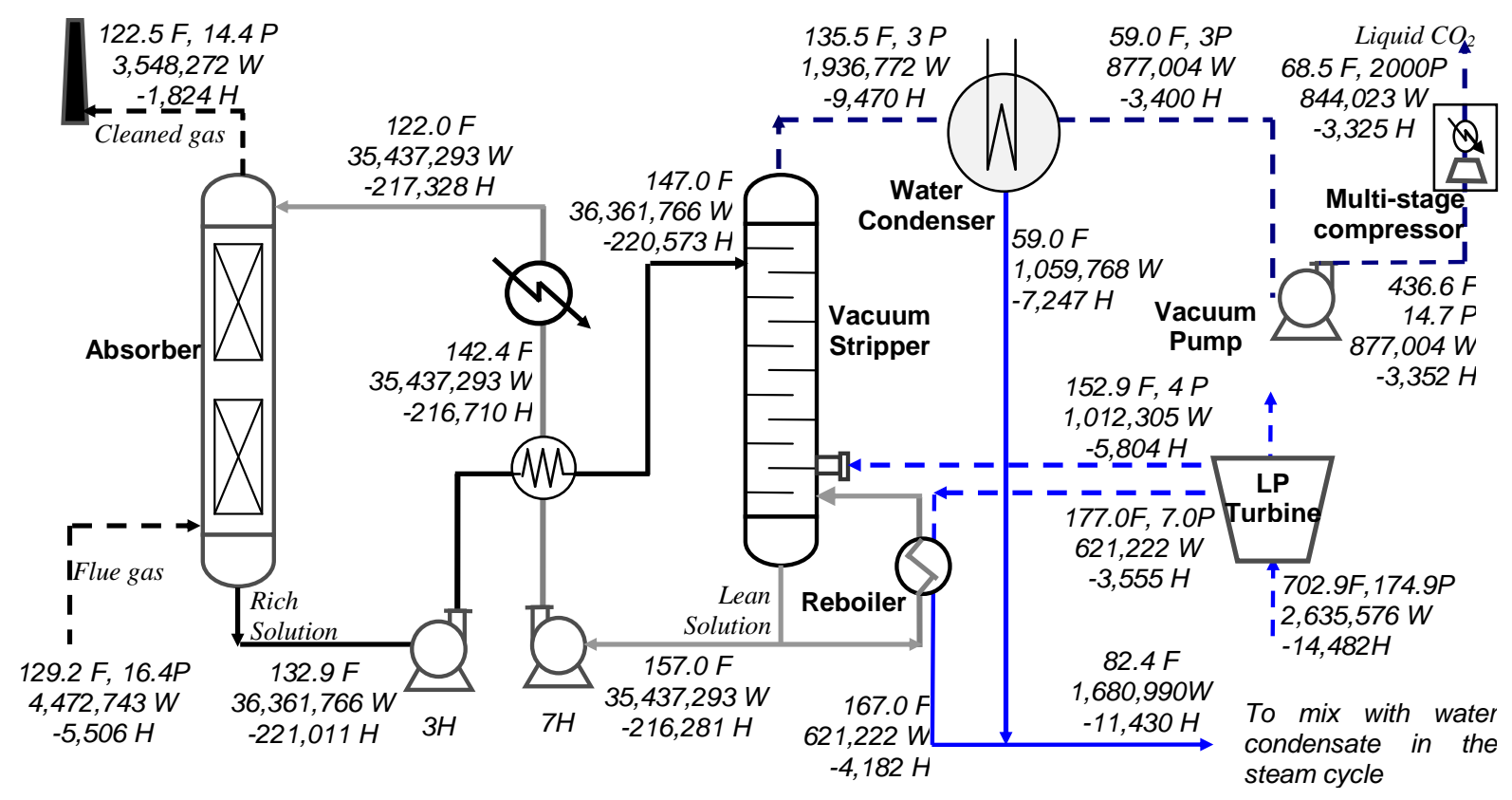

Figure 6-7. Mass and energy balances of the IVCAP under a baseline condition.

The gas stream from the top of the stripper was a mixture of $24.1 \mathrm{vol} \% \mathrm{CO}_{2}$ and $75.9 \mathrm{vol} \%$ water vapor. The majority of the water vapor in the stream was condensed in a direct cooling condenser using water as cooling medium. The condensate was mixed with the condensate from the reboiler and returned to the steam cycle of the power plant. After primary condensation, the gas stream consisted of $91.7 \mathrm{vol} \% \mathrm{CO}_{2}$ and $8.3 \mathrm{vol} \%$ water vapor. The temperature of the mixed condensate was about $28^{\circ} \mathrm{C}\left(82^{\circ} \mathrm{F}\right)$, a temperature close to the exhaust steam condenser in the power plant. In an actual process, the condensate from the $\mathrm{CO}_{2}$ /water vapor stream containing a small amount of dissolved $\mathrm{CO}_{2}(388 \mathrm{ppm})$ in water needs to be treated to meet the water quality requirement for feed water use in the power plant steam cycle. Potential water treatment needs and methods are discussed in Chapter 7 for this purpose.

In the above calculations, the steam used in the stripper and reboiler was distributed to maintain a water balance in the absorption-desorption loop. Introducing an excessive amount of steam to the stripper would result in water accumulation in the process. However, indirect heating through the reboiler would lower the thermal efficiency of the steam usage, because a $\Delta \mathrm{T}$ for heat transfer is necessary. For example, an increase of $\Delta \mathrm{T}$ to $22^{\circ} \mathrm{C}\left(40^{\circ} \mathrm{F}\right)$ could lead to an additional 4 MW electricity loss compared to the $\Delta \mathrm{T}$ of $11^{\circ} \mathrm{C}\left(20^{\circ} \mathrm{F}\right)$ used in this calculation. Due to this 
consideration, direct steam introduction to the stripper was maximized to minimize the $\Delta \mathrm{T}$ and reduce the reboiler heat duty.

Based on the results shown in Figure 6-7, the thermal efficiencies of the power plants without and with installation of the IVCAP and MEA processes were compared. The comparison is summarized in Table 6-2. The electricity needed to compress $\mathrm{CO}_{2}$ to 136 atm $(2,000$ psia) is included. The different electricity use for $\mathrm{CO}_{2}$ compression between the two processes is due to the different starting pressures ( 1 and $1.7 \mathrm{~atm} / 14.7$ and 25psia for the IVCAP and MEA, respectively). The steam extraction loss in the IVCAP process is as low as about $38 \mathrm{MWe}$, of which, $52 \%$ is due to the stripping steam and $48 \%$ due to the reboiler steam. However, in the IVCAP process a significant amount of electricity is consumed by the vacuum pump to pressurize the $\mathrm{CO}_{2}$ stream from the stripping pressure (about $0.2 \mathrm{~atm} / 3$ psia) to one atmospheric pressure (14.7psia). The IVCAP also requires large pumps to circulate the absorption solution due to its higher $\mathrm{L} / \mathrm{G}$ ratio. The thermal efficiencies of the IVCAP and MEA processes are estimated as 29.8 and $27.4 \%$, respectively. Overall, a total of about 104 MWe is consumed for $\mathrm{CO}_{2}$ capture in the baseline IVCAP compared to $137 \mathrm{MWe}$ in the MEA process, an energy saving of about $24 \%$.

Table 6-2. Electricity use and output in the reference pulverized coal-fired plant with either the MEA or the IVCAP installed for $\mathrm{CO}_{2}$ capture

\begin{tabular}{|l|c|c|c|}
\hline Electricity, MWe & $\begin{array}{c}\text { Power plant } \\
\text { w/o CO }\end{array}$ capture & $\begin{array}{c}\text { Power plant with } \\
\text { MEA }\end{array}$ & $\begin{array}{c}\text { Power plant with } \\
\text { IVCAP }\end{array}$ \\
\hline $\mathrm{CO}_{2}$ capture process: & & & \\
\hline Steam extraction loss & $\mathrm{n} / \mathrm{a}$ & 89.43 & 37.8 \\
\hline Gas blower & $\mathrm{n} / \mathrm{a}$ & 10.03 & 11.5 \\
\hline Liquid pump & $\mathrm{n} / \mathrm{a}$ & 1.79 & 2.7 \\
\hline Vacuum pump & $\mathrm{n} / \mathrm{a}$ & 0 & 14.0 \\
\hline $\mathrm{CO}_{2}$ compression & $\mathrm{n} / \mathrm{a}$ & 35.42 & 37.8 \\
\hline Auxiliary energy use in power plant & 34.7 & 32.00 & 33.3 \\
\hline Net electricity output & 492.9 & 358.93 & 390.5 \\
\hline Thermal efficiency, $\%$ & $37.6 \%$ & $27.4 \%$ & $29.8 \%$ \\
\hline
\end{tabular}

\subsubsection{Parametric study of IVCAP process}

Three parameters - the stripping pressure, $\mathrm{CO}_{2}$ loading, and liquid/gas (L/G) ratio - are considered the most important operating parameters and their effect on the energy use performance was analyzed with CHEMCAD. The baseline conditions included a stripping pressure of 3 psia (at the top of stripper), a $\mathrm{CO}_{2}$-lean loading of $1.0 \mathrm{wt} \%$, and a $\mathrm{L} / \mathrm{G}$ ratio of 1.2 $(\mathrm{L} / \mathrm{G})_{\min }$. A $20 \mathrm{wt} \% \mathrm{PC}$ aqueous solution was employed as the solvent in the parametric studies.

\section{(1) Effect of stripping pressure}

The effect of stripping pressure on steam extraction loss and electricity consumption of the vacuum pump, the two most energy-consuming components in the IVCAP, were examined in a stripping pressure range between 0.14 and 0.54 atm ( 2 and 8psia). The steam extraction loss was calculated based on the amount of steam expanded from the extraction pressure to $0.082 \mathrm{~atm}$ (1.2 psia), the common exhaust pressure of the LP turbine. The electricity consumption by the 
vacuum pump was calculated based on compression of the $\mathrm{CO}_{2}$ stream to one atmospheric pressure. Since the absorber and vacuum stripper operated at similar temperatures (closer at a lower stripping pressure), the heat duty of the cross-over heat exchanger for the $\mathrm{CO}_{2}$-lean and rich solutions was significantly reduced compared to that in the MEA process. The values for $\Delta \mathrm{T}$ between the lean-solution inlet and rich-solution outlet were thus selected as 5.6, 8.3, and $11.1^{\circ} \mathrm{C}$ $\left(10,15\right.$, and $\left.20^{\circ} \mathrm{F}\right)$ for the process simulations at stripping pressures of $0.2,0.27$, and $0.54 \mathrm{~atm}(3$, 4 , and 8 psia), respectively. The lean-rich solution heat exchanger was not required at a stripper pressure of $0.14 \mathrm{~atm}$ ( $2 \mathrm{psia}$ ). Note that the stripping pressure is referred to that at the top of the column and the pressure drop through the column is 0.07atm (1 psia).

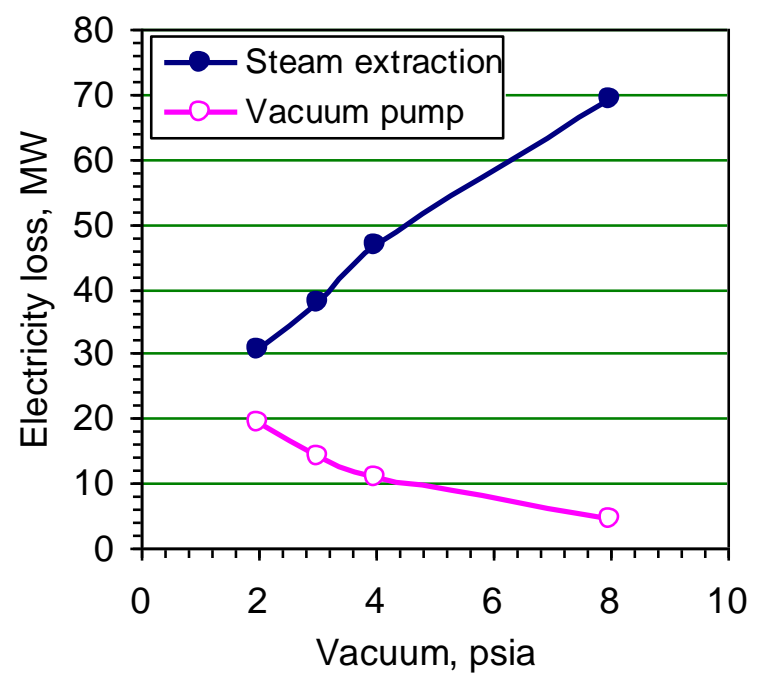

Figure 6-8. Electricity losses at different stripping pressures. (Flue gas: $130^{\circ} \mathrm{F}, 13.9 \% \mathrm{CO}_{2}$; solvent: 20 wt\% PC solution, $1 \% \mathrm{CO}_{2}$ lean loading; $\mathrm{L} / \mathrm{G}$ ratio: $1.2(\mathrm{~L} / \mathrm{G})_{\min }$; stripper pressure drop: 1 psia).

Simulation results showed that the steam extraction loss increased with increasing stripping pressure to a power of 0.59 , while the electricity use of the vacuum pump decreased with increasing operating pressure to a power of -1.07 (see Figure 6-8). Overall, the total electricity loss increased with increasing stripping pressure to a power of 0.29 . The total electricity loss changed from 50 to $74 \mathrm{MW}$ as the stripping pressure increased from 2 to 8 psia at a $\mathrm{L} / \mathrm{G}$ ratio of $1.2(\mathrm{~L} / \mathrm{G})_{\min }$. This corresponds to about 56 to $82 \%$ of the steam extraction loss of the MEA process.

Only considering the energy consumption for the selected operating pressure range, it is expected that a lower stripping pressure allows the use of lower quality steam, which will result in a higher thermal efficiency of the power plant. On the other hand, the lowest operating pressure has a boundary, because steam condensation is limited by the cooling water temperature, which depends on water sources and the season as well. The lowest stripping pressure is also limited by the fact that a lower stripping pressure will lead to a larger stripper size, which in turn, increases the capital cost. An optimal stripping pressure thus exists, at which, the best economic performance is achieved. The effect of stripping pressure on the cost was quantified in the cost sensitivity analysis presented in Section 6.3.

\section{(2) Effect of $\mathrm{CO}_{2}$ loading in lean solution}


$\mathrm{CO}_{2}$ loading in the lean solution affects the equilibrium vapor pressure of $\mathrm{CO}_{2}$ in the gas phase, and thus impacts the minimum $\mathrm{L} / \mathrm{G}$ ratio $\left[(\mathrm{L} / \mathrm{G})_{\min }\right]$ in the absorption column. A lower loading of $\mathrm{CO}_{2}$ in the lean solution favors $\mathrm{CO}_{2}$ absorption, resulting in a reduced $(\mathrm{L} / \mathrm{G})_{\min }$ and actual $\mathrm{L} / \mathrm{G}$ ratio to achieve the same level of $\mathrm{CO}_{2}$ absorption (see Figure 6-9). The $\mathrm{CO}_{2}$ loading in the rich solution only changed slightly with decreasing $\mathrm{CO}_{2}$ loadings in the lean solution.

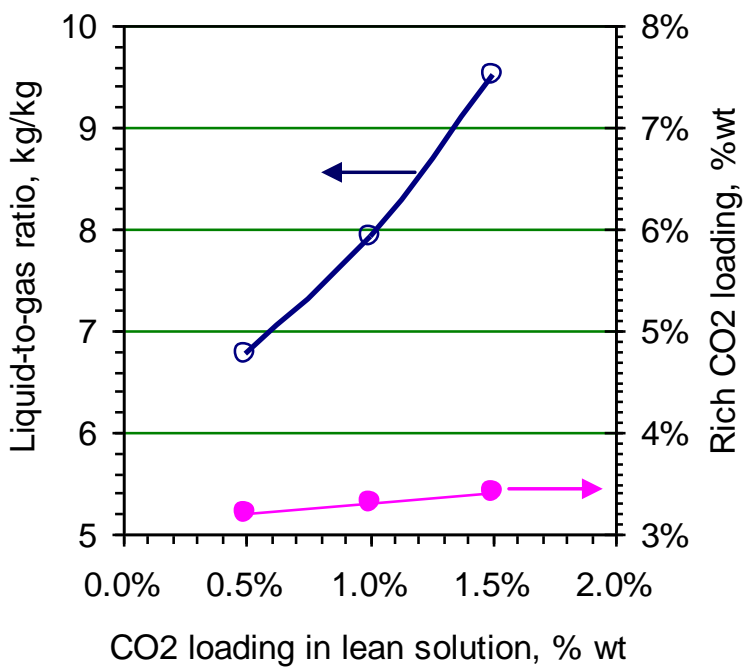

Figure 6-9. $\mathrm{L} / \mathrm{G}$ ratios at different $\mathrm{CO}_{2}$ loadings (Flue gas: $130^{\circ} \mathrm{F}, 13.9 \% \mathrm{CO}_{2}$; Solvent: $20 \mathrm{wt} \% \mathrm{PC}$ solution; L/G ratio: $1.2(\mathrm{~L} / \mathrm{G})_{\min }$; stripping pressure: 3 psia; stripper pressure drop: 1 psia).

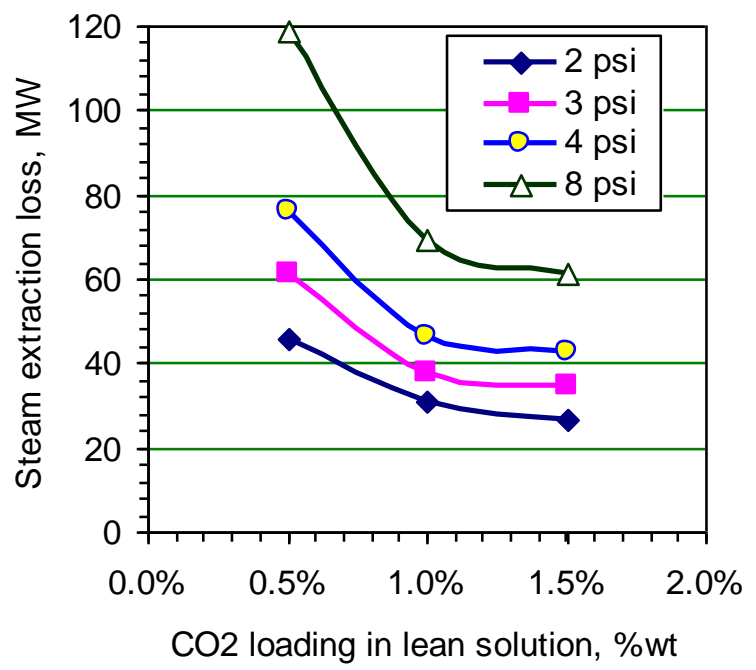

Figure 6-10. Steam extraction losses at different $\mathrm{CO}_{2}$ loadings (Flue gas: $130^{\circ} \mathrm{F}, 13.9 \% \mathrm{CO}_{2}$; Solvent: 20 wt\% PC solution; L/G ratio: $1.2(\mathrm{~L} / \mathrm{G})_{\min }$; Stripping pressure: 3 psia; Stripper pressure drop: 1 psia).

The mass and energy balance calculation showed that a lower lean $\mathrm{CO}_{2}$ loading at the stripper bottom shifted the temperature profile upward in the column compared to a higher $\mathrm{CO}_{2}$ loading. For example, at a stripping pressure of 0.2 atm ( 3 psia), the temperatures at the bottom and top of 
the column increased by about 1.7 and $5.6^{\circ} \mathrm{C}\left(3\right.$ and $\left.10^{\circ} \mathrm{F}\right)$, respectively, when the lean $\mathrm{CO}_{2}$ loading varied from 1.5 to $0.5 \%$. Therefore, more heat was required to provide for higher water vaporization and higher heat duty of the reboiler. Although the $L / G$ ratio decreased with decreasing lean $\mathrm{CO}_{2}$ loading, the resulting reduction in sensible heat was relatively insignificant in comparison to the increased water latent heat requirement. As a result, a decrease of $\mathrm{CO}_{2}$ loading from 1.5 to $0.5 \%$ almost doubled the steam extraction loss (see Figure 6-10). While a lower $\mathrm{CO}_{2}$ loading is not economic, a $\mathrm{CO}_{2}$ loading above $1.5 \%$ would not greatly improve the energy use performance of the process.

\section{(3) Effect of $L / G$ ratio}

The $\mathrm{L} / \mathrm{G}$ ratio affects both the treated gas purity and the heat requirement of the absorption process. In a chemical absorption process, the $\mathrm{L} / \mathrm{G}$ ratio typically ranges between 1.1 and 1.5 times $(\mathrm{L} / \mathrm{G})_{\min }$. The $\mathrm{L} / \mathrm{G}$ ratios examined in this study were $1.0,1.2$ and 1.5 times $(\mathrm{L} / \mathrm{G})_{\min }$. The impact of the $\mathrm{L} / \mathrm{G}$ ratio on the heat requirement of the stripper is shown in Figure 6-11.

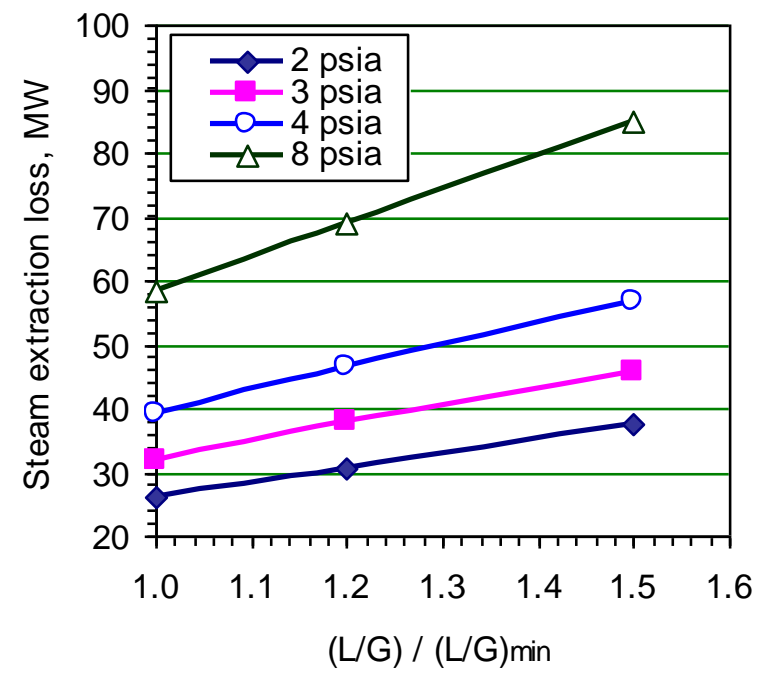

Figure 6-11. Steam extraction losses at different L/G ratios (Flue Gas: $130^{\circ} \mathrm{F}, 13.9 \% \mathrm{CO}_{2}$; solvent: 20 wt $\%$ PC solution $\mathrm{K}_{2} \mathrm{CO}_{3}, 1 \% \mathrm{CO}_{2}$ lean loading).

At $90 \% \mathrm{CO}_{2}$ removal and a $1 \% \mathrm{CO}_{2}$-lean loading in the solution, the $\mathrm{CO}_{2}$-rich loading at the stripper inlet decreased from 3.8 to $2.8 \%$ as the $\mathrm{L} / \mathrm{G}$ increased from 1.0 to 1.5 times $(\mathrm{L} / \mathrm{G})_{\min }$. The temperature at the stripper bottom was related only to the $\mathrm{CO}_{2}$-lean loading in the equilibrium calculation, and thus remained the same. A lower $\mathrm{CO}_{2}$ loading in the rich solution required a slightly higher temperature in the stripping column to drive out the $\mathrm{CO}_{2}$ from solution. Therefore, more water vaporization was expected at a higher L/G ratio. On the other hand, a higher L/G ratio required more sensible heat to heat the solution. However, as mentioned earlier, the sensible heat contributed less than $20 \%$ to the total heat requirement for operations at $1 \%$ $\mathrm{CO}_{2}$ loading and therefore was not considered significant. Combining the increased heat requirement for water vaporization and solution heating, the electricity loss due to steam use increased by about $45 \%$ for a change in the $\mathrm{L} / \mathrm{G}$ ratio from 1.0 to 1.5 times $(\mathrm{L} / \mathrm{G})_{\mathrm{min}}$. 


\subsection{Equipment sizing}

\subsubsection{Sizing of absorption column}

\section{(1) Modeling method and assumptions}

Four packed-bed absorbers were employed in parallel to capture $\mathrm{CO}_{2}$ from the flue gas in the 528 MWe (gross) power plant. The baseline operating conditions used in the sizing calculation are listed in Table 6-3.

Table 6-3. Baseline operating conditions used in the absorber sizing calculation

\begin{tabular}{|l|l|c|}
\hline \multirow{4}{*}{ Feed gas } & Condition & Value or specification \\
\hline \multirow{3}{*}{ Feed liquid* } & $\mathrm{CO}_{2}$ concentration $(\%)$ and partial pressure $(\mathrm{psia})$ & $13.9 \%$ and 2 psia \\
\cline { 2 - 3 } & Gas flow rate $\left(\mathrm{ft}^{3} / \mathrm{hr} @ 300^{\circ} \mathrm{F}\right)$ & $14,576,780 \times 4$ \\
\cline { 2 - 3 } & $\mathrm{CO}_{2}$ removal efficiency $(\%)$ & 90 \\
\hline \multirow{2}{*}{ Packed bed } & $\mathrm{K}_{2} \mathrm{CO}_{3}$ concentration $\left(\mathrm{kmol} / \mathrm{m}^{3}\right)$ & 1.36 \\
\cline { 2 - 3 } & $\mathrm{KHCO}_{3}$ concentration $\left(\mathrm{kmol} / \mathrm{m}^{3}\right)$ & 0.68 \\
\cline { 2 - 3 } & $\mathrm{CA}$ concentration $\left(\mathrm{kg} / \mathrm{m}^{3}\right)$ & 3 \\
\cline { 2 - 3 } & Operation temperature $\left({ }^{\circ} \mathrm{F}\right)$ & 122 \\
\cline { 2 - 3 } & Packing & Structured $\left(350 \mathrm{~m}^{2} / \mathrm{m}^{3}\right)$ \\
\hline
\end{tabular}

* PC concentration of $20 \mathrm{wt} \% \mathrm{~K}_{2} \mathrm{CO}_{3}$-equivalent with $40 \%$ CTB conversation rate

Estimation of absorber diameter. The $\mathrm{CO}_{2}$ absorber operates under counter-current mode. If the $\mathrm{CO}_{2}$ absorption reaches equilibrium at the bottom of the absorber, $(\mathrm{L} / \mathrm{G})_{\min }$ can be estimated based on the following mass balance equation:

$$
\frac{L \rho_{L} w \%\left(1-\alpha_{1}\right)}{M_{K_{2} \mathrm{CO}_{3}}}\left(x^{*}-x_{1}\right)=\frac{G\left(1-y_{1}\right)}{V_{m}}\left(Y_{1}-Y_{2}\right)
$$

where $y_{1}$ is the molar fraction of $\mathrm{CO}_{2}$ in the inlet gas; $Y_{1}$ and $Y_{2}$ are the molar ratios of $\mathrm{CO}_{2}$ to the inert gas at the bottom and top of the absorber, respectively; $G$ is the gas volumetric flow rate; $V_{m}$ is the molar volume of the inert gas; $L$ is the volumetric flow rate of the liquid; $w \%$ is the weight percentage of $\mathrm{K}_{2} \mathrm{CO}_{3}$ in the solution; $M_{K 2 C O 3}$ is the molecular weight of $\mathrm{K}_{2} \mathrm{CO}_{3} ; \rho_{L}$ is the density of the liquid; $x_{1}$ is the CTB conversion level of the PC at the top of the absorber, $x^{*}$ is the CTB conversion level under equilibrium with the $\mathrm{CO}_{2}$ partial pressure at the bottom of the absorber. The value of $(\mathrm{L} / \mathrm{G})_{\min }$ was determined as $8.8\left(\mathrm{~L} / \mathrm{m}^{3}\right)$ based on Eq.(6-1).

In the sizing calculation, the actual $\mathrm{L} / \mathrm{G}$ selected was 1.2 times the $(\mathrm{L} / \mathrm{G})_{\min }$, i.e, $\mathrm{L} / \mathrm{G}=10 \mathrm{~L} / \mathrm{m}^{3}$ $=\sim 10 \mathrm{gm} / \mathrm{gm}$, as typically used in the column calculation. Given the known flue gas volume, the liquid flow rate in each absorber was determined $\left(\mathrm{L}=3,935.7 \mathrm{~m}^{3} / \mathrm{hr} / 17,330 \mathrm{gpm}\right)$.

The capacity parameter $(C s)$ is commonly used to determine the flooding gas velocity:

$$
C_{s}=u_{G}{ }^{\prime}\left(\frac{\rho_{G}}{\rho_{L}-\rho_{G}}\right)^{0.5}
$$


where $u_{G}$ ' is the flooding gas velocity; $\rho_{G}$ is the density of the gas; $\rho_{L}$ is the density of the liquid. For a structured packing with a specific surface area of $250 \mathrm{~m}^{2} / \mathrm{m}^{3}$, the capacity parameter and flooding velocity were determined as: $\mathrm{C}_{\mathrm{s}}=0.062$ and $u_{G}{ }^{\prime}=1.96 \mathrm{~m} / \mathrm{s}(6.43 \mathrm{ft} / \mathrm{s})$. ${ }^{[7]}$

In the current calculation, the operating gas velocity was assumed to be $70 \%$ of that at flooding, i.e., $u_{G}=1.372 \mathrm{~m} / \mathrm{s}(4.5 \mathrm{ft} / \mathrm{s})$. The required diameter of each absorber was then determined as follows:

$$
\text { Diameter }=\sqrt{\frac{4 G}{3600 \pi u_{G}}}=10.2 \mathrm{~m}=\sim 10 \mathrm{~m}(32.8 \mathrm{ft})
$$

Determination of packed bed height. The overall mass transfer coefficient for gas absorption with reaction can be determined by using individual mass transfer coefficients:

$$
\frac{1}{K_{L}}=\frac{H}{k_{G}}+\frac{1}{E k_{L}}
$$

where $K_{L}$ is the overall liquid phase mass transfer coefficient; $k_{L}$ is the liquid phase mass transfer coefficient; $k_{G}$ is the gas phase mass transfer coefficient; $E$ is the enhancement factor of absorption with reaction; and $H$ is the reciprocal of $H$ e, the Henry's law constant.

Considering a mass balance across a differential element of the packed bed gives:

$$
-\frac{L}{A_{\text {cross }}} d\left[\mathrm{CO}_{3}{ }^{2-}\right]=K_{L} a_{e}\left(C^{*}-C^{b}\right) d h
$$

where $A_{\text {cross }}$ is the cross-sectional area of each absorber; $a_{e}$ is the effective interfacial surface; $C^{*}$ is the concentration of $\mathrm{CO}_{2}$ in equilibrium with the gas phase; $C^{b}$ is the concentration of $\mathrm{CO}_{2}$ in the liquid bulk; and $\mathrm{C}_{\mathrm{CO}^{2-}}$ is the concentration of $\mathrm{CO}_{3}{ }^{2-}$ ions.

The value of $C^{b}$ can be determined assuming $\mathrm{H}_{2} \mathrm{CO}_{3}$ dissociation $\left(\mathrm{CO}_{2}+\mathrm{H}_{2} \mathrm{O}=\mathrm{HCO}_{3}{ }^{-}+\mathrm{H}^{+}\right)$, and $\mathrm{HCO}_{3}{ }^{-}$dissociation $\left(\mathrm{HCO}_{3}{ }^{-}=\mathrm{H}^{+}+\mathrm{CO}_{3}{ }^{2-}\right)$ are in equilibrium during the absorption:

$$
C^{b}=\frac{K_{2}}{K_{1}} \frac{\left[\mathrm{HCO}_{3}^{-}\right]^{2}}{\left[\mathrm{CO}_{3}^{2-}\right]}
$$

where $K_{1}$ and $K_{2}$ are the equilibrium constants of the $\mathrm{H}_{2} \mathrm{CO}_{3}$ and $\mathrm{HCO}_{3}{ }^{-}$dissociation reactions, respectively.

Determination of parameters used in calculation. Kinetic data, mass transfer coefficients, and physical properties of the gas and liquid streams were required in the absorber sizing calculation.

$\mathrm{CO}_{2}$ absorption into the PC solution is a pseudo-first order reaction. The absorption is a "fast" reaction (based on classic absorption theory, the reaction is defined as "fast" at $H_{a}>3$ even if it may not be fast in reality) and the enhancement factor $(E)$ is estimated by:

$$
E \approx H a=\frac{\sqrt{D_{C O_{2}, P C} k_{o v}}}{k_{L}}
$$


where $\mathrm{Ha}$ is the Hatta number; $D_{C O}, P C$ is the diffusivity of $\mathrm{CO}_{2}$ in $\mathrm{PC}$ solution; and $k_{o v}$ is the overall rate constant. Two reactions contribute to the overall $\mathrm{CO}_{2}$ absorption; $\mathrm{CO}_{2}$ with $\mathrm{OH}^{-}$ions, and $\mathrm{CO}_{2}$ hydration catalyzed by the $\mathrm{CA}$ enzyme. The overall rate constant is expressed by:

$$
k_{o v}=k_{\mathrm{H}_{2} \mathrm{O}}+k_{\mathrm{OH}}\left[\mathrm{OH}^{-}\right]+k_{\mathrm{CA}}[\mathrm{CA}]
$$

where $\left[\mathrm{OH}^{-}\right]$is the concentration of $\mathrm{OH}^{-}$ions; $[\mathrm{CA}]$ is the concentration of $\mathrm{CA}$ enzyme; $k_{\mathrm{OH}^{-}}$is the rate constant of the $\mathrm{CO}_{2}+\mathrm{OH}^{-}$reaction; and $k_{C A}$ is the enzymatic rate constant (ratio of

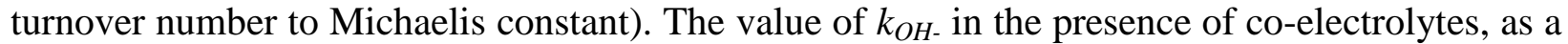
function of temperature, is given by Pohorecki and Moniuk ${ }^{[8]}$ and $k_{C A}$ is based on the measured data reported in Chapter $3 \mathrm{C}$ of this report.

The gas- and liquid-side mass transfer coefficients in the packed-bed column are well documented in the literature. The methods reported in the literature ${ }^{[9,10]}$ were used to calculate the mass transfer coefficients in the structured packed bed. Property data or estimation methods for the flue gas and PC solution, such as viscosity, density, surface tension, diffusivity, and Henry's constant were those summarized in a recent study. ${ }^{[11]}$ The equilibrium constants for the related ionic reactions were obtained from the literature. ${ }^{[12-14]}$

\section{(2) Results of sizing calculation}

A computer program was developed for this study to solve the mass transfer rate model described above. The heights of the absorber with the packing material of different specific surface areas are presented in Table 6-4. The pressure drops listed in the table were estimated based on a correlation chart by Strigle. ${ }^{[15]}$ With increasing specific surface area of the packing, the required bed height decreased significantly. For a "fast" reaction (i.e., $H_{a}>3$ ), the absorption occurs mainly within the liquid film. In our system, it was estimated that $H_{a}$ is $>10$ and a large interfacial area favored the rate of absorption.

The dosage of CA enzyme has a significant effect on the required height of the packed bed, as shown in Figure 6-12. Increasing the CA dosage from 0.3 to $3 \mathrm{~g} / \mathrm{L}$ reduces the height of the packed bed from 72 to $25 \mathrm{~m}$ (236 to $82 \mathrm{ft}$ ). According to our previous modeling work, the rate of absorption would level off when the CA dosage approached $3 \mathrm{~g} / \mathrm{L}$, at which, the rate was limited by the diffusion of the $\mathrm{CO}_{2}$ substrate onto the enzyme. Results in Figure 6-12 confirmed that increasing the enzyme dosage from $0.3 \mathrm{~g} / \mathrm{L}$ to $2 \mathrm{~g} / \mathrm{L}$ impacted a reduction in absorber height more than increasing the dosage from $2 \mathrm{~g} / \mathrm{L}$ to $3 \mathrm{~g} / \mathrm{L}$. In addition, the optimal dosage of the CA enzyme can be determined based on a trade-off between the capital and operating costs.

Table 6-4. Height of the packed-bed absorber with packing of 3 different specific surface areas (the CA concentration was assumed to be $3 \mathrm{~g} / \mathrm{L}$ in the calculation)

\begin{tabular}{|c|c|c|c|c|c|c|}
\hline & \multicolumn{3}{|c|}{ Structured packing } & \multirow[b]{2}{*}{$\begin{array}{l}\text { Diameter of } \\
\text { absorber, } m\end{array}$} & \multirow[b]{2}{*}{$\begin{array}{l}\text { Height of } \\
\text { absorber, m }\end{array}$} & \multirow[b]{2}{*}{$\begin{array}{l}\text { Pressure drop, } \\
\text { inch water } / \mathrm{ft}\end{array}$} \\
\hline & $\begin{array}{c}\text { Surface } \\
\text { area, } \mathrm{m}^{2} / \mathrm{m}^{3}\end{array}$ & $\begin{array}{c}\text { Void } \\
\text { fraction, } \%\end{array}$ & $\begin{array}{l}\text { Corrugation } \\
\text { side }\left(45^{\circ}\right), \mathrm{m}\end{array}$ & & & \\
\hline No.1 & 250 & 97 & 0.0177 & 10 & 35 & $\sim 0.2$ \\
\hline No. 2 & 350 & 94 & 0.0127 & 10 & 25 & $\sim 0.4$ \\
\hline No.3 & 500 & 92 & 0.00891 & 10 & 18 & $\sim 0.9$ \\
\hline
\end{tabular}




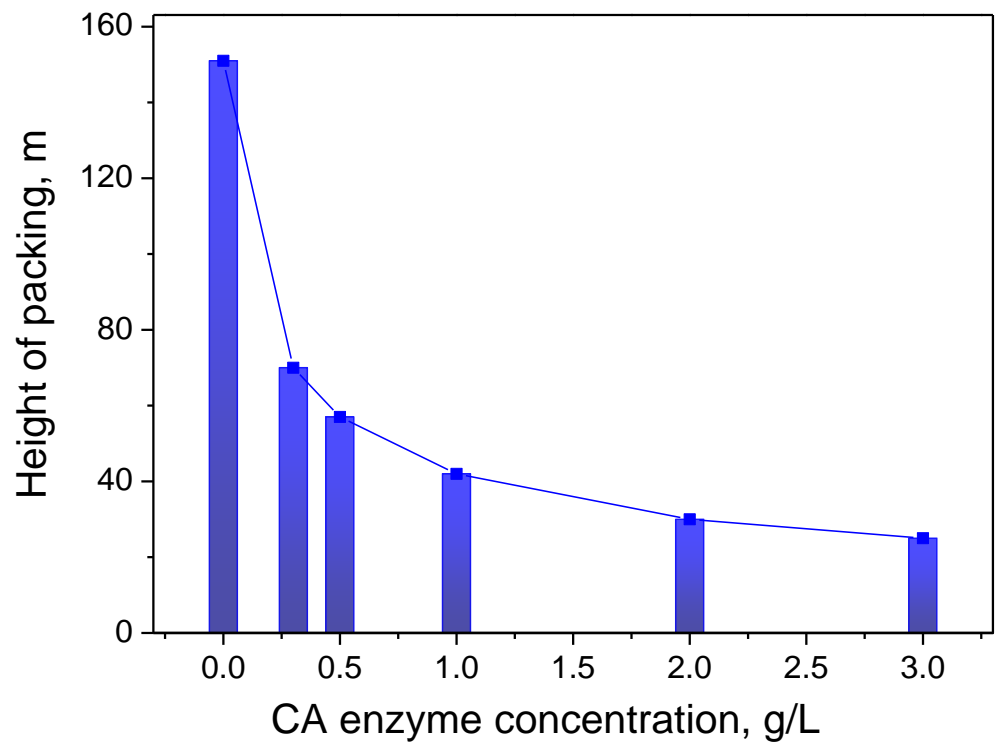

Figure 6-12. Height of packed bed vs. dosage of CA enzyme (the packing with specific surface area of $350 \mathrm{~m}^{2} / \mathrm{m}^{3}$ was assumed in the calculation).

Table 6-5 shows a comparison of absorber height with the use of $20 \mathrm{wt} \%$ PC with 15\% (PC2015 ) and 20\% (PC20-20) CTB conversion levels as the feed solution to the absorber. The PC2015 solution resulted in a reduced liquid flow rate and thus a reduced absorber diameter. However, the volume of the absorber was comparable in both cases. The results indicate that regeneration of the $\mathrm{CO}_{2}$-rich solution to produce the PC20-15 lean solution would need more heat supply in the stripper.

Table 6-5. Height of packed bed using the PC20-20 vs. PC20-15 as the feed solution (the packing with surface area of $350 \mathrm{~m}^{2} / \mathrm{m}^{3}$ and the enzyme concentration of $3 \mathrm{~g} / \mathrm{L}$ were assumed)

\begin{tabular}{|l|c|c|c|c|}
\hline Feed solution & $\mathrm{L} / \mathrm{G}, \mathrm{L} / \mathrm{m}^{3}$ & $\begin{array}{c}\text { Required diameter of } \\
\text { each absorber, } \mathrm{m}\end{array}$ & $\begin{array}{c}\text { Required Height of } \\
\text { packing, } \mathrm{m}\end{array}$ & $\begin{array}{c}\text { Pressure drop, } \\
\text { inch water } / \mathrm{ft}\end{array}$ \\
\hline PC20-20 & 10 & 10 & 25 & $\sim 0.4$ \\
\hline PC20-15 & 8 & 9 & 27 & $\sim 0.4$ \\
\hline
\end{tabular}

From the above calculation, at the baseline conditions and CA dosage of $2 \mathrm{~g} / \mathrm{L}$, each of the four

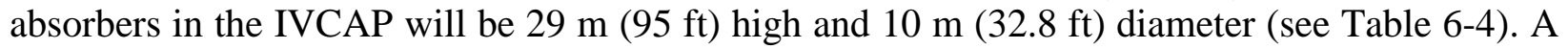
2002 DOE/NETL study for a 1,400 MWth (thermal input, equivalent to $560 \mathrm{MWe}$ electricity gross output) coal-fired power plant equipped with the MEA process showed that 16 absorbers (in four trains), each of $4.4 \mathrm{~m}(14.5 \mathrm{ft})$ in diameter and $24 \mathrm{~m}(80 \mathrm{ft})$ in height, were required, ${ }^{[16]}$ which is equivalent to a total absorber volume $40 \%$ smaller than the IVCAP absorber. Another DOE/NETL study for retrofitting the $463 \mathrm{MWe}$ (gross) Conesville \#5 unit with the MEA process

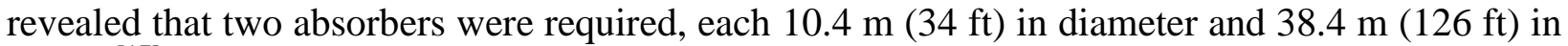
height. ${ }^{[17]}$ Considering the difference in power plant output, the size (total volume) of IVCAP absorber is $23 \%$ larger than that of the MEA in the retrofitting study. In addition, a rate-based equipment design calculation was also performed using Aspen Plus ${ }^{\circledR}$ in this study, and the calculated MEA absorber size was 3\% smaller than that of the IVCAP. 
Due to the discrepancy in calculated MEA absorber sizes described above, the total absorber volume required for the IVCAP was assumed to be $40 \%$ larger than its MEA counterpart in the techno-economic study discussed in Section 6.3.

\subsubsection{Sizing of stripping column}

Four strippers were assumed to operate in parallel to strip off $\mathrm{CO}_{2}$ from the rich PC solution for $\mathrm{CO}_{2}$ capture in the $528 \mathrm{MWe}$ (gross) power plant. Calculation of stripper dimensions for the baseline IVCAP process was conducted based on the operating conditions listed in Table 6-6.

Table 6-6. Baseline operating conditions used in the stripper sizing calculation

\begin{tabular}{|l|l|c|}
\hline & Condition & Value or specification \\
\hline \multirow{3}{*}{$\mathrm{CO}_{2}$-rich solution } & $\mathrm{CO}_{2}$ loading, wt\% & $3.30 \%$ \\
\cline { 2 - 3 } & Liquid flow rate (tonne/hr) & $4,019 \times 4$ \\
\cline { 2 - 3 } & Temperature $\left({ }^{\circ} \mathrm{C}\right)$ & 64 \\
\hline \multirow{4}{*}{ Direct steam injection } & Temperature $\left({ }^{\circ} \mathrm{C}\right)$ & 67 \\
\cline { 2 - 3 } & Pressure $(\mathrm{psia})$ & $4(0.27 \mathrm{~atm})$ \\
\cline { 2 - 3 } & Steam flow rate (tonne/hr) & $115 \times 4$ \\
\hline $\mathrm{CO}_{2}$ recovery & $\mathrm{CO}_{2}$ flow rate (tonne/hr) & $96 \times 4$ \\
\cline { 2 - 3 } & Pressure at the top of stripper $(\mathrm{psia})$ & $3(0.20 \mathrm{~atm})$ \\
\hline $\mathrm{CO}_{2}$-lean solution & $\mathrm{CO}_{2}$ loading, wt\% & $1.0 \%$ \\
\hline
\end{tabular}

The rate equation of mass transfer with reaction in the stripper sizing calculation was similar to that used in the absorber sizing. Since the stripping temperature is highly uneven along the column height, the heat transfer equation had to be coupled with the mass transfer equation. The coupled rate equations, with liquid- and gas-phase thermodynamics calculations by the NRTL model and Rehlich-Kwong equation of state, were solved using Aspen Plus ${ }^{\circledR}$ software since CHEMCAD does not provide mass and heat transfer rate-based models. In the current sizing calculation, a packed-bed configuration was assumed. The packing material was a standard structured Mellapak ${ }^{\text {TM }} 350 \mathrm{Y}$ packing with void fraction of 0.982 and surface area of $350 \mathrm{~m}^{2} / \mathrm{m}^{3}$ $\left(107 \mathrm{ft}^{2} / \mathrm{ft}^{3}\right)$. Mass transfer coefficients used in Aspen Plus ${ }^{\circledR}$ were estimated based on a method in the literature. ${ }^{[18]}$

There are two major desorption reactions in the stripping process. One is the dissociation of $\mathrm{HCO}_{3}{ }^{-}$into $\mathrm{CO}_{2}$ and $\mathrm{OH}^{-}$ions, and the other is reverse hydration at the elevated temperature and low $\mathrm{CO}_{2}$ partial pressure:

$$
\begin{aligned}
& \mathrm{HCO}_{3}^{-}+\mathrm{H}^{+} \underset{k_{12}}{\stackrel{\mathrm{k}_{11}}{\rightleftarrows}} \mathrm{CO}_{2}+\mathrm{H}_{2} \mathrm{O} \\
& \mathrm{HCO}_{3}^{-} \underset{\mathrm{k}_{22}}{\stackrel{\mathrm{k}_{21}}{\rightleftarrows}} \mathrm{CO}_{2}+\mathrm{OH}^{-}
\end{aligned}
$$

where $k_{11}$ and $k_{12}$ are the forward and backward reaction rate constants of Reaction (6-R1); and $k_{21}$ and $k_{22}$ are the forward and backward reaction rate constants of Reaction (6-R2). As previously discussed, the rate of Reaction (6-R1) is extremely slow and thus negligible. When the CA enzyme is present, this reaction becomes significant. The rate constant $k_{12}$ was obtained from the enzymatic kinetic study in Chapter $3 \mathrm{C}$ of this report. Knowing the values of the 
equilibrium constant $\left(1 / \mathrm{K}_{1}\right)$ of Reaction (6-R1) at different temperatures, the values of $k_{11}$ promoted with the CA could be derived $\left(k_{11}=k_{12} / \mathrm{K}_{1}\right)$. The forward and backward rate constants of Reaction (6-R2) were available in Aspen Plus ${ }^{\circledR}$.

The sizing calculation was performed for the process scenarios without and with the CA enzyme. Results show that under the baseline IVCAP condition without the CA enzyme (Table 6-6), each of the four strippers was $12 \mathrm{~m}(39.4 \mathrm{ft})$ in diameter and $92 \mathrm{~m}(302 \mathrm{ft})$ in height for $\mathrm{CO}_{2}$ capture from the $528 \mathrm{MWe}$ power plant. The stripper size significantly decreased with the addition of the CA enzyme as a catalyst. In the presence of $2 \mathrm{~g} / \mathrm{L} \mathrm{CA}$, each of the four strippers was $10.5 \mathrm{~m}(34.5$ $\mathrm{ft}$ ) in diameter and $19 \mathrm{~m}(62.4 \mathrm{ft})$ in height (see Table 6-7). The pressure drop in the packed-bed

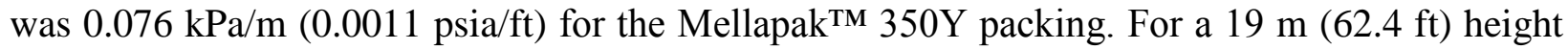
column, this is equivalent to a pressure drop of $1.45 \mathrm{kPa}(0.21 \mathrm{psia})$, indicating that the assumption of $6.9 \mathrm{kPa}$ (1 psia) pressure drop in the energy/mass balance simulation and the techno-economic analysis in Section 6.3 was rather conservative.

Table 6-7. The height and diameter of packed bed stripper under the baseline IVCAP condition (packing with surface area of $350 \mathrm{~m}^{2} / \mathrm{m}^{3}$ and void fraction of 0.98 )

\begin{tabular}{|c|c|c|c|c|}
\hline $\begin{array}{c}\text { Stripping } \\
\text { pressure, psia }\end{array}$ & $\begin{array}{c}\text { CA enzyme } \\
\text { dosage, } \mathrm{mg} / \mathrm{L}\end{array}$ & $\begin{array}{c}\text { Diameter of each } \\
\text { stripper, } \mathrm{m}\end{array}$ & $\begin{array}{c}\text { Height of packing } \\
\text { bed, } \mathrm{m}\end{array}$ & $\begin{array}{c}\text { Pressure drop, } \\
\text { psia }\end{array}$ \\
\hline 3 & 0 & 10.5 & 170 & 1.855 \\
\hline 3 & 300 & 10.5 & 40 & 0.436 \\
\hline 3 & 2,000 & 10.5 & 19 & 0.210 \\
\hline 3 & 3,000 & 10.5 & 16 & 0.178 \\
\hline
\end{tabular}

It should be noted that under the baseline condition, the stripping temperature was higher than $60^{\circ} \mathrm{C}\left(140^{\circ} \mathrm{F}\right)$. The CA enzymes tested in this project were not stable at such temperature levels for a long term. Therefore, a stable CA enzyme, either a new class of thermophilic enzymes or by immobilization, is required for the stripping process.

The size of the stripper also varied with varying stripping pressure, as shown in Table 6-8. With increasing stripping pressure from 13.8 to $55.2 \mathrm{kPa}$ ( 2 to $8 \mathrm{psia}$ ), the diameter of the bed decreased from 12 to $9.5 \mathrm{~m}$ (39.4 to $31.2 \mathrm{ft})$ due to decreasing actual gas volumetric flow rate. Meanwhile, the height of the bed increased from 15 to $40 \mathrm{~m}$ (49.2 to $131.2 \mathrm{ft})$ at a CA dosage of 2 $\mathrm{g} / \mathrm{L}$, because of a reduction in driving force for $\mathrm{CO}_{2}$ mass transfer from the liquid- to gas-phase. Overall, the stripper volume increased by $67 \%$ as the stripping pressure increased from 13.8 to $55.2 \mathrm{kPa}$ (2 to 8 psia).

Table 6-8. Height and diameter of the packed-bed stripper under various stripping pressure conditions (the packing with surface area of $350 \mathrm{~m}^{2} / \mathrm{m}^{3}$ and void fraction of 0.98 )

\begin{tabular}{|c|c|c|c|c|}
\hline $\begin{array}{c}\text { Stripping } \\
\text { pressure, psia }\end{array}$ & $\begin{array}{c}\text { CA enzyme } \\
\text { dosage, } \mathrm{mg} / \mathrm{L}\end{array}$ & $\begin{array}{c}\text { Diameter of each } \\
\text { absorber, } \mathrm{m}\end{array}$ & $\begin{array}{c}\text { Height of packing } \\
\text { bed, } \mathrm{m}\end{array}$ & $\begin{array}{c}\text { Pressure drop, } \\
\text { psia }\end{array}$ \\
\hline 2 & 2,000 & 12 & 15 & 0.150 \\
\hline 3 & 2,000 & 10.5 & 19 & 0.210 \\
\hline 4 & 2,000 & 10 & 35 & 0.327 \\
\hline 8 & 2,000 & 9.5 & 40 & 0.396 \\
\hline
\end{tabular}


In summary, each of the four IVCAP strippers is $10.5 \mathrm{~m}(34.4 \mathrm{ft})$ in diameter and $19 \mathrm{~m}(62.4 \mathrm{ft})$ in height at the baseline conditions and $2 \mathrm{~g} / \mathrm{L} \mathrm{CA}$ enzyme dosage. The 2002 DOE/NETL study ${ }^{[16]}$ showed that the MEA process installed in a $\sim 560 \mathrm{MWe}$ (gross) power plant required four strippers $4.9 \mathrm{~m}(16 \mathrm{ft})$ in diameter and $22.9 \mathrm{~m}$ (75 ft) high in parallel, which is about 3.8 times smaller than the stripper size required for the IVCAP. In a DOE/NETL study for retrofitting the Conesville \#5 unit with the MEA process, two strippers $6.7 \mathrm{~m}(22 \mathrm{ft})$ in diameter, and $15.2 \mathrm{~m}$ (50ft) highwere used. ${ }^{[17]}$ Calibrated with the difference in power plant output, the size (total volume) of the MEA strippers was 5.4 times smaller than that of the IVCAP strippers. Aspen Plus ${ }^{\circledR}$ also was used in this study to calculate the MEA stripper size, and results showed that the MEA stripper size was 1.4 times smaller than that of the IVCAP. Compared to the MEA process, both the stripping pressure (0.2 vs $\sim 1.7$ atm/3 vs. $\sim 25$ psia) and $\mathrm{CO}_{2} /$ water vapor ratio (1:3 vs. $1: 1)$ in the IVCAP are lower, resulting in an increase in gas flow rate and thus stripper size. However, due to the low gas density under vacuum, the gas flooding velocity is high and the operating gas velocity can be significantly increased compared to an atmospheric or a pressurized operation. As a result, the stripper size is not linearly proportional to the operating vacuum pressure.

Based on the above comparison, the stripper size of the IVCAP was assumed to be 3.8 times larger than its MEA counterpart in the techno-economic analysis in Section 6.3.

\subsubsection{Sizing of steam extraction line}

In the IVCAP process, a portion of the steam is used as stripping gas and directly introduced into the stripper. The other portion is sent to the stripper reboiler. The two LP steam streams have different properties (temperature and pressure). The latter requires higher temperature (and thus pressure) to provide the heat transfer driving force for indirect heat exchange.

The steam lines were sized using CHEMCAD's Pipe Sizing and Rating (PIPE) module. A single-phase flow was assumed and the Jain method was used for friction factor modeling of commercial steel pipe. The global enthalpy model was based on the SRK method and the Kvalue model was based on ideal vapor pressure. The transport properties of the steam were based on information in the CHEMCAD database.

The single steam train has two steam pipes, one directly to the stripper, and the other to the reboiler. The baseline steam conditions used in the sizing calculation are listed in Table 6-9.

Table 6-9. Baseline operating conditions used in the steam extraction line sizing calculation

\begin{tabular}{|l|l|c|}
\hline & Condition & Value or specification \\
\hline \multirow{2}{*}{$\begin{array}{l}\text { Steam extracted to stripper } \\
\text { (direct injection) }\end{array}$} & Temperature $\left({ }^{\circ} \mathrm{C}\right)$ & 67.15 \\
\cline { 2 - 3 } & Pressure $($ psia) & $4.0(0.27 \mathrm{~atm})$ \\
\cline { 2 - 3 } & Steam flow rate (tonne/hr) & 460 \\
\hline \multirow{3}{*}{ Steam extracted to reboiler } & Temperature $\left({ }^{\circ} \mathrm{C}\right)$ & 80.6 \\
\cline { 2 - 3 } & Pressure $($ psia) & $7.03(0.48 \mathrm{~atm})$ \\
\cline { 2 - 3 } & Steam flow rate (tonne/hr) & 282 \\
\hline $\begin{array}{l}\text { Stripping temperature at } \\
\text { the stripper bottom }\end{array}$ & Temperature $\left({ }^{\circ} \mathrm{C}\right)$ & 69.4 \\
\hline
\end{tabular}


The results of the piping calculation are presented in Table 6-10. The calculation was based on the assumptions that the steam line from the turbine to the stripper was $50 \mathrm{~m}(164 \mathrm{ft})$ long, and 10 valves and 10 elbow fittings were required to install the piping line. As a preliminary sizing analysis, the adiabatic mode was employed and the heat transfer to ambient was not considered. Results revealed that for the steam extracted for injection to the stripper, a pipe diameter of 4-m was sufficient. The total pressure loss was about $0.69 \mathrm{kPa}(0.1 \mathrm{psia})$ in the $50 \mathrm{~m}(164 \mathrm{ft})$ long pipe with the valves and joints and the temperature dropped by $0.36^{\circ} \mathrm{C}\left(0.65^{\circ} \mathrm{F}\right)$. A pipe of $3 \mathrm{~m}$ $(9.84 \mathrm{ft})$ in diameter was required for the steam extracted to the reboiler. The total pressure drop over such a pipe was estimated as less than $0.69 \mathrm{kPa}(0.1 \mathrm{psia})$ and the temperature drop as $0.06^{\circ} \mathrm{C}\left(0.108^{\circ} \mathrm{F}\right)$. In both pipes, the pressure drops were not significant compared to their extraction pressures from the turbine, because the density of the steam is low at low pressure. Due to the negligible temperature drop, the steam entering the reboiler could be maintained at $80.5^{\circ} \mathrm{C}\left(177^{\circ} \mathrm{F}\right)$, indicating that there was a sufficient temperature driving force for $\mathrm{CO}_{2}$ stripping (required stripping temperature of $69.4^{\circ} \mathrm{C}\left(157^{\circ} \mathrm{F}\right)$ at the baseline conditions).

Table 6-10. Pressure and temperature drops through the extraction steam lines to the stripper and reboiler under the baseline IVCAP condition (a pipe length of $50 \mathrm{~m}$ was assumed; 5 gate valves, 5 ball valves, 5 standard $90^{\circ}$ elbows, and 5 standard $45^{\circ}$ elbows were assumed in the piping system)

\begin{tabular}{|c|c|c|c|c|c|}
\hline \multirow{2}{*}{ Steam } & $\begin{array}{c}\text { Pipe } \\
\text { diameter, } \mathrm{m}\end{array}$ & $\begin{array}{c}\text { Steam } \\
\text { velocity, m/s }\end{array}$ & $\begin{array}{c}\text { Pressure drop } \\
\text { (duct), psia }\end{array}$ & $\begin{array}{c}\text { Pressure drop (duct+ } \\
\text { valves+ fittings), psia }\end{array}$ & $\begin{array}{c}\text { Temperature } \\
\text { drop, }{ }^{\circ} \mathrm{C}\end{array}$ \\
\hline \multirow{3}{*}{$\begin{array}{c}\text { Steam to } \\
\text { stripper }\end{array}$} & 3.0 & 102.3 & $2.37 \times 10^{-2}$ & $4.71 \times 10^{-1}$ & 0.36 \\
\cline { 2 - 6 } & 4.0 & 57.5 & $5.41 \times 10^{-3}$ & $1.29 \times 10^{-1}$ & 0.36 \\
\hline \multirow{2}{*}{$\begin{array}{c}\text { Steam to } \\
\text { reboiler }\end{array}$} & 5.0 & 36.8 & $1.77 \times 10^{-3}$ & $5.04 \times 10^{-2}$ & 0.36 \\
\cline { 2 - 6 } & 2.0 & 83.4 & $4.09 \times 10^{-2}$ & $5.48 \times 10^{-1}$ & 0.06 \\
\cline { 2 - 6 } & 3.0 & 37.1 & $5.22 \times 10^{-3}$ & $9.41 \times 10^{-2}$ & 0.06 \\
\hline
\end{tabular}

\subsection{Cost analysis}

\subsubsection{Method of cost analysis and assumptions}

The cost analysis of the IVCAP process was based on the cost information available for the MEA process, which has been studied extensively and reported in the literature. The Integrated Environmental Control Model (IECM) (version 6.2.4, 2010) ${ }^{[19]}$ was employed to estimate the capital and O\&M cost of the MEA process, based on default financial assumptions built into the model and the process parameters obtained in the process simulation study described in Sections 6.2 and 6.3 of this chapter.

\section{(1) Capital cost}

The bare erected cost (BEC) of equipment in the MEA process was estimated using the IECM model. The total capital requirement (TCR) covers all the expenditures to complete an entire plant. These include facilities, engineering and home office, project contingency cost, process contingency cost, interest charges during construction, royalty, pre-production, spare parts, inventory capital, initial chemicals, and land costs. The assumptions used for calculating the TCR of the MEA process in the IECM model are listed in Table 6-11. These assumptions were 
also used in the cost analysis for the IVCAP.

Table 6-11. Items of capital cost estimation

\begin{tabular}{|c|c|}
\hline (a) & Costs of Individual Process Units (bare erected cost, BEC) \\
\hline & Process Facilities Capital (PFC) $=\sum \mathrm{a}$ \\
\hline (b) & General Facilities Capital (10\% PFC) \\
\hline (c) & Engineering \& Home Office Fees (7\% PFC) \\
\hline (d) & Project Contingency Cost (15\% PFC) \\
\hline (e) & Process Contingency Cost (5\% PFC) \\
\hline (f) & Total Plant Cost (TPC) = PFC $+\mathrm{b}+\mathrm{c}+\mathrm{d}+\mathrm{e}$ \\
\hline & Interest Charges (AFUDC construction time of 3 years) \\
\hline (g) & Royalty Fees (0.5\% PFC) \\
\hline (h) & Preproduction (Startup) Cost (1 month of fixed O\&M; 1 month of variable \\
\hline (i) & In\&entory Capital (0.5\% TPC) \\
\hline & Total Capital Requirement (TCR) $=$ TPI $+\mathrm{g}+\mathrm{h}+\mathrm{i}$ \\
\hline
\end{tabular}

Table 6-12. Process units and scaling parameters

\begin{tabular}{|c|l|l|}
\hline & \multicolumn{1}{|c|}{ Process unit } & \multicolumn{1}{|c|}{ Scaling parameter } \\
\hline 1 & $\mathrm{SO}_{2}$ Polisher/Direct Contact Cooler & n/a \\
\hline 2 & Flue Gas Blower & Scaling factor =1 \\
\hline 3 & $\mathrm{CO}_{2}$ Absorber Vessel & Volume of absorber \\
\hline 4 & Heat Exchangers & Heat duty of heat exchanger \\
\hline 5 & Circulation Pumps & Liquid rate \\
\hline 6 & Sorbent Regenerator & Volume of stripper \\
\hline 7 & Reboiler & Heat duty of reboiler* \\
\hline 8 & Steam Extractor & Scaling factor =1 \\
\hline 9 & Sorbent Reclaimer & Not required for IVCAP \\
\hline 10 & Sorbent Processing & Cooling duty of lean solution exiting stripper \\
\hline & & Quoted price for vacuum pump \\
\hline 11 & Drying and Compression Unit & Scaling factor =1 for other parts \\
\hline 12 & Auxiliary Natural Gas Boiler & n/a \\
\hline 13 & Auxiliary Steam Turbine & n/a \\
\hline
\end{tabular}

* Reboiler cost is related to heat duty, temperature difference for heat transfer and operating pressure. Heat duty is used as a scaling parameter for simplicity. The potential error associated with neglecting other parameters is discussed in Section 6.3.2 below.

The BECs of individual units in the IVCAP process were estimated by a scaling approach based on those of the MEA process. Several important design parameters determine the economics of process scaling. They include absorber and stripper volumes, solvent flow conditions, and heat duty and cooling duty of the heat exchangers and reboiler (see Table 6-12). The flue gas conditions, such as the $\mathrm{CO}_{2}$ concentration and temperature, are the same for the MEA and IVCAP cost modeling, the cost items related to the flue gas were assumed the same for the two processes. A power rule was assumed for cost-scaling with a scaling exponent of 0.60 . The costscaling was expressed as: 


$$
B E C_{I V C A P}=B E C_{M E A} \times\left(\frac{S_{I V C A P}}{S_{M E A}}\right)^{0.60}
$$

where $\mathrm{BEC}_{\mathrm{IVCAP}}$ and $\mathrm{BEC}_{\mathrm{MEA}}$ are the $\mathrm{BEC}$ of an individual unit in the IVCAP and the MEA process, respectively; and $\mathrm{S}_{\mathrm{IVCAP}}$ and $\mathrm{S}_{\mathrm{MEA}}$ are the process parameters used for the cost scaling of an individual unit in the IVCAP and MEA process, respectively.

\section{(2) O\&M Cost}

Fixed $O \& M$ Cost. The fixed O\&M cost includes the cost of operating labor, the maintenance material and labor, and the administrative and support labor (see Table 6-13). The cost of operating labor $(\mathrm{OL})$ was estimated based on the number of operating jobs (OJ), daily operating shift (OS), and the labor rate:

$$
O L=\text { Labor rate } \times O J \times 24(\text { hrs } / \text { day }) / O S \times 365(\text { day } / \text { year })
$$

Annual maintenance labor and material (ML\&M) costs were estimated as a percentage of the total plant cost (TPC). The percentage varies with individual process areas. It was assumed that $40 \%$ of the ML\&M is shared by the maintenance labor. Administrative \& Support (A\&S) labor cost was assumed to be $30 \%$ of the sum of operating labor cost and maintenance labor cost.

$$
A \& S=30 \% \times O L+40 \% \times M L \& M
$$

Table 6-13. Estimation of the fixed O\&M cost

\begin{tabular}{|l|l|}
\hline Fixed O\&M cost & Assumptions \\
\hline Operating labor & $\begin{array}{l}\text { Labor rate: } \$ 33 / \mathrm{hr} / \text { person } \\
\text { Operating jobs: } 2 \text { persons/shift } \\
\text { Operating shifts: } 4.75 \text { shifts/day }\end{array}$ \\
\hline Maintenance & $\begin{array}{l}2.5 \% \text { of TPC }(40 \% \text { for maintenance labor and } 60 \% \text { for Maintenance } \\
\text { materials) }\end{array}$ \\
\hline Administrative \& support & $30 \%$ of total O\&M labor \\
\hline
\end{tabular}

Variable $O \& M$ cost. The variable O\&M cost includes the costs of consumables (chemicals, water, waste disposal, etc.) and fuel. The unit prices used in this study are listed in Table 6-14. A $75 \%$ loading factor of the power plant was assumed for variable O\&M cost.

Table 6-14. Unit prices of consumables used for $\mathrm{CO}_{2}$ capture

\begin{tabular}{|l|c|c|}
\hline Consumable & Unit & Price $(\$)$ \\
\hline MEA & \$/ton & $2,128(\$ 2,343 /$ tonne $)$ \\
\hline MEA inhibitor & $\%$ of MEA & 20 \\
\hline Activated carbon & $\$ /$ ton & $1987(\$ 2,188 /$ tonne $)$ \\
\hline Caustic $(\mathrm{NaOH})$ & $\$ /$ ton & $410(\$ 452 /$ tonne $)$ \\
\hline Water & $\$ / \mathrm{kGal}$ & 1.023 \\
\hline Potassium carbonate $(\mathrm{PC})$ & $\$ /$ ton & $500(\$ 551 /$ tonne $)$ \\
\hline PC corrosion inhibitor & $\%$ of PC & 20 \\
\hline CA enzyme & $\$ / \mathrm{kg}$ & 480 \\
\hline
\end{tabular}

\section{(3) Cost of Electricity}


The levelized cost of electricity (LCOE) is a coal pile-to-busbar cost of power expressed in mills/kWh. As shown in Table 6-15, the financial criteria used in this study were taken from the IECM model. Based on these assumptions, a levelized carrying charge (applied to TCR) is 0.1128. No inflation was considered for categories in the O\& M costs.

Table 6-15. Financial assumptions for the cost estimation

\begin{tabular}{|c|c|c|}
\hline General characteristics & & \\
\hline Plant startup date (year) & \multicolumn{2}{|c|}{2009} \\
\hline Capital cost year dollars & \multicolumn{2}{|c|}{2009} \\
\hline Construction period & \multicolumn{2}{|c|}{3 years } \\
\hline Capacity factor & \multicolumn{2}{|c|}{$75 \%$} \\
\hline \multicolumn{3}{|l|}{ Financial assumptions } \\
\hline Project book life & \multicolumn{2}{|c|}{30 years } \\
\hline Book salvage value & \multicolumn{2}{|c|}{$0 \%$} \\
\hline Project tax life & \multicolumn{2}{|c|}{30 years } \\
\hline Property tax rate & \multicolumn{2}{|c|}{$2 \%$ per year } \\
\hline Insurance tax rate & \multicolumn{2}{|c|}{$1 \%$ per year } \\
\hline Federal income tax rate & \multicolumn{2}{|c|}{$34 \%$} \\
\hline State income tax rate & \multicolumn{2}{|c|}{$4.15 \%$} \\
\hline Investment tax credit (\% eligible) & \multicolumn{2}{|c|}{$0 \%$} \\
\hline Capital structure & $\%$ of total & Cost, $\%$ \\
\hline Debt & 45 & 5.83 \\
\hline Preferred stock & 10 & 5.34 \\
\hline Common equity & 45 & 8.74 \\
\hline Weighted cost of capital (before tax) & \multicolumn{2}{|c|}{$7.09 \%$} \\
\hline General escalation & \multicolumn{2}{|c|}{$0 \%$} \\
\hline
\end{tabular}

A busbar LCOE increase for the $75 \%$ design capacity factor is calculated using the following relationship:

$$
L C O E=\frac{11.28 \% \times T C R+O \& M \cos t}{M W_{e}(n e t) \times 0.75 \times 8760}
$$

\section{(4) Costs of $\mathrm{CO}_{2}$ avoidance and $\mathrm{CO}_{2}$ capture}

The cost of $\mathrm{CO}_{2}$ capture is defined as the increase in LCOE per captured $\mathrm{CO}_{2}$ emissions due to installation of $\mathrm{CO}_{2}$ capture process. It can be expressed as follows:

$$
\text { Cost of } \mathrm{CO}_{2} \text { capture }(\$ / \text { ton })=\frac{(\$ / k W h)_{\text {capture }}-(\$ / k W h)_{\text {reference }}}{\left(\text { ton } \mathrm{CO}_{2} / k W h\right)_{\text {capture }}}
$$

where $(\$ / \mathrm{kWh})_{\text {capture }}$ and $(\$ / \mathrm{kWh})_{\text {reference }}$ are the LCOE of the power plant with and without $\mathrm{CO}_{2}$ capture, respectively; and (ton $\mathrm{CO}_{2} / \mathrm{kWh}$ ) capture is the amount of $\mathrm{CO}_{2}$ captured per net $\mathrm{kWh}$ generation with $\mathrm{CO}_{2}$ capture.

Because a $\mathrm{CO}_{2}$ capture unit consumes considerable electricity and thus reduces the power plant output, the $\mathrm{CO}_{2}$ emissions per net kWh generation increase correspondingly. The actual avoided 
emissions are the difference between net $\mathrm{CO}_{2}$ emissions before and after the installation of the $\mathrm{CO}_{2}$ capture unit. Accordingly, the cost of $\mathrm{CO}_{2}$ avoidance can be expressed as:

Cost of $\mathrm{CO}_{2}$ avoidance $(\$ /$ ton $)=\frac{(\$ / k W h)_{\text {capture }}-(\$ / k W h)_{\text {reference }}}{\left(\text { ton } \mathrm{CO}_{2} / k W h\right)_{\text {reference,emi }}-\left(\text { ton } \mathrm{CO}_{2} / k W h\right)_{\text {captureemi }}}(6-14)$

where (ton $\mathrm{CO}_{2} / \mathrm{kWh}$ ) reference, emi and (ton $\mathrm{CO}_{2} / \mathrm{kWh}$ ) capture, emi are the $\mathrm{CO}_{2}$ emissions per net $\mathrm{kWh}$ generation without and with $\mathrm{CO}_{2}$ capture.

\subsubsection{Cost of baseline IVCAP process}

A cost analysis was first performed for the IVCAP at the baseline case conditions: (1) inlet flue gas at $54.4^{\circ} \mathrm{C}\left(130^{\circ} \mathrm{F}\right)$ containing $13.9 \% \mathrm{CO}_{2}$; (2) $20 \mathrm{wt} \% \mathrm{PC}$ solution with $2 \mathrm{~g} / \mathrm{L} \mathrm{CA}$ enzyme as the solvent; (3) $\mathrm{CO}_{2}$ lean loading of $1 \mathrm{wt} \% \mathrm{CO}_{2}$; (4) $\mathrm{L} / \mathrm{G}$ ratio of $1.2(\mathrm{~L} / \mathrm{G})_{\min }$; (5) stripper operating at $0.2 \mathrm{~atm} / 3 \mathrm{psia}$ (pressure at the stripper top); and (5) stripper pressure drop of $6.9 \mathrm{kPa}$ (1 psia).

Since the cost analysis of the IVCAP referenced the MEA process, the capital and O\&M cost of the MEA process obtained by the IECM model were verified after comparison with those reported by Rao and Rubin. ${ }^{[20]}$

The cost results show that the total capital cost of the baseline IVCAP process was about $33 \%$ higher than that of the MEA process, due to the larger volume of the vacuum stripper, a slightly larger absorber, and the cost of the vacuum pump (see Table 6-16). On the other hand, the solvent reclaimer and solvent processing were eliminated in the IVCAP since the PC solution experiences no degradation and the temperature of the lean solution exiting the stripper is relatively low. The equipment cost was scaled up or down from their counterparts in the MEA using the 0.6 power rule for analog, according to the ratio of liquid flow rate, reboiler heat duty, heat exchanger heat duty, MW scale, volume of stripper/absorber, etc. between the two processes.

In the current study, the cost of the vacuum pump was separated from the compressor system. However, in an actual plant, the vacuum pump will be one stage of the multi-stage $\mathrm{CO}_{2}$ compressor. Vacuum operation in the stripper will significantly increase the gas stream volume especially when the vacuum is high. At 0.2 atm ( 3 psia), the total $\mathrm{CO}_{2}$ volume will be more than $1,020,000 \mathrm{~m}^{3} / \mathrm{hr}(600,000 \mathrm{acfm})$ for a $500 \mathrm{MW}$ power plant. Given the high suction volume, an axial compressor-based vacuum pump may be necessary. The current axial compressor can treat up to a suction volume of 1,001,300 $\mathrm{m}^{3} / \mathrm{hr}(589,000 \mathrm{acfm}) .{ }^{[21]}$ Two compressors may thus be needed, each about $4 \mathrm{~m}(13.2 \mathrm{ft})$ in diameter, to treat half of the gas volume each at a $10 \mathrm{~m} / \mathrm{s}$ $(32.8 \mathrm{ft} / \mathrm{s})$ inlet velocity. Contacts with a compressor vendor indicated that the total BEC of the two compressors would be about $\$ 20$ million. The large size of the vacuum pumps will make the associated capital cost excessive.

The fixed O\&M cost of the IVCAP process was estimated based on a proportion to the capital cost, as previously described. Although there are no solvent degradation/polymerization problems (nominal losses) in the IVCAP, some carbonate and bicarbonate salts loss is expected through stoichiometric reactions with $\mathrm{SO}_{2}$ (stoichiometric losses, $0.85 \mathrm{~kg} \mathrm{~K} \mathrm{CO}_{3} /$ tonne $\mathrm{CO}_{2}$ 
captured). In comparison, the MEA nominal and stoichiometric losses were assumed to be 2.5 and $0.75 \mathrm{~kg} \mathrm{MEA} /$ tonne $\mathrm{CO}_{2}$ captured, respectively. Therefore, the replacement cost of the PC solvent was estimated to be less than $10 \%$ of the cost of MEA losses (including the four-fold solvent price difference). In addition, because no solvent reclamation is needed, the related costs for the MEA are not imposed for the IVCAP. However, use of CA enzyme incurs additional costs not involved in the MEA process. An enzyme dosage of $2 \mathrm{~g} / \mathrm{L}$, an enzyme makeup rate of 3 replacements/year, and an enzyme cost of $\$ 480 / \mathrm{kg}$ were assumed in the baseline-case IVCAP calculation.

Table 6-16. Capital and O\&M costs for the IVCAP and MEA installed in a $528 \mathrm{MWe}$ (gross) power plant

\begin{tabular}{|c|c|c|}
\hline \multicolumn{3}{|c|}{ Total capital cost, M\$ } \\
\hline & MEA & IVCAP \\
\hline Flue gas blower & 5.71 & 5.71 \\
\hline $\mathrm{CO}_{2}$ absorber vessel & 80.70 & 98.75 \\
\hline Heat exchangers & 6.76 & 2.53 \\
\hline Circulation pumps & 13.92 & 21.61 \\
\hline Solvent regenerator & 50.99 & 113.59 \\
\hline Reboiler & 17.57 & 10.85 \\
\hline Steam extractor & 4.40 & 4.40 \\
\hline Solvent reclaimer & 8.20 & $\mathrm{n} / \mathrm{a}$ \\
\hline Solvent processing & 7.99 & $\mathrm{n} / \mathrm{a}$ \\
\hline Drying \& compression unit & 48.27 & 48.27 \\
\hline Vacuum pump & $\mathrm{n} / \mathrm{a}$ & 20.00 \\
\hline Total process facilities capital & 244.51 & 325.72 \\
\hline Total capital requirement & 373.80 & 497.94 \\
\hline Annualized capital cost, M\$/year & 42.16 & 56.16 \\
\hline \multicolumn{3}{|c|}{ Annual O\&M cost, $\mathrm{M} \$ /$ year } \\
\hline Solvent (MEA or PC) & 17.42 & 1.74 \\
\hline CA enzyme & $\mathrm{n} / \mathrm{a}$ & 5.79 \\
\hline Corrosion inhibitor & 3.48 & 0.35 \\
\hline Activated carbon & 0.42 & $\mathrm{n} / \mathrm{a}$ \\
\hline Caustic $(\mathrm{NaOH})$ & 0.33 & $\mathrm{n} / \mathrm{a}$ \\
\hline Reclaimer waste disposal & 3.82 & $\mathrm{n} / \mathrm{a}$ \\
\hline Water & 0.04 & 0.04 \\
\hline Total variable costs (energy costs not included) & 25.47 & 7.92 \\
\hline Operating labor & 0.68 & 0.68 \\
\hline Maintenance labor & 3.35 & 4.46 \\
\hline Maintenance material & 5.02 & 6.69 \\
\hline Admin. \& support labor & 1.21 & 1.54 \\
\hline Total fixed costs & 10.26 & 13.38 \\
\hline
\end{tabular}

Cost results for the baseline IVCAP case showed that a significant amount of the cost was attributed to the capital investment. Due to its lower energy requirement and lower solvent losses, the variable O\&M costs, excluding the expenses associated with energy usage for the IVCAP, were less than half of those of the MEA process. In Table 6-17, the energy cost term is denoted as the increased electricity generation cost of the reference power plant corresponding to 
the parasitic power losses due to $\mathrm{CO}_{2}$ capture. The increase in the LCOE needed to pay for the IVCAP at the baseline conditions is $17 \%$ less than the increase required for the MEA process.

Table 6-17. Comparison of cost performance between IVCAP and MEA

\begin{tabular}{|l|c|c|}
\hline & MEA process & IVCAP process \\
\hline Cost of electricity increase, $\$ / \mathrm{MWh}$ & & 21.91 \\
\hline Capital cost & 17.88 & 5.22 \\
\hline Fixed O\&M & 4.35 & 3.09 \\
\hline Variable O\&M: non-energy & 10.80 & 15.81 \\
\hline Variable O\&M - energy losses & 22.40 & 46.04 \\
\hline Subtotal & 55.43 & 390.5 \\
\hline Net electricity, MW & 358.9 & $75 \%$ \\
\hline Loading factor, $\%$ & $75 \%$ & 1.88 \\
\hline Reference $\mathrm{CO}$ emissions, $\mathrm{lb} / \mathrm{kWh}$ & 1.88 & 0.24 \\
\hline $\mathrm{CO}_{2}$ emissions $w i t h$ control, $\mathrm{lb} / \mathrm{kWh}$ & 0.26 & 46.04 \\
\hline $\mathrm{LCOE}_{\text {increase, } \$ / \mathrm{MWh}}$ & 55.42 & 56.03 \\
\hline $\mathrm{CO}_{2}$ avoidance cost, $\$ /$ ton & 68.47 & \\
\hline
\end{tabular}

The LCOE for a typical coal-fired power plant without $\mathrm{CO}_{2}$ capture at present was assumed to be $\$ 65 / \mathrm{MWh}$ in this study. Therefore, installation of the IVCAP for $\mathrm{CO}_{2}$ capture will result in a $71 \%$ increase in the LCOE at the baseline conditions, compared to an $85 \%$ increase for the MEA.

It should be noted that there are uncertainties associated with equipment cost in the above analysis. However, such uncertainties will not change the overall cost performance of the IVCAP. For example, as previously mentioned, the reboiler cost depends on not only heat duty, but also the temperature difference, steam volume, and pressure. If the IVCAP reboiler cost is assumed to be the same as for the MEA, the LCOE will change by $0.55 \$ / \mathrm{MWh}$. For another example, if the capital cost of the vacuum pump doubles from $\$ 20$ to $\$ 40$ million (see Table 6$16)$, the LCOE will increase by $\$ 1.64 / \mathrm{MWh}$.

\subsection{Cost sensitivity analysis}

It should be noted that the above cost analysis was only for the baseline IVCAP case. A cost sensitivity analysis was conducted to investigate the effects of a few important operating parameters on the costs of the IVCAP.

\subsubsection{Stripping pressure}

In the baseline IVCAP process, the capital costs of the stripper and vacuum pump contributed 35 and 6\% to the TPC, respectively (see Table 6-16). The stripping pressure is a major factor in determining the size of the stripper and the work required for gas compression. Increasing the stripping pressure from 0.14 to 0.54 atm (from 2 to 8 psia) reduced the stripper cost by $34 \%$ and the vacuum pump by $56 \%$, resulting in a $15 \%$ reduction in TPC (see Figure 6-13). The stripping pressure also affects the O\&M cost, because the related material usage changes with stripper size. However, such an effect on the O\&M cost (not including the energy use cost) is not significant (data not shown). It should be noted that an increase in stripping pressure adversely increases the parasitic power losses, because both the quantity and quality (in terms of 
temperature and pressure) of the steam required for $\mathrm{CO}_{2}$ stripping increase. Such a trend was discussed in the process simulation study earlier (see Figure 6-8).

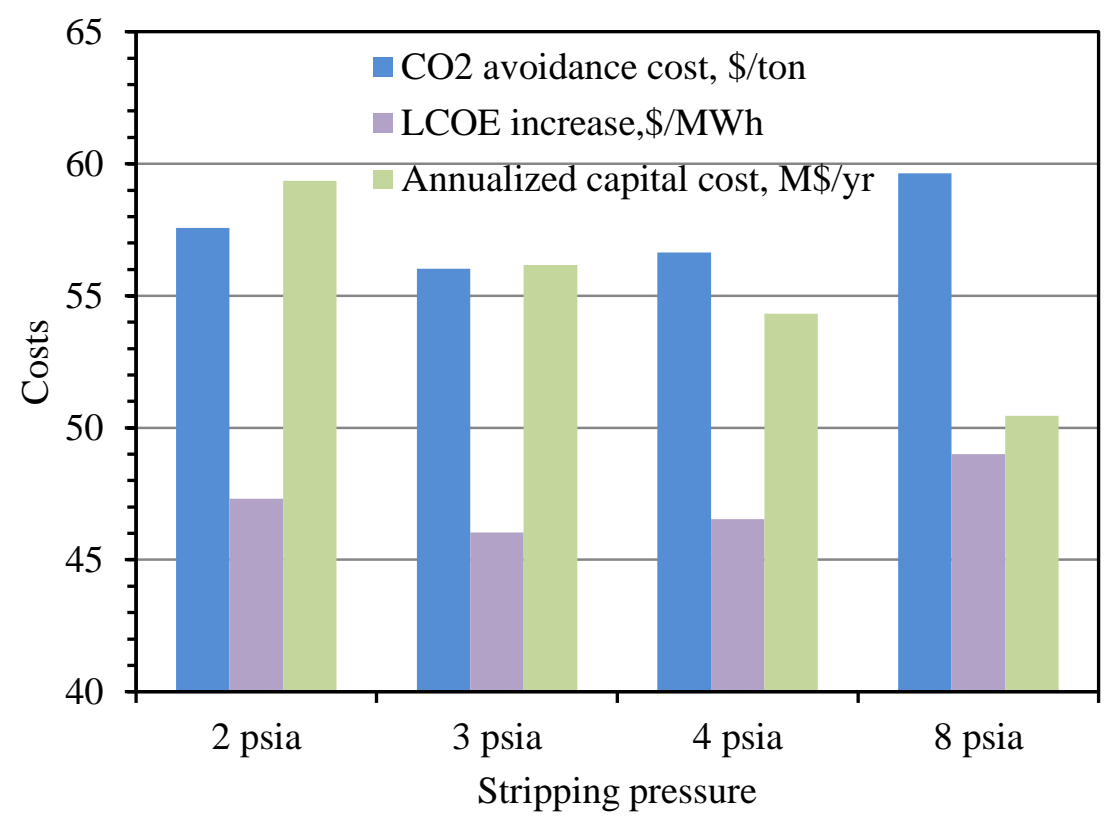

Figure 6-13. Sensitivity of costs of $\mathrm{CO}_{2}$ capture to the stripping pressure (Flue gas: $130^{\circ} \mathrm{F}, 13.9 \% \mathrm{CO}_{2}$; solvent: $20 \mathrm{wt} \% \mathrm{PC} ; 1 \% \mathrm{CO}_{2}$ lean loading; $\mathrm{L} / \mathrm{G}$ ratio: $1.2(\mathrm{~L} / \mathrm{G})_{\min }$; stripper pressure drop: 1 psia).

The impact of stripping pressure on the LCOE increase and $\mathrm{CO}_{2}$ avoidance cost is a combination of its impact on capital cost and energy demand (the O\&M cost related to parasitic power losses). As shown in Figure 6-13, the analysis revealed that the $\mathrm{CO}_{2}$ avoidance cost and LCOE changed slightly with increasing stripping pressure. Overall, at the stripping pressure between 0.14 and 0.54 atm ( 2 and 8 psia), the $\mathrm{CO}_{2}$ avoidance cost and LCOE only changed by about $6 \%$. The minimum costs occurred when the stripping pressure was between 0.2 and 0.27 atm ( 3 and 4 psia) under the baseline conditions.

\subsection{2 $\mathrm{CO}_{2}$ loading in solution}

Three $\mathrm{CO}_{2}$ loading levels in the lean PC solution - 0.5, 1.0, and $1.5 \mathrm{wt} \%$ - were examined in the cost sensitivity analysis. The process simulation study showed that when the lean $\mathrm{CO}_{2}$ loading decreased from 1.5 to $0.5 \%$, more heat was required for increased water vaporization and higher reboiler heat duty. As a result, the steam extraction loss almost doubled for the lowest loading level under the baseline conditions (see Figure 6-9). Meanwhile, $\mathrm{CO}_{2}$ desorption becomes more difficult in the lean solution, resulting in increasing residence time required for $\mathrm{CO}_{2}$ desorption. Process simulation results revealed that decreasing the $\mathrm{CO}_{2}$ loading from 1.5 to $0.5 \%$ increased the size of the stripper by more than three-fold.

The cost analysis showed that an increase in stripper size, corresponding to a decrease in $\mathrm{CO}_{2}$ loading from 1.5 to $0.5 \%$, increased the total capital cost by $31 \%$. There is also a concomitant effect of the $\mathrm{CO}_{2}$ loading on the O\&M cost due to the equipment size change. Results of the cost sensitivity showed that the $\mathrm{CO}_{2}$ avoidance cost and LCOE increased by $41 \%$ when the lean $\mathrm{CO}_{2}$ 
loading decreased from 1.5 to $0.5 \%$, as shown in Figure 6-14. For the cost consideration, a lower $\mathrm{CO}_{2}$ loading in the lean solution is not favorable for the IVCAP process.

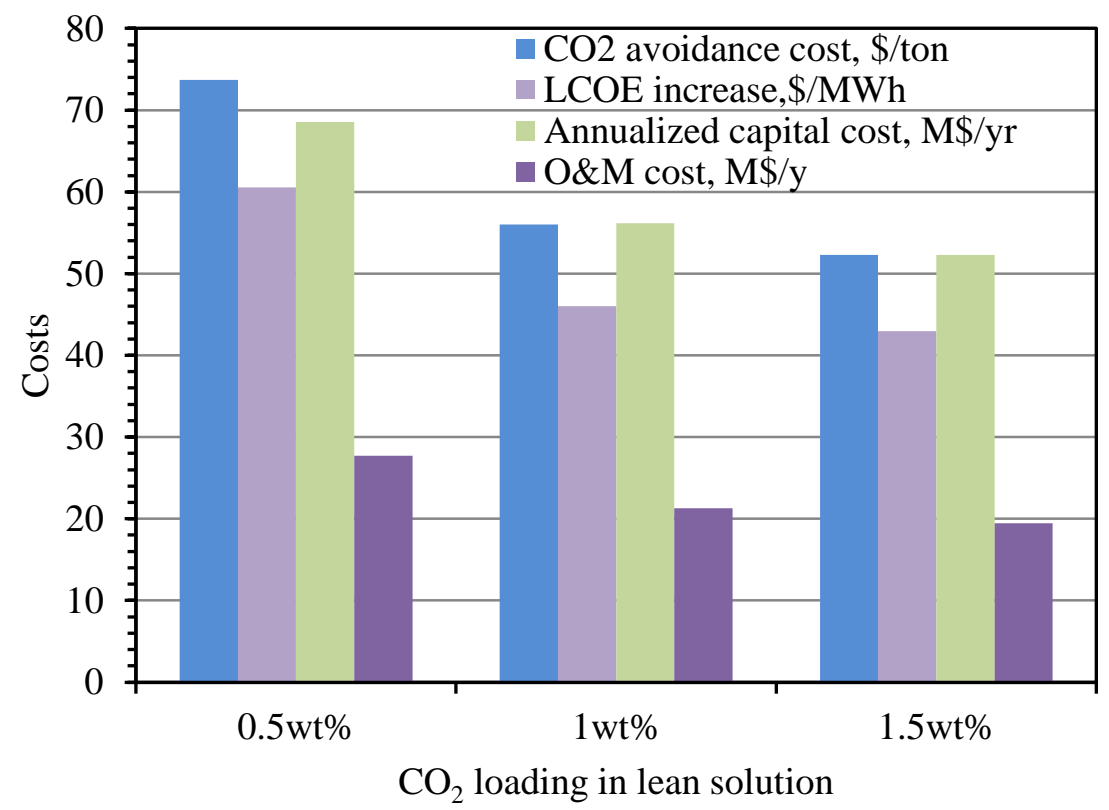

Figure 6-14. Sensitivity of costs of $\mathrm{CO}_{2}$ capture to $\mathrm{CO}_{2}$ loading in lean solution (Flue gas: $130^{\circ} \mathrm{F}, 13.9 \%$ $\mathrm{CO}_{2}$; Solvent: $20 \mathrm{wt} \%$ PC; L/G ratio: $1.2(\mathrm{~L} / \mathrm{G})_{\min }$; stripping pressure: 3 psia; stripper pressure drop: 1 psia).

\subsubsection{Cost of CA enzyme}

Advances in molecular biology and protein biochemistry and engineering have made it possible to produce biocatalysts at a relatively low cost. In the baseline IVCAP case, an enzyme price of $\$ 480 / \mathrm{kg}$ was assumed. Based on this price, the annual CA enzyme cost accounted for $7.5 \%$ of the annual total cost, equivalent to $\$ 2.3 /$ ton of $\mathrm{CO}_{2}$ captured or $\$ 4.2 /$ ton of $\mathrm{CO}_{2}$ avoided. In the cost sensitivity study, an enzyme price range of $\$ 120 / \mathrm{kg}$ to $\$ 1,920 / \mathrm{kg}$ was investigated. Based on recent communications with a leading enzyme manufacturer, it became apparent that the production cost is less than $\$ 480 / \mathrm{kg}$ of CA enzyme based on the company's experience with a pilot-scale CA production program.

Results of the cost sensitivity analysis are shown in Figure 6-15. The O\&M cost varied significantly with the enzyme price. Increasing the CA enzyme price from $\$ 120 / \mathrm{kg}$ to $\$ 1,920 / \mathrm{kg}$ increased the total annual cost (energy use cost not included) by 1.3 times. As a result, the $\mathrm{CO}_{2}$ avoidance cost and LCOE increased by $19 \%$. It is interesting to note that within the price range of $\$ 120 / \mathrm{kg}$ to $\$ 480 / \mathrm{kg}$, increases in the $\mathrm{CO}_{2}$ avoidance cost and the LCOE were not sensitive to the price change. 


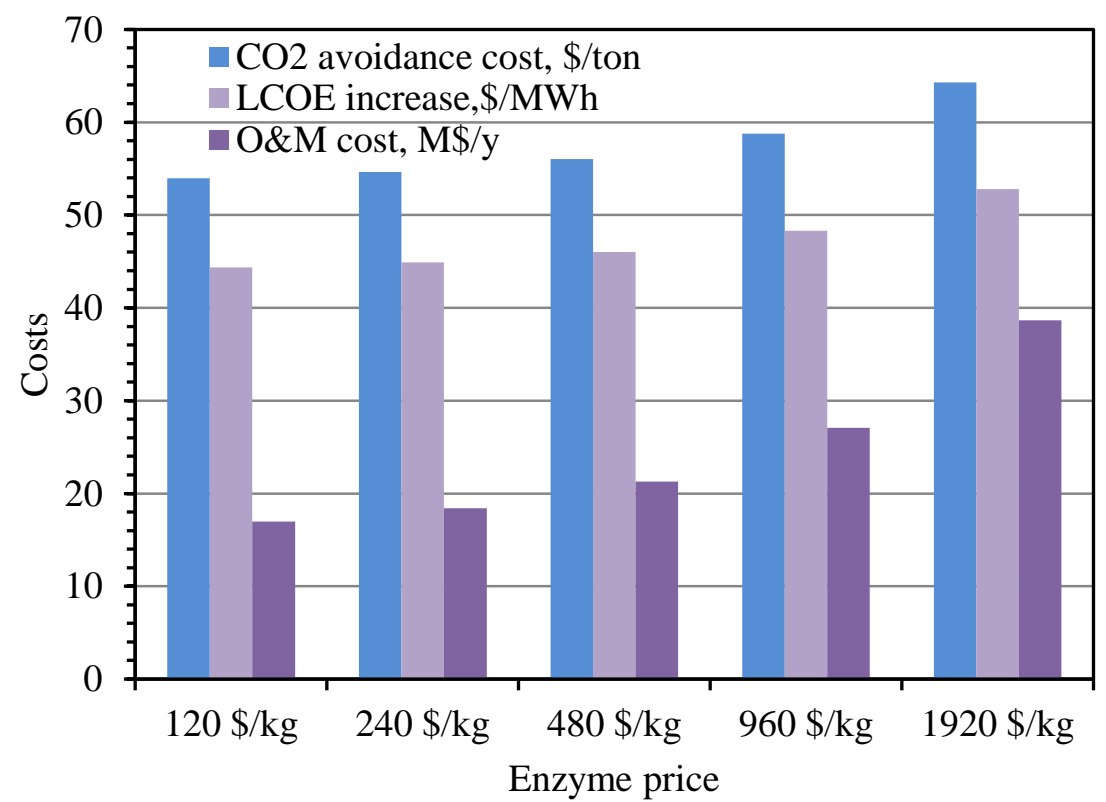

Figure 6-15. Sensitivity of costs of $\mathrm{CO}_{2}$ capture to enzyme price (Flue gas: $130^{\circ} \mathrm{F}, 13.9 \% \mathrm{CO}_{2}$; solvent: 20 wt\% PC; $1 \% \mathrm{CO}_{2}$ lean loading; L/G ratio: $1.2(\mathrm{~L} / \mathrm{G})_{\min }$; stripping pressure: 3 psia, stripper pressure drop: 1 psia).

\subsubsection{Use of additives to reduce water vapor saturation pressure}

In the vacuum stripping process, the $\mathrm{CO}_{2}$ gas stream exiting the stripper contains a large amount of water vapor, indicating that the stripping heat associated with water vaporization is an important part of the process heat use. For example, at the baseline IVCAP condition (e.g., water vapor: $\mathrm{CO}_{2}=\sim 3: 1$ ), the stripping heat accounted for $66 \%$ of the total heat supplied by the extracted steam, whereas the reaction and sensible heat contributed 14 and $20 \%$, respectively. As described in Chapter 2, several additives were found to be effective in lowering the water vapor saturation pressure. For example, the addition of $20 \mathrm{wt} \%$ potassium acetate (KAc) to the $20 \mathrm{wt} \%$ PC reduced the water vapor saturation pressure by about $20 \%$ at $70^{\circ} \mathrm{C}\left(158^{\circ} \mathrm{F}\right)$ and more than $20 \%$ at $50^{\circ} \mathrm{C}\left(122^{\circ} \mathrm{F}\right)$. The cost sensitivity to reduce water vapor saturation pressure by 10 to $30 \%$ was therefore investigated.

Reducing the water vapor saturation pressure by using an additive could potentially lower the steam usage and, thus, the parasitic power losses in the IVCAP. When the water vapor saturation pressure over the PC was lowered by up to $30 \%$, the net electricity output increased from 390.1 to $397.6 \mathrm{MWe}$. In addition, because the total gas flow rate in the stripper and the reboiler duty both decrease with decreasing water vapor saturation pressure, the stripper size also can be reduced, resulting in lower capital and O\&M costs. Results of the cost analysis showed that the $\mathrm{CO}_{2}$ avoidance cost and LCOE increase can be improved by $8 \%$ if the water vapor pressure is reduced by $30 \%$ (see Figure 6-16). 


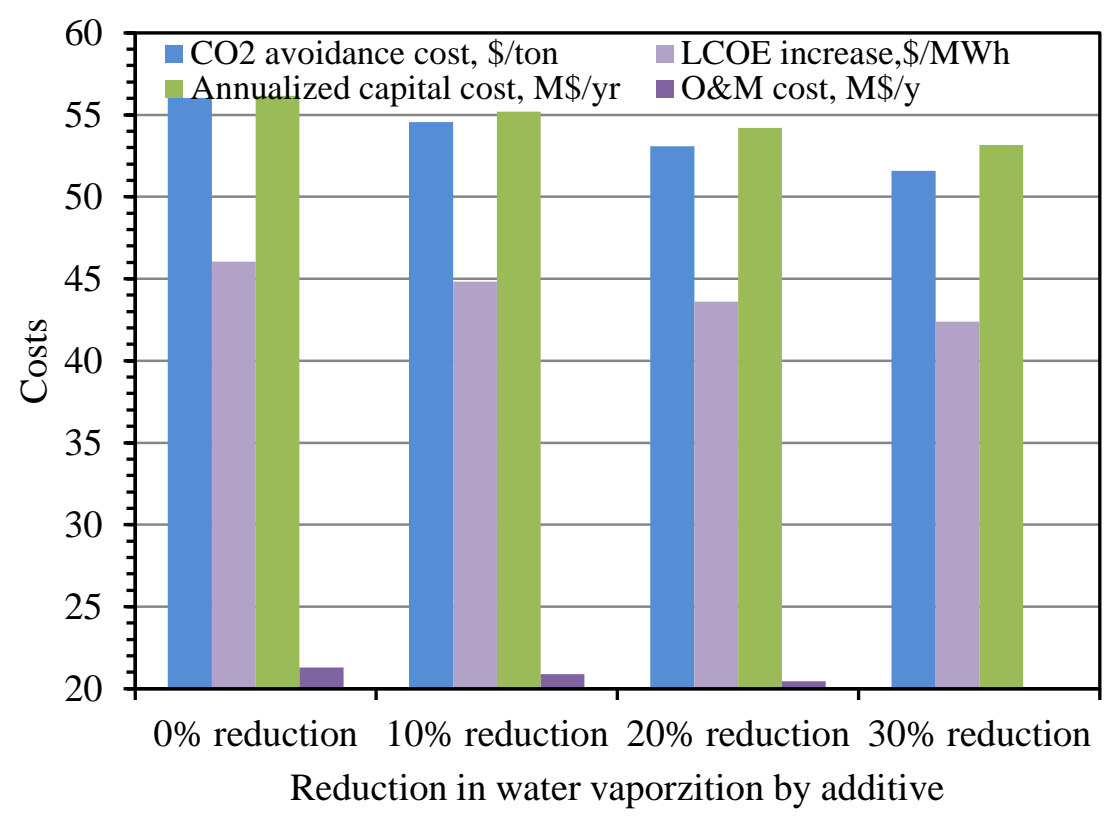

Figure 6-16. Sensitivity of costs of $\mathrm{CO}_{2}$ capture to water vapor saturation reduction by additives (Flue gas: $130^{\circ} \mathrm{F}, 13.9 \% \mathrm{CO}_{2}$; solvent: $20 \mathrm{wt} \% \mathrm{PC} ; 1 \% \mathrm{CO}_{2}$ lean loading; $\mathrm{L} / \mathrm{G}$ ratio: $1.2(\mathrm{~L} / \mathrm{G})_{\min }$; stripping pressure: 3 psia, stripper pressure drop: 1 psia).

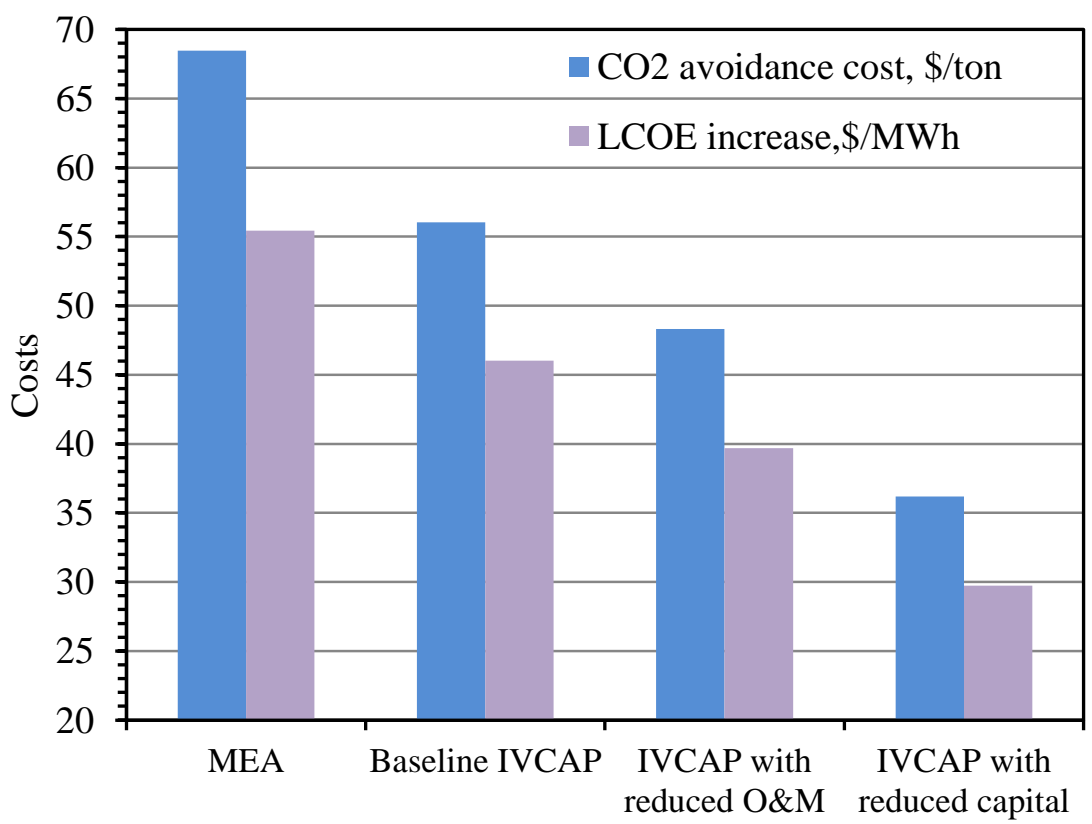

Figure 6-17. Comparison of costs of $\mathrm{CO}_{2}$ capture between MEA, baseline IVCAP, IVCAP with reduced O\&M cost (increased lean $\mathrm{CO}_{2}$ loading, lower enzyme price, and reduced water vapor pressure), and IVCAP with reduced capital cost (less expensive absorber, desorber, compressor and vacuum pump).

In summary, the $\mathrm{CO}_{2}$ avoidance cost and LCOE increase can be reduced by $7 \%$ by increasing the lean $\mathrm{CO}_{2}$ loading from 1 to $1.5 \%$; by $2 \%$ by decreasing the current enzyme price by $50 \%$; and by $5 \%$ by lowering the water vapor saturation pressure by $20 \%$, as compared to the baseline IVCAP process. Considering the O\&M cost reduction parameters listed above, the $\mathrm{CO}_{2}$ avoidance cost 
and LCOE increase of the improved IVCAP are 29 and $28 \%$ lower than those of the MEA, respectively (see the third group of bars in Figure 6-17). The corresponding LCOE increase is estimated to be $\$ 39.7 / \mathrm{MWh}$, about a $61 \%$ increase over the LCOE for the reference plan without $\mathrm{CO}_{2}$ capture.

In the baseline IVCAP, the capital cost contributed $73 \%$ of the total cost, of which, the stripper, absorber, compressor, and vacuum pump are the four most expensive units. With the development of new absorption and desorption devices and packing materials, the size and cost of such equipment tend to be reduced. Advancing compression technologies also provide an opportunity to significantly lower the costs of compressors and vacuum pumps. If the capital costs for these units were reduced by $50 \%$, a substantial reduction in the LCOE could be achieved (about 25\%). As a result, the $\mathrm{LCOE}$ caused by $\mathrm{CO}_{2}$ capture decreased to about $\$ 30 / \mathrm{MWh}$, or a $46 \%$ increase in LCOE over the reference power plant without $\mathrm{CO}_{2}$ capture (see fourth group of bars in Figure 6-17).

\subsection{Summary}

PFDs were developed for the IVCAP integrated with a coal-fired subcritical power plant. Simulations based on the PFDs were performed using CHEMCAD software. VLE and other major property data, thermodynamic models, and equipment modules in CHEMCAD were verified for the IVCAP system. Detailed simulations first were conducted for the IVCAP operating at the baseline conditions $\left(0.2 \mathrm{~atm} / 3\right.$ psia stripping pressure, $11^{\circ} \mathrm{C} / 20^{\circ} \mathrm{F}$ temperature difference in reboiler, $20 \mathrm{wt} \% \mathrm{PC}$ concentration, $1 \mathrm{wt} \% \mathrm{CO}_{2}$ lean-loading, and $\mathrm{L} / \mathrm{G}$ at 1.2 times of $(\mathrm{L} / \mathrm{G})_{\min }$ ). Results of the baseline IVCAP integrated with a $528 \mathrm{MW}$ (gross) power plant showed that the thermal efficiency of the power plant with the IVCAP was $29.8 \%$, compared to $37.6 \%$ for the power plant without $\mathrm{CO}_{2}$ capture and $27.4 \%$ for the plant with an MEA process. Overall, an energy saving of about $24 \%$ was achieved by the baseline IVCAP process compared to the MEA process.

The effects of three major parameters - stripping pressure, $\mathrm{CO}_{2}$ loading, and liquid/gas ratio - on the energy use performance of the process were also investigated. Increasing the stripping pressure resulted in an increase of steam usage and quality, and a decrease of electricity use for the vacuum pump. Overall, as the stripping pressure increased from 0.14 to 0.54 atm (from 2 to 8 psia), the total electricity loss increased at a power of 0.22 . A decrease of $\mathrm{CO}_{2}$ lean-loading from 1.5 to $0.5 \%$ almost doubled the steam extraction loss. However, a $\mathrm{CO}_{2}$ lean-loading higher than $1.0 \%$ did not significantly improve the energy performance of the process. Increasing the L/G ratio from 1.0 to 1.5 times the $(\mathrm{L} / \mathrm{G})_{\min }$ increased the electricity loss due to steam extraction by $45 \%$.

Equipment size modeling was performed to determine the quantity and dimensions of two major devices, the absorber and the vacuum stripper. The absorber height was sensitive to both the specific surface area of the packing and the CA enzyme dosage. At the baseline conditions, the bed height decreased from 72 to $25 \mathrm{~m}$ (from 236 to $82 \mathrm{ft}$ ) when the CA dosage increased from 0.3 to $3 \mathrm{~g} / \mathrm{L}$. Changing the $\mathrm{CO}_{2}$ lean-loading from 20 to $15 \%$ CTB conversion did not significantly impact the absorber size. The baseline IVCAP absorber employed $2 \mathrm{~g} / \mathrm{L}$ CA dosage and $350 \mathrm{~m}^{2} / \mathrm{m}^{3}\left(107 \mathrm{ft}^{2} / \mathrm{ft}^{3}\right)$ structured packing and was $23-40 \%$ larger than the MEA absorber, 
based on the estimates reported in two DOE/NETL studies. Both the mass and heat transfer were considered during stripper sizing. Results revealed that under the baseline IVCAP condition, the stripping process is slow in the absence of the CA enzyme and the size of the stripper is impractically large. The size of the stripper significantly decreased with the addition of the CA enzyme. At $2 \mathrm{~g} / \mathrm{L}$ CA dosage, the IVCAP required four strippers, each $10.5 \mathrm{~m}(34.4 \mathrm{ft})$ diameter and $19 \mathrm{~m}(62.4 \mathrm{ft})$ high, 3.8-5.4 times larger than those for the MEA process.

Cost modeling was performed using the IECM model to estimate the capital cost of individual equipment, materials costs, and fixed operating costs of the MEA process. The capital costs of individual units in the IVCAP process were estimated by scaling from those of the MEA-based process using relevant process parameters. The O\&M cost of the IVCAP was based on the mass and energy balance results from the process simulation. Results revealed that although the capital cost of the baseline IVCAP was about 33\% greater than that of the MEA, the O\&M cost was significantly smaller due to a lower solvent cost and reduced parasitic power losses. In the baseline IVCAP, the LCOE increase due to $\mathrm{CO}_{2}$ capture reached $\$ 46 / \mathrm{MWh}$, about a $71 \%$ increase compared to the power plant without $\mathrm{CO}_{2}$ capture. This LCOE increase for $\mathrm{CO}_{2}$ capture was $17 \%$ less than that for the MEA process.

A cost sensitivity analysis was conducted to investigate the effects of increasing the stripping pressure, the $\mathrm{CO}_{2}$ loading in solution, the price of CA enzymes, the use of additives to reduce the saturation pressure of water vapor, and lower equipment costs on the overall costs of installing and operating the IVCAP. The $\mathrm{CO}_{2}$ avoidance cost and LCOE increase can be reduced by $7 \%$ by increasing the lean $\mathrm{CO}_{2}$ loading from 1 to $1.5 \%$, by $2 \%$ by decreasing the current enzyme price by $50 \%$, and by $5 \%$ by reducing the water vapor saturation pressure by $20 \%$ using an additive, as compared to the baseline conditions. Considering these measures together, the LCOE (about $\$ 40 / \mathrm{MWh}$, a $61 \%$ increase compared to the reference plant without $\mathrm{CO}_{2}$ capture) of the IVCAP was $28 \%$ less than that of the MEA, indicating that the IVCAP is an economically-competitive option for post-combustion $\mathrm{CO}_{2}$ capture. If the capital costs of the absorber, stripper, compressor, and vacuum pump were further reduced by $50 \%$, the LCOE of the IVCAP could be lowered to about $\$ 30 / \mathrm{MWh}$, or a $46 \%$ increase over the $\mathrm{LCOE}$ without $\mathrm{CO}_{2}$ capture (about $50 \%$ of MEA).

\section{References}

1. U.S. Environmental Protection Agency. Compilation of Air Pollutant Emission Factors, AP42, Fifth Edition, Volume I: Stationary Point and Area Sources. 1998. http://www.epa.gov/ttn/chief/ap42/ch01/index.html, as of 1/15/2012.

2. Chemstations, Inc. CHEMCAD Version 6 User Guide. 2011.

3. Gilbert/Commonwealth Inc. Clean Coal Reference Plants: Pulverized Coal Boiler with Flue Gas Desulfurization. DE-AM21-94MC311 66. 1995.

4. Chen S., Bhagwat S., Rostam-Abadi, M. Techno-Economic Studies of Illinois Coal in Future Power Production Processes: Final Technical Report, Illinois Clean Coal Institute Project No. 01-1/2.3C-1, October 2002.

5. DOE/NETL. Cost and Performance Baseline for Fossil Energy Plants Volume 1: Bituminous Coal and Natural Gas to Electricity (Revision 2). DOE/NETL-2010/1397. November 2010 . 
6. Tosh, J.S., Field, J.H., Benson, H.E., Haynes, W.P. Equilibrium study of the system potassium carbonate, potassium bicarbonate, carbon dioxide, and water. United States Bureau of Mines, Report of Investigations No.5484, 1959.

7. Coker A.K. Ludwig's applied process design for chemical and petrochemical plants. Chapter 14 packed tower. ( $4^{\text {th }}$ ed.), Elsevier Science, 2007.

8. Pohorecki R., Moniuk W. Kinetics of reaction between carbon dioxide and hydroxyl ions in aqueous electrolyte solutions. Chemical Engineering Science, 1988, 43:1677-1684.

9. Rocha J.A., Bravo J.L., Fair J.R. Distillation column containing structured packings. A comprehensive model for their performance. 2. Mass transfer model. Industrial Engineering and Chemical Research, 1996, 35: 1660-1667.

10. Wang G.Q., Yuan X.G., Yu K.T. Review of mass-transfer correlations for packed column. Industrial Engineering and Chemical Research, 2005, 44: 8715-8729.

11. Khodayari A. Experimental and theoretical study of $\mathrm{CO}_{2}$ absorption into potassium carbonate solution promoted with enzyme. Master of Science Thesis, University of Illinois at UrbanaChampaign, 2010.

12. Edwards T.J., Maurer G., Newman J., Prausnitz J.M. Vapor-liquid equilibria in multicomponent aqueous solution of volatile weak electrolytes. American Institute of Chemical Engineering Journal, 1978, 24: 966-976.

13. Hikita H., Asai S., Takatsuka T. Absorption of carbon dioxide into aqueous sodium hydroxide and sodium bicarbonate solutions. Chemical Engineering Journal, 1976, 11: 131141.

14. Tsonopoulos C. Ionization constants of water pollutants. Journal of Chemical Engineering Data, 1976, 21: 190-193.

15. Strigle, R.F. Jr. Packed Tower Design and Applications: Random and Structured Packings. ( $2^{\text {nd }}$ ed.). 1994. Gulf Publishing Company. Houston, Texas.

16. Parsons Infrastructure \& Technology Group. Integrated Technical Services, updated cost, and performance estimates for fossil fuel power plants with $\mathrm{CO}_{2}$ removal: 1004483, DOE Interim Report, 2002.

17. DOE/NETL. Carbon Dioxide Capture from Existing Coal-Fired Power Plants (Revision). DOE/NETL-401/110907. November 2007.

18. Billet, R., Schultes, M. Predicting mass transfer in packed columns. Chemical Engineering Technology, 1993, 16: 1-9.

19. Carnegie Mellon University, Integrated Environmental Control Model User Manual, final report to DOE/NETL, DE-AC26-04NT41917, 2010.

20. Rao A.B., Rubin E.S., Identifying cost-effective $\mathrm{CO}_{2}$ control levels for amine-based $\mathrm{CO}_{2}$ capture systems, Industrial Engineering and Chemical Research, 2006, 45: 2421-2429.

21. Bloch H.P. A Practical Guide to Compressor Technology. Second Edition. John Wiley \& Sons, Inc., Hobokon, NJ. 2006. 


\section{CHAPTER 7. EVALUATION OF OTHER MAJOR TECHNICAL RISKS}

In addition to the various technical risks to the success of the IVCAP addressed in the previous chapters of this report (such as the rate of $\mathrm{CO}_{2}$ absorption into $\mathrm{K}_{2} \mathrm{CO}_{3} / \mathrm{KHCO}_{3}$ solution, biocatalyst activity and stability, and combined $\mathrm{CO}_{2}$ capture and $\mathrm{SO}_{2}$ removal), other potential technical risks associated with the IVCAP include: (1) the corrosion tendency of the $\mathrm{K}_{2} \mathrm{CO}_{3} / \mathrm{KHCO}_{3}$ (PC) solution; (2) treatment needed for the water condensate generated in the stripping column to be recycled and used as feed water to the power plant boiler; (3) possible $\mathrm{KHCO}_{3}$ precipitationfrom the $\mathrm{K}_{2} \mathrm{CO}_{3} / \mathrm{KHCO}_{3}$ solution, and (4) the potential impacts of trace components from coal combustion flue gases on the activity and stability of the CA enzyme. These risks were carefully considered based on findings from a literature review.

\subsection{Corrosion risk, inhibition and effect}

The IVCAP process employs a 20 to $30 \mathrm{wt} \%$ PC solution and a CA enzyme catalyst to absorb $\mathrm{CO}_{2}$ from flue gas (partial pressure of 10 to $15 \mathrm{kPa} / 1.5$ to $2.2 \mathrm{psia}$ ) at 40 to $60^{\circ} \mathrm{C}\left(104\right.$ to $140^{\circ} \mathrm{F}$ ). Desorption is carried out by a temperature and pressure swing at 13 to $55 \mathrm{kPa}$ ( 2 to 8 psia) and 50 to $70^{\circ} \mathrm{C}\left(122\right.$ to $\left.158^{\circ} \mathrm{F}\right)$. A potential risk is associated with the corrosion tendency of the $\mathrm{K}_{2} \mathrm{CO}_{3} / \mathrm{KHCO}_{3}$ solution in relation to the materials used to construct the absorbers, strippers, pumps, heat-exchangers, and other components of the IVCAP.

Previous experience with commercial "Hot Potassium Carbonate" processes, such as the Benfield and Catacarb processes, could be used to gain some insight on this issue. The Benfield process employs a 20 to $30 \% \mathrm{PC}$ solution and operates at temperatures between 80 and $130^{\circ} \mathrm{C}$ (176 to $266^{\circ} \mathrm{F}$ ). This process has been commercially-deployed in over 675 units worldwide to remove $\mathrm{CO}_{2}$ and hydrogen sulfide $\left(\mathrm{H}_{2} \mathrm{~S}\right)$ from ammonia synthesis gas, crude hydrogen, natural gas, town gas, etc. The Catacarb Process uses a PC solution containing a corrosion inhibitor and a nontoxic catalyst, such as amine borate. Both the Benfield and Catacarb processes are used to capture $\mathrm{CO}_{2}$ at partial pressures above $210 \mathrm{kPa}(30.5 \mathrm{psia})$.

In this study, corrosion circumstances reported for the hot potassium carbonate processes, including cause and mechanism, and methods for corrosion mitigation using different inhibitors, were reviewed.

\subsubsection{Corrosion circumstances caused by PC solutions}

In more than 200 Benfield installations worldwide, few have reported failure due to corrosion or erosion before 1971. In 1971, Benfield Corporation first reported the localized corrosion, particularly at the high turbulent areas with high gas/liquid flow velocities. ${ }^{[1]}$

Kemira B. V. in Netherland reported corrosion failure of a $\mathrm{CO}_{2}$ absorber tower in the Benfield process. The system operated for seven years without any corrosion concerns and three years with a minor corrosion issue; however, the absorber had to be replaced after corrosion cracking behind the stainless steel shingles was detected. ${ }^{[2]}$ 
Severe operating conditions, such as high turbulence regions, cause serious corrosion in local areas where defects are present. Kuwait National Petroleum Company experienced leakage caused by corrosion at the gas feed nozzle and in a line carrying hot circulating rich carbonate solution that had been operating for about three years. At the gas feed nozzle pipe, severe deep pitting corrosion was observed in the upper and bottom sections of the nozzle pipe extending inside the distributor pipe, and grooving-type corrosion was found on the entire circumference of the weld neck flange. In the hot circulation line, corrosion eroded the wall of the carbon steel pipe from $12 \mathrm{~mm}$ to almost $3 \mathrm{~mm}$. The company explained that the high turbulence at the gas entry exaggerated the corrosion at the gas feed nozzle, and particulate matter suspended in the solution contributed to the corrosion of the circulation line. ${ }^{[1]}$

Chevron reported localized pitting corrosion in the absorption columns of a hot PC process used to treat a $\mathrm{CO}_{2}$ stream near Snyder, Texas. The corrosion was so severe that it damaged the absorber wall within six months. Chevron reported that the high concentration of $\mathrm{H}_{2} \mathrm{~S}$ in the processed gas reduced the corrosion-inhibition efficiency of vanadium pentoxide in the solution. ${ }^{[3]}$

Following more than 5,000 hours of testing, Nikitina et al. ${ }^{[4]}$ reported that the corrosion rates of different steels in PC treating system vessels were acceptable due to self-passivation, except for a location at the top of the carbon steel desorber, as shown in Table 7-1. Stainless steel (18\% Cr, $10 \% \mathrm{Ni}$, with titanium) experienced a much lower corrosion rate, $0.001 \mathrm{~mm} / \mathrm{year}$, than the carbon steel, $0.43 \mathrm{~mm} /$ year. Local damage to the equipment was also observed, because of corrosion in the form of cracks, pits, and pinpoints. They concluded that this damage was caused by a breakdown of the protective layer on certain sections of the metal surface due to the high flow velocities of the solution, which also contained solid potassium bicarbonate particles and particles from breakdown of the packing material. ${ }^{[4]}$

Table 7-1. Corrosion rates of different materials at various equipment sites ${ }^{[1,4,9]}$

\begin{tabular}{|l|c|c|c|c|}
\hline \multirow{2}{*}{$\begin{array}{l}\text { Corrosion rate (mm/yr) for different } \\
\text { construction materials }\end{array}$} & \multicolumn{4}{|c|}{ Site of equipment } \\
\cline { 2 - 5 } & $\begin{array}{c}\text { Top of } \\
\text { absorber }\end{array}$ & $\begin{array}{c}\text { Top of } \\
\text { desorber }\end{array}$ & $\begin{array}{c}\text { Middle of } \\
\text { desorber }\end{array}$ & $\begin{array}{c}\text { Feed line of } \\
\text { regenerated solution }\end{array}$ \\
\hline ST3sp (carbon steel) & 0.06 & 0.43 & 0.01 & 0.026 \\
\hline $\begin{array}{l}\text { 12Kh18N10T (18\% Cr, 10\% Ni, with } \\
\text { titanium) }\end{array}$ & 0.001 & 0.001 & 0.001 & \\
\hline $\begin{array}{l}\text { OKh21N5T (21\% Cr, 5\% Ni, with } \\
\text { titanium) }\end{array}$ & & 0.43 & & 0.026 \\
\hline 16GS (a manganese-silicon steel) & & & & \\
\hline
\end{tabular}

An additional type of carbon steel corrosion caused by the PC solution is stress corrosion cracking (SCC) that may occur under the influence of sufficient tensile stress after several years of operation. SCC is a dangerous corrosion issue that causes leakage. It has been reported that both transgranular and intergranular SCC occurred, depending on operational conditions. When the concentration of bicarbonate ions is above a certain value, iron is dissolved by the bicarbonate ions, resulting in an increase in the growth rate of cracks. ${ }^{[1,5]}$

\subsubsection{Cause and mechanism of corrosion}


It is well accepted that the main cause of PC solution corrosion is the dissolved $\mathrm{CO}_{2}$ and the associated carbonic acid impingement on the surface of the equipment. Zhou investigated the corrosion mechanism and anodic behavior of mild steel in different $\mathrm{K}_{2} \mathrm{CO}_{3}-\mathrm{KHCO}_{3}$ solutions at $90^{\circ} \mathrm{C}\left(194^{\circ} \mathrm{F}\right)$ by electrochemical methods. It is suggested that the corrosion of carbonate solution on ferrous metals is an electrochemical process. At the corrosion potentials, the corrosion process consists of two electrode reactions: ${ }^{6]}$

$$
\begin{aligned}
& \text { Anode reaction: } \mathrm{Fe} \rightarrow \mathrm{Fe}^{2+}+2 e \\
& \text { Cathode reaction: } 2 \mathrm{HCO}_{3}^{-}+2 e \rightarrow 2 \mathrm{CO}_{3}^{2-}+\mathrm{H}_{2} \\
& \text { Overall reaction: } \mathrm{Fe}+2 \mathrm{HCO}_{3}^{-} \rightarrow \mathrm{FeCO}_{3}+\mathrm{H}_{2}
\end{aligned}
$$

The anode oxidation reaction dissolves iron, while the cathode reduction reaction generates hydrogen. The produced hydrogen may not be released, but rather absorbed on the metal surface in the form of either hydrogen atoms or molecules, and diffuses into the metal, leading to hydrogen embrittlement. At the cathode, the $\mathrm{HCO}_{3}{ }^{-}$ions, rather than the carbonate ions or hydroxide ions, contribute to corrosion. The $\mathrm{HCO}_{3}{ }^{-}$ions are produced by the dissolution of $\mathrm{CO}_{2}$ into potassium carbonate solution by the following reaction:

$$
\mathrm{CO}_{2}+\mathrm{H}_{2} \mathrm{O}+\mathrm{K}_{2} \mathrm{CO}_{3} \leftrightarrow 2 \mathrm{KHCO}_{3}
$$

Zhou reported that the mild steel was an active-passive metal and could be easily corroded on a fresh surface. The corrosion potentials of a mild steel in $\mathrm{K}_{2} \mathrm{CO}_{3}-\mathrm{KHCO}_{3}$ solutions were measured to be in the active region for the electrochemical reaction, and small hydrogen bubbles were observed evolving from the surface of the metal. It was found that the critical passivation current density measured in $\mathrm{K}_{2} \mathrm{CO}_{3}$ solution was much smaller than that in the $\mathrm{K}_{2} \mathrm{CO}_{3}-\mathrm{KHCO}_{3}$ solution (1.1 vs. $15-18 \mathrm{~mA} / \mathrm{cm}^{2}$ ), indicating that the $\mathrm{HCO}_{3}{ }^{-}$ions caused the corrosion of the mild steel in the hot $\mathrm{K}_{2} \mathrm{CO}_{3}-\mathrm{KHCO}_{3}$ solution. ${ }^{[6]}$ A smaller value of critical passivation current density indicates that it is much easier for a metal to passivate by forming a protective layer over the surface.

The research by Nikitina et al. also showed that $\mathrm{HCO}_{3}{ }^{-}$ions were the primary cause of corrosion. They measured the corrosion rates of carbon steel in carbonate solutions saturated with $\mathrm{CO}_{2}$ and free of $\mathrm{CO}_{2}$ at different temperatures. As shown in Figure 7-1, the corrosion rates in solutions saturated with $\mathrm{CO}_{2}$ were about two orders-of-magnitude higher than those in the solutions free of $\mathrm{CO}_{2}$. The corrosion rate increased with increasing temperature, but decreased when the temperature reached a critical point. It was explained that at temperatures higher than the critical point, the passivation films might be more easily formed and additional corrosion was inhibited.

Other factors that exaggerate the corrosion include severe operating conditions, such as high turbulence, misdistribution of the gas and liquid flows, particulate matter suspended in the solution, equipment design deficiencies, and defects introduced during the manufacturing process. Breakdown of the protective layer, local corrosion, and high stress are also important factors for corrosion. ${ }^{[1,4,7]}$ Once a surface has locally lost metals, adequate wetting would become more difficult and may result in more serious corrosion. 


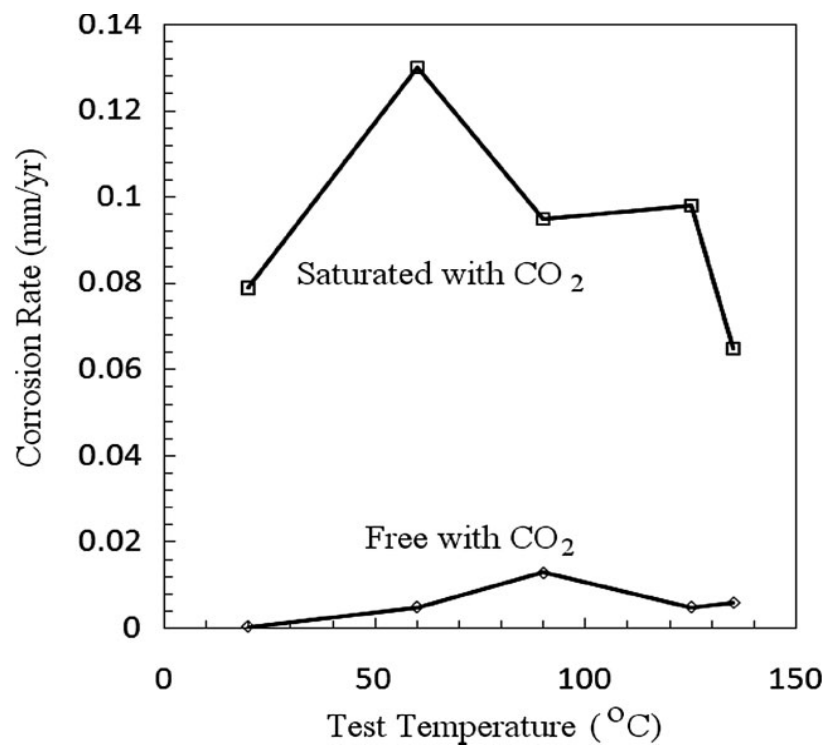

Figure 7-1. Corrosion rate of carbon steel in $25 \mathrm{wt} \% \mathrm{PC}$ solution at different temperatures under a pressure of $2.5 \mathrm{MPa} \mathrm{CO}_{2}$.

\subsubsection{Inhibitors for corrosion mitigation}

Corrosion is sensitive to operating conditions. Lessons learned from commercial operation of hot PC processes indicate that the carbonate system can be corrosion-free when an efficient inhibitor is used at a certain concentration level. For example, a hot $\mathrm{PC}$ system for removing $\mathrm{CO}_{2}$ at a 1,500 tonne/day ammonia plant operated successfully for nearly 17 years without serious corrosion issues when the active vanadium solution was controlled at $0.5 \%$ by weight as $\mathrm{V}_{2} \mathrm{O}_{5}{ }^{\left[{ }^{1]}\right.}$

Efficient corrosion inhibitors reported in the literature include arsenic and vanadium salts, and organic inhibitors, such as 1-(hydroxyethylidene)-1,1-diphosphonic acid (HEDP), 2aminothiophenol (ATP), etc. ${ }^{[8-12]}$ Among them, vanadate in the form of $\mathrm{V}_{2} \mathrm{O}_{5}$ has been successfully applied in various industries. An arsenic salt was once used, but has been abandoned due to its toxicity.

The mechanism and efficiency of these inhibitors have been extensively investigated. Most researchers suggest that the inhibitors serve as an electron acceptor and thus impact the characteristics of the electrochemical corrosion reactions. Zhang and Martin ${ }^{[1]}$ reported that inhibitors containing $\mathrm{V}^{5+}$ accept electrons generated in anodic reactions and deposit a passive magnetite film on the steel surface when the concentration of the inhibitor exceeds a certain value. The deposited film is protective and inhibits the steel from further dissolution. Zhou ${ }^{[6]}$ measured the anodic behavior of a mild steel in the $\mathrm{K}_{2} \mathrm{CO}_{3}-\mathrm{KHCO}_{3}$ solution (PC30-50, i.e., 30 wt\% PC with 50\% CTB conversion rate) with and without the $\mathrm{V}_{2} \mathrm{O}_{5}$ inhibitor $(10 \mathrm{~g} / \mathrm{L})$, and found that the inhibitor shifted the corrosion potential from the active to the passive region. No hydrogen gas was detected from the surface of mild steel. Nikitina et al. ${ }^{[9]}$ studied the effect of inhibitors (e.g., $7 \%$ borax $+0.1 \% \mathrm{~V}_{2} \mathrm{O}_{5}+0.7 \% \mathrm{~K}_{2} \mathrm{Cr}_{2} \mathrm{O}_{7}$ ) and reported that the inhibitors shifted the potential of low-carbon steel and lowered the current in the passive state, and thus reduced the overall corrosion rate and local damage area. 
High-efficiency of these inhibitors has been reported in several plant and lab tests. Bienstock and Field reported that the corrosion rate of carbon steel was nearly equivalent to that of stainless steel 347 (about $0.025 \mathrm{~mm} /$ year) if the total concentration of vanadate was controlled at 0.2 wt $\% .^{[7,8]}$ Kolff ${ }^{[2]}$ reported that an industrial $\mathrm{CO}_{2}$ absorber operated corrosion-free for seven years by adding a total of $3.3 \mathrm{~g} / \mathrm{L}$ vanadate $\left(0.2 \mathrm{~g} / \mathrm{L} \mathrm{V}^{4+}\right.$ and $\left.3.1 \mathrm{~g} / \mathrm{L} \mathrm{V}^{5+}\right)$ to the PC solution.

Additional studies related to inorganic inhibitors that have effectively reduced corrosion rates in various industrial applications are summarized in Table 7-2. In the presence of certain additive concentration levels, the corrosion rates were reduced by at least one order-of-magnitude.

Table 7-2. Corrosion rates of carbon steel in $\mathrm{K}_{2} \mathrm{CO}_{3} / \mathrm{KHCO}_{3}$ solutions with and without using different inhibitors

\begin{tabular}{|c|c|c|c|}
\hline \multirow{2}{*}{ Solution } & \multirow{2}{*}{ Inhibitor } & \multicolumn{2}{|c|}{ Corrosion rate (mm/year) } \\
\hline & & With inhibitor & No inhibitor \\
\hline \multirow{3}{*}{$23 \% \mathrm{~K}_{2} \mathrm{CO}_{3}$ at $60-80^{\circ} \mathrm{C}, 1 \mathrm{~atm}$} & 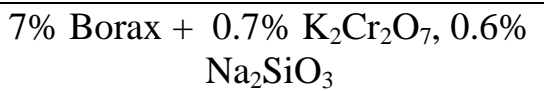 & 0.006 & \multirow{3}{*}{0.096} \\
\hline & $7 \%$ Borax $+0.1 \% \mathrm{~V}_{2} \mathrm{O}_{5}$ & 0.01 & \\
\hline & $\begin{array}{c}7 \% \text { Borax }+0.1 \% \mathrm{~V}_{2} \mathrm{O}_{5}+0.6 \% \\
\mathrm{Na}_{2} \mathrm{SiO}_{3}\end{array}$ & 0.003 & \\
\hline \multirow[b]{2}{*}{$\begin{array}{l}5.6 \% \quad \mathrm{~K}_{2} \mathrm{CO}_{3} \quad \text { and } 17.4 \% \\
\mathrm{KHCO}_{3} \text { at } 70-90^{\circ} \mathrm{C}, 2.3 \mathrm{MPa}\end{array}$} & $7 \%$ Borax $+0.7 \% \mathrm{~K}_{2} \mathrm{Cr}_{2} \mathrm{O}_{7}$ & 0.00745 & \multirow[b]{2}{*}{0.4975} \\
\hline & $\begin{array}{c}7 \% \text { Borax }+0.7 \% \mathrm{~K}_{2} \mathrm{Cr}_{2} \mathrm{O}_{7}+ \\
0.6 \% \mathrm{Na}_{2} \mathrm{SiO}_{3}\end{array}$ & 0.002 & \\
\hline \multirow{2}{*}{$\begin{array}{l}13.6 \% \mathrm{~K}_{2} \mathrm{CO}_{3} \text { and } 9.84 \% \\
\mathrm{KHCO}_{3} \text { at } 100-120^{\circ} \mathrm{C} \text {, 1atm }\end{array}$} & $7 \%$ Borax $+0.7 \% \mathrm{~K}_{2} \mathrm{Cr}_{2} \mathrm{O}_{7}$ & 0.00272 & \multirow[b]{2}{*}{0.6775} \\
\hline & $\begin{array}{c}7 \% \text { Borax }+0.7 \% \mathrm{~K}_{2} \mathrm{Cr}_{2} \mathrm{O}_{7}+ \\
0.6 \% \mathrm{Na}_{2} \mathrm{SiO}_{3}\end{array}$ & 0.001 & \\
\hline $\begin{array}{l}16 \% \quad \mathrm{KHCO}_{3}, \quad 19 \% \quad \mathrm{~K}_{2} \mathrm{CO}_{3} \\
\left.\text { (equivalent } 29 \% \quad \mathrm{~K}_{2} \mathrm{CO}_{3}\right) \quad \text { at } \\
95^{\circ} \mathrm{C}(\mathrm{pH} 9.2) \\
\end{array}$ & $1.3 \mathrm{~g} / \mathrm{L}$ vanadate & 0.065 & 9.0 \\
\hline
\end{tabular}

Several organic inhibitors have been reported to achieve corrosion inhibition efficiencies similar to those of inorganic chemicals at much lower concentrations (100-200 ppm), because they have different mechanisms for corrosion inhibition. Sekine et al. ${ }^{[11,12]}$ reported that the organic inhibitors HEDP, ATP, or their mixtures at a total concentration of $200 \mathrm{ppm}$ attained inhibition efficiencies comparable to that of inorganic inhibitors (e.g., $\mathrm{V}_{2} \mathrm{O}_{5}, \mathrm{Na}_{2} \mathrm{CrO}_{4}$ ). It was explained that these organic inhibitors formed a protective film on the surface of the metal to depress the formation of scale. For example, ATP molecules disturb cathodic reduction reactions by being absorbed on the cathodic point of the metal surface and forming a five-membered-ring complex with the metal. HEDP repressed anodic oxidation by being absorbed on the anodic point of the metal surface and forming a six-membered-ring complex with the metal. Using a mixture of HEDP and ATP at controlled concentrations produced a synergetic effect for corrosion inhibition.

It has also been reported that corrosion can be reduced by optimum system designs, proper material selections, and defect control in the equipment manufacturing process. ${ }^{[1]}$

\subsubsection{Discussion of corrosion inhibition in IVCAP}


It is inferred that the potential corrosion issue in the IVCAP should be more moderate than that in the commercial hot potassium carbonate processes, based on the following reasons: (1) the concentration of $\mathrm{KHCO}_{3}$ in the IVCAP is lower since $\mathrm{CO}_{2}$ absorption is at initial partial pressures of 10 to $15 \mathrm{kPa}$ (1.5 to $2.2 \mathrm{psia}$ ) compared to above $210 \mathrm{kPa}$ (30.5 psia) in the Benfield and Catacarb processes; and (2) the operational conditions in the IVCAP are less severe than those in the commercial hot carbonate processes since a $20 \mathrm{wt} \%$ PC solution is employed for $\mathrm{CO}_{2}$ absorption/desorption at 40 to $70^{\circ} \mathrm{C}\left(104\right.$ to $\left.158^{\circ} \mathrm{F}\right)$ in the IVCAP, whereas a 20 to $30 \mathrm{wt} \%$ $\mathrm{PC}$ solution is used at 80 to $130^{\circ} \mathrm{C}\left(176\right.$ to $\left.266^{\circ} \mathrm{F}\right)$ in the hot potassium carbonate processes.

As demonstrated in the literature, some Benfield and Catacarb units have been operated corrosion-free for more than 17 years when the concentrations of inhibitors were kept above a certain level. The methods for corrosion inhibition in the Benfield and Catacarb processes can be readily applied to the IVCAP. For example, a highly-efficient inhibitor, potassium vanadate $\left(\mathrm{KVO}_{3}\right)$ or $\mathrm{V}_{2} \mathrm{O}_{5}$ can be used in the IVCAP to mitigate corrosion. For this purpose, the effects of adding $4 \mathrm{wt} \% \mathrm{KVO}_{3}$ to the $\mathrm{PC}$ solutions on the rates of $\mathrm{CO}_{2}$ absorption without and with the CA enzyme biocatalyst were investigated.

Figure 7-2 shows the rates of $\mathrm{CO}_{2}$ absorption into the PC20-20 solution (20 wt $\%$ with $20 \%$ CTB conversion rate) containing $4 \mathrm{wt} \% \mathrm{KVO}_{3}$ without and with $300 \mathrm{mg} / \mathrm{L} \mathrm{CA}$ enzyme at $40^{\circ} \mathrm{C}$. It can be seen that using $4 \mathrm{wt} \% \mathrm{KVO}_{3}$ alone (without using the $\mathrm{CA}$ enzyme) increased the rates of $\mathrm{CO}_{2}$ absorption into the PC solution by more than three-fold. When the CA enzyme $(300 \mathrm{mg} / \mathrm{L})$ was used as a catalyst, the presence of $4 \mathrm{wt} \% \mathrm{KVO}_{3}$ in the $\mathrm{PC}$ solution did not impact the activity of the $\mathrm{CA}$ enzyme for enhancing the $\mathrm{CO}_{2}$ absorption.

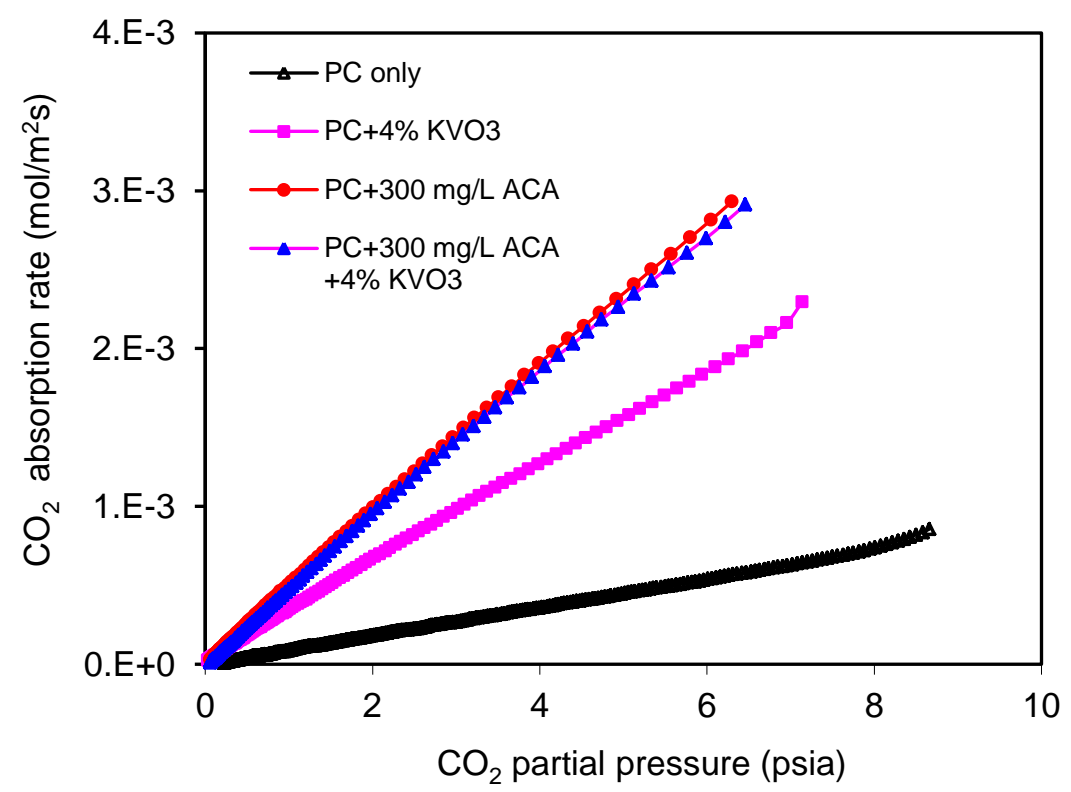

Figure 7-2. Effect of $4 \mathrm{wt} \% \mathrm{KVO}_{3}$ in the $20 \mathrm{wt} \% \mathrm{PC}$ solution with $20 \% \mathrm{CTB}$ conversion on the rates of $\mathrm{CO}_{2}$ absorption without and with the presence of the CA enzyme.

Other recommendations for corrosion inhibition in the IVCAP include: (1) stainless steel in reboiler tubes; (2) stainless steel in accessory parts exposed to the carbonate solution, including control valves, solution pumps, impellers, and inner valves; (3) stress-relieved carbon steel in the 
absorber and stripper, whether using trays or packing; (4) stress-relieved carbon steel in piping; and (5) plastic-coated or gunite-lined stripper columns.

\subsubsection{Summary}

Based on the literature review and consultation with several corrosion experts, it was concluded that the IVCAP could be operated corrosion-free for a sufficiently long period if careful corrosion control is maintained. Corrosion causes and appropriate inhibition measures are as follows:

(1) Corrosion in the IVCAP will be sensitive to operating conditions. Factors that may exaggerate the corrosion risk include high turbulence, misdistribution of the gas and liquid flows, particulate matter suspended in the solution, equipment design deficiencies, and defects introduced during the manufacturing process.

(2) Corrosion of ferrous metals by the $\mathrm{PC}$ solution is an electrochemical process. $\mathrm{HCO}_{3}{ }^{-}$ions are the primary cause for the corrosion and the corrosion rate increases with increasing the $\mathrm{HCO}_{3}{ }^{-}$ concentration.

(3) The corrosion issues can be mitigated by using efficient inhibitors, e.g., vanadium salts or $\mathrm{V}_{2} \mathrm{O}_{5}$, which have been successfully used in the hot carbonate processes. Experimental results from this study also demonstrated that using $\mathrm{KVO}_{3}$ at $4 \mathrm{wt} \%$ in the $\mathrm{PC}$ solution did not appreciably diminish the catalytic activity of CA enzyme.

(4) Optimum system design, material selection, and defect control in the equipment manufacturing process will help mitigate the corrosion issues.

\subsection{Effect of flue gas trace elements on CA enzyme activity and stability}

\subsubsection{Introduction}

Trace elements in the flue gas from a pulverized coal-fired power plant equipped with an ESP and wet FGD include $\mathrm{Hg}, \mathrm{Se}, \mathrm{B}, \mathrm{As}$, and anions (e.g., $\mathrm{SO}_{4}{ }^{2-}, \mathrm{NO}_{3}{ }^{-}$, and $\mathrm{Cl}^{-}$) derived from coal and those introduced by the FGD limestone, such as $\mathrm{As}, \mathrm{Cd}, \mathrm{Fe}, \mathrm{Mn}, \mathrm{Mg}, \mathrm{Si}$, Ti. ${ }^{[13-16]}$ These trace elements may be transferred to the absorption solution in a post-combustion $\mathrm{CO}_{2}$ capture process. Data on the concentrations of these trace elements in the actual $\mathrm{CO}_{2}$ absorption solution are lacking. However, based on reported concentrations of the trace elements in a typical blowdown liquid from a wet FGD unit, the trace element concentrations in the PC solution in the IVCAP $\mathrm{CO}_{2}$ capture process should be much smaller, or at most comparable, with those shown in Table 7-3. Since the IVCAP will be installed either downstream of a wet FGD or combined with the $\mathrm{SO}_{2}$ removal, the presence of these trace elements may affect the activity and/or stability of the CA enzyme. 
Table 7-3. Trace elements in FGD wastewater ${ }^{[17]}$

\begin{tabular}{|c|c|}
\hline Trace elements & Concentration, $\mathrm{mg} / \mathrm{l}$ \\
\hline $\mathrm{Pb}$ & $0.5-1.5$ \\
\hline $\mathrm{Hg}$ & $0.01-0.8$ \\
\hline $\mathrm{Se}$ & $1-4$ \\
\hline $\mathrm{As}$ & $0.5-0.8$ \\
\hline $\mathrm{Mn}$ & $3-20$ \\
\hline $\mathrm{Cd}$ & $0.05-0.1$ \\
\hline $\mathrm{Cu}$ & $0.2-0.8$ \\
\hline $\mathrm{Ni}$ & $2-7$ \\
\hline $\mathrm{Fe}$ & $80-400$ \\
\hline $\mathrm{Co}$ & $0.1-0.8$ \\
\hline $\mathrm{Zn}^{\mathrm{Cr}}$ & $0.5-1.0$ \\
\hline $\mathrm{Cr}$ & $0.3-1$ \\
\hline $\mathrm{BO}_{4}{ }^{2-}$ & $1-10$ \\
\hline $\mathrm{NO}_{3}^{-}$ & $3,000-5,000$ \\
\hline $\mathrm{Cl}^{-}$ & $30-120$ \\
\hline $\mathrm{F}^{-}$ & $10,000-25,000$ \\
\hline & $40-100$ \\
\hline
\end{tabular}

A schematic diagram of the typical CA enzyme structure is shown in Figure 7-3. The effect of flue gas impurities on the activity/stability of the CA enzyme depends on the type and structure of the enzyme. Small structural differences between CA isoforms may result in large differences in metal binding affinities, which are associated with the extent of inhibition by the trace elements. ${ }^{[18]}$

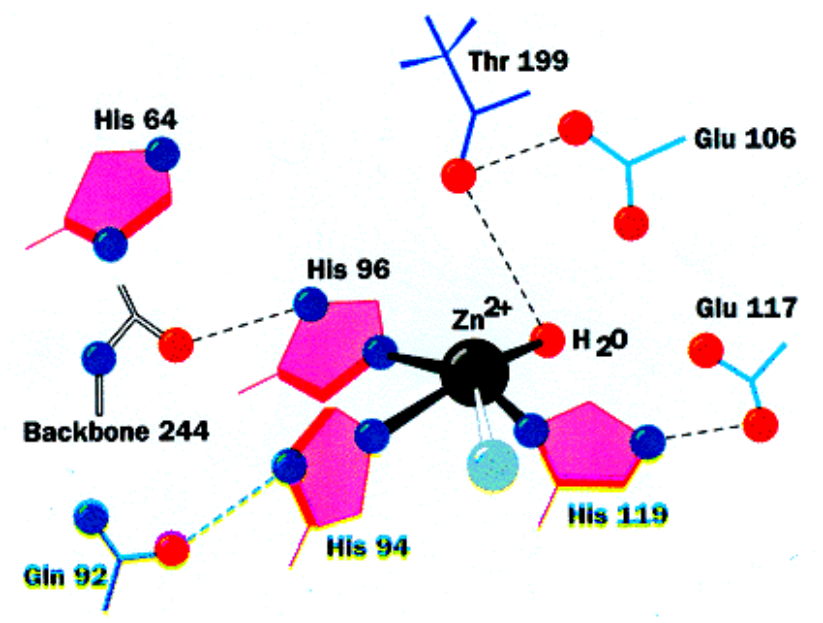

Figure 7-3. A schematic diagram of the structure of human CA enzyme II (Histidine residues (pink), hydroxide group (red), coordinating zinc ion (black)).

In this study, the CA enzymes (ACA1 and ACA2) provided by a leading enzyme manufacturer were produced by microbial fermentation using benign host organisms. The molecular weights of the enzymes are between 25 and $30 \mathrm{kDa}$. The as-received enzyme samples were in concentrated solutions ( $\sim 3 \mathrm{~g} \mathrm{CA} / 1$ and $38 \mathrm{~g} \mathrm{CA} / 1$, respectively), containing small amounts of 
impurities, such as low molecular weight fermentation residues, processing acids, salts, and other proteins.

Knowledge regarding the effect of trace elements in coal combustion flue gas (heavy metals, acid gases, etc) on CA enzymes is rare in general and particularly scarce for the proposed IVCAP operating conditions. Information in the literature for bovine CA, human CA, or CA enzymes in other organisms was used as a reference or analogy for the ACA enzymes used in this project.

\subsubsection{Effect of heavy metals on the activity and stability of CA enzymes}

Heavy metals, such as $\mathrm{Ag}^{+}, \mathrm{Al}^{3+}, \mathrm{Cd}^{2+}, \mathrm{Co}^{2+} \mathrm{Cu}^{2+}, \mathrm{Pb}^{2+}, \mathrm{Hg}^{2+}$, and $\mathrm{Zn}^{2+}$, inhibit the activity of CA enzymes in a variety of organisms, including fishes, crabs, bovines, and humans. ${ }^{[18]}$ The inhibition occurs because these heavy metals bind to the site nearby the His-64 pocket, the socalled "proton shuttle", rather than the specific catalytic site for $\mathrm{CO}_{2}$ hydration (see Figure 73). ${ }^{[19]}$ His-64 is a proton shuttle in the CA enzyme, where the proton from zinc-bound water is accepted to generate zinc-bound hydroxide. ${ }^{[20-22]} \mathrm{Tu}$, et al. ${ }^{[19,21]}$ confirmed such a mechanism of inhibition in their study on the effect of copper on human CA II. It was found that $\mathrm{Cu}^{2+}$ competitively inhibits human CA II by binding to the imidazole side chain of His-64, blocking its role in proton transfer from the zinc-bound water molecule to buffer molecules located outside of the active site region.

Lionetto et al. ${ }^{[18]}$ summarized the values of $K_{\mathrm{i}}$ (binding affinity of the inhibitor), IC50 (half maximal inhibitory concentration), and the type of inhibition by heavy metals on the CA enzymes from different vertebrate and invertebrate species. It was reported that those values significantly varied with the types of species, tissues, and metals. Sharma and Bhattacharya ${ }^{\text {[23] }}$ investigated the inhibition effect of numerous ions on bovine $\mathrm{CA}$ and concluded that the bovine $\mathrm{CA}$ at concentrations over $275 \mathrm{mg} / \mathrm{l}$ retained $55,58,65,68$, and $90 \%$ of the initial activity in the presence of $\mathrm{Pb}^{2+}, \mathrm{Hg}^{2+}, \mathrm{Se}^{2+}, \mathrm{As}^{3+}$, and $\mathrm{Mn}^{2+}$, as shown in Table 7-4. No activity loss was observed in the presence of $\mathrm{Cd}^{2+}, \mathrm{Cu}^{2+}, \mathrm{Ni}^{2+}, \mathrm{Fe}^{2+}, \mathrm{Co}^{2+}$, and $\mathrm{Zn}^{2+}$ at $\mathrm{CA}$ concentrations over 280 $\mathrm{mg} / \mathrm{l}$.

Table 7-4. Effect of heavy metals on the activity of the bovine CA II enzyme ${ }^{[23]}$

\begin{tabular}{|c|c|c|}
\hline Ions & Impurity concentration, $\mathrm{mg} / \mathrm{l}$ & Activity retained, \% \\
\hline $\mathrm{Pb}^{2+}$ & 532 & 55 \\
\hline $\mathrm{Hg}^{2+}$ & 1000 & 58 \\
\hline $\mathrm{Se}^{2+}$ & 395 & 65 \\
\hline $\mathrm{As}^{3+}$ & 375 & 68 \\
\hline $\mathrm{Mn}^{2+}$ & 275 & 90 \\
\hline $\mathrm{Cd}^{2+}$ & 562 & 100 \\
\hline $\mathrm{Cu}^{2+}$ & 320 & 100 \\
\hline $\mathrm{Ni}^{2+}$ & 293 & 100 \\
\hline $\mathrm{Fe}^{2+}$ & 280 & 103 \\
\hline $\mathrm{Co}^{2+}$ & 295 & 107 \\
\hline $\mathrm{Zn}^{2+}$ & 325 & 113 \\
\hline
\end{tabular}




\subsubsection{Effect of anions on CA enzyme activity and stability}

Compared to heavy metals, inhibition from most anions is caused by the binding of anions to the active zinc site of the enzyme. Coal combustion flue gas contains contaminants, such as $\mathrm{SO}_{2}$, $\mathrm{NOx}, \mathrm{HCl}$ and $\mathrm{HF}$, which will be transferred to scrubbing liquids in the form of the related anions $\left(\mathrm{SO}_{4}{ }^{2-}, \mathrm{NO}_{3}{ }^{-}, \mathrm{Cl}^{-}, \mathrm{F}^{-}\right.$, etc.). It has been reported that divalent anions, such as $\mathrm{SO}_{4}{ }^{2-}$, do not inhibit, or only act as very weak inhibitors of human CA II enzyme. ${ }^{[24]}$ A hydrogen-bonded system comprising Glu-106 and Thr-199 groups may act as a "door keeper" to prevent the active site from binding with $\mathrm{SO}_{4}{ }^{2-}$ (see Figure 7-3). At $\mathrm{pH} 6.0$ and in the presence of $2.4 \mathrm{M}\left(\mathrm{NH}_{4}\right)_{2} \mathrm{SO}_{4}$, there was no evidence of sulfate ions bound in the crystal structure of human CA II. ${ }^{[25]}$ Another study showed solutions containing $0.005 \mathrm{M}$ to $0.2 \mathrm{M}$ of $\mathrm{SO}_{4}{ }^{2-}$ and $\mathrm{NO}_{3}{ }^{-}$did not inhibit the CA activity. ${ }^{[26]}$

It is known that monovalent anions may inhibit CA activity. Some monovalent anions simply displace the zinc-bound solvent molecule $\left(\mathrm{H}_{2} \mathrm{O}\right)$ yielding tetrahedral coordination, while other anions form penta-coordinated adducts. ${ }^{[27]}$ Both mechanisms prevent the formation of a coordinated $\mathrm{OH}^{-}$ion, which is an essential participant in catalytic $\mathrm{CO}_{2}$ hydration. ${ }^{[28]}$ The $\mathrm{CN}^{-}$and $\mathrm{NCO}^{-}$anions were found to be the most potent inorganic inhibitors of $\mathrm{CA}^{\left[{ }^{[29]}\right.}$ However, these anions are not generally present in wet FGD scrubbing liquid.

The diverse inhibition profile of these anions against the various isoforms was summarized by De Simone and Supuran. ${ }^{[30]}$ The inhibition constant of CA varies from a sub-micromolar to low micromolar range (e.g., cyanide and cyanate with human CA I, etc.), and to a high millimolar range (e.g., chloride with human CA II, iodide with human CA XII, etc.). Potential inhibition effects of the anions depend on many factors, such as CA enzyme structure and the solution conditions applied.

As discussed in Chapter 3D, the ACA enzyme demonstrated excellent chemical resistance to $\mathrm{Cl}^{-}$, $\mathrm{SO}_{4}{ }^{2-}$, and $\mathrm{NO}_{3}{ }^{-}$anions, the major impurities transferred from the flue gas. Concentration levels of these anions selected in this study, either alone or in combination, were comparable to, or exceeded typical values present in the wastewater of wet FGD scrubbers of power plants burning high-sulfur, high chlorine coals (see Table 7-3). The activity loss of the ACA enzyme caused by these anion impurities at elevated concentrations was less than $12 \%$, and did not increase during the two-month test period.

\subsubsection{Summary}

It can be inferred from published studies that trace elements in coal combustion flue gases may not significantly affect the activity and stability of the CA enzyme under the typical conditions in the IVCAP for the following reasons:

(1) Results from several studies reported in the literature confirm that at heavy metal concentration levels hundreds of times larger than those in the IVCAP PC solution, the activity loss of tested CA enzymes was 10 to $50 \%$. 
(2) The experimental results described in Chapter 3D of this report revealed that the activity loss of the ACA enzymes caused by $\mathrm{Cl}^{-}, \mathrm{SO}_{4}{ }^{2-}$, and $\mathrm{NO}_{3}{ }^{-}$anions at much higher concentrations than expected in the IVCAP PC solution, either alone or in combination, was less than $12 \%$ and did not increase over the two-month test period.

(3) The ACA enzymes used in this project were specifically engineered for potential industrial applications with improved chemical resistance to flue gas impurities.

\subsection{Treatment needed to use IVCAP condensate water as feedwater for power plant boilers}

\subsubsection{Recycled use of IVCAP condensate as feedwater in power plants}

In the IVCAP, portions of the LP steam from the LP turbine are introduced directly to the stripper and the reboiler. In the stripper, the steam strips out $\mathrm{CO}_{2}$ from the solution as it flows from the bottom to the top of the stripper. The gas stream exiting the stripper is a mixture of water vapor and $\mathrm{CO}_{2}$ and enters a condenser to recover the water vapor. The condensed water is recycled to the power plant steam cycle for use as boiler feed water. Based on the results from a process simulation study, negligible impurities are present in the gas stream exiting the stripper and, therefore, the water condensate contains negligible impurity concentrations. However, it does contain some amount of dissolved $\mathrm{CO}_{2}$, which should be removed prior to its use as boiler feed water.

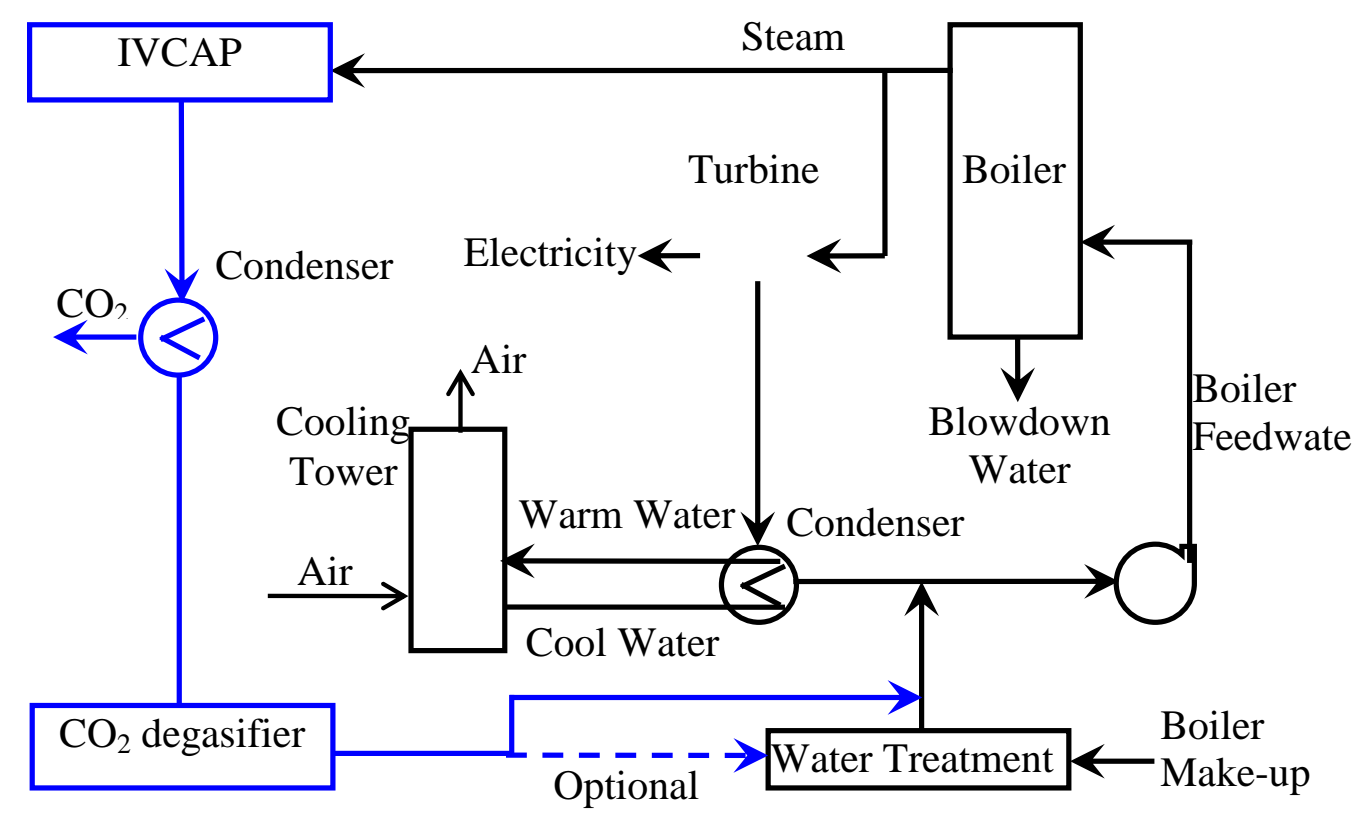

Figure 7-4. A schematic of use of water condensate from the IVCAP $\mathrm{CO}_{2}$-water vapor stream as boiler feed water in a coal-fired power plant.

Recycling the recovered water from the IVCAP process balances the water use of the power plant steam cycle, increases energy efficiency, and reduces the cost of $\mathrm{CO}_{2}$ capture in the IVCAP. Figure 7-4 is a schematic diagram of the water recycling loop in a power plant integrated with the IVCAP. The water condensate is degasified in a degasification unit to recover 
the dissolved $\mathrm{CO}_{2}$ prior to entering a feed water system. The water treatment unit is only necessary if experimental studies confirm that the water condensate needs further purification due to its $\mathrm{pH}$ and alkalinity, which could promote corrosion or scaling of the heat exchanger tubes in the boiler. In this study, the feasibility/viability of using the condensed water in the plant's boiler was investigated by calculating the value of $\mathrm{pH}$ and alkalinity $\left(\mathrm{HCO}_{3}{ }^{-}+\mathrm{CO}_{3}{ }^{2-}\right)$ of the water collected in the IVCAP condenser.

\subsubsection{Quality of water condensate from IVCAP stripper}

The water condensed from the $\mathrm{CO}_{2}$-water vapor stream exiting the IVCAP stripper is equilibrated with $\mathrm{CO}_{2}$ gas at pressures between 0.14 and 0.54 atm $\left(2\right.$ and 8 psia) at 25 to $40^{\circ} \mathrm{C}$ (77 to $104^{\circ} \mathrm{F}$ ). As $\mathrm{CO}_{2}$ dissolves into water, carbonic acid $\left(\mathrm{H}_{2} \mathrm{CO}_{3}\right)$ is produced. This weak acid dissociates to produce $\left[\mathrm{H}^{+}\right],\left[\mathrm{HCO}_{3}{ }^{-}\right]$, and $\left[\mathrm{CO}_{3}{ }^{2-}\right]$. The following elementary reactions govern the concentrations of these species:

$$
\begin{aligned}
& \mathrm{CO}_{2}+\mathrm{H}_{2} \mathrm{O} \Leftrightarrow \mathrm{HCO}_{3}^{-}+\mathrm{H}^{-} \\
& \mathrm{HCO}_{3}^{-} \stackrel{\mathrm{K} 2}{\Leftrightarrow} \mathrm{CO}_{3}^{2-}+\mathrm{H}^{+} \\
& \mathrm{H}_{2} \mathrm{O} \Leftrightarrow \mathrm{OH}^{-}+\mathrm{H}^{+}
\end{aligned}
$$

The solubility of $\mathrm{CO}_{2}$ in water can be calculated using the Henry's law coefficient: ${ }^{[31,32]}$

$$
\mathrm{He}_{\mathrm{CO} 2}=3.54 \times 10^{-7} \exp (2044 / \mathrm{T}) \quad\left(\mathrm{mol} \cdot \mathrm{m}^{-3} \cdot \mathrm{Pa}^{-1}\right)
$$

This formula has been widely used in the temperature range between 20 and $90^{\circ} \mathrm{C}(68$ and $\left.194^{\circ} \mathrm{F}\right)$. Based on chemical reaction equilibria and material/charge balances:

$$
\begin{aligned}
& {\left[\mathrm{H}^{+}\right] \times\left[\mathrm{HCO}_{3}^{-}\right]=\mathrm{K}_{1} \times\left[\mathrm{CO}_{2}\right]} \\
& {\left[\mathrm{H}^{+}\right] \times\left[\mathrm{CO}_{3}^{2-}\right]=\mathrm{K}_{2} \times\left[\mathrm{HCO}_{3}^{2-}\right]} \\
& {\left[\mathrm{H}^{+}\right] \times\left[\mathrm{OH}^{-}\right]=K_{W}} \\
& {\left[\mathrm{H}^{+}\right]=2 \times\left[\mathrm{CO}_{3}^{2-}\right]+\left[\mathrm{HCO}_{3}^{-}\right]+\left[\mathrm{OH}^{-}\right] \quad \text { (charge balance) }}
\end{aligned}
$$

Correlations or the values of the equilibrium constants, $\mathrm{K}_{1}, \mathrm{~K}_{2}$, and $\mathrm{K}_{\mathrm{w}}$ reported in the literature were used to solve these equations. ${ }^{[33-36]}$ The values calculated for $\mathrm{pH}$ and alkalinity $\left(\left[\mathrm{CO}_{3}{ }^{2-}\right]+\right.$ $\left.\left[\mathrm{HCO}_{3}{ }^{-}\right]\right)$for the water condensate of the IVCAP process are listed in Table 7-5. The $\mathrm{pH}$ value ranged between 4.0 and 4.3 when $\mathrm{P}_{\mathrm{CO} 2}$ varies from 0.14 to 0.54 atm $\left(2\right.$ to 8 psia) at 25 to $40^{\circ} \mathrm{C}$ ( 77 to $104^{\circ} \mathrm{F}$ ). The alkalinity value is approximately $10^{-5} \mathrm{mg} / \mathrm{L} \mathrm{CaCO}_{3}$.

Table 7-5. Calculated values of $\mathrm{pH}$ and alkalinity $\left(\left[\mathrm{CO}_{3}{ }^{2-}\right]+\left[\mathrm{HCO}_{3}{ }^{-}\right]\right)$of water condensate from the IVCAP

\begin{tabular}{|c|c|c|c|c|}
\hline \multirow{2}{*}{$\mathrm{P}_{\mathrm{CO} 2}$ (psia) } & \multirow{2}{*}{$\left({ }^{\circ} \mathrm{C}\right)$} & $p H$ & $\begin{array}{c}\text { Dissolved } \mathrm{CO}_{2}, \\
\mathrm{mg} / \mathrm{L}\end{array}$ & $\begin{array}{c}\text { Alkalinity }\left(\mathrm{HCO}_{3}+\mathrm{CO}_{3}\right), \\
\mathrm{mg} / \mathrm{L} \mathrm{CaCO}_{3}{ }^{*}\end{array}$ \\
\cline { 1 - 5 } 8 & 25 & 4.0 & 815 & $7.4 \times 10^{-5}$ \\
\cline { 2 - 5 } & 40 & 4.1 & 590 & $6.2 \times 10^{-5}$ \\
\hline \multirow{2}{*}{2} & \multirow{2}{*}{25} & 4.3 & 205 & $3.7 \times 10^{-5}$ \\
\cline { 1 - 3 } & & 4.2 & 410 & $5.3 \times 10^{-5}$ \\
\cline { 3 - 5 } & & 4.1 & 610 & $6.4 \times 10^{-5}$ \\
\hline
\end{tabular}

* Carbonate alkalinity as $\mathrm{CO}_{3}{ }^{2-}(\mathrm{mg} / \mathrm{L})=0.6$ *arbonate alkalinity as $\mathrm{CaCO}_{3}(\mathrm{mg} / \mathrm{L})$;

Bicarbonate alkalinity as $\mathrm{HCO}_{3}{ }^{-}(\mathrm{mg} / \mathrm{L})=1.22 *$ bicarbonate alkalinity as $\mathrm{CaCO}_{3}(\mathrm{mg} / \mathrm{L})$ 


\subsubsection{Quality required for boiler feedwater}

The Association of Electrical and Steam Unit Owners (APAVE) and the American Boiler Manufacturers Association (ABMA) recommend the limits for purity levels of boiler feed water to guarantee the purity of the steam at pressures up to $99 \mathrm{~atm}(1,450$ psia) and the volume of water to properly control the blow down rate in the boiler (see Table $7-6$ ). ${ }^{[37]}$ The quality of boiler feed water must meet these standards in order to prevent scale formation and corrosion that will adversely affect the performance of a power plant system. ${ }^{[38]}$

Table 7-6. Chemistry limits for boiler feed water

\begin{tabular}{|c|c|c|c|}
\hline Impurity levels & Unit & APAVE standard & ABMA standard \\
\hline Dissolved $\mathrm{O}_{2}$ or $\mathrm{CO}_{2}$ & \multirow{6}{*}{$\mathrm{mg} / \mathrm{l}$} & 0.007 & 0.02 \\
\hline Total iron & & 0.01 & 0.03 \\
\hline Total copper & & 0.01 & 0.01 \\
\hline Total hardness $\left(\mathrm{CaCO}_{3}\right)$ & & Non detectable & 0.05 \\
\hline Non-volatile TOC & & 0.2 & 0.2 \\
\hline Oily matter & & 0.2 & 0.05 \\
\hline $\mathrm{pH}\left(\right.$ at $\left.25^{\circ} \mathrm{C}\right)$ & & $9.0-9.6$ & $>8.5$ \\
\hline
\end{tabular}

Among the required impurity levels, dissolved $\mathrm{CO}_{2}$ and $\mathrm{pH}$ are important factors. Dissolved $\mathrm{CO}_{2}$ reacts with water to form $\mathrm{H}_{2} \mathrm{CO}_{3}$. Carbonic acid dissociates to produce carbonate and bicarbonate ions. These ions and $\mathrm{H}_{2} \mathrm{CO}_{3}$ cause corrosion in the boiler's heat exchanger tubes and steam and return pipes. In addition, the low $\mathrm{pH}$ resulting from the dissolved $\mathrm{CO}_{2}$ enhances the corrosive effect of oxygen.

The $\mathrm{pH}$ value of water is a measure of alkalinity or acidity and is associated with the corrosive properties. Low $\mathrm{pH}$ in local areas is the most common cause of corrosion in mild steel boilers and can destroy the magnetite film of corrosion protection; therefore, boiler water needs be maintained in a $\mathrm{pH}$ range between 9.0 and 9.6.

\subsubsection{Treatment options for IVCAP water condensate}

From Tables 7-5 and 7-6, it appears that the concentration of dissolved $\mathrm{CO}_{2}$ and $\mathrm{pH}$ value of the water condensate from the IVCAP must be addressed if it is to be used as boiler feedwater. The water condensate contains high concentrations of dissolved $\mathrm{CO}_{2}$ (410-815 vs. ABMA standard $0.02 \mathrm{mg} / \mathrm{L})$ and high $\left[\mathrm{H}^{+}\right](\mathrm{pH} 4.0-4.3$ vs. APAVE standard 9.0-9.6), while no other impurities are expected to be present. At $\mathrm{pH}$ below 4.5, the equilibrium reactions (7-R5 and 7-R6) are shifted toward the left side. Thus, most of the dissolved $\mathrm{CO}_{2}$ in water exists as molecular $\mathrm{CO}_{2}$ and can be removed efficiently in a degasifier.

Three types of degasifiers are commercially-available to recover dissolved $\mathrm{CO}_{2}$ in the IVCAP process water. They include forced draft degasifiers, vacuum degasifiers, and membrane contactor degasifiers. The forced draft degasifier is the most common type used in industrial water treatment. It consists of a tower filled with a packing material, as shown in Figure 7-5. Water enters the top of the tower and is sprayed over a packed-bed. As the water runs over the packing material, air is forced up counter-currently through the bed. As air has a low $\mathrm{CO}_{2}$ partial 
pressure (400 ppm), the dissolved $\mathrm{CO}_{2}$ molecules in the water are swept away and transfer into air. The forced draft tower generally has a low capital cost, but a large footprint and height, and a second pump is required for re-pressurization. ${ }^{[39,40]}$

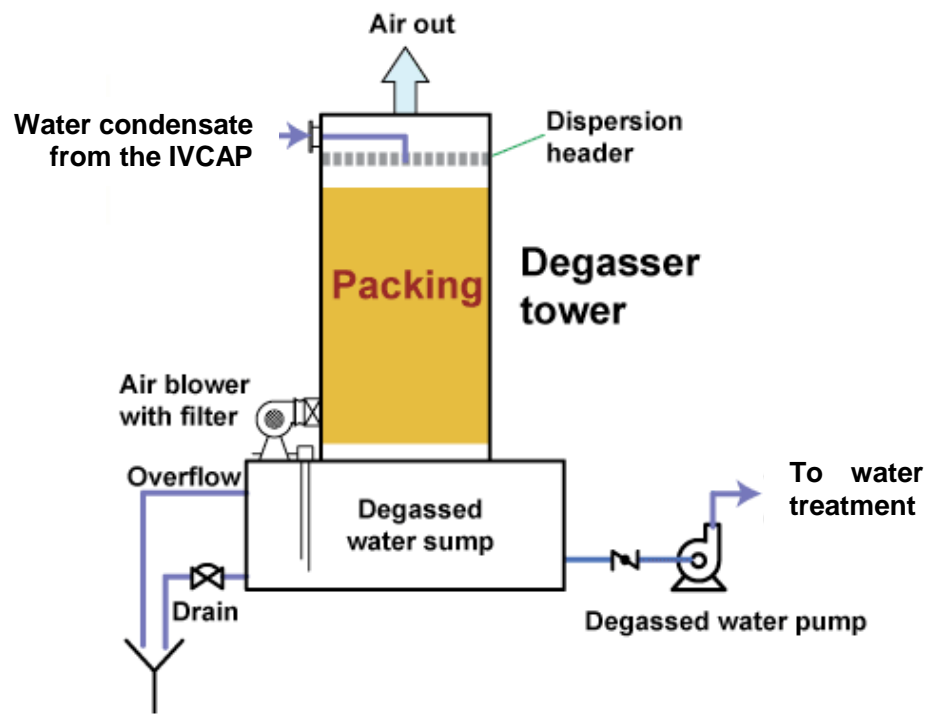

Figure 7-5. A schematic of a forced draft degasifier.

A vacuum degasifier is a packed-bed tower that operates under vacuum. It is generally customdesigned for a specific application. It is typically between 6 and $18 \mathrm{~m} \mathrm{(20} \mathrm{and} 60 \mathrm{ft})$ in height. A vacuum degasifier can remove the dissolved $\mathrm{CO}_{2}$ efficiently, but has a high capital cost, large footprint, and requires an additional pump for re-pressurization. ${ }^{[40,41]}$

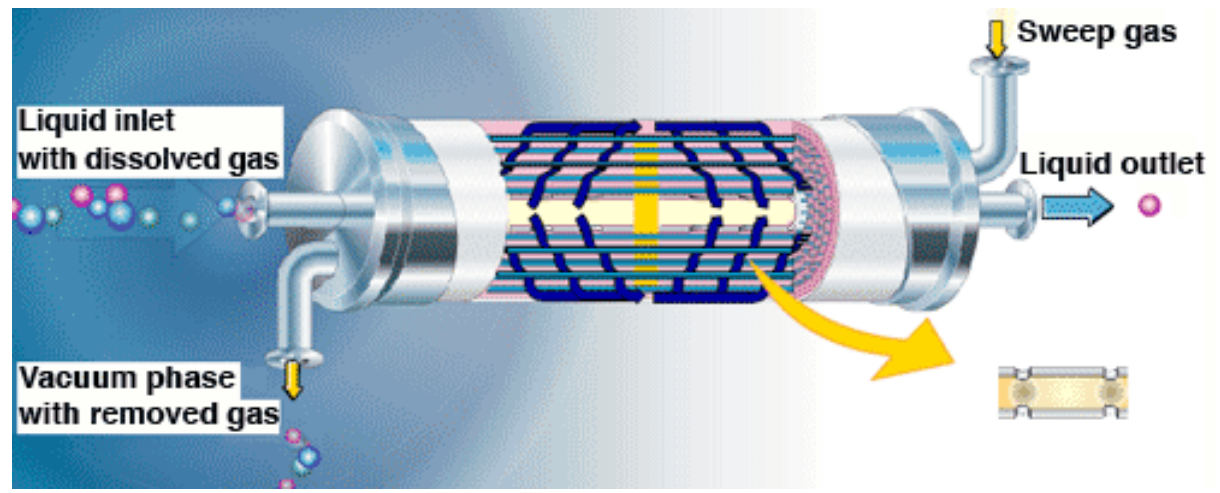

Figure 7-6. A schematic of a membrane contactor degasifier.

A membrane contactor degasifier consists of thousands of micro-porous polypropylene hollow fibers arranged to form a tube-and-shell configuration, as shown in Figure 7-6. In operation, water flows on the shell side (outside of the hollow fibers) radially across the hollow fiber array using the specifically-designed baffles, while a strip gas, vacuum, or combination of the two flows counter-currently inside the hollow fiber tubes. Since the hollow fiber membrane is hydrophobic, the liquid stream will not penetrate the pores. Thus, the gas/liquid interface is immobilized at the pores of the membrane fibers. $\mathrm{CO}_{2}$ partial pressure is the driving force causing the dissolved $\mathrm{CO}_{2}$ in the water to diffuse from the liquid to the gasphase through the 
liquid-gas interface. A membrane contactor degasifier is inherently modular, has a low cost and footprint, and does not need a second pump. ${ }^{[41]}$

Making $\mathrm{CO}_{2}$-free water may require further purification, such as by aerification and alkalization. In the aerification process, increasing the temperature, the retaining time, and the surface area of packing materials improves the removal efficiency. In the alkalization process, the water will be alkalized to $\mathrm{pH} 9$ or higher by adding an alkaline agent, such as sodium hydroxide (caustic soda) or volatile ammonia.

\subsubsection{Summary}

The water recovered from condensation of the $\mathrm{CO}_{2}$-water stream exiting the IVCAP stripper contains dissolved $\mathrm{CO}_{2}$ which acidifies the water to $\mathrm{pH}$ levels between 4.0 and 4.3 at 0.14 to 0.54 atm ( 2 to 8 psia) $\mathrm{CO}_{2}$ partial pressure and 25 to $40^{\circ} \mathrm{C}$ ( 77 to $\left.104^{\circ} \mathrm{F}\right)$. One option is to remove the dissolved $\mathrm{CO}_{2}$ in the condensed water in a degasified and recycle it for use as boiler feed water. There are three commercially-available technologies to remove free $\mathrm{CO}_{2}$ from water; forced draft degasifier, vacuum degasifier, and membrane contactor degasifier. A membrane contactor degasifier has advantages of modular size/arrangement, low cost and footprint.

\subsection{Potential for precipitation of potassium bicarbonate from PC solution}

The IVCAP employs a $20 \mathrm{wt} \% \mathrm{~K}_{2} \mathrm{CO}_{3} / \mathrm{KHCO}_{3}$ solution $\left(\mathrm{K}_{2} \mathrm{CO}_{3}\right.$-equivalent $)$ to absorb $\mathrm{CO}_{2}$ at a typical flue gas temperature between 40 to $60^{\circ} \mathrm{C}\left(104\right.$ and $\left.140^{\circ} \mathrm{F}\right)$. Phase equilibrium data for the $20 \mathrm{wt} \% \mathrm{~K}_{2} \mathrm{CO}_{3} / \mathrm{KHCO}_{3}$ solution generated using CHEMCAD are presented in Figure 7-7. For the VLE data at $104^{\circ} \mathrm{F}$, the two red horizontal lines in the figure represent the $\mathrm{CO}_{2}$ partial pressures of the flue gas at the inlet $(0.14 \mathrm{~atm} / 2 \mathrm{psia})$ and outlet $(0.014 \mathrm{~atm} / 0.2 \mathrm{psia})$ of the absorber, corresponding to $90 \% \mathrm{CO}_{2}$ removal. The two red vertical lines represent the maximum CTB conversion levels in the lean $(32 \%)$ and rich solutions $(66 \%)$. These parameters determine the operating range of CTB conversion in the solution. The operating range of the CTB conversion depends on the absorption temperature. At temperatures above $40^{\circ} \mathrm{C}\left(104^{\circ} \mathrm{F}\right)$, the two vertical lines in the figure will shift to the left (lower conversion) side, resulting in a decrease in the maximum CTB conversion level in the rich solution exiting the absorber. Therefore, for the $20 \mathrm{wt} \% \mathrm{~K}_{2} \mathrm{CO}_{3} / \mathrm{KHCO}_{3}$ solution to achieve a $90 \% \mathrm{CO}_{2}$ removal at absorption temperatures of 40 to $60^{\circ} \mathrm{C}\left(104\right.$ to $\left.140^{\circ} \mathrm{F}\right)$, the maximum $\mathrm{CTB}$ conversion allowed is $66 \%$.

In the $\mathrm{K}_{2} \mathrm{CO}_{3} / \mathrm{KHCO}_{3}$ solution, $\mathrm{KHCO}_{3}$ has lower solubility than $\mathrm{K}_{2} \mathrm{CO}_{3}$ and will be the component to precipitate first. The solubility of $\mathrm{KHCO}_{3}$ in the $\mathrm{K}_{2} \mathrm{CO}_{3} / \mathrm{KHCO}_{3}$ solution is available in the literature ${ }^{[42]}$ and presented in Figure 7-8. It can be seen that even at $40{ }^{\circ} \mathrm{C} / 104^{\circ} \mathrm{F}$ (the lowest end of the absorption temperature), $\mathrm{KHCO}_{3}$ will not precipitate from the $20 \mathrm{wt} \%$ $\mathrm{K}_{2} \mathrm{CO}_{3} / \mathrm{KHCO}_{3}$ solution until almost a $100 \%$ CTB conversion level is reached. In comparison, the maximum allowable CTB conversion in the IVCAP absorption process is $66 \%$. Thus, there appears to be no risk associated with precipitation of $\mathrm{KHCO}_{3}$ during the absorption process. In the IVCAP stripper, precipitation will not occur even at $100 \%$ CTB conversion, because the stripping temperature is higher than the absorption temperature. 
In summary, it is not likely that precipitation of $\mathrm{KHCO}_{3}$ will occur in the IVCAP system under the normal operating conditions. Even in some extreme circumstances where local cooled areas exist, $\mathrm{KHCO}_{3}$ will not precipitate from the $20 \mathrm{wt} \%$ solution (with $66 \% \mathrm{~K}_{2} \mathrm{CO}_{3}$ conversation) as long as the temperature is above about $40^{\circ} \mathrm{F}$, based on extrapolation of the solubility data provided in Figure 7-8.

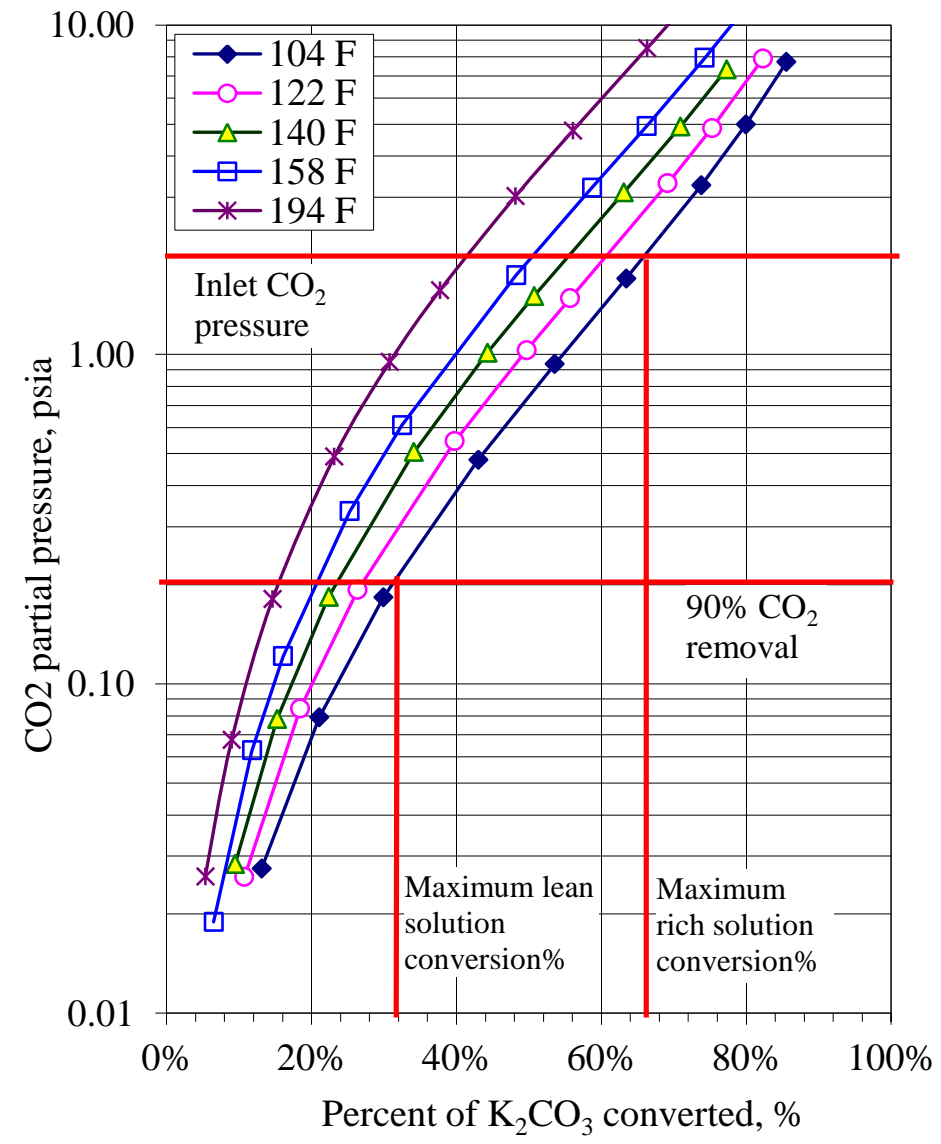

Figure 7-7. Vapor-liquid equilibrium of $\mathrm{CO}_{2}-\mathrm{K}_{2} \mathrm{CO}_{3} / \mathrm{KHCO}_{3}\left(20 \mathrm{wt} \% \mathrm{~K}_{2} \mathrm{CO}_{3}\right.$-equivalent) system (data generated using CHEMCAD software). 


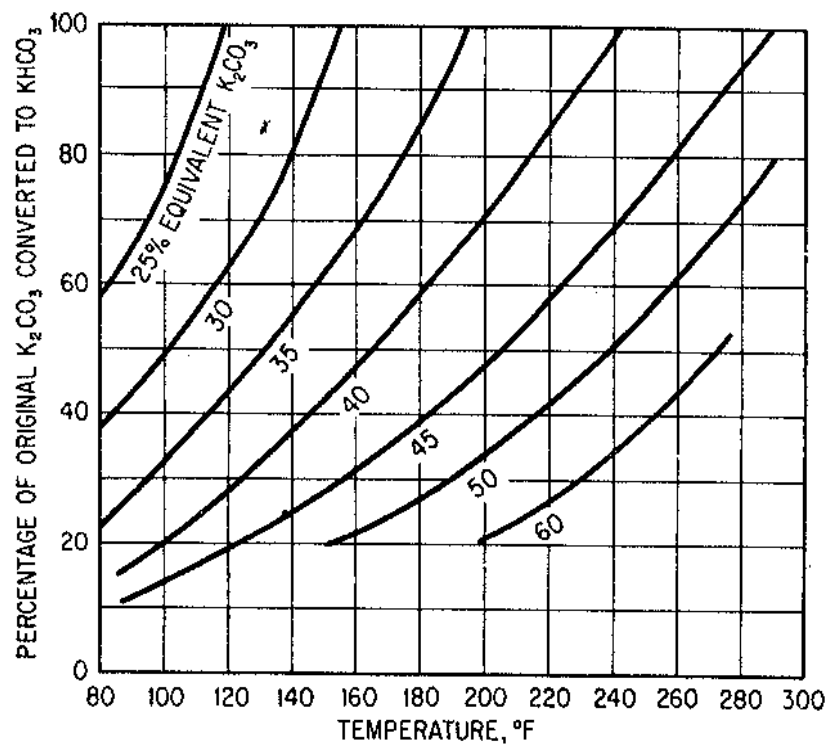

Figure 7-8. Solubility of bicarbonate in PC solution.

\section{References}

1. Zhang J., Martin F.J. Corrosion of steel by carbonate-bicarbonate solution for $\mathrm{CO}_{2}$ capture. Materials and Corrosion 2012, doi: 10.1002/maco.201106235, early online view.

2. Kolff S.W. Corrosion of a $\mathrm{CO}_{2}$ absorber tower. Plant/Operations Progress, 1986, 5:65-72.

3. Ferguson K., Stutheit A. Vessel corrosion repair -2. unusual weld overlay project stressed quality, safety. Oil and Gas Journal, 1992, 90:69-74.

4. Nikitina A.K., Vershinina L.P., Khvatkova V.P., Umnyashkina V.M. Steel corrosion rate in potash treatment of gases to remove $\mathrm{CO}_{2}$. Chemistry and Technology of Fuels and Oils, 1982, 18: 562-564.

5. Foroulis Z.A. Stress corrosion cracking of carbon steel in hot potassium carbonate/bicarbonate solution. Corrosion Engineering, 1987, 36(11): 689-695.

6. Zhou B. Anodic behavior of mild steel and corrosion inhibition mechanism of vanadate and vanadium pentoxide in hot potassium carbonate solutions containing amine catalysts. Bulletin of Electrochemistry -11, 1988, 4(1): 11-16.

7. Bienstock D., Field J.H. Corrosion of steels in boiling potassium carbonate saturated with carbon dioxide and hydrogen sulfide. Corrosion (Houston, TX, U.S.), 1961, 17: 337t-339t.

8. Bienstock D., Field J.H. Corrosion inhibitors for hot-carbonate systems. Corrosion (Houston, TX, U.S.), 1961, 17: 571t-574t.

9. Nikitina A.K., Khvatkova V.P., Umnyashkina V.M., Vershinina L.P. Effect of inhibitors on corrosion rate of carbon steels in $\mathrm{CO}_{2}$-saturated potassium carbonate solutions. Chemistry and Technology of Fuels and Oils, 1984, 20: 379-382.

10. Lunarska E. and Szyprowski A. Inhibitor protection and corrosion monitoring in Benfield installation to purify gas for synthesis. British Corrosion Journal, 1994, 29(3): 226-232. 
11. Sekine I., Shimode T., Yuasa M. Corrosion inhibition of structural steels in the carbon dioxide absorption process by 1-(hydroxyethylidene)-1,1-diphosphonic acid. Industrial \& Engineering Chemistry Research, 1990, 29(7): 1460-1466.

12. Sekine I., Shimode T., Yuasa M. Corrosion inhibition of structural steels in the carbon dioxide absorption process by organic inhibitors. 2. corrosion inhibition of structural steels in carbon dioxide absorption process by organic inhibitor composed of 2-aminothiophenol, (1hydroxyethylidene)bis(phosphonic acid), and diethanolamine. Industrial \& Engineering Chemistry Research, 1992, 31(1): 434-439.

13. Gauthier R.Y.D., Flamant, G., Partitioning of trace elements in the flue gas from coal combustion. Combustion and Flame, 2001, 125:942-954.

14. Meij R. Trace element behavior in coal-fired power plants, Fuel Processing Technology, 1994, 39: 199-217.

15. Zevenhoven R., Kilpinen P. 2001. Control of pollutants in flue gases and fuel gases, 951-225527-8, Helsinki University of Technology, Espoo, Finland Report TKK-ENY-4, Chapter 8. URL: http://www.hut.fi/ rzevenho/gasbook

16. Xu M., Yan R., Zheng C., Qiao Y., Han J., Sheng C. Status of trace element emission in a coal combustion process: a review, Fuel Processing Technology, 2003, 85: 215-237.

17. Pudvay M. Operating experience on the treatment on FGD scrubber blowdown from existing generating stations. http://www.degremont-technologies.com/, as of May 26, 2011.

18. Lionetto M.G., Caricato R., Giordano M.E., Erroi E., Schettino T. 2012. Carbonic Anhydrase and Heavy Metals. Biochemistry. Deniz Ekinci (Ed.), ISBN: 978-953-51-0076-8, InTech. http://www.intechopen.com/books/biochemistry/carbonic-anhydrase-and-heavy-metals

19. Tu C., Wynns G.C., Silverman D.N. Inhibition by cupric ions of ${ }^{18} \mathrm{O}$ exchange catalyzed by human carbonic anhydrase II. Relation to the interaction between Carbonic Anhydrase and Hemoglobin. Journal of Biological Chemistry, 1981, 256:9466-9470.

20. Liang J.Y., Lipscomb W.N. Hydration of $\mathrm{CO}_{2}$ By Carbonic Anhydrase: Intramolecular proton transfer between Zn-Bound water and histidine-64 in human Carbonic Anhydrase II. Biochemistry, 1988, 27:8676-8682.

21. Tu, C., Silverman, D.N., Forsman, C., Jonsson, B.H., Lindskog, S., Role of histidine-64 in the catalytic mechanism of human Carbonic Anhydrase II studied with a site-specific mutation. Biochemistry, 1989, 28: 7913-7918.

22. Vedani A., Huhta D.W., Jacober S.P., Metal-coordination, hydrogen-bond network formation, and protein-solvent interactions in native and complexed human Carbonic Anhydrase I: a molecular mechanism study. Journal of the American Chemical Society, 1989, 111: 4075-4081.

23. Sharma A., Bhattacharya A. Enhanced biomimetic sequestration of $\mathrm{CO}_{2}$ into $\mathrm{CaCO}_{3}$ using purified carbonic anhydrase from indigenous bacterial strains, Journal of Moledular Catalysis: B-Enzymatic, 2010, 67:122-128.

24. Simonsson I., Lindskog S. The interaction of sulfate with carbonic-anhydrase, European Journal of Biochemistry, 1982, 123:29-36. 
25. Hakansson K., Carlsson M., Svensson L.A., Liljas A. Structure of Native and Apo Carbonic Anhydrase II and Structure of Some of Its Anion-Ligand Complexes. Journal of Molecular Biology, 1992, 227: 1192-1204.

26. Bond G. M., Medina M.-G., Stringer J., Simsek-Ege F. A. $\mathrm{CO}_{2}$ Capture from Coal-Fired Utility Generation Plant Exhausts, and Sequestration by a Biomimetic Route Based on Enzymatic Catalysis - Current Status, First National Conference on Carbon Sequestration, Washington, DC, May 14-17, 2001.

27. Bertini I., Canti G., Luchinat C., Scozzafava A., Characterization of cobalt(II) bovine carbonic anhydrase and of its derivatives. Journal of the American Chemical Society, 1978, 100: 4873-4877.

28. Bertini I., Luchinat C. Cobalt(ii) as a probe of the structure and function of carbonicanhydrase, Acc. Chem. Res., 1983, 16: 272-279.

29. Lindskog S. Structure and Mechanism of Carbonic Anhydrase, Pharmacological Thermodynamics, 1997, 74(1): 1-20.

30. De Simone G., Supuran C.T. (In)organic anions as carbinc anhydrase inhibitors, Journal of Inorganic Biochemistry, 2012, 111: 117-129.

31. Versteeg G.F., Van Swaalj W. Solubility and diffusivity of acid gases (carbon dioxide, nitrous oxide) in aqueous alkanolamine solutions. Journal of Chemical \& Engineering Data, 1988, 33:29-34.

32. Weisenberger S., Schumpe A. Estimation of gas solubilities in salt solutions at temperatures from $273 \mathrm{~K}$ to $363 \mathrm{~K}$. American Institute of Chemical Engineers Journal, 1996, 42:298-300.

33. Astarita G., Savage D.W., Bisio A. 1983. Gas treating with chemical solvents, Wiley, New York. pp.493.

34. Danckwerts P.V., Sharma M.M. Absorption of carbon dioxide into solutions of alkalis and amines. Journal of Chemcial Engineering Reviews Series No 2, The Chemical Engineer, CE, 1966: $244-280$.

35. Tseng P.C., Ho W.S., Savage D.W. Carbon dioxide absorption into promoted carbonate solutions. Amnerican Institute of Chemical Engineers Journal, 1988, 34:922-31.

36. "Mickey" Haynes W.M., David R.L. (internet edition) In CRC Handbook of Chemistry and Physics, 91st edition, internet version 2011.

37. Water treatment solutions for boiler feed water. http://www.lenntech.com/boiler-feedwater.htm (accessed June 15, 2012)

38. Ciferno J. Use of non-traditional water for power plant applications: An overview of DOE/NETL R\&D efforts. (2009), November 1: pp.10-20

39. Degasifiers. http://dardel.info/IX/processes/degasser.html (accessed June 10, 2012)

40. Lantec Products, I. $\mathrm{CO}_{2}$ Degasifiers / Drinking Water Corrosion Control Air Stripper Tower Design for EPA Lead and Copper Rule Compliance. http://www.lantecp.com/ (accessed June 10, 2012) 
41. Polypore International, I. Liqui-Cel® Membrane Contactors are widely used in the soft drink and brewing industries to Control dissolved gasses,

http://www.liquicel.com/uploads/documents/TB63\%207-

07\%20Beverage\%20Market\%20Summary.pdf (accessed June 10, 2012)

42. Kohl A.S., Nielsen R.B. 1997. Gas Purification 5th Edition, Houston: Gulf Publishing, Houston. 


\section{CHAPTER 8. CONCLUSIONS AND RECOMMENDATIONS}

\subsection{Conclusions}

This research and development program was aimed at obtaining process engineering and scaleup data through a laboratory-scale study necessary to determine the technical and economic feasibility of a patented post-combustion $\mathrm{CO}_{2}$ capture process-the Integrated Vacuum Carbonate Absorption Process (IVCAP). Unique features of the process include its ability to be fullyintegrated with the power plant's steam cycle and the potential for combined $\mathrm{SO}_{2}$ removal and $\mathrm{CO}_{2}$ capture. The major conclusion of the project is that the IVCAP is technically-feasible and economically-superior to commercial MEA-based processes. For a $528 \mathrm{MWe}$ (gross) coal-fired plant, the cost of $\mathrm{CO}_{2}$ avoidance with the IVCAP is about $30 \%$ lower than the MEA process. The increase in the LCOE of the IVCAP is about 60 to $70 \%$ compared to a reference plant without this $\mathrm{CO}_{2}$ capture retrofit.

This R\&D program sought answers to the following technical questions:

1- What additives can effectively reduce the water vapor saturation pressure and energy requirement for water vaporization in the vacuum stripper of the IVCAP process?

2- What catalysts can promote $\mathrm{CO}_{2}$ absorption into the $\mathrm{PC}$ solution to achieve an overall absorption rate comparable to MEA and are they stable at the IVCAP's normal operating conditions and in a flue gas environment?

3- Is it feasible to combine $\mathrm{SO}_{2}$ and $\mathrm{CO}_{2}$ removal in the IVCAP and are there any process modifications needed to achieve this?

A series of carefully designed laboratory-scale experiments and process simulation studies were performed to obtain detailed information pertinent to the above questions. The results and conclusions of those studies are summarized below.

Vapor-liquid-equilibrium (VLE) measurements. Potassium Acetate (KAc), potassium formate (KA), and ethylene glycol (EG) were identified as effective additives to lower the saturation pressure of water vapor over the PC solution. Adding $20 \mathrm{wt} \% \mathrm{KAc}$ or KA in the $20 \mathrm{wt} \% \mathrm{PC}$ solution that is the $\mathrm{CO}_{2}$ solvent in the IVCAP reduced the water vapor saturation pressure by about $20 \%$ at $70^{\circ} \mathrm{C}\left(158^{\circ} \mathrm{F}\right)$ and more than $20 \%$ at $50^{\circ} \mathrm{C}\left(122^{\circ} \mathrm{F}\right)$. These additives also enhanced the solubility of $\mathrm{CO}_{2}$ into the $\mathrm{PC}$ to some degree.

Kinetics and catalysts of $\mathrm{CO}_{2}$ absorption. Numerous catalysts and promoters to enhance the rate of $\mathrm{CO}_{2}$ absorption into $\mathrm{PC}$ solutions were experimentally evaluated. The addition of $4 \mathrm{wt} \%$ $\mathrm{NaVO}_{3}$, a Lewis base-type additive, increased the $\mathrm{CO}_{2}$ absorption rate by 3.8 times at $25^{\circ} \mathrm{C}$ $\left(77^{\circ} \mathrm{F}\right)$ and 3.5 times at $40^{\circ} \mathrm{C}\left(104^{\circ} \mathrm{F}\right)$.

The CA enzyme was identified to be the most effective catalyst for promoting $\mathrm{CO}_{2}$ absorption into the PC. The enzymatic rate constants $\left(k_{c a t} / K_{M}\right)$ of a CA enzyme - ACA1 (a CA enzyme produced in a pilot unit by Enzyme manufacturing company A) in $20 \mathrm{wt} \%$ PC solutions were 
empirically determined to be 8.1-9.4 $\times 10^{7} \mathrm{M}^{-1} \cdot \mathrm{s}^{-1}$ at temperatures between 25 and $50^{\circ} \mathrm{C}(77$ and $122^{\circ} \mathrm{F}$ ) without significant dependence on $\mathrm{CO}_{2}$ loading. The enzymatic reactivity was higher at $40^{\circ} \mathrm{C}\left(104^{\circ} \mathrm{C}\right)$, but comparable at 25 and $50^{\circ} \mathrm{C}\left(77\right.$ and $\left.122^{\circ} \mathrm{F}\right)$. The rate constants were comparable to, or slightly higher than, those reported in the literature for the natural human $\mathrm{CA}$ II enzymes under similar basic conditions at $25^{\circ} \mathrm{C}\left(77^{\circ} \mathrm{F}\right)$.

The rate of $\mathrm{CO}_{2}$ absorption was measured in pure, vacuum $\mathrm{CO}_{2}$ gas using a batch Stirred Tank Reactor (STR) with negligible gas-phase diffusion resistance. Absorption rates were increased by about 3 to 9 times at a dosage of $300 \mathrm{mg} / \mathrm{l}$ of ACA1 in the $20 \mathrm{wt} \% \mathrm{PC}$ at temperatures between 25 and $50^{\circ} \mathrm{C}\left(77\right.$ and $\left.122^{\circ} \mathrm{F}\right)$. Further increase in absorption rate was observed at higher CA concentrations.

The $\mathrm{CO}_{2}$ absorption rate into the PC20-20 ( $\mathrm{CO}_{2}$-lean PC solution) at $300 \mathrm{mg} / \mathrm{l} \mathrm{ACA} 1$ dosage was several times lower than the MEA5-40 in the STR at $50^{\circ} \mathrm{C}\left(122^{\circ} \mathrm{F}\right)$, while the rate into the PC20$40\left(\mathrm{CO}_{2}\right.$ rich $)$ at the same ACA1 dosage was comparable to the MEA5-90. Modeling predictions suggested that in a packed-bed absorption column where gas diffusion resistance is significant for fast reactions, the difference between the $\mathrm{CO}_{2}$ absorption rates into the MEA and PC+CA become less, especially when the $\mathrm{CO}_{2}$ loading of the solutions is high.

The ACA1 enzyme demonstrated excellent chemical stability to resist flue gas impurities. The $\mathrm{CO}_{2}$ hydration activity loss of ACA1 was less than $12 \%$ in the presence of typical concentrations of flue gas impurities and did not change over two months. The activity of the CA enzyme may not be significantly affected by other additives, but was adversely affected by the water vaporization inhibitors.

The ACA1 enzyme had satisfactory stability at $25^{\circ} \mathrm{C}\left(77^{\circ} \mathrm{F}\right)$, but not at temperatures higher than $40^{\circ} \mathrm{C}\left(104^{\circ} \mathrm{F}\right)$. The ACA2 enzyme (a thermophilic CA provided by Enzyme manufacturing company A) demonstrated excellent stability at $40^{\circ} \mathrm{C}\left(104^{\circ} \mathrm{F}\right)$; losing only about $15 \%$ of its initial activity after 6 months. At $50^{\circ} \mathrm{C}\left(122^{\circ} \mathrm{F}\right)$, the ACA2 enzyme had a half-life of about two months. The BCA1 (a CA enzyme provided by a university) and ACA1 enzyme demonstrated a comparable thermal stability at 40 to $50^{\circ} \mathrm{C}\left(104\right.$ to $\left.122^{\circ} \mathrm{F}\right)$.

CA enzyme immobilization. Results from enzyme immobilization and stability tests indicated that the immobilization effectively improved the CA enzyme's stability for $\mathrm{CO}_{2}$ hydration under the expected IVCAP conditions.

Covalent bonding methods were developed and optimized to immobilize the CA enzymes (SCA from Sigma Aldrich and ACA1) onto micron-sized, porous CPG, AC, and Eupergit C materials. Compared to the AC and CPG100 (CPG with pore size of $100 \mathrm{~nm}$ ) support materials, the mesoporous CPG38 support (CPG with pore size of $38 \mathrm{~nm}$ ) provided a good tradeoff between pore size and pore volume for achieving high CA loading (32.6 mg SCA /g and $27.1 \mathrm{mg}$ $\mathrm{ACA} 1 / \mathrm{g}$ ) and $\mathrm{CO}_{2}$ hydration activity.

The CA enzymes immobilized on the porous materials exhibited significantly improved thermal stability for $\mathrm{CO}_{2}$ hydration. They retained 62 to $92 \%$ of their initial activities at $50^{\circ} \mathrm{C}\left(122^{\circ} \mathrm{F}\right)$ after 90 days, as compared to about $33 \%$ activity retention for their free counterparts. The 
immobilization also improved the chemical resistance of the CA enzyme to the concentrations of sulfate, nitrate and chloride impurities typically entrained in coal combustion flue gas.

A new class of nanosized $(<100 \mathrm{~nm})$ support/carrier particles, including silica $(\mathrm{SN}), \mathrm{SiO}_{2}-\mathrm{ZrO}_{2}$ (SZ) and $\mathrm{SiO}_{2}-\mathrm{Fe}_{2} \mathrm{O}_{3}$ (SF) were synthesized using a FSP method. Compared with CA enzyme immobilization onto porous materials, the FSP nanoparticles generally exhibited a high enzyme activity, a larger enzyme loading, and improved stability. The immobilized enzymes maintained a high activity at $\mathrm{pH}$ conditions typical in the IVCAP. The loading of the immobilized enzyme increased with decreasing size of the nanoparticles. Compared to ACA1-SN, the stability of ACA1-SZ was significantly improved. ACA1-SZ1 retained $100 \%$ of its original activity after 30 days at $50^{\circ} \mathrm{C}\left(122^{\circ} \mathrm{F}\right)$. The activity of the immobilized ACA1 was reduced by 22 to $27 \%$ after 60 days in the presence of $\mathrm{SO}_{4}{ }^{2-}, \mathrm{NO}_{3}{ }^{-}$, and $\mathrm{Cl}^{-}$anions.

${\underline{\text { Combined } \mathrm{SO}_{2}}}_{2}$ removal and $\mathrm{CO}_{2}$ capture. Based on batch test results, a two-stage reclaiming process was proposed to recover $\mathrm{K}_{2} \mathrm{SO}_{4}$ from the $\mathrm{PC}$ solution. In the first stage, a high-pressure $\mathrm{CO}_{2}$ gas stream is used to lower the $\mathrm{CO}_{3}{ }^{2-}$ concentration in the $\mathrm{PC}$ solution. In the second stage, lime/hydrated lime and high-pressure $\mathrm{CO}_{2}$ are introduced to precipitate calcium sulfate from the $\mathrm{PC}-\mathrm{K}_{2} \mathrm{SO}_{4}$ solution.

Rates of CTB conversion in a high-pressure $\mathrm{CO}_{2}$ gas stream (about 34 atm/500 psia) at room temperature were rapid when the CTB conversion levels were less than $71 \%$. At higher CTB conversion levels, especially at CTB conversions above $89 \%$, rates were significantly reduced. Semi-continuous tests to precipitate $\mathrm{CaSO}_{4}$ using hydrated lime in 37 atm (550 psia) $\mathrm{CO}_{2}$ gas revealed that at PC concentrations between 5 and $20 \mathrm{wt} \%$, vaterite (an unstable polymorph of $\left.\mathrm{CaCO}_{3}\right)$ was the only crystal phase formed. Gypsum $\left(\mathrm{CaSO}_{4} \cdot 2 \mathrm{H}_{2} \mathrm{O}\right.$ and/or syngenite $\left(\mathrm{K}_{2} \mathrm{Ca}\left(\mathrm{SO}_{4}\right)_{2} \cdot \mathrm{H}_{2} \mathrm{O}\right)$ precipitated in the $\mathrm{PC}$ solutions with lower concentrations.

Experimental results suggested that further modifications could improve the economic performance of $\mathrm{SO}_{2}$ removal in the IVCAP. For example, one option would be to decouple the $\mathrm{SO}_{2}$ scrubbing and the $\mathrm{CO}_{2}$ absorption and use a different scrubbing $\mathrm{PC}$ solution with a low concentration $(\leq 0.2 \mathrm{M})$ and high CTB conversion level to obtain high $\mathrm{SO}_{4}{ }^{2-} / \mathrm{CO}_{3}{ }^{2}$. The other option would be to precipitate $\mathrm{K}_{2} \mathrm{SO}_{4}$ directly from the PC solution, because $\mathrm{K}_{2} \mathrm{SO}_{4}$ is less soluble than other potassium salts, followed by reclamation of the $\mathrm{K}_{2} \mathrm{SO}_{4}$ precipitate via reaction with lime.

Techno-economics of IVCAP. Process simulation studies revealed that the IVCAP integrated with a $528 \mathrm{MWe}$ (gross) coal-fired power plant at a baseline condition lowered parasitic power losses by $24 \%$ compared to a MEA process. The stripping pressure, $\mathrm{CO}_{2}$ loading, and liquid/gas ratio were identified to be the most important parameters impacting the energy use performance of the IVCAP process.

For the baseline conditions and $2 \mathrm{~g} / \mathrm{L}$ CA dosage, equipment sizing calculations revealed that the dimensions of the IVCAP absorber had to be about 23 to $40 \%$ larger, and the vacuum stripper about 3.8 to 5.4 times larger, than the equivalent equipment for the MEA process (employing $5 \mathrm{M}$ or $30 \mathrm{wt} \%$ MEA as a solvent), respectively. 
The capital cost of the baseline IVCAP was about 33\% higher than that for the MEA process, but its O\&M cost was about $40 \%$ lower, due to its low solvent cost and reduced parasitic power losses. The resulting LCOE (about $\$ 46 / \mathrm{MWh}$ ) was a $71 \%$ increase over the reference power plant without $\mathrm{CO}_{2}$ capture. The increase in LCOE of the baseline IVCAP was $17 \%$ less than that of the MEA process.

A cost sensitivity analysis indicated that the LCOE increase of the IVCAP (about \$40/MWh or a $61 \%$ increase compared to the reference power plant) could be further reduced to be $28 \%$ less than the MEA by optimizing $\mathrm{CO}_{2}$ loading in the solution, reducing enzyme production cost, and using an additive to reduce the stripping heat associated with water vaporization. Advances in the development of the absorber, stripper, compressor, and vacuum pump to reduce the capital cost by about $50 \%$ could decrease the LCOE of the IVCAP to about $\$ 30 / \mathrm{MWh}$, or a $46 \% \mathrm{LCOE}$ increase compared to the reference plant without $\mathrm{CO}_{2}$ capture.

Other major technical risks. Corrosion tendency of the PC solution in the IVCAP was compared to that of the commercial "Hot Potassium Carbonate" processes (i.e., Benfield and Catacarb processes). $\mathrm{HCO}_{3}{ }^{-}$ions are the active agents and the rate of corrosion increases with increasing $\mathrm{HCO}_{3}{ }^{-}$concentration. Many Benfield and Catacarb units have been operating corrosion-free for many years by using corrosion inhibitors, such as vanadium salts or $\mathrm{V}_{2} \mathrm{O}_{5}$. The IVCAP operates at less severe conditions $\left(\mathrm{CO}_{2}\right.$ pressure and temperature) than the "Hot Potassium Carbonate" processes.

A literature review suggested that trace elements in coal combustion flue gas do not significantly affect the activity and stability of the CA enzyme under the typical conditions in the IVCAP.

The water recovered from condensation of the $\mathrm{CO}_{2}$-water stream exiting the IVCAP stripper contains dissolved $\mathrm{CO}_{2}$ and has a $\mathrm{pH}$ level between 4.0 and 4.3. To recycle the water to the boiler as feedwater, it should be degasified to remove the dissolved $\mathrm{CO}_{2}$. Commercial technologies are available to achieve this.

It is unlikely that precipitation of $\mathrm{KHCO}_{3}$ would occur in the IVCAP system under the normal operating conditions or even in some extreme circumstances where local cool spots are present.

\subsection{Recommendations}

Development of thermophilic CA enzymes. The CA enzymes examined in this study degraded significantly at temperatures higher than $50^{\circ} \mathrm{C}\left(122^{\circ} \mathrm{F}\right)$. A more stable CA enzyme can help improve both the absorption and stripping processes in the IVCAP. Development of CA enzymes with long-term stability at temperatures up to 70 to $75^{\circ} \mathrm{C}\left(158\right.$ to $\left.167^{\circ} \mathrm{F}\right)$ and resistant to deactivation by flue gas contaminants is recommended.

Kinetics study of $\mathrm{CO}_{2}$ stripping. The kinetics of $\mathrm{CO}_{2}$ desorption under the IVCAP conditions, especially the role of the CA biocatalyst, need to be experimentally investigated and validated.

Scale-up test of IVCAP. Our laboratory-scale process development studies revealed that the IVCAP is an economically-competitive option for post-combustion $\mathrm{CO}_{2}$ capture. A scale-up 
study using a slipstream of actual flue gas at the pilot-scale is recommended. The project team will include an enzyme manufacturing company to develop and produce adequate amounts of a thermophilic biocatalyst, an engineering company to design and construct the scaled-up IVCAP unit, and a test center or utility host site. A few industrial collaborators have shown interest in participating in such a scale-up study. Partial support from the State of Illinois through the Office of Coal Development and Marketing is also highly likely for such a study.

Development of combined $\mathrm{SO}_{2}$ removal and $\mathrm{CO}_{2}$ capture process. Studies of the technical feasibility and economic performance of a modified process concept for combined $\mathrm{SO}_{2}$ removal and $\mathrm{CO}_{2}$ capture by either direct precipitation of $\mathrm{K}_{2} \mathrm{SO}_{4}$, or $\mathrm{SO}_{2}$ removal in a separate $\mathrm{PC}$ scrubber are recommended. 


\section{APPENDIX A. STATEMENT OF PROJECT OBJECTIVES}

\section{A. Objectives}

ISGS-UIUC has developed a novel Integrated Vacuum Carbonate Absorption Process (IVCAP) for post-combustion $\mathrm{CO}_{2}$ capture. This process shows large potential improvement in the energy use and $\mathrm{CO}_{2}$ capture cost compared to the MEA processes. The overall objectives of the proposed project are to: 1) perform an experimental study to test the proof-of-concept of the IVCAP process; 2) identify an effective catalyst for accelerating the $\mathrm{CO}_{2}$ absorption and an effective additive for further reducing the stripping heat, and 3) evaluate a modified IVCAP process as a multi-pollutant control process for combined $\mathrm{SO}_{2}$ and $\mathrm{CO}_{2}$ removal.

The goal in year $1(10 / 1 / 2008-4 / 30 / 2010)$ is to identify the catalyst and process conditions to achieve a $\mathrm{CO}_{2}$ absorption rate in the catalyzed potassium carbonate aqueous solution comparable to that of the MEA-based absorption process. The goal in year $2(5 / 1 / 2010-4 / 30 / 2011)$ is to identify the best additive for suppressing water vaporization. The goal in year $3(5 / 1 / 2011$ $4 / 30 / 2012$ ) is to prove a novel concept of combining the $\mathrm{SO}_{2}$ removal in the IVCAP process and perform a techno-economic study.

\section{B. Scope of Work}

The rate of $\mathrm{CO}_{2}$ absorption in the $\mathrm{K}_{2} \mathrm{CO}_{3}$ solution is critical to the IVCAP process. An enzyme catalyst and other selected inorganic catalysts will be evaluated and the related process conditions will be identified to accelerate the rate of $\mathrm{CO}_{2}$ absorption by 2-3 folds. The focus will be placed on the enzyme catalyst and its immobilization.

Since the stripping heat contributes to $70-80 \%$ of the heat use in the IVCAP process, the study on additives to suppress the water vapor saturation pressure is another important work. The vaporliquid equilibrium measurement will be performed to evaluate the effectiveness of the selected additives in lowering the water vapor pressure in the $\mathrm{K}_{2} \mathrm{CO}_{3}$ solution.

Combining $\mathrm{SO}_{2}$ removal with the $\mathrm{CO}_{2}$ capture in the IVCAP process can potentially eliminates the installation of a separate FGD system in the power plant. A kinetic study on the reclamation of the solvent reacted with $\mathrm{SO}_{2}$ will be conducted to evaluate the novel process concept proposed in this project.

Finally, a techno-economic study based on the process simulation will be performed for a conceptual full-scale pulverized coal-fired power plant equipped with the IVCAP.

\section{Tasks to Be Performed}

\section{Project Year 1}

Task 1. Screening and Development of Absorption Catalysts

Subtask 1.1: A continuous stirring tank reactor (CSTR) system available at the ISGS will be modified and re-assembled for the activity testing of the catalysts. The pre-test will be carried 
out to determine the performance of the gas-phase and liquid-phase mass transfers in this system.

Subtask 1.2: An enzyme catalyst will be tested and evaluated in the CSTR system for its activity of catalyzing the $\mathrm{CO}_{2}$ absorption/desorption in the $\mathrm{K}_{2} \mathrm{CO}_{3}$ solution. The effect of flue gas impurities on the enzyme activity will also be investigated.

Subtask 1.3: The selected inorganic catalysts will also be tested and evaluated in the CSTR system for their catalytic activities for $\mathrm{CO}_{2}$ absorption/desorption in the $\mathrm{K}_{2} \mathrm{CO}_{3}$ solution. The results in this subtask will be compared to Subtask 1.2.

\section{Project Year 2}

Task 1.4: The immobilization of the examined enzyme into the substrate support will be investigated using the conventional carrier-binding method. Different supports, including carbon-based, cellulose and polymer materials will be evaluated. A packing column packed with the support bound with the immobilized enzyme will be built, and the activity of the immobilized enzyme will be measured.

Task 1.5: The additives identified in Task 2 that are effective for suppressing water vaporization will be investigated for the potential ion effects on the activity of the catalysts.

\section{Task 2. Vapor-Liquid Equilibrium Measurement of $\mathrm{K}_{2} \mathrm{CO}_{3}$ Solutions with Additives}

Subtask 2.1: An experimental system will be built for measuring the vapor-liquid equilibrium of the $\mathrm{K}_{2} \mathrm{CO}_{3}$ system added with additives. The system setup will follow the one employed in an early study on the hot-potassium process by the Bureau of Mines.

Subtask 2.2: The measurement will be carried out for the $\mathrm{K}_{2} \mathrm{CO}_{3}$ solutions without additives at a temperature range of 25 to $70^{\circ} \mathrm{C}\left(77\right.$ to $\left.158^{\circ} \mathrm{F}\right)$. The results will be compared to reported data in literature and to verify the current measurement.

Subtask 2.3: The measurement will be carried out for the $\mathrm{K}_{2} \mathrm{CO}_{3}$ solutions with the selected additives at $25-70^{\circ} \mathrm{C}\left(77\right.$ to $\left.158^{\circ} \mathrm{F}\right)$. Three additives initially selected include the sodium chlorine (a common salt), potassium sulfate (an existing component in the absorption solution), and ethylene glycol (a potential promoter for $\mathrm{CO}_{2}$ absorption).

\section{Task 3. Kinetic Study on the Reclamation of the Solvent Reacted with $\mathrm{SO}_{2}$}

Subtask 3.1: A batch experimental system will be set up to study the kinetics of the reactions involving in the solvent reclamation process. The batch test will then carried out in the simulated solution condition. The kinetics will be obtained for the major reclamation reactions.

\section{Project Year 3}

Subtask 3.2: A semi-continuous experimental system (continuous gas flow) will first be built in this subtask. The kinetics in a simulated reaction condition will be studied to identify the optimal process condition for the solvent reclamation. 
Subtask 3.3: The additives identified effective in Task 2 and inorganic catalysts in Task 1 potentially have the impact on the solvent reclamation process. Their impacts will be evaluated both using the batch and the semi-continuous experimental systems.

\section{Task 4. Techno-Economic Analysis}

Subtask 4.1: The process simulation will be performed for the IVCAP process installed in a conceptual $500 \mathrm{MW}$ pulverized coal-fired power plant. The process design/simulation software, Chemcad, will be used in this subtask.

Subtask 4.2: Cost estimation will be conducted based on the performance simulation results from Subtask 4.1. The increase of the cost of electricity $(\mathrm{COE})$ and the cost of $\mathrm{CO}_{2}$ avoidance will be estimated.

\section{Project Year 1-3}

Task 5- Project Management and Planning and Technical Report

Biweekly meetings will be arranged and monthly activity from each member will be reported to the PI. Any revising of the project management plan will be discussed among team members. The required progress and final reports will be prepared.

Due to the importance to the technology development, two new research activities are proposed for Project Year 3:

\section{New Task 1: Evaluation of thermophilic CA enzymes}

Two thermophilic CA enzymes have recently been provided by a leading enzyme manufacturing company and a research organization, respectively. The providers indicated that these two new enzymes could tolerate elevated temperatures and alkaline $\mathrm{pH}$ conditions compared to existing bovine CA enzymes. The objective of this new task is to evaluate the activity and stability of these two enzymes as dissolved facilitators to promote the $\mathrm{CO}_{2}$ absorption into the potassium carbonate (PC) solution.

Parametric tests will be firstly performed using the existing STR system to evaluate the activity of the new enzymes in the $20 \mathrm{wt} \% \mathrm{PC}$. The parameters to be examined will include temperature $\left(40-70^{\circ} \mathrm{C} / 104-158^{\circ} \mathrm{F}\right), \mathrm{CO}_{2}$ loading in the $\mathrm{PC}, \mathrm{CA}$ dosage, and $\mathrm{CO}_{2}$ partial pressure.

Stability tests will then be performed using the STR system to evaluate the thermal and chemical stability of the two CA enzymes in the $20 \mathrm{wt} \%$ PC. The thermal stability test will be conduced for 4-5 selected conditions of temperature, $\mathrm{CA}$ dosage, and $\mathrm{CO}_{2}$ loading level for three months. The chemical stability will be carried out to investigate the impacts of the presence of $\mathrm{SO}_{4}{ }^{2-}, \mathrm{NO}_{3}{ }^{-}$and $\mathrm{Cl}^{-}$impurities on the CA activity in the $\mathrm{PC}$.

New Task 2: Development and evaluation of novel support/carrier materials and methods for CA enzyme immobilization 
Enzyme immobilization can improve the enzyme stability, but will also result in a significant loss of the activity. The activity loss is not only related to the coupling reaction between the enzyme and support, but also to the significant diffusion resistance of $\mathrm{CO}_{2}$ in the support. Employing nanosized $(<100 \mathrm{~nm})$ support/carrier particles or thin layers of support coated on packings can minimize or eliminate the impact of intra-particle diffusion. In addition, if nanosized particle carriers are employed and the immobilized CA enzyme can not tolerate an elevated temperature in the stripper, particles need to be separated from the solvent prior to entering the stripper. The objective of this new task is to develop nanosized silica- or carbonbased support/carrier materials that can minimize the impact of intra-particle diffusion, and if needed, can be easily separated from the solvent prior to the stripper.

Nanosized silica (or carbon) particles and silica-magnetite (or carbon-magnetite) particles will be synthesized using flame spray pyrolysis (FSP) technique, and if necessary, be further tailored by conventional chemistry methods. Magnetic particles are easy for solid-liquid separation. Si precursors or Si-Fe mixture precursors will be screened for the FSP. The prepared materials will be characterized for their morphology, crystal structure, surface functionality, and size using various analysis techniques. A FSP experimental system is currently available to use in our lab.

The CA enzyme will be immobilized onto the new support/carrier materials. The immobilization methods previously established in this project will be optimized for this purpose. Further experiments will be performed to evaluate the activity and stability of the immobilized enzymes using a manometric method previously developed.

\section{Deliverables}

On a quarterly basis, Federal Assistance Reporting/ Technical Progress Reports and Financial Status Reports will be submitted to DOE/NETL. A Final Scientific/Technical Report and a Final Financial Status Report will be issued at the end of the program. A Patent Certificate and a Property Certificate consisting of a Report of Termination or Completion Inventory will be submitted at the end of the program.

\section{E. Briefings/Technical Presentations}

Detailed briefings shall be given to the COR in order to explain the plans, progress, and results

of the project. A technical paper shall be presented at the DOE/NETL Annual Contractor's Review Meeting. 